\title{
Environmental Report 1998
}

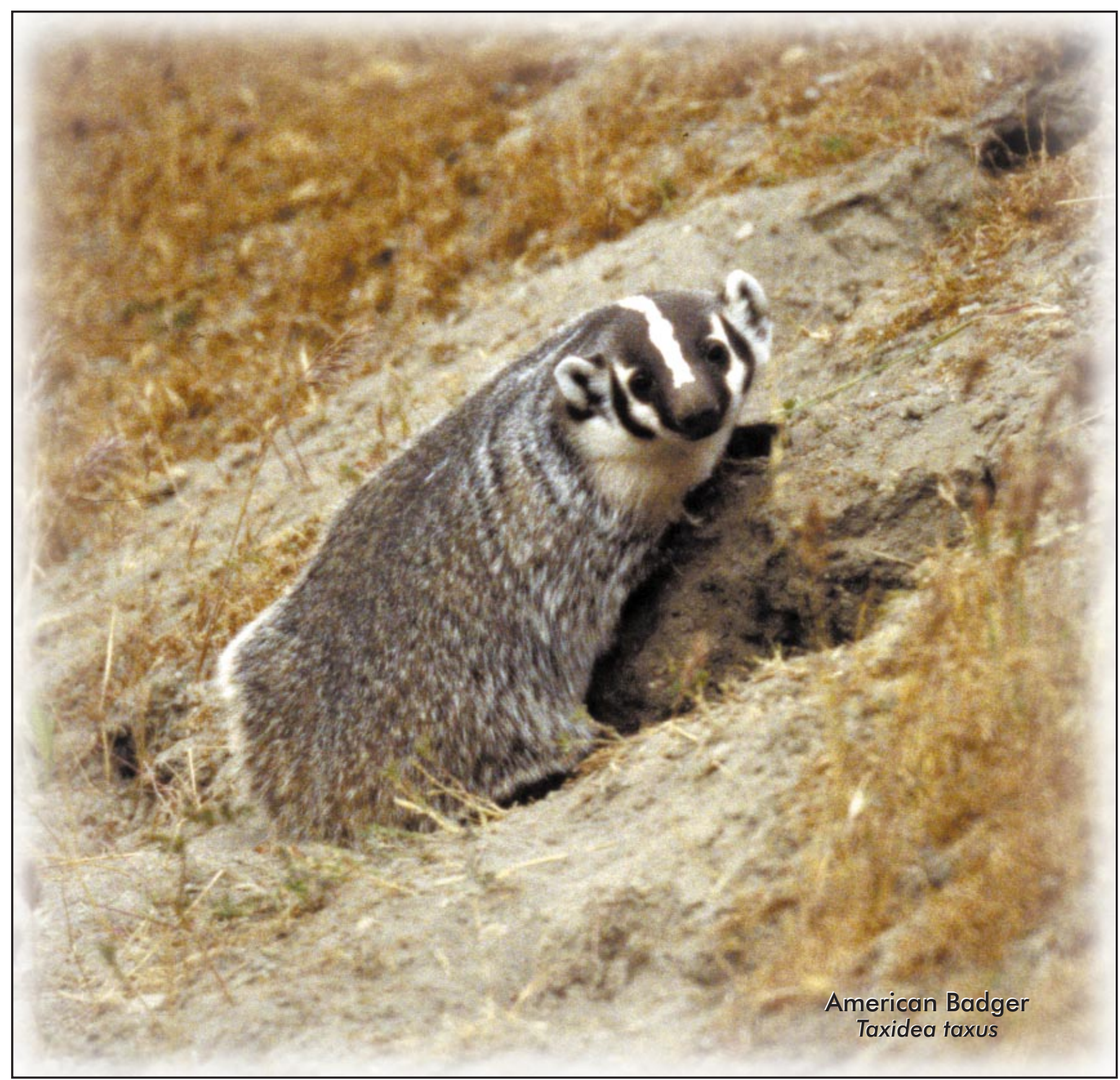

Lawrence Livermore National Laboratory 


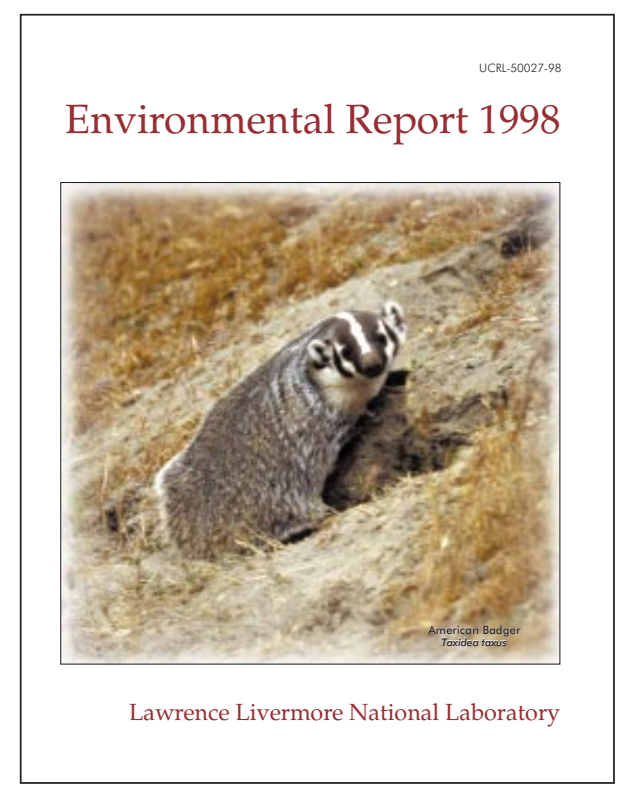

\section{Composition}

Beverly L. Chamberlain

Sherry A. Emmons

\section{Art and Design \\ Lee A. Dravidzius \\ Brett S. Clark}

\section{Proofreader}

Jill S. Sprinkle

Ellen S. Bradley

\section{Cover}

The American badger (Taxidea taxus), a relatively rare animal in California, receives protection at Site 300 as one of three keystone species. American badgers are nocturnal fossorial creatures with long, well-developed claws to dig dens and pursue ground-dwelling prey such as ground squirrels. Dens may be 5 to $30 \mathrm{ft}$ long and contain an enlarged chamber of 2 to $3 \mathrm{ft}$ for birthing. The badgers at Site 300 are significant creators of microhabitat that can be used by other special-status wildlife including western burrowing owls, California red-legged frogs, and San Joaquin whipsnakes. At LLNL, field reconnaissance surveys are conducted before ground is disturbed to determine if animals are present. If occupied dens are discovered during field evaluations, certain restrictions may be implemented to protect the badger during project development.

Jim S. Woollett, Jr., LLNL's wildlife biologist, provided the cover photo.

For further information about this report contact: Bert Heffner, LLNL Public Affairs Department, P.O. Box 808, Livermore, CA 94550, (510) 424-4026. This report can be accessed on the Internet at http:/ / www.llnl.gov/saer. It is also available to DOE employees and DOE contractors from: Office of Scientific and Technical Information, P.O. Box 62, Oak Ridge, TN 37831 and to the public from: National Technical Information Service, U.S. Department of Commerce, 5285 Port Royal Road, Springfield, VA 22161.

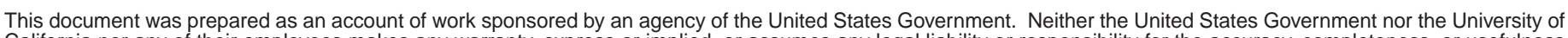

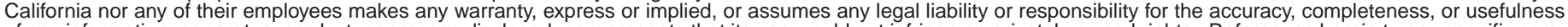

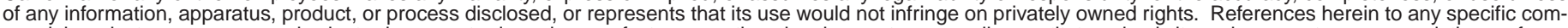

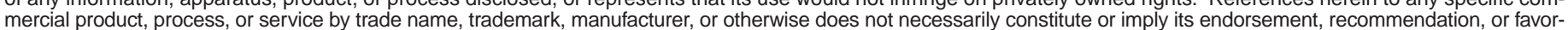

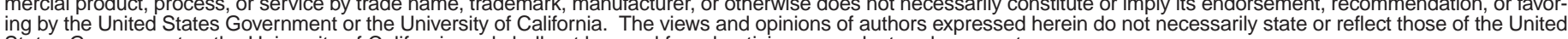
States Government or the University of California and shall not be used for advertising or product endorsement purposes. 


\section{Environmental Report 1998}

\section{Authors}

Jennifer M. Larson

Robert J. Harrach

Lucinda M. Garcia

Paris E. Althouse

Ted A. Giesing

Nicholas A. Bertoldo

Arthur H. Biermann

Allen R. Grayson

Richard G. Blake Linda C. Hall

Erich R. Brandstetter

Donald H. MacQueen

Shari L. Brigdon

Sandra Mathews

Richard A. Brown

S. Ring Peterson

Eric Christofferson

Michael J. Taffet

Karen J. Folks

Paula J. Tate

Gretchen M. Gallegos

Robert J. Vellinger

Rebecca J. Ward

\section{Editors}

Howard L. Lentzner Geoff S. Siemering

Karen S. Rath 



\section{Department of Energy \\ Oakland Operations Office \\ 1301 Clay Street \\ Oakland, California 94612-5208 \\ SEP 271999}

Distribution:

Subject: 1998 Site Annual Environmental Report (SAER) for the Lawrence Livermore National Laboratory (LLNL)

This report, prepared by LLNL for the Department of Energy, Oakland Operations Office (DOE-OAK), provides a comprehensive summary of the environmental program activities at LLNL for calendar year 1998. Site Annual Environmental Reports (SAERs) are prepared annually for all DOE sites with significant environmental activities, and distributed to relevant external regulatory agencies and other interested organizations or individuals.

To the best of my knowledge, this report accurately summarizes the results of the 1998 environmental monitoring, compliance, impacts assessment, and restoration program at LLNL. This assurance can be made based on DOE-OAK and LLNL review of the SAER, and quality assurance protocols applied to monitoring and data analyses at LLNL.

A reader survey form is provided with the SAER to provide comments or suggestions for future versions of the report. Your response is appreciated. Questions or comments regarding this report may also be made directly to DOE-OAK, by contacting Ron Sommer at (925) 422-3390.

Sincerely,

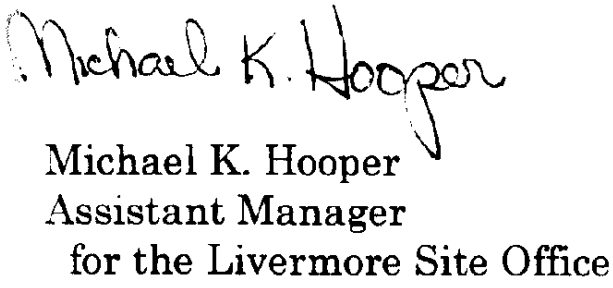





\section{Preface}

The Environmental Report 1998 is prepared for the U.S. Department of Energy (DOE), as required by DOE Order 5400.1 and DOE Order 231.1, by the Environmental Protection Department at the Lawrence Livermore National Laboratory (LLNL). The results of LLNL's environmental monitoring and compliance efforts and an assessment of the impact of LLNL operations on the environment and the public are presented in this publication.

Two important changes have been made in the 1998 report. First, a new chapter, Chapter 8: Ground Water Investigation and Remediation has been added to more thoroughly cover Comprehensive Environmental Response, Compensation and Liability Act (CERCLA) efforts to remove contamination from ground water at the Livermore site and Site 300. Second, soil and sediment analysis for metals and organic compounds that is part of the Ground Water Protection Plan, previously reported in the Ground Water chapter, will now be found in Chapter 10, Soil and Sediment Monitoring.

To produce a more readable and useful document for our diverse readership, which includes regulators, scientists and engineers, educators, the media, public interest groups, and interested citizens, we have divided this report into two volumes: main volume and Data Supplement. The main volume describes LLNL's environmental impact and compliance activities and features descriptive and explanatory text, summary data tables, and plots showing data trends. The summary data include measures of the central tendency of the data (i.e. mean and medium), their spread or variability, and their extreme values. The main volume contains the Executive Summary and the Compliance Summary; it features individual chapters on monitoring of air, sewage, surface water, ground water, soil and sediment, vegetation and food stuff, and environmental radiation; and it contains chapters on site overview, environmental program information, ground water investigation and remediation, radiological dose assessment, and quality assurance. Information on both the Livermore site and Site 300 is presented in each chapter. The Data Supplement provides individual data points, where applicable, some summary data, and more detailed accounts of sample collection and analytical methods.

The main volume contains the information of interest to most of our readers and will be distributed. The Data Supplement will be sent only upon request; a card for this purpose is included on the last page of this volume. Both the main volume and the Data Supplement are available on the Internet at http://www.llnl.gov/saer. 
As in our previous annual reports, data are presented in Système International (SI) units. In particular, the primary units we use for radiological results are becquerels and sieverts for activity and dose, respectively, with curies and rem used secondarily $\left(1 \mathrm{~Bq}=2.7 \times 10^{-11} \mathrm{Ci} ; 1 \mathrm{~Sv}=100 \mathrm{rem}\right)$. If the data are available, radioactivities are reported as the measured concentration with an uncertainty ( $\pm 2 \sigma$ counting error); if not, they are reported as being less than a detection limit. If the concentration is less than the uncertainty, the result is considered to be indistinguishable from a zero concentration. Units are discussed in Supplement 13-1 of Chapter 13, Radiological Dose Assessment, and in Chapter 14, Quality Assurance, in the main volume.

This document is the responsibility of the Operations and Regulatory Affairs Division of the Environmental Protection Department. Monitoring data were obtained through the combined efforts of the Operations and Regulatory Affairs Division, Environmental Restoration Division, the Chemistry and Materials Science Environmental Services Laboratories, and the Hazards Control Department of LLNL. Special recognition is deserved for the dedication and professionalism of the technicians who carried out environmental monitoring-Gary A. Bear, David J. Castro, Paul C. Dickinson, David L. Graves, Charles Hunt, Renee Needens, Terrance W. Poole, Donald G. Ramsey, and Robert Williams - and to the data management personnel-Jennifer Clark, Kimberly A. Stanford, Louise Morris, Beth Schad, Suzanne Chamberlain, Connie Wells, Della Burruss, and Susan Lambaren. Betty Cuevas provided secretarial support and collated and distributed drafts.

Special thanks go to Bill Hoppes for his strong support of the project and careful and timely reviews of all the drafts; Kris Surano for reviewing many of the chapters; Gretchen Gallegos, Sandra Mathews, and Rob Vellinger for their comments and help with chapters other than their own; and Charlene Grandfield for adopting the Compliance Summary. In addition, the following people contributed significantly to this report: Janice Butler, Richard Crawford, Keith V. Gilbert, C. Susi Jackson, Albert L. Lamarre, Grace Massa, Patricia L. Ottesen, Duane W. Rueppel, Jeffrey Sketchley, Brenda Staley, Judy Steenhoven, Horacio Jaramillo, Kim Heyward, and Janet Tanaka. 


\section{Table of Contents}

List of Figures .............................................................................................................. xvii

List of Tables ............................................................................................................. xxiii

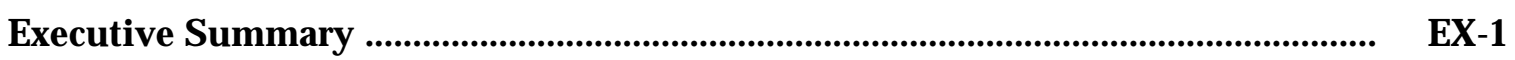

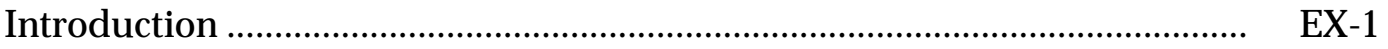

Environmental Monitoring Results ……................................................... EX-1

Air Monitoring …........................................................................ EX-2

Stack Air Effluent Monitoring ................................................................ EX-2

Sewerable Water Monitoring …............................................................. EX-3

Surface Water Monitoring ….................................................................... EX-3

Ground Water Monitoring .................................................................. EX-4

Soil and Sediment Monitoring ............................................................... EX EX

Vegetation and Foodstuff Monitoring ….................................................. EX-5

Radiological Dose Assessment ................................................................. EX-6

Environmental Compliance and Program Activities ...................................... EX-7

Ground Water Remediation ................................................................... EX-7

Waste Minimization and Pollution Prevention ........................................ EX-8

Air, Wastewater, and Water Compliance ……......................................... EX-9

Environmental Occurrences ................................................................... EX-9

Endangered Species ............................................................................. EX-9

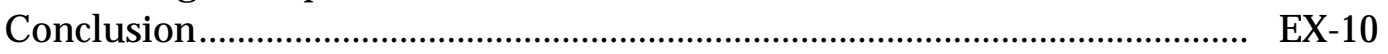

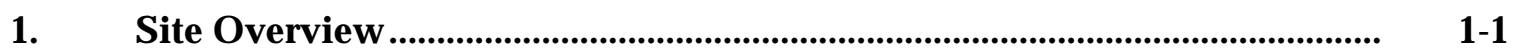

Introduction ......................................................................................... $1-1$

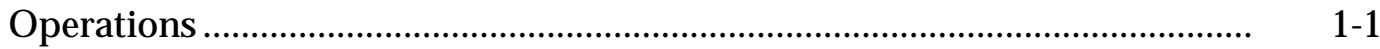

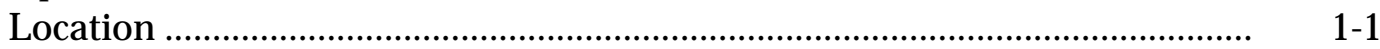

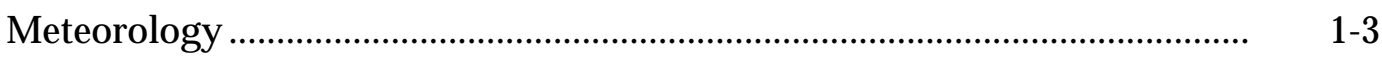

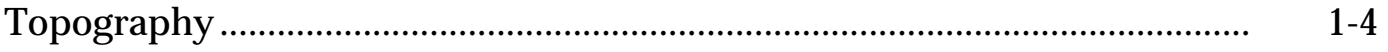

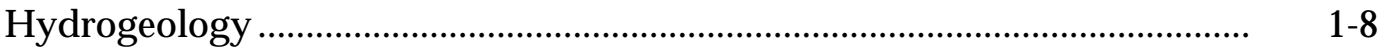

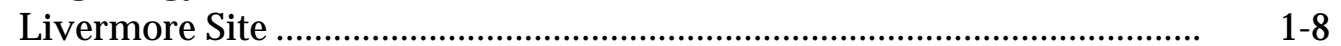

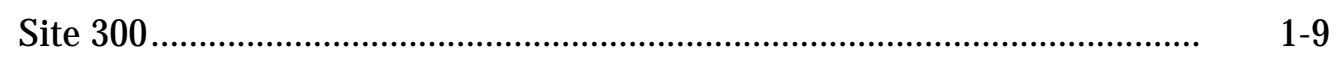

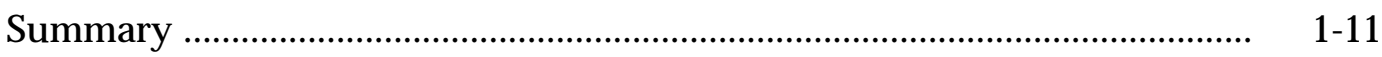

2. Compliance Summary …..................................................................... $2-1$

Introduction .......................................................................................... $2-1$

CERCLA …..................................................................................................... 2

Livermore Site Ground Water Project .................................................... $\quad 2-1$

Documentation .................................................................................. $2-2$

Treatment Facilities ............................................................... $2-2$

Community Relations ................................................................... $2-2$ 
Site 300 CERCLA Project ....................................................................... 2-3

Documentation ................................................................................. 2-3

Treatment Facilities ........................................................................ 2-3

Community Relations.................................................................... 2-4

Big Trees Park Soil Sampling and Analysis ............................................ 2-. 2-4

Site Evaluations Prior to Construction ....................................................... 2 2-5

SARA, Title III .......................................................................................... 2 2-5

Clean Air Act_-Air Quality Management Activities .................................... 2 2-5

National Emission Standards for Hazardous Air Pollutants ................... 2 2-6

Clean Water Act and Related State Programs.............................................. 2 2-10

Ground Water and Surface Water .......................................................... 2 2-13

Sewerable Water ........................................................................................ 2 2-13

Streambed Alteration Agreements and Nationwide Permits ................. . 2-15

Tank Management ............................................................................... 2-17

Resource Conservation and Recovery Act .................................................. 2 2-19

Hazardous Waste Permits ............................................................................ 2 2-19

Livermore Site ...................................................................... 2-18

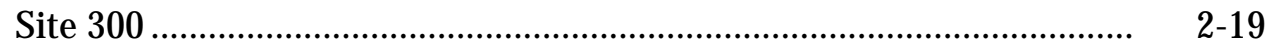

Hazardous Waste Reports ......................................................................... 2 2-20

Hazardous Waste Transport Registration .............................................. $\quad$ 2-20

Waste Accumulation Areas ....................................................................... 2 2-21

California Medical Waste Management Act ................................................. 2 2-21

Federal Facility Compliance Act ............................................................... 2-22

Toxic Substances Control Act ................................................................... 2 2-22

National Environmental Policy Act .......................................................... 2 2-22

California Environmental Quality Act....................................................... 2-23

National Historic Preservation Act................................................................ 2 2-23

Endangered Species Acts and Sensitive Natural Resources ........................ 2 2-24

Antiquities Act (of 1906): Paleontological Resources .................................. 2-26

Environmental Occurrences .......................................................................... 2-26

Contributing Authors Acknowledgment .................................................. 2-28

3. Environmental Program Information.............................................................. 3-1

Introduction ........................................................................................ $3-1$

Integrated Environmental, Safety, and Health Management System ........... 3-1

Work Smart Standards ................................................................................ 3-2

Environmental Protection Department ........................................................ 3-3

Operations and Regulatory Affairs Division ........................................... 3 3-5

Hazardous Waste Management Division .............................................. $\quad 3-5$

Environmental Restoration Division .................................................... 3-6

Performance Measures Summary ............................................................. $\quad 3-7$

DOE Pollution Prevention Goals ............................................................... 3-7

Waste Minimization/Pollution Prevention ................................................... 3-9

Nonhazardous Solid Waste Minimization ............................................. 3 $3-11$ 
Diverted Waste

Source Reduction and Pollution Prevention .............................................. 3-13

Toxic Reporting Inventory Information............................................ 3-13

Implementing Cost-Saving Pollution Prevention (P2) Projects .............. 3- 3-14

Review of New Processes or Experiments .............................................. 3- 3-14

Design for Environment ........................................................................ 3-15

Implementing P2 Employee Training and Awareness Programs .......... 3 3-15

Current Return-on-Investment Projects ................................................. 3-16

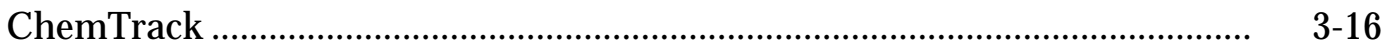

Current Issues and Actions .................................................................. 3-17

ATSDR Assessment .......................................................................... 3-17

Miniature Optical Lair Explorer ......................................................... 3-18

Leaking Underground Fuel Tank Studies .............................................. 3-18

Initiative to Improve VOC Cleanup Process by Using Historical

Case Analysis ....................................................................................... 3 $\quad$ 3-20

Spill Reporting .................................................................................... $3-21$

Response to Spills and Other Environmental Emergencies .......................... 3-21

Environmental Training .......................................................................... $3-22$

LLNL's Other Environmental Programs .................................................. 3-23

Contributing Authors Acknowledgment ….................................................. 3-23

4. Air Effluent Monitoring …........................................................................ 4-1

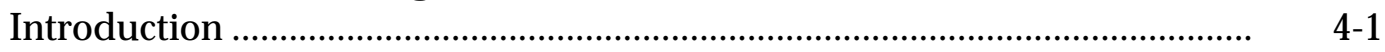

Air Quality Laws ...............................................................................

Monitored Emissions ............................................................................. $4-1$

Operation of Monitoring Systems ............................................................. 4-3

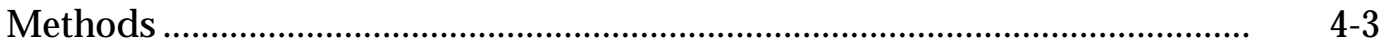

Measured Radioactive Air Emissions .......................................................... 4

Livermore Site ..................................................................................

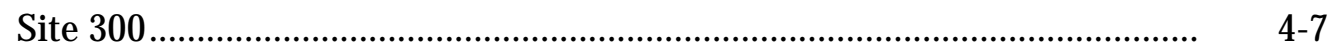

All Potential Sources of Radioactive Air Emissions ........................................ $\quad$ 4-8

Nonradioactive Air Emissions ..................................................................... $4-9$

Environmental Impact ............................................................................ $4-10$

5. Surveillance Air Monitoring …................................................................. 5-1

Introduction .......................................................................................... $5-1$

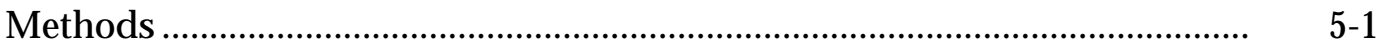

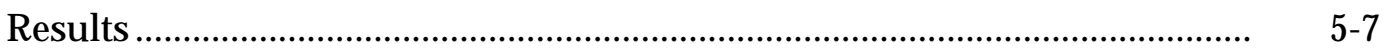

Livermore Site ............................................................................ $\quad$ 5-7

Airborne Radioactivity .............................................................. $\quad 5-7$

Beryllium in Air ......................................................................... $5-19$

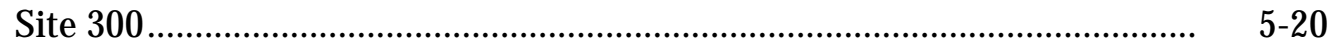

Airborne Radioactivity .......................................................... $\quad 5-20$

Beryllium in Air ....................................................................... $5-21$ 
Environmental Impact .......................................................................... $\quad 5-22$

Radioactive Materials ............................................................................... $\quad$ 5-22

Nonradioactive Materials ....................................................................... 5 5-22

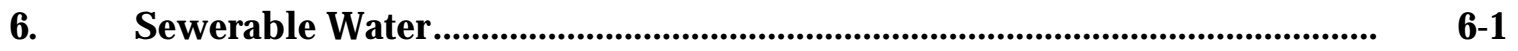

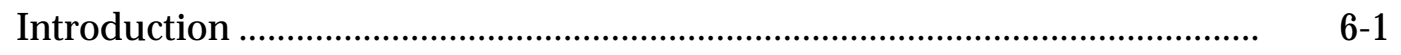

Preventive Measures ..............................................................................

Monitoring ............................................................................................

Monitoring at the Sewer Monitoring Station ..................................... 6-3

Monitoring at the Upstream pH Monitoring Station ....................... . 6-3

Diversion System .............................................................................. $6-4$

Pretreatment Discharges ........................................................................ $6-4$

Categorical Discharges ............................................................................ 6-6

Discharges of Treated Ground Water ............................................................ $\quad$ 6-8

Radioactive Pollutants in Sewage ............................................................... 6-9

Monitoring Results ............................................................................... $\quad 6-9$

Environmental Impact ....................................................................... $\quad 6-12$

Nonradioactive Pollutants in Sewage ....................................................... 6 6-16

Monitoring Results ........................................................................... $\quad 6-16$

Environmental Impact ..................................................................... $\quad 6-17$

7. Surface Water ........................................................................................................... $\quad 7-1$

Overview .....................................................................................................

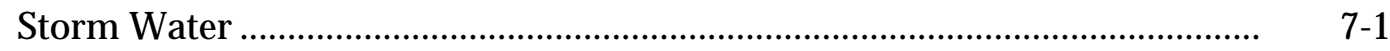

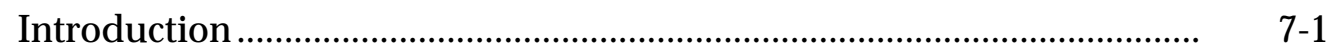

Permits ........................................................................................... $7-1$

Constituent Criteria ...................................................................... $\quad$ 7-3

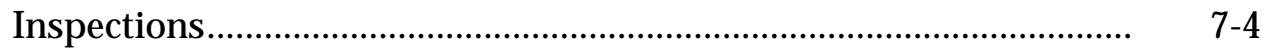

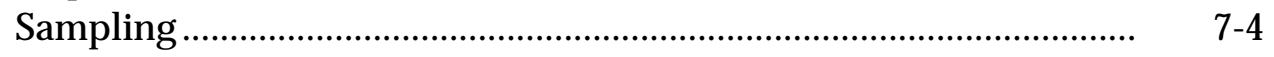

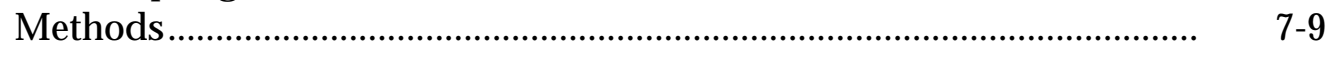

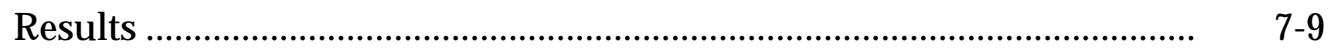

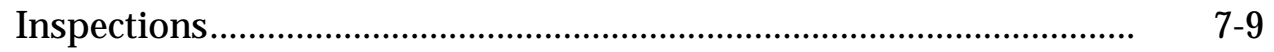

Livermore Sampling ….......................................................... $\quad$ 7-10

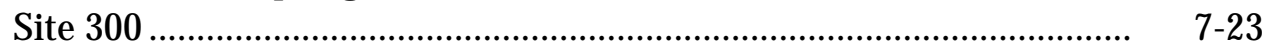

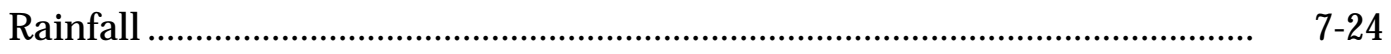

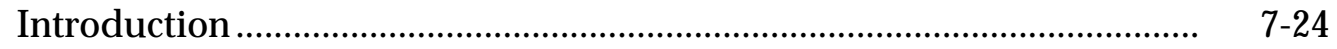

Results .................................................................................. $\quad$ 7-25

Livermore Site Drainage Retention Basin …............................................ $\quad$ 7-26

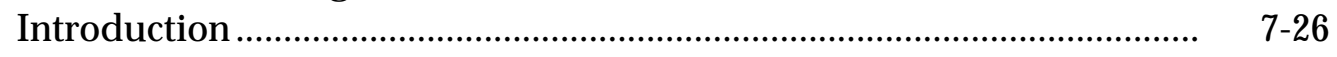

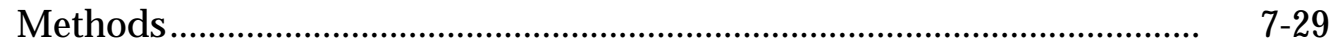

Results .......................................................................................... $\quad$ 7-30

Dissolved Oxygen ................................................................... $\quad$ 7-30

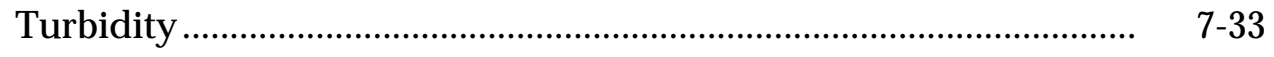

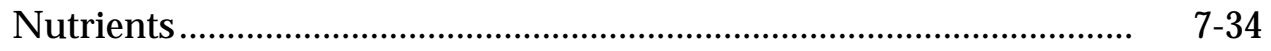


Biological Monitoring ..................................................................... $\quad$ 7-34

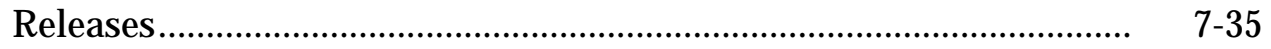

Site 300 Cooling Towers ............................................................................ $\quad$ 7-36

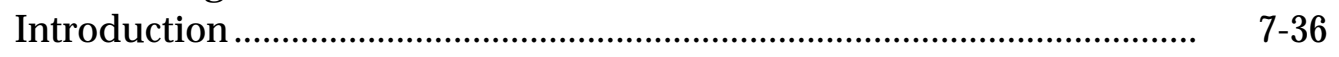

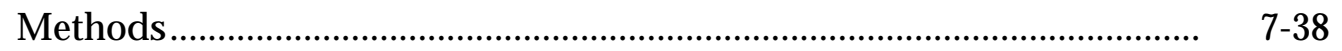

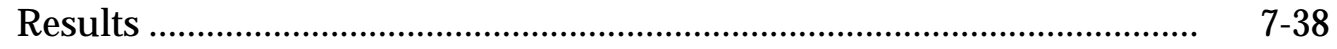

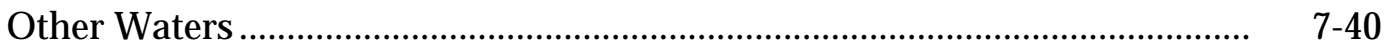

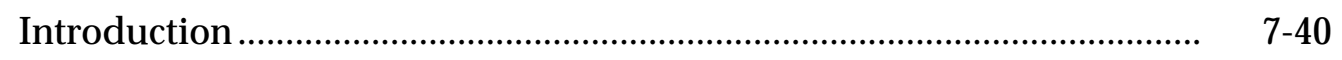

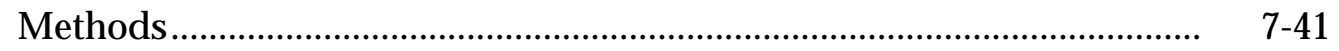

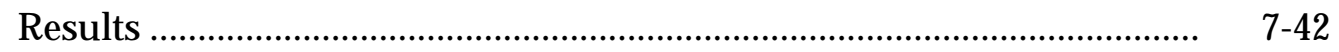

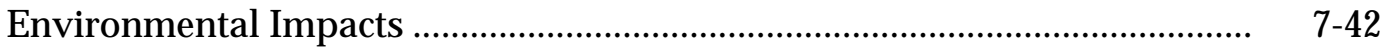

Storm Water ........................................................................... $\quad$ 7-42

Rainfall ............................................................................... $\quad$ 7-43

Drainage Retention Basin ...................................................................... 7-43

Cooling Towers ............................................................................... $\quad$ 7-44

Other Waters ................................................................................................ $\quad$ 7-44

8. Ground Water Investigation and Remediation ............................................ 8-1

Introduction ....................................................................................... $8-1$

Livermore Site Ground Water Project ........................................................... $\quad 8-1$

Physiographic Setting …........................................................................ $8-1$

Hydrogeology .................................................................................. $8-2$

Remedial Activities ...................................................................... $\quad 8-2$

Treatment Facility A ….............................................................. $8-4$

Treatment Facility B .................................................................. 8

Treatment Facility C …............................................................... $8-6$

Treatment Facility D ............................................................ $\quad 8-7$

Treatment Facility E ................................................................ $8-12$

Treatment Facility G ................................................................. $8-13$

Treatment Facility 406 ............................................................. 8 $8-13$

Ground Water Treatment Facility 518 .......................................... 8 8-14

Treatment Facility 5475 ............................................................... 8-15

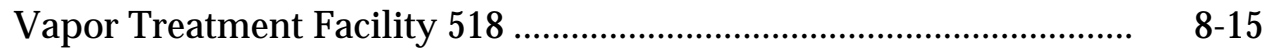

Ground Water Flow and Transport Modeling ........................................ 8 8-16

Treatment Facility A and B Model ................................................ 8 8-16

Sitewide Model for all HSUs .......................................................... 8 8-16

Trailer 5475 Model ..................................................................... $\quad 8-17$

Zone 7 Project.................................................................................... 8-17

Regulatory Compliance .................................................................. $\quad 8-17$

CERCLA Documents ................................................................... 8 8

Community Relations ............................................................... $8-18$

Environmental Impact .......................................................................... $8-19$ 
Site 300 Ground Water Project .................................................................. 8 $8-20$

Geology of Site 300 ............................................................................ $\quad 8-20$

Hydrogeology of Site 300 ..................................................................... $\quad$ 8-22

Study Area Highlights and Activities .................................................... 8. 8

General Services Area .............................................................. $\quad 8-28$

Building 834 Area ...................................................................... 8 8-28

Explosives Process Area ................................................................. 8 8-29

East and West Firing Areas ............................................................ 8 8-32

Building 854 Study Area ................................................................ 8 8-34

Pit 6 Area ….............................................................................. 8-36

Building 832 Canyon Study Area .................................................. 8 8-37

Environmental Remediation at Site 300 ................................................. 8-37

General Services Area ................................................................. 8-39

Building 834 Complex ................................................................... 8

Explosives Process Area ............................................................... 8 8-42

Pit 6 Landfill Area ................................................................................. 8 8-43

Building 832 Canyon .................................................................. $8-43$

Community Relations ........................................................................ 8 $8-43$

9. Ground Water Monitoring …..................................................................... 9-1

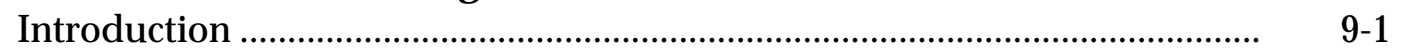

Surveillance Monitoring ........................................................................ 9-1

Compliance Monitoring ...................................................................... $9-2$

Livermore Site and Environs ............................................................... $9-2$

Livermore Valley ...................................................................... $9-2$

Livermore Site Perimeter ............................................................. 9 9-4

Livermore Site .................................................................... $9-5$

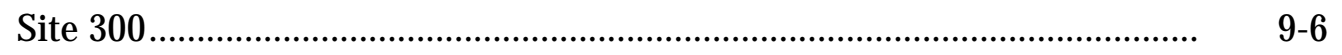

Elk Ravine Drainage Area............................................................ 9-8

Corral Hollow Creek Drainage Area ................................................ $\quad 9-12$

Surface Impoundments .............................................................. 9-14

Percolation Pits .......................................................................... 9 9-15

Sewage Evaporation and Percolation Ponds ................................... 9 9-16

Sampling and Analytical Methods ............................................................... 9-16

Results ............................................................................................. $\quad{ }_{9}$

Livermore Site and Environs ............................................................... 9-18

Livermore Valley .......................................................................... 9-18

Livermore Site Perimeter ............................................................... 9-18

Livermore Site ......................................................................... $9-20$

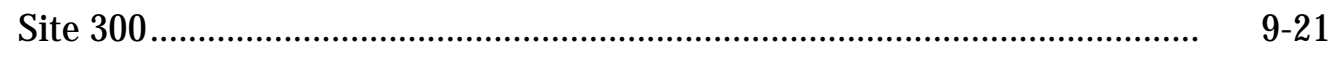

Elk Ravine Drainage Area.............................................................. 9-21

Corral Hollow Creek Drainage Area ..................................................... 9-24

Surface Impoundments ............................................................ 9

Percolation Pits ................................................................ 9-27 
Water Supply Wells ..................................................................... 9-27

Sewage Evaporation and Percolation Ponds .................................... 9. 9-27

Off-Site Water Supply Wells.......................................................... 9.. 9-29

Environmental Impacts ............................................................................ 9-29

Livermore Site and Environs ................................................................ 9-29

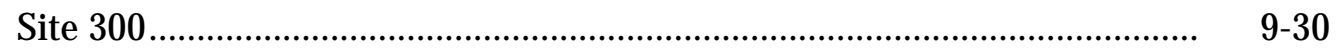

10. Soil and Sediment Monitoring ........................................................................ 10-1

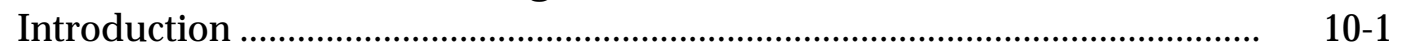

Surface Soils and Sediments .................................................................. 10 10

Methods.............................................................................. 10 10

Livermore Valley Results ................................................................. 10 10

Site 300 Results .............................................................................. 10-9

Environmental Impact ................................................................ 10 10

Livermore Site …................................................................. 10 - 10

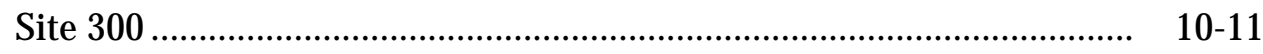

Vadose Zone Soils ................................................................................. 10-11

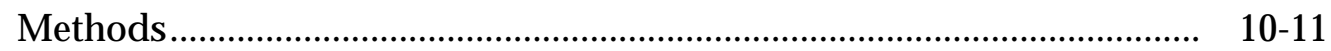

Vadose Zone Soil Results ....................................................................... 10 10

Environmental Impact .................................................................... 10. 10

Big Trees Park ........................................................................................ 10-13

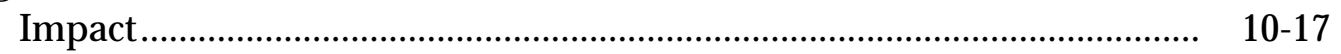

11. Vegetation and Foodstuff Monitoring …............................................................ 11-1

Introduction ….................................................................................... $11-1$

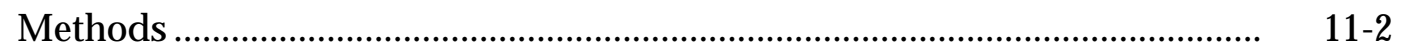

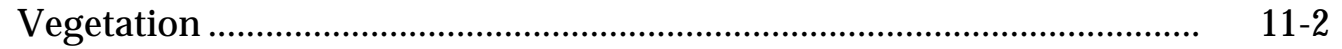

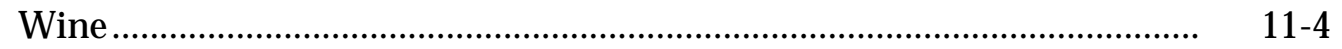

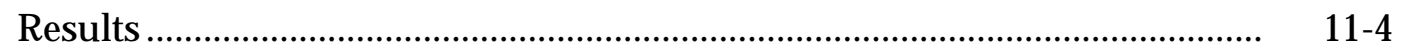

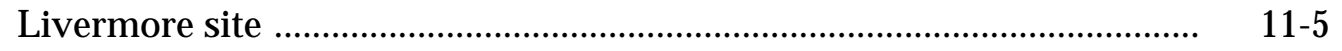

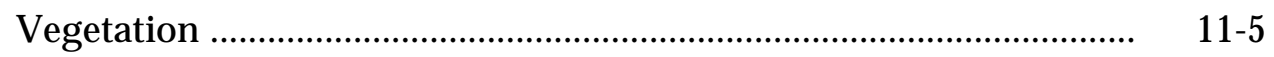

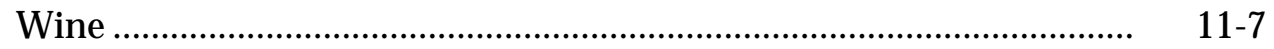

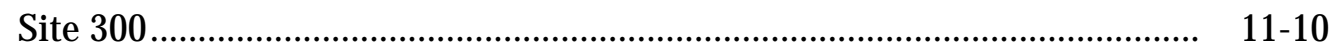

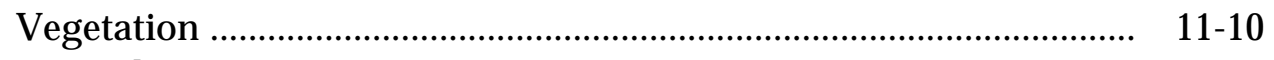

Environmental Impact ..................................................................... 11-11

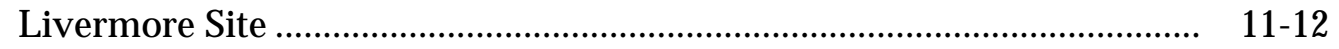

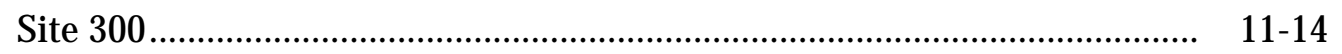

12. Environmental Radiation Monitoring …..................................................... 12-1

Introduction ....................................................................................... $12-1$

Cosmic Radiation Component ............................................................ 12 12-1

Terrestrial Radiation Component........................................................... 12-1

General Methods ................................................................................ 12-2

Monitoring Locations ......................................................................... 12-2

Collocated Monitoring Locations .............................................................. $12-4$ 
Results of Gamma Monitoring ….............................................................. 12-5

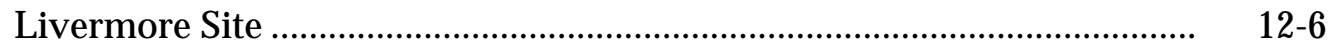

Collocated Sites …............................................................................ 12-7

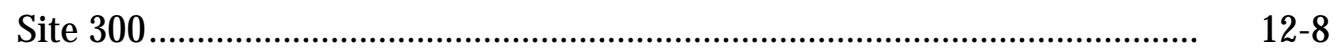

Environmental Impact ........................................................................ 12-9

13. Radiological Dose Assessment............................................................... 13-1

Introduction ........................................................................................... 13-1

Background Information ...................................................................... 13-1

Releases of Radioactivity to Air ............................................................ 13-1

Air Dispersion and Dose Models ........................................................... 13-2

Radiation Protection Standards ........................................................... 13-3

Reporting Requirements ................................................................ 13-4

Evaluation of Sources of Radioactive Emissions ........................................ 13-5

Inventoried Sources ..................................................................... 13-5

Monitored Sources........................................................................... 13-6

Stack Effluent Monitoring ............................................................ 13-6

Surveillance Air Monitoring ........................................................... 13-7

Determinations of Dose ............................................................................. 13-8

Principal Modeling Approaches........................................................... 13-8

Identification of Key Receptors .............................................................. 13-9

Assessment Assumptions Regarding Tritium ........................................ 13-10

Relative Contributions to Dose from HTO and HT Emissions ......... 13-10

Dose-rate Conversion Factor for Tritium ........................................... 13-11

Over-estimate of Ingestion Dose for Tritium .................................... 13-11

Special Modeling Problems .................................................................. 13-11

Diffuse Sources ............................................................................. 13-11

Modeling Dose Impacts from Explosives Experiments at Site 300 ... 13-12

Radiological Doses from 1998 Operations ..................................................... 13-13

Dose Breakdown by Facility ............................................................. 13-14

Unplanned Releases ......................................................................... 13-14

Doses to Site-Wide Maximally Exposed Individuals ............................ 13-18

Temporal Trends in Dose to the SW-MEI....................................................... 13-21

Collective Doses to Exposed Populations ................................................... 13-22

Summary and Conclusion ...................................................................... 13-24

Chapter 13 Supplements ....................................................................... 13-25

Supplement 13-1: Radiation Basics ...................................................... 13-25

Supplement 13-2: Radiation Control Measures at LLNL....................... 13-29

14. Quality Assurance ...................................................................................................... 14-1

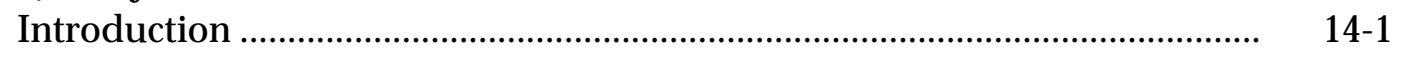

Quality Assurance Activities .................................................................... 14-2

Analytical Laboratories ............................................................................. 14-2

Participation in Laboratory Intercomparison Studies ............................. 14-3

Duplicate Analyses ......................................................................... $14-4$ 
Deviations and Changes to the Sampling Program ..................................... 14-10

Changes to Environmental Monitoring Networks .................................. 14-11

Sampling Completeness ................................................................... 14-11

Statistical Methods ...................................................................................... 14-13

Radiological Data ............................................................................ 14-14

Nonradiological Data ........................................................................ 14 14

Statistical Comparisons ...................................................................... 14-15

Summary Statistics .................................................................... 14 14

Radiation Units .............................................................................. 14-15

Quality Assurance Process for the Environmental Report .......................... 14-16

Appendix A. Methods of Dose Calculations .................................................................... A-1

Appendix B. Reports for Regulatory Agencies ...................................................... B-1

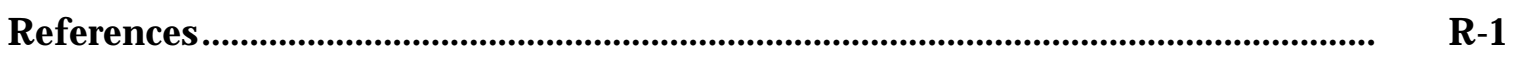

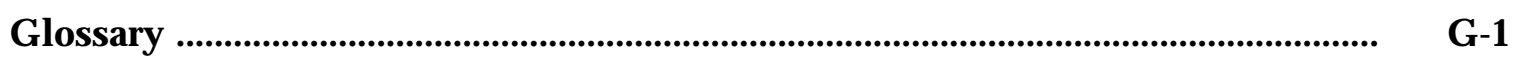

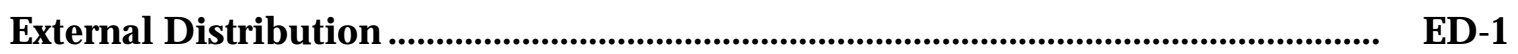





\section{List of Figures}

Figure 1-1. Locations of LLNL Livermore site and Site 300 .................................. 1-2

Figure 1-2. Wind rose showing the frequency of occurrence for wind speed

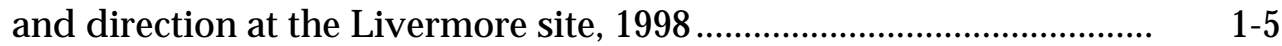

Figure 1-3. Wind rose showing the frequency of occurrence for wind speed and direction at Site 300, 1998......

Figure 1-4. 1998 approximate ground water and surface elevation contours, Livermore site and vicinity

Figure 1-5. 1998 approximate ground water elevations in principal continuous water-bearing zones at Site 300

Figure 4-1. Buildings at the Livermore site with air monitoring systems for

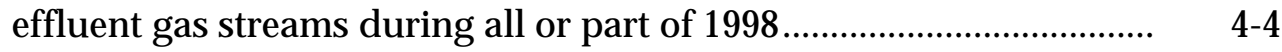

Figure 4-2. Tritium Facility HTO and HT emissions between 1981 and 1998 ....... 4 4-6

Figure 5-1. Air particulate and tritium sampling locations on the Livermore site, 1998

Figure 5-2. Air particulate and tritium sampling locations in the Livermore Valley, 1998

Figure 5-3. Air particulate and tritium sampling locations at Site 300, 1998 .........

Figure 5-4. Monthly median gross alpha concentrations in particulate air samples from the LLNL perimeter, Livermore Valley, and Site 300 sampling locations, 1998

Figure 5-5. Monthly median gross beta concentrations in particulate air samples from the LLNL perimeter, Livermore Valley, and Site 300 sampling locations, 1998

Figure 5-6. Median plutonium concentrations in air particulate samples at two locations, SALV and FCC, 1982 to 1998.

Figure 5-7. Median concentration of beryllium in air particulate samples taken at the Livermore site perimeter, 1974 to 1998

Figure 6-1. LLNL sanitary sewer system monitoring stations and diversion facility

Figure 6-2. Historical trend in tritium concentration in LLNL sewage

Figure 6-3. Historical trends in average monthly plutonium and cesium concentration in LLNL sewage

Figure 6-4. Average monthly concentrations of eight metals in LLNL sanitary sewer effluent showing trends from 1994 through 1998 
Figure 6-5a. Results as percentages of effluent pollutant limits (EPLs) for seven of the nine metals regulated in LLNL sewage

Figure 6-5b. Results as percentages of effluent pollutant limits (EPLs) for two of the nine metals regulated in LLNL sewage

Figure 7-1. Surface water flow in the vicinity of LLNL ....................................... $\quad$ 7-6

Figure 7-2. Storm water runoff and Drainage Retention Basin discharge sampling locations, Livermore site and vicinity, 1998

Figure 7-3. Rain and storm water runoff sampling locations, Site 300 and vicinity, 1998 ......

Figure 7-4. Annual median gross alpha concentrations in LLNL storm water compared with the maximum contaminant level (MCL)..........

Figure 7-5. Annual median gross beta concentrations in LLNL storm water compared with the maximum contaminant level (MCL).

Figure 7-6. Annual median tritium concentrations in LLNL storm water compared with the maximum contaminant level (MCL)

Figure 7-7. Tritium concentrations in Livermore site runoff on November 30, 1998

Figure 7-8. Rain sampling locations, Livermore site and Livermore Valley, 1998.

Figure 7-9. Tritium concentration in stormwater runoff at the Livermore site plotted against the tritium concentration of rain sampled at Building 343 (November, 1997 through December 1998)

Figure 7-10. Trends of median tritium activity in rain and total stack emissions of HTO from the LLNL Livermore site and Sandia/California, 1990 to 1998 .

Figure 7-11. Sampling locations within the Drainage Retention Basin, 1998

Figure 7-12. Monthly average dissolved oxygen vs. temperature at each depth location in the Drainage Retention Basin from January through December 1998.

Figure 7-13. Dissolved oxygen concentration variations from the beginning of Drainage Retention Basin operations

Figure 7-14. Seasonal temperature variation measured at sample top, middle, and bottom levels from the start of operation in 1993

Figure 7-15. Water discharged from the Drainage Retention Basin in 1998

Figure 7-16. Site 300 cooling tower locations and receiving water monitoring locations, 1998

Figure 7-17. Surface and drinking water sampling locations, Livermore Valley, 1998 
Figure 8-1. Map and cross section of the Livermore site showing hydrostratigraphic units and the locations of the treatment plants

Figure 8-2. Total VOC mass removed from the subsurface of the Livermore site between 1989 and 1998

Figure 8-3. Isoconcentration contour map of total VOCs within hydrostratigraphic unit (HSU) 1B

Figure 8-4. Isoconcentration contour map of total VOCs within hydrostratigraphic unit (HSU) 2

Figure 8-5. Isoconcentration contour map of total VOCs within hydrostratigraphic unit (HSU) 3A

Figure 8-6. Isoconcentration contour map of total VOCs within hydrostratigraphic unit (HSU) 4

Figure 8-7. Isoconcentration contour map of total VOCs within hydrostratigraphic unit (HSU) 5 ....

Figure 8-8. Environmental restoration study areas at Site 300.

Figure 8-9. Site 300 stratigraphy

Figure 8-10. Approximate ground water elevations in the principal continuous water-bearing zone at Site 300

Figure 8-11. Extent of ground water contamination at LLNL Site 300.

Figure 8-12. Total VOC concentrations in ground water in the eastern GSA and vicinity (second quarter, 1998)

Figure 8-13. Total VOC concentrations in ground water in the central GSA (fourth quarter, 1998)

Figure 8-14. Distribution of trichloroethene in the Building 834 area (second quarter, 1998)

Figure 8-15. Distribution of trichloroethene in the Explosives Process area (second quarter, 1998)

Figure 8-16. Distribution of tritium in ground water in the first waterbearing zone in the Building 850/Pit 3 and 5 area (second quarter, 1998)

Figure 8-17. Distribution of trichloroethene in ground water in the Building 854 area (second quarter, 1998)

Figure 8-18. Distribution of trichloroethene in ground water in the Pit 6 area (second quarter, 1998)

Figure 8-19. Distribution of trichloroethene in the combined Qal, Tnbs, and Tnsc $_{1}$ aquifers in the Building 832 Canyon (second quarter, 1998) 
Figure 9-1. Locations of off-site tritium monitoring wells in the Livermore Valley

Figure 9-2. Locations of routine surveillance ground water monitoring wells at the Livermore site.....

Figure 9-3. Locations of surveillance ground water wells, Barcads, and springs, Site 300 .

Figure 9-4. Locations of compliance ground water monitoring wells, Pit 7 complex.

Figure 9-5. Locations of Pit 2 surveillance Barcads (K1-02A, K2-01A, K20-1B, and K2-02A) and surveillance well K2-02B, and Pit 1 compliance ground water monitoring wells (K1-01C, -07, -02B, $-03,-04,-05,-08$, and -09 )

Figure 9-6. Locations of surveillance ground water monitoring wells, Pit 8, 1998 .

Figure 9-7. Locations of surveillance ground water monitoring wells, Pit 9, 1998

Figure 9-8. Locations of Pit 6 ground water monitoring wells

Figure 9-9. Locations of compliance ground water monitoring wells in the Explosives Process Area

Figure 9-10. Sewage evaporation and percolation ponds, compliance ground water monitoring wells, and wastewater monitoring locations.

Figure 10-1. Soil sampling locations, Livermore Valley, 1998

Figure 10-2. Site 300 soil sampling locations, 1998.

Figure 10-3. Arroyo and drainage basin sediment sampling locations, 1998.

Figure 10-4. Median 239+240 Pu activities in surface soils, 1976 to 1998

Figure 10-5. Uranium-238 concentrations in surface soils, 1976 to 1998.

$10-10$

Figure 10-6. Bar graphs of radionuclide concentrations at grid locations at Big Trees Park in Livermore

Figure 10-7. Plutonium and americium concentrations measured at grid locations on Radial 1 and in tree wells .

Figure 11-1. Livermore Valley vegetation sampling locations, 1998.

Figure 11-2. Site 300 vegetation sampling locations, 1998

Figure 11-3. Median tritium activities in Livermore Valley vegetation samples, 1971 to 1998

Figure 11-4. Mean tritium in retail wines, 1977 to 1998, plotted as measured for each sampling year 


\section{List of Figures}

Figure 11-5. Mean tritium concentrations in retail wines decay-corrected from the sampling year to the vintage year..

Figure 11-6. Median tritium activities in vegetation at Site 300 sampling locations 1971 to 1998.

Figure 12-1. Gamma dosimeter locations, Livermore site, 1998.

Figure 12-2. Gamma dosimeter locations, Livermore Valley, 1998

Figure 12-3. Gamma dosimeter locations, Site 300 and vicinity, 1998

Figure 12-4. Comparison of gamma dose rates measured by collocated CDHS-RHB and LLNL TLDs at several LLNL perimeter, Livermore Valley, Site 300, and off-site locations

Figure 12-5. Quarterly gamma dose measurements at the Livermore site perimeter, Livermore Valley, and Site 300, 1988 to 1998.

Figure 13-1. Dose to the site-wide maximally exposed individual member of the public, 1990 to 1998 .

Figure 13-2. Typical annual radiation doses from natural and man-made sources

Figure 14-1. Air-filter gross beta concentrations from collocated samples

Figure 14-2. Ground water gross alpha concentrations from collocated samples showing two outliers

Figure 14-3. Air-filter gross alpha concentration from collocated samples showing a lot of scatter 



\section{List of Tables}

Table 1-1. Wind rose data for LLNL's Livermore site at the 10-m level for 1998.

Table 1-2. Wind rose data for LLNL's Site 300 at the 10-m level for 1998 ........... 1-8

Table 2-1. Summary of LLNL compliance with EPCRA in 1998 .......................... 2-6

Table 2-2. $\quad$ Livermore site, SARA, Title III, Section 311, Chemical List ................. 2-7

Table 2-3. Site 300, SARA, Title III, Section 311, Chemical List ............................ 2-8

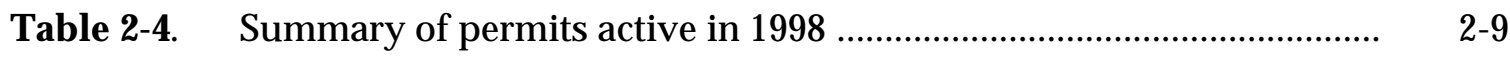

Table 2-5a. Inspections and tours of the Livermore site by external agencies in 1998

Table 2-5b. Inspections and tours of Site 300 by external agencies in 1998........... 2 2-12

Table 2-6. Summary of nonconformances with NPDES permits ......................... 2-14

Table 2-7. Summary of streambed alteration agreements, 404 Nationwide Permits, and 401 Waivers ..................................................................... 2 2-16

Table 2-8. Status of in-service tanks, December 31, 1998 .................................... 2-17

Table 2-9. Tabulation of Environmental Occurrences reported under the Occurrence Reporting System, 1998

Table 3-1. Contract 48 environmental protection performance measures ........... 3-8

Table 3-2. Routine waste generation totals, 1993 to 1998 (in tons) ....................... 3-10

Table 3-3. Routine waste reduction, 1998 ............................................................ 3-10

Table 3-4. Nonhazardous landfill totals (in tons), 1998 ...................................... 3-11

Table 3-5. Waste diversion summary table, 1998 ................................................... 3-12

Table 3-6. High Return-on-Investment projects in 1998 ...................................... 3-16

Table 3-7. EPD training courses ........................................................................ $3-22$

Table 4-1. Air effluent sampling locations and systems ..................................... $4-5$

Table 4-2. Measured radiological air effluent emissions for the Livermore

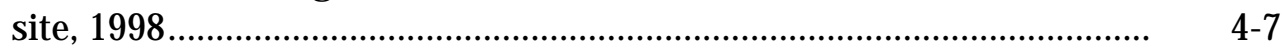

Table 4-3. Nonradioactive air emissions, Livermore site and Site 300, 1998 ....... $\quad$ 4-9

Table 5-1. Sampling locations listed by monitoring network ............................... $\quad 5-2$

Table 5-2. Gross alpha and gross beta in air particulate samples summarized by month, 1998

Table 5-3. Gamma activity in air particulate samples, Livermore site perimeter and Site 300, 1998 
Table 5-4. Plutonium-239+240 activity in air particulate samples $\left(10^{-9} \mathrm{~Bq} / \mathrm{m}^{3}\right), 1998$

Table 5-5. Uranium mass concentration in air particulate samples, 1998 ............ 5-16

Table 5-6. Tritium in air samples (in $10^{-3} \mathrm{~Bq} / \mathrm{m}^{3}$ ), 1998 ................................... 5-18

Table 5-7. Beryllium in air particulate samples (in $\mathrm{pg} / \mathrm{m}^{3}$ ), Livermore site perimeter and Site 300, 1998

Table 6-1. Limits under Permit 1250 for discharges into the municipal sewer

Table 6-2. Discharge limits for nonradioactive pollutants in wastewaters at point of discharge into LLNL sewer...

Table 6-3. LLNL's internal discharge limits for radioisotopes in wastewaters.

Table 6-4. Estimated total radioactivity in LLNL sanitary sewer effluent, 1998.

Table 6-5. Tritium, cesium, and plutonium in sanitary sewer effluents, LLNL and LWRP, 1998

Table 6-6. Sewer discharge release limits for ${ }^{3} \mathrm{H},{ }^{137} \mathrm{Cs}$, and ${ }^{239} \mathrm{Pu}$.

Table 6-7. Radioactive liquid effluent releases from the Livermore site, 1989-1998

Table 6-8. Average monthly results for metals in LLNL sanitary sewer effluent (in mg/L), 1998

Table 6-9. Monthly monitoring results for physical and chemical characteristics of the LLNL sanitary sewer effluent, 1998

Table 7-1. Analyses conducted on storm water samples, 1998

Table 7-2 Radioactivity (in Bq/L) in storm water runoff, Livermore site, 1998.

Table 7-3. Metal constituents above comparison criteria (see Table 7-1 of the Data Supplement) in storm water runoff, Livermore site, 1998

Table 7-4 Nonradioactive constituents above comparison criteria (see Table 7-1 of the Data Supplement) in storm water runoff, Livermore site, 1998

Table 7-5. Constituents above comparison criteria in storm water runoff, Site 300, 1998

Table 7-6. Tritium activities (in Bq/L) in rainfall for the LLNL Livermore site and the Livermore Valley.

Table 7-7. Summary of Drainage Retention Basin monitoring at sampling location CDBE exceeding management action levels 
Table 7-8. Annual mass loading for detected metals and organic compounds in samples collected from Drainage Retention Basin sampling location CDBX

Table 7-9. Summary data from compliance monitoring of Site 300 primary cooling towers, 1998.

Table 7-10. Summary data from operational monitoring of Site 300 primary cooling towers, 1998

Table 7-11 Radioactivity (in $\mathrm{Bq} / \mathrm{L}$ ) in surface and drinking water in the Livermore Valley, 1998

Table 8-1. Volatile organic compounds (VOCs) removed from ground water and soil at the Livermore site

Table 8-2. 1998 extraction wells and extraction rates

Table 8-3. Wells installed in 1998

Table 8-4. Major contaminants of concern found in soil, rock, and ground water at Site 300

Table 8-5. Volatile organic compounds (VOCs) removed from ground water and soil at Site 300

Table 8-6. General Services Area ground water treatment system surface discharge permit requirements

Table 9-1. Concentration ranges for three major anions in upgradient and downgradient monitoring wells

Table 9-2. Sewage pond monitoring results, location ESWP

Table 9-3. Wastewater effluent monitoring results, location ISWP

Table 10-1. Summary of soil and sediment analytical data, 1998

Table 10-2. Special soil studies

Table 11-1. Tritium in vegetation (in Bq/L), 1998

Table 11-2. Tritium in retail wine (in Bq/L), 1998

Table 12-1. Summary of dose calculations for gamma-monitoring locations at all sites in 1998 (in $\mathrm{mSv}$ ).

Table 12-2. Annual dose by year at the Livermore site perimeter due to direct gamma radiation

Table 13-1. Sources of radiation dose from LLNL releases (measured and potential) to air: stacks and other exhaust pathways from buildings containing radioactive materials management areas, and diffuse area sources

Table 13-2. Doses ( $\mu \mathrm{Sv}$ ) calculated for the site-wide maximally exposed individual for the Livermore site and Site 300, 1990 to 1998 


\section{List of Tables}

Table 13-3. Annual dose to the SW-MEI from explosives experiments on firing tables at Site 300, 1990-1998, related to the total quantity of depleted uranium used in the experiments and the total quantity of high explosives (HE) driving the detonations

Table 13-4. Major contributors to LLNL's radiation dose via airborne emissions, 1998

Table 13-5. Comparison of background (natural and man-made) and LLNL radiation doses, 1998

Table 14-1. Quality assurance duplicate sampling. Summary statistics for analytes with more than eight pairs in which both results were above the detection limit

Table 14-2. Quality assurance duplicate sampling. Summary statistics for analytes with eight or fewer pairs in which both results were above the detection limit

Table 14-3. Quality assurance duplicate sampling. Summary statistics for analytes with at east four pairs in which both results were below the detection limit

Table 14-4. Changes to environmental monitoring networks in 1998

Table 14-5. Sampling completeness in 1998, Livermore site and Site 300 


\section{Executive Summary}

Jennifer M. Larson

Robert J. Harrach

\section{Introduction}

Lawrence Livermore National Laboratory (LLNL), a U.S. Department of Energy (DOE) facility operated by the University of California, serves as a national resource of scientific, technical, and engineering capabilities. The Laboratory's mission focuses on nuclear weapons and national security, and over the years has been broadened to include areas such as strategic defense, energy, the environment, biomedicine, technology transfer, the economy, and education. The Laboratory carries out this mission in compliance with local, state, and federal environmental regulatory requirements. It does so with the support of the Environmental Protection Department, which is responsible for environmental monitoring and analysis, hazardous waste management, environmental restoration, and assisting Laboratory organizations in ensuring compliance with environmental laws and regulations.

LLNL comprises two sites: the Livermore site and Site 300. The Livermore site occupies an area of 3.28 square kilometers on the eastern edge of Livermore, California. Site 300, LLNL's experimental testing site, is located 24 kilometers to the east in the Altamont Hills, and occupies an area of 30.3 square kilometers. Environmental monitoring activities are conducted at both sites as well as in surrounding areas.

This summary provides an overview of LLNL's environmental activities in 1998, including radiological and nonradiological surveillance, effluent, and compliance monitoring, remediation, assessment of radiological releases and doses, and determination of the impact of LLNL operations on the environment and public health.

\section{Environmental Monitoring Results}

During 1998, the Environmental Protection Department sampled air, sewerable water, ground water, surface water, soil and sediment, and vegetation and foodstuff. Samples were analyzed for radioactive and nonradioactive substances using (1) standard methods approved by the U.S. Environmental Protection Agency (EPA), (2) special systems such as the continuous monitoring system for Livermore site sewage, or (3) special analytical techniques designed to measure very low levels of radionuclides. Environmental 


\section{Executive Summary}

radiation was also measured directly using dosimeters. Over 15,000 environmental samples were taken, and results were obtained for more than 244,000 analytes.

\section{Air Monitoring}

Air was monitored for various airborne radionuclides (including particles and tritiated water vapor) and beryllium at the Livermore site, Site 300, and off-site locations throughout the Livermore Valley and Tracy area. Concentrations of all monitored radionuclides and beryllium at all of these locations were well below levels that would endanger the environment or public health according to current regulatory standards. For example, in 1998, the highest median plutonium concentration for samples collected at any air monitoring station was $0.0021 \%$ of the federal Derived Concentration Guide (DCG). The DCG specifies the concentration of radionuclides in air or water that could be inhaled or ingested continuously 365 days a year without exceeding the DOE radiation protection standard for the public. Median concentrations of tritiated water vapor collected at Livermore Valley sampling locations showed a highest median value of $0.0007 \%$ of the DCG, while the highest median values on the Livermore site perimeter and within the site boundaries were, respectively, $0.005 \%$ and $0.5 \%$ of the DCG. The highest median concentrations of beryllium on the Livermore site and Site 300 were both $0.1 \%$ of the guideline level established by the Bay Area Air Quality Management District and the EPA and are representative of naturally occurring levels.

\section{Stack Air Effluent Monitoring}

In 1998, LLNL operated 101 samplers for measuring radioactivity in air effluent at eight facilities at the Livermore site. These samplers extract a measured volume of air from the exhaust stack of a facility or process and collect particles or vapor in a collection medium. Measured radiological air emissions from Livermore site operations remain well below levels of health and environmental concern. Building 331 emissions accounted for $72 \%$ of the estimated total tritium emissions from the site in 1998; emissions from this facility remain at a level far below those of the 1980s and cause public dose impacts far below levels allowed by regulatory standards. Radionuclide emissions from the other monitored facilities were very low.

Nonradioactive air emissions from exempt and permitted sources at LLNL were quite small and typical of values in previous years. For example, total emission of nitrogen oxides from the Livermore site in 1998 was about $56 \mathrm{~kg}$ /day, which is $0.006 \%$ of the quantity of this air pollutant released daily over the entire Bay Area; corresponding numbers for reactive organics were $25 \mathrm{~kg}$ / day and $0.02 \%$. The total emission of criteria 
air pollutants (nitrogen oxides, volatile organics, sulfur oxides, particulate matter, carbon monoxide, and lead) was approximately $100 \mathrm{~kg} /$ day for the Livermore site and about 25 times smaller for Site 300.

\section{Sewerable Water Monitoring}

Discharges of radioactive and hazardous material to the combined sanitary and industrial sewer at the Livermore site are controlled by use of administrative and engineering controls, including limiting the disposal of those materials, and routing some discharged material to retention tanks for later characterization and treatment. Flow-proportional and instantaneous samples of discharged wastewater are regularly collected and analyzed (for metals, radioactivity, toxic chemicals, and water-quality parameters) to assure that LLNL's sewage effluent meets the requirements of the permit granted by the City of Livermore. In addition, the site effluent is monitored continuously for $\mathrm{pH}$, regulated metals, and radioactivity. If concentrations are detected above warning levels, an alarm sounds and the effluent is automatically contained by LLNL's sewer diversion system. The diversion system captures all but the initial minutes of wastewater flow that causes an alarm, thereby protecting the Livermore Water Reclamation Plant (LWRP) and minimizing any required cleanup. With the 1998 addition of a new monitoring and diversion capability for $\mathrm{pH}$, even the initial minutes of a pH-related release are contained on site.

In 1998, the Livermore site discharged an average of 0.95 million liters per day of wastewater to the City of Livermore sewer system, an amount that constitutes $4.0 \%$ of the total flow to the system (about $14 \%$ of the Livermore site effluent was generated by Sandia National Laboratories/California). The Livermore site's sanitary sewer effluent is monitored continuously and sampled daily, weekly, and monthly to satisfy various permit compliance requirements.

LLNL achieved 100\% compliance during 1998 with LWRP permit limits covering discharges into the City of Livermore's and LLNL's sanitary sewer system. In 1998, no sewer releases exceeded discharge limits for radioactive materials.

\section{Surface Water Monitoring}

Surface water sampling and analysis are a large part of the LLNL surveillance and compliance monitoring effort for the Livermore site, Site 300, and their surrounding regions. The waters monitored include storm water (runoff water), rainfall, water in the Livermore site Drainage Retention Basin, wastewater discharges from cooling towers at 


\section{Executive Summary}

Site 300, and a variety of other waters that include reservoirs and ponds, drinking water taps both on and off site, and the Livermore site swimming pool.

To evaluate the overall impact of LLNL operations on storm water quality, storm water is sampled where it enters and where it leaves the site. In the 1997/1998 rainy season, tritium was found to be higher in effluent water than in influent water. The maximum tritium activity in all storm water was still only $4 \%$ of the amount of tritium California allows in drinking water (referred to as the maximum contaminant level or MCL). In addition, maximum gross alpha and gross beta activities in storm water were $68 \%$ and $17 \%$ of their respective MCLs. Although aluminum, iron, lead, manganese, and zinc were also found to be higher in effluent than influent storm water and above criteria set by either EPA or the Regional Water Quality Control Board, fish toxicity tests conducted in 1997 for the $1997 / 1998$ wet season indicated that LLNL storm water runoff had no adverse impact on off-site biota.

The highest tritium activity measured in rainwater was $23 \%$ of the tritium MCL, and the highest tritium activity measured in surface water bodies was $1 \%$ of the tritium MCL. In drinking water sources, the highest tritium activity measured was $0.03 \%$ of the MCL. A person drinking 2 liters of water per day for a year at the highest level measured in drinking water would receive $0.06 \%$ of the DOE standard allowable dose of 0.04 millisieverts ( 4 millirems) for drinking water systems. The sampling data indicated that operations at the Livermore site had a negligible impact on surface and drinking waters.

\section{Ground Water Monitoring}

Ground water in the Livermore Valley and the Altamont Hills is monitored to assess the progress of remediation efforts in areas of known contamination, to test the impact of LLNL operations on local water sources, and to comply with numerous federal, state, and local permits. Ground water samples are routinely measured for tritium, uranium, and other radioisotopes; gross radioactivity; toxic metals; a wide range of organic chemicals; and other general contaminant indicators. Special consideration is given to monitoring those dissolved elements and organic compounds that are known to be toxic in trace amounts.

The impact of Livermore site and Site 300 operations on off-site ground water continued to be minimal in 1998. In the Livermore Valley, no monitored radioactive or inorganic nonradioactive constituent was found to exceed primary drinking water MCLs in any off-site well. In on-site wells, chromium and nitrates have been detected above the primary MCL, but these constituents have not migrated off site. The maximum tritium 
activity detected in any sample of ground water measured in the Livermore Valley was $1.5 \%$ of the MCL, as measured at an on-site location. At Site 300 , tritiated water and depleted uranium have been released to ground water from landfills and firing tables, but the boundaries of the slowly-moving ground water plumes lie entirely within site boundaries. The shallow ground water beneath Site 300 contains volatile organic compounds (VOCs), tritium, nitrates, Freon, and depleted uranium, but presents no current health risks because this contaminated water is not used as a potable domestic, livestock, or industrial water supply and presents no other pathways to environmental receptors. LLNL works with the regulatory agencies to contain or cleanup ground water contamination, where needed.

\section{Soil and Sediment Monitoring}

The impact of Laboratory operations on soil and sediment at the Livermore site in 1998 was insignificant and unchanged from previous years. The highest level of plutonium (isotopes 239 and 240), measured at the LWRP, represented 1.6\% of the EPA preliminary remediation goal for commercial or industrial sites. Other constituents of concern were measured at background or trace concentrations or were below the limit of detection. At Site 300, the concentrations of radionuclides and beryllium in soil samples were generally representative of background or naturally occurring levels, as in previous years. Elevated concentrations of uranium-238 found in Site 300 soils in 1998 were attributed to contamination by debris from firing-table experiments.

Sampling of soil below the surface but above the water table (vadose zone), which was carried out as part of the Livermore Ground Water Management Program, showed that ground water on the Livermore site is not being affected by contaminants carried in storm water.

Soil was sampled at Big Trees Park in Livermore during August and September of 1998 to provide information about the vertical and lateral distribution of plutonium in the soil, the pathway by which plutonium got to the park, and distribution of plutonium in areas of public concern. All sample results indicated that plutonium concentrations were below the risk-based preliminary remediation goal for residential areas. Pathway analysis indicates that plutonium most likely reached the park in the sewage sludge that was used as soil amendment. The EPA, the California Department of Health Services, and the Agency for Toxic Substances and Disease Registry all concurred that there was no unacceptable risk to human health or the environment from the levels of plutonium present at Big Trees Park. 


\section{Vegetation and Foodstuff Monitoring}

LLNL impacts on vegetation and food in the Livermore Valley remained minimal in 1998. Tritium, which is the radionuclide of most interest in the vegetation and foodstuff monitoring program, was estimated to be well below levels of concern, even when organically bound tritium was taken into account. In 1998, as in the past, tritium concentrations in Livermore Valley wines were slightly above those for wines tested from Europe and other locations in California, but the tritium levels were quite low. Mean levels for the 1998 sampling year, using data from all areas, were not significantly different from those reported for the past several sampling years. Even the highest detected tritium value represented only $1.1 \%$ of the amount of tritium California allows in drinking water (no health standards exist for radionuclides in wine).

\section{Radiological Dose Assessment}

Radiological dose-assessment modeling-using conservative EPA-mandated computer models, actual LLNL meteorology, population distributions appropriate to the two sites, and 1998 radionuclide usage inventory and monitoring data-was conducted this past year for key facilities. Emissions from more than 200 points were reported in 1998. These sources were of several types: stacks and other exhaust pathways from buildings, diffuse area sources generally external to buildings, and open-air firing tables at Site 300 where explosives experiments were conducted.

LLNL reports public doses resulting from air releases of radionuclides during routine operations and from accidents. The principal exposure pathways taken into account are internal exposures from inhalation of air and ingestion of foodstuff and drinking water contaminated by the air releases. Releases of radioactivity from LLNL via water do not directly contribute to the public dose, because this water is not used as a potable domestic or industrial water supply or for agriculture.

The most significant radiological effluent for the Livermore site from the standpoint of public dose continues to be tritium, the radioactive isotope of hydrogen. The calculated total potential dose for the sitewide maximally exposed individual (SW-MEI), (i.e., a hypothetical member of the public having the greatest possible exposure from Livermore site operations in 1998) was 0.49 microsievert (0.049 millirem). This is about half of last year's total, reflecting decreased emissions from the stacks of the Tritium Facility. This result was calculated based on LLNL's standard assumptions regarding potential public dose caused by tritium releases from these stacks. In 1998, the EPA mandated that LLNL's compliance evaluations use a more conservative assumption, in which gaseous tritium is to be treated as though it were tritiated water vapor. This resulted in a $12 \%$ higher dose or 0.55 microsievert ( 0.055 millirem) to the 
SW-MEI. Trends in this SW-MEI dose for the Livermore site over the last seven years show levels in the range 1.0 to 0.4 microsievert/y ( 0.1 to 0.04 millirem/y), down from 2.40 microsievert/y (0.24 millirem/y) in 1990. These small radiation quantities exhibit large percentage but small absolute value fluctuations from year to year.

At Site 300, depleted uranium (containing isotopes with atomic weights 238, 235, and 234) remains by far the principal contributor to off-site dose. The calculated total potential dose to a hypothetical public individual having the greatest possible exposure at Site 300 during 1998 was 0.24 microsievert (0.024 millirem), which is slightly higher than in 1997 but still well within the range of concentrations measured over the past nine years.

Conservatively calculated radiological doses to the maximally exposed public individuals from Livermore site and Site 300 emissions amounted to about $0.49 \%(0.55 \%$ using EPA assumptions) and 0.24\%, respectively, of the EPA National Emission Standards for Hazardous Air Pollutants (NESHAPs) regulatory standard. These doses are a small fraction (about 1/6000) of the doses received by these populations from natural background radiation. Thus, the potential radiological doses from LLNL operations in 1998 were well within regulatory limits and were very small compared to doses from natural background radiation sources.

\section{Environmental Compliance and Program Activities}

LLNL works to ensure that its operations comply with all environmental laws and federal, state, and local regulatory guidelines. Many activities related to water, air, waste, waste reduction, community "right to know," and other environmental issues were addressed in 1998.

\section{Ground Water Remediation}

As a Superfund site, LLNL continued to treat ground water at both the Livermore site and Site 300 under the jurisdiction of the Comprehensive Environmental Response, Compensation and Liability Act. LLNL's primary treatment method to remediate contaminated ground water is pump-and-treat technology. In 1998, nearly 150 kilograms of VOCs plus smaller quantities of dissolved fuel hydrocarbons were removed from almost a billion liters of ground water and 140,000 cubic meters of water vapor from soil at the Livermore site. These efforts at control and remediation have reduced VOC concentrations throughout the site, stopped the off-site westward migration of VOC plumes from the Livermore site, and reduced plume sizes. 


\section{Executive Summary}

Significant progress occurred in the TF5475 area, where both tritium and VOCs are present in the same hydrostratigraphic unit. TF5475-1 was activated in 1998 to treat VOCs in ground water while keeping the tritium in the subsurface layer. TF5475-1 uses down-hole, in situ catalytic reductive dehalogenation to treat VOCs in ground water. A mathematical model of the T5475 area was developed to evaluate potential extraction and injection well configurations to improve overall remediation performance.

Significant progress was also made at Site 300, where 22 kilograms of VOCs were removed from soil and ground water in four treatment areas. In the Eastern General Services Area, the plume of high trichloroethene concentrations was reduced by $1400 \mathrm{~m}$ and now extends only $30 \mathrm{~m}$ beyond the site boundary.

Treated ground water discharges and VOCs vented to air all were within permit limits during 1998.

\section{Waste Minimization and Pollution Prevention}

LLNL continued to employ a weighted ranking system to prioritize and evaluate its waste streams. Cost, type of waste, and operational aspects were emphasized rather than simple considerations of total waste volume. Transuranic and transuranic-mixed and low-level wastes continued to be of highest priority for LLNL, even though their relative quantities were low.

Comparing 1998 to the 1993 baseline, levels of waste in three of the four categoriesradioactive, hazardous, and sanitary-continued to decrease. However, in 1998, levels of mixed waste did not diminish because increased quantities of low-level mixed waste were processed with the result that increased quantities of solid, low-level mixed waste were produced. The total waste diverted from landfills in 1998 was more than 30,000 tons, significantly less than the diversion total for 1997, but comparable to the 1996 total. The high quantities of waste diverted in 1997 predominantly resulted from the reuse of large quantities of soil from the construction of the National Ignition Facility. LLNL's recycling percentage for nonhazardous waste was $87 \%$ in 1998, far in excess of the DOE's stated 1999 goal of 33\%.

ChemTrack, LLNL's computerized chemical inventory system, tracked 178,000 chemicals in 1998 through the use of bar codes, hand-held bar code laser scanners, and customized software. 


\section{Air, Wastewater, and Water Compliance}

LLNL continued to perform all activities necessary to comply with clean air and clean water requirements. In 1998, the Bay Area Air Quality Management District issued or renewed 138 operating permits for the Livermore site. The San Joaquin Valley Unified Air Pollution Control District issued or renewed 47 permits for Site 300 operations. LLNL has permits for underground and aboveground storage tanks and for discharge of treated ground water, industrial and sanitary sewage, and storm water. Site 300 has additional permits for inactive landfills, cooling tower discharges, operation of the sewer lagoon, septic tanks, and leach fields. The Laboratory complies with all requirements for self-monitoring and inspections associated with these permits.

\section{Environmental Occurrences}

Notification of environmental occurrences at the Laboratory is required under a number of environmental laws, regulations, and DOE orders. LLNL responded to five incidents that required federal and/or state agency notification during 1998. None of these caused adverse impact to human health or the environment.

\section{Endangered Species}

LLNL meets the requirements of both the U.S. Endangered Species Act and the California Endangered Species Act as they pertain to endangered or threatened species and other species of special concern that may exist or are known to exist at the LLNL sites. In 1998, biological assessment surveys were performed for special-status species at 51 LLNL project construction (ground disturbance) areas. Although no active San Joaquin kit fox dens were discovered, four occupied American badger dens were found. In addition, 12 active burrowing owl dens and a population of the federal candidate species California tiger salamander (Ambystoma tigrinum) were discovered at Site 300. A new population of the federally threatened red-legged frog (Rana aurora draytonii) was identified in the northwestern portion of Arroyo Las Positas on the Livermore site. Measures to mitigate the potential for future impacts to the frogs were developed in conjunction with the U.S. Fish and Wildlife Service. Also at the Livermore site, six separate pairs of white-tailed kites (Elanus lecurus), a state-protected raptor, successfully nested and fledged 14 young.

Two of the three known natural populations of the large-flowered fiddleneck (Amsinckia grandiflora), a federally listed endangered plant species, occur at Site 300, where a portion of the site has been designated as critical habitat for the plant. In spite of 


\section{Executive Summary}

attempts to reduce exotic ground cover with herbicides, the number of native plants dropped by $42 \%$ in 1998 . Investigations into the use of herbicides, controlled burns, and native bunch grass transplantation to reduce the amount of exotic grass cover are currently underway.

Monitoring of the big tarplant (Blepharazonia plumosa), a California Native Plant Society "rare" plant), and the Diamond-petaled poppy (Eschscholzia rhombipetala), a plant not seen in California since 1950) continued in 1998. The big tarplant continued to be widespread throughout Site 300. A total of 26 diamond-petaled poppy plants were located; of these, 18 plants produced seed-bearing pods.

\section{Conclusion}

The current techniques used at LLNL for environmental monitoring are very sensitive, allowing detection of extremely low levels of constituents. The combination of surveillance and effluent monitoring, source characterization, and computer modeling show that radiological doses to the public caused by LLNL operations are less than $1.0 \%$ of regulatory standards and are about 6000 times smaller than the doses received from background radiation. The analytical results and evaluations generally show continuing low contaminant levels, reflecting both decreased operations and the responsiveness of the Laboratory in controlling pollutants.

In 1998, LLNL successfully engaged in environmental compliance activities related to water, air, waste, and waste reduction. Ground water remediation activities stopped the westward migration of plumes at the Livermore site, waste minimization efforts reduced the amount of waste generated in LLNL operations, and recycling efforts diminished the quantity of waste sent to landfills. Actions to protect endangered species at both LLNL sites continued on several fronts.

In summary, the results of the 1998 environmental programs demonstrate that LLNL is committed to protecting the environment and ensuring that its operations are conducted in accordance with applicable federal, state, and local laws and regulations. The environmental impacts of LLNL operations are minimal and pose no threat to the public or the environment. 


\section{Site Overview}

\section{Introduction}

Meteorology and geography play primary roles in how the environment is affected by human actions. Dispersal of particles in air, for example, is influenced by the wind and rain, which in turn are influenced by geographical characteristics. Similarly, the movement of ground water is constrained by the particular geology of a site. Thus, knowledge of wind, rainfall, geology, and geographical characteristics is used to model the effects that operations at Lawrence Livermore National Laboratory might have on the surrounding environment. Some history and a description of these characteristics help us understand the importance of the Laboratory's meteorological and geographic setting.

\section{Operations}

The mission of LLNL is to serve as a national resource in science and engineering, with a special responsibility for nuclear weapons. Laboratory activities focus on global security, energy, global ecology, biomedicine, economic competitiveness, and science and mathematics education. The Laboratory's mission is dynamic and has broadened over the years to meet new national needs.

LLNL is a full-service research laboratory with the infrastructure-engineering, maintenance, and waste management activities, as well as security, fire, and medical departments—necessary to support its operations and about 8500 personnel.

\section{Location}

LLNL consists of two sites-the main laboratory site located in Livermore, California (Livermore site) in Alameda County, and the Experimental Test Site (Site 300) located near Tracy, California, in San Joaquin and Alameda counties (Figure 1-1). Each site is unique, requiring a different approach for environmental monitoring and protection. 


\section{Site Overview}

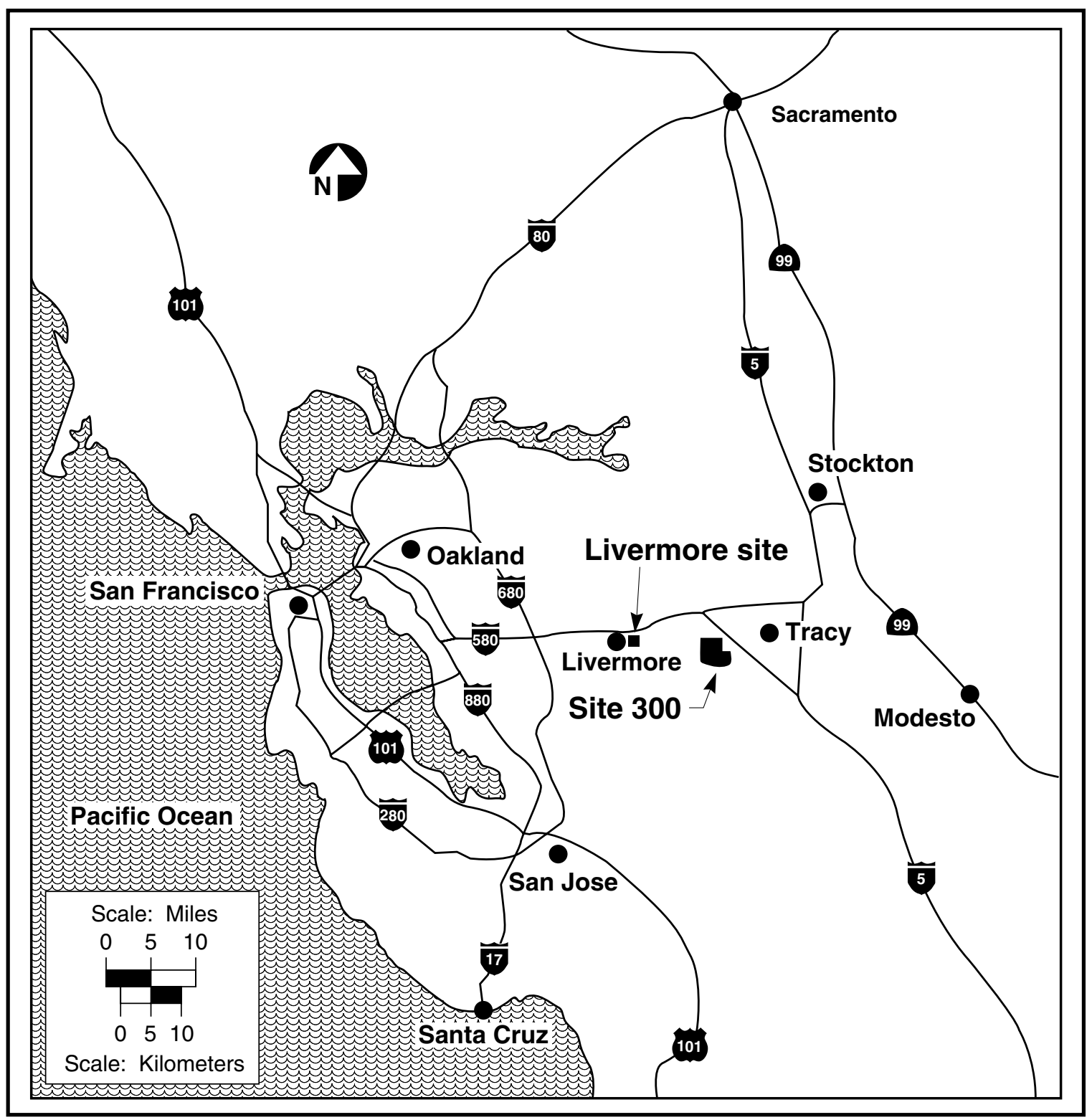

Figure 1-1. Locations of LLNL Livermore site and Site 300.

LLNL was founded at the Livermore site in 1952 at a former U.S. Navy training base. At that time the location was relatively isolated, being approximately $1.6 \mathrm{~km}$ from the Livermore city limits. Over time, Livermore evolved from a small town of fewer than 7000 people when the Laboratory began to its present population of about 70,900. The economy, which had been primarily agricultural, diversified to include light industry and business parks. Within the last few years, low-density, single-family 
residential developments have begun to fill the formerly vacant fields. Livermore residences are now near LLNL's western boundary.

LLNL's Livermore site occupies an area of $3.28 \mathrm{~km}^{2}$, including the land that serves as a buffer zone around the site. Immediately to the south is Sandia National Laboratories / California (Sandia/California) operated by Lockheed-Martin under Department of Energy (DOE) contract. Sandia/California engages in research and development associated with nuclear weapons systems engineering as well as related national security tasks. Although their primary missions are similar, LLNL and Sandia/ California are separate entities, each with its own management and each reporting to a different DOE operations office.

To the south of LLNL, there are also some low-density residential areas and agricultural areas devoted to grazing, orchards, and vineyards. A business park lies to the southwest. Farther south, property is primarily open space and ranchettes, with some agricultural use. High-density residential development lies to the west. A very small amount of low-density residential development lies to the east of the Livermore site, and agricultural land extends to the foothills that define the eastern margin of the Livermore Valley. A business park is located to the north, and a 200-hectare parcel of open space to the northeast has been rezoned to allow development of light industry.

Site 300, LLNL's Experimental Test Facility, is located $20 \mathrm{~km}$ east of the Livermore site in San Joaquin and Alameda counties in the Altamont Hills of the Diablo Range; it occupies an area of $30.3 \mathrm{~km}^{2}$. It is in close proximity to two other testing sites:

PRIMEX/Physics International operates a testing site that is adjacent and to the east of Site 300, and SRI International operates another site, located approximately $1 \mathrm{~km}$ south of Site 300. The Carnegie State Vehicular Recreation Area is located south of the western portion of Site 300, and wind turbine generators line the hills to the northwest. The remainder of the surrounding area is in agricultural use, primarily as grazing land for cattle and sheep. The nearest residential area is the town of Tracy (population 50,300), located $10 \mathrm{~km}$ to the northeast.

\section{Meteorology}

Meteorological data (including wind speed, wind direction, rainfall, relative humidity, solar radiation, and air temperature) are continuously gathered at both the Livermore site and Site 300. Mild, rainy winters and warm, dry summers characterize the climate of the Livermore Valley. A detailed review of the climatology for LLNL can be found in Climatology of Lawrence Livermore National Laboratory (Gouveia and Chapman 1989). The 


\section{Site Overview}

mean annual temperature for both sites in 1998 was $15^{\circ} \mathrm{C}$. Temperatures range from $-5^{\circ} \mathrm{C}$ during some predawn winter mornings to $40^{\circ} \mathrm{C}$ during some summer afternoons.

Both rainfall and wind exhibit strong seasonal patterns. Annual wind data for the Livermore site are given in Figure 1-2 and Table 1-1. These data show that greater than $50 \%$ of the wind comes from the south-southwest to westerly direction.

These wind patterns tend to be dominated by the thermal draw of the warm San Joaquin Valley that results in wind blowing from the cool ocean toward the warm valley, increasing in intensity as the valley heats up. The wind blows from the northeast primarily during the winter storm season. Most precipitation occurs between October and April, with very little rainfall during the warmer months. The highest and lowest annual rainfalls on record are 812 and $122 \mathrm{~mm}$. The average annual rainfall is $368 \mathrm{~mm}$. In 1998, the Livermore site received $522 \mathrm{~mm}$ of rain.

The meteorological conditions at Site 300, while generally similar to the Livermore site, are modified by higher elevation and more pronounced topological relief. The complex topography of the site significantly influences local wind and temperature patterns. Annual wind data are presented in Figure 1-3 and Table 1-2. The data show that winds are more consistently from the west-southwest and reach greater speeds than the Livermore site. The increased wind speed and elevation of much of Site 300 result in afternoon temperatures that are typically lower than those for the Livermore site. Rainfall for 1998 was $475 \mathrm{~mm}$ at Site 300.

\section{Topography}

The Livermore site is located in the southeastern portion of the Livermore Valley, a topographic and structural depression oriented east-west within the Diablo Range of the California Coast Range Province. The Livermore Valley, the most prominent valley in the Diablo Range, is an east-west trending structural and topographic trough that is bounded on the west by Pleasanton Ridge and on the east by the Altamont Hills. The valley floor is covered by alluvial, lake, and swamp deposits consisting of gravels, sands, silts, and clays, at an average thickness of about $100 \mathrm{~m}$. The valley is approximately 25-km long and averages $11 \mathrm{~km}$ in width. The valley floor is at its highest elevation of $220 \mathrm{~m}$ above sea level along the eastern margin and gradually dips to $92 \mathrm{~m}$ at the southwest corner. The major streams passing through the Livermore Valley are Arroyo del Valle and Arroyo Mocho, which drain the southern highlands and flow intermittently. Major arroyos are depicted in Chapter 7 (Figure 7-1). 


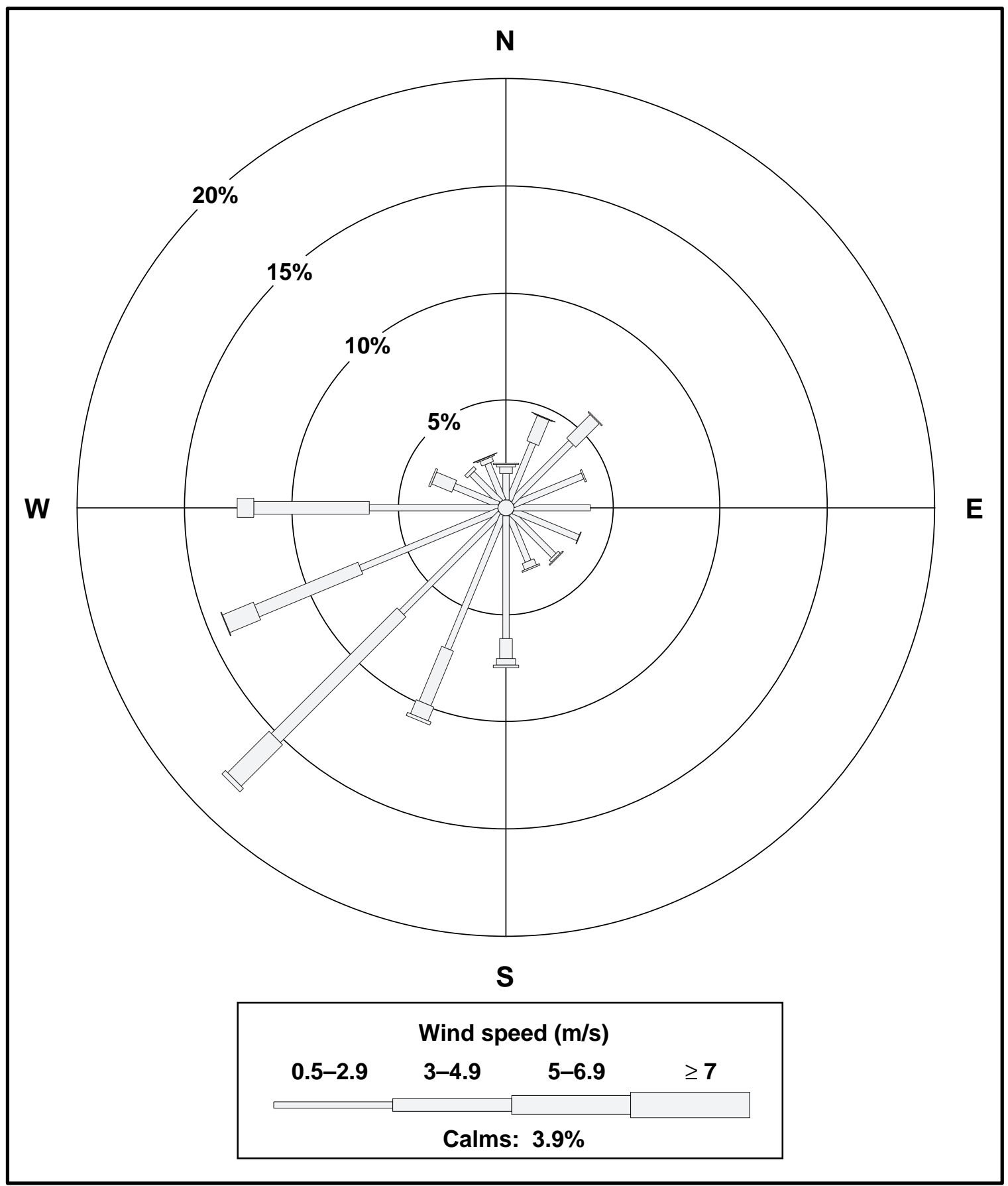

Figure 1-2. Wind rose showing the frequency of occurrence for wind speed and direction at the Livermore site, 1998. 


\section{Site Overview}

Table 1-1. Wind rose data for LLNL's Livermore site at the 10-m level for 1998. Values are frequency of occurrence (in percent). Columns and rows may not exactly sum to the listed totals due to rounding.

\begin{tabular}{|l|c|c|c|c|c|c|}
\hline \multirow{2}{*}{ Direction } & \multicolumn{7}{|c|}{ Wind speed range (m/s) } \\
\cline { 2 - 7 } NNE & $\mathbf{0 . 0 - 0 . 4}$ & $\mathbf{0 . 5 - 2 . 9}$ & $\mathbf{3 . 0 - 4 . 9}$ & $\mathbf{5 . 0 - 6 . 9}$ & $\geq \mathbf{7 . 0}$ & Total \\
NE & 0.24 & 2.89 & 1.27 & 0.03 & 0.00 & 4.4 \\
ENE & 0.24 & 3.92 & 1.55 & 0.05 & 0.00 & 5.8 \\
E & 0.24 & 3.49 & 0.07 & 0.00 & 0.00 & 3.8 \\
ESE & 0.24 & 3.55 & 0.00 & 0.00 & 0.00 & 3.8 \\
SE & 0.24 & 3.27 & 0.03 & 0.00 & 0.00 & 3.5 \\
SSE & 0.24 & 2.78 & 0.13 & 0.06 & 0.00 & 3.2 \\
S & 0.24 & 2.32 & 0.31 & 0.07 & 0.00 & 2.9 \\
SSW & 0.24 & 5.72 & 0.93 & 0.30 & 0.12 & 7.3 \\
SW & 0.24 & 6.73 & 2.75 & 0.70 & 0.15 & 10.6 \\
WSW & 0.24 & 6.51 & 8.27 & 2.73 & 0.23 & 18.0 \\
W & 0.24 & 6.97 & 5.21 & 1.55 & 0.03 & 14.0 \\
WNW & 0.24 & 5.99 & 5.38 & 0.77 & 0.00 & 12.4 \\
NW & 0.24 & 2.24 & 1.01 & 0.09 & 0.00 & 3.6 \\
NNW & 0.24 & 1.88 & 0.17 & 0.00 & 0.00 & 2.3 \\
N & 0.24 & 1.85 & 0.23 & 0.06 & 0.02 & 2.4 \\
\hline Total & 0.24 & 1.22 & 0.31 & 0.12 & 0.05 & 1.9 \\
\hline
\end{tabular}

The topography of Site 300 is much more irregular than that of the Livermore site; a series of steep hills and ridges is oriented along a generally northwest-southeast trend and is separated by intervening ravines. The Altamont Hills, where Site 300 is located, are part of the California Coast Range Province and separate the Livermore Valley to the west from the San Joaquin Valley to the east. The elevation ranges from approximately $538 \mathrm{~m}$ above sea level at the northwestern corner of the site to approximately $150 \mathrm{~m}$ in the southeast portion. 


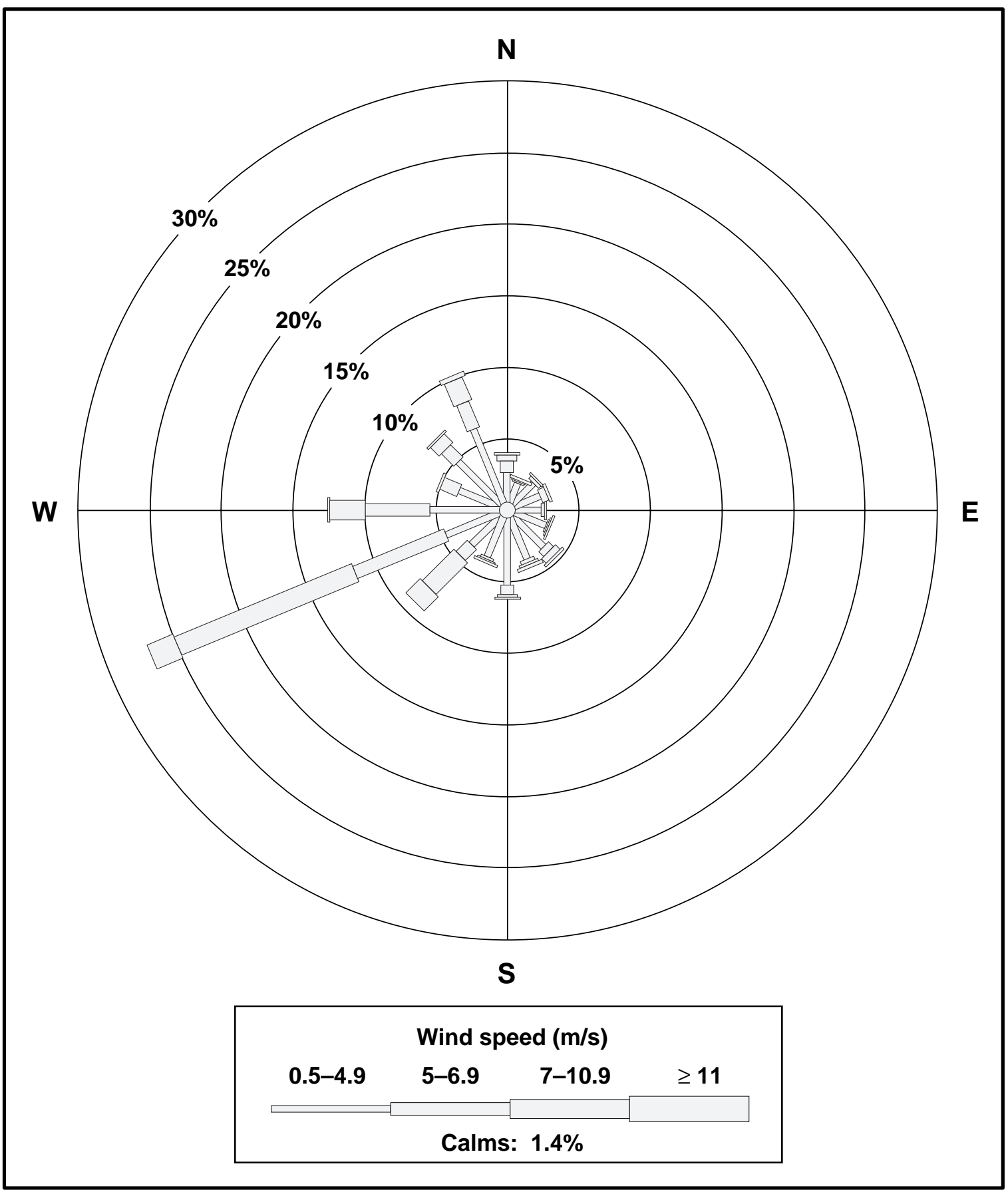

Figure 1-3. Wind rose showing the frequency of occurrence for wind speed and direction at Site 300, 1998. 


\section{Site Overview}

Table 1-2. Wind rose data for LLNL's Site 300 at the 10-m level for 1998. Values are frequency of occurrence (in percent). Columns and rows may not exactly sum to the listed totals due to rounding.

\begin{tabular}{|l|c|c|c|c|c|c|}
\hline \multirow{2}{*}{ Direction } & \multicolumn{7}{|c|}{ Wind speed range (m/s) } \\
\cline { 2 - 7 } NNE & $\mathbf{0 . 0 - 0 . 4}$ & $\mathbf{0 . 5 - 4 . 9}$ & $\mathbf{5 . 0 - 6 . 9}$ & $\mathbf{7 . 0 - 1 0 . 9}$ & $\geq \mathbf{1 1 . 0}$ & Total \\
NE & 0.09 & 1.55 & 0.15 & 0.03 & 0.07 & 1.9 \\
ENE & 0.09 & 2.10 & 0.31 & 0.00 & 0.00 & 2.5 \\
E & 0.09 & 1.99 & 0.51 & 0.08 & 0.00 & 2.7 \\
ESE & 0.09 & 1.87 & 0.25 & 0.02 & 0.00 & 2.2 \\
SE & 0.09 & 2.41 & 0.15 & 0.08 & 0.00 & 2.7 \\
SSE & 0.09 & 3.10 & 0.48 & 0.49 & 0.06 & 4.2 \\
S & 0.09 & 3.11 & 0.26 & 0.23 & 0.15 & 3.8 \\
SSW & 0.09 & 4.68 & 0.64 & 0.22 & 0.06 & 5.7 \\
SW & 0.09 & 2.98 & 0.18 & 0.11 & 0.07 & 3.4 \\
WSW & 0.09 & 2.89 & 1.11 & 3.11 & 1.36 & 8.6 \\
W & 0.09 & 4.01 & 6.86 & 13.35 & 1.93 & 26.2 \\
WNW & 0.09 & 4.80 & 4.48 & 2.52 & 0.05 & 11.9 \\
NW & 0.09 & 3.07 & 1.28 & 0.11 & 0.00 & 4.6 \\
NNW & 0.09 & 4.24 & 1.21 & 0.89 & 0.03 & 6.5 \\
N & 0.09 & 5.57 & 1.94 & 1.72 & 0.27 & 9.6 \\
\hline Total & 0.09 & 2.11 & 0.78 & 0.43 & 0.07 & 3.5 \\
\hline
\end{tabular}

\section{Hydrogeology}

\section{Livermore Site}

The hydrogeology and movement of ground water in the vicinity of the Livermore site have been the subjects of several investigations (Stone and Ruggieri 1983; Carpenter et al. 1984; Webster-Scholten and Hall 1988; and Thorpe et al. 1990). This section has been summarized from the reports of these investigations and from data supplied by Alameda County Flood Control and Water Conservation District Zone 7, the agency responsible for ground water management in the Livermore Valley basin (San Francisco Bay Regional Water Quality Control Board [RWQCB] 1982a and b).

The Livermore Formation (and overlying alluvial deposits) contains the aquifers of the Livermore Valley ground water basin, an important water-bearing formation. Natural recharge occurs primarily along the fringes of the basin and through the arroyos during 
periods of winter flow. Artificial recharge, if needed to maintain ground water levels, is accomplished by releasing water from Lake Del Valle or from the South Bay Aqueduct into arroyo channels in the east. Ground water flow in the valley generally moves toward the central east-west axis of the valley and then westward through the central basin. Ground water flow in the basin is primarily horizontal, although a significant vertical component probably exists in fringe areas, under localized sources of recharge, and in the vicinity of heavily used extraction (production) wells.

Beneath the Livermore site, the water table varies in depth from the surface from about 10 to $40 \mathrm{~m}$. Figure 1-4 shows a contour map of water table elevations (meters above mean sea level) for the Livermore site area. Although water table elevations vary slightly with seasonal and year-to-year differences in both natural and artificial recharge, the qualitative patterns shown in Figure 1-4 are generally maintained. At the eastern edge of the Livermore site, ground water gradients (change in vertical elevation per unit of horizontal distance) are relatively steep, but under most of the site and farther to the west, the contours flatten to a gradient of approximately 0.003 .

Ground water flow under most of the site is southwesterly. This flow direction diverges from the generally westward regional flow and from flow patterns demonstrated for the site in the 1980s. This shift in flow direction is a consequence of ground water recovery and remediation in the southwest portion of the site and agricultural pumping. Aquifer tests on monitoring wells in the vicinity of the Livermore site indicate that the hydraulic conductivity (a measure of the rate of flow) of the permeable sediments ranges from 1 to $16 \mathrm{~m} /$ day (Isherwood et al. 1991). This, in combination with the observed water table gradients, yields an estimated average ground water velocity of $20 \mathrm{~m} / \mathrm{y}$ (Thorpe et al. 1990). The range in these values reflects the heterogeneity typical of the more permeable alluvial sediments that underlie the area.

\section{Site 300}

Gently dipping sedimentary bedrock dissected by steep ravines generally underlies Site 300. The bedrock is made up primarily of interbedded sandstone, siltstone, and claystone. Most ground water occurs in the Neroly Formation upper and lower blue sandstone aquifers. Significant ground water is also locally present in permeable Quaternary alluvium valley fill. Much less ground water is present within perched aquifers in the unnamed Pliocene nonmarine unit. Perched aquifers contain unconfined water separated from an underlying main body of water by impermeable layers; 


\section{Site Overview}

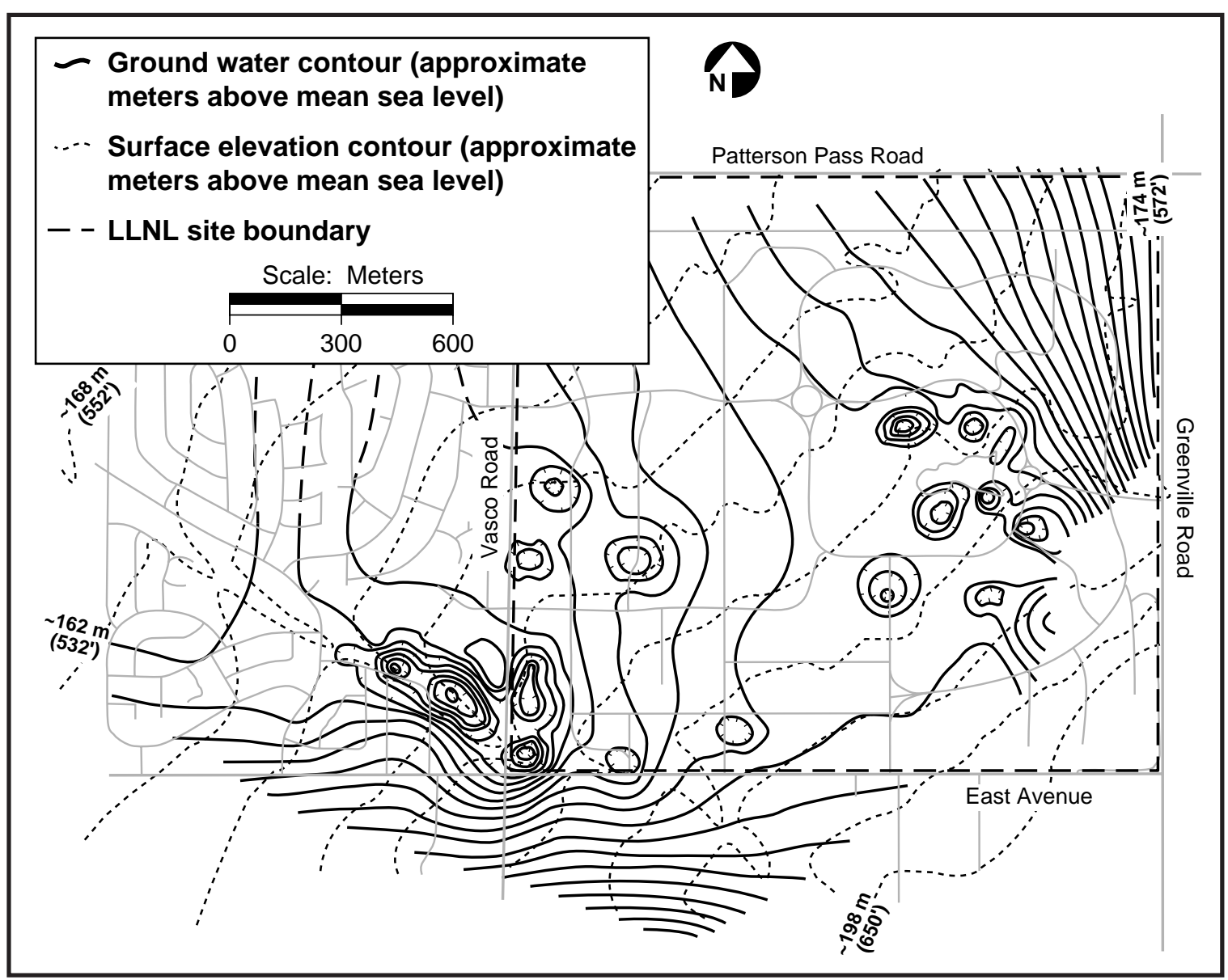

Figure 1-4. 1998 approximate ground water and surface elevation contours, Livermore site and vicinity.

normally they are discontinuous and highly localized. Because water quality generally is poor and yields are low, these perched water-bearing zones do not meet the State of California criteria for aquifers that are potential water supplies.

Fine-grained siltstone and claystone interbeds may confine the ground water and act as aquitards, confining layers, or perching horizons. Ground water is present under confined conditions in parts of the deeper bedrock aquifers but is generally unconfined elsewhere.

Ground water flow in most aquifers follows the attitude of the bedrock. In the northwest part of Site 300, ground water in bedrock generally flows northeast except where it is locally influenced by the geometry of alluvium-filled ravines. In the southern half of Site 300, ground water in bedrock flows roughly south-southeast, approximately coincident with the attitude of bedrock strata. 
The thick Neroly lower blue sandstone, stratigraphically near the base of the formation, generally contains confined water. Wells located in the western part of the General Services Area (GSA) (see Figure 8-8) are completed in this aquifer and are used to supply drinking and process water.

Figure 1-5 shows the elevation contours for water in the regional aquifer at Site 300. This map of the piezometric surface (the elevation to which water rises in a well that penetrates a confined or unconfined aquifer) is based primarily on water levels in the Neroly lower blue sandstone aquifer.

Recharge occurs predominantly in locations where saturated alluvial valley fill is in contact with underlying permeable bedrock or where permeable bedrock strata crop out because of structure or topography. Local recharge also occurs on hilltops, creating some perched water-bearing zones. Low rainfall, high evapotranspiration, steep topography, and intervening aquitards generally preclude direct vertical recharge of the bedrock aquifers.

Further information on the hydrology of both the Livermore site and Site 300 can be found in the ground water protection information in Chapters 8 and 9.

\section{Summary}

LLNL recognizes the importance of our geology, hydrogeology, climate, and geographical relationships with our neighbors in assessing potential impacts of operations at the Livermore site and Site 300. Each year we gain additional information that allows us to better predict, interpret, and avoid potential impacts. Each environmental medium that is discussed in this document-air, soil, water, vegetation, and foodstuffmay be affected differently. The environmental scientists at LLNL take into account the unique locations of the Livermore site and Site 300 to tailor sampling and analysis programs for each method used to monitor the environment.

We acknowledge the work of Frank Gouveia, Michael Taffet, Richard Blake, William Hoppes, and Janice Butler in preparing this chapter. 


\section{Site Overview}

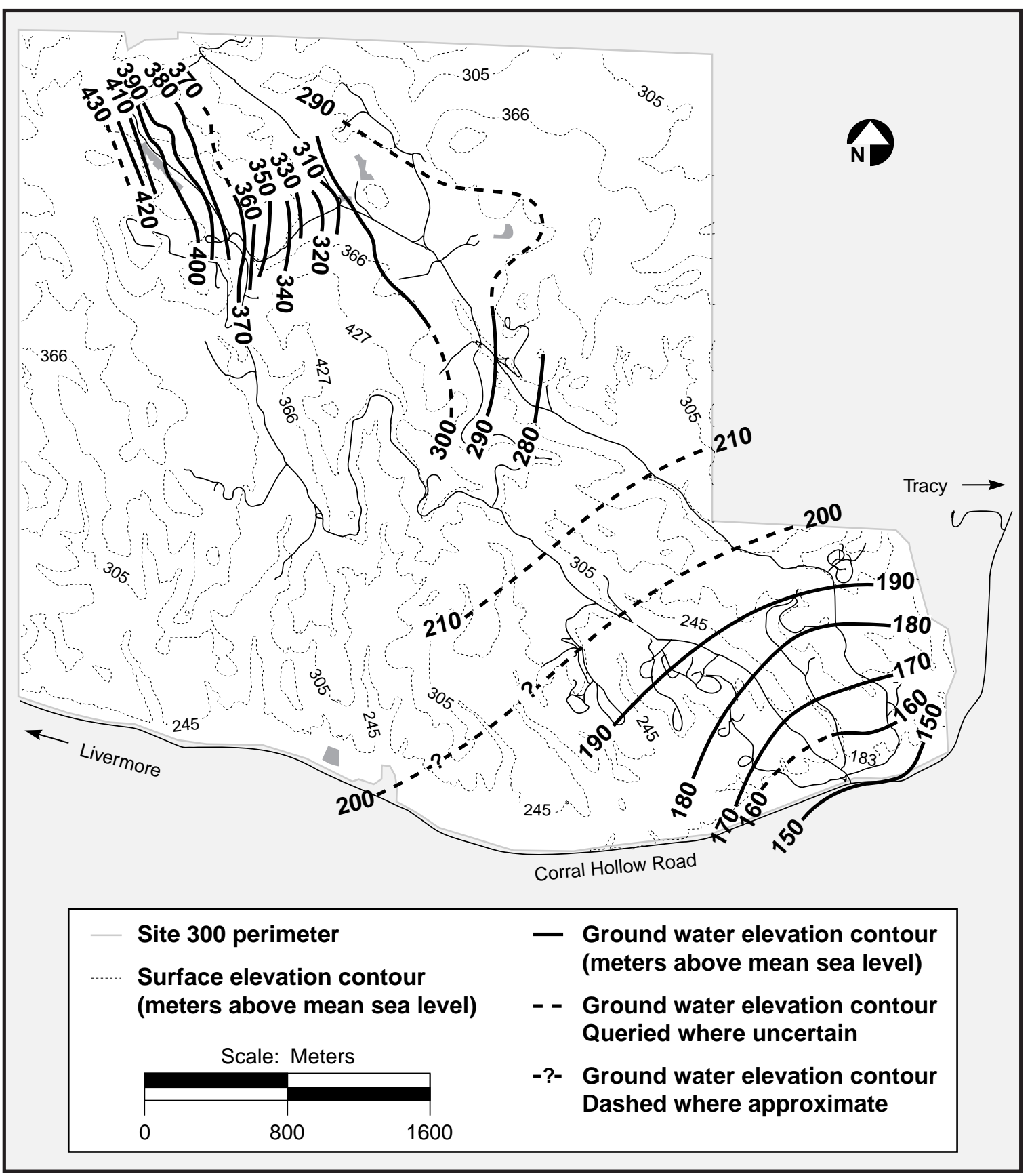

Figure 1-5. 1998 approximate ground water elevations in principal continuous waterbearing zones at Site 300 . 


\section{Compliance Summary}

\section{Introduction}

During 1998, Lawrence Livermore National Laboratory (LLNL) participated in numerous activities to comply with federal, state, and local environmental regulations as well as internal requirements and Department of Energy (DOE) orders. Activities related to air, water, waste, waste reduction, community "right to know," protection of sensitive resources, and other environmental issues were carried out at the Livermore site and Site 300. This chapter is organized according to the various laws and regulations that drive LLNL's compliance activities. Many documents concerned with these activities and other environmental issues are available for public viewing at the LLNL Visitors Center and the Livermore and Tracy public libraries. A wide range of compliance activities is summarized in the following sections.

\section{CERCLA}

The Livermore Site Ground Water Project (GWP) and the Site 300 CERCLA Project are under the jurisdiction of the Comprehensive Environmental Response, Compensation and Liability Act (CERCLA)/Superfund Amendment and Reauthorization Act (SARA), Title 1. Soil sampling at Big Trees Park was conducted under CERCLA/SARA. In addition, the CERCLA Record of Decision (ROD) for the Livermore site requires that a preconstruction site evaluation be completed prior to any soil excavation at the Livermore site.

\section{Livermore Site Ground Water Project}

The ground water project at the Livermore site complies with provisions specified in a federal facility agreement (FFA) entered into by the U.S. Environmental Protection Agency (EPA), DOE, the California EPA's Department of Toxic Substances Control (DTSC), and the San Francisco Bay Regional Water Quality Control Board (SFBRWQCB). As required by the agreement, the project addresses compliance issues by investigating potential contamination source areas (such as suspected old release sites, solvent handling areas, and leaking underground tank systems) and continuous monitoring 


\section{Compliance Summary}

and remediation of ground water. The ground water contaminants (constituents of concern) are volatile organic compounds (VOCs), primarily trichloroethene (TCE) and tetrachloroethene (PCE). These contaminants are present primarily within the site boundary and to some extent at the site boundary and beyond, mainly to the west and south of the site (see Figures 8-3 to 8-7, Chapter 8). In 1998, GWP activities included preparing the required CERCLA documents, operating ground water treatment facilities, and maintaining liaison with community groups.

\section{Documentation}

Two major CERCLA documents were published in 1998 to comply with the 1998 amended schedule of the Remedial Action Implementation Plan schedule (RAIP). With submission of the Draft Final and Final Remedial Design Report No. 4 (Berg et al. 1998), LLNL met all the primary CERCLA document milestones due before the second FiveYear Review in August 2002. Twelve additional documents or letter reports were submitted to the regulatory agencies in 1998 and are summarized in Chapter 8.

\section{Treatment Facilities}

In 1998, LLNL operated ground water treatment facilities in the TFA, TFB, TFC, TFD, TFE, TFG, TF406, TF518, and TF5475 areas. Sixty extraction wells operated at 16 separate locations treating about 2.7 million liters (ML) of ground water per day. The vapor treatment facility VTF518 treated about $2000 \mathrm{~m}^{3}$ /day of soil vapor. Together, these treatment facilities removed approximately $150 \mathrm{~kg}$ of VOCs in 1998. Since remediation efforts began in 1989, $3100 \mathrm{ML}$ of ground water and almost 0.32 million $\mathrm{m}^{3}$ of vapor have been treated, and more than $483 \mathrm{~kg}$ of VOCs have been removed. Remediation activities at the Livermore site are discussed in greater detail in Chapter 8, Ground Water Investigations and Remediation.

\section{Community Relations}

The Ground Water Project maintains ties with the surrounding community in various ways. The Community Work Group provides a forum for members of the community to meet with representatives from LLNL, DOE, the regional water quality control board, and state and federal regulators. The Community Work Group met once in 1998 to discuss the DOE budget, progress on the Livermore site cleanup, and the Livermore site Priority List/Consensus Statement. Correspondence and communication with Community Work Group members continued throughout the year. DOE/LLNL also met three times with members of Tri-Valley Communities Against a Radioactive Environment (Tri-Valley CAREs) and their scientific advisor as part of the activities funded by an EPA technical assistance grant. Other Livermore site community relations 


\section{Compliance Summary}

activities in 1998 included: communicating and meeting with neighbors, community organizations, and local, regional, and national interest groups; giving public presentations to local realtors and national and Northern California peace leaders; producing and distributing the Environmental Community Letter; maintaining the Information Repositories and the Administrative Record; conducting tours of the site environmental activities; and responding to public and news media inquiries.

\section{Site 300 CERCLA Project}

Investigations and remedial activities are ongoing at Site 300, which became a CERCLA/Superfund site in 1991, when it was placed on the National Priorities List. Investigations and remedial activities are conducted under the joint oversight of the EPA, the Central Valley Regional Water Quality Control Board (CVRWQCB), and the California EPA's DTSC and the authority of a FFA for the site. (There are separate FFAs for Site 300 and the Livermore site.) During October 1998, an addendum containing updated scope and milestone due dates was added to the FFA after approval by the regulatory agencies (U.S. Department of Energy 1998a).

During 1998, LLNL submitted all required regulatory documents (see Chapter 8) on or ahead of schedule, performed all actions stipulated in the FFA, and maintained liaison with community groups. Ground water monitoring activities are discussed in detail in Chapter 9. Results and status for Site 300 environmental restoration study areas are discussed in Chapter 8. Background information for LLNL environmental characterization and restoration activities at Site 300 can be found in the Final SiteWide Remedial Investigation Report, Lawrence Livermore National Laboratory Site 300 (Webster-Scholten 1994).

\section{Documentation}

LLNL submitted the required documentation to oversight agencies on time in 1998. Final design documents, quarterly reports, action memoranda, and work plans were among the documents submitted.

\section{Treatment Facilities}

VOCs (primarily TCE) are the main contaminants at Site 300. High explosives, tritium, depleted uranium, organosilicate oil, nitrates, and perchlorates are also found in ground water. Four treatment facilities that remove and treat VOCs, primarily TCE, operated throughout 1998. Additionally, a portable treatment unit was used to treat ground 


\section{Compliance Summary}

water extracted during a short-term pump test at a landfill (Pit 6). These facilities are discussed in more detail in Chapter 8, Ground Water Investigations and Remediation. Chapter 8 also includes maps of the study areas and details of the distribution of contaminants in ground water at Site 300.

\section{Community Relations}

The Site 300 CERCLA project maintains proactive communication with the surrounding communities of Tracy and Livermore. Community relations activities in 1998 included continued dialogue with Tri-Valley CAREs; maintenance of the information repositories and administrative records; Site 300 tours for scientists and students from universities and local public schools; off-site, private well-sampling activities; and preparation of a third Site 300 Environmental Restoration fact sheet (Heffner 1998). Quarterly meetings were held with Tri-Valley CAREs, which receives an annual technical assistance grant from EPA to independently evaluate CERCLA activities at Site 300.

On March 9, 1998, the Remedial Project Managers held a public workshop to present the initial phase of the planned Building 815 ground water cleanup to the community and to solicit verbal and written comments. Nine verbal and five written comments were submitted by the community during the public comment period from February 5 to March 30, 1998. These comments were addressed in the Action Memorandum for the Building 815 Operable Unit Removal Action (Jakub 1998).

\section{Big Trees Park Soil Sampling and Analysis}

Big Trees Park in the city of Livermore has been the object of public scrutiny since 1993, when a single soil sample was found to contain plutonium at a concentration higher than would have been expected from global fallout alone. In 1998, LLNL resampled soil in the park to determine the vertical and lateral extent of plutonium contamination and the likelihood of possible pathways. Before starting sampling, DOE/LLNL held a public workshop in August 1998 to ensure that the sampling plan included input from the regulatory agencies and the community. Soil from Big Trees Park was sampled for radiochemical analysis in August and September. Results of the sampling and analysis are summarized in Chapter 10, Soils and Sediment Monitoring. 


\section{Compliance Summary}

\section{Site Evaluations Prior to Construction}

Before construction begins, the CERCLA ROD requires that the project site be evaluated to determine if soil or rubble (concrete and asphalt) is contaminated. Soil is sampled and analyzed for potential radioactive and/or hazardous contamination. Depending on the analytical results, soil may be reused on site or disposed of according to established procedures. Depending on the potential for radioactive contamination, rubble may be either surveyed or analyzed for radioactivity. During 1998, soil and rubble were evaluated at 74 construction sites.

\section{SARA, Title III}

Title III of the SARA of 1986 is known as the Emergency Planning and Community Right-to-Know Act (EPCRA). It requires owners or operators of facilities that handle certain hazardous chemicals on site to provide information on the release, storage, and use of those chemicals to organizations responsible for emergency response planning. Executive Order 12856 directs all federal agencies to comply with the requirements of EPCRA, including the SARA 313 Toxic Release Inventory Program.

EPCRA requirements and LLNL compliance are summarized in Table 2-1. Tables 2-2 and 2-3 identify those chemicals reported by LLNL for the Livermore site and Site 300, respectively, under Title III, Section 311, during 1998.

\section{Clean Air Act-Air Quality Management Activities}

Air permits are obtained from the Bay Area Air Quality Management District (BAAQMD) for the Livermore site and from the San Joaquin Valley Unified Air Pollution Control District (SJVUAPCD) for Site 300. In 1998, BAAQMD issued or renewed air permits for 138 air emission sources for the Livermore site. In 1998, SJVUAPCD issued or renewed air permits for 47 air emission sources for Site 300 (see Table 2-4). During 1998, BAAQMD inspectors found no deficiencies at the Livermore site (see Table 2-5a for a summary of inspections in 1998). At Site 300, SJUVAPCD and the California Air Resources Board (CARB) met, toured, and inspected on January 8, 1998, to evaluate open burn and explosive burning operations. Inspectors found no deficiencies at Site 300 (See Table 2-5b). On September 17, 1998, SJVUAPCD implemented the revised Rule 2020 (Exemptions) to make the detonation of explosives for research and development activities exempt from air permit requirements. 


\section{Compliance Summary}

Table 2-1. Summary of LLNL compliance with EPCRA in 1998.

\begin{tabular}{|c|c|c|}
\hline EPCRA requirement & Brief description & Compliance \\
\hline $\begin{array}{l}302 \text { Planning } \\
\text { notification }\end{array}$ & $\begin{array}{l}\text { Operator must notify } \operatorname{SERC}^{(\mathrm{a})} \text { of } \\
\text { presence of extremely hazardous } \\
\text { substances. }\end{array}$ & $\begin{array}{l}\text { In California, operator must notify } \\
\text { CEPRC(b) of presence of extremely } \\
\text { hazardous substances above threshold } \\
\text { planning quantities. } \\
\text { Originally submitted May } 1987 \text {. }\end{array}$ \\
\hline $\begin{array}{l}303 \text { Planning } \\
\text { notification }\end{array}$ & $\begin{array}{l}\text { Operator must designate a facility } \\
\text { representative to serve as emergency } \\
\text { response coordinator. }\end{array}$ & Update submitted February 10, 1998. \\
\hline $\begin{array}{l}304 \text { Release } \\
\text { notification }\end{array}$ & $\begin{array}{l}\text { Releases of certain hazardous } \\
\text { substances must be reported to SERC } \\
\text { and LEPC. } \text { (c) }\end{array}$ & $\begin{array}{l}\text { No EPCRA-listed extremely hazardous } \\
\text { substances were released above } \\
\text { reportable quantities. }\end{array}$ \\
\hline $\begin{array}{l}311 \mathrm{MSDS}^{(\mathrm{d})} / \text { Chemical } \\
\text { inventory }\end{array}$ & $\begin{array}{l}\text { Operator must submit MSDSs or } \\
\text { chemical list to SERC, LEPC, and fire } \\
\text { department. }\end{array}$ & $\begin{array}{l}\text { Tables 2-2 and 2-3. } \\
\text { Updated February 16, } 1998 .\end{array}$ \\
\hline $\begin{array}{l}312 \text { MSDS/Chemical } \\
\text { inventory }\end{array}$ & $\begin{array}{l}\text { Operator must submit hazardous } \\
\text { chemical inventory to appropriate } \\
\text { county. }\end{array}$ & $\begin{array}{l}\text { Business Plans and chemical inventory } \\
\text { submitted to San Joaquin County } \\
\text { (January 15, 1998) and Alameda } \\
\text { County (January 15, 1998). }\end{array}$ \\
\hline $\begin{array}{l}313 \text { Toxic Release } \\
\text { Inventory }\end{array}$ & $\begin{array}{l}\text { Operator must submit Form R to U.S. } \\
\text { EPA and California EPA for toxic } \\
\text { chemicals released. }\end{array}$ & $\begin{array}{l}\text { Form } R \text { for Freon } 113 \text { submitted } \\
\text { June } 15,1998 \text { to DOE; DOE forwarded } \\
\text { to U.S. EPA and California EPA on } \\
\text { June } 30,1998 \text {. }\end{array}$ \\
\hline
\end{tabular}

a $\mathrm{SERC}=$ State Emergency Response Commission.

b $\quad$ CEPRC $=$ Chemical Emergency Planning and Response Commission.

c $\quad$ LEPC $=$ Local Emergency Planning Committee.

d MSDS = Material Safety Data Sheet.

\section{National Emission Standards for Hazardous Air Pollutants}

In order to comply with the National Emission Standards for Hazardous Air Pollutants (NESHAPs) for radionuclide emissions to air (Radionuclide NESHAPs, 40 CFR 61, Subpart $\mathrm{H}$ ), all potential sources must be evaluated, and the potential radiological dose to the sitewide maximally exposed public individual (SW-MEI) must be determined. Compliance with two dose limits must be evaluated. First, the integrated dose to the 


\section{Compliance Summary}

Table 2-2. Livermore site, SARA, Title III, Section 311, Chemical List. (a)

\begin{tabular}{|c|c|c|c|c|c|}
\hline \multirow{2}{*}{$\begin{array}{l}\text { Livermore site } \\
\text { chemicals }\end{array}$} & \multicolumn{3}{|c|}{ Physical hazard } & \multicolumn{2}{|c|}{ Health hazard } \\
\hline & Fire & Pressure & Reactivity & Acute & Chronic \\
\hline Acetylene & $x$ & $x$ & & $x$ & \\
\hline Ammonia, anhydrous & & $x$ & & $x$ & \\
\hline Ammonium hydroxide & & & & $x$ & \\
\hline Argon & & $x$ & & $x$ & \\
\hline Brayco 889, coolant & $x$ & & & & \\
\hline Carbon, activated & $x$ & & & & \\
\hline Chlorine & & $x$ & $x$ & $x$ & \\
\hline Cobalt & $x$ & & & $x$ & $x$ \\
\hline Diesel fuel & $x$ & & & & \\
\hline Ethyl alcohol & $x$ & & & $x$ & $x$ \\
\hline Freon 113 & & & & $x$ & \\
\hline Gasoline & $x$ & & & $x$ & $x$ \\
\hline Helium & & $x$ & & $x$ & \\
\hline Hydrochloric acid & & & & $x$ & $x$ \\
\hline Hydrofluoric acid & & $\begin{array}{c}\text { Some } \\
\text { containers }\end{array}$ & $x$ & $x$ & $x$ \\
\hline Hydrogen & $x$ & $x$ & & $x$ & \\
\hline Hydrogen peroxide $(<52 \%)$ & & & $x$ & & \\
\hline Insulating oil, inhibiting & $x$ & & & & \\
\hline Lead (bricks and ingots) & & & & $x$ & $\mathrm{x}$ \\
\hline Methane & $x$ & $x$ & & $x$ & \\
\hline Nitric acid & $x$ & & $x$ & $x$ & $x$ \\
\hline Nitric oxide & & $x$ & $x$ & $x$ & \\
\hline Nitrogen & & $x$ & & $x$ & \\
\hline Oxygen & & $x$ & $x$ & & \\
\hline Paint & $x$ & & & & \\
\hline Sulfuric acid & & & $x$ & $x$ & $x$ \\
\hline
\end{tabular}

a Physical and health hazard information obtained primarily from Material Safety Data Sheets.

SW-MEI from all sources of radionuclide emissions to air at a site must not exceed 100 microsieverts per year ( $\mu \mathrm{Sv} / \mathrm{y})(10$ millirem per year $[\mathrm{mrem} / \mathrm{y}])$. Second, each point source (stack) having the potential to emit radionuclides that would result, without accounting for mitigation, in a dose greater than $1 \mu \mathrm{Sv} / \mathrm{y}(0.1 \mathrm{mrem} / \mathrm{y})$, must be continuously monitored. 


\section{Compliance Summary}

Table 2-3. Site 300, SARA, Title III, Section 311, Chemical List. (a)

\begin{tabular}{|c|c|c|c|c|c|}
\hline \multirow{2}{*}{$\begin{array}{l}\text { Site } 300 \\
\text { chemicals }\end{array}$} & \multicolumn{3}{|c|}{ Physical hazard } & \multicolumn{2}{|c|}{ Health hazard } \\
\hline & Fire & Pressure & Reactivity & Acute & Chronic \\
\hline Argon & & $x$ & & $x$ & \\
\hline Carbon, activated & $x$ & & & & \\
\hline Chlorine & & $x$ & & $x$ & \\
\hline $\begin{array}{l}\text { Bis(2,2-dinitro-2-fluoroethyl) formal in } \\
\text { methylene chloride }\end{array}$ & - (b) $^{\text {(b) }}$ & & - (b) $^{(b)}$ & $x$ & $x$ \\
\hline Diesel fuel & $x$ & & & & \\
\hline Gasoline & $x$ & & & $x$ & $x$ \\
\hline Helium & & $x$ & & $x$ & \\
\hline High explosives & & & $x$ & & \\
\hline Lead (bricks) & & & & $x$ & $x$ \\
\hline Nitrogen & & $x$ & & & \\
\hline Oil, hydraulic & $x$ & & & & \\
\hline Oil, inhibited insulating & $x$ & & & & \\
\hline Oil, transformer & $x$ & & & & \\
\hline
\end{tabular}

a Physical and health hazard information obtained primarily from Material Safety Data Sheets.

b Dangerous fire or explosion risk in neat form (solvent evaporates).

The LLNL NESHAPs 1998 Annual Report (Biermann et al. 1999), submitted to DOE and EPA, reported that the total calculated SW-MEI radiological doses for the Livermore site and Site 300 were $0.49 \mu \mathrm{Sv} / \mathrm{y}(0.049 \mathrm{mrem} / \mathrm{y})$ and $0.24 \mu \mathrm{Sv} / \mathrm{y}(0.024 \mathrm{mrem} / \mathrm{y})$, respectively, for 1998. Using the EPA mandated assumption that gaseous tritium be treated as though it were tritiated water, yielded a dose of $0.55 \mu \mathrm{Sv}(0.055 \mathrm{mrem})$ for Livermore site operations. The reported doses include contributions from both point sources and diffuse sources. Modeling was based on a combination of effluent monitoring data and radionuclide usage data. The totals are well below the $100 \mu \mathrm{Sv} / \mathrm{y}$ (10 mrem/y) dose limits defined by the NESHAPs regulations. The details of these data are included in this report (see Chapter 13, Radiological Dose Assessment).

In 1998, LLNL continuously monitored radionuclide emissions from Building 331 (the Tritium Facility), Building 332 (the Plutonium Building), the seismically strengthened portion of Building 251, and five other buildings (see Chapter 4). There were no unplanned atmospheric releases at the Livermore site or at Site 300 in 1998. 


\section{Compliance Summary}

Table 2-4. Summary of permits active in 1998. (a)

\begin{tabular}{|c|c|c|}
\hline $\begin{array}{c}\text { Type of } \\
\text { permit }\end{array}$ & Livermore site & Site 300 \\
\hline Air & $\begin{array}{l}\text { BAAQMD issued } 138 \text { permits for operation of various } \\
\text { types of equipment, including boilers, emergency } \\
\text { generators, cold cleaners, ultrasonic cleaners, } \\
\text { degreasers, printing press operations, manual wipe- } \\
\text { cleaning operations, metal machining and finishing } \\
\text { operations, silk-screening operations, silk-screen } \\
\text { washers, paint spray booths, adhesives operations, } \\
\text { diamond-turning machine cleaning operation, image tube } \\
\text { fabrication, optic coating operations, gravity retort, storage } \\
\text { tanks containing VOCs in excess of } 10 \% \text {, planetary } \\
\text { mixers, plating tanks, drum crusher, semiconductor } \\
\text { operations, diesel air-compressor engines, ground water } \\
\text { air strippers/dryers, ovens, material-handling equipment, } \\
\text { sewer diversion system, wave soldering machine, oil and } \\
\text { water separator, fire test cells, oil shale hopper and } \\
\text { preheater, oil shale combuster, gasoline-dispensing } \\
\text { operation, resin-mixing operation, paper-pulverizer } \\
\text { system, and firing tank. }\end{array}$ & $\begin{array}{l}\text { SJVUAPCD issued } 47 \text { permits for operation of } \\
\text { various types of equipment, including boilers, } \\
\text { emergency generators, paint spray booth, ground } \\
\text { water air strippers, soil vapor extraction units, } \\
\text { woodworking cyclone, gasoline-dispensing } \\
\text { operation, and drying ovens. }\end{array}$ \\
\hline Water & $\begin{array}{l}\text { WDR (b) Order No. } 88-075 \text { for discharges of treated } \\
\text { ground water from Treatment Facility A to percolation pits } \\
\text { and recharge basin. } \\
\text { WDR Order No. } 95-174, \text { NPDES(c) Permit } \\
\text { No. CA0030023 for discharges of storm water associated } \\
\text { with industrial activities and low-threat non-storm water } \\
\text { discharges to surface waters. } \\
\text { WDR Order No. 92-08-DWQ, NPDES(c) General Permit } \\
\text { No. CAS000002, Building } 132 \text {, Site ID No. } 201 \text { S300881, } \\
\text { DWTF(d) Site ID No. } 201 \text { S } 305140 \text {, Soil Reuse Project ID } \\
\text { No. } 2015305529 \text { and National lgnition Facility, Site ID No. } \\
201 \text { S306762=-for discharges of storm water associated } \\
\text { with construction activities impacting two hectares or } \\
\text { more. } \\
\text { Two projects completed under ACOE }{ }^{(e)} \text { Nationwide } \\
\text { Permits and Clean Water Act Section } 401 \text { Waivers of } \\
\text { Water Quality Certification. } \\
\text { Two projects completed under streambed alteration } \\
\text { agreements. } \\
\text { Federal facility agreement, ground water } \\
\text { investigation/remediation. }\end{array}$ & $\begin{array}{l}\text { WDR Order No. 92-08-DWQ, NPDES(c) General } \\
\text { Permit No. CASO00002, Contained Firing } \\
\text { Facility/Chemistry Magazine Loop, Site ID } \\
\text { No. 5B39S307131 for discharges of storm water } \\
\text { associated with construction activities impacting two } \\
\text { hectares or more. } \\
\text { WDR Order No. } 93-100 \text { for post-closure monitoring } \\
\text { requirements for two Class I landfills. } \\
\text { WDR Order No. 94-131, NPDES Permit } \\
\text { No. CA0081396 for discharges of storm water } \\
\text { associated with industrial activities and from cooling } \\
\text { towers. } \\
\text { WDR Order No. 96-248 for operation of two Class II } \\
\text { surface impoundments, a domestic sewage lagoon, } \\
\text { and percolation pits. } \\
\text { WDR Order No. } 97-242 \text {, NPDES Permit } \\
\text { No. CA0082651 for discharges of treated ground } \\
\text { water from the eastern General Services Area } \\
\text { treatment unit. } \\
\text { Two projects completed under ACOE Nationwide } \\
\text { Permits and } 401 \text { Waivers of Water Quality } \\
\text { Certification. } \\
\text { Three projects completed under streambed } \\
\text { alteration agreements. } \\
\text { Federal Facility Agreement for ground water } \\
\text { investigation/remediation. } \\
52 \text { registered, Class V injection wells. }\end{array}$ \\
\hline
\end{tabular}




\section{Compliance Summary}

Table 2-4. Summary of permits active in 1998 (concluded).

\begin{tabular}{|c|c|c|}
\hline $\begin{array}{l}\text { Type of } \\
\text { permit }\end{array}$ & Livermore site & Site 300 \\
\hline $\begin{array}{l}\text { Hazardous } \\
\text { waste }\end{array}$ & $\begin{array}{l}\text { EPD ID No. CA2890012584. } \\
\text { Authorization to mix resin in Units CE231-1 and CE443-1 } \\
\text { under Conditional Exemption tiered permitting. } \\
\text { Closure under interim status of the Building } 513 \\
\text { Shredding Unit, Building } 419 \text { size reduction unit, and } \\
\text { Building } 419 \text { solidification unit. } \\
\text { Continued authorization to operate } 18 \text { waste storage } \\
\text { units and nine waste treatment units under interim status. }\end{array}$ & $\begin{array}{l}\text { EPA ID No. CA2890090002. } \\
\text { Part B Permit-Container Storage Area } \\
\text { (Building 883) and Explosives Waste Storage } \\
\text { Facility (issued May 23, 1996). } \\
\text { Part B Permit-Explosives Waste Treatment } \\
\text { Facility (issued October 9, 1997). } \\
\text { Docket HWCA 92/93-031. Closure and Post- } \\
\text { Closure Plans for landfill Pit } 6 \text { and the Building } 829 \\
\text { Open Burn Facility. }\end{array}$ \\
\hline $\begin{array}{l}\text { Sewerable } \\
\text { waste }\end{array}$ & $\begin{array}{l}\text { Discharge Permit No. } 1250 \text { ( } 97 / 98 \text { and } 98 / 99) \text { for } \\
\text { discharges of wastewater to the sanitary sewer. } \\
1510 G(98) \text { for discharges of sewerable ground water } \\
\text { from CERCLA restoration activities. }\end{array}$ & \\
\hline $\begin{array}{l}\text { Storage } \\
\text { tanks }\end{array}$ & $\begin{array}{l}13 \text { permits for underground petroleum and hazardous } \\
\text { waste storage. }\end{array}$ & $\begin{array}{l}\text { One permit covering five underground petroleum } \\
\text { product tanks. }\end{array}$ \\
\hline
\end{tabular}

a Permit numbers are based on actual permitted units maintained and renewed by LLNL during 1998.

b $\quad$ WDR $=$ Waste Discharge Requirements.

c NPDES $=$ National Pollutant Discharge Elimination System.

d DWTF = Decontamination and Waste Treatment Facility.

e $\mathrm{ACOE}=$ Army Corps of Engineers.

\section{Clean Water Act and Related State Programs}

Preserving clean water is one objective of local, state, and federal regulations. The National Pollutant Discharge Elimination System (NPDES) under the Federal Clean Water Act establishes permit requirements for discharges into navigable waterways. In addition, the State of California requires permits, known as Waste Discharge Requirements (WDRs), for any waste discharges affecting the beneficial uses of waters of the state. The regional water quality control boards are responsible for issuing and enforcing both permits. The Livermore Water Reclamation Plant (LWRP) requires permits for discharges of sewerable water to the city sanitary sewer system. The Army Corps of Engineers (ACOE) issues permits for work in navigable waterways below the ordinary high-water mark and for controlling fill operations in waters of the United 


\section{Compliance Summary}

Table 2-5a. Inspections and tours of the Livermore site by external agencies in 1998.

\begin{tabular}{|c|c|c|c|c|}
\hline Medium & Description & $\operatorname{Agency}^{(a)}$ & Date & Finding \\
\hline Air & Emission sources & BAAQMD & $\begin{array}{c}1 / 21 \\
1 / 28 \\
2 / 4 \\
2 / 18 \\
2 / 27 \\
3 / 11 \\
4 / 1 \\
8 / 28 \\
9 / 10 \\
10 / 1 \\
10 / 22 \\
11 / 10 \\
12 / 3\end{array}$ & No violations \\
\hline \multirow[t]{4}{*}{ Water } & \multirow[t]{2}{*}{ Streambed alteration } & CDFG & $3 / 3$ & No violations \\
\hline & & $\begin{array}{l}\text { SFBRWQCB/ } \\
\text { USFWS/ } \\
\text { CDFG }\end{array}$ & $3 / 31$ & No violations \\
\hline & Discharge to Arroyo Mocho from drinking water tanks & SFBRWQCB & $5 / 11$ & No violations \\
\hline & Arroyo Maintenance Project & SFBRWQCB & $10 / 13$ & No violations \\
\hline \multirow[t]{4}{*}{ Waste } & $\begin{array}{l}\text { Investigation of a DTSC complaint regarding July 2, 1997, } \\
\text { Building } 513 \text { shredder incident }\end{array}$ & DTSC & $\begin{array}{l}11 / 12 / 97 \\
\text { and } 2 / 5 / 98\end{array}$ & $\begin{array}{l}7 \text { alleged } \\
\text { violations }^{(b)}\end{array}$ \\
\hline & Hazardous waste management facilities & DTSC & $5 / 26-5 / 27$ & $\begin{array}{l}\text { Inspection not } \\
\text { yet closed }\end{array}$ \\
\hline & Medical waste & ACDEH & $9 / 15$ & No violations \\
\hline & Motor vehicles & $\mathrm{CHP}$ & $12 / 8-12 / 9$ & Two violations \\
\hline \multirow{2}{*}{$\begin{array}{l}\text { Sewerable } \\
\text { waste }\end{array}$} & Compliance sampling & LWRP & $11 / 23-11 / 24$ & No violations \\
\hline & Categorical sampling & LWRP & $12 / 11$ & No violations \\
\hline Storage tanks & $\begin{array}{l}\text { Compliance with underground storage tank upgrade } \\
\text { requirements }\end{array}$ & ACEHS & $10 / 20$ & No violations \\
\hline
\end{tabular}

a See Glossary for list of acronyms.

b LLNL disputes these alleged violations. DTSC, DOE, and LLNL are developing an agreement for resolving the issues. 


\section{Compliance Summary}

Table 2-5b. Inspections and tours of Site 300 by external agencies in 1998.

\begin{tabular}{|c|c|c|c|c|}
\hline Medium & Description & $\operatorname{Agency}^{(a)}$ & Date & Finding \\
\hline Air & Emission sources & $\begin{array}{l}\text { SJVUAPCD/ } \\
\text { CARB }\end{array}$ & $1 / 8$ & No violations \\
\hline Water & Streambed alteration & CDFG & $9 / 16$ & No violations \\
\hline \multirow[t]{2}{*}{ Waste } & Various facilities & DTSC & $\begin{array}{c}6 / 16-6 / 17 \\
7 / 7, \text { and } \\
10 / 9\end{array}$ & Two violations \\
\hline & Vehicles used for transporting hazardous materials & $\mathrm{CHP}$ & $12 / 4$ & Two violations \\
\hline \multirow[t]{3}{*}{ Wastewater } & Permitted operations & CVRWQCB & $4 / 21$ & No violations \\
\hline & $\begin{array}{l}\text { Observation of wastewater-generating activities that might } \\
\text { discharge wastewater at the Livermore site. }\end{array}$ & LWRP & $6 / 19$ & No violations \\
\hline & Evaluation of sewage evaporation and percolation ponds & SWRCB & $6 / 29$ & No violations \\
\hline Storage tanks & $\begin{array}{l}\text { Compliance with underground storage tank upgrade } \\
\text { requirements }\end{array}$ & SJCEHD & $12 / 21$ & No violations \\
\hline
\end{tabular}

a See Glossary for list of acronyms.

States. The State Water Resources Control Board (SWRCB) issues water quality certifications for this work if the regional water quality control boards do not waive the requirement for the water quality certifications or independently issue WDRs. The California Department of Fish and Game (CDFG) under the Fish and Game Code Section 1601 et seq. requires streambed alteration agreements for any work that may disturb or impact rivers, streams, or lakes. The Safe Drinking Water Act requires registration and management of injection wells to protect underground sources of drinking water. Injection well registration is provided to the United States Environmental Protection Agency. Finally, Alameda County Health Services and San Joaquin County Environmental Health Services issue permits for operating underground storage tanks containing hazardous materials as required under the California Health and Safety Code. Water-related permits are summarized in Table 2-4 and discussed in detail in Chapters 6, 7, and 9.

In 1998, there was no change in the number and distribution of injection wells at Site 300, and no significant changes were made to the technology or practices documented in the Spill Control and Countermeasures Plan (Campbell 1995). 


\section{Compliance Summary}

\section{Ground Water and Surface Water}

Discharges of treated ground water to surface water drainage courses and percolation ponds at LLNL are governed by NPDES permits, WDRs, and CERCLA Records of Decision (see Table 2-4). Details of surface water discharges are found in Chapter 7 of this report. Details of ground water monitoring are found in Chapter 9 of this report, the LLNL Ground Water Project 1998 Annual Report (Aarons et al. 1998), and the LLNL Remedial Program Manager's quarterly reports (Littlejohn and Lamarre 1997 and Bainer and Littlejohn 1998). LLNL discharges storm water associated with industrial activities, low-threat nonstorm water, various process waters, and domestic wastewater to surface waters, percolation pits, surface impoundments, and a sewage lagoon under four NPDES permits and three WDRs (see Chapters 7 and 9). LLNL received no Notices of Violation (NOVs) in 1998 from the regional water quality control boards that issued the NPDES and WDR permits; however, LLNL identified nonconformance with one of the four permits. NPDES permit nonconformances are summarized in Table 2-6. In addition, LLNL was unable to comply with prohibitions in WDR No. 96-248 on February 3, when a retention tank system at Site 300 filled with rainwater and overflowed into the secondary containment and then onto the ground. This discharge was reported by phone and in writing to the CVRWQCB.

LLNL continued construction operations on four projects and completed one project during 1998. These activities are covered by the California General Construction Activity permit (see Table 2-4). LLNL submitted a Notice of Termination, concluding permit coverage for the completed Building 132 construction project. Continuing operations included construction of the nonhazardous waste portions of the Decontamination and Waste Treatment Facility (DWTF), the Soil Reuse Project, and the National Ignition Facility at the Livermore site and the Contained Firing Facility/ Chemistry Magazine Loop project at Site 300.

The SFBRWQCB visited drinking water tanks at Arroyo Mocho to observe the effects of the tank release on the arroyo, and the CVRWQCB inspected the Site 300 permitted facilities in April 1998. No violations were found at either site (see Table 2-5).

\section{Sewerable Water}

The Livermore site's sanitary sewer discharges are sampled continuously, daily, weekly, and monthly to satisfy various permit compliance requirements. The monitoring results for the LLNL effluent are reported monthly to the LWRP. In 1998, LLNL achieved 100\% compliance with LWRP Permit 1250 covering wastewater discharges to the sanitary 


\section{Compliance Summary}

Table 2-6. Summary of nonconformances with NPDES permits.

\begin{tabular}{|c|c|c|c|c|}
\hline $\begin{array}{l}\text { Permit } \\
\text { No. }\end{array}$ & Outfall & Nonconformance & $\begin{array}{c}\text { Date(s) of } \\
\text { nonconformance }\end{array}$ & $\begin{array}{l}\text { Description- } \\
\text { solution }\end{array}$ \\
\hline \multirow[t]{7}{*}{ CAS000002 } & $\begin{array}{l}\text { Arroyo Las Positas } \\
\text { (Livermore site) }\end{array}$ & $\begin{array}{l}\text { National Ignition Facility: Failure to } \\
\text { follow BMPs (a) for dewatering }\end{array}$ & $8 / 97^{(b)}$ & $\begin{array}{l}\text { Halted activity, implemented } \\
\text { BMP, and issued deficiency } \\
\text { notice to subcontractor }\end{array}$ \\
\hline & & $\begin{array}{l}\text { National Ignition Facility: Failure to } \\
\text { follow, perform, and document } \\
\text { inspections }\end{array}$ & $12 / 97-3 / 98$ & $\begin{array}{l}\text { Held internal refresher } \\
\text { training and sent key staff for } \\
\text { off-site training }\end{array}$ \\
\hline & & $\begin{array}{l}\text { National Ignition Facility: Failure to } \\
\text { follow BMP for road cleaning }\end{array}$ & $3 / 98$ & $\begin{array}{l}\text { Halted activity and required } \\
\text { subcontractor to sweep roads }\end{array}$ \\
\hline & & $\begin{array}{l}\text { National Ignition Facility: Failure to } \\
\text { document changed construction } \\
\text { activities in SWPPP prior to } \\
\text { implementation }\end{array}$ & $6 / 98$ & $\begin{array}{l}\text { Updated SWPPP(c), and } \\
\text { issued reminder to } \\
\text { construction staff regarding } \\
\text { SWPPP updates }\end{array}$ \\
\hline & $\begin{array}{l}\text { Arroyo Las Positas, } \\
\text { Arroyo Seco } \\
\text { (Livermore site) }\end{array}$ & $\begin{array}{l}\text { Soil Reuse Project: Failure to } \\
\text { implement erosion control BMP }\end{array}$ & 9/97 & $\begin{array}{l}\text { Implemented sediment } \\
\text { control BMP and revised } \\
\text { SWPPP }\end{array}$ \\
\hline & & $\begin{array}{l}\text { Soil Reuse Project: Failure to } \\
\text { perform inspections prior to } \\
\text { predicted storm events }\end{array}$ & & $\begin{array}{l}\text { Provided sources of weather } \\
\text { service forecasts to the } \\
\text { project inspector }\end{array}$ \\
\hline & $\begin{array}{l}\text { Elk Ravine } \\
\text { (Site 300) }\end{array}$ & $\begin{array}{l}\text { Contained Firing Facility/Chemistry } \\
\text { Magazine Loop project: Failure to } \\
\text { document inspections }\end{array}$ & $12 / 97-5 / 98$ & $\begin{array}{l}\text { Briefed construction staff on } \\
\text { documentation requirements }\end{array}$ \\
\hline CA0030023 & $\begin{array}{l}\text { Arroyo Las Positas } \\
\text { and Arroyo Seco } \\
\text { (Livermore site) }\end{array}$ & None & None & None \\
\hline CA0081396 & $\begin{array}{l}\text { Corral Hollow } \\
\text { Creek (Site 300) }\end{array}$ & None & None & None \\
\hline CA0082651 & $\begin{array}{l}\text { Corral Hollow } \\
\text { Creek (Site 300) }\end{array}$ & None & None & None \\
\hline
\end{tabular}

a $\mathrm{BMP}=$ Best management practice.

b The construction inspection program is based on the reporting period June 1997 through May 1998.

c $\quad$ SWPPP $=$ Storm Water Pollution Prevention Plan.

sewer. However, the LWRP issued two NOVs for permit violations that occurred in 1997. One was issued in January 1998 for exceeding the lead concentration limit on October 31 and November 1, 1997. The lead exceedances were minor, and no correction was required. The other NOV covered four different $\mathrm{pH}$ exceedances in December 1997. These exceedances were considered to be part of the pattern of $\mathrm{pH}$ exceedances discussed in a previous NOV issued October 1997. LLNL closed out the $\mathrm{pH}$ NOVs by successfully installing the Upstream pH Trigger Monitoring Station in September 1998. 


\section{Compliance Summary}

This station monitors the $\mathrm{pH}$ of the sanitary sewer and diverts wastewater to the Sewer Diversion Facility tank farm when the wastewater falls outside the allowable $\mathrm{pH}$ range (5-10). LWRP permit exceedances and corrective measures are discussed in detail in Chapter 6. Self-monitoring of categorical processes continued during 1998, as required in the permit.

Discharges from ground water treatment facilities to sanitary sewer under Permit 1510G (1998) are monitored as they occur and reported annually to the LWRP. These selfmonitoring programs and the associated analytical results documenting compliance with the self-monitoring provisions of the permit are discussed in Chapter 6. In 1998, LLNL achieved 100\% compliance with the permit limits of 1510G.

On November 23 and 24, LWRP collected split samples of site effluent at Building 196 as part of the annual compliance sampling. On December 11, LWRP collected categorical process samples from abrasive (water) jet machines and semiconductor processes in Buildings 321C and 153, respectively. LWRP staff toured Site 300 wastewater generating activities on June 19, 1998. No violations were found at either site (Table 2-5).

\section{Streambed Alteration Agreements and Nationwide Permits}

The California Department of Fish and Game (CDFG), SFBRWQCB, and ACOE all issue permits for work in streambeds. At the Livermore site, CDFG issued three streambed alteration agreements for maintenance projects within arroyos during 1998 (see Table 2-7). The Fish and Game Warden made a site visit to Arroyos Las Positas in connection with the Arroyo Las Positas Maintenance Project.

LLNL applied for three nationwide permits from the ACOE for LLNL projects at the Livermore site and vicinity. The ACOE declined jurisdiction for the request associated with the Arroyo Las Positas Maintenance Project because of the recent court ruling on the Tulloch Rule, which rescinded the ACOE's authority for projects that involve only dredging, with no filling, except for incidental fallback. ACOE staff did not inspect any Livermore site projects in 1998. 


\section{Compliance Summary}

Table 2-7. Summary of streambed alteration agreements, 404 Nationwide Permits, and 401 Waivers.

\begin{tabular}{|c|c|c|c|}
\hline Project & Location & $\begin{array}{c}\text { Agency/ } \\
\text { type of permit }\end{array}$ & $\begin{array}{c}\text { Date } \\
\text { submitted }\end{array}$ \\
\hline Emergency bank stabilization & Arroyo Seco & CDFG/SAA(a) & $2 / 20 / 98$ \\
\hline Culvert replacement & $\begin{array}{l}\text { Tributary to Corral Hollow } \\
\text { Creek (unnamed) }\end{array}$ & $\begin{array}{l}\text { CDFG/SAA } \\
\text { ACOE/Nationwide } \\
\text { Permit } 3 \\
\text { CVRWQCB/ } 401 \text { Waiver }\end{array}$ & $\begin{array}{l}3 / 11 / 98 \\
3 / 11 / 98 \\
3 / 11 / 98\end{array}$ \\
\hline Bank stabilization & Arroyo Seco & $\begin{array}{l}\text { CDFG/ SAA } \\
\text { SFBRWQCB/ } 401 \text { Waiver } \\
\text { ACOE/404 Nationwide } \\
\text { Permit } 6\end{array}$ & $\begin{array}{l}2 / 20 / 98(b) \\
5 / 29 / 98 \\
5 / 29 / 98\end{array}$ \\
\hline Sampling activities & Arroyo Seco & $\begin{array}{l}\text { SFBRWQCB/ } 401 \text { Waiver } \\
\text { ACOE/404 Nationwide } \\
\text { Permit } 6\end{array}$ & $\begin{array}{l}7 / 31 / 98 \\
9 / 8 / 98\end{array}$ \\
\hline Vegetation cutting & Arroyo Las Positas & CDFG/SAA & $8 / 3 / 98$ \\
\hline Bank stabilization & Elk Ravine & $\begin{array}{l}\text { CDFG/SAA } \\
\text { CVRWQCB/ } 401 \text { Waiver } \\
\text { ACOE/404 Nationwide } \\
\text { Permit } 13\end{array}$ & $\begin{array}{l}8 / 10 / 98 \\
8 / 6 / 98 \\
8 / 6 / 98\end{array}$ \\
\hline $\begin{array}{l}\text { Arroyo Las Positas Maintenance } \\
\text { Project }\end{array}$ & Arroyo Las Positas & $\begin{array}{l}\text { CDFG/SAA } \\
\text { SFBRWQCB/ WDR(c) }\end{array}$ & $8 / 20 / 98$ \\
\hline Well drilling & $\begin{array}{l}\text { Tributary to Corral Hollow } \\
\text { Creek (832 Canyon) }\end{array}$ & CDFG/SAA & $10 / 23 / 98$ \\
\hline $\begin{array}{l}\text { Maintenance (five-year } \\
\text { agreement) }\end{array}$ & Site 300 drainage culverts & CDFG, SAA & 1995 \\
\hline
\end{tabular}

a $\mathrm{SAA}=$ Streambed Alteration Agreement.

b CDFG included this work as part of the SAA issued for the emergency bank stabilization.

c $\mathrm{WDR}=$ Waste discharge requirements.

The SFBRWQCB issued waivers from 401 Water Quality Certification for Arroyo Seco bank stabilization and sampling at the direction of the SFBRWQCB. LLNL submitted a Report of Waste Discharge for the Arroyo Las Positas Maintenance Project. The SFBRWQCB is expected to issue waste discharge requirements (WDRs) for this project in 1999. The SFBRWQCB chose to issue WDRs instead of a Water Quality Certification because the project does not require a nationwide permit and it is phased over a fiveyear period. The SFBRWQCB visited LLNL in connection with the permit requested for the Arroyo Las Positas Maintenance Project, and no violations were found. See

Table 2-5a for a summary of the inspections. 


\section{Compliance Summary}

At Site 300, LLNL continued to operate under a five-year CDFG streambed alteration agreement issued in 1995 for maintenance of drainage channels. LLNL also obtained three streambed alteration agreements for projects completed in 1998. Two of these projects were also subject to Clean Water Act, Section 404, permitting requirements and were covered by ACOE nationwide permits. The CVRWQCB issued waivers from 401 Water Quality Certification for the projects covered by nationwide permits.

\section{Tank Management}

LLNL manages its underground storage tanks and aboveground storage tanks through the use of underground tank permits, monitoring programs, operational plans, closure and leak documentation, and inspections. At LLNL, underground storage tanks contain diesel fuel, gasoline, waste oil, and process wastewater; aboveground storage tanks contain diesel fuel, insulating oil, and process wastewater. Some wastewater systems are a combination of underground storage tanks and aboveground storage tanks. Table 2-8 shows the status of tanks at the Livermore site and Site 300 as of December 31, 1998.

Table 2-8. Status of in-service tanks, December 31, 1998.

\begin{tabular}{|l|c|c|c|c|c|c|}
\hline \multirow{2}{*}{ Tank type } & \multicolumn{3}{|c|}{ Livermore site } & \multicolumn{3}{c|}{ Site 300 } \\
\cline { 2 - 7 } & Permitted & $\begin{array}{c}\text { Permits } \\
\text { not } \\
\text { required }\end{array}$ & Total & Permitted & $\begin{array}{c}\text { Permits } \\
\text { not } \\
\text { required }\end{array}$ & Total \\
\hline $\begin{array}{l}\text { Underground storage tanks } \\
\text { Diesel fuel }\end{array}$ & 7 & 0 & 7 & 4 & 0 & 4 \\
Gasoline & 2 & 0 & 2 & 1 & 0 & 1 \\
Waste oil & 1 & 0 & 1 & 0 & 0 & 0 \\
Process wastewater & 3 & 31 & 34 & 0 & 7 & 7 \\
\hline$\quad$ Subtotal & $\mathbf{1 3}$ & $\mathbf{3 1}$ & $\mathbf{4 4}$ & $\mathbf{5}$ & $\mathbf{7}$ & $\mathbf{1 2}$ \\
\hline Aboveground storage tanks & 0 & 26 & 26 & 0 & 7 & 7 \\
Diesel fuel & 0 & 1 & 1 & 0 & 1 & 1 \\
Insulating oil & 10 (a) & 56 & 66 & 0 & 12 & 12 \\
Process wastewater & $\mathbf{1 0}$ & $\mathbf{8 3}$ & $\mathbf{9 3}$ & $\mathbf{0}$ & $\mathbf{2 0}$ & $\mathbf{2 0}$ \\
\hline$\quad$ Subtotal & $\mathbf{2 3}$ & $\mathbf{1 1 4}$ & $\mathbf{1 3 7}$ & $\mathbf{5}$ & $\mathbf{2 7}$ & $\mathbf{3 2}$ \\
\hline
\end{tabular}

a These 10 tanks are located at the LLNL Treatment and Storage Facility and are operated under interim status. 


\section{Compliance Summary}

Upon completion of closure activities, closure reports for underground hazardous product, hazardous waste, and mixed-waste underground storage tanks must be submitted to the regulatory agencies for review and approval. Three closure reports for hazardous waste underground storage tanks were submitted to the Alameda County Environmental Health Services agency for review in 1998. All three have been approved and were closed by removing the tanks. In 1998, two closure plans were prepared for aboveground hazardous-waste tank systems.

In 1992, LLNL began to upgrade or close wastewater retention tanks (for nonhazardous, hazardous, mixed, and radioactive waste) and product retention tanks (for petroleum products) in accordance with existing local, state, and federal tank regulations. This action was taken to decrease the potential for environmental contamination resulting from a release from a tank or its appurtenances. Work to bring LLNL into compliance with California and federal requirements for underground storage tanks was completed before the December 1998 deadline. The underground storage tanks were inspected, and no violations were found (see Table 2-5).

\section{Resource Conservation and Recovery Act}

The Resource Conservation and Recovery Act (RCRA) provides the framework at the federal level for regulating the generation and management of solid wastes, including wastes designated as hazardous. Similarly, the California Hazardous Waste Control Act (HWCA) sets requirements for managing hazardous wastes in California. RCRA and HWCA also regulate hazardous waste treatment, storage, and disposal facilities, including permit requirements. Because RCRA program authorization was delegated to the State of California in 1992, LLNL now works with DTSC on compliance issues and in obtaining hazardous waste permits.

\section{Hazardous Waste Permits}

\section{Livermore Site}

Hazardous waste storage and treatment management units at the Livermore site continued to operate under interim status provisions (ISD CA2890012584) while DTSC reviewed the latest modification to the Livermore site Part B permit application. Waste management units include container storage, tank storage, and various treatment processes (e.g., wastewater filtration, blending, and size reduction). 


\section{Compliance Summary}

A public hearing was held in October 1997, regarding the draft hazardous waste facility permit, including the proposed finding of the Initial Study conducted under the California Environmental Quality Act (CEQA). This Initial Study analyzed the potential environmental impacts of the proposed hazardous waste facility on the surrounding environment. The Initial Study found that the proposed facility does not significantly affect the environment, and a Negative Declaration was issued.

A number of comments were received at the public hearing and during the subsequent public comment period. During 1998, DTSC drafted responses to public comments and reviewed permit issues in consultation with LLNL. As a result, the permit application was revised in October, 1998.

As reported in the Environmental Report 1997 (Harrach et al. 1998), the Building 513 shredder incident on July 2, 1997, resulted in DOE and DTSC investigations. The DOE/OAK Type B Accident Investigation Committee issued their report on October 31, 1997, which included several Judgments of Need (JONs). LLNL, in turn, submitted an action plan in response to the JONs, and on March 11, 1999, DOE validated the completion of corrective actions derived from the JONs. DTSC representatives visited LLNL on November 12, 1997, and February 5, 1998. Their investigation of the shredder incident resulted in a Summary of Violations (SOV) dated February 9, 1998, which is still being disputed by LLNL. The shredder unit involved in the incident has undergone RCRA closure and the shredder equipment has been removed from service.

On May 26 and 27, 1998, DTSC conducted a Compliance Evaluation Inspection (CEI) of hazardous waste storage and treatment facilities at the Livermore site. DTSC reviewed inspection logs, training records, and treatment logs. Characterization documentation was requested for 10 containers, which included mixed, combined, and hazardous wastes. There was an extensive discussion of Hazardous Waste Management's waste acceptance process, including waste disposal requisitions, waste profiling, and the hold and verification process. A request for additional information was received on September 21, 1998. LLNL provided this information on October 15, 1998. To date, LLNL has not received an inspection report (see Table 2-5a).

\section{Site 300}

The Explosives Waste Storage Facility (EWSF), which augments the storage capability at Site 300 by providing a separate dedicated facility to store explosives waste, became operational in March 1998. Also, the Explosives Waste Treatment Facility (EWTF), which replaced the closed Building 829 Open Burn Facility, became operational in March 1999. Upon receiving DTSC approval, closure operations for the Building 829 


\section{Compliance Summary}

Open Burn Facility began in October 1997. The facility was closed in accordance with the Closure Plan for the High-Explosives Open Burn Facility at Lawrence Livermore National Laboratory Experimental Test Site 300 (Mathews and Taffet 1997). The closure report, Construction Quality Assurance for the RCRA Closure of Building 829 High Explosives Open Burn Treatment Facility, was submitted to DTSC in February 1999.

From June 16-17, 1998, DTSC conducted a Compliance Evaluation Inspection of Site 300 hazardous waste generator areas, the Building 883 Container Storage Area, and the EWSF. Because operations at the EWTF had not begun, the EWTF was not inspected. Two violations were issued as a result of the inspection (see Table $\mathbf{2 - 5 b}$ ). The first was issued for failing to provide specific training records in a timely manner. In the violation response letter to DTSC, LLNL agreed to provide training records related to the hazardous waste management program upon request by the inspector. The second violation was issued because training plans contained in facility permits were modified without obtaining permit modifications from DTSC. In response, LLNL agreed to update the training plans, including training course descriptions and numbers as well as job titles and descriptions, since the permits were issued in 1996 and 1997. The corrective action for the violation required LLNL to submit a permit modification request to DTSC pursuant to 22 CCR 66270.42. LLNL submitted the permit modification request to DTSC on January 19, 1999.

\section{Hazardous Waste Reports}

The biennial reports, Hazardous Waste Report-Mainsite and Hazardous Waste ReportSite 300, are required under 40 CFR 262.41, 264.75, and 265.75. These reports which address 1997 waste handling information, were completed and delivered to DTSC by the March 1, 1998, deadline. Two annual facilities reports, one for the Livermore site and the other for Site 300, which address 1998 waste handling information, were completed and submitted to meet DTSC's March 31, 1999, deadline. The annual reports are required under 22 CCR 66264.75 and are on file at LLNL.

\section{Hazardous Waste Transport Registration}

Transportation of hazardous waste over public roads (e.g., from one LLNL site to another) requires DTSC registration (22 CCR 66263.10). Conditions for registration may include annual inspections of transport vehicles and trailers by the California Highway Patrol (CHP), biennial terminal inspections, and special training and annual physical 


\section{Compliance Summary}

examinations for drivers. The registration was renewed by DTSC in November 1998. In 1998, the CHP in Alameda County opted to conduct vehicle safety compliance checks of vehicles assigned to the Livermore site and Site 300. The inspection of the Livermore site on December 9 resulted in two violations (see Table 2-5a). The inspection of Site 300 vehicles took place on December 4 and resulted in two violations (see Table $\mathbf{2 - 5 b}$ ). However, since the violations were vehicle-specific and LLNL received a satisfactory "current terminal rating," they were considered to be minor.

\section{Waste Accumulation Areas}

In January 1998, there were 26 Waste Accumulation Areas (WAAs) at the Livermore site. Consolidation efforts resulted in the closure of 8 WAAs; additionally, two temporary WAAs were put into service, resulting in a total of 20 WAAs at the Livermore site. Program representatives conducted formal inspections at least weekly at all WAAs to ensure that they were operated in compliance with regulatory requirements. Approximately 1183 formal WAA inspections were conducted at the Livermore site. In addition, personnel from LLNL's Environmental Protection Department (EPD) conducted informal biweekly walkthroughs at all WAAs to help programs manage their WAAs and wastes in compliance with state and federal regulatory requirements. EPD personnel performed 491 biweekly WAA walkthroughs at the Livermore site.

During 1998, program representatives conducted 104 formal inspections of two WAAs at Site 300. EPD personnel performed 40 biweekly WAA walkthroughs at Site 300 during 1998.

\section{California Medical Waste Management Act}

LLNL is registered with the Alameda County Department of Environmental Health $(\mathrm{ACDEH})$ as a generator of medical waste and has a treatment permit. A September 15, 1998, ACDEH inspection of buildings at Health Services, the Biology and Biotechnology Research Program, and the Medical Photonics Laboratory found neither compliance issues or violations (see Table 2-5a). All LLNL medical waste management operations comply with the California Medical Waste Management Act, Health and Safety Code Sections 117600-118360. 


\section{Compliance Summary}

\section{Federal Facility Compliance Act}

LLNL is continuing to work with DOE to maintain compliance with the Site Treatment Plan (STP) that was signed in February 1997. In 1998, LLNL reached 13 of its STP milestones, the majority by using commercial disposal facilities. The use of commercial facilities has and will allow earlier disposal of some waste streams than the dates listed in the STP.

\section{Toxic Substances Control Act}

LLNL began studying methods for treating and disposing of polychlorinated biphenyls (PCBs) after obtaining approval to conduct destruction studies from the EPA in August 1998. Authorizations were granted pursuant to section 6(e)(1) of the Toxic Substances Control Act, Public Law No. 94-469, and the Federal PCB Regulations, 40 CFR 761.60(I)(2), 761.60(e), and 761.65(d)(2). In 1998, LLNL chemists investigated the destruction of PCBs by molten salt oxidation and direct chemical oxidation. The processes are described in more detail in Chapter 3.

\section{National Environmental Policy Act}

The National Environmental Policy Act (NEPA-42 U.S.C. 4321 et seq.) established federal policy for protecting environmental quality. The major method for achieving established NEPA goals is the requirement for preparing an Environmental Impact Statement (EIS) for any major federal or federally funded project that may have significant impact on the quality of the human environment. If the need for an EIS is not clear, or if the project does not meet DOE's criteria for requiring an EIS, an Environmental Assessment (EA) is prepared. A Finding Of No Significant Impact (FONSI) is issued when an EIS is determined to be unnecessary.

Certain groups of actions that do not have a significant effect on the environment either individually or cumulatively can be categorically excluded from a more in-depth NEPA review (i.e., preparation of either an EA or EIS). DOE NEPA implementing procedures (61 FR 36222) identify those categorical exclusions and the eligibility criteria for their application. If a proposed project does not clearly fit one of the exclusion categories, DOE determines which type of assessment document may be needed. 


\section{Compliance Summary}

In 1998, one FONSI for the Environmental Assessment of the Arroyo Las Positas Maintenance Project was issued by DOE. Another EA for the construction and operation of the proposed Terascale Simulation Facility is being prepared. Eighteen categorical exclusion applications were approved by DOE, and there were no proposed actions at LLNL that required separate DOE floodplain or wetlands assessments under 10 CFR 1022.

\section{California Environmental Quality Act}

In November 1992, UC and LLNL made a commitment to implement 67 mitigation measures identified by the 1992 Final Environmental Impact Statement and Environmental Impact Report for Continued Operation of Lawrence Livermore National Laboratory and Sandia National Laboratories, Livermore (1992 Sitewide EIS/EIR U.S. Department of Energy and University of California 1992a and b) and to provide annual reports on their implementation. The measures are being implemented in accordance with the approved 1992 Mitigation Monitoring and Reporting Program associated with that joint DOE/UC EIS/EIR. The fiscal year 1996 annual report was published in 1998; the next annual report will cover fiscal year 1997 activities.

\section{National Historic Preservation Act}

The National Historic Preservation Act of 1966 (NHPA), as amended through 1992, requires federally operated and funded installations such as LLNL to balance agency missions with cultural values by integrating historic preservation into federal agency programs. Federal agencies must take into account the effects their projects may have on "historic properties" (cultural resources), and they must allow a reasonable time period for the Advisory Council on Historic Preservation (the Council) to comment. LLNL has three significant types of cultural resources: (1) prehistoric; (2) historic (turn-of-the-century homesteading, ranching, and industrial); and (3) historic (World War II and Cold War science and technology).

A draft Programmatic Agreement (PA) was developed by LLNL in 1997 in consultation with the DOE/Oakland Operations Office (DOE/OAK), the Council, and the California State Historic Preservation Office (SHPO) to help LLNL implement applicable federal and state cultural resource laws and regulations. These activities include cultural overviews, development of theme and context for significance evaluation, research designs, archaeological site identification and evaluation methods, and records and collection 


\section{Compliance Summary}

management. The activities will also generate needed data and methods in order to develop a Cultural Resource Management Plan (CRMP), the final objective of the PA.

As a result of consultation with the Council and the SHPO during a joint meeting with DOE in December 1998, the 1997 Draft PA is being modified and finalized. Also as a result of these consultations, LLNL will be able to relocate sections of an existing fire trail that cross through a known archaeological site. Grading of these sections has been suspended since 1994 and over the last few years, the trail has been cleared of vegetation by hand. However, it has become increasingly difficult to balance protection of the archaeological site with the labor, safety, and security needs of Site 300 personnel. To solve the dilemma, with the Council and SHPO concurrence, LLNL proposes to cut a new section of fire trail away from the archaeological site and discontinue use of the sections that now cross through the site. Final documentation of this proposed project has been submitted to DOE/OAK for review and submittal to the oversight agencies.

\section{Endangered Species Acts and Sensitive Natural Resources}

LLNL must meet the requirements of the U.S. Endangered Species Act, the California Endangered Species Act, and the California Native Plant Protection Act as they pertain to endangered or threatened species and other species of special concern that may exist or are known to exist at the LLNL sites. For example, in implementing the 1992 Mitigation Monitoring and Reporting Program in 1998, biological assessment surveys were performed for special-status species at 51 LLNL project construction (ground disturbance) areas. Presence data for the San Joaquin kit fox (Vulpes macrotis mutica), American badger (Taxidea taxus), and Western burrowing owl (Speotyto cunicularia) were collected at each project location, and other applicable mitigation measures were implemented where appropriate.

During 1998, no active San Joaquin kit fox dens were discovered, but five potential dens were found. Four occupied American badger dens were discovered, and 24 unoccupied dens were identified. Twelve active burrowing owl dens were discovered, and two potential dens were identified. A new population of the federally threatened red-legged frog (Rana aurora draytonii) was identified in the northwestern portion of Arroyo Las Positas on the Livermore site. Measures to mitigate the potential for future impacts to the frogs were developed through formal consultation with the U.S. Fish and Wildlife Service, which issued a "No Jeopardy" biological opinion in August 1998. In addition, a new population of the federal candidate species California tiger salamander (Ambystoma tigrinum) was found at a wetlands location at Site 300. 


\section{Compliance Summary}

Also, at the Livermore site, four pairs of white-tailed kites (Elanus lecurus), a state fully-protected raptor, successfully nested and fledged 14 young from these nests.

Two of the three known natural populations of the large-flowered fiddleneck (Amsinckia grandiflora), a federally listed endangered plant species, occur at Site 300. A portion of Site 300 has been designated as federal critical habitat for the plant. In addition, LLNL has established an experimental population within the designated critical habitat. LLNL is currently working with the U.S. Fish and Wildlife Service on continued monitoring of native and experimental Amsinckia populations, and to further develop habitat restoration and maintenance techniques. Investigations into the use of herbicides, controlled burns, and native bunch grass transplantation to reduce the amount of exotic grass cover are currently under way. A progress report was prepared and submitted to the U.S. Fish and Wildlife Service in September 1998 (Carlsen et al. 1998).

It appears that the smaller of the two native populations of fiddleneck was extirpated in 1997 when the bank containing the population was washed away. No plants were observed at this site in 1998. In January 1998, the remaining native population and the experimental population were treated with herbicide to reduce the amount of exotic grass cover at the site. Such grass cover has been shown to negatively impact Amsinckia size and reproductive output. However, even with this treatment, the number of fiddleneck plants remained low in the native population (218 plants), dropping an additional $42 \%$ compared to the number of plants observed in 1997 . The number of fiddleneck plants observed in the experimental population also declined by $90 \%$ (down to 64 plants) compared to 1997.

Although both populations were treated to reduce grass cover, the decline in the number of plants may still be due to the presence of exotic grass cover. It has been previously observed that increases in fiddleneck numbers in response to herbicide treatment can be delayed until the following growing season. A controlled burn was also conducted in part of the experimental site that no longer contains fiddleneck plants. The areas that underwent the controlled burn and were treated with herbicide will be monitored for the presence of fiddleneck plants in future years. In addition, investigations indicated a high level of seed predation at both sites. Thus, it is also possible that several years of heavy grass cover resulted in increased numbers of seed predators.

Monitoring of the big tarplant (Blepharazonia plumosa plumosa), a California Native Plant Society "rare" plant), and the diamond-petaled poppy (Eschscholzia rhombipetala, a plant thought to be extinct) continued in 1998. The big tarplant remained widespread throughout Site 300. A total of 26 diamond-petaled poppy plants were located. Of these, 18 plants produced seed-bearing pods. 


\section{Compliance Summary}

\section{Antiquities Act (of 1906): Paleontological Resources}

During soil excavation for the National Ignition Facility (NIF) at the Livermore site in 1997, a molar from a 14,000-year-old mammoth was found at a depth of about $10 \mathrm{~m}$ below the surface. After this discovery, LLNL obtained an excavation permit from the Department of Interior under the provisions of the Antiquities Act of 1906 and removed bones from the construction area in late 1997 and early 1998. The bones (including 11 ribs, three vertebrae, one humerus, one complete and one partial tusk, and a partial skull with palate, jawbone, and molars) are being accessioned into the U.C. Berkeley Museum of Paleontology collection and are being prepared for possible later presentation at LLNL.

\section{Environmental Occurrences}

Notification of environmental occurrences is required under a number of environmental laws and regulations, DOE Order 232.1, Occurrence Reporting and Processing of Operations Information, and DOE Order 5484.1, Environmental Protection, Safety, and Health Protection Information Reporting Requirements. DOE Order 232.1 provides guidelines to contractor facilities regarding categorization and reporting of environmental occurrences to DOE and divides occurrences into three categories: emergency occurrences, unusual occurrences, and off-normal occurrences

The EPD response to environmental occurrences is part of the larger LLNL on-site emergency response organization that also includes representatives from Hazards Control (including the LLNL Fire Department), Health Services, Plant Engineering, Public Affairs, Safeguards and Security, and Site 300. In 1998, six environmental incidents were categorized as Off-Normal Occurrences and one incident was categorized as an Unusual Occurrence according to the DOE Order 232.1 Implementing Procedures. On June 17, 1998, LLNL's revised Implementing Procedures for DOE Order 232.1 were approved by the DOE Oakland Operations Office. Reporting requirements for environmental and transportation incidents in the new Implementing Procedures were changed to correlate better with regulatory reporting criteria. These changes reduced the number of reportable occurrences by eliminating less significant occurrences from the DOE 232.1 reporting requirement.

None of the environmental occurrences, summarized in Table 2-9, caused any adverse impact to the public or the environment. Agencies notified of these incidents included EPA, DOE, Alameda County Health Care Services Agency, SFRWQCB, Office of Emergency Services, LWRP, and DTSC. 


\section{Compliance Summary}

Table 2-9. Tabulation of Environmental Occurrences reported under the Occurrence Reporting System, 1998.

\begin{tabular}{|c|c|c|}
\hline Date ${ }^{(a)}$ & $\begin{array}{c}\text { Occurrence } \\
\text { category }\end{array}$ & Description \\
\hline Jan 12 & Off-Normal & $\begin{array}{l}\text { A container of waste shipped to a TSDF contained three aerosol cans that were not listed on the } \\
\text { manifest. The hazardous contents of the cans were identified; however, the manifest failed to } \\
\text { note the materials were contained in aerosol cans. An error on a waste manifest meets the } \\
\text { requirements of an Off-Normal Occurrence under the Transportation Section. OR 1998-0001. }\end{array}$ \\
\hline Feb 2 & Off-Normal & $\begin{array}{l}\text { LLNL was notified on 2-2-98 by a commercial TSDF }{ }^{(b)} \text { that waste shipped to the facility by LLNL } \\
\text { had the incorrect } \mathrm{pH} \text { identified on the Uniform Hazardous Waste Manifest. The shipping papers } \\
\text { listed the waste as having a pH of } 3 \text {, while the TSDF verification sampling found a pH of } 13 \text {. A } \\
\text { violation of Department of Transportation regulations meets the requirements of an Off-Normal } \\
\text { Occurrence. OR 1998-0006. }\end{array}$ \\
\hline Feb 2 & Off-Normal & $\begin{array}{l}\text { Under the terms stipulated in our Wastewater Discharge Permit, LLNL reported findings of low } \\
\text { pH-and lead-bearing materials in } 1997 \text {. Lead was detected in daily composite samples of the } \\
\text { effluent to the LWTP(c) on } 10 / 31(28 \mathrm{mg} / \mathrm{L}) \text { and } 11 / 1(25 \mathrm{mg} / \mathrm{L}) \text {. On December } 5,15,19 \text {, and } \\
24,1997 \text {, on-line monitoring equipment detected a period during which the pH was below the } \\
\text { permit limit of } 5 \text {. On February } 2,1998, \text { LLNL received an NOV(d) from the LWTP for a violation } \\
\text { of the Sanitary Sewer Permit discharge limit for lead and pH. Receiving an NOV meets the } \\
\text { requirements of an Off-Normal Occurrence. OR } 1998-0008 \text {. }\end{array}$ \\
\hline Mar 18 & Off-Normal & $\begin{array}{l}\text { On March } 17,1998 \text {, a Building } 611 \text { motor pool employee observed that the suction pump in the } \\
\text { gasoline dispenser housing was leaking and notified his supervisor of the leak on that day. The } \\
\text { pump was immediately locked and repairs were ordered. On March } 18 \text {, the contaminated gravel } \\
\text { was excavated and the pump repaired. It is estimated that approximately one gallon of gasoline } \\
\text { was released, and that } 100 \% \text { of the released material was recovered. On March } 19 \text {, the } \\
\text { Alameda County Health Care Services Agency was notified of the release by voice mail. A } \\
\text { written report was provided to the agency on March } 25,1998 \text {. Written notification to a regulatory } \\
\text { agency meets the requirements of an Off-Normal Occurrence. OR 1998-0018. }\end{array}$ \\
\hline Oct 21 & Off-Normal & $\begin{array}{l}\text { LLNL received an NOV from the California DTSC during the } 1998 \text { Compliance Evaluation } \\
\text { Inspection of Hazardous Waste Management (HWM) operations. On October } 21,1998 \text {, the } \\
\text { DTSC (e) issued two violations to LLNL/Site } 300 \text {. One violation was received for failure to } \\
\text { provide specific employee training records promptly upon request, and a second violation was } \\
\text { received for failing to follow } 22 \text { CCR } 66270.42 \text {, Permit Modifications at the Request of the } \\
\text { Permittee, prior to modifying training plans for the employees working in the Explosive Waste } \\
\text { Storage Facility (EWSF) and Building } 883 \text {. Receiving an NOV meets the requirements of an } \\
\text { Off-Normal Occurrence. OR 1998-0059. }\end{array}$ \\
\hline Nov 25 & Off-Normal & $\begin{array}{l}\text { LLNL was notified by a TSDF that waste received from LLNL exceeded the facilities radioactivity } \\
\text { acceptance criteria of }<20 \mu R \text {. The finding was based on a survey of the waste container } \\
\text { indicating an activity level of } 26 \mu \mathrm{R} \text {. The container was returned to LLNL for verification and } \\
\text { found to contain thorium. Exceeding an offsite facility acceptance criteria meets the } \\
\text { requirements of an Off-Normal Occurrence. OR 1998-0063. }\end{array}$ \\
\hline
\end{tabular}




\section{Compliance Summary}

Table 2-9. Tabulation of Environmental Occurrences reported under the Occurrence Reporting System, 1998 (concluded).

\begin{tabular}{|l|l|l|}
\hline Date (a) & $\begin{array}{c}\text { Occurrence } \\
\text { category }\end{array}$ & \multicolumn{1}{c|}{ Description } \\
\hline Dec 18 & Unusual & $\begin{array}{l}\text { In October 1998, excavated soil from LLNL's East Traffic Circle was staged on and covered } \\
\text { with plastic in the Maintenance and Operations Soil Staging Area. Samples obtained from the } \\
\text { soil piles were analyzed for metals, volatiles, PCBs, and radioactivity. Results received from } \\
\text { the analytical laboratory indicated PCB contamination in excess of EPA Reportable Quantity. } \\
\text { Exceeding the EPA's Reportable Quantity meets the requirement of an Unusual Occurrence. } \\
\text { OR 1998-0064. }\end{array}$ \\
\hline
\end{tabular}

a The date indicated is the date the occurrence was categorized, not the date of its discovery.

b $\quad$ TSDF $=$ Treatment, storage, and disposal facility.

c $\quad$ LWTP $=$ Livermore Water Treatment Plant.

d NOV $=$ Notice of Violation.

e DTSC $=$ Department of Toxic Substance Control.

\section{Contributing Authors Acknowledgment}

Many authors significantly contributed to this large and diverse chapter. We acknowledge here the work of Jamie Bennett, Richard Blake, Winifred Burks-Houck, Tina Carlsen, Karen Doiron, Karen Folks, Gretchen Gallegos, Rod Hollister, Bill Hoppes, Jennifer Larson, Saverio Mancieri, Sandra Mathews, Willie Montemayor, Barbara Nisbet, Bill Schwartz, Judy Steenhoven, Michael Taffet, Stan Terusaki, Charlotte Van Warmerdam, Robert Vellinger, Joseph Woods, Jim Woollett, Jr., and Kenneth Zahn. 


\section{Environmental Program Information}

\section{Introduction}

Lawrence Livermore National Laboratory is committed to operating in a manner that preserves the quality of the environment. The Environmental Protection Department leads this effort in the areas of environmental compliance and accountability. This chapter begins with a brief description of LLNL's integrated Environmental, Safety, and Health (ES\&H) Management System, and continues with discussions of Work Smart Standards, missions, and activities of EPD and its three divisions. Performance measures (PMs) used by DOE to evaluate the Laboratory's environmental protection efforts are then summarized. The bulk of the chapter is devoted to an account of LLNL's activities and progress in waste minimization and pollution prevention in 1998. Following descriptions of current issues and actions in the environmental program arena, this chapter concludes with a brief discussion of spill response and EPD environmental training.

\section{Integrated Environmental, Safety, and Health Management System}

Protecting people and the environment is the most important consideration in day-today operations at LLNL. Attention to environmental, safety, and health factors is fully integrated into the Laboratory's research programs and operational culture. This integrated management approach requires accountability at all levels of the organization, project planning with protection in mind, and excellence in program execution. The ES\&H Program at LLNL employs a process of assessing hazards and the environmental implications of work; designing and implementing standards-based methods intended to control risks; and complying with the applicable ES\&H regulations. This process is implemented using a graded approach, which increases the level of risk management as the hazard increases. An overview of the Laboratory's current ES\&H Program and a general description of how the Laboratory manages ES\&H activities can be found in The Environmental, Safety, and Health Program at Lawrence Livermore National Laboratory (Lawrence Livermore National Laboratory 1996). 


\section{Environmental Program Information}

In October 1996, the Department of Energy issued DOE Policy 450.4: Safety Management System Policy. This policy provides a formal, organized process whereby employees plan, assess, and improve safety in their work. In this policy statement the term "safety" is used comprehensively to include environment, safety, and health. The policy was developed taking into consideration various consensus management standards such as International Standards Organization (ISO) 14000, Voluntary Protection Program (VPP), and Recommendation 95-2 from the Defense Nuclear Facility Safety Board. Integrated ES\&H management systems are defined as having five functions: to define the scope of work, analyze hazards, develop and implement standards-based controls, perform work, and provide feedback and improvement. Though the current LLNL ES\&H management process reflects the requirements of these five functions, LLNL is moving towards a formal integrated safety management system (ISMS). In December of 1998, LLNL submitted its ISMS description to DOE. This description articulates the institutional requirements for all LLNL operations and the requirements to be used in the institutional ES\&H manuals and individual directorate implementation plans. The description also includes a description of the major tasks, schedules, and milestones for implementation of ISMS. It also describes the parallel preparation of the Work Smart Standard Process, an integral part of ISMS that identifies the standards to be implemented under ISMS. Full implementation of ISMS will occur in 2000.

\section{Work Smart Standards}

In 1997, LLNL and DOE's Oakland Operations Office (DOE/OAK) inaugurated a Work Smart Standards (WSS) process, whereby safety professionals from both organizations identify hazards and establish standards of operation appropriate for the particular work environment. WSS will improve both safety and the working relationship between the DOE and LLNL and are expected to become part of the DOE contract with the University of California. DOE made the use of an environmental, safety, and health management system a policy (DOE Policy 450.4), an acquisition regulation (48 CFR 970.5204-2), and a contract requirement.

The WSS process (DOE M450.3-1) requires an understanding of the work, an analysis of the hazards associated with the work, and the selection of standards from which hazard controls are developed. LLNL has traditionally identified and controlled hazards to protect the LLNL staff, the public, and the environment, but the WSS process differs from the past in that responsibility for selection of appropriate and necessary standards is in the hands of both the DOE field office and LLNL. This process empowers the Laboratory and local DOE staffs, through consensus, to focus on the work being 
performed and to select sitewide environmental, safety, and health standards based on the actual work being conducted and its associated hazards and threats to the environment. During 1998, several hundred individuals participated in the WSS process, including over 100 subject matter experts who identified standards based on the work and the hazards. In addition, requirements for managing processes were identified to better connect project planning and execution with the standards, thereby providing protection to people and the environment. This process resulted in the identification of almost 700 individual requirements, with over 250 directly related to environmental protection. The WSS process also identified the need to develop nine local standards to either fill gaps or enhance existing standards; these ranged from standards on ergonomics to HEPA filters. Specifically, radioactive waste storage facility and tank system design criteria standards (Wood et al. 1999) were developed to ensure that requirements for facility design protect the environment.

These standards were approved at the management level closest to the work. Others cannot approve the set, require concurrence, or second-guess the standards selected. The LLNL Director and DOE Oakland Operations Office Manager will approve the final set of sitewide standards when they are confirmed in 1999 by an independent panel of external experts. Reaching these agreements with DOE on new work-based standards will align the Laboratory with industry practice; establish common environmental, safety, and health expectations for DOE and the University of California; and facilitate the tailoring of requirements to streamline and increase the effectiveness of management at the Laboratory. The existing ES\&H methodologies and documentation are being modified to incorporate the newly identified set of standards and to reflect the requirements of ISMS.

Meeting new expectations for integrated ES\&H management at the Laboratory will take several years, but the WSS approach coupled with enhanced, integrated management promises further safety improvements and lower costs.

\section{Environmental Protection Department}

The Environmental Protection Department (EPD) is the lead organization for environmental support to operations at LLNL. It is responsible for environmental monitoring, environmental regulatory compliance, environmental restoration, and hazardous waste management in support of the Laboratory's programs. EPD prepares and maintains environmental plans and guidelines, provides environmental guidance 


\section{Environmental Program Information}

and support to Laboratory personnel, informs management about pending changes in environmental regulations pertinent to LLNL, represents the Laboratory in day-to-day interactions with regulatory agencies, and assesses the effectiveness of pollution control programs.

EPD monitors air, water, soil, and foodstuff, as well as direct radiation; evaluates possible contaminant sources; and models the impact of LLNL operations on humans and the environment. In 1998, 15,686 samples were taken from air, sewage, ground water, surface water, soil, sediments, vegetation, and foodstuff. Almost 244,000 analytes were tested. These numbers represent a substantial decrease in the number of samples taken and a small decrease in the number of analytes tested, compared to 1997 values. The type of samples collected at a specific location depends on the site and the potential pollutants to be monitored; see the specific chapters of this report for discussions of each environmental medium.

A principal part of EPD's mission is to work with LLNL programs to ensure that operations are conducted in a manner that limits environmental impacts and is in compliance with regulatory guidelines. EPD helps LLNL programs manage and minimize hazardous, radioactive, and mixed wastes; determines the concentrations of environmental contaminants remaining from past activities; cleans up environmental contamination to acceptable standards; responds to emergencies in order to minimize and assess any impact on the environment and the public; and provides training programs to improve the ability of LLNL employees to comply with environmental regulations.

LLNL programs are supported by EPD's four ESTs. The ESTs are integrated into the Environmental, Safety and Health Teams (ES\&H Teams) at the Laboratory through the Environmental Analyst who chairs the ESTs. Each EST includes representatives from environmental specialties within the Operations and Regulatory Affairs Division (ORAD), along with a field technician from the Hazardous Waste Management Division. Some ESTs also include a representative from the Environmental Restoration Division (ERD), the ES\&H Teams, or the organizations supported by the ESTs. These teams evaluate operations, determine potential environmental impacts, and provide guidance on environmental regulations and DOE orders for existing and proposed projects. ESTs assist programs in planning, implementing, and operating projects and in understanding and meeting their environmental obligations. When permits are obtained from regulatory agencies, ESTs aid the program in evaluating the permit conditions and implementing recordkeeping requirements. 


\section{Operations and Regulatory Affairs Division}

ORAD currently consists of eight groups that specialize in environmental compliance and monitoring and provide laboratory programs with a wide range of information, data, and guidance to make more informed environmental decisions.

ORAD prepares the environmental permit applications and related documents for submittal to federal, state, and local agencies; provides the liaison between LLNL and regulatory agencies conducting inspections; tracks chemical inventories; prepares National Environmental Policy Act (NEPA) documents; conducts related field studies for DOE; oversees wetland protection and floodplain management requirements; coordinates cultural and wildlife resource protection and management; facilitates and provides support for the pollution prevention and recycling programs; teaches numerous environmental training courses; coordinates the tank environmental compliance program; conducts compliance and surveillance monitoring; and provides environmental impact modeling and analysis, risk assessment, and reporting.

ORAD also actively assists in responding to environmental emergencies such as spills. During normal working hours, an Environmental Analyst from the ORAD Environmental Operations Group responds to environmental emergencies and notifies a specially trained Environmental Duty Officer. Environmental Duty Officers are on duty 24 hours a day and coordinate with LLNL's ES\&H Team and other first responders or environmental specialists.

\section{Hazardous Waste Management Division}

All hazardous, radioactive, and mixed wastes generated at LLNL facilities are managed by the Hazardous Waste Management (HWM) Division in accordance with state and federal requirements. HWM processes, stores, packages, solidifies, treats, and prepares waste for shipment and disposal, recycling, or discharge to the sanitary sewer.

As part of its waste management activities, HWM tracks and documents the movement of hazardous, mixed, and radioactive wastes from waste accumulation areas (WAAs) located near the waste generator to final disposition; develops and implements approved standard operating procedures; decontaminates LLNL equipment; ensures that containers for shipment of waste meet the specifications of the U.S. Department of Transportation (DOT) and other regulatory agencies; responds to emergencies; and participates in the cleanup of potential hazardous and radioactive spills at LLNL facilities. HWM prepares numerous reports, including the annual and biennial 


\section{Environmental Program Information}

hazardous waste reports required by the state and federal environmental protection agencies (see Appendix C). HWM also prepares waste acceptance criteria documents, safety analysis reports, and various waste guidance and management plans.

HWM meets regulations requiring the treatment and disposal of LLNL's mixed waste in accordance with the requirements of the Federal Facility Compliance Act. The schedule for this treatment is negotiated with the State of California and involves developing new on-site treatment options, as well as finding off-site alternatives.

HWM is responsible for implementing a program directed at eliminating the backlog of legacy waste (waste that is not presently certified for disposal). This effort includes a large characterization effort to identify all components of the waste, and a certification effort, which will provide appropriate documentation for the disposal site.

\section{Environmental Restoration Division}

The Environmental Restoration Division (ERD) was established to evaluate and remediate contaminated soil and ground water resulting from past hazardous materials handling and disposal and from leaks and spills that have occurred at the Livermore site and Site 300, both prior to and during LLNL operations. ERD investigates field sites at both the Livermore site and Site 300 to characterize the existence, extent, and impact of contamination. ERD evaluates and develops various remediation technologies, makes recommendations, and implements actions for site restoration. ERD is responsible for managing remedial activities, such as soil removal and ground water extraction, and for assisting in closing inactive facilities in a manner designed to prevent environmental contamination.

As part of its responsibility for Comprehensive Environmental Response, Compensation and Liability Act (CERCLA) compliance issues, ERD plans, directs, and conducts assessments to determine both the impact of past releases on the environment and the restoration activities needed to reduce contaminant concentrations to protect human health and the environment. ERD is responsible for interacting with the community on these issues. Several public meetings are held each year as required in the ERD CERCLA Community Relations Plans. To comply with CERCLA ground water remedial actions at the Livermore site, ERD has to date designed, constructed, and operated five fixed ground water treatment facilities and associated pipeline networks and wells, seven portable ground water treatment units and two soil vapor extraction facilities (see Chapters 7 and 8). At Site 300, ERD has designed, constructed, and operated two soil vapor extraction facilities and four ground water extraction and treatment facilities. 
ERD is actively designing, testing, and applying innovative remediation and assessment technologies to contaminant problems at the Livermore site and Site 300. ERD provides the sampling and data management support for ground water surveillance and compliance monitoring activities.

\section{Performance Measures Summary}

Since 1992, the contract that the University of California has to manage and operate LLNL for DOE has contained performance objectives, criteria, and measures. Four of these performance measures (PMs) were used to evaluate LLNL's environmental protection activities.

At the end of 1998, DOE gave LLNL an average score of excellent for its environmental performance in 1997. DOE scores for individual performance measures are shown in Table 3-1. Performance is described in the Environmental Report 1997 (Harrach et al. 1998). Data for calendar year 1998 will be included in the annual self-assessment and evaluation conducted August through December 1999.

\section{DOE Pollution Prevention Goals}

The Secretary of Energy has committed the Department to the following Pollution Prevention (P2) goals, which are to be achieved throughout the complex by December 31, 1999, using 1993 as a baseline:

1. Reduce total releases and off-site transfers for treatment and disposal of Emergency Planning and Community Right-to-Know Act (EPCRA) 313 toxic chemicals from routine operations by $50 \%$.

2. Reduce the generation of radioactive waste from routine operations by $50 \%$.

3. Reduce the generation of low-level mixed waste from routine operations by $50 \%$.

4. Reduce the generation of hazardous waste from routine operations by $50 \%$.

5. Reduce the generation of sanitary waste (after recycling) from routine operations by $33 \%$.

6. Divert 33\% of sanitary waste from all operations for recycling.

7. Increase the affirmative procurement of Environmental Protection Agency (EPA) designated recycled products to $100 \%$. 


\section{Environmental Program Information}

Table 3-1. Contract 48 environmental protection performance measures.

\begin{tabular}{|c|c|c|c|}
\hline $\begin{array}{c}\text { PM } \\
\text { designator }\end{array}$ & Performance measure & Location in Environmental Report 1998 & Score \\
\hline 1.5.b & $\begin{array}{l}\text { Radiation Dose to the Public } \\
\text { Public radiation doses to the maximally exposed } \\
\text { individual from DOE operations will be measured } \\
\text { or calculated and controlled to assure that doses } \\
\text { are kept as low as reasonably achievable. }\end{array}$ & $\begin{array}{l}\text { Chapter 12: Radiological Dose Assessment; } \\
\text { section on Radiological Doses from } 1998 \\
\text { operations. } \\
\text { Chapter 2: Compliance Summary section on } \\
\text { National Emission Standards for Hazardous } \\
\text { Air Pollutants. }\end{array}$ & Outstanding \\
\hline $1.5 . \mathrm{g}$ & $\begin{array}{l}\text { Process and Solid Waste Generation } \\
\text { (Waste Reduction and Recycling) } \\
\text { The Laboratory continues to progress towards } \\
\text { meeting the DOE's pollution prevention goals for } \\
\text { the year } 2000 .\end{array}$ & $\begin{array}{l}\text { This chapter, section on Waste } \\
\text { Minimization/Pollution Prevention. }\end{array}$ & Excellent \\
\hline 1.5.h & $\begin{array}{l}\text { Environmental Violations } \\
\text { The rate of validated environmental violations } \\
\text { from inspections and reporting requirements } \\
\text { from regulatory agencies is kept low. }\end{array}$ & $\begin{array}{l}\text { Chapter 2: Compliance Summary, } \\
\text { Table 2-8. }\end{array}$ & Excellent \\
\hline 1.5. $\mathrm{i}$ & $\begin{array}{l}\text { Environmental Releases } \\
\text { The Laboratory controls occurrences of } \\
\text { environmental releases exceeding regulatory or } \\
\text { permitted levels imposed by local, state, or } \\
\text { federal agencies. }\end{array}$ & $\begin{array}{l}\text { Chapter 2: Compliance Summary, } \\
\text { Table 2-13. }\end{array}$ & Marginal \\
\hline
\end{tabular}

Progress toward achieving these goals is reported annually to the Secretary of Energy in DOE's Annual Report on Waste Generation and Pollution Prevention Progress (U.S. Department of Energy 1994, 1996a, 1997, 1998d, and 1999).

The DOE's Pollution Prevention Program Plan 1996 (U.S. Department of Energy 1996b) established six immediate priorities, due to be implemented by fiscal year 1998, which will help DOE Headquarters, the Operations Offices, and the sites focus resources on the most critical aspects of DOE's P2 program.

The six priorities are to: (1) establish senior management commitment to P2 implementation, (2) set quantitative, site-specific waste reduction and recycling goals, (3) institute performance measures, (4) implement cost-saving P2 projects, (5) design P2 into new products, processes, and facilities, and (6) ensure that site programs comply with federal, state, and DOE requirements. 
LLNL prepared a P2 Plan that meets the requirements of (1) DOE Orders 5820.2A and 5400.1; (2) RCRA Sections 3002(b) and 3005(h); and (3) Title 22 of the California Code of Regulations. This plan is reviewed annually and updated every three years; it was last updated and submitted to the DOE in May 1997 (Celeste 1997). The plan reviews past and current pollution prevention activities and states the objectives of LLNL's waste minimization and pollution prevention efforts.

The P2 Program at LLNL is an organized, comprehensive, and continuing effort to systematically reduce solid, hazardous, radioactive, and mixed-waste generation. The P2 Program is designed to eliminate or minimize pollutant releases to all environmental media from all aspects of the site's operations. These efforts help protect public health and the environment by reducing or eliminating waste management and compliance costs, resource usage, inventories and releases of hazardous chemicals, and civil and criminal liabilities under environmental laws.

In accordance with EPA guidelines and DOE policy, a hierarchical approach to waste reduction (i.e., source elimination or reduction, material substitution, reuse and recycling, and treatment and disposal) has been adopted and is applied to all types of waste.

\section{Waste Minimization/Pollution Prevention}

LLNL is required by UC Contract performance measure $1.4 \mathrm{~g}$ to annually review its waste generation for pollution prevention opportunities and to propose implementation projects. Previously, waste streams at LLNL were evaluated in terms of the total quantities of waste generated. However, the waste streams of greatest concern are not necessarily those having the largest volume. Each process that generates waste must be considered, as well as the individual characteristics of the components within each waste stream.

LLNL continues to use a weighted system to better rank the waste streams and to improve the prioritization of waste minimization efforts. The methodology assigns to each waste stream three weighting factors plus a factor based on annual quantity of waste generated. The three weighting factors use the following criteria: cost, waste type (which includes compliance and liability considerations), and operational aspects (such as routine vs nonroutine) as discussed in the 1997 Comprehensive Opportunity Assessment for Pollution Prevention at Lawrence Livermore National Laboratory (Celeste et al. 1998). 


\section{Environmental Program Information}

In general, the 20 waste stream components having the highest priority (ranked by summing the four weighting factors) are entirely different from the top 20 sources ranked by quantity only. For example, transuranic waste (TRU)/TRU mixed and lowlevel wastes, which are problematic at LLNL, are now ranked as having the highest priority, though their relative quantities are somewhat low.

Routine waste generation by waste category, from 1993 through 1998, is shown in Table 3-2. In fall 1998, DOE/OAK expressed concern that the quantity of waste that LLNL reported for 1993 may not have been tracked and recorded as accurately as the waste quantities that were reported using criteria that were developed after 1993. Additionally, since 1994, LLNL has reported the waste quantities using new, improved technologies and procedures. Waste volumes for the years 1994 through 1997 were plotted using regression analysis to estimate the amount of waste generated in 1993.

Those new values for the years 1993 to 1998 are shown in Table 3-2. The trend from 1993 on shows a dramatic reduction in all waste categories, which is the result of a proactive P2 program at LLNL.

Table 3-2. Routine waste generation totals, 1993 to 1998 (in tons).

\begin{tabular}{|l|c|r|r|r|r|r|}
\hline \multicolumn{1}{|c|}{ Waste category } & $\begin{array}{c}1993 \\
\text { (Baseline) }\end{array}$ & $\mathbf{1 9 9 4}$ & $\mathbf{1 9 9 5}$ & $\mathbf{1 9 9 6}$ & $\mathbf{1 9 9 7}$ & $\mathbf{1 9 9 8}$ \\
\hline Low-level radioactive & 256 & 181 & 136 & 91 & 68 & 73 \\
Low-level mixed & 34 & 26 & 36 & 23 & 21 & 25 \\
Hazardous & 628 & 368 & 368 & 360 & 240 & 232 \\
Sanitary & 2600 & 2246 & 2246 & 2001 & 2017 & 2201 \\
\hline \multicolumn{1}{|c|}{ LLNL totals } & 3518 & 2821 & 2786 & 2475 & 2346 & 2531 \\
\hline
\end{tabular}

Table 3-3 presents the percent reductions in routine waste generation for 1998 compared to the 1993 baseline. With the decreases in routine radioactive and hazardous waste generation in 1998, the laboratory has already met the 50\% reduction goal for the performance measure. In the last two quarters of 1998, operational changes resulted in added processing of low-level, liquid mixed waste. This reprocessing added to the total solid low-level mixed waste. 


\section{Environmental Program Information}

Table 3-3. Routine waste reduction, 1998.

\begin{tabular}{|l|c|}
\hline \multicolumn{1}{|c|}{ Waste category } & Reduction 1998 vs 1993 (\%) \\
\hline Radioactive & 71.5 \\
Mixed & 26.5 \\
Hazardous & 63.1 \\
Sanitary & 15.3 \\
\hline
\end{tabular}

\section{Nonhazardous Solid Waste Minimization}

In 1998, LLNL sent 4705 tons of nonhazardous waste, including routine and nonroutine, (designated sanitary waste in the above tables) to a landfill. The routine portion was 2201 tons, and the nonroutine portion was 2504 tons. The breakdown is shown in

Table 3-4.

Table 3-4. Nonhazardous landfill totals (in tons), 1998.

\begin{tabular}{|l|r|}
\hline \multicolumn{1}{|c|}{ Landfill } & $\mathbf{1 9 9 8}$ total \\
\hline Routine & 2093 \\
Compacted & 52 \\
Industrial (TWMS)(a) $^{(\text {Routine subtotal }}$ & 2201 \\
\hline Nonroutine & \\
Construction demo (non-compacted) & 2446 \\
Industrial (TWMS) & 58 \\
Nonroutine subtotal & 2504 \\
\hline$\quad$ LLNL total & 4705 \\
\hline
\end{tabular}

a $\quad$ TWMS $=$ Total Waste Management System.

\section{Diverted Waste}

The total waste diverted from landfills in 1998 was 31,513 tons. This year's total is comparable with that for 1996, although it is significantly less than the diversion total for 1997. Last year there was a more than 25-fold increase over 1996 because there was an increase in soil reuse, which was predominately driven by the National Ignition Facility (NIF) construction. Soil is reused on site and at the landfill for daily cover, and we continue to use asphalt as road base material at the landfill (3860 tons). The waste diversion summary is shown in Table 3-5. 


\section{Environmental Program Information}

For 1998, the total of the diverted waste and nonhazardous waste sent to landfill was 36,218 tons. The recycling rate for nonhazardous waste is calculated by dividing the diverted waste by the total of the landfill plus the diverted waste total. This results in a recycling rate of $87 \%$ for the nonhazardous waste for 1998 .

One component of the LLNL waste stream that is successfully recycled consists of wood waste created by broken pallets, shipping crates, and demolition or construction scrap. This wood cannot be cost-effectively reused on site, so it is gathered in a collection yard for vendor removal at a cost lower than that of other disposal alternatives. Intact pallets and other reusable wood remain on site for internal reuse. In 1998, LLNL diverted 346 tons of wood from its solid waste stream.

Table 3-5. Waste diversion summary table, 1998.

\begin{tabular}{|l|c|}
\hline \multicolumn{1}{|c|}{ Description } & Cumulative $\mathbf{1 9 9 8}$ total (tons) \\
\hline Asphalt & 3,860 \\
Batteries & 30 \\
Cardboard & 120 \\
Compost & 297 \\
Cooking grease/food & 3 \\
Diverted soil & 24,606 \\
Hazardous Waste Management recycled materials & 343 \\
Magazines, newspapers and phone books & 161 \\
Metals & 1,434 \\
Paper & 290 \\
Tires and scrap & 25 \\
Toner cartridges & 2 \\
Wood & 346 \\
\hline LLNL diversion total & 31,517 \\
\hline
\end{tabular}

Another waste reduction method converts landscape clippings from the site's lawns, trees, shrubs, and annual plantings into compost. Once it is properly aged, the compost is used on site as a soil amendment. By generating its own soil builders, LLNL benefits twice: by eliminating an organic waste stream (with no tipping fees or hauling required), and by saving the purchase cost of new material. Gardeners also create a bright and attractive mulch by chipping office Christmas trees at the end of the holiday season. This mulch is stockpiled for year-round use because it reduces the amount of dry-season irrigation necessary in tree wells. LLNL also collects and recycles phone 


\section{Environmental Program Information}

books issued by regional telecommunications companies. These external phone books would otherwise contribute to the solid waste stream. In 1997, the laboratory recycled external phone books through a local vendor who emptied the bins when requested. In 1998, this program was incorporated into the LLNL newspaper/magazine drop-off recycling program.

The most visible component of the LLNL recycling effort is the office-paper collection and reclamation project. The laboratory operates a full-site program, with more than 120 facility collection points. Unclassified paper is transported to a contract firm where it is shredded and recycled into toilet paper and egg cartons. Classified paper is preprocessed at the Livermore site using a hammer mill destruction process.

For LLNL's UC contract, the goal is to reduce the routine nonhazardous (compactible and industrial) waste by 33\% by December 31, 1999. As shown in Table 3-4, LLNL generated 2201 tons of routine nonhazardous waste in 1998.

Cities and counties have been required by California law to reduce nonhazardous solid waste by 25\% and 50\% between 1990 and 1995 and 2000, respectively. Thus, LLNL tracks and reports waste diversions to the County of Alameda. Significant reductions in 1998 have already been achieved. Compared to 1990, LLNL reduced its nonhazardous waste by almost $26 \%$, which compares favorably with unincorporated Alameda County $(8.9 \%)$ and the City of Livermore (13.8\%), for 1995. Additional details are discussed in Assessing the Nonhazardous Solid Waste Stream at Lawrence Livermore National Laboratory (Wilson 1999).

\section{Source Reduction and Pollution Prevention}

In 1998, LLNL continued to survey on-site operations for opportunities to eliminate, reduce, recover, or recycle potential pollutants to all media, including air, water, soil, sediments, and biota.

\section{Toxic Reporting Inventory Information}

At LLNL only one chemical, Freon 113 (1,1,2-trichloro-1,2,2-trifluoroethane, also known as CFC 113), was tracked and reported as part of the Toxic Release Inventory for 1998. This reporting is required by the Emergency Planning and Community Right-to-Know Act. All other chemicals are present in quantities below the threshold reporting levels or are in a form that does not require reporting. 


\section{Environmental Program Information}

Freon 113, which is used in parts cleaning operations and as a coolant or refrigerant, is an ozone depleting substance whose consumption and production is slated for elimination by the year 2000. For this reason, the replacement and recycling of Freon 113 is a high priority at LLNL.

\section{Implementing Cost-Saving Pollution Prevention (P2) Projects}

As previously reported (Celeste et al. 1998) Pollution Prevention Opportunity Assessments (PPOAs) are conducted before the implementation of Pollution Prevention (P2) projects. The purpose of PPOAs is to characterize waste streams and identify those $\mathrm{P} 2$ options that can be implemented cost effectively.

The DOE funds P2 projects through the High-Return-on-Investment P2 Program. To date, DOE has funded High-Return-on-Investment projects at LLNL worth over $\$ 2.6$ million, which has resulted in a projected annual savings in excess of \$5.4 million. LLNL additionally uses return on investment calculations and estimates of project costeffectiveness to prioritize P2 projects for resource allocation and implementation at the Laboratory.

\section{Review of New Processes or Experiments}

Many organizations at LLNL use a "front-end" review process that applies to new programs, projects, or experiments that could have a significant impact on the environment. In this review process, the initial hazardous materials projected to be used are identified, and concentrations of both the starting materials and the wastes produced are estimated. The possibility for chemical substitution, process changes, and recycling is then addressed. If an opportunity for P2 is identified, the Pollution Prevention Group will assist the generator in evaluating the options. Researchers and project managers are encouraged to implement alternatives that are less hazardous or nonhazardous.

In general, P2 activities are covered by the pertinent directorate's P2 Plan. New activities are reviewed to identify possible P2 techniques. All personnel are encouraged to implement reasonable P2 opportunities that have been identified. 


\section{Design for Environment}

In general, any means of accomplishing the goal of minimizing environmental life-cycle impacts can be thought of as an element of design for environment, a concept that involves developing an understanding of and consideration for minimizing environmental impact over the lifetime of a project, and mitigating potential environmental impacts by overlaying this understanding directly onto the design of the project. Federal facilities are now required, under Executive Order 12856, to apply life-cycle analysis and total cost accounting principles to the greatest extent practicable when estimating P2 opportunities. Both of these can be considered elements of a new federally funded facility. In addition, Executive Order 13101, which replaced Executive Order 12873 in September 1998, requires federal facilities to implement P2 by giving preference to the purchase of environmentally preferable products and requires that pollution prevention and life-cycle analysis be considered when plans, drawings, work statements, and specifications are developed. Executive Order 13101 also allows the use of "multi-media" EPA inspections of federal facilities, including compliance with this order.

The first NIF Pollution Prevention and Waste Minimization Plan was completed in 1998 (Cantwell and Celeste 1998). In 1997, the Pollution Prevention Group and NIF project management completed a design-for-environment evaluation of the opportunities within the NIF Project (Harrach et al. 1998). Based on this evaluation, the laboratory is implementing recycling programs during NIF construction, developed a Pollution Prevention Plan for NIF, and implemented aqueous cleaning concepts in the design for parts and optics cleaning. The NIF Pollution Prevention Plan included PPOAs on the predicted waste streams identified in the Preliminary Environmental Impact Statement (PEIS). The PPOAs are aimed at developing waste minimization options prior to the operational phases of NIF.

Additionally, P2 measures that are technically and economically practicable are being considered in the design of the Site 300 Contained Firing Facility (CFF). Lists from architectural information exchanges and from P2 design documents are provided to the CFF design team for evaluation. The CFF project has an individual designated as the P2 coordinator for the project.

\section{Implementing P2 Employee Training and Awareness Programs}

Pollution prevention awareness information, which covers all disciplines, is disseminated in documents such as the Pollution Prevention Plan (Celeste 1997) and $A$ 


\section{Environmental Program Information}

Comprehensive Opportunity Assessment for Pollution Prevention at Lawrence Livermore National Laboratory (Celeste et al. 1998); posters and videos at events such as Earth Day; training and orientation; conferences and workshops; membership on LLNL committees; and formal presentations to groups such as ES\&H Working Group's Environmental Subcommittee.

Pollution prevention awareness is promoted through Newsline (LLNL's weekly newspaper) articles and administrative memos. The Pollution Prevention Group has developed a website to electronically distribute P2 information and also prepares brochures that briefly describe the P2 program at LLNL.

The Pollution Prevention Group reviews Hazardous Waste Management's Total Waste Management System (TWMS) database monthly. By reviewing this database, which tracks waste generation, the Pollution Prevention Group can identify waste streams with potential problems for each directorate and address issues in a timely manner.

\section{Current Return-on-Investment Projects}

Based on the results of some of the Pollution Prevention Opportunity Assessments, LLNL prepared some High Return-On-Investment P2 project proposals in 1998. Major High Return-On-Investment projects that were completed, were ongoing projects, or began in 1998 are listed in Table 3-6.

Table 3-6. High Return-on-Investment projects in 1998.

\begin{tabular}{|l|l|}
\hline \multicolumn{1}{|c|}{ Operation } & \multicolumn{1}{c|}{ Project } \\
\hline Solvent-based parts washers & Replaced with water-based small parts washers \\
Machine shop coolant, Building 321 & Installed with cold evaporators for coolant recycling \\
Freon 113 parts cleaning & Replaced with ultrasonic cleaning unit \\
Radiograph, Building 329 & Installed digital conversion radiography equipment \\
\hline
\end{tabular}

\section{ChemTrack}

ChemTrack, which is a computerized chemical inventory system, serves as an important tool for ensuring that LLNL complies with the Superfund Amendment and Reauthorization Act (SARA) Title III and California Business Plan reporting requirements and for improving the overall management of hazardous materials. ChemTrack enhances LLNL's ability to obtain the toxic release information necessary to complete SARA 313 


\section{Environmental Program Information}

submittals, to improve emergency response capabilities and management of Material Safety Data Sheets (MSDSs), to more closely track specific high-hazard chemicals and other regulated substances, and to screen selected LLNL facilities for preliminary hazard analyses. ChemTrack currently has an inventory of approximately 178,000 chemical containers ranging from 210-L drums to gram-quantity vials.

\section{Current Issues and Actions}

Many current issues and actions are described in this report according to chapter subjects. This section lists several not covered elsewhere.

\section{ATSDR Assessment}

The Agency for Toxic Substances and Disease Registry (ATSDR) is a federal public health agency whose mission is to prevent exposure and adverse human health effects and diminished quality of life associated with exposure to hazardous substances from waste sites, unplanned releases, and other sources of pollution in the environment. As part of its mission, ATSDR is mandated by Congress to conduct Public Health Assessments (PHAs) at sites, such as LLNL, that appear on the National Priorities List.

In 1997, ATSDR conducted site team meetings to identify site-related health concerns to be evaluated as part of the PHA review process. ATSDR worked with the California Department of Health Services (CDHS) to complete two health consultations related to Livermore site operations, which will likely be part of the final PHA for LLNL. The first draft health consultation report assessed concerns related to the discovery of plutonium at levels above background in Big Trees Park, Livermore. The second draft report assessed the potential impacts on water quality of the municipal water supply that serves the city of Livermore and identified private wells located in the vicinity of LLNL.

Although neither draft report identified any health risks, each report made several recommendations for further action. To resolve public concern raised during the process, LLNL voluntarily initiated another sampling program for Big Trees Park. The first sampling program was conducted in 1995 and led the EPA to determine that any plutonium in the park was below the level of health concern; no further action was suggested by regulatory agencies. The 1998 sampling plan and activity was directed by the EPA, CDHS, and the Regional Water Quality Control Board (RWQCB). LLNL completed the sampling by late summer and sent the results to two independent 


\section{Environmental Program Information}

laboratories for analysis. (See Chapter 9 for more information the sampling and analysis.) The EPA, CDHS, and RWQCB released a statement to the media any plutonium the park was below the level of health concern. ATSDR will issue a "pathways" analysis in late 1999. LLNL continues to work with ATSDR to resolve comments on the reports.

\section{Miniature Optical Lair Explorer}

In 1994, the Operations and Regulatory Affairs Division (ORAD) developed and began using the Miniature Optical Lair Explorer (MOLE) to perform biological assessment studies at Site 300. The MOLE is a miniature tracked vehicle with a tiny camera that allows scientists to investigate subterranean tunnel systems of special-status wildlife species to determine animal presence and numbers. LLNL performs surveys for the San Joaquin kit fox, burrowing owl, and American badger before starting ground-disturbing activities to ensure they are protected, if they are present.

The MOLE was used successfully at LLNL in 1998 to survey for the presence of several special-status species with subterranean habits: the burrowing owl, American badger, California tiger salamander, and California red-legged frog. Further development and use of the MOLE will continue in 1999.

\section{Leaking Underground Fuel Tank Studies}

In 1995, LLNL led a team of researchers from the Laboratory and four University of California campuses in a collaborative study of underground contamination from leaking underground fuel tanks (LUFTs). The study, performed for the California State Water Resources Control Board (SWRCB), found that once fuel leak sources have been removed, fuel contamination generally does not spread far from the leak site. Given time, naturally occurring microbes in the soil and ground water will usually break down most of the pollutants before they can reach a source of drinking water. On the basis of this study, the SWRCB is revising its overall ground water cleanup policy, ranking cleanup sites by their risk to drinking water sources, and selecting appropriate cleanup techniques based on risk.

One of the important recommendations of the study was to identify a series of LUFT demonstration sites and to form a panel of experts made up of scientific professionals from universities, private industry, and federal and state regulatory agencies. This 


\section{Environmental Program Information}

panel would provide professional interpretations and recommendations regarding LUFT evaluations and closures at demonstration sites.

As a result of this recommendation the California Military Environmental Coordination Committee Water Process Action Team, Department of Defense (DoD) sites were selected in 1996. Site selection was coordinated through. Sites were selected to represent each branch of the military services with bases in California, as well as a number of Regional Water Quality Control Boards (RWQCBs) and the diverse hydrogeologic settings in California where fuel hydrocarbon contaminant cleanup problems occur. The sites selected and their corresponding RWQCB regions are: Army Presidio at San Francisco, San Francisco RWQCB; Barstow Marine Corps Logistic Center, Lahontan RWQCB; Camp Pendleton Marine Corps Base, San Diego RWQCB; Castle Air Force Base, Central Valley RWQCB; China Lake Naval Weapons Center, Lahontan RWQCB; El Toro Marine Corps Air Station, San Diego RWQCB, George Air Force Base, Lahontan RWQCB; Port Hueneme Naval Construction Battalion Center, Los Angeles RWQCB; Travis Air Force Base, San Francisco RWQCB; and Vandenberg Air Force Base, Central Coast RWQCB.

The Expert Oversight Panel, formed as part of the demonstration project, recommended an appropriate risk-management strategy at each site and the set of actions needed to achieve site closure. The strategy was based on developing conceptual models that identify potential hazards associated with sources, pathways, and receptors. The recommendations also included site-specific findings regarding natural attenuation potential and discussion with regulators.

All sites in the demonstration project were reviewed and site specific recommendations submitted to each site. A Final Program Report was released in October 1998.

As part of continuing leaking underground fuel tank studies, LLNL completed an 18-month study evaluating impacts of the fuel oxygenate methyl tertiary-butyl ether (MTBE) and submitted it to the California SWRCB. The study concluded that:

- $\quad$ MTBE is a frequent and widespread contaminant in shallow ground water throughout California. Of the 32,409 leaking underground fuel tank sites recognized in the state, hydrocarbons are known to have impacted ground water at 13,278. A minimum estimate of the number of MTBE-impacted sites in California is greater than 10,000.

- $\quad$ MTBE plumes in ground water behave differently from other semiwatersoluble fuel components such as benzene, toluene, ethylbenzene, and xylenes (BTEX). 


\section{Environmental Program Information}

- $\quad$ Evidence to date indicates that MTBE is not significantly biodegraded in ground water. Assuming MTBE resistance to biodegradation, concentrations of dissolved MTBE in ground water will eventually diminish sufficiently to meet regulatory concentration goals because of dispersion, although the time it may take to diminish may be significantly longer than for the more biodegradable BTEX compounds.

- $\quad$ MTBE has the potential to impact regional ground water resources and may present a cumulative contamination hazard because of the chemical's apparent resistance to biodegradation and its mobility. With a compound that appears both ubiquitous and stable, water resource management on the regional scale will become increasingly important.

- $\quad$ Leak prevention is a critical requirement for the continued use of MTBE to ensure future protection of drinking water resources.

\section{Initiative to Improve VOC Cleanup Process by Using Historical Case Analysis}

The goal of this initiative is to evaluate a large number of nationwide historical cases to identify common volatile organic compound (VOC) release conditions that pose low risks and can be managed with minimal effort and cost, versus release conditions that pose higher risks and warrant larger expenditures. The key to this initiative is a crosscutting evaluation of the large amount of VOC case data that is available.

As part of this initiative, two groups have been formed: a Working Task Force (WTF) and a Peer Review Panel (PeerRP). The WTF will focus on technical issues of historical VOC case data collection and analysis and prepare draft findings and conclusions based on the data analysis. The PeerRP will review key deliverables, raise technical issues, and review and comment on draft findings, conclusions, and any recommendations. WTF includes members from the DOE, DoD, U.S. Navy and Air Force, EPA, California RWQCBs, and the Environmental Council of States' Interstate Technology and Regulatory Cooperation (ITRC) working group.

A Phase 1 final report titled, "Historical Case Analysis of Chlorinated Volatile Organic Compound Plumes" has been prepared, reviewed and submitted to the ITRC working group. 


\section{Spill Reporting}

The federal government and the State of California have several distinct statutory and regulatory provisions that require responsible persons to report releases or threatened releases of hazardous materials or pollutants into the environment. DOE has also established various orders that require reporting of incidents to DOE Headquarters. These provisions have varying requirements regarding the types of releases that must be reported, the timing of the report or notification (immediate and follow-up), the content of the report (e.g., source of the release, nature of the material, and the quantity released), and the particular agencies that must be notified. Many releases must be reported under more than one provision, and compliance with one provision will not necessarily satisfy another applicable provision.

\section{Response to Spills and Other Environmental Emergencies}

All spills and leaks (releases) that are potentially hazardous to the environment are investigated and evaluated. The release response process includes identifying the release, shutting off the source (if safe to do so), eliminating ignition sources, contacting appropriate emergency personnel, cordoning off the area containing the released material, absorbing and neutralizing the released material, assisting in cleanup, determining if a release must be reported to regulatory agencies, and verifying that cleanup (including decontaminating and replenishing spill equipment) is complete. Environmental analysts provide guidance to the programs on preventing spill recurrence.

To maximize efficient and effective emergency environmental response, EPD established a 7-days-a week, 24-hours-a-day, on-call rotational position entitled the Environmental Duty Officer (EDO). Specialized EDO training includes simulated accidents to provide the staff with the experience of working together to resolve environmental issues within the regulatory structure. The on-duty EDO can be reached by pager or cellular phone at any time.

During normal work hours, Laboratory employees report all environmental incidents to the Environmental Operations Group (EOG) environmental analyst assigned to support their program area. The EOG environmental analyst then notifies the on-duty EDO of the incident, and together, they determine applicable reporting requirements to local, state, and federal regulatory agencies and to the DOE. The EDO and the EOG environmental analyst also notify and consult with program management and have 7-days-a-week, 24-hours-a-day access to the office of Laboratory Counsel for questions concerning regulatory reporting requirements. 


\section{Environmental Program Information}

During off-hours, Laboratory employees report all environmental incidents to the Fire Dispatcher, who, in turn, notifies the EDO and possibly the Fire Department. The EDO then calls out additional EPD support to the incident scene as necessary, and follows the same procedures as outlined above for normal work hours.

\section{Environmental Training}

Major efforts are ongoing to provide LLNL employees with training on environmental topics aimed at improved compliance. Training tasks address both specialized training for environmental professionals and training in a variety of environmental topics for employees at all levels throughout LLNL. Courses presented by EPD's Training Section are listed in Table 3-7.

Table 3-7. EPD training courses.

\begin{tabular}{|l|}
\hline Hazardous Waste Generation and Certification \\
\hline Hazardous Waste Generation and Certification Review \\
\hline Emergency Response for Environmental Duty Officers \\
\hline Waste Retention Tank Management \\
\hline Waste Accumulation Area Operations \\
\hline Hazardous Waste Transportation \\
\hline Storm Water Pollution Prevention \\
\hline National Environmental Policy Act (NEPA) Compliance \\
\hline Spill Prevention, Control and Countermeasure Training \\
\hline TRU Waste Generation and Certification \\
\hline Legacy Waste Process Knowledge Evaluation \\
\hline Waste Process and Matrix Identification \\
\hline Waste Characterization Approval \\
\hline Field Fingerprint Identification \\
\hline
\end{tabular}

\begin{tabular}{|l|}
\hline RCRA $^{(a)}$ Facility Management \\
\hline RCRA for EWSF/EWTF(b) \\
\hline New Hire Orientation \\
\hline Petroleum Product Storage Tank Management \\
\hline Hazardous Waste Sampling \\
\hline Identification of Hazardous Material \\
\hline Low-Level Waste Generation and Certification \\
\hline SARA/OSHA ${ }^{(c)}$ Refresher Training \\
\hline SARA/OSHA Field Experience \\
\hline Packaging and Shipping Operations \\
\hline Environmental Duty Officer Briefings \\
\hline Waste Management Unit OJT(d) \\
\hline Air Source Management \\
\hline Drills and Exercises for HWM \\
\hline
\end{tabular}

a $\mathrm{RCRA}=$ Resource Conservation and Recovery Act.

b EWSF/EWTF = Explosive Waste Storage Facility/Explosive Waste Treatment Facility.

c SARA/OSHA $=$ Superfund Amendment and Reauthorization Act/Occupational Safety and Health Administration.

d OJT = On-the-job training. 


\section{LLNL's Other Environmental Programs}

While EPD plays a central role, every directorate at LLNL is responsible for environmental compliance and minimizing the impacts of its operations. Several directorates have taken particularly noteworthy steps in this direction. These include the plans for Defense Nuclear Technologies Program's Contained Firing Facility at Site 300 that will move explosive tests inside a facility where the debris is contained, the Laser Program's efforts to design the National Ignition Facility to have minimal environmental impact, Engineering's Metal Finishing Group's efforts to reduce waste and substitute less hazardous chemicals in many of their processes, and the Education Program's efforts to enhance environmental education.

Integral to LLNL's environmental research is the Environmental Programs Directorate that conducts multidisciplinary research to assess and mitigate environmental and human risk from natural and man-made hazards and to develop and demonstrate new tools and technologies for environmental restoration. This work includes studies in the design, analysis, and testing of advanced waste-treatment technologies; in situ environmental remediation using natural and engineered processes; pathway, dosimetry, and risk analysis of radioactive and toxic substances; atmospheric dynamics; subsurface imaging and characterization; and seismic processes.

\section{Contributing Authors Acknowledgment}

Major contributors to this diverse chapter were, Sabre J. Coleman, Winifred A. Burks-Houck, C. Susi Jackson, Constance E. DeGrange, David Rice, Stephanie S. Goodwin, and James S. Woollett, Jr. 



\section{Air Effluent Monitoring}

Arthur H. Biermann

Linda C. Hall

Paula J. Tate

\section{Introduction}

Lawrence Livermore National Laboratory performs continuous air effluent sampling of atmospheric discharge points at several facilities. LLNL assesses air effluent emissions from facility operations to evaluate compliance with local, state, and federal regulations and to ensure that human health and the environment are protected from hazardous and radioactive air emissions.

\section{Air Quality Laws}

LLNL complies with local, state, and federal environmental air quality laws and Department of Energy (DOE) regulations. DOE Orders 5400.1, General Environmental Protection Program, and 5400.5, Radiation Protection of the Public and the Environment define standards for controlling exposures to the public from operations at DOE facilities. Subpart H of the National Emission Standards for Hazardous Air Pollutants (NESHAPs), 40 Code of Federal Regulations (CFR) 61, requires the continuous monitoring of certain discharge points and the estimation of dose to the public resulting from operations at DOE facilities. Guidance on air effluent sampling is provided in the Environmental Regulatory Guide for Radiological Effluent Monitoring and Environmental Surveillance (U.S. Department of Energy 1991), 40 CFR 60, and NESHAPs-cited American National Standards Institute (ANSI) standards. In general, LLNL analyzes for most constituents at levels that are far below regulatory standards in order to determine any potential environmental impacts.

\section{Monitored Emissions}

LLNL uses a variety of radioisotopes for research purposes, including uranium, transuranics, biomedical tracers, tritium, and mixed-fission products. The major radionuclide released to the atmosphere from the Livermore site is tritium. In addition to effluent sampling for tritium, a number of facilities at the Livermore site have air effluent samplers to detect the release of uranium and transuranic aerosols. The air 


\section{Air Effluent Monitoring}

effluent sampling systems described in this chapter apply to stationary and point source discharges. LLNL also monitors diffuse, or nonpoint, sources to fulfill NESHAPs requirements. Sampling methods to evaluate LLNL diffuse sources are described in Chapter 5 of the Data Supplement. Summary data from these diffuse sources can be found in Chapter 5 of this volume.

Assessment of air effluent emissions and resulting dose to the public is performed by monitoring emissions and/or evaluating potential emissions. Currently, the air effluent sampling program measures only radiological emissions. LLNL has operations with nonradiological discharges; however, permits for these operations are obtained through local agencies having enforcement authority for the Clean Air Act, and monitoring of the effluent is not required. The agencies with oversight responsibility for LLNL compliance with air regulations are Environmental Protection Agency (EPA) Region IX, the Bay Area Air Quality Management District (BAAQMD) for the Livermore site, and the San Joaquin Valley Unified Air Pollution Control District (SJVUAPCD) for Site 300. The California Air Toxics "Hot Spots" legislation requires facilities to prepare an air toxics emissions inventory and risk assessment, which LLNL has completed. Based on the assessment, the BAAQMD and the SJVUAPCD have ranked LLNL as a low-risk facility.

Historically, monitoring of radionuclide air effluents at LLNL has been implemented according to the DOE as low as reasonably achievable (ALARA) policy. This policy is meant to ensure that DOE facilities are capable of monitoring routine and nonroutine radiological releases, so that the dose to members of the public can be assessed, and so that doses are ALARA. In addition, the NESHAPs 40 CFR 61, Subpart H regulations require that facility radiological air effluents must be continuously monitored if the potential off-site dose equivalent is greater than $1 \mu \mathrm{Sv} / \mathrm{y}(0.1 \mathrm{mrem} / \mathrm{y})$, as calculated using the EPA-mandated air dispersion dose model and assuming that there are no emission control devices. The results from monitoring the air discharge points provide the actual emission source information for modeling, which is used to ensure that the NESHAPs standard, $100 \mu \mathrm{Sv} / \mathrm{y}(10 \mathrm{mrem} / \mathrm{y})$ total site effective dose equivalent, is not exceeded. Discharges from operations that have the potential to release radionuclides but that are not monitored are also evaluated according to the NESHAPs regulations, and the corresponding doses are added to those obtained by modeling monitored emissions to determine radiological NESHAPs compliance. 


\section{Air Effluent Monitoring}

\section{Operation of Monitoring Systems}

Air effluent monitoring of atmospheric discharge points is used to determine the actual radionuclide releases from individual facilities and processes during routine and nonroutine operations, to confirm the operation of facility emission control systems, and to corroborate and aid in the resolution of air surveillance measurement results for the site. (The relationship can also work the other way as well-air surveillance measurements can corroborate effluent monitoring.) Measurements made by the air surveillance samplers located on and off site are reported in Chapter 5.

\section{Methods}

Air effluent monitoring involves the extraction of a measured volume of air from the exhaust of a facility or process and subsequent collection of particles by filters or of vapors by a collection medium. After collection, the various radionuclides in the sample are measured by appropriate analytical methods.

In 1998, LLNL operated 101 samplers for radioactivity from air exhausts at eight facilities at the Livermore site (see Figure 4-1). These systems are listed in Table 4-1 along with the analytes of interest, the type of sampler, and the number of samplers.

LLNL reassesses the need for continuous monitoring on an annual basis and more often if warranted by new operations or changes in operations. After NESHAPs assessments of operations during 1998, LLNL installed two new continuous sampling systems to detect radioactive particles. One sampler was placed on the high-efficiency particulate air (HEPA) filtered discharge from the Extractor Test Facility in Building 177. The other sampler was installed on the HEPA-filtered exhaust from the Expedited Technology of Molten Salt Oxidation project in Building 292. Many of the other sampling systems still in place are not required by regulation; however, LLNL continues to operate these systems as a best management practice (see Table 4-1).

Sampling for particles containing radioactivity was conducted in seven of the facilities; sampling for tritium was conducted in one facility (Building 331). All sampling systems operated continuously. Samples were collected weekly or biweekly depending on the facility. Most air samples for particulate emissions were extracted downstream of HEPA filters and before the emissions were discharged to the atmosphere. Particles in the extracted air were collected on sample filters and analyzed for gross alpha and beta activity. Tritium is collected using molecular sieves. In addition to sample collection for environmental reporting, some facilities used real-time alarm monitors (also listed in Table 4-1) at discharge points to provide faster notification in the event of a release of 


\section{Air Effluent Monitoring}

radioactivity. If the data are available, analytical results from the continuous samplers are reported as a measured concentration per volume of air, or as less than the minimum detection concentration (MDC) when no activity is detected. In all cases, the MDC is more than adequate for demonstrating compliance with the pertinent regulatory requirements for radionuclides that are present or may be present in the sampled air. Further details of LLNL air effluent sampling systems are included in Chapter 4 of the Environmental Monitoring Plan (Tate et al. 1995).

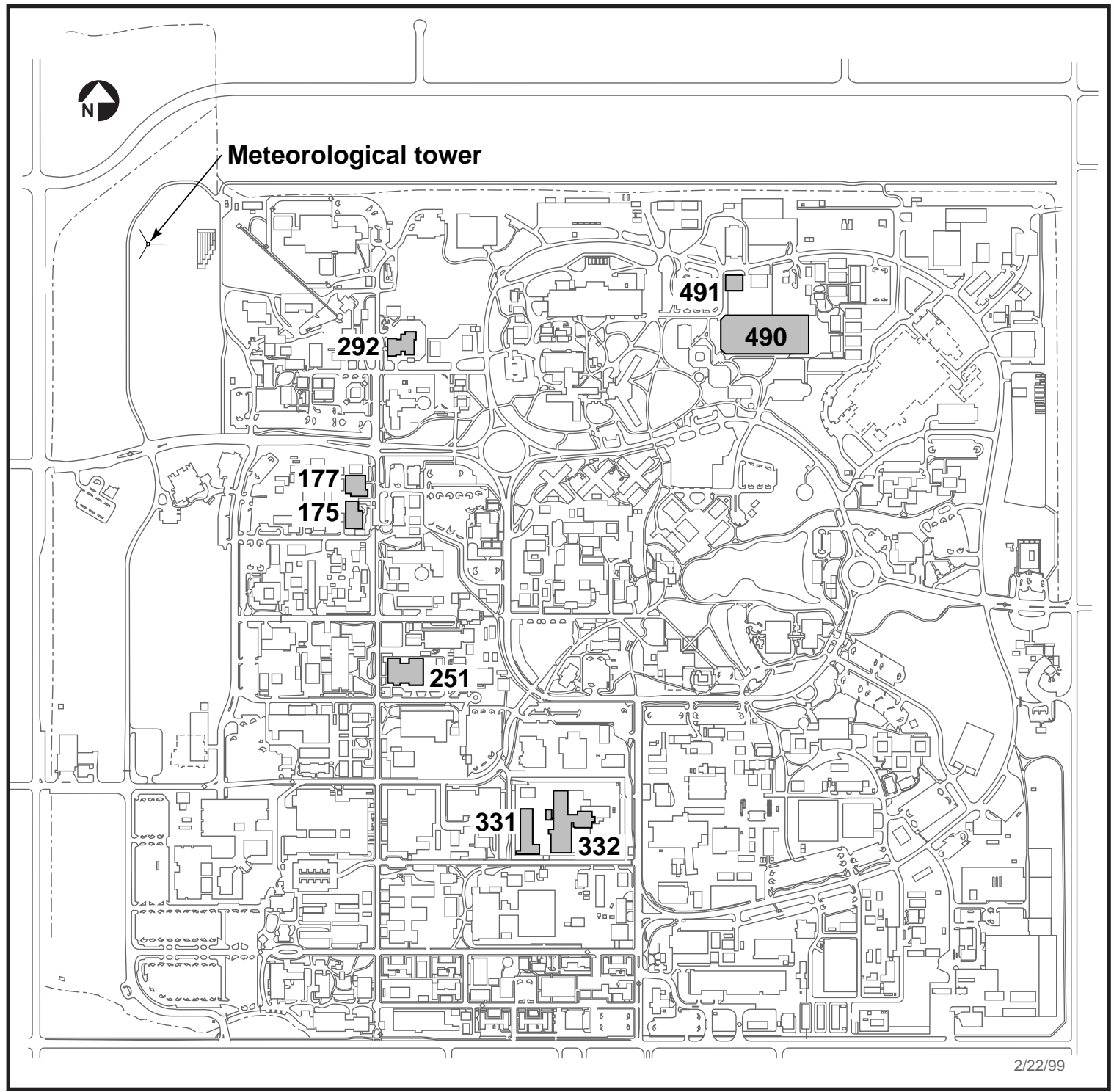

Figure 4-1. Buildings at the Livermore site with air monitoring systems for effluent gas streams during all or part of 1998. 
Table 4-1. Air effluent sampling locations and systems.

\begin{tabular}{|c|c|c|c|c|}
\hline Building & Facility & Analytes & $\begin{array}{l}\text { Sampler } \\
\text { type }\end{array}$ & $\begin{array}{c}\text { Number } \\
\text { of } \\
\text { samplers }\end{array}$ \\
\hline 175 & MARS & Gross $\alpha, \beta$ on particles & Filter & 6 \\
\hline 177 & Extractor Test Facility & Gross $\alpha, \beta$ on particles & Filter & 1 \\
\hline \multirow[t]{4}{*}{251} & Heavy elements & & & \\
\hline & Unhardened area & Gross $\alpha, \beta$ on particles & Filter & 44 \\
\hline & Hardened area & Gross $\alpha, \beta$ on particles & Filter & 4 \\
\hline & Hardened area & Gross $\alpha, \beta$ on particles & $\mathrm{CAM}^{(\mathrm{a})}$ & 4 \\
\hline 292 & Molten salt oxidation & Gross $\alpha, \beta$ on particles & Filter & 1 \\
\hline \multirow[t]{2}{*}{331} & Tritium & Tritium & Ionization chamber(b) & 4 \\
\hline & & $\begin{array}{l}\text { Gaseous tritium and } \\
\text { tritiated water vapor }\end{array}$ & Molecular sieves & 4 \\
\hline \multirow[t]{2}{*}{332} & Plutonium & Gross $\alpha, \beta$ on particles & $\mathrm{CAM}^{(\mathrm{a})}$ & 12 \\
\hline & & Gross $\alpha, \beta$ on particles & Filter & 16 \\
\hline 490 & Laser isotope separation & Gross $\alpha, \beta$ on particles & Filter & 4 \\
\hline 491 & Laser isotope separation & Gross $\alpha, \beta$ on particles & Filter & 1 \\
\hline
\end{tabular}

a $\mathrm{CAM}=$ Eberline continuous air monitors.

b Alarmed systems.

\section{Measured Radioactive Air Emissions}

This section discusses the radiological air emissions from facilities that have continuously monitored discharge points.

\section{Livermore Site}

In 1998 , a total of $4.1 \times 10^{12} \mathrm{~Bq}(110 \mathrm{Ci})$ of tritium was released from the Tritium Facility (Building 331). Of this, approximately $3.1 \times 10^{12} \mathrm{~Bq}(85 \mathrm{Ci})$ were released as tritiated water vapor (HTO). The remaining tritium released, $9.3 \times 10^{11} \mathrm{~Bq}(25 \mathrm{Ci})$, was elemental tritium gas (HT). HTO emissions from the facility ranged from $220 \mathrm{~Bq} / \mathrm{m}^{3}$ $\left(5.9 \times 10^{-9} \mathrm{Ci} / \mathrm{m}^{3}\right)$ to $2.0 \times 10^{4} \mathrm{~Bq} / \mathrm{m}^{3}\left(5.4 \times 10^{-7} \mathrm{Ci} / \mathrm{m}^{3}\right)$, while HT emissions ranged from $19 \mathrm{~Bq} / \mathrm{m}^{3}\left(5.1 \times 10^{-10} \mathrm{Ci} / \mathrm{m}^{3}\right)$ to $3.5 \times 10^{4} \mathrm{~Bq} / \mathrm{m}^{3}\left(9.5 \times 10^{-7} \mathrm{Ci} / \mathrm{m}^{3}\right)$. The highest single weekly stack emission from the facility was $3.2 \times 10^{11} \mathrm{~Bq}(8.7 \mathrm{Ci})$, of which $5.8 \times 10^{10} \mathrm{~Bq}$ (1.6 Ci) was HTO. Building 331 emissions continued to remain considerably lower than during the 1980s. Figure 4-2 illustrates the HTO and HT emissions from the facility since 


\section{Air Effluent Monitoring}

1981. In 1998, emissions from Building 331 accounted for $72 \%$ of the estimated potential tritium emissions from the Livermore site.

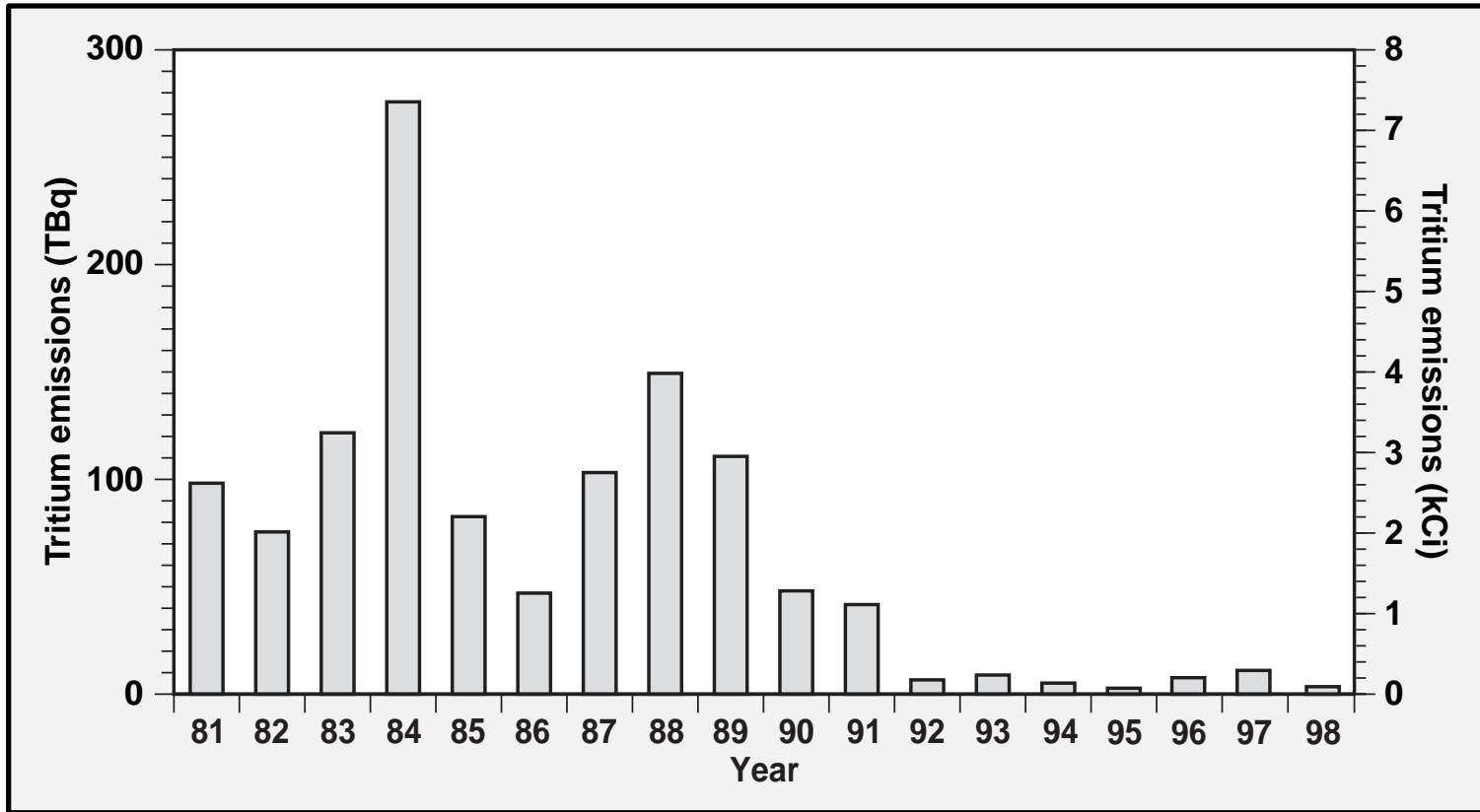

Figure 4-2. Tritium Facility HTO and HT emissions between 1981 and 1998.

Most sample results from the continuously sampled discharge points that have the potential for releasing particulate radionuclides were below the MDC of the analysis. Sometimes as few as one to four samples (out of 25 to 50 samples per year) exhibited concentrations greater than the MDC. Generally, these few samples with results above the MDC were only marginally above the MDC. In addition, because of the way some exhaust systems were configured, the monitoring systems sometimes sampled air from the ambient atmosphere and HEPA-filtered air from facility operations, which means that background atmospheric radioactivity was also collected. LLNL uses zero values for these results based on knowledge of the facility, the use of HEPA filters in all significant release pathways, and alpha-spectroscopy-based isotopic analyses of selected air sampling filters. These analyses demonstrate the presence of naturally occurring radionuclides, such as radon daughters, like polonium. Even if LLNL used the MDC values to calculate the emission estimates for these facilities (which would be an extremely conservative approach) the total dose to a member of the public attributable to LLNL activities would not be significantly affected. 
In 1998, a significant number of the samples collected throughout the year from four emission points at Building 251 (the unhardened area) yielded gross alpha results greater than the MDC. We use gross alpha as the primary indicator of potential emissions for operations, such as those at Building 251 that involve the use of uranium and transuranic materials. We use gross beta results to further corroborate those gross alpha results with concentrations above the MDC. The gross alpha and gross beta activity emissions for Building 251 were $2.7 \times 10^{3} \mathrm{~Bq} / \mathrm{y}\left(7.3 \times 10^{-8} \mathrm{Ci} / \mathrm{y}\right)$ and $2.3 \times 10^{4} \mathrm{~Bq} / \mathrm{y}\left(6.1 \times 10^{-7} \mathrm{Ci} / \mathrm{y}\right)$. Because of the number of samples with values above the MDC, we have taken a conservative approach and are reporting gross alpha and gross beta measurements as actual emissions.

The gross alpha monitoring concentrations for Building 251 ranged from $-3.0 \times 10^{-4} \mathrm{~Bq} / \mathrm{m}^{3}\left(-8.2 \times 10^{-15} \mathrm{Ci} / \mathrm{m}^{3}\right)$ to $1.4 \times 10^{-3} \mathrm{~Bq} / \mathrm{m}^{3}\left(3.7 \times 10^{-14} \mathrm{Ci} / \mathrm{m}^{3}\right)$. The Building 251 facility was in a standby, limited mode of operation, so emissions were not anticipated. It is likely that Building 251 measurements were caused by naturally occurring or background radioactivity and by the facility exhaust configuration as previously mentioned. In either case, the gross alpha and gross beta from all Livermore site operations did not a significantly contribute to the radiological dose to the public.

Table 4-2 lists total radiological emissions as determined from the continuous sampling of facility exhausts for 1998. Radioactive effluent concentrations from individual discharge points at all monitored facilities are reported in Chapter 4, Data Supplement.

Table 4-2. Measured radiological air effluent emissions for the Livermore site, 1998.

\begin{tabular}{|c|c|c|c|}
\hline \multicolumn{3}{|c|}{ Tritium } \\
\hline Building & Facility & $\begin{array}{c}\text { Elemental, HT } \\
\mathbf{( B q})\end{array}$ & $\begin{array}{c}\text { Tritiated water, HTO } \\
\mathbf{( B q )}\end{array}$ \\
\hline 331 & Tritium & $9.3 \times 10^{11}$ & $3.1 \times 10^{12}$ \\
\hline \multicolumn{2}{|c|}{ Gross alpha and gross beta } \\
\hline Building & Facility & $\begin{array}{c}\text { Gross alpha } \\
\text { (Bq) }\end{array}$ & $\begin{array}{c}\text { Gross beta } \\
\text { (Bq) }\end{array}$ \\
\hline 251 & Heavy element & $2.7 \times 10^{3}$ & $2.3 \times 10^{4}$ \\
\hline
\end{tabular}

\section{Site 300}

Currently, there is no requirement for air effluent monitoring of facilities at Site 300. Air surveillance monitoring is performed for Site 300, and results are reported in Chapter 5 (Air Monitoring). 


\section{Air Effluent Monitoring}

\section{All Potential Sources of Radioactive Air Emissions}

This section discusses the evaluation of all sources of radionuclide emissions to air at the Livermore site and Site 300. LLNL evaluates all discharge points with the potential to release radionuclides to the air according to 40 CFR 61, Subpart $H$ of the NESHAPs regulations. LLNL uses radionuclide usage inventories and/or monitoring data, along with EPA-accepted release factors for operations and EPA-suggested reduction factors for emission control devices, to estimate the potential release for each individual discharge point. Potential emissions are calculated using radionuclide usage inventories as distinguished from emissions-based air effluent sampling. We conduct this evaluation annually to assess the potential dose to the public from all LLNL operations and the need for continuous sampling of individual discharge points.

In 1998, LLNL evaluated potential emissions of radionuclides from approximately 50 facilities to determine their contribution of dose to a member of the public. Potential emissions were estimated based on radionuclide usage inventories specific to individual discharge points, physical state of the materials involved in the processes, and reductions due to emission control systems. The effective dose equivalent (EDE) to a member of the public from specific operations at the Livermore site and Site 300 were published in LLNL NESHAPs 1998 Annual Report (Biermann et al. 1999a) and are summarized in Chapter 13 (Radiological Dose Assessment) of this report.

The radionuclide isotope responsible for the majority of the 1998 EDE was tritium. Emissions from the Tritium Facility in the form of HTO accounted for $47 \%$ of the potential EDE to the maximally exposed member of the public from the Livermore site (see Chapter 13). The dose from tritium gas is approximately 25,000 times lower than the dose from a comparable release of tritiated water; therefore, the tritiated hydrogen gas emissions did not contribute significantly to the overall tritium dose. The other measured emissions shown in Table 4-2 (Building 251) contributed negligibly to the EDE for the maximally exposed member of the public.

When determining if continuous sampling is needed at a discharge point, LLNL evaluates operations to determine if the potential dose to the maximally exposed member of the public will exceed 0.1 mrem for the calendar year. This evaluation is similar to the evaluation of EDE previously described except no credit is allowed for emission control systems (according to the regulations). In 1998, LLNL evaluated approximately 60 potential discharge points and/or discharges at the Livermore site and Site 300. As a result of the evaluation, LLNL determined that the discharge points at Buildings 177 and 292 were the only additional discharge points that required continuous sampling. 


\section{Nonradioactive Air Emissions}

The Livermore site currently emits approximately $100 \mathrm{~kg}$ /day of criteria air pollutants (e.g., nitrogen oxides, sulfur oxides, particulate matter [PM-10], carbon monoxide, and lead, as defined by the Clean Air Act). The largest sources of criteria pollutants from the Livermore site are surface-coating operations, internal combustion engines, solvent operations, and, when grouped together, boilers (oil and natural gas fired). Table 4-3 lists the estimated Livermore site 1998 total airborne releases for criteria pollutants.

Table 4-3. Nonradioactive air emissions, Livermore site and Site 300, 1998.

\begin{tabular}{|l|c|c|}
\hline \multirow{2}{*}{\multicolumn{1}{|c|}{ Pollutant }} & \multicolumn{2}{|c|}{ Estimated releases (kg/day) } \\
\cline { 2 - 3 } & Livermore site & Site $\mathbf{3 0 0}$ \\
\hline Organics/volatile organics & 25 & 0.90 \\
Oxides of nitrogen & 56 & 2.1 \\
Carbon monoxide & 11 & 0.48 \\
Particulates (PM-10) & 5.7 & 0.53 \\
Oxides of sulfur & 0.72 & 0.15 \\
\hline
\end{tabular}

When comparing the estimated releases from exempt and permitted sources of air pollutants at the Livermore site to daily releases of air pollutants for the entire Bay Area, LLNL emissions are very low. For example, the total emissions of oxides of nitrogen released in the Bay Area for 1997 was approximately $1.0 \times 10^{5} \mathrm{~kg} /$ day compared to an estimate for LLNL releases of $56 \mathrm{~kg}$ / day for the Livermore site $(0.056 \%$ of total Bay Area emissions). The BAAQMD estimate for reactive organic emissions was $1.2 \times 10^{5} \mathrm{~kg} /$ day, versus Livermore site's estimated releases of $25 \mathrm{~kg} /$ day $(0.02 \%$ of total Bay Area emissions) in 1998.

Certain operations at Site 300 require permits from SJVUAPCD. The total estimated air emissions during 1998 from operations (permitted and exempt air sources) at Site 300 are given in Table 4-3. The largest sources of criteria pollutants at Site 300 include internal combustion engines, boilers, a gasoline-dispensing operation, open burning, paint spray booths, drying ovens, and soil vapor extraction operations. 


\section{Air Effluent Monitoring}

\section{Environmental Impact}

Measured radiological air emissions from the Livermore site operations for 1998 are well below levels that should cause concern for public health according to existing regulatory standards for radioactive dose. The dose to the hypothetical maximally exposed member of the public due to the measured air emissions reported here (that is, due to emissions from monitored stacks $)$ is $0.23 \mu \mathrm{Sv} / \mathrm{y}(0.023 \mathrm{mrem} / \mathrm{y})$, far below the NESHAPs standard of $100 \mu \mathrm{Sv} / \mathrm{y}(10 \mathrm{mrem} / \mathrm{y})$ and doses from naturally occurring radiation. Thus, the estimated radiological dose caused by measured air emissions from LLNL operations is minimal. See Table 13-2 in Chapter 13 for a summary of all doses, monitored or otherwise. Nonradioactive air effluents, which are also very small compared to emissions in surrounding areas, are well below standards and are not a threat to the environment or public health. 


\section{Surveillance Air Monitoring}

Paris E. Althouse

Paula J. Tate

\section{Introduction}

Air surveillance monitoring is performed to evaluate compliance with local, state, and federal laws and regulations and to ensure that human health and the environment are protected from hazardous and radioactive air emissions. Federal environmental air quality laws and Department of Energy (DOE) regulations include 40 Code of Federal Regulations (CFR) 61, the National Emissions Standards for Hazardous Air Pollutants (NESHAPs) section of the Clean Air Act, and DOE Orders 5400.1, General Environmental Protection Program, and 5400.5, Radiation Protection of the Public and the Environment. The Environmental Regulatory Guide for Radiological Effluent Monitoring and Environmental Surveillance (U.S. Department of Energy 1991) provides the guidance for implementing DOE Orders 5400.1 and 5400.5. The California Air Toxics "Hot Spots" Information and Assessment Act of 1987 (AB2588) also governs air quality. In general, the constituents that LLNL analyzes are at levels far below the regulatory standards.

LLNL conducts surveillance monitoring of ambient air to determine if airborne radionuclides or hazardous materials are being released by Laboratory operations, what the concentrations are, and what the trends are in the LLNL environs. In the air monitoring program, LLNL collects particles on filters and chemically traps vapors on a collection medium. Concentrations of various airborne radionuclides (including particles and tritiated water vapor) and beryllium are measured at the Livermore site, Site 300, and at off-site locations throughout the Livermore Valley and in Tracy. In addition, some point sources and diffuse, or nonpoint sources, are monitored to fulfill NESHAPs requirements (Gallegos et al. 1998).

\section{Methods}

Several monitoring networks are established for surveillance of air particulates in the environs of LLNL and Site 300, as well as in the surrounding Livermore Valley and in Tracy. The sampling locations for each monitoring network are listed in Table 5-1 and shown on Figures 5-1, 5-2, and 5-3. All monitoring networks use continuously 


\section{Surveillance Air Monitoring}

operating samplers. The radiological high-volume sampling networks use glass fiber filters, the beryllium high-volume networks use cellulose filters, and the low volume network uses Millipore AW-19 filters.

Table 5-1. Sampling locations listed by monitoring network.

\begin{tabular}{|c|c|c|c|}
\hline $\begin{array}{c}\text { High-volume } \\
\text { radiological } \\
\text { (glass fiber filters) }\end{array}$ & $\begin{array}{c}\text { High-volume } \\
\text { beryllium } \\
\text { (cellulose filters) }\end{array}$ & $\begin{array}{l}\text { Low-volume gross } \\
\text { alpha and beta } \\
\text { (millipore filters) }\end{array}$ & $\begin{array}{c}\text { Tritium } \\
\text { (silica gel) }\end{array}$ \\
\hline \multicolumn{4}{|c|}{ Livermore site locations } \\
\hline SALV & SALV & & SALV \\
\hline CAFE & CAFE & & CAFE \\
\hline VIS & VIS & & VIS \\
\hline cow & cow & & cow \\
\hline MET & MET & & MET \\
\hline MESQ & MESQ & & MESQ \\
\hline B531(a) & & & POOL \\
\hline CRED $^{(a)}$ & & & B292 (a) \\
\hline & & & B331(a) \\
\hline & & & $\mathrm{B} 514^{(\mathrm{a})}$ \\
\hline & & & $\mathrm{B} 624(\mathrm{a})$ \\
\hline \multicolumn{4}{|c|}{ Livermore Valley locations } \\
\hline FCC & & FCC & FIRE \\
\hline FIRE & & HOSP & XRDS \\
\hline HOSP & & & ZON7 \\
\hline CHUR & & & VET \\
\hline PATT & & & HOSP \\
\hline ZON7 & & & $\mathrm{AMON}^{(b)}$ \\
\hline TANK & & & \\
\hline $\mathrm{AMON}^{(\mathrm{b})}$ & & & \\
\hline LWRP & & & \\
\hline \multicolumn{4}{|c|}{ Site 300} \\
\hline $801 E$ & EOBS & & \\
\hline ECP & GOLF & & \\
\hline EOBS & $801 \mathrm{E}$ & & \\
\hline GOLF & & & \\
\hline NPS & & & \\
\hline WCP & & & \\
\hline WOBS & & & \\
\hline \multicolumn{4}{|c|}{ Site $\mathbf{3 0 0}$ off site } \\
\hline $\begin{array}{l}\text { TFIR } \\
\text { PRIM }\end{array}$ & TFIR & & PRIM \\
\hline
\end{tabular}

a These locations are in areas of diffuse sources and are monitored to fulfill NESHAPs requirements.

b Location AMON replaced location ALTA which was removed from service in April 1997. 


\section{Surveillance Air Monitoring}

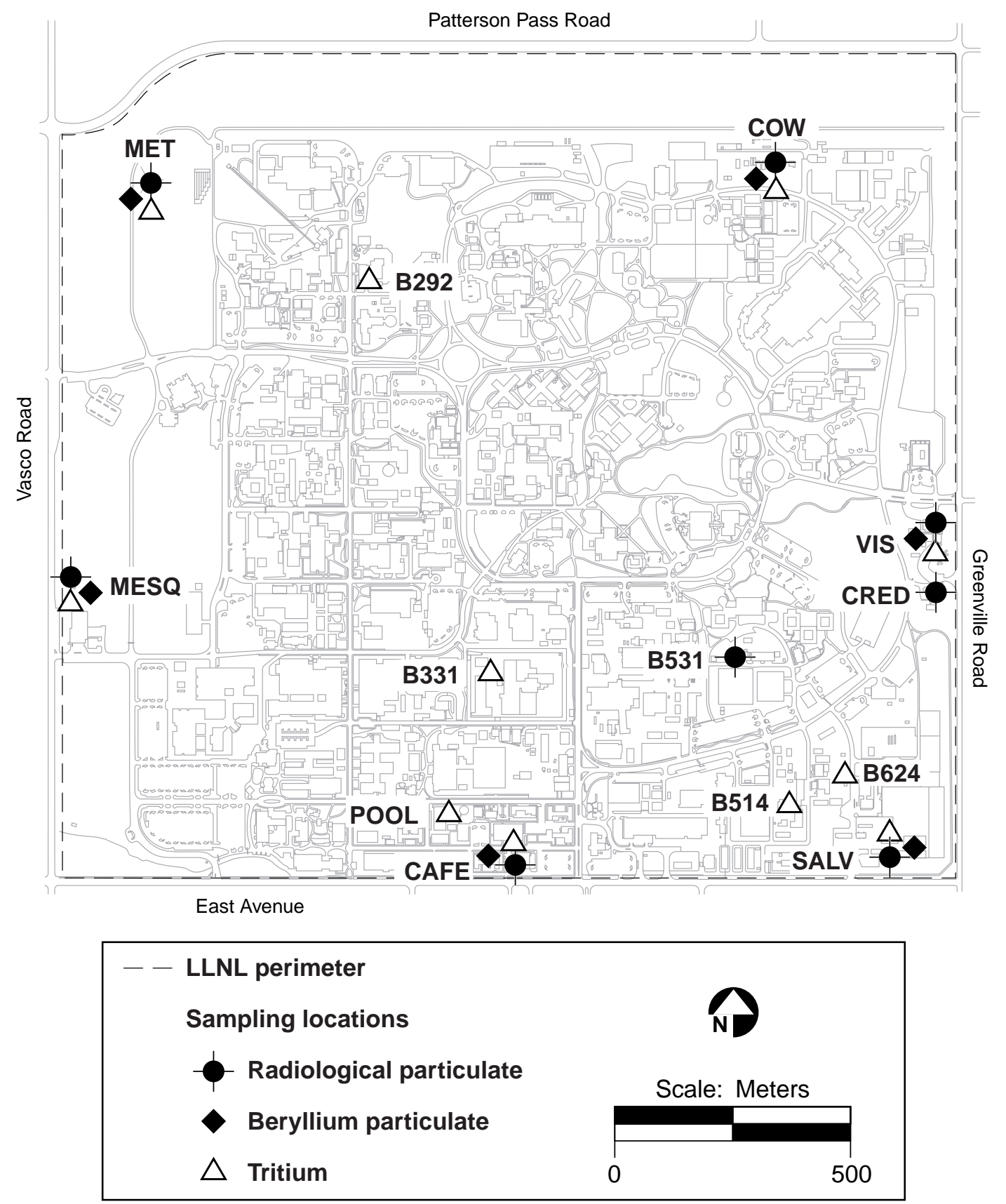

Figure 5-1. Air particulate and tritium sampling locations on the Livermore site, 1998. 


\section{Surveillance Air Monitoring}

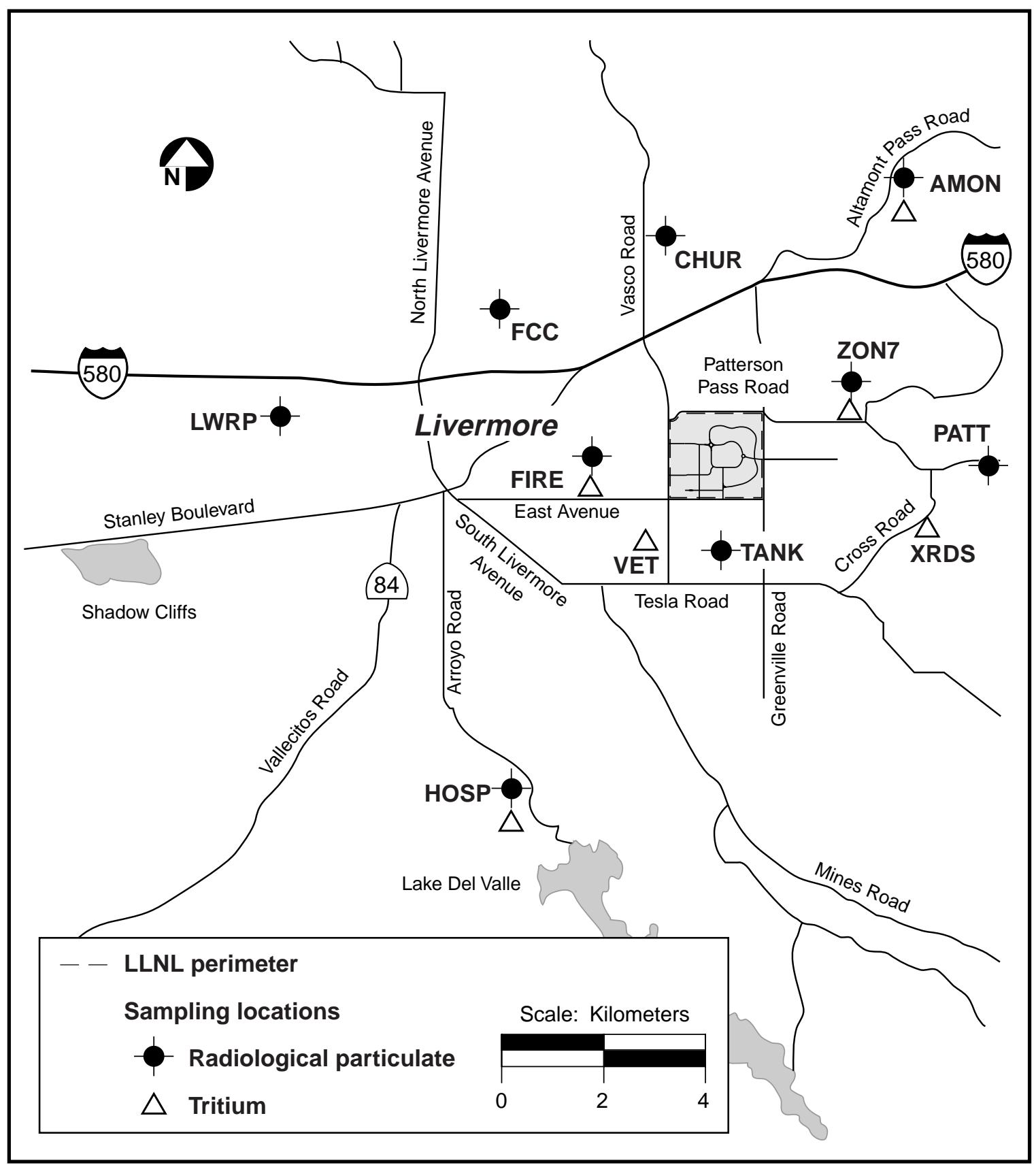

Figure 5-2. Air particulate and tritium sampling locations in the Livermore Valley, 1998. 


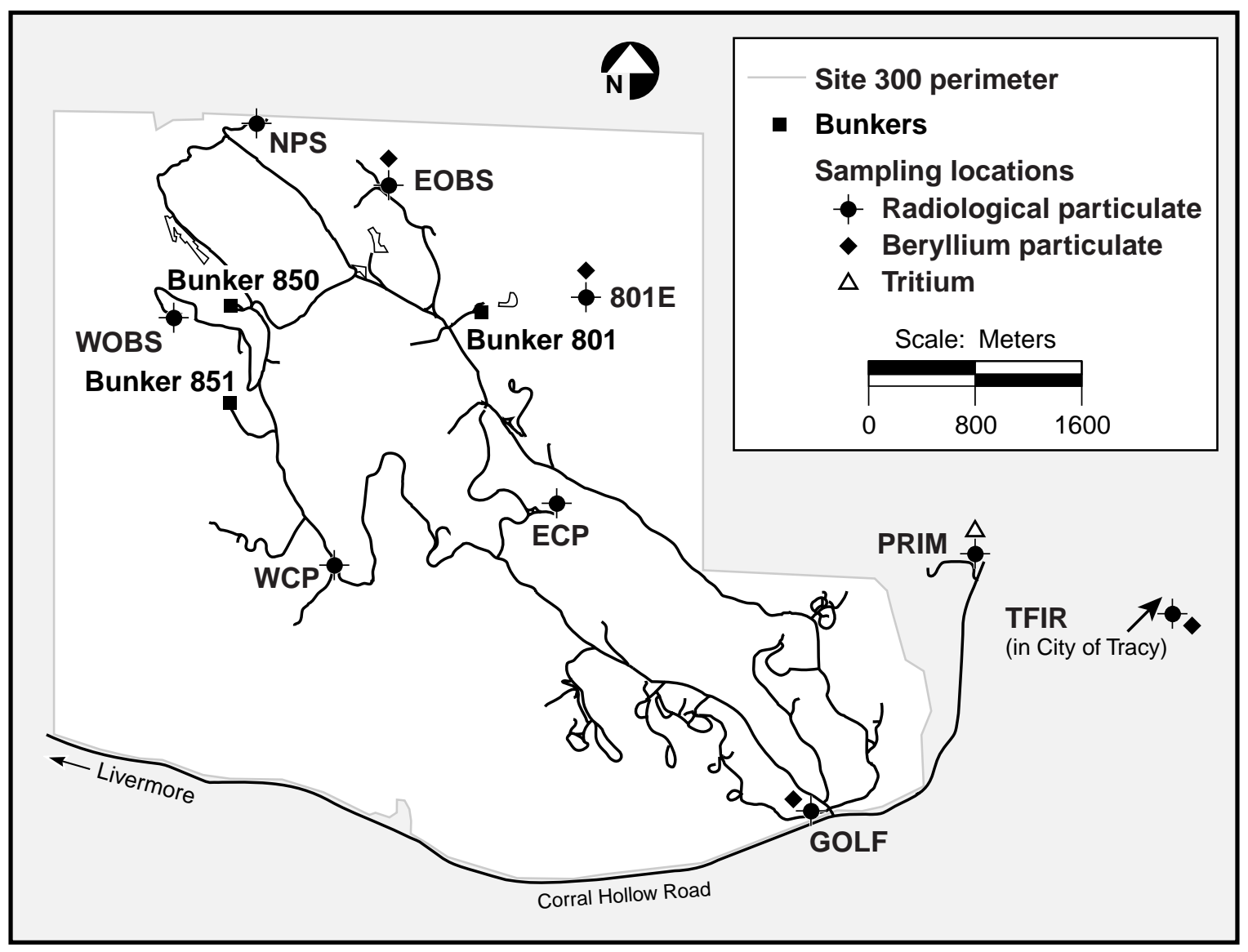

Figure 5-3. Air particulate and tritium sampling locations at Site 300, 1998.

The Livermore site radiological air particulate network consists of six samplers at the perimeter. In addition, two areas of special interest (B531 and CRED) are monitored for plutonium only. These two locations are areas of known plutonium contamination in the southeast quadrant attributed to historic operations, which included the operation of solar evaporators for plutonium-containing liquid waste. The Livermore Valley network consists of air samplers located in all compass directions. For the purposes of data analysis, four samplers located in the least prevalent wind directions (FCC, FIRE, HOSP, and CHUR) are considered to be upwind or representative of background locations, and four samplers located in the most prevalent downwind directions (PATT, ZON7, TANK, and AMON) are considered most likely to be affected by Laboratory operations. An additional sampler is located in another area of special interest, the Livermore Water Reclamation Plant (LWRP), because of a plutonium release to the sanitary sewer system in 1967 with subsequent soil contamination and potential resuspension (see Results section below). 


\section{Surveillance Air Monitoring}

Livermore site beryllium monitoring continues at the six perimeter locations. To satisfy beryllium reporting requirements and determine the effects of the Laboratory's beryllium operations, in 1997, LLNL conducted a technical assessment of the beryllium monitoring locations at Site 300. There is no requirement to sample for beryllium at Site 300; however, as a best management practice, LLNL has decided to continue beryllium monitoring at three locations on site and at TFIR in the City of Tracy.

All air samplers are positioned to provide reasonable probability that, if there is any significant concentration of radioactive particulate or beryllium effluents from LLNL operations, it will be detected. The geographical details of the particulate sampling locations are outlined in a procedure in Appendix B of the Environmental Monitoring Plan (Tate et al. 1995).

Two sampling systems were added in July 1997 as part of the new low-volume air surveillance sampling network. The samplers are situated at the FCC and HOSP locations, sites that are generally upwind of the Livermore site. The results are used to establish background levels of gross alpha and beta activity for direct comparison to results from the air effluent samplers (see Chapter 4). The sampling systems are very similar to the air effluent samplers used in facilities, including sampling system design, sampler operation, filter media, sample tracking, sample analysis, and processing of results.

LLNL also maintains 11 continuously operating airborne tritium samplers on the Livermore site (Figure 5-1), six samplers in the Livermore Valley (Figure 5-2), and one sampler near Site 300 (Figure 5-3) to assess historical and current activities that influence environmental impacts. Four of the Livermore site locations (B331, B292, B514, and B624) monitor diffuse tritium emissions. The tritium sample locations are detailed in Appendix B of the Environmental Monitoring Plan (Tate et al. 1995).

Particulate filters are changed each week at all locations, and tritium samples are changed every two weeks. Duplicate quality control samplers are operated for two months in parallel with the permanent sampler at a given site, and samples are analyzed to confirm results.

As outlined in Environmental Regulatory Guide for Radiological Effluent Monitoring and Environmental Surveillance (U.S. Department of Energy 1991), gross alpha and gross beta air filter results are used as trend indicators; specific radionuclide analysis is done for plutonium, uranium, and gamma emitters. Radiological analytical results are reported as a measured concentration per volume of air, or as less than the minimum detection concentration (MDC) when no activity is detected. In all cases, the MDC is more than adequate for demonstrating compliance with the pertinent regulatory requirements 
for radionuclides that may be or are present in the air sample and for evaluating LLNLinduced environmental impacts. Particle size distributions are not determined because the estimated effective dose equivalent to the maximally exposed individual is well below the 0.01-mSv (1-mrem) allowable limit as discussed in the above-mentioned Environmental Regulatory Guide. Gross alpha and gross beta activities are determined by gas-flow proportional counting, plutonium by alpha spectrometry, uranium by mass spectrometry, and gamma by gamma spectroscopy. Further details of the surveillance monitoring methods are included in the Data Supplement, Chapter 5.

\section{Results}

This section discusses the air monitoring results from all air surveillance locations at the Livermore site, Site 300, and all off-site surveillance locations.

In April 1997, the air particulate sampling filter media was changed from cellulose to glass fiber; however, blank glass-fiber filters contain detectable amounts of some naturally occurring radiological isotopes (Althouse 1998) including $235 \mathrm{U},{ }^{238} \mathrm{U},{ }^{40} \mathrm{~K}$, ${ }^{226} \mathrm{Ra},{ }^{228} \mathrm{Ra}$, and ${ }^{228} \mathrm{Th}$. LLNL adjusted the measured concentrations of these isotopes according to U.S. Environmental Protection Agency (EPA) procedures (Eadie and Bernhardt 1976) and subtracted the appropriate blank filter content from the gross analytical result to obtain a corrected net result.

\section{Livermore Site}

\section{Airborne Radioactivity}

Table 5-2 summarizes the monthly gross alpha and gross beta results for the LLNL perimeter, Livermore Valley, and Site 300 sampling locations. Detection frequencies, median concentrations, interquartile ranges (IQR), and maximum concentrations values for each network are included. (See Data Supplement, Tables 5-1, 5-2, and 5-3 for detailed location results for all high-volume networks for gross alpha and gross beta concentrations.) The monthly median gross alpha and gross beta concentrations are plotted in Figures 5-4 and 5-5, respectively. The gross beta results follow a similar pattern to previous years' data. The gradual increase in beta activity throughout the summer is most likely due to an increase in resuspension of soils that occurs during the dry season. 


\section{Surveillance Air Monitoring}

Table 5-2. Gross alpha and gross beta concentration in air particulate samples summarized by month, 1998. (a)

\begin{tabular}{|c|c|c|c|c|c|c|c|c|}
\hline \multirow[b]{2}{*}{ Month } & \multicolumn{4}{|c|}{ Gross alpha $\left(10^{-6} \mathrm{~Bq} / \mathrm{m}^{3}\right)$} & \multicolumn{4}{|c|}{ Gross beta $\left(10^{-6} \mathrm{~Bq} / \mathrm{m}^{3}\right)$} \\
\hline & $\begin{array}{c}\text { Detection } \\
\text { frequency }{ }^{(b)}\end{array}$ & Median & $\operatorname{IQR}^{(\mathrm{c})}$ & Maximum & $\begin{array}{l}\text { Detection } \\
\text { frequency }\end{array}$ & Median & IQR & Maximum \\
\hline \multicolumn{9}{|c|}{ LLNL perimeter } \\
\hline Jan & $5 / 30$ & 26.8 & 39.3 & 141 & $30 / 30$ & 247 & 197 & 902 \\
\hline Feb & $0 / 24$ & -5.84 & 18.5 & 28.4 & $17 / 24$ & 142 & 66.1 & 273 \\
\hline Mar & $0 / 24$ & -1.83 & 34.2 & 36.5 & $24 / 24$ & 283 & 167 & 634 \\
\hline Apr & $0 / 24$ & -2.54 & 26.3 & 35.0 & $23 / 24$ & 251 & 130 & 599 \\
\hline May & $1 / 30$ & -2.47 & 34.5 & 73.9 & $30 / 30$ & 174 & 58.5 & 531 \\
\hline Jun & $8 / 24$ & 32.3 & 40.5 & 78.2 & $19 / 24$ & 180 & 78.8 & 373 \\
\hline Jul & $9 / 30$ & 26.6 & 49.8 & 110 & $30 / 30$ & 378 & 120 & 555 \\
\hline Aug & $8 / 24$ & 34.5 & 30.8 & 74.7 & $24 / 24$ & 606 & 154 & 849 \\
\hline Sep & $0 / 24$ & 13.1 & 53.4 & 57.5 & $24 / 24$ & 484 & 269 & 980 \\
\hline Oct & $2 / 30$ & 6.22 & 36.0 & 68.3 & $30 / 30$ & 488 & 222 & 805 \\
\hline Nov & $1 / 24$ & 10.5 & 41.3 & 78.2 & $23 / 24$ & 304 & 258 & 648 \\
\hline Dec & $4 / 24$ & 23.9 & 30.3 & 90.8 & $24 / 24$ & 617 & 564 & 1520 \\
\hline \multicolumn{9}{|c|}{ Livermore Valley upwind } \\
\hline Jan & $3 / 20$ & 31.4 & 33.0 & 66.5 & $20 / 20$ & 244 & 235 & 972 \\
\hline Feb & $0 / 16$ & 1.44 & 10.2 & 33.4 & $16 / 16$ & 133 & 60.8 & 243 \\
\hline Mar & $1 / 16$ & 2.03 & 28.3 & 63.0 & $16 / 16$ & 298 & 193 & 533 \\
\hline Apr & $0 / 16$ & -7.07 & 23.4 & 28.6 & $15 / 16$ & 219 & 152 & 540 \\
\hline May & $1 / 20$ & 6.49 & 25.7 & 62.9 & $19 / 20$ & 131 & 111 & 470 \\
\hline Jun & $2 / 16$ & 25.6 & 31.9 & 59.0 & $13 / 16$ & 163 & 95.7 & 304 \\
\hline Jul & $2 / 20$ & 21.2 & 22.5 & 80.2 & $20 / 20$ & 371 & 102 & 657 \\
\hline Aug & $1 / 16$ & 20.2 & 33.2 & 55.5 & $16 / 16$ & 639 & 174 & 832 \\
\hline Sep & $0 / 16$ & 9.44 & 41.5 & 55.5 & $16 / 16$ & 495 & 281 & 1050 \\
\hline Oct & $0 / 20$ & 9.69 & 36.6 & 46.9 & $20 / 20$ & 438 & 191 & 911 \\
\hline Nov & $1 / 16$ & 9.57 & 31.4 & 61.9 & $15 / 16$ & 234 & 304 & 564 \\
\hline Dec & $1 / 16$ & 11.9 & 14.8 & 78.0 & $16 / 16$ & 621 & 470 & 1620 \\
\hline
\end{tabular}


Table 5-2. Gross alpha and gross beta concentration in air particulate samples summarized by month, 1998 (concluded). (a)

\begin{tabular}{|c|c|c|c|c|c|c|c|c|}
\hline \multirow[b]{2}{*}{ Month } & \multicolumn{4}{|c|}{ Gross alpha $\left(10^{-6} \mathrm{~Bq} / \mathrm{m}^{3}\right)$} & \multicolumn{4}{|c|}{ Gross beta $\left(10^{-6} \mathrm{~Bq} / \mathrm{m}^{3}\right)$} \\
\hline & $\begin{array}{c}\text { Detection } \\
\text { frequency }(b)\end{array}$ & Median & $\operatorname{IQR}^{(\mathbf{c})}$ & Maximum & $\begin{array}{l}\text { Detection } \\
\text { frequency }\end{array}$ & Median & IQR & Maximum \\
\hline \multicolumn{9}{|c|}{ Livermore Valley downwind } \\
\hline Jan & $0 / 20$ & 16.4 & 42.7 & 46.5 & $19 / 20$ & 232 & 244 & 936 \\
\hline Feb & $0 / 16$ & -9.38 & 12.0 & 22.4 & $14 / 16$ & 141 & 40.9 & 205 \\
\hline Mar & $2 / 15$ & 19.3 & 30.9 & 67.0 & $15 / 15$ & 288 & 127 & 648 \\
\hline Apr & $0 / 16$ & -5.71 & 34.6 & 32.9 & $14 / 16$ & 248 & 150 & 684 \\
\hline May & $0 / 20$ & -8.57 & 28.0 & 48.4 & $19 / 20$ & 175 & 71.0 & 500 \\
\hline Jun & $3 / 16$ & 18.0 & 28.8 & 119 & $16 / 16$ & 192 & 64.0 & 388 \\
\hline Jul & $1 / 19$ & 15.9 & 29.6 & 76.1 & $19 / 19$ & 445 & 94.9 & 712 \\
\hline Aug & $5 / 16$ & 27.4 & 46.3 & 118 & $16 / 16$ & 648 & 125 & 813 \\
\hline Sep & $1 / 16$ & 16.3 & 34.8 & 113 & $16 / 16$ & 531 & 153 & 1050 \\
\hline Oct & $2 / 20$ & 0.924 & 26.0 & 92.0 & $20 / 20$ & 450 & 207 & 858 \\
\hline Nov & $0 / 15$ & 10.2 & 18.7 & 54.2 & $15 / 15$ & 283 & 304 & 685 \\
\hline $\mathrm{Dec}$ & $2 / 16$ & 6.86 & 39.4 & 55.7 & $16 / 16$ & 645 & 922 & 1440 \\
\hline \multicolumn{9}{|c|}{ Site $300^{(d)}$} \\
\hline Jan & $8 / 35$ & 24.4 & 46.8 & 81.6 & $33 / 35$ & 229 & 223 & 634 \\
\hline Feb & $1 / 28$ & -3.55 & 32.1 & 64.3 & $23 / 28$ & 112 & 64.3 & 237 \\
\hline Mar & $0 / 28$ & 5.90 & 25.9 & 65.3 & 27/28 & 284 & 208 & 584 \\
\hline Apr & $2 / 27$ & 6.57 & 41.5 & 61.0 & $25 / 27$ & 376 & 335 & 667 \\
\hline May & $3 / 33$ & -2.04 & 35.0 & 86.3 & $27 / 33$ & 154 & 120 & 381 \\
\hline Jun & $1 / 28$ & 10.3 & 34.0 & 53.1 & $28 / 28$ & 217 & 44.0 & 297 \\
\hline Jul & $7 / 34$ & 30.7 & 27.8 & 104 & $34 / 34$ & 516 & 124 & 784 \\
\hline Aug & $14 / 28$ & 43.9 & 56.4 & 108 & $28 / 28$ & 653 & 194 & 1080 \\
\hline Sep & $5 / 28$ & 19.5 & 59.9 & 154 & $28 / 28$ & 598 & 538 & 1180 \\
\hline Oct & $1 / 35$ & 3.96 & 32.2 & 73.9 & $35 / 35$ & 534 & 304 & 927 \\
\hline Nov & $1 / 28$ & 14.9 & 42.7 & 56.2 & $28 / 28$ & 294 & 333 & 771 \\
\hline Dec & $1 / 27$ & 23.2 & 37.3 & 65.9 & $25 / 27$ & 685 & 566 & 1680 \\
\hline
\end{tabular}

a Negative values occur when the activity of the analytical background filters is greater than that of the filters being analyzed.

b Detection frequency is the number of samples with results above the detection limit divided by the number of samples.

c $\quad I Q R=$ Interquartile range.

d Results for location TFIR and PRIM are given in the Data Supplement, Table 5-15. 


\section{Surveillance Air Monitoring}

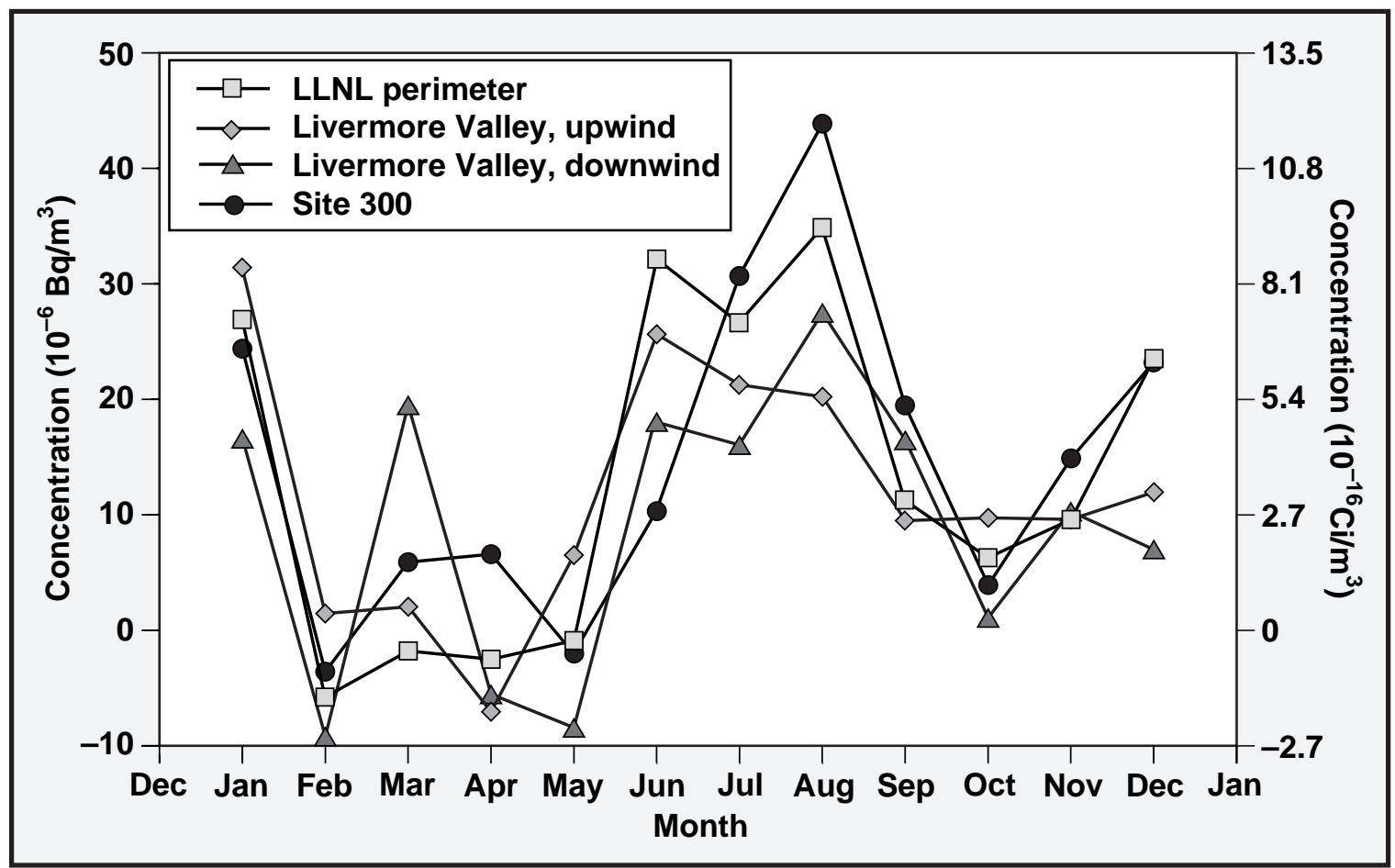

Figure 5-4. Monthly median gross alpha concentrations in particulate air samples from the LLNL perimeter, Livermore Valley and Site 300 sampling locations, 1998.

The gross alpha data are much more variable because of the standard analytical method capabilities, and most of the data are very close to the minimum detection limit of the method.

Typical gross alpha activity (median value) for the LLNL perimeter is $1.2 \times 10^{-5} \mathrm{~Bq} / \mathrm{m}^{3}$ $\left(3.2 \times 10^{-16} \mathrm{Ci} / \mathrm{m}^{3}\right)$; for the upwind Livermore Valley stations, the value is $6.9 \times 10^{-6} \mathrm{~Bq} / \mathrm{m}^{3}\left(1.9 \times 10^{-16} \mathrm{Ci} / \mathrm{m}^{3}\right)$; and for the downwind Livermore Valley stations the value is $2.1 \times 10^{-5} \mathrm{~Bq} / \mathrm{m}^{3}\left(5.7 \times 10^{-16} \mathrm{Ci} / \mathrm{m}^{3}\right)$. Negative values occur when the activity of the analytical background filters is higher than the activity on the filters being analyzed. Typical gross beta activity (median value) for the LLNL perimeter is $3.3 \times 10^{-4} \mathrm{~Bq} / \mathrm{m}^{3}\left(8.9 \times 10^{-15} \mathrm{Ci} / \mathrm{m}^{3}\right)$; for the upwind Livermore Valley stations, the value is $3.0 \times 10^{-4} \mathrm{~Bq} / \mathrm{m}^{3}\left(8.1 \times 10^{-15} \mathrm{Ci} / \mathrm{m}^{3}\right)$; and for the downwind Livermore stations, the value is $3.4 \times 10^{-4} \mathrm{~Bq} / \mathrm{m}^{3}\left(9.2 \times 10^{-15} \mathrm{Ci} / \mathrm{m}^{3}\right)$. These values are similar to those obtained from previous monitoring data during the past several years. The primary sources of the alpha and beta activities are the naturally occurring radioisotopes of uranium and thorium, and any residual fallout from atmospheric weapons testing and the Chernobyl reactor accident in 1986. 


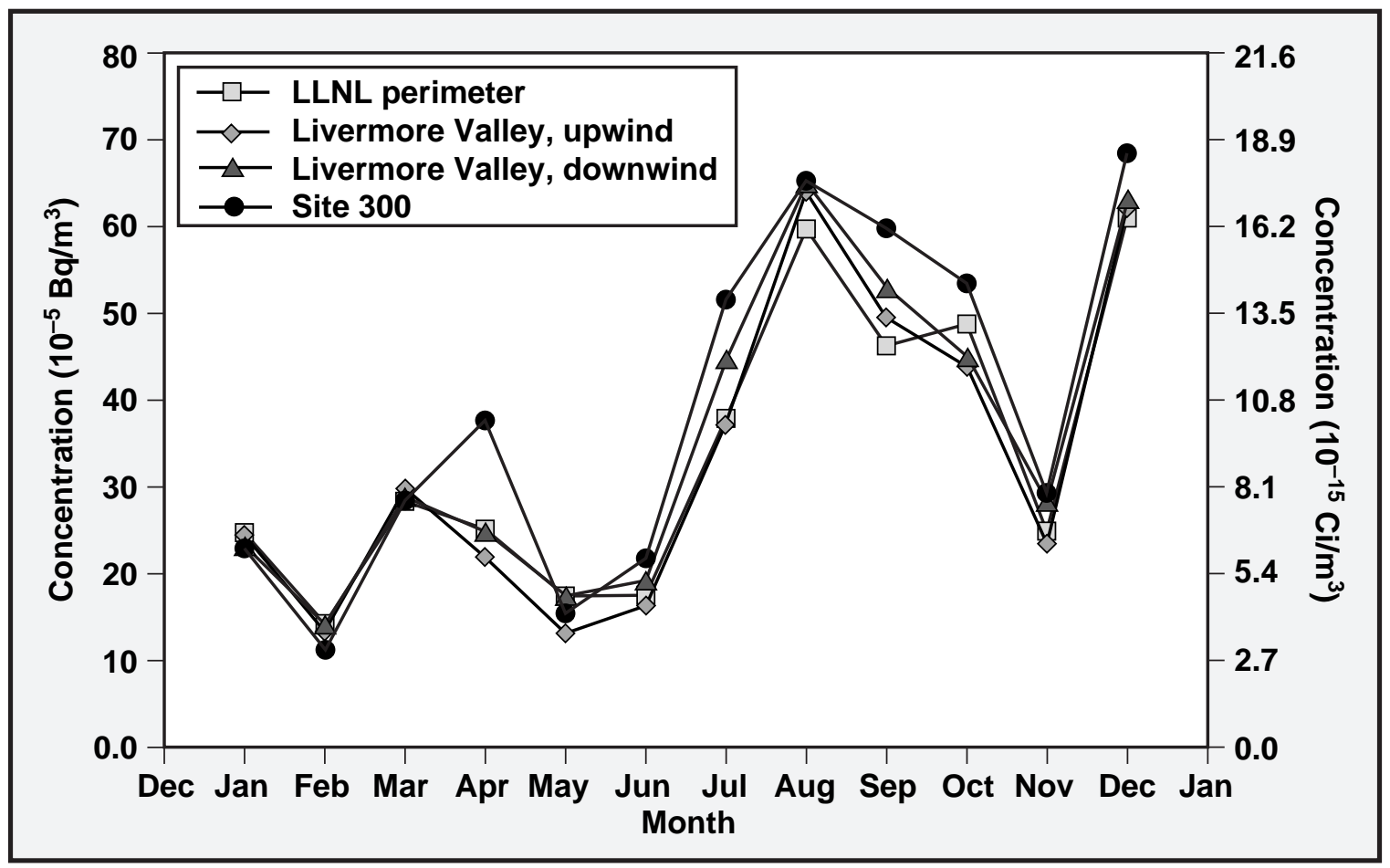

Figure 5-5. Monthly median gross beta concentrations in particulate air samples from the LLNL perimeter, Livermore Valley, and Site 300 sampling locations, 1998.

Gamma-emitting radionuclide concentrations in air that contribute to the activity in the Livermore site perimeter samples are summarized in Table 5-3. (See Data Supplement, Table 5-4 for monthly gamma activity data.) Of the nuclides tabulated, ${ }^{7} \mathrm{Be},{ }^{40} \mathrm{~K},{ }^{226} \mathrm{Ra}$, ${ }^{228} \mathrm{Ra}$, and ${ }^{228} \mathrm{Th}$ occur naturally. The primary source of ${ }^{137} \mathrm{Cs}$ is long-term global fallout and fallout resuspension.

By analyzing these radionuclides, LLNL can monitor the containment of the small inventories of mixed fission products and radiochemical tracers used at LLNL as well as obtain baseline data on global fallout. The Derived Concentration Guides (DCGs) for these radionuclides are shown in Table 5-3. For air, DCGs specify the concentrations of radionuclides that could be inhaled continuously 365 days a year without exceeding the DOE primary radiation protection standard for the public, which is $1 \mathrm{mSv} / \mathrm{y}$ (100 mrem/y) effective dose equivalent (DOE Order 5400.5). (Chapter 13, Radiological Dose Assessment, provides an explanation of this and other units of dose.) Table 5-3 also presents the median fraction of the DCGs, which demonstrates that the level of gamma activity present in air at the Livermore site perimeter is far below the DCGs. 


\section{Surveillance Air Monitoring}

Table 5-3. Gamma activity in air particulate samples, Livermore site perimeter and Site 300, 1998.

\begin{tabular}{|c|c|c|c|c|c|c|c|}
\hline & ${ }^{7} \mathrm{Be}$ & ${ }^{40} \mathrm{~K}$ & ${ }^{137} \mathrm{Cs}$ & ${ }^{22} \mathrm{Na}$ & ${ }^{226} \mathrm{Ra}$ & ${ }^{228} \mathrm{Ra}$ & ${ }^{228} \mathrm{Th}$ \\
\hline & $\left(10^{-3} \mathrm{~Bq} / \mathrm{m}^{3}\right)$ & \multicolumn{6}{|c|}{$\left(10^{-6} \mathrm{~Bq} / \mathrm{m}^{3}\right)$} \\
\hline \multicolumn{8}{|c|}{ Livermore perimeter } \\
\hline Median & 3.4 & 14 & $<0.22$ & $<0.25$ & 0.03 & 0.76 & 0.88 \\
\hline Interquartile range & 1.4 & 18 & -(a) & -(a) & 3.7 & 1.0 & 1.0 \\
\hline Maximum & 4.4 & 51 & $<0.28$ & $<0.35$ & 1.2 & 1.8 & 1.9 \\
\hline $\begin{array}{l}\text { Median fraction of } \\
\operatorname{DCG}^{(b)}\end{array}$ & $2.3 \times 10^{-6}$ & $4.3 \times 10^{-7}$ & $<1.5 \times 10^{-8}$ & $<6.9 \times 10^{-9}$ & $3.1 \times 10^{-5}$ & $6.9 \times 10^{-6}$ & $5.8 \times 10^{-4}$ \\
\hline \multicolumn{8}{|c|}{ Site 300} \\
\hline Median & 3.4 & 26 & $<0.21$ & $<0.25$ & -0.04 & 0.64 & 1.0 \\
\hline Interquartile range & 2.2 & 55 & -(a) $^{(\mathrm{n}}$ & -(a) $^{\text {(a) }}$ & 3.8 & 1.5 & 2.4 \\
\hline Maximum & 6.5 & 53 & 0.46 & 0.86 & 1.6 & 1.9 & 2.5 \\
\hline Median fraction of DCG & $1.5 \times 10^{-6}$ & $7.7 \times 10^{-7}$ & $<1.4 \times 10^{-8}$ & $<6.8 \times 10^{-9}$ & $4.3 \times 10^{-5(c)}$ & $5.8 \times 10^{-6}$ & $6.9 \times 10^{-4}$ \\
\hline $\mathrm{DCG}\left(\mathrm{Bq} / \mathrm{m}^{3}\right)$ & $1.5 \times 10^{3}$ & $3.3 \times 10^{1}$ & $1.5 \times 10^{1}$ & $3.7 \times 10^{1}$ & $3.7 \times 10^{-2}$ & $1.1 \times 10^{-1}$ & $1.5 \times 10^{-3}$ \\
\hline
\end{tabular}

Note: Radioactivities are reported as the measured concentration and either an uncertainty ( $\pm 2 \sigma$ counting error) or as being less than or equal to the detection limit. If the concentration is less than or equal to the uncertainty or the detection limit, the result is considered to be a nondetection. See the main volume, Chapter 14, Quality Assurance.

a No measure of dispersion calculated. See Chapter 14, Quality Assurance.

b Derived Concentration Guide.

c Fraction of DCG calculated with maximum value since the median is negative.

Table 5-4 shows the concentrations of airborne ${ }^{239+240} \mathrm{Pu}$ on air filters from the LLNL perimeter locations. (See Data Supplement, Table 5-6, for the monthly data by location.) The highest concentration was registered at location VIS in June 1998; the concen tration value is reported as $4.4 \times 10^{-8} \mathrm{~Bq} / \mathrm{m}^{3}\left(1.2 \times 10^{-18} \mathrm{Ci} / \mathrm{m}^{3}\right)$, which represents $0.01 \%$ of the DCG. The median concentration at location VIS is $8.6 \times 10^{-9} \mathrm{~Bq} / \mathrm{m}^{3}\left(2.3 \times 10^{-19} \mathrm{Ci} / \mathrm{m}^{3}\right)$, which is slightly higher than that for the previous year.

Table 5-4 also shows the detection frequency, median concentration, IQR, maximum concentration, and median fraction of DCG for the concentration of plutonium on air filter samples collected in the Livermore Valley. (See Data Supplement, Table 5-5 for monthly data.) The highest off-site median concentration of $239+240 \mathrm{Pu}$ occurred at ZON7. Soils near ZON7 contain some detectable plutonium, principally resulting from historic operations of solar evaporators for plutonium-containing liquid waste in the southeast quadrant (Silver et al. 1974) (see Chapter 10, Soil and Sediment Monitoring). Resuspension of these soils probably accounts for the slightly higher median ${ }^{239+240} \mathrm{Pu}$ in air concentrations; however, the median observed value is $<0.001 \%$ of the DCG. 
Table 5-4. Plutonium-239+240 activity in air particulate samples $\left(10^{-9} \mathrm{~Bq} / \mathrm{m}^{3}\right), 1998$.

\begin{tabular}{|c|c|c|c|c|c|}
\hline $\begin{array}{l}\text { Sampling } \\
\text { location }^{(a)}\end{array}$ & $\begin{array}{c}\text { Detection } \\
\text { frequency }{ }^{(b)}\end{array}$ & Median & $\begin{array}{l}\text { Interquartile } \\
\text { range }\end{array}$ & Maximum & $\begin{array}{l}\text { Median fraction } \\
\text { of } \mathrm{DCG}^{(\mathrm{c})}\end{array}$ \\
\hline \multicolumn{6}{|c|}{ Livermore Valley downwind locations } \\
\hline AMON & $2 / 10$ & 1.8 & 4.5 & 19 & $2.5 \times 10^{-6}$ \\
\hline PATT & $0 / 12$ & 1.1 & 2.5 & $6.0^{(\mathrm{d})}$ & $1.6 \times 10^{-6}$ \\
\hline TANK & $1 / 11$ & 1.2 & 3.5 & 5.8 & $1.7 \times 10^{-6}$ \\
\hline ZON7 & $1 / 12$ & 5.4 & 5.8 & 11 & $7.4 \times 10^{-6}$ \\
\hline \multicolumn{6}{|c|}{ Livermore Valley upwind locations } \\
\hline FCC & $0 / 12$ & 1.6 & 2.0 & $7.0^{(d)}$ & $2.2 \times 10-6$ \\
\hline FIRE & $1 / 12$ & 2.8 & 3.3 & 10 & $3.8 \times 10-6$ \\
\hline HOSP & $1 / 12$ & 3.3 & 3.9 & 11 & $4.4 \times 10-6$ \\
\hline CHUR & $0 / 12$ & 1.8 & 3.3 & $4.4^{(d)}$ & $2.4 \times 10-6$ \\
\hline \multicolumn{6}{|c|}{ LLNL perimeter } \\
\hline CAFE & $1 / 12$ & 5.9 & 2.7 & 16 & $8.0 \times 10^{-6}$ \\
\hline cow & $2 / 12$ & 2.4 & 4.6 & 10 & $3.2 \times 10^{-6}$ \\
\hline MESQ & $1 / 12$ & 2.3 & 4.2 & 9.0 & $3.1 \times 10^{-6}$ \\
\hline MET & $1 / 12$ & 1.4 & 2.5 & 7.6 & $1.9 \times 10^{-6}$ \\
\hline SALV & $1 / 12$ & 4.4 & 3.7 & 5.6 & $5.9 \times 10^{-6}$ \\
\hline VIS & $8 / 12$ & 8.6 & 7.2 & 44 & $1.2 \times 10^{-5}$ \\
\hline \multicolumn{6}{|c|}{ Diffuse on-site sources } \\
\hline B531 & $10 / 12$ & 16 & 51 & 110 & $2.1 \times 10^{-5}$ \\
\hline CRED & $1 / 12$ & 1.2 & 3.3 & 9.9 & $1.6 \times 10^{-6}$ \\
\hline \multicolumn{6}{|c|}{ Special interest } \\
\hline LWRP & $5 / 12$ & 4.5 & 12 & 25 & $6.0 \times 10^{-6}$ \\
\hline \multicolumn{6}{|c|}{ Site 300 on-site } \\
\hline S300 composite & $3 / 12$ & 1.6 & 1.4 & 16 & $2.1 \times 10^{-6}$ \\
\hline \multicolumn{6}{|c|}{ Site 300 off-site } \\
\hline PRIM & $2 / 12$ & 2.2 & 3.4 & 11 & $2.9 \times 10^{-6}$ \\
\hline TFIR & $1 / 12$ & 0.86 & 5.2 & 11 & $1.2 \times 10^{-6}$ \\
\hline
\end{tabular}

a See Figures 5-1, 5-2, and 5-3 for sampling locations.

b Detection frequency is the number of samples with results above the detection limit divided by the number of samples.

c $\quad D C G=$ Derived Concentration Guide of $7.4 \times 10^{-4} \mathrm{~Bq} / \mathrm{m}^{3}\left(2 \times 10^{-8} \mu \mathrm{Ci} / \mathrm{m}^{3}\right)$ for ${ }^{239} \mathrm{Pu}$ activity in air.

d Maximum value shown is less than the reported error and considered a nondetect. 


\section{Surveillance Air Monitoring}

Table 5-4 shows the median concentrations of airborne ${ }^{239+240} \mathrm{Pu}$ at the two diffuse source locations (B531 and CRED). (See Data Supplement, Table 5-7 for monthly data.) The median concentration of $1.6 \times 10^{-8} \mathrm{~Bq} / \mathrm{m}^{3}\left(4.3 \times 10^{-19} \mathrm{Ci} / \mathrm{m}^{3}\right)$ at location $\mathrm{B} 531$ is higher than the median concentration for any of the other air particulate sampling locations, but it is still only $0.01 \%$ of the DCG. The higher concentrations are attributed to historic waste management operations, which included the operation of solar evaporators for plutonium-containing liquid waste (Silver et al. 1974).

Figure 5-6 shows the annual median concentrations of $239+240 \mathrm{Pu}$ for locations SALV (on site) and FCC (off site) from 1982 to 1998. Location FCC represents a typical upwind background location, and SALV represents a typical perimeter location. The annual median concentration for FCC was $1.6 \times 10^{-9} \mathrm{~Bq} / \mathrm{m}^{3}\left(4.3 \times 10^{-20} \mathrm{Ci} / \mathrm{m}^{3}\right)$. Figure 5-6 uses a log scale; for the years in which a negative median concentration was calculated, the positive value closest to the median is plotted. The higher values in the past at SALV may be attributed to historical activities at LLNL; operational processes in the immediate work area have contributed to the observed downward trend of the data. The downward trend at location FCC is the result of decreasing global fallout.

The median ${ }^{235} \mathrm{U}$ and ${ }^{238} \mathrm{U}$ mass concentrations in air samples from the Livermore site perimeter are shown in Table 5-5. (See Data Supplement, Table 5-8, for monthly data.) The maximum measured concentration of $238 \mathrm{U}$ (at location VIS during September) is less than $0.07 \%$ of the DCG. All ${ }^{235} \mathrm{U} /{ }^{238} \mathrm{U}$ median ratios are as expected for naturally occurring uranium; however, monthly data in the Data Supplement show some unexpected $235 \mathrm{U} / 238 \mathrm{U}$ ratios. These ratios are most likely caused by the change to more efficient filter media that contain sufficient levels of uranium to interfere with the measurements. No significant environmental impact stems from the observed ratios.

Typical gross alpha and gross beta activity from the low-volume sampling locations HOSP and FCC is $5.4 \times 10^{-11} \mathrm{~Bq} / \mathrm{mL}\left(1.5 \times 10^{-21} \mathrm{Ci} / \mathrm{mL}\right)$ and $5.0 \times 10^{-10} \mathrm{~Bq} / \mathrm{mL}$ $\left(1.4 \times 10^{-20} \mathrm{Ci} / \mathrm{mL}\right)$, respectively. (See Data Supplement, Tables 5-9 and 5-10, for monthly median data.) These gross alpha values are higher than those reported from the high-volume sampling systems at the same locations. The difference is probably due to differences in the filter type, and LLNL is conducting a study to determine the cause of the differences. 


\section{Surveillance Air Monitoring}

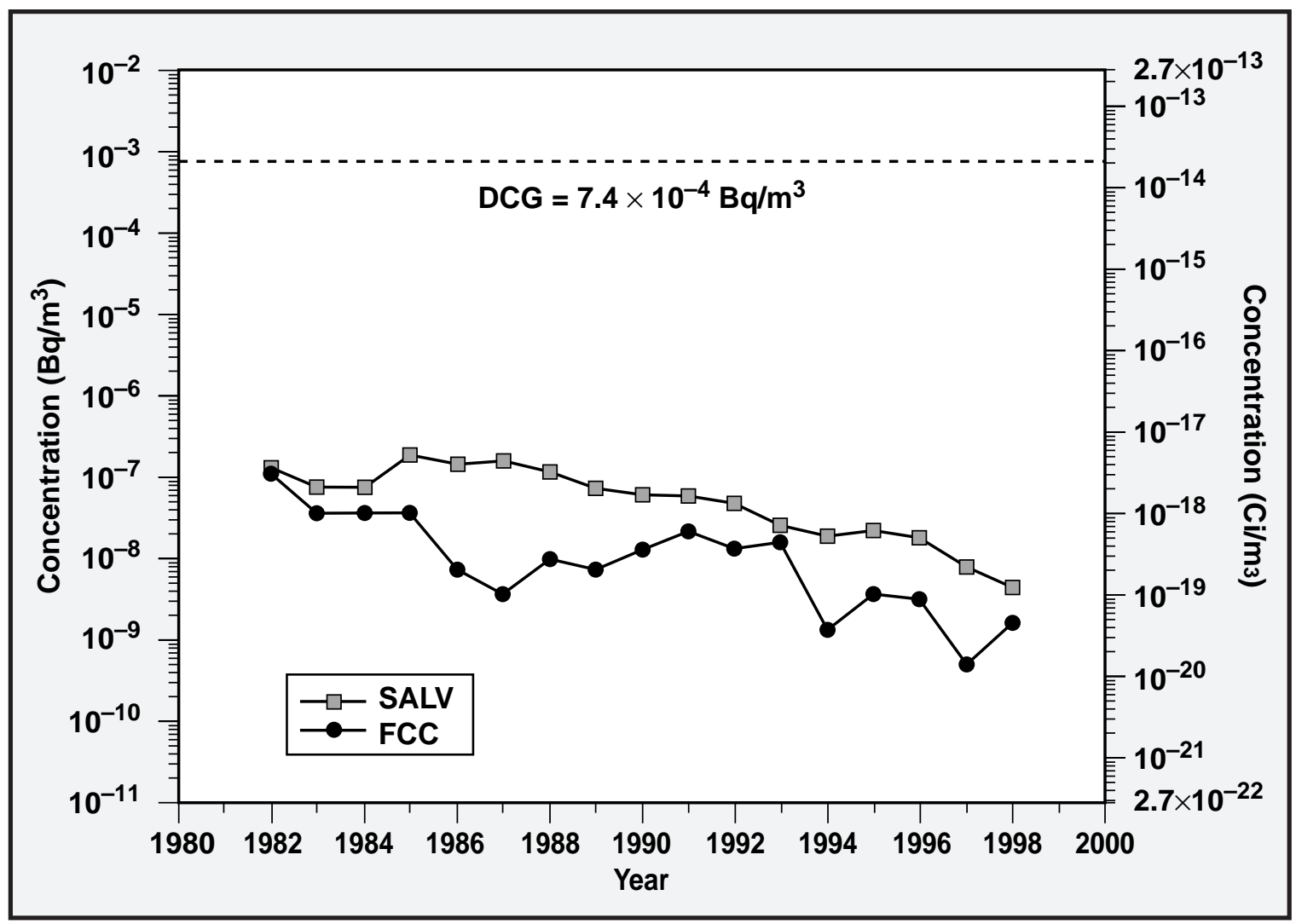

Figure 5-6. Median plutonium concentrations in air particulate samples at two locations, SALV and FCC, 1982 to $1998\left(\mathrm{DCG}=7.4 \times 10^{-4} \mathrm{~Bq} / \mathrm{m}^{3}\right)$.

Table 5-6 shows the median concentrations of tritiated water vapor for the Livermore Valley sampling locations. (See Data Supplement, Table 5-11, for biweekly data for each location.) The highest annual median concentration was observed at location ZON7. At approximately $2.5 \times 10^{-2} \mathrm{~Bq} / \mathrm{m}^{3}\left(6.6 \times 10^{-13} \mathrm{Ci} / \mathrm{m}^{3}\right)$, this concentration represents $0.0007 \%$ of the DCG. The highest biweekly concentration was observed in January at ZON7. If it were a yearly average, this concentration, $7.3 \times 10^{-2} \mathrm{~Bq} / \mathrm{m}^{3}$ $\left(2.0 \times 10^{-12} \mathrm{Ci} / \mathrm{m}^{3}\right)$, would be $0.002 \%$ of the DCG. The 1998 tritium values are generally similar to those reported last year.

Table 5-6 also shows the median concentrations of tritiated water vapor that were observed at the Livermore site perimeter sampling locations. (See Data Supplement, Table 5-12, for biweekly data.) The highest annual median concentration was observed at location POOL, which was $0.18 \mathrm{~Bq} / \mathrm{m}^{3}\left(4.9 \times 10^{-12} \mathrm{Ci} / \mathrm{m}^{3}\right)$, or $0.005 \%$ of the DCG. 


\section{Surveillance Air Monitoring}

Table 5-5. Uranium mass concentration in air particulate samples, 1998.

\begin{tabular}{|c|c|c|c|}
\hline $\begin{array}{l}\text { Sampling } \\
\text { location(a) }^{(a)}\end{array}$ & $\begin{array}{c}{ }^{238} U^{(b)} \\
\left(10^{-5} \mu g / m^{3}\right)\end{array}$ & $\begin{array}{c}{ }^{235} \mathrm{U}^{(\mathrm{c})} \\
\left(10^{-7} \mu \mathrm{g} / \mathrm{m}^{3}\right)\end{array}$ & $\begin{array}{c}{ }^{235} \mathrm{U}^{/ 238} \mathrm{U}^{(\mathrm{d})} \\
\left(10^{-3}\right)\end{array}$ \\
\hline \multicolumn{4}{|l|}{ CAFE } \\
\hline Median & 3.35 & 1.90 & 6.05 \\
\hline Interquartile range & 3.81 & 2.75 & 2.25 \\
\hline Maximum & 13.8 & 9.99 & $N A^{(e)}$ \\
\hline Median fraction of DCG $(\mathrm{f})$ & $1.12 \times 10^{-4}$ & $4.04 \times 10^{-6}$ & NA \\
\hline \multicolumn{4}{|l|}{ cow } \\
\hline Median & 2.80 & 1.44 & 6.12 \\
\hline Interquartile range & 3.87 & 3.15 & 1.41 \\
\hline Maximum & 14.0 & 10.1 & NA \\
\hline Median fraction of DCG & $9.35 \times 10^{-5}$ & $3.07 \times 10^{-6}$ & NA \\
\hline \multicolumn{4}{|l|}{ MESQ } \\
\hline Median & 3.70 & 2.21 & 6.31 \\
\hline Interquartile range & 4.72 & 3.43 & 0.926 \\
\hline Maximum & 15.8 & 11.6 & NA \\
\hline Median fraction of DCG & $1.23 \times 10^{-4}$ & $4.71 \times 10^{-6}$ & NA \\
\hline \multicolumn{4}{|l|}{ MET } \\
\hline Median & 2.76 & 1.33 & 6.25 \\
\hline Interquartile range & 5.31 & 3.91 & 1.02 \\
\hline Maximum & 13.9 & 9.93 & NA \\
\hline Median fraction of DCG & $9.18 \times 10^{-5}$ & $2.83 \times 10^{-6}$ & NA \\
\hline \multicolumn{4}{|l|}{ SALV } \\
\hline Median & 2.21 & 1.00 & 5.67 \\
\hline Interquartile range & 4.53 & 3.32 & 2.43 \\
\hline Maximum & 11.5 & 8.11 & NA \\
\hline Median fraction of DCG & $7.35 \times 10^{-5}$ & $2.12 \times 10^{-6}$ & NA \\
\hline \multicolumn{4}{|l|}{ VIS } \\
\hline Median & 3.56 & 2.16 & 6.25 \\
\hline Interquartile range & 6.33 & 4.16 & 1.43 \\
\hline Maximum & 19.7 & 13.9 & NA \\
\hline Median fraction of DCG & $1.19 \times 10^{-4}$ & $4.61 \times 10^{-6}$ & NA \\
\hline \multicolumn{4}{|l|}{ Site $\mathbf{3 0 0}$ (composite) } \\
\hline Median & 3.18 & 1.48 & 5.19 \\
\hline Interquartile range & 10.7 & 7.49 & 3.27 \\
\hline Maximum & 58.1 & 14.6 & NA \\
\hline Median fraction of DCG & $1.06 \times 10^{-4}$ & $3.15 \times 10^{-6}$ & NA \\
\hline
\end{tabular}


Table 5-5. Uranium mass in concentration air particulate samples, 1998 (concluded).

\begin{tabular}{|c|c|c|c|}
\hline $\begin{array}{l}\text { Sampling } \\
\text { Iocation(a) }^{(a)}\end{array}$ & $\begin{array}{c}{ }^{238} \mathrm{U}^{(\mathrm{b})} \\
\left(10^{-5} \mu \mathrm{g} / \mathrm{m}^{3}\right)\end{array}$ & $\begin{array}{c}{ }^{235} \mathrm{U}^{(\mathrm{c})} \\
\left(10^{-7} \mu \mathrm{g} / \mathrm{m}^{3}\right)\end{array}$ & $\begin{array}{c}{ }^{235} U^{238} U^{(d)} \\
\left(10^{-3}\right)\end{array}$ \\
\hline \multicolumn{4}{|l|}{ PRIM } \\
\hline Median & 3.96 & 1.63 & 5.76 \\
\hline Interquartile range & 5.64 & 3.75 & 1.86 \\
\hline Maximum & 16.5 & 11.8 & $N A^{(e)}$ \\
\hline Median fraction of DCG $(\mathrm{f})$ & $1.32 \times 10^{-4}$ & $3.47 \times 10^{-6}$ & NA \\
\hline
\end{tabular}

a See Figures 5-1 and 5-3 for sampling locations.

b Derived Concentration Guide $=0.3 \mu \mathrm{g} / \mathrm{m}^{3}$ for ${ }^{238} \mathrm{U}$ activity in air. Uranium-238 activities in $\mathrm{Bq} / \mathrm{m}^{3}$ can be determined by dividing the weight in $\mu \mathrm{g} / \mathrm{m}^{3}$ by 80.3 , and $\mathrm{pCi} \mathrm{m}^{3}$ can be determined by dividing by 2.97 .

c Derived Concentration Guide $=0.047 \mu \mathrm{g} / \mathrm{m}^{3}$ for ${ }^{235} \mathrm{U}$ activity in air. Uranium-235 activities in $\mathrm{Bq} / \mathrm{m}^{3}$ can be determined by dividing the weight in $\mu \mathrm{g} / \mathrm{m}^{3}$ by 12.5 , and $\mathrm{pCi} \mathrm{m} \mathrm{m}^{3}$ can be determined by dividing by 0.463 .

d Naturally occurring uranium has a ${ }^{235} \mathrm{U} /{ }^{238} \mathrm{U}$ ratio of $7.1 \times 10^{-3}$.

e $\mathrm{NA}=$ Not applicable.

f $\quad$ DCG $=$ Derived Concentration Guide.

Diffuse sources of tritium on the Livermore site are monitored at air tritium sampling locations B331, B292, B514, and B624. Table 5-6 shows the median concentrations of tritiated water vapor for these sampling locations. (See Data Supplement, Table 5-13, for biweekly data.) The highest median concentration was observed at location B331. This concentration was $16.6 \mathrm{~Bq} / \mathrm{m}^{3}\left(4.5 \times 10^{-10} \mathrm{Ci} / \mathrm{m}^{3}\right)$ and represents $0.4 \%$ of the DCG. The highest biweekly tritium concentration, $62.2 \mathrm{~Bq} / \mathrm{m}^{3}\left(1.7 \times 10^{-9} \mathrm{Ci} / \mathrm{m}^{3}\right)$, was observed in September at location B331. If it were a yearly average, this concentration would represent $2 \%$ of the DCG.

The B331 location is near the Tritium Facility (Building 331), where LLNL personnel have reduced operations in recent years and performed significant inventory reduction and cleanup activities. During this process, tritium-contaminated equipment slated for disposal is stored in a waste accumulation area before being sent to Hazardous Waste Management facilities. During 1998, outgassing from such waste processing released an estimated $2.2 \times 10^{11} \mathrm{~Bq}(6 \mathrm{Ci})$ of tritium to the atmosphere outside of Building 331 .

The B624 location is situated in the Building 612 yard, which is dedicated to hazardous waste, radioactive waste, and mixed-waste management activities. The yard has several areas where waste containers that are outgassing tritium are stored outdoors. 


\section{Surveillance Air Monitoring}

Table 5-6. Tritium in air samples (in 10-3 Bq/m³), 1998.

\begin{tabular}{|l|c|c|c|c|c|c|}
\hline $\begin{array}{c}\text { Sampling } \\
\text { location(a) }\end{array}$ & $\begin{array}{c}\text { Detection } \\
\text { frequency }\end{array}$ & Median & IQR $^{\text {(c) }}$ & Maximum & $\begin{array}{c}\text { Median } \\
\text { fraction of } \\
\text { DCG(d) }\end{array}$ & $\begin{array}{c}\text { Median } \\
\text { dose } \\
\text { (mSv) (e) }\end{array}$ \\
\hline \multicolumn{7}{|c|}{ Livermore Valley } \\
\hline ZON7 & $22 / 26$ & 24.5 & 18.8 & 72.5 & $6.6 \times 10^{-6}$ & $5.4 \times 10^{-6}$ \\
AMON & $14 / 21$ & 16.0 & 19.4 & 58.1 & $4.3 \times 10^{-6}$ & $3.5 \times 10^{-6}$ \\
XRDS & $12 / 26$ & 7.59 & 13.4 & 29.4 & $2.1 \times 10^{-6}$ & $1.7 \times 10^{-6}$ \\
FIRE & $10 / 26$ & 8.92 & 17.1 & 34.0 & $2.4 \times 10^{-6}$ & $1.9 \times 10^{-6}$ \\
VET & $14 / 26$ & 14.0 & 24.5 & 46.3 & $3.8 \times 10^{-6}$ & $3.0 \times 10^{-6}$ \\
HOSP & $6 / 25$ & 1.76 & 16.7 & 45.5 & $4.8 \times 10^{-7}$ & $3.8 \times 10^{-7}$ \\
\hline \multicolumn{7}{|c|}{ Livermore perimeter } \\
\hline SALV & $22 / 22$ & 55.1 & 35.8 & 117 & $1.5 \times 10^{-5}$ & $1.2 \times 10^{-5}$ \\
MESQ & $22 / 26$ & 20.4 & 39.9 & 108 & $5.5 \times 10^{-6}$ & $4.4 \times 10^{-6}$ \\
CAFE & $25 / 25$ & 90.3 & 92.1 & 437 & $2.4 \times 10^{-5}$ & $2.0 \times 10^{-5}$ \\
MET & $20 / 26$ & 23.9 & 28.8 & 57.4 & $6.5 \times 10^{-6}$ & $5.2 \times 10^{-6}$ \\
VIS & $23 / 23$ & 91.4 & 40.7 & 147 & $2.5 \times 10^{-5}$ & $2.0 \times 10^{-5}$ \\
COW & $25 / 25$ & 50.7 & 44.0 & 124 & $1.4 \times 10^{-5}$ & $1.1 \times 10^{-5}$ \\
POOL & $25 / 25$ & 180 & 155 & 648 & $4.9 \times 10^{-5}$ & $3.9 \times 10^{-5}$ \\
\hline \multicolumn{7}{|c|}{ Diffuse on-site sources } \\
\hline B292 & $24 / 25$ & 91.0 & 61.8 & 207 & $2.5 \times 10^{-5}$ & $2.0 \times 10^{-5}$ \\
B331 & $24 / 24$ & 16,600 & 24,900 & 62,200 & $4.5 \times 10^{-3}$ & $3.6 \times 10^{-3}$ \\
B514 & $24 / 24$ & 2,700 & 3,850 & 10,100 & $7.3 \times 10^{-4}$ & $5.9 \times 10^{-4}$ \\
B624 & $25 / 25$ & 4,770 & 1,480 & 10,500 & $1.3 \times 10^{-3}$ & $1.0 \times 10^{-3}$ \\
\hline \multicolumn{7}{|c|}{ Site 300 off site } \\
\hline PRIM & $4 / 23$ & 2.43 & 6.89 & 41.1 & $6.6 \times 10^{-7}$ & $5.3 \times 10^{-7}$ \\
\hline
\end{tabular}

a See Figures 5-1, 5-2, and 5-3 for sample locations.

b Detection frequency is the number of samples with results above the detection limit divided by the number of samples..

c $\quad$ IQR $=$ Interquartile range.

d $\quad$ DCG $=$ Derived Concentration Guide of $3.7 \times 10^{3} \mathrm{~Bq} / \mathrm{m}^{3}$.

e $1 \mathrm{mSv}=100 \mathrm{mrem}$.

The B514 sampling location is in a hazardous waste management area where tritiumcontaminated waste is treated, and the B292 location is near an underground retention tank that had previously leaked. The concentrations in air at the B514 sampling location are variable because of the changing concentrations of tritium in the waste stream. The 1998 median concentrations at B292 are similar to the median concentrations in 1997. 


\section{Beryllium in Air}

The median concentrations of airborne beryllium for the Livermore site perimeter sampling locations are shown in Table 5-7. (See Data Supplement, Table 5-14, for monthly data.) The highest value of $20 \mathrm{pg} / \mathrm{m}^{3}$ was found in the July composite at location MESQ and was most likely the result of construction activities west of LLNL that cause greater amounts of resuspended particulate. The median concentration for this location is $0.09 \%$ of the monthly ambient concentration limit (ACL) of $10,000 \mathrm{pg} / \mathrm{m}^{3}$ established by the Bay Area Air Quality Management District (BAAQMD) and the EPA.

Table 5-7. Beryllium in air particulate samples (in $\mathrm{pg} / \mathrm{m}^{3}$ ), Livermore site perimeter, and Site 300, 1998.

\begin{tabular}{|l|c|c|c|c|}
\hline $\begin{array}{c}\text { Sampling } \\
\text { location }^{(\mathbf{a})}\end{array}$ & $\begin{array}{c}\text { Detection } \\
\text { frequency } \\
(\mathbf{b})\end{array}$ & Median & $\begin{array}{c}\text { Interquartile } \\
\text { range }\end{array}$ & Maximum \\
\hline \multicolumn{5}{|c|}{ Livermore perimeter } \\
\hline SALV & $11 / 12$ & 4.3 & 5.6 & 9.4 \\
MESQ & $12 / 12$ & 8.6 & 7.2 & 20 \\
CAFE & $12 / 12$ & 7.4 & 7.6 & 12 \\
MET & $12 / 12$ & 5.0 & 6.9 & 13 \\
VIS & $12 / 12$ & 4.8 & 7.9 & 15 \\
COW & $12 / 12$ & 6.3 & 6.8 & 14 \\
\hline \multicolumn{5}{|c|}{ Site $\mathbf{3 0 0}$} \\
\hline EOBS & $11 / 12$ & 5.1 & 6.9 & 21 \\
GOLF & $11 / 12$ & 4.4 & 4.9 & 13 \\
801E & $11 / 12$ & 8.1 & 8.3 & 37 \\
TFIR & $12 / 12$ & 6.9 & 7.2 & 18 \\
\hline
\end{tabular}

a See Figures 5-1 and 5-3 for sampling locations.

b Detection frequency is the number of samples with results above the detection limit divided by the number of samples.

Figure 5-7 is a plot of the median beryllium concentration at the Livermore site perimeter from 1974 through 1998. The decrease in median concentration in 1993 was the result of a change in the analytical laboratory that was used. The overall median concentration during this time period was calculated to be $0.2 \%$ of the ACL. Unless there is a change in LLNL's operations, the beryllium levels are expected to remain unchanged. 


\section{Surveillance Air Monitoring}

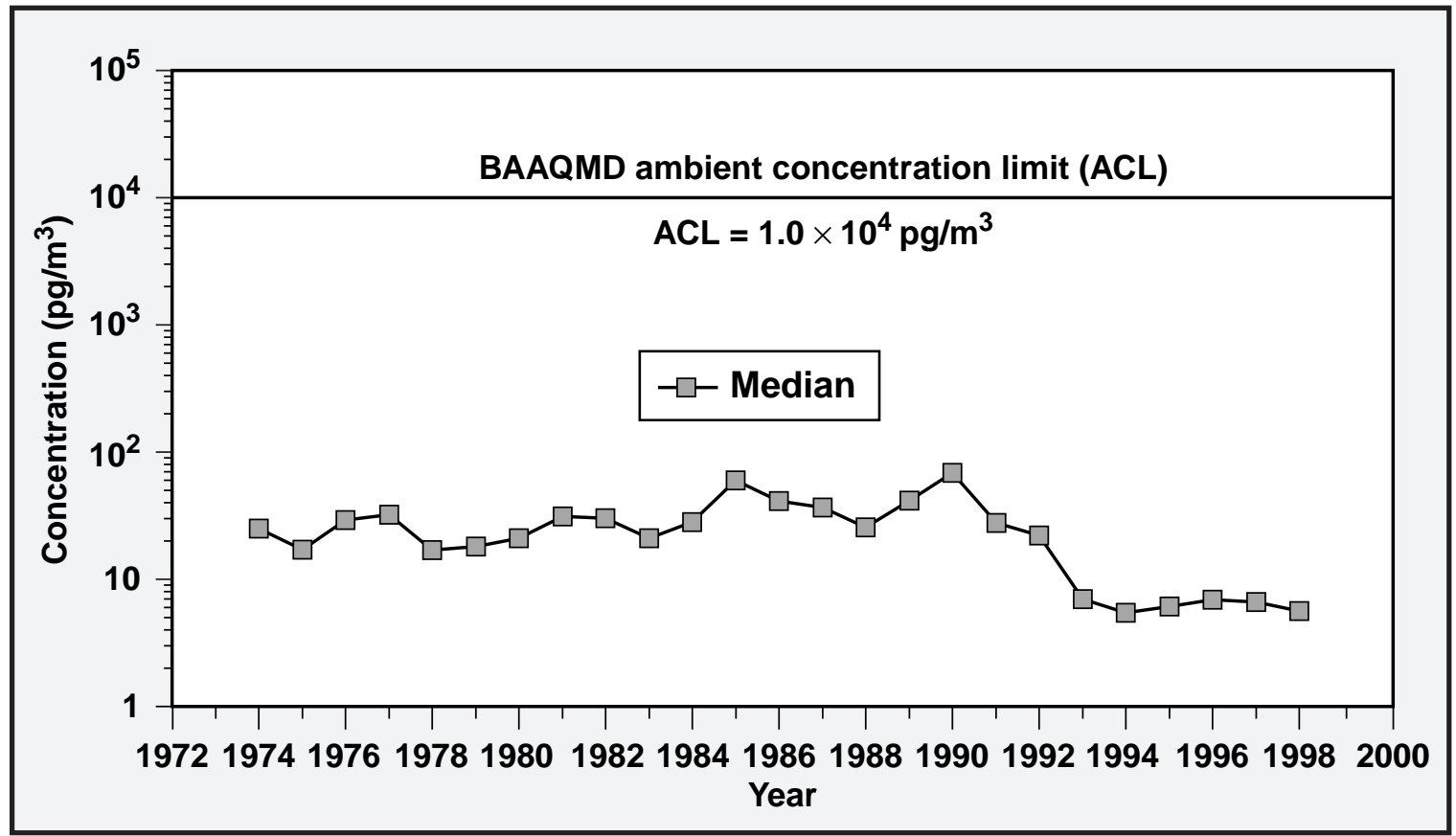

Figure 5-7. Median concentration of beryllium in air particulate samples taken at the Livermore site perimeter, 1974 to 1998.

Site 300

\section{Airborne Radioactivity}

Most gross alpha determinations at Site 300 were at or near the analytical limit of detection for the method and similar to those in previous years. Table 5-2 shows the detection frequency and the monthly gross alpha and gross beta median, IQR, and maximum for sampling locations at Site 300. (See Data Supplement, Table 5-15 for monthly data.) The monthly median gross alpha and gross beta concentrations are shown in Figures 5-4 and 5-5. The Site 300 gross alpha and gross beta results show a similar pattern to those found at the Livermore site. Typical gross alpha activity is $1.4 \times 10^{-5} \mathrm{~Bq} / \mathrm{m}^{3}\left(3.8 \times 10^{-16} \mathrm{Ci} / \mathrm{m}^{3}\right)$. Typical gross beta activity is $3.6 \times 10^{-4} \mathrm{~Bq} / \mathrm{m}^{3}$ $\left(9.7 \times 10^{-15} \mathrm{Ci} / \mathrm{m}^{3}\right)$.

The primary sources of observed gross alpha and gross beta activity are naturally occurring radioisotopes of uranium and thorium, their decay products, and any residual fallout from atmospheric weapons testing and the Chernobyl reactor accident in 1986. 
Table 5-4 shows the median concentration of $239+240 \mathrm{Pu}$ on air-filter samples collected from Site 300. (See Data Supplement, Table 5-17 for monthly data.) The highest concentration of ${ }^{239} \mathrm{Pu}$ was observed in the April composite at a level of $1.6 \times 10^{-8} \mathrm{~Bq} / \mathrm{m}^{3}\left(4.3 \times 10^{-19} \mathrm{Ci} / \mathrm{m}^{3}\right)$, or $0.002 \%$ of the DCG.

Table 5-5 shows the median concentration of $238 \mathrm{U}, 235 \mathrm{U}$, and the $235 \mathrm{U} / 238 \mathrm{U}$ ratio on air samples from Site 300. (See Data Supplement, Table 5-18 for monthly data.) The highest concentration of $238 \mathrm{U}$ was observed in the March composite at a level of $5.8 \times 10^{-4} \mu \mathrm{g} / \mathrm{m}^{3}\left(0.2 \%\right.$ of the DCG). The highest concentration of ${ }^{235} \mathrm{U}$ was also observed in the March composite at a level of $1.4 \times 10^{-6} \mu \mathrm{g} / \mathrm{m}^{3}(0.003 \%$ of the DCG). The overall levels were essentially the same as those reported in previous years.

The ratio of $235 \mathrm{U}$ to $238 \mathrm{U}$ can be used to identify the source of the uranium. Both $235 \mathrm{U}$ and ${ }^{238} \mathrm{U}$ occur naturally in the area, but only $0.7 \%$ of the naturally occurring uranium is $235 \mathrm{U}$, and the remainder is almost entirely ${ }^{238} \mathrm{U}$. Because Site 300 operations use depleted uranium that contains very little ${ }^{235} \mathrm{U}$, it follows that if the ratio remains constant and near $0.7 \%$ (within the limit of sampling and analytical error), then the ${ }^{238} \mathrm{U}$ measured is from natural sources. The ${ }^{235} \mathrm{U} /{ }^{238} \mathrm{U}$ ratios in March, June, and August are less than expected for natural sources, which indicates some impact from operations at Site 300. The median concentration of $238 \mathrm{U}$ for 1998 , however, is only $0.01 \%$ of the DCG.

Table 5-6 shows the median concentration of tritiated water vapor that was observed at the new sampling location (PRIM) near Site 300. (See Data Supplement, Table 5-19 for biweekly data.) The annual median concentration is $2.4 \times 10^{-3} \mathrm{~Bq} / \mathrm{m}^{3}$ $\left(6.5 \times 10^{-14} \mathrm{Ci} / \mathrm{m}^{3}\right)$, or $0.0001 \%$ of the DCG.

\section{Beryllium in Air}

The detection frequency, median concentration, IQR, and maximum concentrations of airborne beryllium for the Site 300 sampling locations are shown in Table 5-7. (See Data Supplement, Table 5-20 for monthly data.) The highest beryllium concentration of $37 \mathrm{pg} / \mathrm{m}^{3}$ occurred in March at location 801E. The median concentration for this location is $0.08 \%$ of the federal and state ambient concentration limit, which is $10,000 \mathrm{pg} / \mathrm{m}^{3}$. 


\section{Surveillance Air Monitoring}

\section{Environmental Impact}

The environmental impacts from both radioactive and nonradioactive effluents are described in this section.

\section{Radioactive Materials}

LLNL operations involving radioactive materials had little impact on radionuclide concentrations in ambient air during 1998. Radionuclide concentrations in air at the Livermore site and in the Livermore Valley are well below levels that would cause concern to the environment or public health according to existing regulatory standards.

The diffuse tritium sources at B292, B331, B514, and B624 have a localized effect; typically tritium concentrations detected at the site perimeter or off site are not from diffuse sources.

The concentrations of radionuclides measured around Site 300 and in the City of Tracy were well below all standards and, except for uranium isotopes, reflect background or naturally occurring levels of these materials. (See Chapter 13, Radiological Dose Assessment, for a discussion of estimated dose from these data.) The $235 \mathrm{U} / 238 \mathrm{U}$ ratios in March, June, and August are less than the ratio of naturally occurring concentrations of these isotopes, which suggests the presence of depleted uranium in Site 300 air samples. This depleted uranium can result from current testing of explosives or resuspension of material left over from testing in previous years. Nevertheless, the detected levels remain far below regulatory standards.

\section{Nonradioactive Materials}

The concentrations of beryllium at both sites can be attributed to resuspension of surface soil containing naturally occurring beryllium. Local soils contain approximately $1 \mathrm{ppm}$ of beryllium, and the air of the Livermore area and Central Valley typically contains 10 to $100 \mu \mathrm{g} / \mathrm{m}^{3}$ of particulates. Using a value of $50 \mu \mathrm{g} / \mathrm{m}^{3}$ for an average dust load and $1 \mathrm{ppm}$ for beryllium content of dust, a conservative airborne beryllium concentration of $50 \mathrm{pg} / \mathrm{m}^{3}$ can be predicted. The overall annual medians for the Livermore site and Site 300 are $5.6 \mathrm{pg} / \mathrm{m}^{3}$ and $6.5 \mathrm{pg} / \mathrm{m}^{3}$, respectively. These data are lower than predicted, well below standards, and do not indicate the presence of a threat to the environment or public health. 


\section{Sewerable Water}

\section{Introduction}

Jennifer M. Larson Robert J. Vellinger

Allen R. Grayson

Ted A. Giesing

Shari L. Brigdon

In 1998, the Livermore site discharged approximately 1 million liters (ML) per day of wastewater to the City of Livermore sewer system, an amount that constitutes $4.0 \%$ of the total flow to the system. This volume includes wastewater generated by Sandia National Laboratories California, which is discharged to the LLNL collection system and combines with LLNL sewage before it is released at a single point to the municipal collection system (Figure 6-1). In 1998, Sandia/California generated approximately $14 \%$ of the total effluent discharged from the Livermore site. LLNL's wastewater contains sanitary sewage and industrial wastewater and is discharged in accordance with permit requirements and the City of Livermore Municipal Code, as discussed below in the Pretreatment and Categorical Discharges sections.

The effluent is treated at the Livermore Water Reclamation Plant (LWRP). As part of the Livermore-Amador Valley Wastewater Management Program, the treated sanitary wastewater is transported out of the valley through a pipeline and discharged into San Francisco Bay. A small portion of this treated wastewater is used for summer irrigation of the adjacent municipal golf course. Sludge from the treatment process is disposed of in sanitary landfills.

LLNL receives water from two suppliers. LLNL's primary water source is the HetchHetchy Aqueduct. Secondary or emergency water deliveries are taken from the Alameda County Flood Control and Water Conservation District Zone 7. This water is a mixture of ground water and water from the South Bay Aqueduct of the State Water Project. Water quality parameters for the two sources are obtained from the suppliers and are used to evaluate compliance with the discharge permit conditions that limit changes in water quality between receipt and discharge.

\section{Preventive Measures}

Administrative and engineering controls at the Livermore site are designed to prevent potentially contaminated wastewater from being discharged directly to the sanitary 


\section{Sewerable Water}

sewer. Waste generators receive training on proper waste handling. LLNL personnel review facility procedures and inspect processes for inappropriate discharges. Retention tanks collect wastewater from processes that might release contaminants in quantities sufficient to disrupt operations at the LWRP; in 1998, there were approximately 40 retention tank systems in use at the Livermore Site. Wastewater that cannot be discharged into one or more of surface water collection units at LLNL's Remote Test Facility is transported to LLNL's Livermore site and managed under Livermore site retention tank administrative controls. Ground water generated from startup operations associated with new, portable ground water treatment units; tests of experimental treatment units, and maintenance of existing treatment facilities is analyzed for pollutants of concern and must meet permitted criteria, or LWRP approval must be obtained before it can be discharged to the sanitary sewer. Finally, to verify the success of training and control equipment, wastewater is sampled and analyzed not only at the significant points of generation, as defined by type and quantity of contaminant generated, but also at the point of discharge to the municipal sewer system.

For facilities with installed retention tank systems, collected wastewater is discharged to the sanitary sewer only if analytical laboratory results show that pollutant levels are within allowable limits (Grandfield 1989). LLNL developed internal discharge guidelines for specific sources and operations to ensure that sewer effluent for the entire site complies with LLNL's waste discharge permit. If pollutant levels exceed permissible concentrations, the wastewater is treated to reduce pollutants to the lowest levels practical and below LLNL guidelines, or it is shipped to an off-site treatment or disposal facility. Liquids containing radioactivity are handled on site and may be treated using processes that reduce the activity to levels well below those required by DOE Order 5400.5. Internal guidelines for retention tank systems and specific sources and operations are discussed later in the Categorical Discharges section. Process wastewater generation and discharge frequency from retention tanks vary from monthly to yearly depending upon the process. During 1998, LLNL discharged an average of 23 wastewater retention tanks each month, with an average volume of approximately 10,300 liters per tank.

For the year as a whole, the monitoring data reflect the success of LLNL's discharge control program in preventing any significant impact on the operations of Livermore's treatment plant and are generally consistent with past values. 


\section{Monitoring}

\section{Monitoring at the Sewer Monitoring Station}

LLNL's sanitary sewer discharge permit requires continuous monitoring of the effluent flow rate and $\mathrm{pH}$. Samplers collect flow-proportional composite samples and instantaneous grab samples that are analyzed for metals, radioactivity, toxic chemicals, and water-quality parameters. In addition, as a best management practice, the outflow to the municipal collection system is sampled continuously and analyzed in real time for conditions that might upset the LWRP treatment process or otherwise impact the public welfare. The effluent is continuously analyzed for $\mathrm{pH}$, selected metals, and radioactivity. If concentrations above warning levels are detected, an alarm is registered at the LLNL Fire Dispatcher's Station, which is attended 24 hours a day, and the site effluent is diverted to the Sewer Diversion Facility (SDF), discussed in the Diversion System section. The monitoring system provides a continuous check on sewage control, and the LWRP is notified of contaminant alarms. Trained staff respond to all alarms to evaluate the cause and take appropriate action.

\section{Monitoring at the Upstream pH Monitoring Station}

During 1998, LLNL designed and built the $\mathrm{pH}$ Monitoring Station (pHMS) in response to Notices of Violations for 1996 and $1997 \mathrm{pH}$ excursions that exceeded the permitted range. This project was completed and became operational in October 1998 (see Figure 6-1 for a system diagram). The station continuously monitors $\mathrm{pH}$ between 7 a.m. and 7 p.m. during the work week and will divert $\mathrm{pH}$ discharges outside the permitted 5 to 10 range to the SDF. Generally, the pHMS duplicates the $\mathrm{pH}$ monitoring and diversion capabilities of the main Sewer Monitoring Station (SMS), but because it is located upstream of the SDF it is able to initiate diversion earlier. Earlier detection allows LLNL to divert all of the unpermitted site effluent, whereas, previously some effluent was released because of the physical locations of the SMS and the SDF. Although the 1996 and 1997 releases of the first few minutes of $\mathrm{pH}$ excursions had no impact on the LWRP treatment process or public welfare, they were, nonetheless, releases exceeding the permitted range, for which the LWRP issued Notices of Violation. Ultimately, as a best management practice, the pHMS supplements the SMS continuous monitoring system.

The upstream station is located in the northwest corner of the LLNL site where the two main trunk lines, running from east to west and south to north converge. This is also where the site effluent is monitored in the SMS shortly before discharge to the Livermore City sanitary sewer system (see Figure 6-1). In each of the main trunk lines, just prior to their point of convergence, manholes were installed with stainless steel channels for wastewater flow and grinders to homogenize the solid materials in 


\section{Sewerable Water}

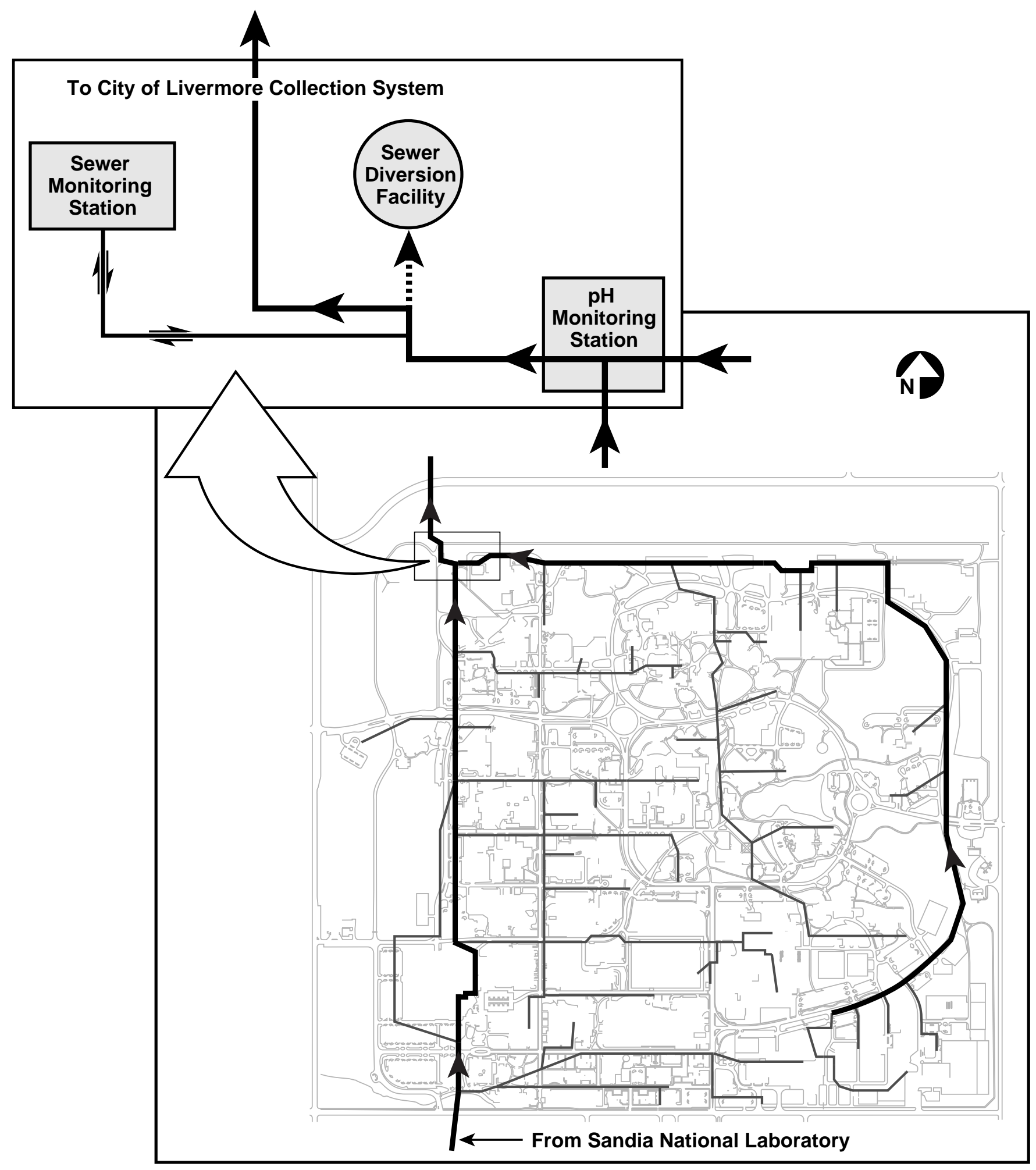

Figure 6-1. LLNL sanitary sewer system monitoring stations and diversion facility. 


\section{Sewerable Water}

the flow. At the convergence, an underground vault was installed with a stainless steel channel to convey flow and stainless steel tubes angled into the flow stream to serve as conduits for monitoring probe insertion. The flow $\mathrm{pH}$ is monitored continuously at the point of convergence, as well as the in each of the main trunk lines (providing some measure of spill-traceback capability and confirmation of properly operating monitoring equipment). To measure flow rate in the combined stream, a Parshall flume and a sonic sensor head were also installed; flow-monitoring probes measure flow rate in each of the two main trunk lines entering the vault. The flowrate data are transmitted to the nearby monitoring building, constructed to house a data logger and three samplers, which, activated by $\mathrm{pH}$ events, collects samples from the combined effluent and each of the two main trunk lines.

\section{Diversion System}

LLNL operates and maintains a diversion system that activates automatically when either the SMS continuous monitoring system or the pHMS sounds an alarm. The SDF ensures that all but the first few minutes of the potentially affected wastewater flow is retained at LLNL, thereby protecting the LWRP and minimizing any required cleanup. During $\mathrm{pH}$ excursions even the first few minutes of affected wastewater flow is retained, as described in the previous section. Up to 775,000 L of potentially contaminated sewage can be held pending analysis to determine the appropriate handling method. The diverted effluent may be returned to the sanitary sewer (if it meets LLNL's wastewater discharge permit limits), shipped for off-site disposal, or treated at LLNL's Hazardous Waste Management Facility. All diverted sewage in 1998 was returned to the sanitary sewer.

\section{Pretreatment Discharges}

The general pretreatment regulations establish both general and specific standards for the discharge of prohibited substances (40 CFR 403.5) that apply to all industrial users. These regulations apply even if LLNL is subject to other federal, state, or local pretreatment standards. The pretreatment standards contain prohibitions that are intended to protect the LWRP and its operations from interference with its treatment processes or passthrough that would cause the LWRP to violate its own effluent limitations. The LWRP, under the authorization of the SFRWQCB, requires self-monitored pretreatment programs at both the Livermore site and Site 300. The sampling and monitoring of 


\section{Sewerable Water}

nondomestic, industrial sources covered by pretreatment standards defined in 40 CFR 403 is required in the 1998-1999 Wastewater Discharge Permit (No. 1250) issued for the discharge of wastewater from LLNL into the City of Livermore sewer system. Permit 1250 lists all the self-monitoring parameters that are applied at the SMS before wastewater enters the municipal collection system (see Figure 6-1). Those parameters with numerical limits are listed in Table 6-1. Other required parameters such as flow rate, biological oxygen demand, total dissolved solids, total suspended solids, and tributyltin are also monitored at the SMS but have no specific numerical limits.

Table 6-1. Limits under Permit 1250 for discharges into the municipal sewer.

\begin{tabular}{|l|c|}
\hline \multicolumn{1}{|c|}{ Constituent } & Discharge limit \\
\hline Metals (mg/L) & \\
Arsenic & 0.06 \\
Cadmium & 0.14 \\
Copper & 1.0 \\
Chromium (total) & 0.62 \\
Lead & 0.20 \\
Mercury & 0.01 \\
Nickel & 0.61 \\
Silver & 0.20 \\
Zinc & 3.00 \\
Cyanide (mg/L) & 0.04 \\
Total Toxic Organics (mg/L) & 1.00 \\
$\mathrm{pH}$ (pH units) & $5-10$ \\
\hline
\end{tabular}

\section{Categorical Discharges}

The Environmental Protection Agency (EPA) publishes categorical standards as regulations separate from the general pretreatment regulations and developed for broad categories of specific industrial processes determined to be the most significant contributors to point source water pollution. These standards contain specific numerical limits for the discharge of industry-specific pollutants from individual processes. The number of processes at LLNL utilizing these pollutants is subject to rapid and frequent change as programmatic requirements dictate. During 1998, the LWRP identified 20 specific LLNL wastewater generating processes that fall under the definition of two categorical standards: Electrical and Electronic Components (40 CFR 469), and Metal Finishing (40 CFR 433). The discharge limits for these standards are shown in Table 6-2. Under the terms in the permit, only those processes that discharge to the sanitary sewer require sampling, inspection, and reporting. Three of the 20 identified processes meet 


\section{Sewerable Water}

these criteria. In 1998, LLNL analyzed samples for all regulated parameters from these three processes and the results showed that LLNL complies with all federal categorical discharge limits.

Table 6-2. Discharge limits for nonradioactive pollutants in wastewaters at point of discharge into LLNL sewer.

\begin{tabular}{|c|c|c|c|c|}
\hline \multirow[b]{2}{*}{ Parameter } & \multicolumn{4}{|c|}{ Discharge limit } \\
\hline & Internal $^{(a)}$ & $\begin{array}{c}\text { Metal } \\
\text { finishing }^{(b)}\end{array}$ & $\begin{array}{c}\text { Electric } \\
\text { component }^{(b)}\end{array}$ & Permit 1510G \\
\hline \multicolumn{5}{|l|}{ Metals (mg/L) } \\
\hline Arsenic & $N A^{(c)}$ & -(d) $^{(\mathrm{d}}$ & 0.83 & 0.06 \\
\hline Cadmium & 0.9 & 0.07 & $-^{(d)}$ & 0.14 \\
\hline Chromium (total) & 4.9 & 1.71 & -(d) $^{(\mathrm{d}}$ & 0.62 \\
\hline Copper & 10 & 2.07 & $-^{(\mathrm{d})}$ & 1.00 \\
\hline Lead & 4.9 & 0.43 & $-^{(\mathrm{d})}$ & 0.20 \\
\hline Mercury & 0.05 & -(d) $^{(\mathrm{d}}$ & -(d) $^{(\mathrm{d}}$ & 0.01 \\
\hline Nickel & 5 & 2.38 & (d) $^{(d)}$ & 0.61 \\
\hline Silver & 1 & 0.24 & -(d) $^{(\mathrm{d})}$ & 0.20 \\
\hline Zinc & 15 & 1.48 & $-^{(\mathrm{d})}$ & 3.00 \\
\hline \multicolumn{5}{|l|}{ Organics $(\mathrm{mg} / \mathrm{L})$} \\
\hline TTO(e) & 4.57 & 2.13 & 1.37 & 1.00 \\
\hline \multicolumn{5}{|l|}{ Other (mg/L) } \\
\hline Cyanide ${ }^{(\mathrm{f})}$ & 5 & 0.65 & -(d) $^{\text {(d) }}$ & $0.04^{(g)}$ \\
\hline pH (pH units) & $5-10$ & $5-10$ & $5-10$ & $5-10$ \\
\hline
\end{tabular}

Note: Permit $1510 \mathrm{G}$ is discussed in the following section, Discharges of Treated Ground Water.

a These standards were established to meet the City of Livermore's requirements at the point of discharge to the Municipal Sewer (SMS).

b These standards were specified by EPA. By regulation, the EPA or City of Livermore limit is used, whichever is lower. Internal limits apply where no other standard is specified.

c NA = Not applicable. There is no specific internal discharge limit; therefore, the discharge limit in Permit 1250 is used as a guideline for this parameter.

d There is no specific categorical limit for this parameter; therefore, internal discharge limits apply.

e Total toxic organics, as defined by the Livermore Municipal Code.

f Limits apply to cyanide discharges other than cyanide salts. Cyanide salts are classified by the State of California as "extremely hazardous waste" and cannot be discharged to the sewer.

g Although Permit 1510G lists a discharge limit for cyanide, sample collection is not required by the self monitoring program.

The first of the three categorical processes that discharge directly into the sanitary sewer system is an abrasive jet machine (or water-jet) that is regulated under the Metalfinishing Point Source Category. The water-jet uses about 4-6 liters (1-1.5 gallons) of 


\section{Sewerable Water}

water per minute and is in use from four to six hours per day. Approximately 75 liters (20 gallons) per cycle of the filtered water are discharged to the sanitary sewer. The remaining water is pumped back into the water-jet for reuse.

The other two discharging categorical processes are both regulated under the Federal Electrical and Electronic Component Point Source Category. One is a series of processes clustered within a single building housing research-scale microfabrication laboratories used for developing prototype semiconductor devices. These laboratories discharge into a building wastewater retention system, and because they are housed within the same building, with no diluting flow, they share a single point of compliance. The second activity is a small gallium arsenide cutting operation; this process discharges directly to the sanitary sewer.

The non discharging processes, all regulated under the Metal-Finishing Point Source Category (40 CFR 433), are printed circuit board manufacture, electrolysis plating, chemical etching, electroplating, anodizing, coating, painting, cleaning, electrical discharge machining, irridite process, and abrasive jet machining (water-jet). The wastewater from these processes is contained for removal and appropriate disposal by LLNL's Hazardous Waste Management Division (HWM).

Tables 6-2 and 6-3 show LLNL's internal discharge limits for wastewater discharged to the sanitary sewer. Those processes that discharge to the sanitary sewer are subject to the pretreatment self-monitoring program specified in the Wastewater Discharge Permit issued by the LWRP. In 1998, no exceedances of the pollutant limitations in the discharge permit were observed.

Table 6-3. LLNL's internal discharge limits for radioisotopes in wastewaters. There is no gross gamma limit; isotope-specific limits apply.

\begin{tabular}{|l|l|l|}
\hline \multicolumn{1}{|c|}{ Parameter } & Individual discharge & Total daily limit for site \\
\hline Gross alpha & $11.1 \mathrm{~Bq} / \mathrm{L}(300 \mathrm{pCi} / \mathrm{L})$ & $185 \mathrm{kBq}(5.0 \mu \mathrm{Ci})$ \\
Gross beta & $111 \mathrm{~Bq} / \mathrm{L}(3000 \mathrm{pCi} / \mathrm{L})$ & $1.85 \mathrm{MBq}(50.0 \mu \mathrm{Ci})$ \\
Tritium & $185 \mathrm{kBq} / \mathrm{L}(5.0 \mu \mathrm{Ci} / \mathrm{L})$ & $3.7 \mathrm{GBq}(100.0 \mathrm{mCi})$ \\
\hline
\end{tabular}

\section{Discharges of Treated Ground Water}

LLNL's ground water discharge permit $(1510 \mathrm{G}, 1998)$ allows treated ground water from site-wide CERCLA cleanup activities to be discharged in the City of Livermore sanitary sewer in compliance with Table 6-2 effluent limitations taken from the Livermore Municipal Code. 


\section{Sewerable Water}

During 1998, the volume of ground water discharged to the sanitary sewer was approximately 62,100 liters. Water discharges during this period were related to startup operations associated with new portable treatment units being built and installed throughout the site, testing of an experimental nitrate removal treatment system, and maintenance of existing ground water treatment facilities. Eleven separate discharges were sampled and discharged to the sewer during this period, all in compliance with self-monitoring permit provisions of Permit 1510G. Concentrations of regulated compounds were all below discharge limits. Complete monitoring data are presented in the Data Supplement, Chapter 6.

\section{Radioactive Pollutants in Sewage Monitoring Results}

LLNL determines the total radioactivity released from tritium, alpha emitters, and beta emitters based either on the measured radioactivity in the effluent or on the limit of sensitivity, whichever is higher (see Table 6-4). The 1998 combined releases of tritium and alpha and beta sources were $10 \mathrm{GBq}(0.27 \mathrm{Ci})$. The total is based on the results shown in Table 6-4; unlike the years prior to 1996, the total does not include a contribution from Sandia/California, which concluded all of its tritium research activities as of October 1994. The cleanup activities at their former tritium research laboratories were completed by October 1995. The annual mean concentration of tritium in LLNL sanitary sewer effluent was $0.029 \mathrm{~Bq} / \mathrm{mL}(0.78 \mathrm{pCi} / \mathrm{mL})$.

Table 6-4. Estimated total radioactivity in LLNL sanitary sewer effluent, 1998.

\begin{tabular}{|l|c|c|}
\hline $\begin{array}{c}\text { Radioactive } \\
\text { emitter }\end{array}$ & $\begin{array}{c}\text { Estimate based on effluent } \\
\text { activity (GBq) }\end{array}$ & $\begin{array}{c}\text { Limit of sensitivity } \\
\text { (GBq) }\end{array}$ \\
\hline Tritium & 10 & 3.9 \\
Alpha sources & 0.042 & 0.034 \\
Beta sources & 0.29 & 0.044 \\
\hline
\end{tabular}

a $37 \mathrm{Gbq}=3.7 \times 10^{10} \mathrm{~Bq}=1 \mathrm{Ci}$.

The concentrations of ${ }^{239} \mathrm{Pu},{ }^{137} \mathrm{Cs}$, and tritium measured in the sanitary sewer effluent from LLNL and LWRP are presented in Table 6-5. The tritium numbers are based on the flow-weighted average of the individual daily sample results for a given month. The plutonium and cesium numbers are the direct result of analysis of monthly composite samples of LLNL and LWRP effluent, and quarterly composites of LWRP sludge. At the bottom of the table, the total activity released is given by radioisotope. This was 


\section{Sewerable Water}

Table 6-5. Tritium, cesium, and plutonium in sanitary sewer effluents, LLNL and LWRP, 1998.

\begin{tabular}{|c|c|c|c|c|c|c|c|}
\hline \multirow[t]{2}{*}{ Month } & \multicolumn{2}{|c|}{$\begin{array}{c}{ }^{3} \mathrm{H} \\
(\mathrm{mBq} / \mathrm{mL})^{(a)}\end{array}$} & \multicolumn{2}{|c|}{$\begin{array}{c}{ }^{137} \mathrm{Cs} \\
(\mu \mathrm{Bq} / \mathrm{mL})^{(\mathrm{a})}\end{array}$} & \multicolumn{2}{|c|}{$\begin{array}{c}{ }^{239} \mathrm{Pu} \\
(\mathrm{nBq} / \mathrm{mL})^{(\mathrm{a})}\end{array}$} & \multirow{2}{*}{\begin{tabular}{|c|}
$\begin{array}{c}{ }^{239} \mathrm{Pu} \\
(\mathrm{mBq} / \mathrm{dry} \mathrm{g})^{(\mathrm{a})}\end{array}$ \\
LWRP sludge $^{(\mathrm{b})}$ \\
\end{tabular}} \\
\hline & LLNL & LWRP & LLNL & LWRP & LLNL & LWRP & \\
\hline Jan & 3.8 & -3.0 & $1.4 \pm 0.7$ & $<0.41$ & $214 \pm 45$ & $1.35 \pm 8.40$ & \\
\hline Feb & $31 \pm 4$ & -2.7 & $1.6 \pm 0.7$ & $<0.38$ & $307 \pm 57$ & $-5.40 \pm 7.29$ & \\
\hline Mar & $32 \pm 4$ & 3.1 & $1.1 \pm 0.7$ & $<0.38$ & $147 \pm 43$ & $5.4 \pm 20.7$ & $0.30 \pm 0.06$ \\
\hline Apr & 3.9 & -0.26 & $1.4 \pm 0.8$ & $<0.47$ & $189 \pm 41$ & $0.35 \pm 6.14$ & \\
\hline May & $37 \pm 4$ & 3.1 & $1.2 \pm 0.5$ & $0.47 \pm 0.53$ & $437 \pm 66$ & $1.60 \pm 6.48$ & \\
\hline Jun & $21 \pm 4$ & 2.8 & $1.5 \pm 0.7$ & $<0.46$ & $185 \pm 43$ & $56.2 \pm 26.9$ & $0.32 \pm 0.05$ \\
\hline Jul & 3.5 & -2.2 & $1.3 \pm 0.6$ & $<0.45$ & $264 \pm 49$ & $16.3 \pm 21.9$ & \\
\hline Aug & 9.5 & -4.1 & $1.6 \pm 0.4$ & $<0.39$ & $148 \pm 44$ & $-6.1 \pm 11.7$ & \\
\hline Sep & 8.9 & 1.8 & $1.5 \pm 0.7$ & $<0.39$ & $137 \pm 30$ & $2.18 \pm 4.70$ & $0.21 \pm 0.03$ \\
\hline Oct & $26 \pm 4$ & 2.9 & $1.8 \pm 0.8$ & $<0.56$ & $180 \pm 65$ & $5.07 \pm 5.85$ & \\
\hline Nov & $31 \pm 6$ & 4.3 & $0.93 \pm 0.13$ & $<0.41$ & $131 \pm 34$ & $-2.43 \pm 8.70$ & \\
\hline Dec & $61 \pm 5$ & 3.6 & $0.85 \pm 1.02$ & $0.32 \pm 0.63$ & $314 \pm 54$ & $4.63 \pm 7.96$ & $0.20 \pm 0.03$ \\
\hline Median & 24 & $<2.8$ & 1.4 & $<0.41$ & 187 & 1.9 & 0.25 \\
\hline \multirow[t]{2}{*}{$I Q R^{(c)}$} & 24 & -(d) $^{\text {(d) }}$ & 0.4 & -(d) $^{\text {(d) }}$ & 126 & 5.5 & 0.10 \\
\hline & \multicolumn{6}{|c|}{$\mathrm{pCi} / \mathrm{mL}^{(\mathrm{e})}$} & $\mathrm{pCi} /$ dry g $^{(\mathrm{e})}$ \\
\hline Median & 0.64 & $<0.08$ & $4.7 \times 10^{-5}$ & $<1.1 \times 10^{-5}$ & $5.1 \times 10^{-6}$ & $5.1 \times 10^{-8}$ & 0.0069 \\
\hline \multirow[t]{3}{*}{$I_{Q} R^{(c)}$} & 0.64 & 0.13 & $1.3 \times 10^{-5}$ & -(d) $^{(\mathrm{d})}$ & $3.4 \times 10^{-6}$ & $1.5 \times 10^{-7}$ & 0.0026 \\
\hline & \multicolumn{7}{|c|}{ Annual total discharges by radioisotope } \\
\hline & \multicolumn{2}{|c|}{${ }^{3} \mathrm{H}$} & \multicolumn{2}{|c|}{${ }^{137} \mathrm{Cs}$} & \multicolumn{2}{|c|}{${ }^{239} \mathrm{Pu}$} & Total(f) \\
\hline \multirow{3}{*}{$\begin{array}{l}\mathrm{Bq} / \mathrm{y} \\
\mathrm{Ci} / \mathrm{y}\end{array}$} & \multirow{2}{*}{\multicolumn{2}{|c|}{$\begin{array}{c}1.0 \times 10^{10} \\
0.27\end{array}$}} & \multirow{2}{*}{\multicolumn{2}{|c|}{$\begin{array}{l}4.7 \times 10^{5} \\
1.3 \times 10^{-5}\end{array}$}} & \multirow{2}{*}{\multicolumn{2}{|c|}{$\begin{array}{c}7.7 \times 10^{4} \\
2.1 \times 10^{-6}\end{array}$}} & $1.0 \times 10^{10}$ \\
\hline & & & & & & & 0.27 \\
\hline & \multicolumn{7}{|c|}{ Fraction of limit $(\mathbf{g})$} \\
\hline DOE & \multirow{2}{*}{\multicolumn{2}{|c|}{$\begin{array}{c}7.8 \times 10^{-5} \\
0.054\end{array}$}} & \multirow{2}{*}{\multicolumn{2}{|c|}{$\begin{array}{l}2.4 \times 10^{-6} \\
3.7 \times 10^{-6}\end{array}$}} & \multirow{2}{*}{\multicolumn{2}{|c|}{$\begin{array}{l}6.0 \times 10^{-7} \\
3.0 \times 10^{-5}\end{array}$}} & $7.8 \times 10^{-5}$ \\
\hline 10 CFR 20 & & & & & & & -(h) $^{(\mathrm{n}}$ \\
\hline
\end{tabular}

Note: Radioactivities are reported as the measured concentration and either an uncertainty ( $\pm 2 \sigma$ counting error) or as being less than or equal to the detection limit. If the concentration is less than or equal to the uncertainty or the detection limit, the result is considered to be a nondetection. See Main Volume Chapter 14, Quality Assurance.

a Ranges are only listed for activities that are above the limit of sensitivity.

b Sludge from LWRP digesters is dried before analysis. The resulting data indicate the plutonium concentration of the sludge prepared by LWRP workers for disposal at the Vasco Road Landfill in Alameda County.

c $\quad \mathrm{QQR}=$ Interquartile range.

d Because of the large number of nondetections, the interquartile range is omitted. See Chapter 14, Quality Assurance.

e $1 \mathrm{Ci}=3.7 \times 10^{10} \mathrm{~Bq}$.

$f$ Does not include gross alpha and beta results shown in Table 6-4.

$g$ Fraction of limit calculations are based on the annual total discharge for a given isotope and the corresponding monthly concentrationbased limit (multiplied by the annual volume of Livermore site effluent) or, preferably the annual limit, if one exists.

$\mathrm{h}$ The fraction of the 10 CFR 20 limit is not presented because tritium discharges have an annual limit and cesium and plutonium discharges have monthly concentration-based limits. See the individual fractions for each of these radioisotopes. 


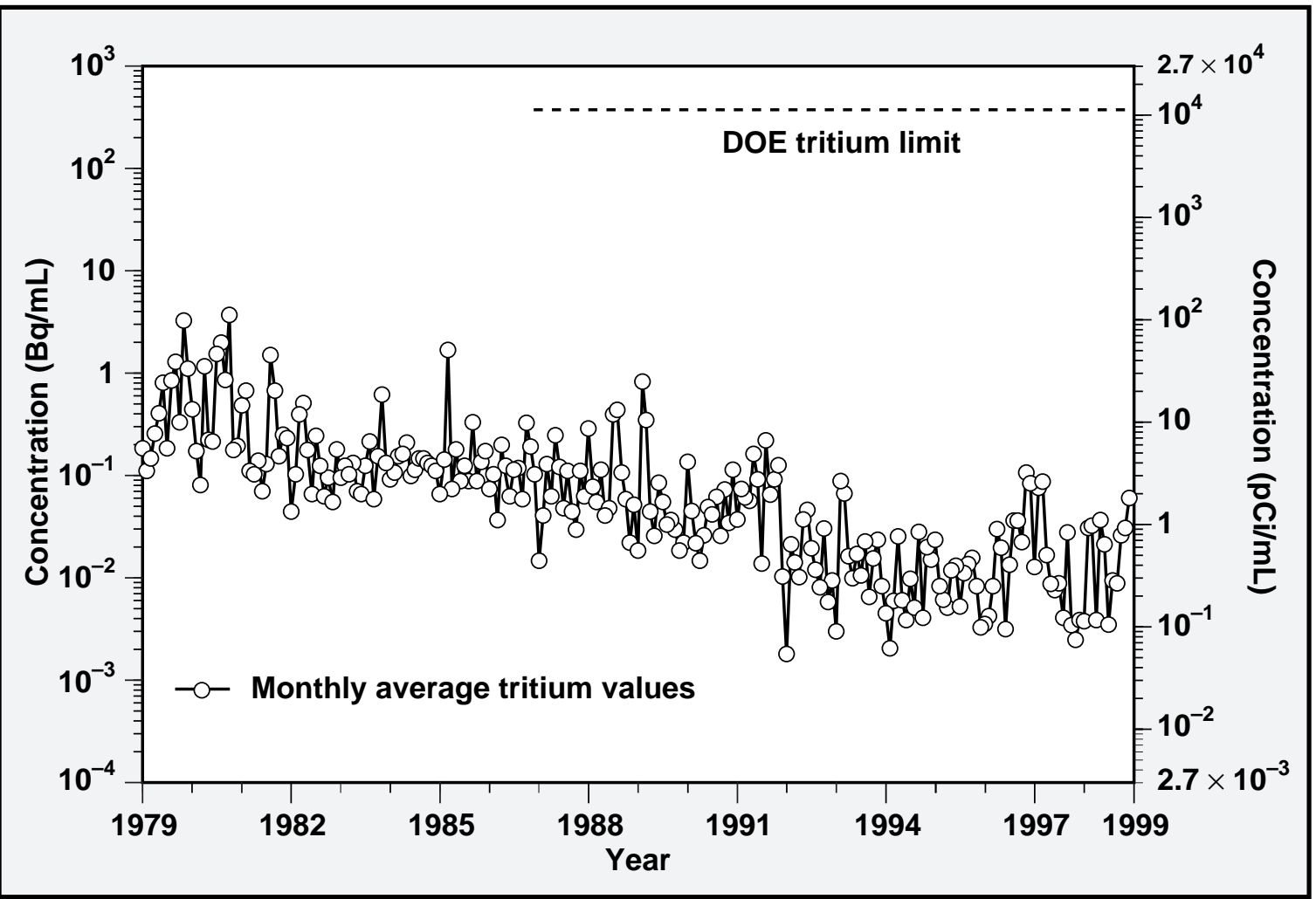

Figure 6-2. Historical trend in tritium concentration in LLNL sewage.

calculated by multiplying each sample result by the total flow volume over which the sample was collected, and summing up over all samples. The total activity released for each radioisotope is a conservative value; the limit of sensitivity was used in the calculation when the limit of sensitivity was greater than the actual activity reported. Also included in the table are fractions of DOE and 10 CFR 20 limits, discussed in the Environmental Impact section that follows.

The historical trend in the monthly average concentration of tritium is shown in Figure 6-2. Also included in the figure is the DOE tritium limit (370 Bq/mL), discussed in the Environmental Impact section of this chapter. The trend indicates a wellcontrolled tritium discharge, orders of magnitude below the DOE tritium limit.

Figure 6-3 shows the average monthly plutonium and cesium concentrations in sewage since 1989 . The annual mean concentration of ${ }^{137} \mathrm{Cs}$ was $1.4 \mu \mathrm{Bq} / \mathrm{mL}$ $\left(3.8 \times 10^{-5} \mathrm{pCi} / \mathrm{mL}\right)$; the annual mean ${ }^{239} \mathrm{Pu}$ concentration was $0.22 \mu \mathrm{Bq} / \mathrm{mL}$ $\left(5.9 \times 10^{-6} \mathrm{pCi} / \mathrm{mL}\right)$. 


\section{Sewerable Water}

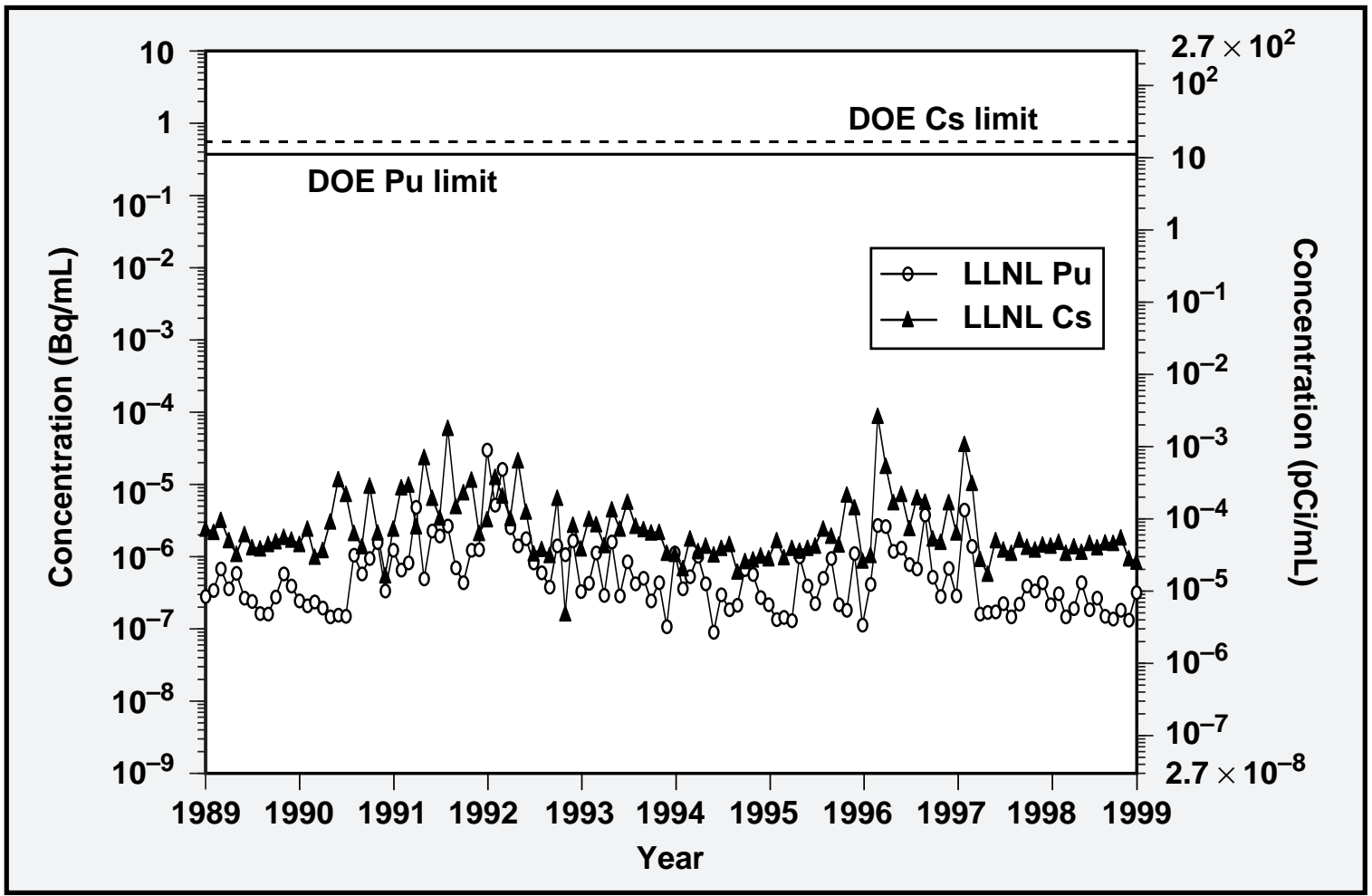

Figure 6-3. Historical trends in average monthly plutonium and cesium concentrations in LLNL sewage.

\section{Environmental Impact}

During 1998, no inadvertent releases exceeded any discharge limits for release of radioactive materials to the sanitary sewer system.

DOE Order 5400.5 established DOE policy requiring that radiological releases to the sanitary sewer comply with legally applicable local and state regulations and that LLNL implement standards generally consistent with those of the Nuclear Regulatory Commission. The most stringent of these limits was adopted in Title 17 of the California Code of Regulations. As a federal facility, LLNL is formally exempt from the requirements of state regulations but follows those requirements under the guidance of DOE. Title 17 contained a limit on discharges of radioactivity in sewage of 37 GBq (1 Ci) each year; it also listed limits on the daily, monthly, and annual concentration for each specific radionuclide. 


\section{Sewerable Water}

In 1994, the discharge requirements previously found in Title 17 were removed, and the requirements in Title 10 of the Code of Federal Regulations, Part 20, were incorporated by reference. Title 10 contains a limit for the total discharge activity of tritium $(185 \mathrm{GBq}$ or $5 \mathrm{Ci}),{ }^{14} \mathrm{C}$ (37 GBq or $1 \mathrm{Ci}$ ), and all other radionuclides combined (37 GBq or $1 \mathrm{Ci}$ ); in addition, it specifies that the discharge material must be soluble and lists limits on monthly concentrations.

Table 6-6 summarizes the discharge requirements of Title 10. Because Title 10 permits and therefore applies to only soluble discharges, and because the plutonium in LLNL effluent is in both the soluble and insoluble forms, LLNL follows the discharge requirements for ${ }^{239} \mathrm{Pu}$ in DOE Order 5400.5, Radiation protection of the Public and Environment. This assumption is supported by our experience during the sewer system evaluation in the early nineties, when increased cleaning ware correlated with higher plutonium concentrations in LLNL sewage (Gallegos et al. 1992). This indicates that a portion of the plutonium discharges from LLNL facilities is deposited on the sewer pipes, and when these deposits are liberated and discharged from the LLNL site, they are, by their nature, insoluble.

Table 6-6. Sewer discharge release limits for ${ }^{3} \mathrm{H},{ }^{137} \mathrm{Cs}$, and ${ }^{239} \mathrm{Pu}$.

\begin{tabular}{|l|c|c|c|}
\hline & ${ }^{\mathbf{3}}$ & ${ }^{137} \mathbf{C s}$ & ${ }^{\mathbf{2 3 9}} \mathbf{P u}$ \\
\hline 10 CFR 20 concentrations used to establish release limits $(\mathrm{Bq} / \mathrm{mL})$ & 370 & 0.37 & 0.0074 \\
Monthly $20(\mathrm{GBq})$ & & & \\
Yearly & $185^{(\mathrm{a})}$ & 11 & 0.21 \\
DOE annualized discharge limit for application of BAT & \\
\hline
\end{tabular}

a 10 CFR 20 imposes a $185-\mathrm{GBq}(5-\mathrm{Ci})$ limit for the tritium radiation released.

b 10 CFR 20 imposes a 37-GBq (1-Ci) combined limit on the total of all radiation released (excluding tritium and ${ }^{14} \mathrm{C}$, which have separate $10 \mathrm{CFR} 20$ limits of $185 \mathrm{GBq}$ and $37 \mathrm{GBq}$, respectively); i.e., the total release of all isotopes must not exceed $37 \mathrm{GBq}$. If a total of $37 \mathrm{GBq}$ of a particular isotope were released during the year, this would require that no other isotopes be released.

c $B A T=$ best available technology. The DOE annualized discharge limit for application of BAT is five times the Derived Concentration Guide (DCG; ingested water) for each radionuclide released.

Table 6-6 also includes the total activity that could have been discharged by LLNL during a given period (monthly and annually) using 10 CFR 20 monthly concentrations in conjunction with the annual caps and assuming the 1998 average monthly flow rate and total flow volume. As the table shows, the Title 10 concentration limits for tritium for facilities such as LLNL that generate wastewater in large volumes are overridden by the limit on total tritium activity (185 GBq) dischargeable during a single year. In 1998, the total LLNL tritium release was $5.4 \%$ of the corresponding 


\section{Sewerable Water}

Title 10 limit. Total LLNL releases (Table 6-4), in the form of alpha and beta emitters (excluding tritium), were $0.90 \%$ of the corresponding Title 10 limit.

DOE has also established criteria for the application of best available technology to protect public health adequately and minimize degradation of the environment. These criteria (the Derived Concentration Guides, or DCGs) limit the concentration of each specific radionuclide discharged to publicly owned treatment works. If a measurement of the monthly average concentration of a radioisotope exceeded its concentration limit, LLNL would be required to improve discharge control measures until concentrations were again below the DOE limits. Table 6-6 presents the DCGs for the specific radioisotopes of most interest at LLNL.

The annual average concentration of tritium in LLNL sanitary sewer effluent was $7.8 \times 10^{-5}$ (that is, $0.0078 \%$ ) of the DOE DCG (and the Title 10 limit); the annual average concentration of ${ }^{137} \mathrm{C}$ s was $2.4 \times 10^{-6}(0.00024 \%)$ of the DOE DCG (and $3.7 \times 10^{-6}$ or $0.00037 \%$ of the Title 10 limit); and the annual average ${ }^{239} \mathrm{Pu}$ concentration was $6.0 \times 10^{-7}(0.000060 \%)$ of the ${ }^{239} \mathrm{Pu}$ DOE DCG, and $3.0 \times 10^{-5}(0.0030 \%)$ of the Title 10 limit. These results are shown at the end of Table 6-5.

LLNL also compares annual discharges with historical values to evaluate the effectiveness of ongoing discharge control programs. Table 6-7 summarizes the radioactivity in liquid effluent released over the past 10 years. During 1998, a total of 10 GBq (0.27 Ci) of tritium was discharged to the sanitary, an amount that is well within environmental protection standards and is comparable to the amounts reported for the last several years. Moreover, the total tritium released by LLNL in 1998 (and the years from 1992 through 1997) is below the range reported prior to 1992.

Figure 6-3 summarizes the ${ }^{239} \mathrm{Pu}$ monitoring data over the past 10 years. The historical levels observed since 1989 average $1 \mu \mathrm{Bq} / \mathrm{mL}\left(3 \times 10^{-5} \mathrm{pCi} / \mathrm{mL}\right)$. These historical levels generally are three-millionths (0.000003) of the DOE DCG for the ${ }^{239} \mathrm{Pu}$. The greatest part of the plutonium discharged in LLNL effluent is ultimately concentrated in LWRP sludge, which is dried and disposed of at a landfill. The median plutonium concentration observed in 1998 sludge (Table 6-5), $0.25 \mathrm{mBq} /$ dry g is approximately 370 times lower than the EPA preliminary remediation goal for residential soil (93 mBq/dry g) and is nearly 1500-times lower than the remediation goal for industrial or commercial soil (370 mBq/dry g). 
Table 6-7. Radioactive liquid effluent releases from the Livermore site, 1989-1998.

\begin{tabular}{|l|c|c|}
\hline \multirow{2}{*}{ Year } & \multicolumn{2}{|c|}{ Liquid effluent (GBq) } \\
\cline { 2 - 3 } & $\mathbf{3}^{\mathbf{H}}$ & ${ }^{339} \mathrm{Pu}$ \\
\hline 1989 & 59 & $1.8 \times 10^{-4}$ \\
$1990^{(\mathrm{a})}$ & 25 & $2.3 \times 10^{-4}$ \\
1991 & 32 & $6.1 \times 10^{-4}$ \\
1992 & 8 & $1.9 \times 10^{-3}$ \\
1993 & 13 & $2.6 \times 10^{-4}$ \\
$1994^{(\mathrm{b})}$ & 6.9 & $1.9 \times 10^{-4}$ \\
1995 & 6.0 & $1.2 \times 10^{-4}$ \\
1996 & $12^{(\mathrm{c})}$ & $4.2 \times 10^{-4}$ \\
1997 & 9.1 & $2.1 \times 10^{-4}$ \\
1998 & 10 & $7.7 \times 10^{-5}$ \\
\hline
\end{tabular}

a The 1990 DOE Order 5400.5 required compliance with legally applicable local and state regulations. California Title 17 mandated a $37 \mathrm{GBq}(1 \mathrm{Ci})$ combined limit on the total of all radiation released.

b In 1994, the discharge requirements previously found in Title 17 were changed to correspond to the requirements in Title 10 of the Code of Federal Regulations, Part 20. Title 10 contains a limit for the total discharge activity of tritium (185 GBq or $5 \mathrm{Ci}$ ), ${ }^{14} \mathrm{C}(37 \mathrm{GBq}$ or $1 \mathrm{Ci}$ ), and all other radionuclides combined (37 $\mathrm{GBq}$ or $1 \mathrm{Ci})$.

c In 1995, Sandia National Laboratories/California (SNL/CA) ceased all tritium facility operations. Therefore, the annual tritium totals beginning with the 1996 value do not include contributions from Sandia/California.

As first discussed in the Environmental Report 1991 (Gallegos et al. 1992), plutonium and cesium concentrations were slightly elevated during 1991 and 1992 over the lowest values seen historically. As was established in 1991, the overall upward trend was related to sewer cleaning with new, more-effective equipment. During 1993, as utility personnel worked to complete an assessment of the condition of the sewer system, cleaning activity around the site was less extensive, resulting in slightly lower plutonium and cesium concentrations in LLNL effluent. During 1994, in conjunction with the installation of the synthetic sock lining in the sewer system, the cleaning activity around the site was more extensive than in 1993. However, by the end of 1993 the new sewer cleaning equipment had been used on LLNL's entire sewer system; this was reflected in 1994 and the majority of 1995 by the continuation of the slightly lower plutonium and cesium concentrations that were observed in the 1993 effluent.

The plutonium and cesium concentrations in 1996 and the first quarter of 1997 are slightly higher than the concentrations observed in 1993 through 1995, and slightly lower than the observed concentrations of 1990 through 1992, with the exception of a cesium peak early in 1997. This peak, pictured in Figure 6-3, is attributable to a controlled release from an 


\section{Sewerable Water}

LLNL retention tank system and is well below the applicable DOE DCG. The slightly higher plutonium and cesium concentrations of 1996 and the first quarter of 1997 are well below applicable DOE DCG's and remain indicative of well-controlled discharges. The final three quarters of 1997 and all of the 1998 plutonium and cesium concentrations are comparable to the concentrations observed in 1993 through 1995, and, as such, are also well below the applicable DOE DCGs.

\section{Nonradioactive Pollutants in Sewage Monitoring Results}

Table 6-8 presents monthly average metal concentrations in LLNL's sanitary sewer effluent. The averages were obtained by a flow-proportional weighting of the results from analysis of the weekly composite samples collected each month. Each result was weighted by the total flow volume recorded by the SMS for the period during which the sample was collected. The results are generally typical of the values seen during previous years, 1994-1997, as discussed in the following section, Environmental Impact. Figure 6-4 presents the average monthly results from 1994 through 1998 for eight metals. Weekly and 24-hour composite sample concentrations of metals in LLNL sewage are each presented as a percentage of the corresponding effluent pollutant limit (EPL) in Figures 6-5a and 6-5b. The EPL is equal to the maximum pollutant concentration allowed per 24-hour composite sample, as specified by the LLNL wastewater discharge permit. When a weekly sample concentration is at or above $50 \%$ of its EPL, the corresponding daily (24-hour composite) samples collected in the SMS must be analyzed to determine if any of their concentrations are above the EPL.

Detections of anions, metals, and organic compounds and data concerning other physical and chemical characteristics of the sanitary sewer effluent are provided in Table 6-9. Although the samples were analyzed for bromide, nitrite (as N), carbonate alkalinity (as $\mathrm{CaCO}_{3}$ ), hydroxide alkalinity (as $\mathrm{CaCO}_{3}$ ), the full suite of polychlorinated biphenyls, the full suite of organochlorine pesticides, and cyanide, those analytes were not detected in any sample acquired during 1998, and so are not presented in the table. (Analysis of samples for polychlorinated biphenyls and organochlorine pesticides was discontinued in June 1998 after receiving a letter from the LWRP disallowing the need for these analyses.) The results are quite typical of those seen in previous years. 
Table 6-8. Average monthly results for metals in LLNL sanitary sewer effluent (in mg/L), 1998.

\begin{tabular}{|c|c|c|c|c|c|c|c|c|c|c|c|c|}
\hline \multirow[b]{2}{*}{ Month } & \multicolumn{12}{|c|}{ Parameter (mg/L) } \\
\hline & $\mathbf{A g}$ & Al & As & $\mathrm{Be}$ & Cd & $\mathrm{Cr}$ & $\mathrm{Cu}$ & $\mathrm{Fe}$ & $\mathrm{Hg}$ & $\mathrm{Ni}$ & $\mathrm{Pb}$ & $\mathrm{Zn}$ \\
\hline Jan & $<0.010$ & 0.59 & 0.0039 & $<0.00050$ & $<0.0050$ & 0.013 & 0.099 & 1.5 & 0.00054 & 0.0079 & 0.017 & 0.30 \\
\hline Feb & 0.011 & 1.1 & 0.0057 & $<0.00050$ & 0.010 & 0.024 & 0.17 & 2.6 & 0.00060 & 0.012 & 0.039 & 0.81 \\
\hline Mar & 0.011 & 0.78 & 0.0035 & $<0.00050$ & $<0.0050$ & 0.031 & 0.16 & 2.4 & 0.00052 & 0.011 & 0.024 & 0.43 \\
\hline Apr & $<0.010$ & 0.29 & 0.0022 & $<0.00050$ & $<0.0050$ & 0.012 & 0.067 & 1.0 & 0.00031 & 0.0055 & 0.0052 & 0.21 \\
\hline May & $<0.010$ & 0.32 & $<0.0020$ & $<0.00050$ & $<0.0050$ & 0.017 & 0.075 & 1.1 & 0.0027 & 0.0071 & 0.012 & 0.20 \\
\hline Jun & $<0.010$ & 0.27 & 0.0022 & $<0.00050$ & 0.0056 & 0.015 & 0.082 & 0.9 & 0.00030 & 0.0066 & 0.0052 & 0.18 \\
\hline Jul & $<0.010$ & 0.33 & 0.0028 & $<0.00050$ & $<0.0050$ & 0.012 & 0.086 & 1.0 & 0.00023 & 0.0078 & 0.014 & 0.27 \\
\hline Aug & $<0.010$ & 0.25 & $<0.0020$ & $<0.00050$ & $<0.0050$ & $<0.010$ & 0.077 & 1.3 & 0.00038 & 0.0064 & 0.009 & 0.15 \\
\hline Sep & $<0.010$ & 0.31 & 0.0023 & $<0.00050$ & $<0.0050$ & 0.011 & 0.12 & 0.8 & 0.00023 & 0.0050 & 0.035 & 0.19 \\
\hline Oct & 0.016 & 0.68 & 0.0026 & $<0.00050$ & $<0.0050$ & 0.026 & 0.15 & 1.9 & 0.00047 & 0.013 & 0.021 & 0.31 \\
\hline Nov & 0.023 & 0.46 & 0.0026 & $<0.00050$ & $<0.0050$ & 0.019 & 0.087 & 1.3 & 0.00048 & 0.0090 & 0.016 & 0.20 \\
\hline Dec & $<0.010$ & 0.54 & $<0.0020$ & $<0.00050$ & $<0.0050$ & 0.015 & 0.11 & 1.6 & 0.0021 & 0.015 & 0.022 & 0.26 \\
\hline Median & $<0.010$ & 0.40 & 0.0025 & $<0.00050$ & $<0.0050$ & 0.015 & 0.093 & 1.3 & 0.00048 & 0.0079 & 0.017 & 0.24 \\
\hline $1 Q R^{(a)}$ & -(b) & 0.3 & 0.0008 & $-^{(b)}$ & $-^{(b)}$ & 0.008 & 0.047 & 0.7 & 0.00025 & 0.0047 & 0.011 & 0.11 \\
\hline $\mathrm{EPL}^{\text {(c) }}$ & 0.2 & -(d) $^{(\mathrm{d}}$ & 0.06 & $-^{(d)}$ & 0.14 & 0.62 & 1 & - (d) $^{\text {(d) }}$ & 0.01 & 0.61 & 0.2 & 3.0 \\
\hline $\begin{array}{l}\text { Median } \\
\text { percentage of } \\
\text { EPL }\end{array}$ & $<0.05$ & - (d) $^{(\mathrm{s})}$ & 0.04 & $-^{(d)}$ & $<0.04$ & 0.02 & 0.09 & $-^{(d)}$ & 0.05 & 0.01 & 0.08 & 0.08 \\
\hline
\end{tabular}

Note: Monthly values are presented with less than signs when all weekly composite sample results for the month are below the detectable concentration.

a $\quad \mathrm{IQR}=$ Interquartile range.

b Because of the large number of nondetects, the interquatrile range cannot be calculated for these metals. See Chapter 14 , Quality Assurance.

c Effluent pollutant limit (LLNL Waste water Discharge Permit 1997-1998 and 1998-1999).

d No established limit for this metal.

\section{Environmental Impact}

At the bottom of Table 6-8, the annual median concentration for each metal detected in LLNL's sanitary sewer effluent is compared to the discharge limit. In 1998, the ratio of the annual median concentration of each metal to its corresponding discharge limit was either the same as 1997, or lower. The metal that approached closest to the discharge limit was copper at $9.3 \%$. 


\section{Sewerable Water}
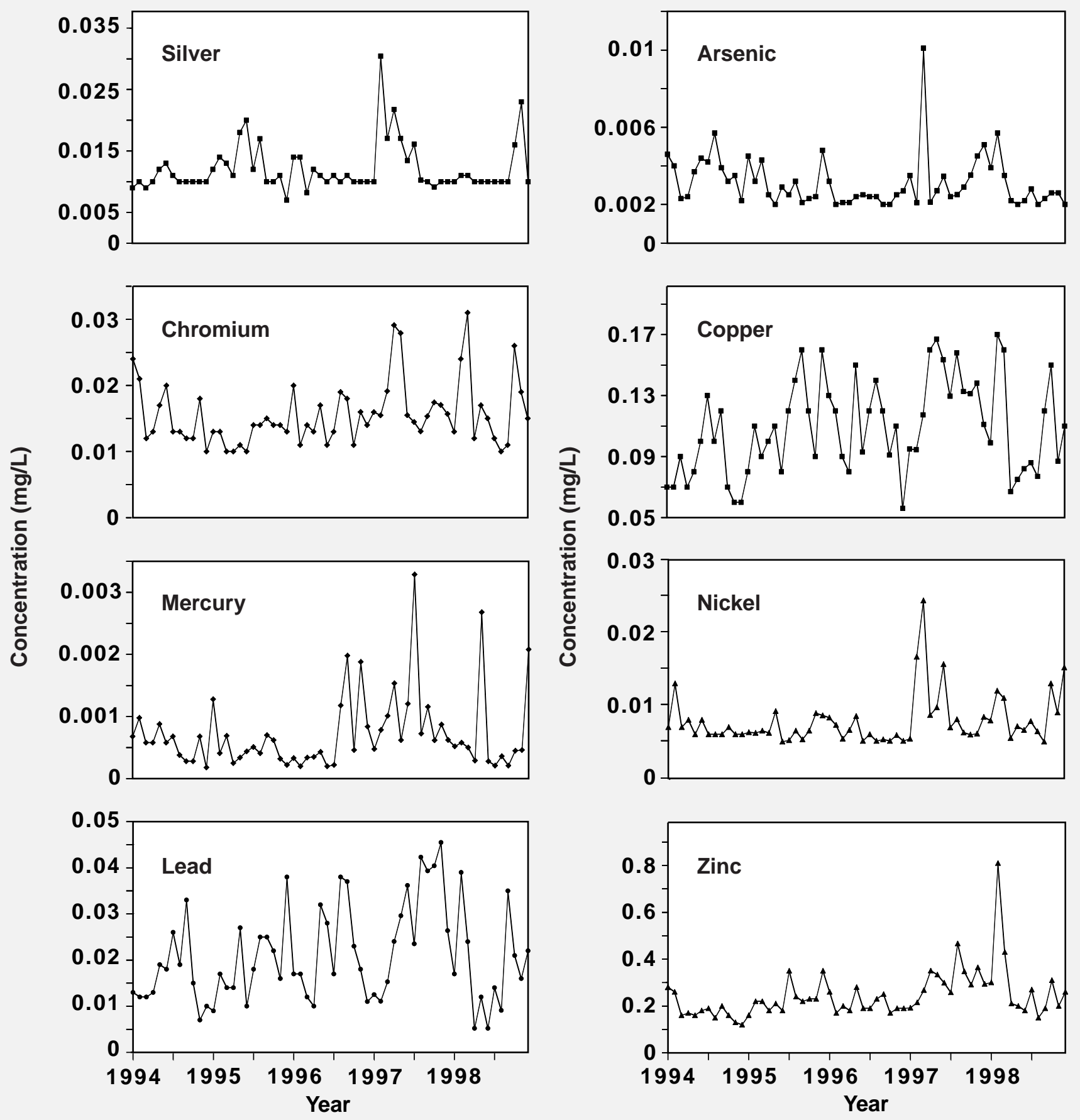

Figure 6-4. Average monthly concentrations of eight metals in LLNL sanitary sewer effluent showing trends from 1994 through 1998. 


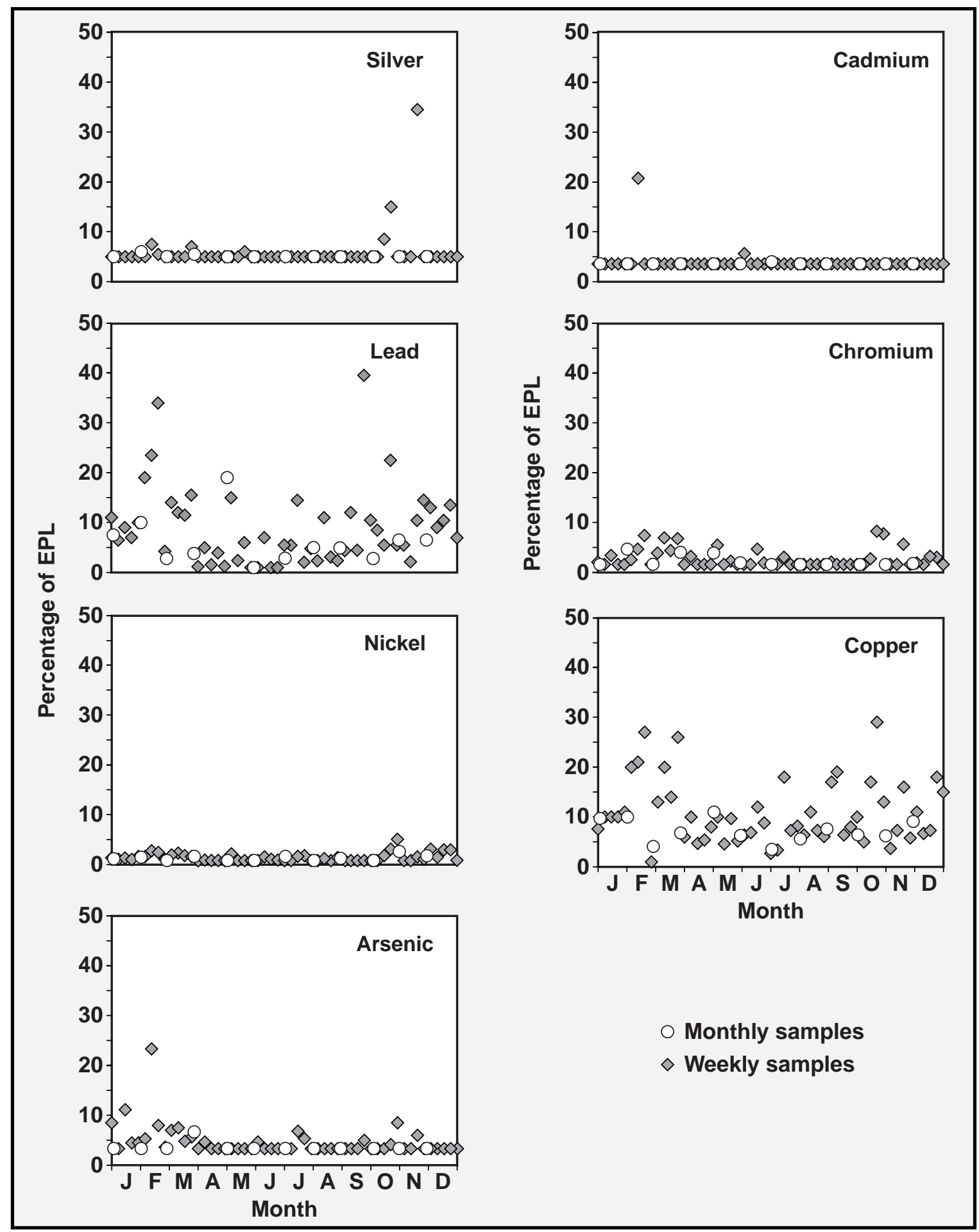

Figure 6-5a. Results as percentages of effluent pollutant limits (EPLs) for seven of the nine metals regulated in LLNL sewage. 


\section{Sewerable Water}

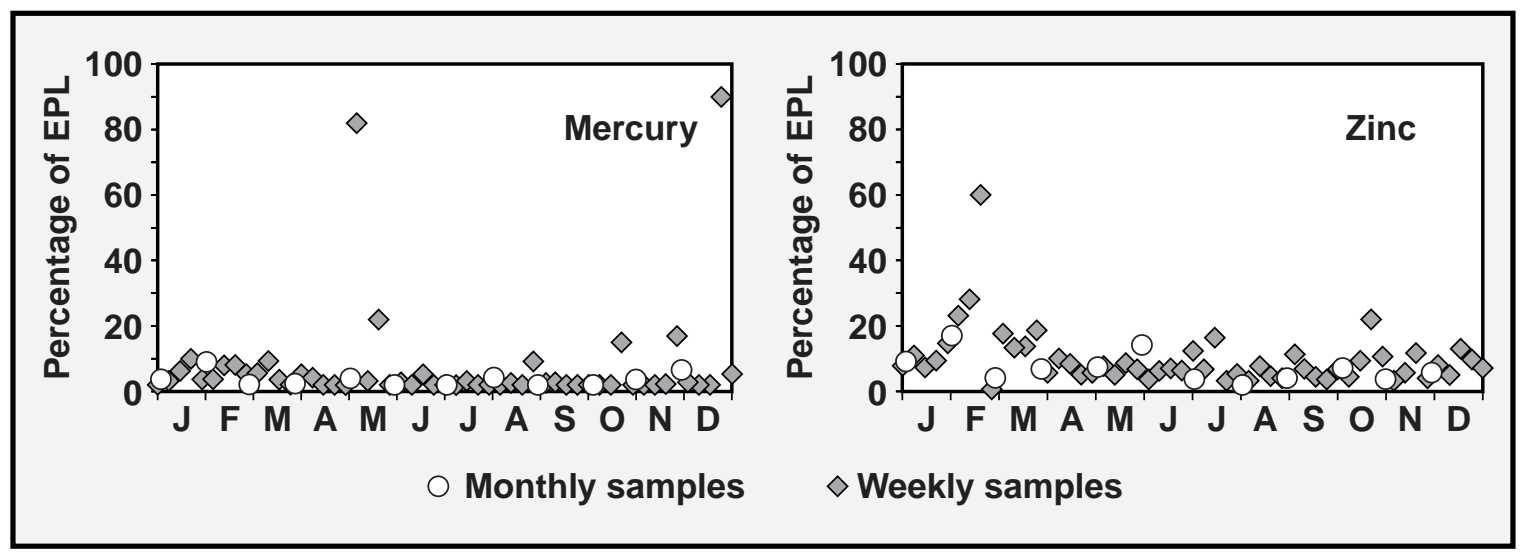

Figure 6-5b. Results as percentages of effluent pollutant limits (EPLs) for two of the nine metals regulated in LLNL sewage.

Although well below discharge limits, slightly elevated arsenic levels were seen in 1992 through 1995. These levels did not continue in 1996, but returned during the beginning of both 1997 and 1998. First discussed in the Environmental Report 1993 (Gallegos et al. 1994), the elevated arsenic levels were the subject of an extended investigation during 1993, which concluded that the presence of arsenic in the sewer was associated with the ground water cleanup at the gas pad along the southern border of the site. The gas pad cleanup operation was continued in 1994, and the slightly elevated arsenic levels of 1993 continued in 1994. During 1995, the gas pad cleanup operations were reduced, and the elevated arsenic levels were seen less frequently. In 1996, the gas pad operations were concluded, and arsenic levels returned to pre-1992 concentrations. In 1997, gas pad operations were performed separately using portable treatment units, and the arsenic concentrations rose slightly. During 1998, groundwater clean-up activities were accelerated with the deployment of several new portable treatment units, and slightly elevated arsenic concentrations reflected this increased activity.

The 1998 monthly mercury values continued to reflect the slightly elevated trend that began in mid-1996. However, only two of the analytical results for mercury in 1998 exceeded the action level in LLNL's Wastewater Discharge Permit, which states that archived daily composite samples must be analyzed for the pollutant of concern when the result for a weekly composite sample is $50 \%$ of, or greater than, the applicable effluent pollutant limit. The first mercury analytical result $(0.0082 \mathrm{mg} / \mathrm{L})$ exceeding the action level $(0.005 \mathrm{mg} / \mathrm{L})$ occurred in May (see Figure 6-5b). The archived daily samples that corresponded to the appropriate weekly composite sampling period of May 5-11 were submitted for mercury analysis. All of the analytical results for the daily 
Table 6-9. Monthly monitoring results for physical and chemical characteristics of the LLNL sanitary sewer effluent, 1998. (a)

\begin{tabular}{|c|c|c|c|c|c|}
\hline $\begin{array}{l}\text { 24-hour composite sample parameter } \\
\text { (mg/L) }\end{array}$ & $\begin{array}{c}\text { Detection } \\
\text { frequency }(\mathrm{b})\end{array}$ & Minimum & Maximum & Median & $\operatorname{IQR}^{(\mathrm{c})}$ \\
\hline \multicolumn{6}{|l|}{ Alkalinity } \\
\hline Bicarbonate alkalinity $\left(\right.$ as $\left.\mathrm{CaCO}_{3}\right)$ & $12 / 12$ & 180 & 240 & 200 & 25 \\
\hline Total alkalinity $\left(\mathrm{as} \mathrm{CaCO}_{3}\right)$ & $12 / 12$ & 180 & 240 & 200 & 25 \\
\hline \multicolumn{6}{|l|}{ Anions } \\
\hline Chloride & $11 / 11$ & 33 & 63 & 45 & 16 \\
\hline Fluoride & $11 / 12$ & $<0.050$ & 0.42 & 0.095 & 0.044 \\
\hline Nitrate $\left(\right.$ as $\left.\mathrm{NO}_{3}\right)$ & $4 / 12$ & $<0.50$ & 1.7 & $<0.50$ & - \\
\hline Orthophosphate & $12 / 12$ & 1.3 & 23 & 16 & 13 \\
\hline Sulfate & $11 / 11$ & 13 & 21 & 15 & 3.0 \\
\hline \multicolumn{6}{|l|}{ Nutrients } \\
\hline Ammonia nitrogen (as $\mathrm{N}$ ) & $12 / 12$ & 35 & 76 & 49 & 9.5 \\
\hline Total Kjeldahl nitrogen & $12 / 12$ & 26 & 65 & 47 & 14 \\
\hline \multicolumn{6}{|l|}{ Oxygen demand } \\
\hline Biochemical oxygen demand & $12 / 12$ & 100 & 610 & 235 & 123 \\
\hline Chemical oxygen demand & $12 / 12$ & 140 & 680 & 290 & 153 \\
\hline \multicolumn{6}{|l|}{ Solids } \\
\hline Solid settling rate $(\mathrm{mL} / \mathrm{L} / \mathrm{h})$ & $10 / 12$ & $<0.50$ & 62 & 25 & 18 \\
\hline Total dissolved solids & $12 / 12$ & 130 & 720 & 250 & 45 \\
\hline Total suspended solids & $12 / 12$ & 53 & 400 & 245 & 195 \\
\hline Volatile solids & $12 / 12$ & 55 & 380 & 230 & 125 \\
\hline \multicolumn{6}{|l|}{ Total metals } \\
\hline Calcium & $12 / 12$ & 9.7 & 21 & 12 & 4.3 \\
\hline Magnesium & $12 / 12$ & 2.1 & 3.9 & 2.8 & 1.1 \\
\hline Potassium & $12 / 12$ & 14 & 21 & 18 & 2.5 \\
\hline Sodium & $12 / 12$ & 23 & 47 & 35 & 8.3 \\
\hline Total organic carbon & $12 / 12$ & 46 & 110 & 66 & 19 \\
\hline Tributyltin (ng/L) & $12 / 12$ & 15 & 160 & 30 & 32 \\
\hline \multicolumn{6}{|l|}{ Semivolatile organic compounds } \\
\hline Benzyl Alcohol & $2 / 12$ & $<10$ & 100 & $<10$ & - \\
\hline Bis(2-ethylhexyl)phthalate & $6 / 12$ & $<5.0$ & 50 & 8.5 & - \\
\hline Di-n-butylphthalate & $1 / 12$ & $<5.0$ & 120 & $<5.0$ & - \\
\hline Diethylphthalate & $7 / 12$ & $<5.0$ & 50 & 9.2 & 5.9 \\
\hline $\mathrm{m}$ - and p-Cresol & $2 / 12$ & $<5.0$ & 50 & $<5.0$ & - \\
\hline Total oil and grease & $12 / 12$ & 18 & 26 & 21 & 1.8 \\
\hline Total recoverable phenolics & $12 / 12$ & 0.019 & 0.12 & 0.038 & 0.030 \\
\hline
\end{tabular}




\section{Sewerable Water}

Table 6-9. Monthly monitoring results for physical and chemical characteristics of the LLNL sanitary sewer effluent, 1998 (concluded).(a)

\begin{tabular}{|c|c|c|c|c|c|}
\hline $\begin{array}{l}\text { 24-hour composite sample parameter } \\
(\mathrm{mg} / \mathrm{L})\end{array}$ & $\begin{array}{c}\text { Detection } \\
\text { frequency }^{(b)}\end{array}$ & Minimum & Maximum & Median & $\operatorname{IQR}^{(\mathrm{c})}$ \\
\hline \multicolumn{6}{|l|}{ Volatile organic compounds (ug/L) } \\
\hline 1,4-Dichlorobenzene & $3 / 12$ & $<1.0$ & 4.3 & $<1.0$ & - \\
\hline Acetone & $12 / 12$ & 91 & 290 & 170 & 48 \\
\hline Chloroform & $12 / 12$ & 7.5 & 21 & 9.6 & 4.0 \\
\hline Ethylbenzene & $1 / 12$ & $<1.0$ & 13 & $<1.0$ & - \\
\hline Freon 113 & $2 / 12$ & $<1.0$ & 7 & $<1.0$ & - \\
\hline Styrene & $1 / 12$ & $<1.0$ & 67 & $<1.0$ & - \\
\hline Toluene & $1 / 12$ & $<1.0$ & 1.3 & $<1.0$ & - \\
\hline Trichlorofluoromethane & $2 / 12$ & $<1.0$ & 1.4 & $<1.0$ & - \\
\hline
\end{tabular}

a The 24-hour composite sample results plotted in Figures 6-5a and 6-5b and reported in the Data Supplement, Chapter 6 are not reported in this table.

b The number of times an analyte was positively identified, followed by the number of samples that were analyzed (generally 12, one sample for each month of the year).

c IQR = Interquartile range. Where the detection frequency is less than or equal to $50 \%$, the interquartile range is omitted.

samples were less than the effluent pollutant limit of $0.01 \mathrm{mg} / \mathrm{L}$. The other mercury analytical result $(0.047 \mathrm{mg} / \mathrm{L})$ exceeding the action level occurred in December (see Figure 6-5b). The archived daily samples for the weekly composite sampling period of December 22-28 were submitted for mercury analysis. All of the analytical results for the daily samples were less than the effluent pollutant limit of $0.01 \mathrm{mg} / \mathrm{L}$.

In two single instances, once for zinc and once for arsenic, weekly metals concentrations exceeded the permit action level. In February, a zinc concentration of $1.8 \mathrm{mg} / \mathrm{L}$ (see Figure 6-5b) exceeded the $1.5 \mathrm{mg} / \mathrm{L}$ action level. The daily samples for the sampling period of February 16-23 were analyzed, and all of the results were below the effluent pollutant limit of $3.0 \mathrm{mg} / \mathrm{L}$. Finally, the arsenic analytical result $(0.037 \mathrm{mg} / \mathrm{L})$ exceeding the action level $(0.03 \mathrm{mg} / \mathrm{L})$ occurred in December; this sample concentration is not reflected in the arsenic plot of Figure 6-5a because it is a quality assurance data result, and data shown in Figures 6-5 a and 6-5b are exclusively from primary, non-quality assurance analyses. The archived daily samples that corresponded to the appropriate weekly composite sampling period of December 22-28 were submitted for arsenic analysis, and all of the analytical results were less than the effluent pollutant limit of $0.06 \mathrm{mg} / \mathrm{L}$. 
In 1998, the continuous monitoring system detected two inadvertant discharges. Both discharges occurred on January 31 and contained elevated levels of zinc. Analysis of the January 31 daily sample gave a result of $1.0 \mathrm{mg} / \mathrm{L}$, which was below the discharge limit of $3.0 \mathrm{mg} / \mathrm{L}$ and thus in compliance with the permit requirement. Unconfined $\mathrm{pH}$, metals or radiation releases of sufficient concentration and duration outside of the effluent pollutant limits could disrupt treatment plant operations or cause the treated wastewater to exceed allowable concentration limits for discharge to the San Francisco Bay. (For comparison, 13, 1, 1, 1, 0, and 13 such diversions occurred in 1997, 1996, 1995, 1994, 1993, and 1992, respectively.)

Monitoring results for 1998 reflect an outstanding year for LLNL's sewerable water discharge control program and Livermore site personnel. LLNL achieved 100\% compliance with the provisions of its wastewater discharge permit, and only two inadvertant discharges were detected by the continuous monitoring system. 



\section{Surface Water}

Erich R. Brandstetter

Shari L. Brigdon

Karen J. Folks

Ted A. Giesing

\section{Overview}

Sandra Mathews

Lawrence Livermore National Laboratory monitors surface water at the Livermore site, in surrounding regions of the Livermore Valley, and at Site 300 and vicinity in the nearby Altamont Hills. At the Livermore site and vicinity, LLNL monitors reservoirs and ponds, the Livermore site swimming pool, the Drainage Retention Basin (DRB), rainfall, tap water, and storm water runoff. At Site 300 and vicinity, surface water monitoring encompasses rainfall, cooling tower discharges, and storm water runoff.

The water samples are analyzed for radionuclides, high explosives, total organic carbon, total organic halides, total suspended solids, conductivity, $\mathrm{pH}$, chemical oxygen demand, total dissolved solids, oil and grease, metals, minerals, anions, and a wide range of organic compounds. In addition, bioassays are performed annually on water entering and leaving the Livermore site via the Arroyo Las Positas pathway, discharges from the DRB, and water contained in the DRB.

\section{Storm Water}

This section discusses general storm water information (including permits, constituent criteria, inspections, and sampling), sampling methods, and results.

\section{Introduction}

\section{Permits}

The goals of the storm water (runoff water) monitoring program are to demonstrate compliance with permit requirements, aid in implementing the Storm Water Pollution Prevention plans (SWPPPs) (Eccher et al. 1994a and b), and measure the effectiveness of the Best Management Practices (BMPs) in preventing contamination of storm water discharges. 


\section{Surface Water}

LLNL monitors storm water at the Livermore site in accordance with a "Waste Discharge Requirements and National Pollutant Discharge Elimination System Permit" (NPDES Permit No. CA0030023, WDR 95-174) issued in 1995 by the San Francisco Bay Regional Water Quality Control Board. In 1994, the Central Valley Regional Water Quality Control Board (RWQCB) issued a "Waste Discharge Requirements and National Pollutant Discharge Elimination System Permit" (NPDES Permit No. CA0081396, WDR 94-131) for Site 300. These permits replaced the Statewide General NPDES Permit for Storm Water Discharges Associated with Industrial Activities (Order No. 91-13-DWQ). These permits include specific monitoring and reporting requirements. LLNL monitors additional storm water constituents not required by the permits to provide a more complete water quality profile. The current list of analyses requested for storm water samples is given in Table 7-1.

Table 7-1. Analyses conducted on storm water samples, 1998.

\begin{tabular}{|l|l|}
\hline \multicolumn{1}{|c|}{ Livermore site } & \multicolumn{1}{c|}{ Site $\mathbf{3 0 0}$} \\
\hline Specific conductance & Specific conductance \\
Total suspended solids & Total suspended solids \\
$\mathrm{pH}$ & $\mathrm{pH}$ \\
Chemical oxygen demand & Potassium \\
Biochemical oxygen demand & Beryllium \\
Fish bioassay (fathead minnow) & Mercury \\
Anions & Volatile organic compounds \\
General minerals & Semivolatile organic compounds \\
Metals & Pesticides \\
Herbicides & Total organic halides \\
Oil and grease & Total organic carbon \\
Total organic carbon & Explosives \\
Gross alpha and beta & Gross alpha and beta \\
Tritium & Tritium \\
Plutonium & Uranium \\
& Plutonium \\
\hline
\end{tabular}

The NPDES permits for storm water require that LLNL sample effluent two times per year. In addition, LLNL is required to visually inspect the storm drainage system monthly during the wet season, whenever significant storms occur, and twice during the dry season to identify any dry weather flows. Influent sampling is also required at the Livermore site. LLNL monitors up to two more storm events each year (a total of four 
sampling events) in support of DOE Orders 5400.1 and 5400.5. In addition, annual facility inspections are required to ensure that the Best Management Practices are adequate and implemented.

Storm water monitoring is also driven by the requirements in the Environmental Regulatory Guide for Radiological Effluent Monitoring and Environmental Surveillance (U.S. Department of Energy 1991); DOE Order 5400.1, General Environmental Protection Program; DOE Order 5400.5, Radiation Protection of the Public and the Environment; and the Comprehensive Environmental Response, Compensation and Liability Act (CERCLA) Record of Decision (ROD).

\section{Constituent Criteria}

Currently, there are no numerical criteria that limit concentrations of specific constituents in storm water effluent. The Environmental Protection Agency (EPA) established benchmark values for 41 parameters, but stressed that these concentrations were not intended to be interpreted as effluent limits. Rather, the values are levels that the EPA has used to determine if storm water discharged from any given facility merits further monitoring. These and other water quality criteria developed by California and the federal government were used as comparisons with LLNL storm water analytical results in this report. Although these criteria are not directly applicable to storm water effluent, use of a broad range of criteria can help evaluate LLNL's storm water management program and ensure high quality storm water effluent.

Storm water sample results for the Livermore site were also compared with criteria listed in the Water Quality Control Plan, San Francisco Bay Basin (San Francisco Bay RWQCB 1995), and results for Site 300 were compared with criteria listed in The Water Quality Control Plan (Basin Plan) for the California Regional Water Quality Control Board, Central Valley Region (Longley et al. 1994). Criteria in the basin plans include surface water quality objectives for the protection of aquatic life and water quality objectives for waters designated for use as domestic or municipal supply or agricultural supply. These criteria include, by reference, California Maximum Contaminant Levels (MCLs) for drinking water. In addition, results were compared with EPA MCLs and ambient water quality criteria (AWQC), as well as California AWQC. Criteria not specifically listed in the basin plans were obtained from A Compilation of Water Quality Goals (Marshack 1998). Criteria are summarized in Table 7-1 in the Data Supplement, which lists Primary Maximum Contaminant Level/Secondary Maximum Contaminant Level (PMCL/SMCL), Ambient Water Quality Criteria/Criteria for Agricultural Use (AWQC/Ag), and the EPA benchmark. 


\section{Surface Water}

In addition to chemical-specific monitoring, LLNL is required by NPDES permit (WDR 95-174) to conduct acute and chronic fish toxicity testing in Arroyo Las Positas (Livermore Site) once per "wet season" (defined as October of one year through April of the following year). LLNL is currently not required to test for fish toxicity at Site 300.

\section{Inspections}

Each directorate at LLNL conducts an annual inspection of its facilities to verify implementation of the Storm Water Pollution Prevention Plans (SWPPPs) and to ensure that measures to reduce pollutant loadings to storm water runoff are implemented. The Associate Directors certify that their facilities comply with the provisions of WDR 94-131, WDR 95-174, and the SWPPPs. The Deputy Director for Operations certifies for facilities directly reporting to the Director's Office, except those facilities in the Laboratory Site Operations organization, which are certified by the Laboratory Site Manager. LLNL submits annual storm water monitoring reports to the San Francisco Bay RWQCB and to the Central Valley RWQCB, reporting the results of sampling, observations, and inspections.

LLNL also meets the storm water compliance monitoring requirements of the General Construction Activity Storm Water Permit for construction projects disturbing two hectares of land or more. Monitoring for these construction projects included visual observations of sites before and after storms to assess the effectiveness of implemented best management practices. Annual compliance certifications summarize these inspections.

As they have for the past two years, the San Francisco Bay RWQCB requested submission of compliance status reports for the Livermore site projects. Since the inception of the General Construction Activity Storm Water Permit, the Central Valley RWQCB has not requested these status reports for projects located at Site 300. The 1997 compliance certifications covered the period of June 1997 through May 1998. During this period, three Livermore site projects were inspected: the Decontamination and Waste Treatment Facility (DWTF), the National Ignition Facility (NIF), and the areas associated with the Soil Reuse Project. One Site 300 project, the Contained Firing Facility (CFF), was also inspected under this program.

\section{Sampling}

To evaluate the overall impact of Livermore site and Site 300 operations on storm water quality, storm water flows are sampled where they enter and exit the sites. Flow patterns at the Livermore site are such that storm water at sampling locations includes water from other sources, such as neighboring agricultural land, parking lots, and landscaped areas. In contrast, storm water at Site 300 is sampled at locations that target 
specific industrial activities, with negligible run-on from other sources. These samples provide information used to evaluate the effectiveness of LLNL's storm water pollution control program.

\section{Livermore Site}

The natural drainage at the LLNL Livermore site was altered by construction activities several times up to 1966 (Thorpe et al. 1990) so that the current northwest flow of Arroyo Seco and the westward flow of Arroyo Las Positas do not represent historical flow paths. About $1.6 \mathrm{~km}$ to the west of the Livermore site, Arroyo Seco merges with Arroyo Las Positas, which continues to the west to eventually merge with Arroyo Mocho (see Figure 7-1).

The Drainage Retention Basin (DRB) was excavated and constructed for storm water diversion and flood control. It collects about one-fourth of the surface water runoff from the site and a portion of the Arroyo Las Positas drainage (Figure 7-2). This basin was lined to prevent infiltration.

The DRB discharges north to a culvert that leads to Arroyo Las Positas. The remainder of the site drains either directly or indirectly into the two arroyos by way of storm sewers and ditches. Arroyo Seco cuts across the southwestern corner of the site. Arroyo Las Positas, diverted from its natural course, follows the northeastern and northern boundaries of the site and exits the site near the northwest corner.

The Livermore site storm water runoff sampling network consists of 13 locations (Figure 7-2). Six locations characterize storm water either entering (influent: ALPE, ALPO, GRNE, and ASS2) or exiting (effluent: WPDC and ASW) the Livermore site. Locations $\mathrm{CDB}$ and $\mathrm{CDB} 2$ characterize runoff from the southeastern quadrant of the Livermore site entering the DRB, and location CDBX characterizes water leaving the DRB. Four on-site locations (196E, 196S, WPDS, and WPDW) were used in a tritium source investigation.

\section{Site 300}

Surface water at Site 300 consists of seasonal stream runoff, springs, and natural and man-made ponds. The primary waterway in the Site 300 area is Corral Hollow Creek, an ephemeral stream that borders the site to the south and southeast. No continuously flowing streams are present in the Site 300 area. Elk Ravine is the major drainage channel for most of Site 300; it extends from the northwest portion of the site to the east-central area (see Figure 9-3). Elk Ravine drains the center of the site into Corral Hollow Creek, 


\section{Surface Water}

which drains eastward to the San Joaquin River Basin. Some smaller canyons in the northeast portion of the site drain to the north and east toward Tracy.

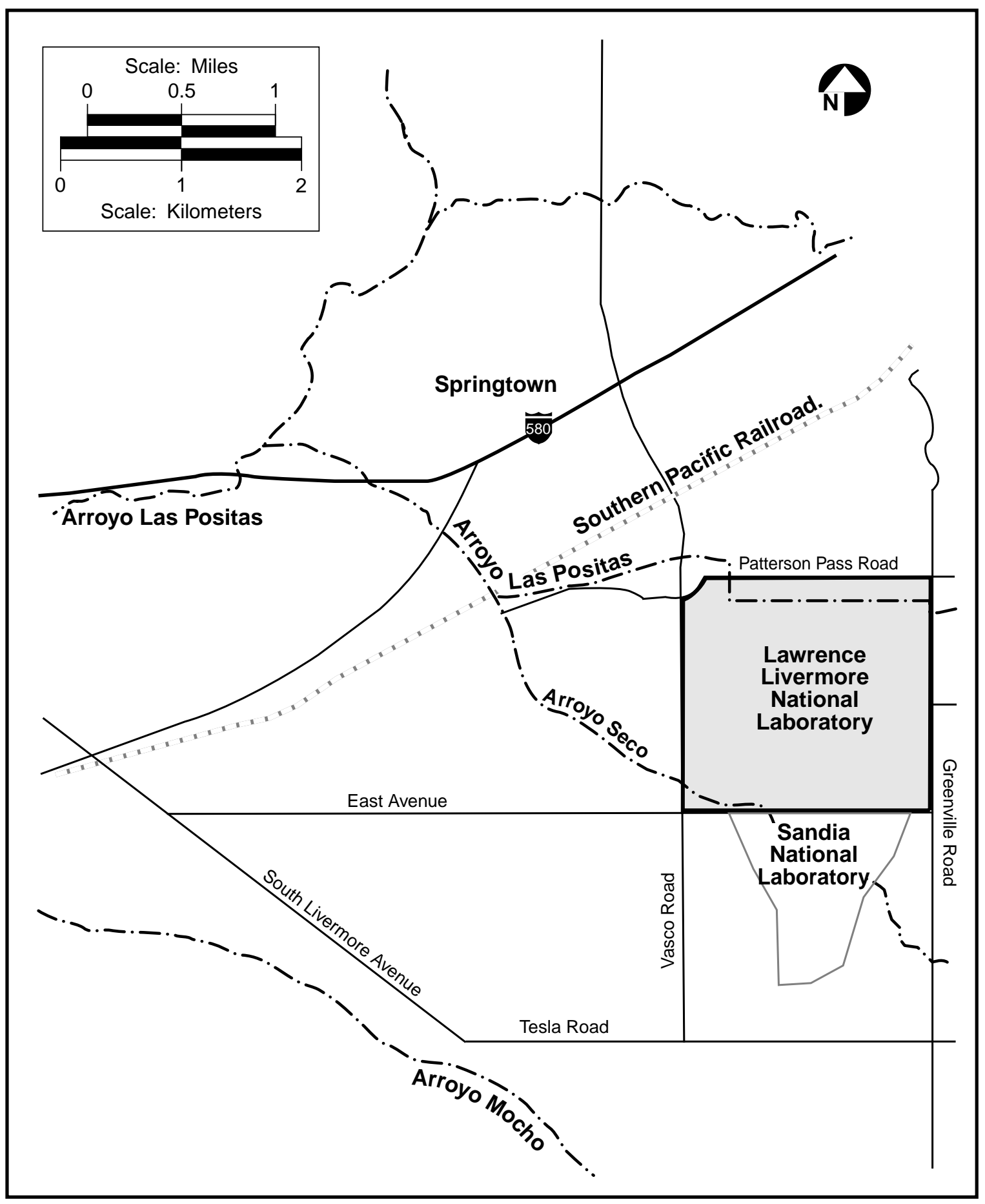

Figure 7-1. Surface water flow in the vicinity of LLNL. 


\section{Surface Water}

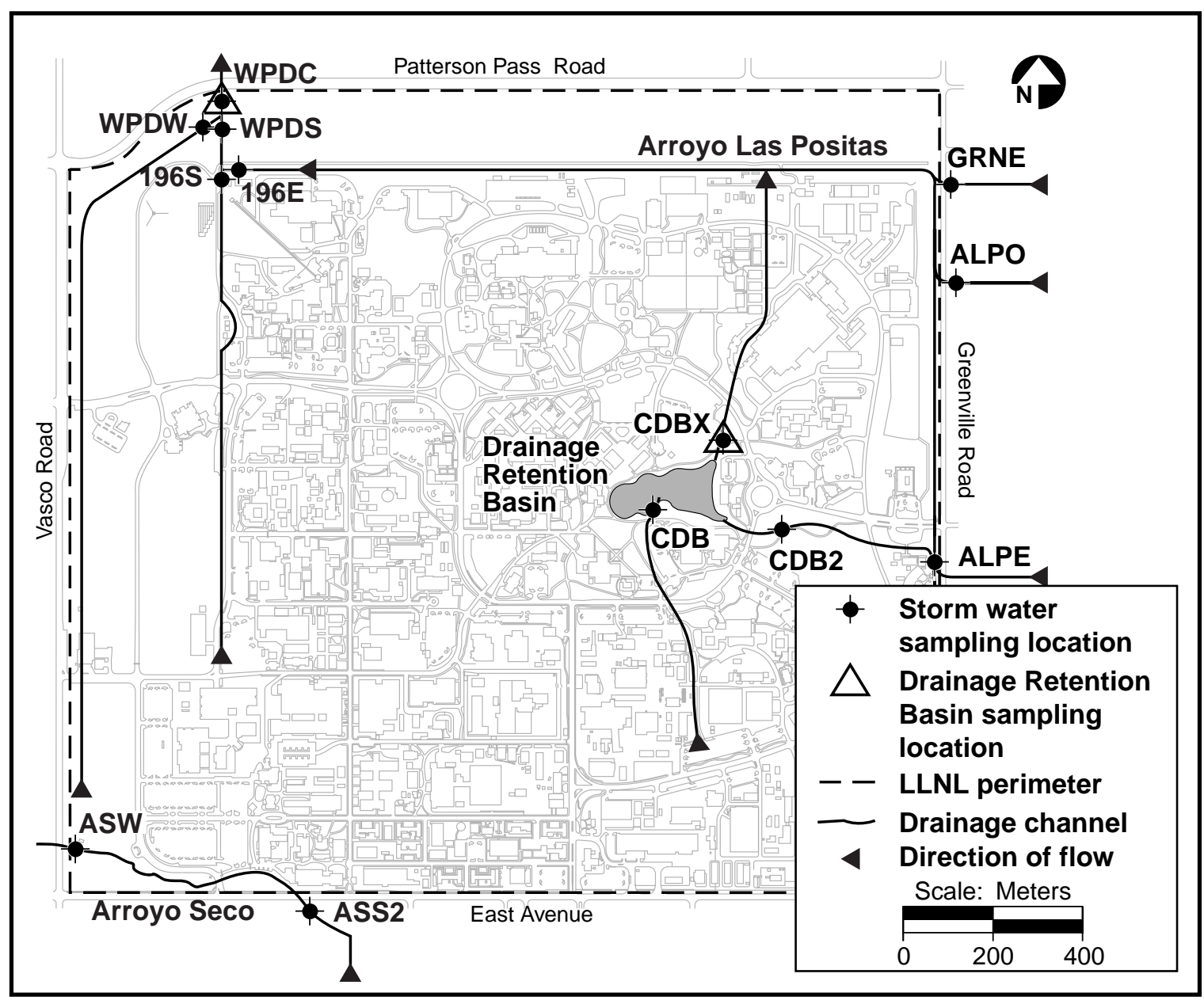

Figure 7-2. Storm water runoff and Drainage Retention Basin discharge sampling locations, Livermore site and vicinity, 1998.

There are at least 23 springs at Site 300. Nineteen are perennial, and four are intermittent. Most of the springs have very low flow rates and are recognized only by small marshy areas, pools of water, or vegetation. A number of surface water bodies are present at Site 300 and vicinity. A sewage evaporation pond and a sewage percolation pond are located in the southeast corner of the site in the General Services Area (GSA), and two lined high explosives (HE) process water impoundments are located to the west in the Explosives Process Area. Monitoring results associated with these facilities are reported in Chapter 9.

Other surface water flow at Site 300 results from blowdown water from cooling towers in the Building 801 complex in the East/West Firing Area and Building 836 in the 832 


\section{Surface Water}

canyon. Cooling tower discharges and their potential impact are discussed in the Final Site-Wide Remedial Investigation Report (Webster-Scholten 1994).

The Site 300 storm water sampling network began in 1994 with six locations and now consists of seven locations (Figure 7-3). Location CARW is used to characterize runoff in Corral Hollow Creek upgradient and, therefore is unaffected by Site 300 activities.

Location GEOCRK is used to characterize runoff in Corral Hollow Creek, downgradient of Site 300. The remaining locations were selected to characterize storm water runoff at locations that could be affected by specific Site 300 activities.

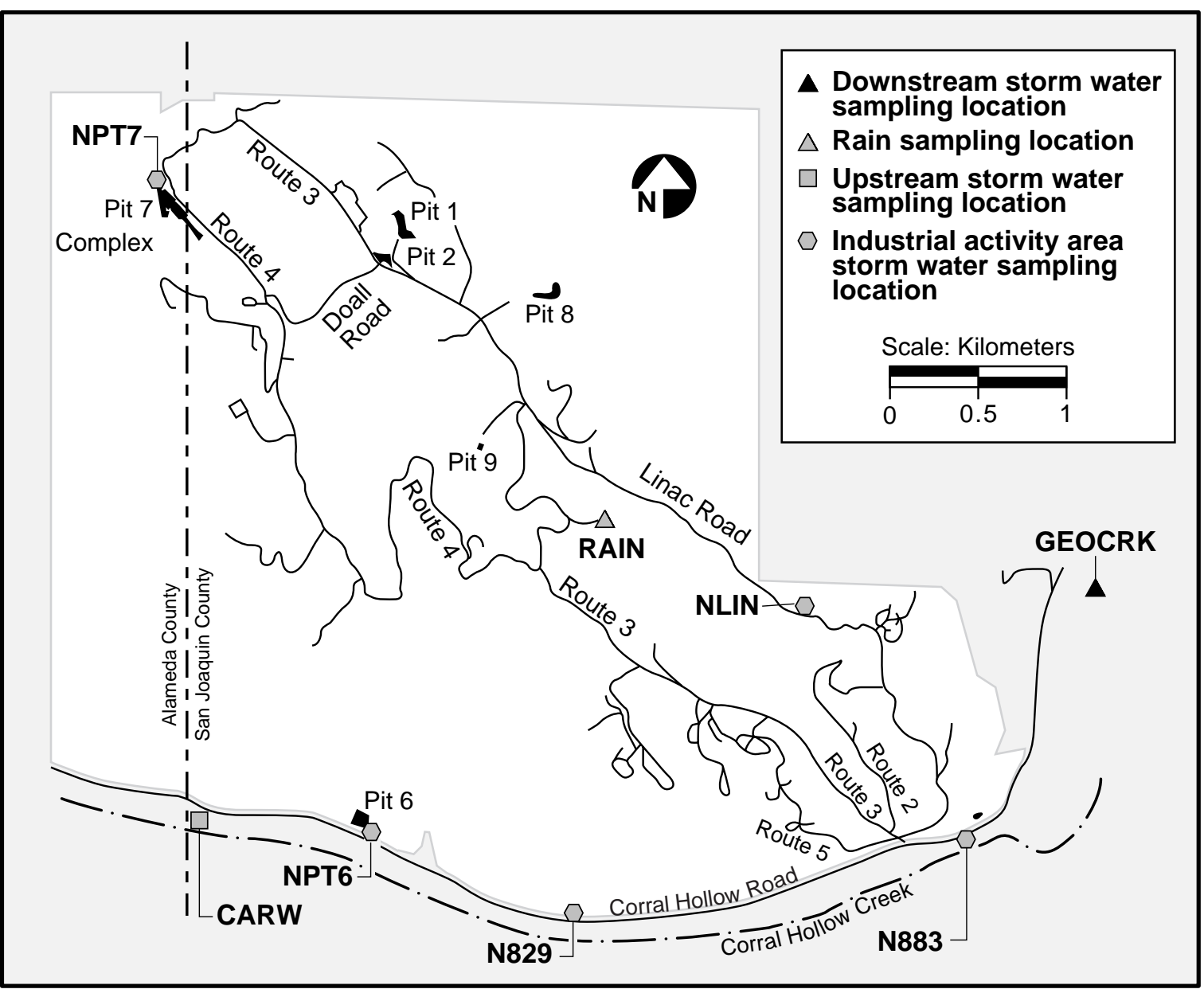

Figure 7-3. Rain and storm water runoff sampling locations, Site 300 and vicinity, 1998. 


\section{Methods}

Samples are collected by grab sampling from the runoff flow at specified locations. Sample bottle requirements, special sampling techniques, and preservation requirements for each analyte are specified in the Environmental Monitoring Plan (Tate et al. 1995), and summarized below.

If the water to be sampled is accessible to the technician, grab samples are collected by partially submerging sample bottles directly into the water and allowing them to fill with the sample water. If the water to be sampled is not directly accessible, a stainless steel bucket is used for sampling. The bucket is triple-rinsed with the water to be sampled, then dipped or submerged into the water, and withdrawn in a smooth motion. Sampling is conducted away from the edge of the water to minimize the collection of sediment with the sample matrix. Sample vials for volatile organics are filled first, before sample vials for all other constituents and parameters.

\section{Results}

\section{Inspections}

Inspections at the Livermore site noted a few instances of products or equipment stored uncovered outside, a product storage compartment in need of repairs, two pieces of equipment leaking oil, and one drain to ground that was not appropriately labeled. Inspections at Site 300 noted one leaking faucet. Clean-up and repairs are under way in all cases. A number of findings were associated with the LLNL cafeterias. Trash-bin lids were damaged or missing, small amounts of tallow oil (from 1 tablespoon to 3 cups) had been spilled to soil, and grease had leaked from two fume hoods. Clean-up is in progress, and training is being given to the subcontractors to prevent any recurrences.

The following exceptions to the General Construction Activity Storm Water Permit requirements were documented:

- Inspections of the CFF construction site at Site 300 were not documented during the shut down of construction activities from December 1997 through May 1998.

- Inspections based on the prediction of a rain event were not performed for the Soil Reuse Project at the Livermore site. 


\section{Surface Water}

- $\quad$ An erosion control Best Management Practice (BMP) for the Soil Reuse Project at the Livermore site was not implemented as specified in the SWPPP. However, no erosion resulted from this BMP lapse.

Finally, there were four exceptions associated with the National Ignition Facility (NIF) project at the Livermore site. Two of these were for failure to implement the correct BMP. In addition, water from a broken line was drained into a trench without filtering entrained sediments, and on one occasion a road was cleaned by flushing it with water rather than sweeping. Inspections were not performed or documented for one subproject that was fast-tracked.

\section{Livermore Sampling}

LLNL collected storm water samples at all Livermore site locations on February 12, March 31, and November 30, 1998. Fish toxicity testing for the 1998/1999 season was delayed into 1999 because the laboratory could not meet the holding time requirement for the November 30, 1998, sample.

\section{Livermore Site Radioactive Constituents.}

Storm water tritium, gross alpha, and gross beta results are summarized in Table 7-2. Complete results are in the Data Supplement, Table 7-2. Median activities were $10 \%$ or less than the respective MCLs. Figures 7-4 and 7-5, which show the historical trend in storm water gross alpha and gross beta, respectively, do not reveal a discernible trend. In these and other storm water historical trend figures in this chapter, all available data for the influent and effluent locations of the two runoff pathways through the Livermore site have been aggregated. Also, data have been aggregated on a wet season basis-that is, October of one year through May of the next-rather than on a calendar year basis. The 1998 points represent a partial wet season, pending collection of 1999 data, and are based on only one sampling event (November 30, 1998).

Table 7-2. Radioactivity (in Bq/L) in storm water runoff, Livermore site, 1998.

\begin{tabular}{|l|c|c|c|}
\hline & Tritium & Gross alpha & Gross Beta \\
\hline Median & 2.40 & 0.05 & 0.11 \\
Minimum & 0.21 & 0.01 & 0.004 \\
Maximum & 31.4 & 0.38 & 0.32 \\
Interquartile range & 5.37 & 0.08 & 0.08 \\
MCL (a) & 740 & 0.555 & 1.85 \\
\hline
\end{tabular}

a $\mathrm{MCL}=$ Maximum Contamination Level 


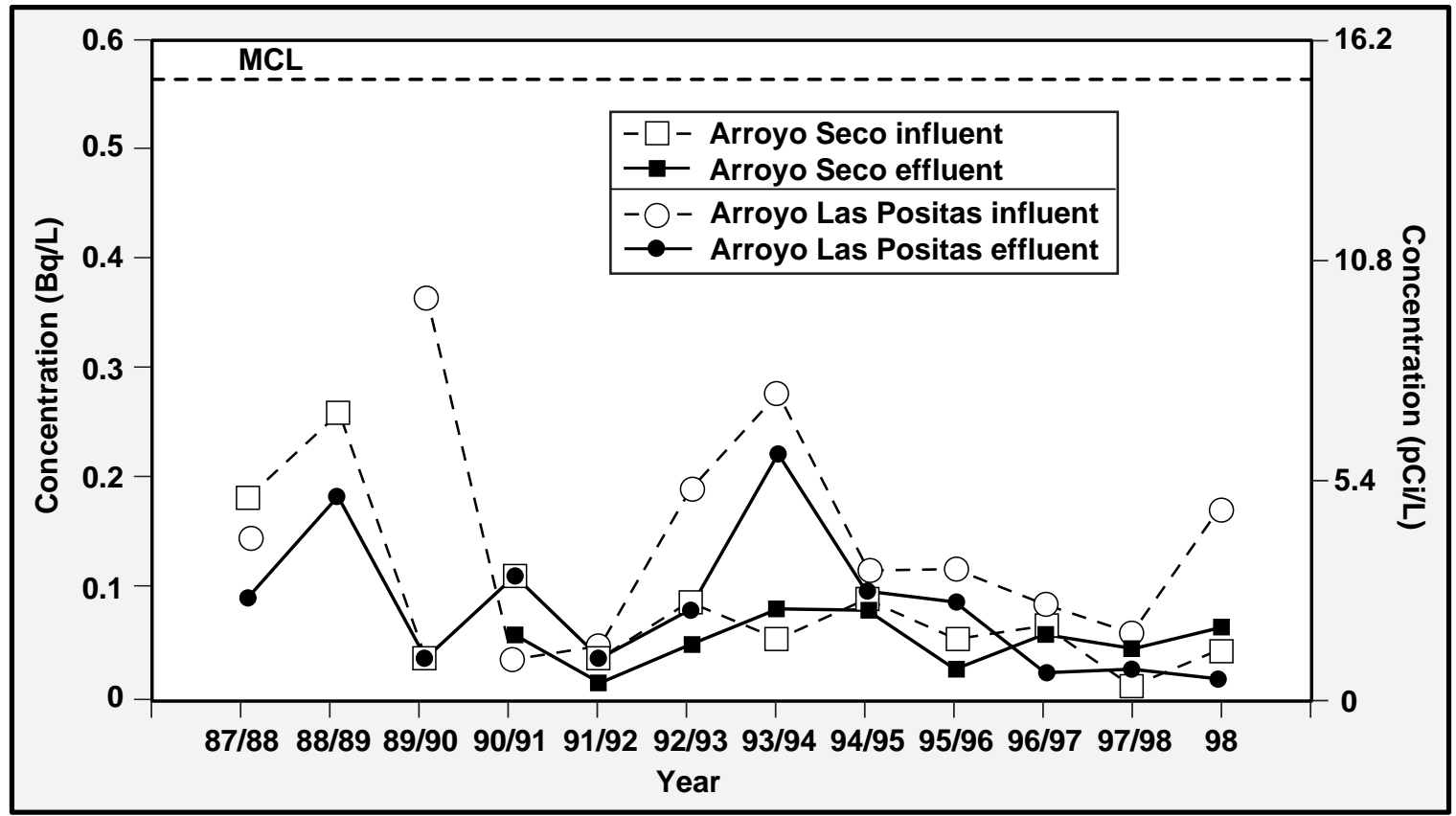

Figure 7-4. Annual median gross alpha concentrations in LLNL storm water compared with the maximum contaminant level (MCL).

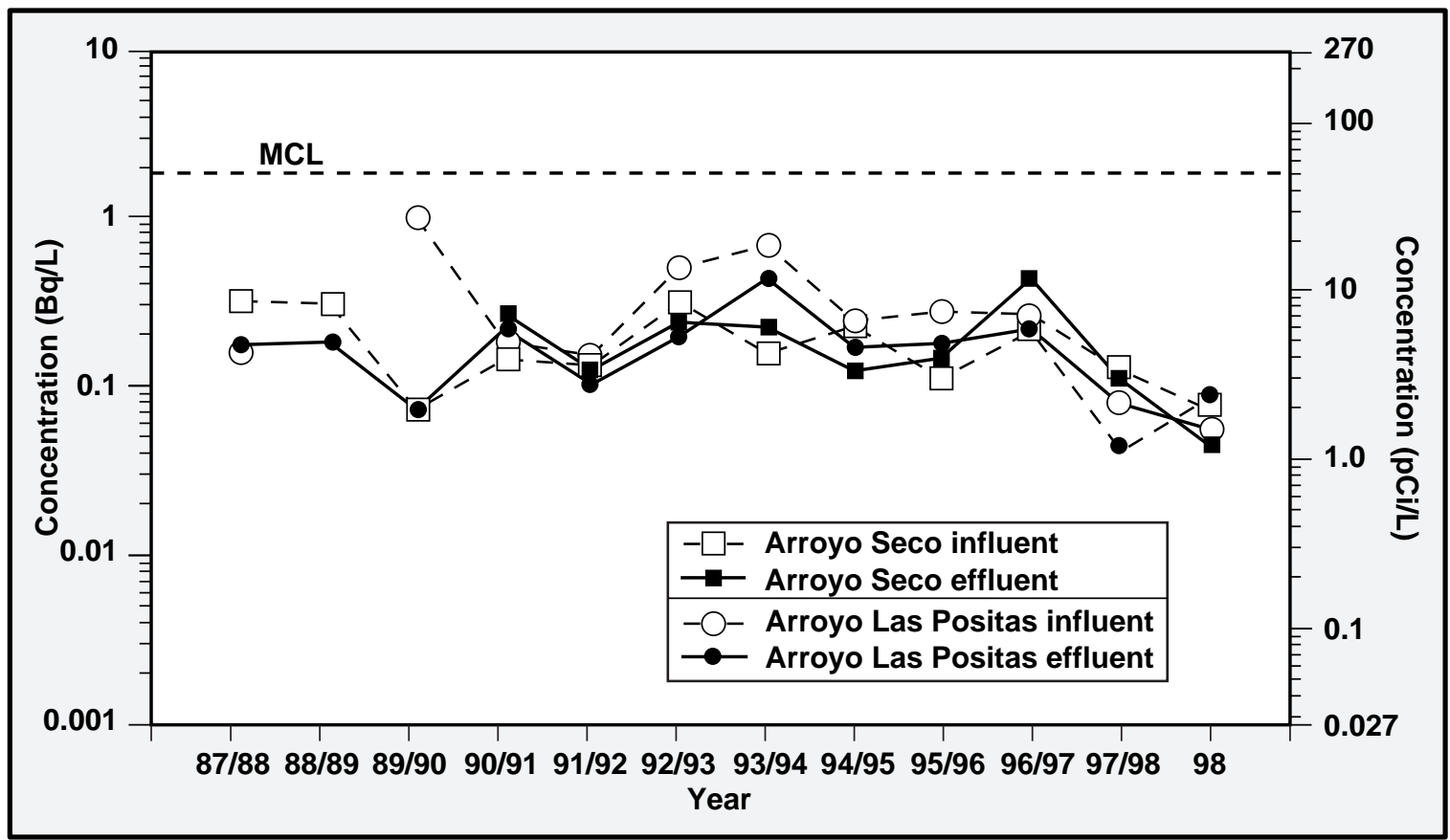

Figure 7-5. Annual median gross beta concentrations in LLNL storm water compared with the maximum contaminant level (MCL). 


\section{Surface Water}

The historical trend in tritium levels (Figure 7-6), which correlates with decreased emissions (see Chapter 5), indicates generally decreasing tritium levels in storm water from a peak in the 1988/1989 season. However, for the 1996/1997 and 1997/1998 seasons, the tritium concentration in Arroyo Las Positas was higher when storm water left the site than when it entered the site. In addition, on May 23, 1997, at location WPDC, where effluent is measured, a single, higher-than-typical result for tritium in storm water (359 Bq/L) was measured. Also, although the November 30, 1998, WPDC tritium result was 1.1 Bq/L just upstream at location WPDS, the tritium concentration was $31 \mathrm{~Bq} / \mathrm{L}$. The reason for this apparent discrepancy was that the samples were taken several hours apart and the peak discharge was probably missed at WPDC. Thus, at some point, the tritium concentration of the effluent could have reached $30 \mathrm{~Bq} / \mathrm{L}$.

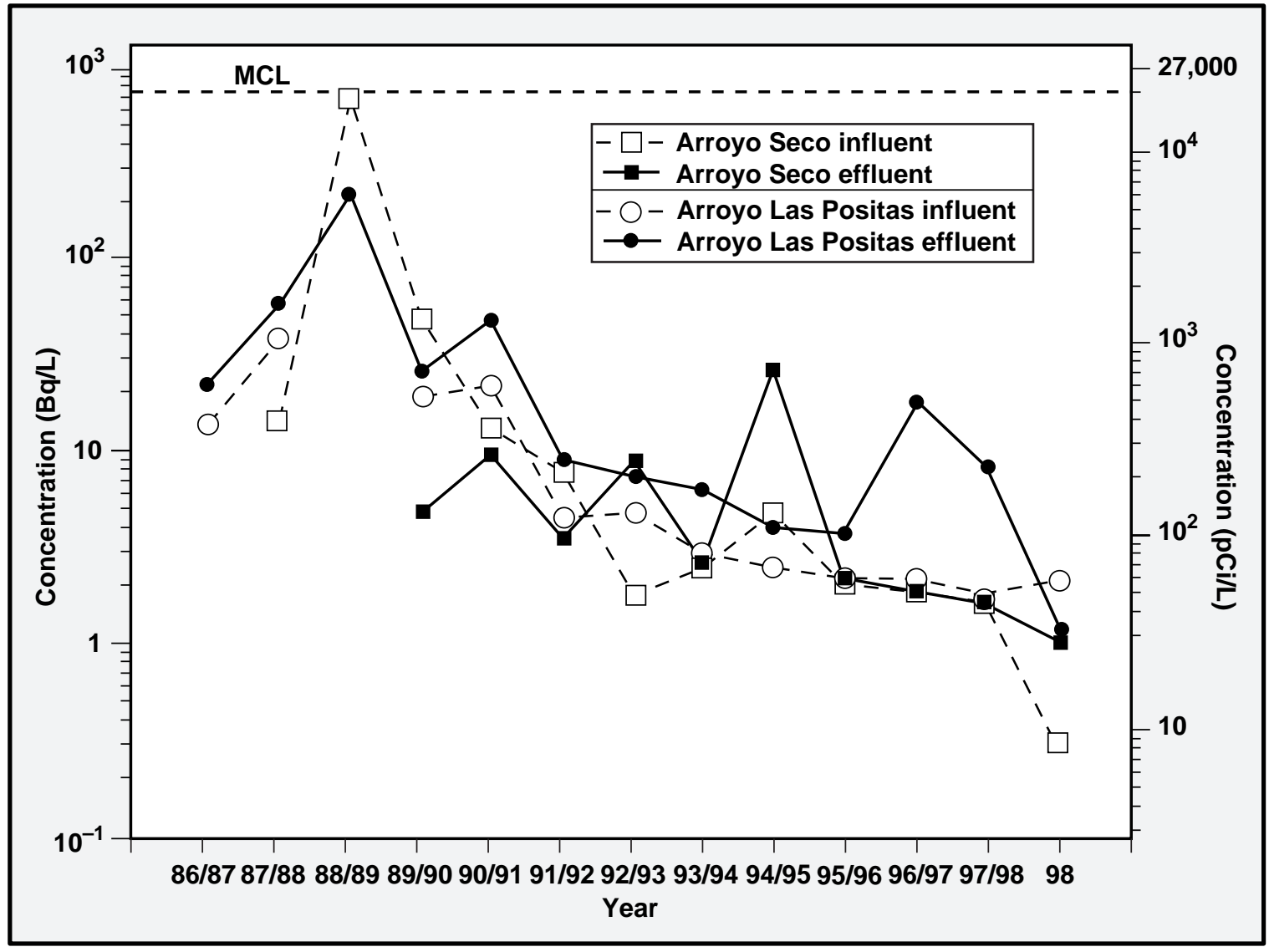

Figure 7-6. Annual median tritium concentrations in LLNL storm water compared with the maximum contamination level (MCL). 
In response to the high effluent tritium concentrations, additional tritium investigations were initiated in the fall of 1998, to reconfirm the current evidence that effluent tritium concentration is greater than influent tritium concentration, and to identify sources for the higher tritium concentrations. These investigations included:

- $\quad$ Review of air tritium sampling results (the air tritium data during and prior to 1998 did not indicate a source for the tritium).

- Increased frequency of rain sampling.

- Increased frequency and number of locations of storm water sampling.

The initial approach taken to evaluate tritium flow patterns across the Livermore site was to evaluate two locations (WPDW and 196S) where the storm drainage channels join the main Arroyo Las Positas channel slightly upstream of where Arroyo Las Positas leaves the Livermore site effluent location (WPDC). Beginning on November 30, 1998 two samples were taken for each juncture: one sample in the incoming channel and one in Arroyo Las Positas just upstream of the juncture, for a total of four locations (WPDS, WPDW, 196E, and 196S). Figure 7-7 depicts tritium concentrations at each location on this date. Tritium was not detected in the incoming channels (locations WPDW and 196S), but was high in the main Arroyo Las Positas channel (31 Bq/L at both WPDS and 196E). The data do not indicate a source in either of the two storm drainage channels closest to the Arroyo Las Positas effluent location. Additional locations will be added in 1999 to confirm this, and to further evaluate tritium flow patterns.

Evaluation of rain tritium revealed that, after November 7, 1997, tritium concentrations at rain location B343, designed to monitor results from the Building 331 Tritium Facility, (see Figure 7-8) were higher than at all other rain locations for every sample through the end of 1998 (8 sample dates in all). Tritium concentrations at the B343 location were at least $20 \mathrm{~Bq} / \mathrm{L}$ higher than the next highest rain location during this time period and up to a maximum of $152 \mathrm{~Bq} / \mathrm{L}$ higher than the next highest location on November 30, 1998. Figure 7-9 plots "runoff increase" against B343 rainfall tritium concentration for available data from 1996-1998 (in this plot, the WPDS result was used for November 30, 1998 runoff effluent). Runoff increase was calculated as the difference between effluent (location WPDC) tritium concentration and the highest influent (location ALPE, ALPO, or GRNE) tritium concentration. The data suggest a relationship between tritium in rainfall at the Tritium Facility and tritium levels in storm water at WPDC. Additional data points are needed to test this hypothesis. 


\section{Surface Water}

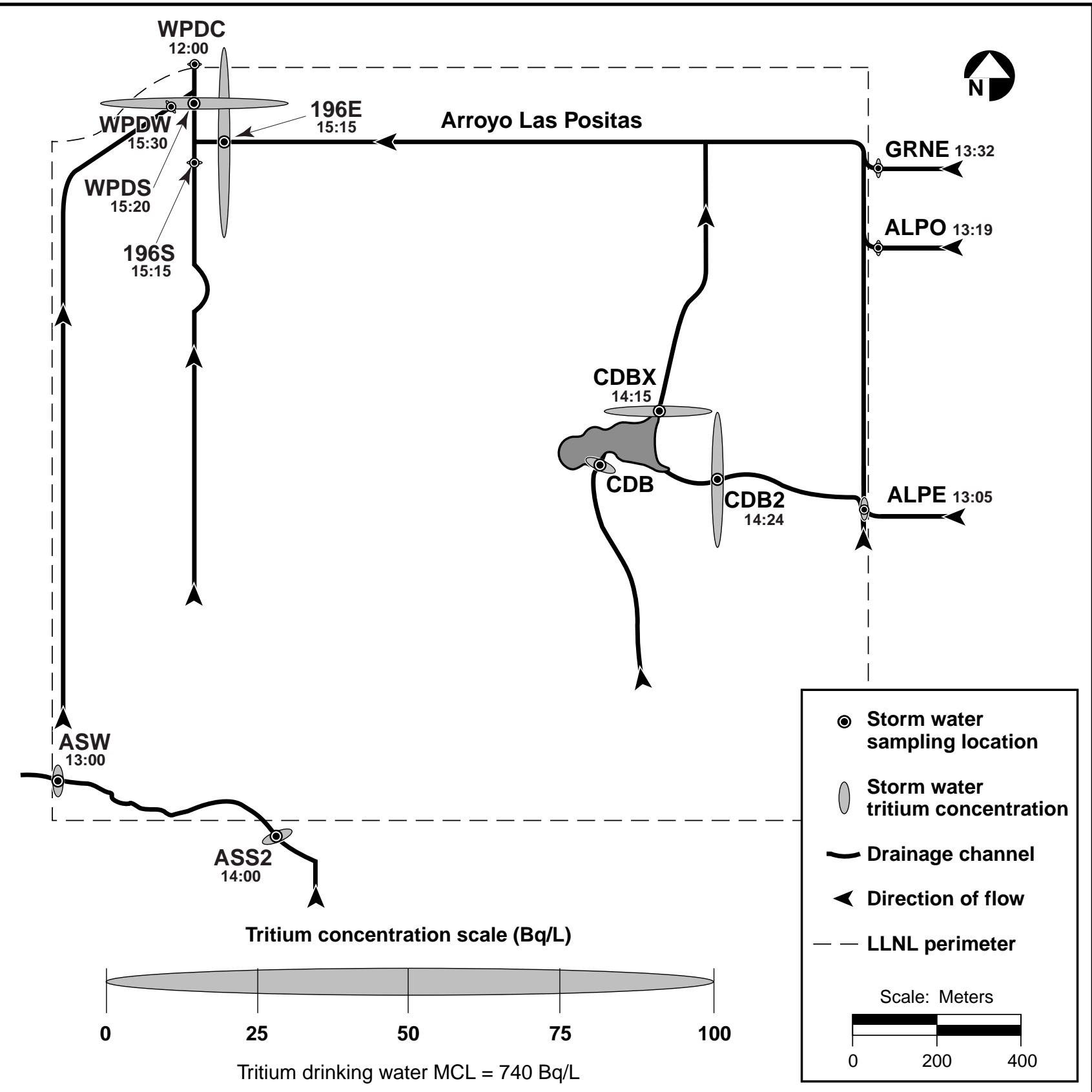

Figure 7-7. Tritium concentrations in Livermore site runoff on November 30, 1998. Time of sampling is indicated at sampling locations. 


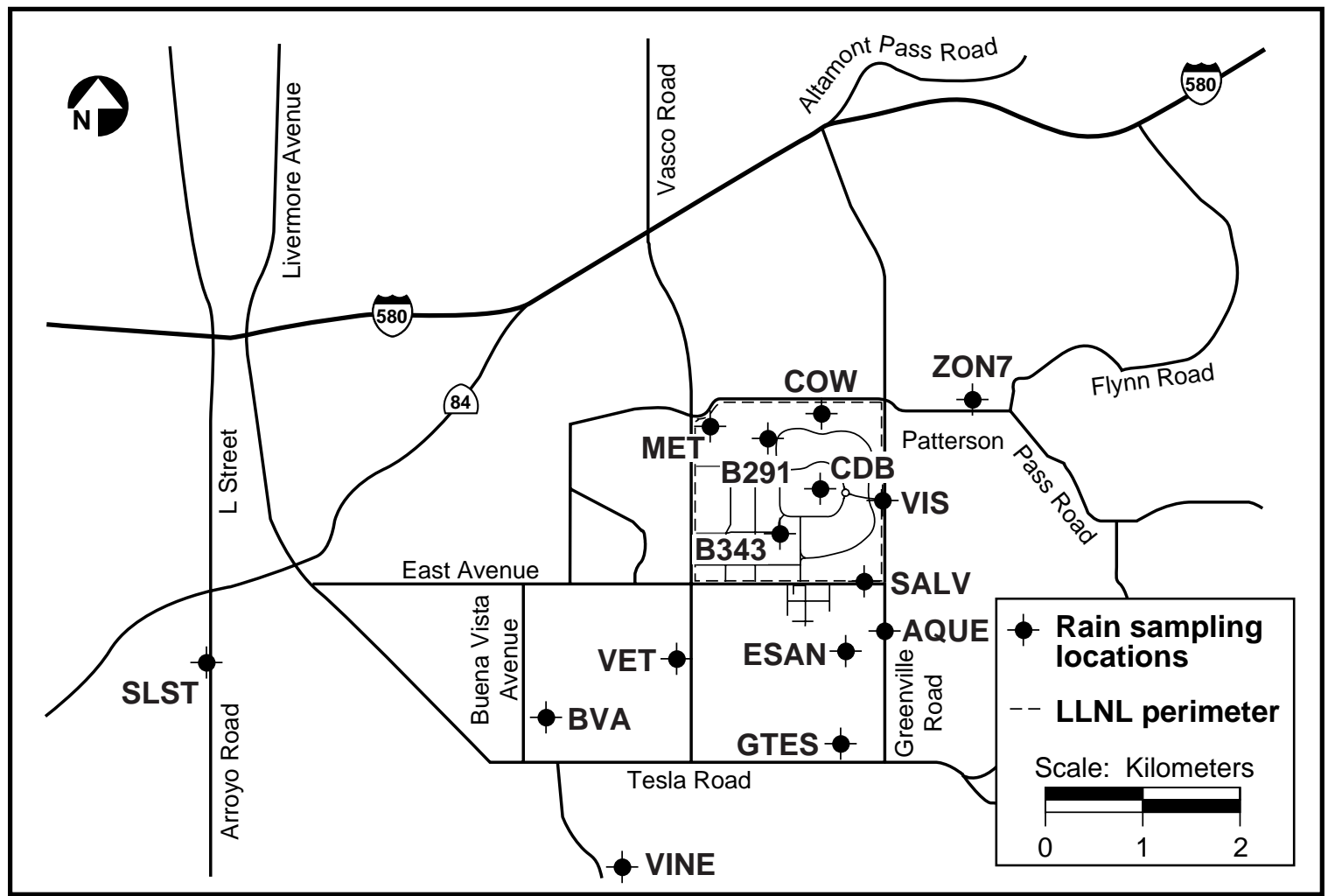

Figure 7-8. Rain sampling locations, Livermore site and Livermore Valley, 1998.

LLNL began analyzing for plutonium in runoff in 1998. Sampling was conducted at the Arroyo Seco effluent location (ASW) on February 12, and at both the Arroyo Seco and Arroyo Las Positas effluent locations (ASW and WPDC) on March 31, May 4, and November 30. In addition to analyzing plutonium in runoff water, on each date all or a portion of the sample was filtered, and the sediment analyzed to determine the plutonium levels in the sediments carried with the runoff. The only plutonium detected in runoff was $3.17 \times 10^{-4} \mathrm{~Bq} / \mathrm{L}$ of plutonium-238 on May 4 at location ASW, in the unfiltered sample. However, plutonium was not detected in filtered runoff or filtrate, indicating that this plutonium was caused by low levels (below background) of plutonium in the sediments. Sediment plutonium ${ }^{239+240}$ in this sample was measured at $1.44 \times 10^{-4} \mathrm{~Bq} / \mathrm{g}\left(3.910^{-3} \mathrm{pCi} / \mathrm{g}\right)$. This value is comparable to plutonium ${ }^{239+240}$ levels routinely seen in sediments at the location, and well below the background level $\left(4.44 \times 10^{-4} \mathrm{~Bq} / \mathrm{g}\left(1.2 \times 10^{-2} \mathrm{pCi} / \mathrm{g}\right)\right)$ for sediments. This background concentration reflects worldwide fallout and naturally occurring concentrations (See Chapter 9). The plutonium-238 result in sediment at location WPDC on November 30 was $0.0144 \pm 0.0141 \mathrm{~Bq} / \mathrm{g}$, an error of over $97 \%$. Other plutonium samples, counted for 


\section{Surface Water}

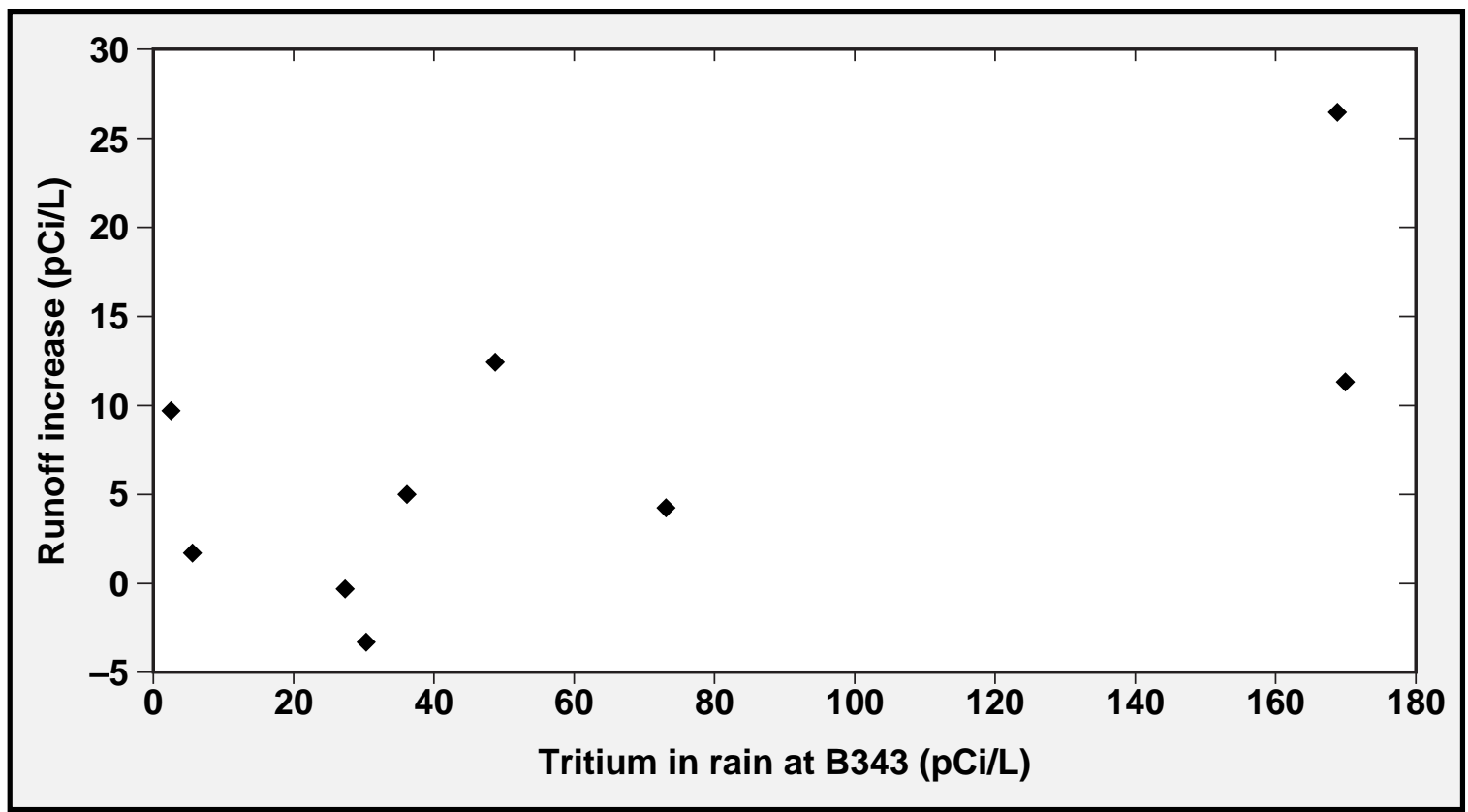

Figure 7-9. Tritium concentration in stormwater runoff at the Livermore site plotted against the tritium concentration of rain sampled at Building 343 (November, 1997 through December, 1998).

longer times, had lower detection limits, and were judged to be nondetects, indicating that the November 30 result was probably an artifact of a high detection limit. This was confirmed by submitting an archived portion of this sample reanalysis with lower detection limits. The result was no detectable plutonium (detection limit $=$ $3.7 \times 10^{-3} \mathrm{~Bq} / \mathrm{g}(0.1 \mathrm{pCi} / \mathrm{g})$, and calculated activity of $\left.4.5 \times 10^{-4} \mathrm{~Bq} / \mathrm{g}(0.05 \mathrm{pCi} / \mathrm{g})\right)$. Future samples will be counted longer to eliminate false positives at high detection limits. Thus, plutonium activities in runoff can be attributed to background levels and worldwide fallout. Complete plutonium results are found in Data Supplement Table 7-3.

\section{Livermore Site Nonradioactive Constituents}

Table 7-3 and 7-4 list metals, organics, and nonradioactive constituents found above comparison criteria in Livermore site storm water. (Complete storm water results are presented in Tables 7-4, 7-5, and 7-20 of the Data Supplement.) Of greatest concern are constituents that exceeded comparison criteria at effluent points, and whose concentrations are lower in influent than in effluent. If influent concentrations are higher than effluent concentrations, the source is generally assumed to be unrelated to LLNL operations, and therefore, further investigation is not warranted. 
Table 7-3. Metal constituents above comparison criteria (see Table 7-1 of the Data Supplement) in storm water runoff, Livermore site, 1998.

\begin{tabular}{|c|c|c|c|c|c|c|c|}
\hline \multirow{4}{*}{$\begin{array}{l}\text { Metal } \\
(\mathrm{mg} / \mathrm{L})\end{array}$} & \multirow{4}{*}{$\begin{array}{l}\text { Requested } \\
\text { analysis }\end{array}$} & \multirow{4}{*}{$\begin{array}{c}\text { EPA } \\
\text { analysis } \\
\text { method }\end{array}$} & \multirow{4}{*}{$\begin{array}{l}\text { Storm } \\
\text { date }\end{array}$} & \multicolumn{4}{|c|}{ Arroyo Seco } \\
\hline & & & & \multirow{2}{*}{\multicolumn{2}{|c|}{$\begin{array}{c}\text { Influent } \\
\text { ASS2 }\end{array}$}} & \multirow{2}{*}{\multicolumn{2}{|c|}{$\begin{array}{c}\text { Effluent } \\
\text { ASW }\end{array}$}} \\
\hline & & & & & & & \\
\hline & & & & Dissolved & Total & Dissolved & Total \\
\hline \multirow[t]{5}{*}{ Aluminum } & GENMIN & 200.7 & $2 / 12$ & & 43 & & 6.8 \\
\hline & GENMIN & 200.7 & $3 / 31$ & & 0.69 & & 0.55 \\
\hline & NPDESMETAL & 200.7 & & & 0.98 & & 0.75 \\
\hline & GENMIN & 200.7 & $11 / 30$ & 0.28 & 2.5 & & 3.7 \\
\hline & NPDESMETAL & 200.7 & & 0.27 & 2.9 & 0.21 & 4.0 \\
\hline Antimony & NPDESMETAL & 204.2 & $3 / 31$ & & 0.006 & & \\
\hline \multirow[t]{2}{*}{ Copper } & GENMIN & 200.7 & $2 / 12$ & & 0.057 & & \\
\hline & NPDESMETAL & 220.2 & & & 0.088 & & 0.026 \\
\hline \multirow[t]{5}{*}{ Iron } & GENMIN & 200.7 & $2 / 12$ & & 61 & & 8.1 \\
\hline & GENMIN & 200.7 & $3 / 31$ & & 0.97 & & 0.71 \\
\hline & NPDESMETAL & 200.7 & & & 1.3 & & 0.95 \\
\hline & GENMIN & 200.7 & $11 / 30$ & & 3 & & 4.4 \\
\hline & NPDESMETAL & 200.7 & & & 3.5 & & 5.1 \\
\hline \multirow[t]{2}{*}{ Lead } & NPDESMETAL & 239.2 & $2 / 12$ & & 0.027 & & \\
\hline & NPDESMETAL & 239.2 & $3 / 31$ & & 0.061 & & \\
\hline \multirow[t]{5}{*}{ Manganese } & GENMIN & 200.7 & $2 / 12$ & & 1.2 & & 0.22 \\
\hline & GENMIN & 200.7 & $3 / 31$ & & & & \\
\hline & NPDESMETAL & 200.7 & & & 0.05 & & \\
\hline & GENMIN & 200.7 & $11 / 30$ & & 0.068 & & 0.088 \\
\hline & NPDESMETAL & 200.7 & & & 0.074 & & 0.097 \\
\hline \multirow[t]{2}{*}{ Nickel } & GENMIN & 200.7 & $2 / 12$ & & 0.12 & & \\
\hline & NPDESMETAL & 249.2 & & & 0.12 & & \\
\hline \multirow[t]{6}{*}{ Zinc } & GENMIN & 200.7 & $2 / 12$ & & 0.19 & & 0.069 \\
\hline & NPDESMETAL & 200.7 & & & & & 0.032 \\
\hline & GENMIN & 200.7 & $3 / 31$ & & 0.042 & & 0.061 \\
\hline & NPDESMETAL & 200.7 & & & 0.04 & & 0.07 \\
\hline & GENMIN & 200.7 & $11 / 30$ & 0.066 & 0.096 & 0.058 & 0.1 \\
\hline & NPDESMETAL & 200.7 & & 0.055 & 0.1 & 0.054 & 0.12 \\
\hline
\end{tabular}




\section{Surface Water}

Table 7-3. Metal constituents above comparison criteria (see Table 7-1 of the Data Supplement) in storm water runoff, Livermore site, 1998 (continued).

\begin{tabular}{|c|c|c|c|c|c|c|c|c|c|c|c|}
\hline \multirow{4}{*}{$\begin{array}{l}\text { Metal } \\
(\mathrm{mg} / \mathrm{L})\end{array}$} & \multirow{4}{*}{$\begin{array}{l}\text { Requested } \\
\text { analysis }\end{array}$} & \multirow{4}{*}{$\begin{array}{c}\text { EPA } \\
\text { analysis } \\
\text { method }\end{array}$} & \multirow{4}{*}{$\begin{array}{c}\text { Storm } \\
\text { date }\end{array}$} & \multicolumn{8}{|c|}{ Arroyo Los Positas } \\
\hline & & & & \multicolumn{6}{|c|}{ Influent } & \multirow{2}{*}{\multicolumn{2}{|c|}{$\begin{array}{c}\text { Effluent } \\
\text { WPDC }\end{array}$}} \\
\hline & & & & \multicolumn{2}{|c|}{ ALPE } & \multicolumn{2}{|c|}{ ALPO } & \multicolumn{2}{|c|}{ GRNE } & & \\
\hline & & & & Dissolved & Total & Dissolved & Total & Dissolved & Total & Dissolved & Dissolved \\
\hline \multirow[t]{5}{*}{ Aluminum } & GENMIN & 200.7 & $2 / 12$ & & 2.1 & & 13 & & 27 & & 7 \\
\hline & GENMIN & 200.7 & $3 / 31$ & & 5.6 & & 2.0 & & 2.4 & & 1.8 \\
\hline & NPDESMETAL & 200.7 & & & 7.3 & & 2.9 & & 2.8 & & 2.7 \\
\hline & GENMIN & 200.7 & $11 / 30$ & & 5.6 & & 1.7 & & 7.5 & & 2.8 \\
\hline & NPDESMETAL & 200.7 & & & 5.7 & & 2.5 & & 9.7 & & 2.9 \\
\hline Antimony & NPDESMETAL & 204.2 & $3 / 31$ & & & & & & & & \\
\hline \multirow[t]{2}{*}{ Copper } & GENMIN & 200.7 & $2 / 12$ & & & & & & & & \\
\hline & NPDESMETAL & 220.2 & & & & & 0.038 & & & & \\
\hline \multirow[t]{5}{*}{ Iron } & GENMIN & 200.7 & $2 / 12$ & & 1.9 & & 13 & & 29 & & 7.8 \\
\hline & GENMIN & 200.7 & $3 / 31$ & & 6.5 & & 2.1 & & 2.6 & & 2.2 \\
\hline & NPDESMETAL & 200.7 & & & 7.3 & & 2.6 & & 2.9 & & 3.3 \\
\hline & GENMIN & 200.7 & $11 / 30$ & & 5.1 & & 1.6 & & 8.0 & & 3 \\
\hline & NPDESMETAL & 200.7 & & & & & 2.2 & & 9.7 & & 3.4 \\
\hline \multirow[t]{2}{*}{ Lead } & NPDESMETAL & 239.2 & $2 / 12$ & & & & & & & & 0.035 \\
\hline & NPDESMETAL & 239.2 & $3 / 31$ & & & & & & & & \\
\hline \multirow[t]{5}{*}{ Manganese } & GENMIN & 200.7 & $2 / 12$ & & 0.23 & & 0.33 & & 0.53 & & 0.17 \\
\hline & GENMIN & 200.7 & $3 / 31$ & & 0.18 & & 0.1 & & 0.05 & & 0.055 \\
\hline & NPDESMETAL & 200.7 & & & 0.2 & & 0.12 & & 0.05 & & 0.07 \\
\hline & GENMIN & 200.7 & $11 / 30$ & & 0.1 & & & & 0.15 & & 0.061 \\
\hline & NPDESMETAL & 200.7 & & & 0.1 & & & & 0.16 & & 0.066 \\
\hline \multirow[t]{2}{*}{ Nickel } & GENMIN & 200.7 & $2 / 12$ & & & & & & & & \\
\hline & NPDESMETAL & 249.2 & & & & & & & & & \\
\hline \multirow[t]{6}{*}{ Zinc } & GENMIN & 200.7 & 2/12 & & 0.034 & & 0.061 & & 0.14 & & 0.15 \\
\hline & NPDESMETAL & 200.7 & & & & & & & & & \\
\hline & GENMIN & 200.7 & $3 / 31$ & & 0.062 & & & & 0.12 & 0.041 & 0.11 \\
\hline & NPDESMETAL & 200.7 & & & 0.06 & & & 0.04 & 0.13 & 0.05 & \\
\hline & GENMIN & 200.7 & $11 / 30$ & & 0.04 & & & & 0.085 & & 0.092 \\
\hline & NPDESMETAL & 200.7 & & & & & & & 0.098 & & 0.093 \\
\hline
\end{tabular}


Table 7-3. Metal constituents above comparison criteria (see Table 7-1 of the Data Supplement) in storm water runoff, Livermore site, 1998 (concluded).

\begin{tabular}{|c|c|c|c|c|c|c|c|c|c|}
\hline \multirow{4}{*}{$\begin{array}{l}\text { Metal } \\
(\mathrm{mg} / \mathrm{L})\end{array}$} & \multirow{4}{*}{$\begin{array}{l}\text { Requested } \\
\text { analysis }\end{array}$} & \multirow{4}{*}{$\begin{array}{c}\text { EPA } \\
\text { analysis } \\
\text { method }\end{array}$} & \multirow{4}{*}{$\begin{array}{c}\text { Storm } \\
\text { date }\end{array}$} & \multicolumn{6}{|c|}{ Drainage Retention Basin } \\
\hline & & & & \multicolumn{4}{|c|}{ Influent } & \multirow{2}{*}{\multicolumn{2}{|c|}{$\begin{array}{c}\text { Effluent } \\
\text { CDBX }\end{array}$}} \\
\hline & & & & \multicolumn{2}{|c|}{ CDB } & \multicolumn{2}{|c|}{ CDB2 } & & \\
\hline & & & & Dissolved & Total & Dissolved & Total & Dissolved & Total \\
\hline \multirow[t]{5}{*}{ Aluminum } & GENMIN & 200.7 & $2 / 12$ & & 4.3 & & 8.1 & & 5.9 \\
\hline & GENMIN & 200.7 & $3 / 31$ & & 2.1 & & 0.87 & & \\
\hline & NPDESMETAL & 200.7 & & & 1.9 & & 1.1 & & \\
\hline & GENMIN & 200.7 & $11 / 30$ & 0.28 & 2.8 & 0.29 & 6.2 & & 2.1 \\
\hline & NPDESMETAL & 200.7 & & 0.26 & 3 & 0.3 & 6.1 & & 2.4 \\
\hline Antimony & NPDESMETAL & 204.2 & $3 / 31$ & & & & & & \\
\hline \multirow[t]{2}{*}{ Copper } & GENMIN & 200.7 & $2 / 12$ & & & & & & \\
\hline & NPDESMETAL & 220.2 & & & & & & & \\
\hline \multirow[t]{5}{*}{ Iron } & GENMIN & 200.7 & $2 / 12$ & & 4.3 & & 8.5 & & 5.4 \\
\hline & GENMIN & 200.7 & $3 / 31$ & & 2.4 & & 1 & & \\
\hline & NPDESMETAL & 200.7 & & & 2.3 & & 1 & & \\
\hline & GENMIN & 200.7 & $11 / 30$ & & 2.9 & & 6.3 & & 2.1 \\
\hline & NPDESMETAL & 200.7 & & & 3.2 & & 6.3 & & 2.4 \\
\hline \multirow[t]{2}{*}{ Lead } & NPDESMETAL & 239.2 & $2 / 12$ & & & & & & \\
\hline & NPDESMETAL & 239.2 & $3 / 31$ & & & & & & \\
\hline \multirow[t]{5}{*}{ Manganese } & GENMIN & 200.7 & $2 / 12$ & & 0.087 & & 0.18 & & 0.087 \\
\hline & GENMIN & 200.7 & $3 / 31$ & & 0.052 & & 0.081 & & \\
\hline & NPDESMETAL & 200.7 & & & 0.05 & & 0.08 & & \\
\hline & GENMIN & 200.7 & $11 / 30$ & & 0.064 & & 0.11 & & 0.052 \\
\hline & NPDESMETAL & 200.7 & & & 0.069 & & 0.11 & & 0.057 \\
\hline \multirow[t]{2}{*}{ Nickel } & GENMIN & 200.7 & $2 / 12$ & & & & & & \\
\hline & NPDESMETAL & 249.2 & & & & & & & \\
\hline \multirow[t]{6}{*}{ Zinc } & GENMIN & 200.7 & $2 / 12$ & & 0.11 & & 0.068 & & 0.039 \\
\hline & NPDESMETAL & 200.7 & & 0.039 & 0.035 & & & & \\
\hline & GENMIN & 200.7 & $3 / 31$ & & 0.12 & & & & \\
\hline & NPDESMETAL & 200.7 & & & 0.12 & & & & \\
\hline & GENMIN & 200.7 & $11 / 30$ & 0.088 & 0.13 & 0.049 & 0.11 & & 0.034 \\
\hline & NPDESMETAL & 200.7 & & 0.087 & 0.17 & 0.046 & 0.11 & & 0.038 \\
\hline
\end{tabular}




\section{Surface Water}

Table 7-4. Nonradioactive constituents above comparison criteria (see Table 7-1 in the Data Supplement) in storm water runoff, Livermore site, 1998.

\begin{tabular}{|c|c|c|c|c|c|c|c|c|c|c|}
\hline \multirow{3}{*}{ Parameter } & \multirow{3}{*}{$\begin{array}{c}\text { Storm } \\
\text { date }\end{array}$} & \multicolumn{2}{|c|}{ Arroyo Seco } & \multicolumn{4}{|c|}{ Arroyo Las Positas } & \multicolumn{3}{|c|}{ Drainage Retention Basin } \\
\hline & & \multirow{2}{*}{$\begin{array}{c}\text { Influent } \\
\text { ASS2 }\end{array}$} & \multirow{2}{*}{$\begin{array}{c}\text { Effluent } \\
\text { ASW }\end{array}$} & \multicolumn{3}{|c|}{ Influent } & \multirow{2}{*}{$\begin{array}{c}\text { Effluent } \\
\text { WPDC }\end{array}$} & \multicolumn{2}{|c|}{ Influent } & \multirow{2}{*}{\begin{tabular}{|c|} 
Effluent \\
CDBX
\end{tabular}} \\
\hline & & & & ALPE & ALPO & GRNE & & CDB & CDB2 & \\
\hline \multicolumn{11}{|l|}{ Physical (mg/L) } \\
\hline Chemical oxygen demand & $3 / 31$ & & & 124 & & & & & & \\
\hline \multirow[t]{3}{*}{ Total suspended solids (TSS) } & $2 / 12$ & 454 & & 370 & 280 & 748 & 158 & 154 & 160 & \\
\hline & $3 / 31$ & & & 179 & & & & & & \\
\hline & $11 / 30$ & & & & & 131 & & & & \\
\hline \multicolumn{11}{|l|}{ Anions (mg/L) } \\
\hline \multirow[t]{3}{*}{ Chloride } & $2 / 12$ & & & & 250 & & & & & \\
\hline & $3 / 31$ & & & 388 & 333 & & & & 302 & \\
\hline & $11 / 30$ & & & & & & & & & 93 \\
\hline \multirow[t]{3}{*}{ Fluoride } & $2 / 12$ & & & & 0.95 & & & & & \\
\hline & $3 / 31$ & & & 1.2 & 1.4 & & & & 1.2 & \\
\hline & $11 / 30$ & & & & 1 & & & & & \\
\hline \multirow[t]{3}{*}{ Nitrate (as N) } & $2 / 12$ & 2.8 & 2.8 & & & 0.71 & & & & \\
\hline & $3 / 31$ & 1.6 & 1.5 & & 2.9 & 4.9 & & 1.8 & & \\
\hline & $11 / 30$ & & & & 2.2 & 3.3 & 0.89 & & & 1.7 \\
\hline \multirow[t]{3}{*}{ Nitrate (as $\mathrm{NO}_{3}$ ) } & $2 / 12$ & 12 & 12 & & 15 & 3.1 & & & & \\
\hline & $3 / 31$ & 7.2 & 6.7 & & 13 & 22 & & 8 & & \\
\hline & $11 / 30$ & & & & 9.5 & 14 & 4 & & & 7.5 \\
\hline \multirow[t]{2}{*}{ Sulfate } & $2 / 12$ & & & & 304 & & & & & \\
\hline & $3 / 31$ & & & 317 & 355 & & & & & \\
\hline \multicolumn{11}{|l|}{ General minerals (mg/L) } \\
\hline Chloride & $3 / 31$ & & & 365 & 331 & & & & 303 & \\
\hline \multirow[t]{4}{*}{ Fluoride } & $2 / 12$ & & & & 0.97 & & & & & \\
\hline & $3 / 31$ & & & 1.2 & 1.4 & & & & 1 & \\
\hline & $11 / 30$ & & & & 1 & & & & & \\
\hline & $11 / 30$ & & & & 1 & & & & & \\
\hline \multirow[t]{4}{*}{ Nitrate (as N) } & $2 / 12$ & 2.8 & 2.8 & & 3.3 & 0.72 & & & & \\
\hline & $3 / 31$ & 1.7 & 1.5 & & 2.9 & 4.9 & 0.74 & 1.8 & & \\
\hline & $11 / 30$ & & & & 2.2 & 3.4 & 0.98 & & & 1.8 \\
\hline & $11 / 30$ & & & & 2.2 & 3.2 & 0.95 & & & 1.8 \\
\hline \multirow[t]{4}{*}{ Nitrate $\left(\right.$ as $\left.\mathrm{NO}_{3}\right)$} & $2 / 12$ & 12 & 12 & & 15 & 3.2 & & & & \\
\hline & $3 / 31$ & 7.4 & 6.7 & & 13 & 22 & 3.3 & 7.9 & & \\
\hline & $11 / 30$ & & & & 9.8 & 15 & 4.3 & & & 7.8 \\
\hline & $11 / 30$ & & & & 9.5 & 14 & 4.2 & & & 7.8 \\
\hline
\end{tabular}


Table 7-4. Nonradioactive constituents above comparison criteria (see Table 7-1 in the Data Supplement) in storm water runoff, Livermore site, 1998 (concluded).

\begin{tabular}{|c|c|c|c|c|c|c|c|c|c|c|}
\hline \multirow{3}{*}{ Parameter } & \multirow{3}{*}{$\begin{array}{c}\text { Storm } \\
\text { date }\end{array}$} & \multicolumn{2}{|c|}{ Arroyo Seco } & \multicolumn{4}{|c|}{ Arroyo Las Positas } & \multicolumn{3}{|c|}{ Drainage Retention Basin } \\
\hline & & \multirow{2}{*}{$\begin{array}{c}\text { Influent } \\
\text { ASS2 } \\
\end{array}$} & \multirow{2}{*}{$\begin{array}{c}\text { Effluent } \\
\text { ASW }\end{array}$} & \multicolumn{3}{|c|}{ Influent } & \multirow{2}{*}{$\begin{array}{c}\text { Effluent } \\
\text { WPDC }\end{array}$} & \multicolumn{2}{|c|}{ Influent } & \multirow{2}{*}{\begin{tabular}{|c|} 
Effluen \\
CDBX \\
\end{tabular}} \\
\hline & & & & ALPE & ALPO & GRNE & & CDB & CDB2 & \\
\hline \multicolumn{11}{|l|}{$\begin{array}{l}\text { General Minerals (mg/L) } \\
\text { (continued) }\end{array}$} \\
\hline \multirow[t]{2}{*}{$\mathrm{pH}$} & $2 / 12$ & & & & & & & & & 5.57 \\
\hline & $3 / 31$ & & & & & & & & 8.57 & \\
\hline \multirow[t]{4}{*}{ Specific conductance $(\mu \mathrm{mho})$} & 2/12 & 795 & 735 & & 1830 & & & & & \\
\hline & $3 / 31$ & 930 & 855 & 2300 & 2230 & & & & 1940 & \\
\hline & $11 / 30$ & & & & 1520 & & & & & 765 \\
\hline & $11 / 30$ & & & 866 & 1530 & & & & & 761 \\
\hline \multirow[t]{2}{*}{ Sulfate } & $2 / 12$ & & & & 302 & & & & & \\
\hline & $3 / 31$ & & & 297 & 352 & & & & & \\
\hline \multirow[t]{3}{*}{ Total alkalinity $\left(\mathrm{as} \mathrm{CaCO}_{3}\right)$} & $2 / 12$ & & & & & & & 7.1 & & \\
\hline & $11 / 30$ & 15 & 19 & 20 & & & & & & \\
\hline & $11 / 30$ & 19 & 16 & & & & & & & \\
\hline \multirow[t]{4}{*}{ Total dissolved solids (TDS) } & $2 / 12$ & 508 & & & 1200 & & & & & \\
\hline & $3 / 31$ & 563 & 517 & 1450 & 1460 & & & & 1220 & \\
\hline & $11 / 30$ & & & & 890 & & & & & \\
\hline & $11 / 30$ & & & 517 & 937 & & & & & \\
\hline \multirow[t]{4}{*}{ Total phosphorus (as P) } & $2 / 12$ & 2.1 & 0.45 & 0.68 & 0.86 & 0.35 & 0.24 & 0.13 & 0.37 & 0.68 \\
\hline & $3 / 31$ & 0.15 & 0.13 & 0.49 & 0.21 & 0.13 & 0.2 & 0.15 & 0.27 & \\
\hline & $11 / 30$ & 0.26 & 0.29 & 0.44 & 0.16 & 0.26 & 0.24 & 0.12 & 0.26 & 0.23 \\
\hline & $11 / 30$ & 0.24 & 0.23 & 0.42 & 0.14 & 0.27 & 0.21 & 0.12 & 0.24 & 0.21 \\
\hline \multicolumn{11}{|l|}{ Miscellaneous organics (mg/L) } \\
\hline \multirow[t]{3}{*}{ Total organic carbon (TOC) } & $2 / 12$ & 9.5 & 12 & 14 & 14 & 6.1 & 3.4 & 2.9 & 9.6 & 12 \\
\hline & $3 / 31$ & 7.1 & 6.8 & 20 & 8.7 & 5.1 & 8.7 & 5.5 & 24 & \\
\hline & $11 / 30$ & 7.8 & 8 & 15 & 6.8 & 3.5 & 5.5 & 9 & 10 & 5.8 \\
\hline
\end{tabular}

In 13 effluent samples, the total metal concentrations for aluminum, iron, lead, manganese, and zinc were above both criteria and influent concentrations. There was only one case (for zinc) in which the dissolved metal concentration was above both criteria and influent concentrations. Other constituents, which were above criteria and also at higher concentrations at effluent than at influent locations, were total phosphorous (two samples), and total organic carbon (four samples). In addition, for one sample, total alkalinity was less than the AWQC minimum at effluent location ASW, and less than the corresponding influent location (ASS2). A number of other 


\section{Surface Water}

constituents in LLNL runoff were also above comparison criteria. In every case, however, when the concentration exceeded a criterion at an effluent point, there was a corresponding influent point with a higher concentration, indicating an off-site or possibly naturally occurring source.

LLNL has more than 10 years of storm water metals data. Recent data seem to indicate that concentrations of some metals are increasing in LLNL storm water effluent. However, this trend may have been influenced by changes in testing laboratories, or changes in analytical procedures used at the laboratories (specifically, a shift from procedures that recover dissolved metals to procedures that recover total metal concentrations). It was also not clear how much of the trend results from sediment loads, natural concentrations, LLNL discharges, or off-site contributions.

Beginning in the 1997/1998 wet season, source investigations were conducted to determine the relative quantities of metals being transported in solution and as suspended solids. The study also evaluated how much of the loading in each fraction (dissolved and suspended) originated off site, how much was contributed by on-site sources, and how concentrations of constituents in storm water related to concentrations of total suspended solids for a particular storm and location.

To accomplish these goals, samples for applicable constituents were collected in duplicate. One sample was analyzed for total concentration (i.e., dissolved and suspended) of the constituents of interest. The second sample was filtered in order to evaluate the dissolved component. LLNL's contracts with the analytical laboratories are designed around collections or "suites" of analyses. Metals are included in two suites identified by GENMIN (general minerals) and NPDESMETALS (metals required under NPDES). Because there is some overlap in the metals specified in these two suites, some metals were analyzed twice. In such cases, all analyses were utilized. Samples were also analyzed for concentration of total suspended solids (TSS). Metals detected above comparison criteria are presented in Table 7-3 (full results are in Table 7-4 of the Data Supplement).

In 1997, a review of metals data collected over the previous five years revealed that chromium, copper, iron, and zinc had been detected above comparison criteria in more than one year, and effluent values were higher than influent values more often in recent years. These metals were therefore selected for detailed analysis, and the results reported in the 1998 Livermore Site Annual Storm Water Monitoring Report for WDR 95-174 (Brandstetter 1998). The results of that analysis are summarized as follows:

- A clear relationship was found between TSS and total metals concentrations, although there was notable variability. This variability 


\section{Surface Water}

could be reduced by homogenizing a large storm water sample volume and then separating it into the bottles submitted for the various analyses. In 1999 samples will be collected in this manner.

- There was no relationship between dissolved concentrations and TSS. Only in the case of zinc was a relationship observed between dissolved concentrations and total concentrations.

- Where effluent metal concentrations were higher than influent concentrations, the data indicated that this was caused by higher TSS.

- The data indicated that the apparent trend in increasing metals concentrations was caused by a change from analyses that measure the dissolved portion (i.e., filtered), to analyses that measure total metals. This was compounded by the observed increase in total suspended solids in Arroyo Seco storm water, and the presence of metals that naturally occur in sediments.

Thus, while it is not completely clear how much of the historical record should be attributed to total metals analyses, it is clear that high metal concentrations are caused by the suspended solids transported in the storm water.

\section{Site 300}

LLNL procedures specify sampling of a minimum of two storms per rainy season from Site 300. Typically, a single storm will not produce runoff at all Site 300 locations because Site 300 receives relatively little rainfall and is largely undeveloped. Therefore, at many locations, a series of large storms is required to saturate the ground before runoff occurs. In 1998, samples were collected at locations with flow on January 12, February 2, May 5, and November 30. Results are presented in Tables 7-6 and 7-7 of the Data Supplement. There was no detectable tritium in Site 300 storm water during 1998. Maximum gross alpha and gross beta were 0.14 and $0.28 \mathrm{~Bq} / \mathrm{L}$, respectively, approximately $25 \%$ and $15 \%$ of their MCLs ( 0.56 and $1.85 \mathrm{~Bq} / \mathrm{L})$. Table 7-5 lists constituents found above comparison criteria in Site 300 storm water runoff. Total suspended solids were above the EPA benchmark (100 mg/L) (see Table 7-1 in the Data Supplement) five times at effluent locations, with a maximum of $6480 \mathrm{mg} / \mathrm{L}$. All other on-site TSS concentrations were less than $1,000 \mathrm{mg} / \mathrm{L}$. 


\section{Surface Water}

Table 7-5. Constituents above comparison criteria in storm water runoff, Site 300, 1998.

\begin{tabular}{|c|c|c|c|c|c|c|c|}
\hline \multirow{2}{*}{ Parameter } & \multirow{2}{*}{ Date } & \multirow{2}{*}{$\begin{array}{c}\text { Upstream } \\
\text { location } \\
\text { CARW }\end{array}$} & \multicolumn{4}{|c|}{ Effluent location } & \multirow{2}{*}{$\begin{array}{c}\text { Downstream } \\
\text { location } \\
\text { GEOCRK }\end{array}$} \\
\hline & & & N883 & NLIN & NPT6 & NPT7 & \\
\hline \multirow[t]{2}{*}{ Specific conductance $(\mu \mathrm{mho} / \mathrm{cm})$} & $2 / 2$ & & & & & & 1140 \\
\hline & $5 / 5$ & 1098 & & & & & 1120 \\
\hline \multirow[t]{3}{*}{ Total suspended solids (TSS) (mg/L) } & $1 / 12$ & & & & 6480 & 149 & \\
\hline & $2 / 2$ & 676 & & 940 & 485 & & \\
\hline & $5 / 5$ & 1760 & & & 586 & & 796 \\
\hline \multirow[t]{2}{*}{$\mathrm{pH}$ (pH units) } & $2 / 2$ & & 6.0 & & & & \\
\hline & $11 / 30$ & & & & & 9.4 & \\
\hline \multirow[t]{4}{*}{ Total organic carbon (TOC) (mg/L) } & $1 / 12$ & & 3.0 & & 4.1 & 2.1 & \\
\hline & $2 / 2$ & 7.8 & 6.3 & 5.5 & 3.3 & & 8.3 \\
\hline & $5 / 5$ & 6.1 & 16 & & 11 & 5.7 & 4.1 \\
\hline & $11 / 30$ & & 17 & & & 2.9 & \\
\hline
\end{tabular}

Historically, upstream total suspended solid levels are frequently above 1000 to $2000 \mathrm{mg} / \mathrm{L}$, indicating that most of these values are due to erosion typical of the region. Specific conductance was above the secondary MCL $(900 \mu \mathrm{mho} / \mathrm{cm})$ and agricultural criterion $(700 \mu \mathrm{mho} / \mathrm{cm})$ once at upstream location CARW $(1098 \mu \mathrm{mho} / \mathrm{cm})$ and twice at downstream location GEOCRK (1120 and $1140 \mu \mathrm{mho} / \mathrm{cm})$, but was never above criteria at effluent locations. At location N883 there was one sample with a $\mathrm{pH}$ of 5.98, below the secondary MCL minimum of 6.5, and at location NPT7, there was one sample with a $\mathrm{pH}$ of 9.38 , above the secondary MCL maximum of 8.5. All other parameters were below comparison criteria. Results of Pit 6 post-closure runoff monitoring are shown in Data Supplement Table 7-8.

\section{Rainfall}

\section{Introduction}

Rainfall is sampled for tritium according to written procedures described in Appendix A of the Environmental Monitoring Plan (Tate et al. 1995). Historically, the tritium activity measured in rainfall in the Livermore Valley has resulted primarily from atmospheric emissions of tritiated water vapor (HTO) from stacks at LLNL's Tritium Facility (Building 331), and Sandia National Laboratories/California's former Tritium Research 
Laboratory. The Building 343 rain sampling location is near the Tritium Facility (Building 331), where LLNL personnel have reduced operations in recent years and performed significant inventory reduction and cleanup activities. The total measured atmospheric emission of HTO from LLNL facilities in 1998 was $3.2 \mathrm{TBq}$ (85 Ci) (see Chapter 4, Air Effluent Monitoring). The rain sampling locations for the Livermore site and Livermore Valley are shown on Figure 7-9. The fixed sampling locations are positioned to record a wide spectrum of tritium activities in rainfall, from the maximum expected down to background levels.

\section{Results}

LLNL collected rainfall samples twice at the Livermore site and Livermore Valley in 1998. Complete data are shown in Table 7-9 of the Data Supplement. The Livermore site rainfall has exhibited elevated tritium activities in the past (Gallegos et al. 1994). During 1998, however, measurements of tritium activity in rainfall were all far below the $740 \mathrm{~Bq} / \mathrm{L}$ (20,000 pCi/L) MCL established by the EPA for drinking water. The highest overall activity was $169 \mathrm{~Bq} / \mathrm{L}$ (see Table 7-6) measured on December 1, 1998, near Building 343, just to the north of the Tritium Facility. This value is approximately $23 \%$ of the MCL for tritium. The highest off-site activity was $4.63 \mathrm{~Bq} / \mathrm{L}$, recorded in a sample collected from location ESAN on February 12, 1998.

Table 7-6. Tritium activities (in Bq/L) in rainfall for the LLNL Livermore site and the Livermore Valley.

\begin{tabular}{|l|c|c|}
\hline & Livermore site & Livermore Valley \\
\hline Median & 5.59 & 1.50 \\
Maximum & 169 & 4.63 \\
Minimum & 1.19 & 0.20 \\
Interquartile range & 9.03 & 1.66 \\
Number of samples & 14 & $15^{(a)}$ \\
\hline
\end{tabular}

a One sample from AQUE was not collected.

The median tritium activity measured in rainfall on site at LLNL has slightly increased from $3.85 \mathrm{~Bq} / \mathrm{L}$ (104 pCi/L) in 1997 to $5.59 \mathrm{~Bq} / \mathrm{L}$ (151 pCi/L) in 1998. However, median tritium activity measured in rainfall on site at LLNL has decreased more than tenfold since 1990, down from $65.9 \mathrm{~Bq} / \mathrm{L}(1780 \mathrm{pCi} / \mathrm{L})$ to $5.59 \mathrm{~Bq} / \mathrm{L}(151 \mathrm{pCi} / \mathrm{L})$ (see Figure 7-10). This decrease mirrors the downward trend in total HTO emissions from LLNL's Tritium Facility and the closure of Sandia/California's Tritium Research Laboratory. A more than tenfold decrease in total HTO emissions has occurred since 


\section{Surface Water}

1990, down from 34.9 TBq (943 Ci) to 3.2 TBq (85 Ci). Values for median tritium activity are derived from the six on-site rain sampling locations (Building 343, Building 291, CDB, SALV, VIS, and COW) that historically have given the highest activities. MET was not included because it is upwind of tritium sources.

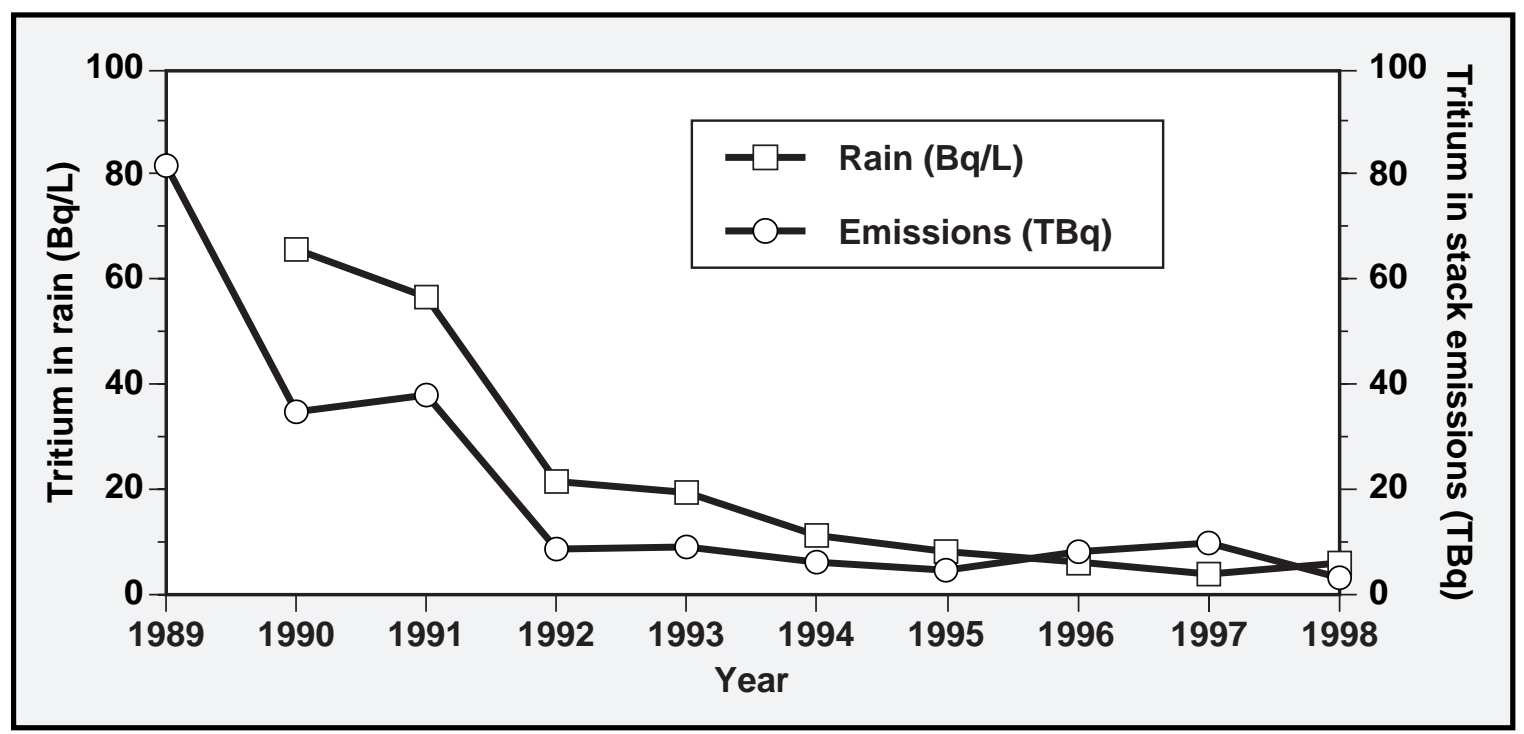

Figure 7-10. Trends of median tritium activity in rain and total stack emissions of HTO from the LLNL Livermore site and Sandia/California, 1990 to 1998.

Emissions from 1996-1998 are from LLNL only.

One central location is used to collect rainfall for tritium activity measurements at LLNL's Experimental Test Site, Site 300 (Figure 7-3). Rainfall samples are composited (added together) for each month and analyzed when there is sufficient volume. During 1998, rainfall samples were taken at Site 300 in February, March, April, May, November, and December. The measured activities were all either less than the minimum detectable activity or less than the $2 \sigma$ uncertainty. Over the past 26 years, 166 measurements of rainfall samples collected at Site 300 give a maximum tritium activity of only $9.1 \mathrm{~Bq} / \mathrm{L}$. The tritium activity measured in rainfall at Site 300 has been indistinguishable from atmospheric background levels over the past 26 years.

\section{Livermore Site Drainage Retention Basin Introduction}

The history of the construction and management of the Drainage Retention Basin (DRB) has been recounted in previous Environmental Annual Reports (see Harrach et al. 


\section{Surface Water}

1995-1997). In 1997, treated ground water began to be discharged routinely to the DRB. In 1998 discharges from Treatment Facility D, Treatment Facility E-East, and portable treatment units became a year round source of water entering the DRB. Wet weather flows into the DRB are still dominated by storm water runoff, but dry weather discharges from the treatment facilities now make up a substantial portion of the total water discharging into the DRB.

The San Francisco Bay RWQCB regulates discharges from the DRB according to the Livermore site CERCLA Record of Decision, as modified by the Explanation of Significant Differences for Metals Discharge Limits at the Lawrence Livermore National Laboratory Livermore Site (Berg 1997c). The Livermore site CERCLA Record of Decision establishes discharge limits for all remedial activities at the Livermore site to meet applicable, relevant, and appropriate requirements derived from the Federal Clean Water Act, the Federal and State Safe Drinking Water Acts, and the Porter-Cologne Water Quality Act.

Changes in the DRB sampling program that were agreed upon in 1997 (Galles 1997) and implemented in 1998 included modifying the parameters and constituents monitored, adding three-level chronic toxicity tests, and establishing a dry season sampling plan. The program consists of monitoring wet and dry weather releases for compliance with discharge limits, monitoring internal DRB water quality to support management actions, characterizing the quality of water before its release, and reporting.

LLNL samples discharges from the DRB (location CDBX) and the corresponding site storm water outfall (location WPDC) during the first release of the rainy season and from a minimum of one additional storm (chosen in conjunction with storm water runoff monitoring). During the dry season, samples are collected from each discrete discharge event. Discharge sampling locations CDBX and WPDC are shown in Figure 7-2. Samples are collected at CDBX to determine compliance with discharge limits. Sampling at WPDC is done to identify any change in water quality as DRB discharges travel through the LLNL storm water drainage system and leave the site. Sampling frequencies for CDBX and WPDC and effluent limits for discharges from the DRB, applied at CDBX, are found in Table 7-10 of the Data Supplement.

The routine management constituents, management action levels, and the monitoring frequency are identified in Data Supplement Table 7-11. Sampling to determine whether water quality management objectives are met is conducted at several points within the DRB. Dissolved oxygen (DO) content and temperature are measured at eight locations (Figure 7-11). Because of limited variability among sampling locations, all samples, other than those for dissolved oxygen and temperature, are routinely collected from sample location CDBE, located at the middle depth of the DRB. 


\section{Surface Water}

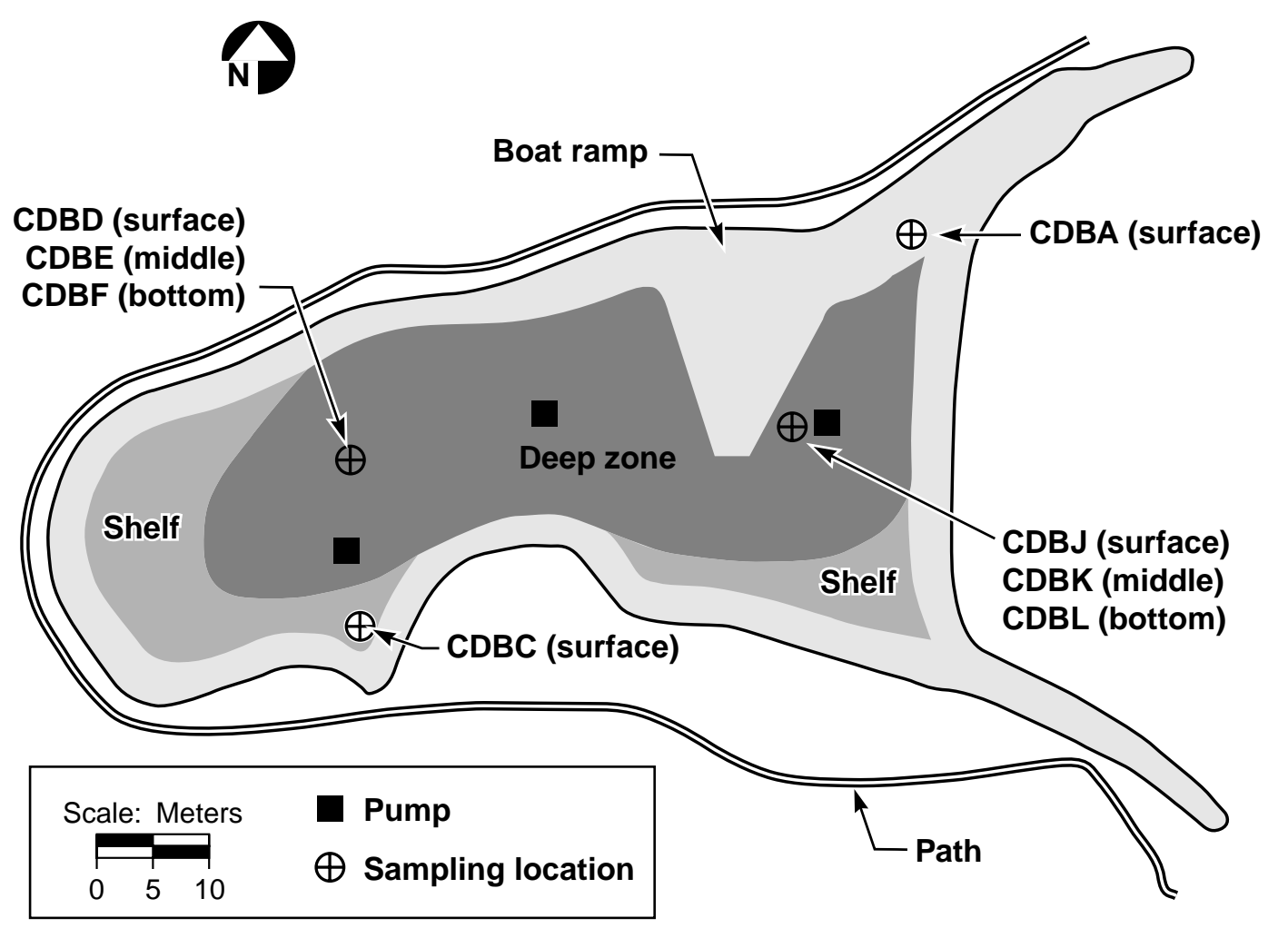

Figure 7-11. Sampling locations within the Drainage Retention Basin, 1998.

For purposes of determining discharge monitoring requirements and frequency, the wet season is defined as October 1 through May 31, the period when rain-related discharges usually occur (Galles 1997). Discharge limits are applied to the wet and dry seasons as defined in the Explanation of Significant Differences for Metals Discharge Limits at the Lawrence Livermore National Laboratory Livermore Site (Berg 1997) (wet season December 1 through March 31, dry season April 1 through November 30).

By agreement with the San Francisco Bay RWQCB, every quarter LLNL submits a report summarizing weekly, monthly, quarterly, semiannual, and annual monitoring of the basin as specified in the amended Drainage Retention Basin Management Plan (The Limnion Corporation 1991).The DRB Management Plan also identifies biological and microbiological surveys that are to be used as the primary means to assess the longrange environmental impact of the DRB. Probable impacts identified in the DRB Management Plan include increased riparian vegetation in Arroyo Las Positas and in the lower portions of the drainage channels tributary to the DRB, and the establishment of sensitive amphibian and bird species within the basin or in Arroyo Las Positas. 
LLNL monitors plant and animal species at the DRB, the drainage channels discharging into the DRB, and down stream portions of Arroyo Las Positas. These surveys are conducted semiannually to identify the presence or absence of species. Surveys include amphibians, birds, fishes, and mammals. Plant surveys are also done in the spring and the fall. Microbiological surveys include quarterly sampling for microbiological organisms (zooplankton, algae, and total bacteria counts, blue-green algae, and sulfate producing bacteria). Samples to characterize heterotrophic bacteria sulfate reducing bacteria, and blue green algae populations are collected at location CDBF. Zooplankton and phytoplankton (algae) samples are collected from a measured length of the DRB surface water.

\section{Methods}

Sample collection procedures are discussed in the Environmental Monitoring Plan (Tate et al. 1995) and detailed in procedure EMP-W-S. Discharges from the DRB are collected as grab samples from sample locations CDBX and WPDC. Samples collected within the DRB are also collected as grab samples. Field measurements for dissolved oxygen and temperature are made using a dissolved oxygen/temperature meter. Turbidity is measured using a Secchi disk. Samples collected for physical and chemical characterization at locations CDBE, CDBX, and WPDC are analyzed by certified laboratories.

Biological and microbiological methods are discussed in detail in the Environmental Monitoring Plan (Tate et al. 1995). Biological surveys are conducted by LLNL's biologist. Animal surveys follow standard survey protocols such as Raptor Management Techniques Manual (Pendleton 1987), Inventory and Monitoring of Wildlife Habitat (Cooperrider 1986), and Wildlife Management Techniques Manual (Schemnitz 1980). Vegetation surveys use protocols identified in the U.S. Army Corps of Engineers Wetlands Delineation Manual (Environmental Laboratory 1987).

Discrete at-depth grab samples are collected from sample location CDBF for microbiological measurements of heterotrophic bacteria, sulfate producing bacteria, and bluegreen algae. Zooplankton and phytoplankton populations are characterized from samples collected from the DRB surface water across a measured length and concentrated using a $20-\mu \mathrm{m}-\mathrm{mesh}$ plankton net. Zooplankton and phytoplankton are viewed, identified, and counted under a microscope in both fresh and preserved water samples. Total bacterial counts are made following Standard Methods for the Examination of Water and Wastewater (Greenberg et al. 1996) using an epifluorescent technique. Heterotrophic bacteria are enumerated using spread-plate methods. Sulfate-reducing bacteria and blue-green algae are characterized by using Hach Biological Activity Reaction Tests. 


\section{Surface Water}

\section{Results}

Samples collected during 1998 within the DRB at CDBE did not meet the management action levels for dissolved oxygen, temperature, turbidity, nitrate, ammonia, phosphorus, total dissolved solids, chemical oxygen demand, $\mathrm{pH}$, and fecal coliform (Table 7-7). No action was taken to adjust nutrient levels. Operating the pumps to increase the dissolved oxygen level resulted in increased turbidity. No action was taken in response to the temperature changes since the low temperatures were consistent with normal seasonal patterns. All release samples collected at CDBX were below discharge limits.

Table 7-7. Summary of Drainage Retention Basin monitoring at sampling location CDBE exceeding management action levels.

\begin{tabular}{|c|c|c|c|c|c|c|c|c|c|c|c|c|c|}
\hline Parameter & $\begin{array}{c}\text { Management } \\
\text { action } \\
\text { level }\end{array}$ & Jan & Feb & Mar & Apr & May & Jun & Jul & Aug & Sep & Oct & Nov & Dec \\
\hline $\begin{array}{c}\text { Dissolved oxygen, } \\
\text { monthly average } \\
(\%) \\
(\mathrm{mg} / \mathrm{L}),\end{array}$ & $\begin{array}{c}<80 \% \text { saturation } \\
>5 \mathrm{mg} / \mathrm{L}\end{array}$ & $\begin{array}{l}62 \\
-\end{array}$ & $\begin{array}{l}66 \\
-\end{array}$ & $\begin{array}{l}54 \\
-\end{array}$ & $\begin{array}{l}77 \\
-\end{array}$ & - & - & $\begin{array}{l}50 \\
4.2\end{array}$ & $\begin{array}{l}54 \\
4.5\end{array}$ & $\begin{array}{l}65 \\
-\end{array}$ & - & $\begin{array}{l}75 \\
-\end{array}$ & - \\
\hline $\begin{array}{l}\text { Temperature } \\
\left({ }^{\circ} \mathrm{C}\right) \text {, monthly } \\
\text { average }\end{array}$ & $\begin{array}{l}<15.6 \\
>26.7\end{array}$ & 10.4 & 10.4 & 13.0 & - & - & - & - & - & - & - & 13.9 & 9.2 \\
\hline $\begin{array}{l}\text { Turbidity (Secchi } \\
\text { disk) (m), monthly } \\
\text { average }\end{array}$ & $<0.91$ & 0.18 & 0.15 & 0.23 & 0.59 & 0.73 & 0.76 & 0.53 & 0.28 & 0.28 & 0.42 & 0.44 & 0.70 \\
\hline $\begin{array}{l}\text { Nitrate (as N) } \\
(\mathrm{mg} / \mathrm{L})\end{array}$ & $>0.2$ & 0.79 & 0.5 & 0.43 & - & 0.21 & - & - & 0.4 & $0.7^{(\mathrm{a})}$ & 1.1 & .82 & 1.9 \\
\hline $\begin{array}{l}\text { Ammonia } \\
\text { nitrogen (mg/L) }\end{array}$ & $>0.1$ & - & 0.12 & 0.16 & - & 0.15 & - & 0.26 & 0.2 & - & - & - & 0.19 \\
\hline $\begin{array}{l}\text { Phosphate (as P) } \\
(\mathrm{mg} / \mathrm{L})\end{array}$ & $>0.02$ & 0.28 & 0.67 & 1.3 & 0.85 & 0.34 & 0.25 & 0.37 & 0.38 & 0.35 & 0.33 & - & 0.21 \\
\hline $\begin{array}{l}\text { Total dissolved } \\
\text { solids (mg/L) }\end{array}$ & $>360$ & 366 & - & - & - & - & - & - & 394 & 402 & 440 & - & 440 \\
\hline $\begin{array}{l}\text { Chemical oxygen } \\
\text { demand }(\mathrm{mg} / \mathrm{L})\end{array}$ & $>20$ & 32 & - & - & 27 & - & - & - & 22 & - & 27 & - & - \\
\hline $\mathrm{pH}$ (pH units) & $<6.0$ and $>9.0$ & - & - & - & 9.01 & - & 9.35 & - & - & - & - & - & - \\
\hline $\begin{array}{l}\text { Fecal coliform } \\
\text { (MPN/100 mL) }\end{array}$ & $>400$ & $>1600$ & 900 & - & - & - & - & - & - & - & - & - & - \\
\hline
\end{tabular}

a Sample preserved so could only detect nitrate plus nitrite as $\mathrm{N}$. 


\section{Dissolved Oxygen}

Surface water dissolved oxygen concentration monthly averages were at or above the management action level of at least $80 \%$ saturation of oxygen all but three months. Middle and bottom depth samples monthly averages indicated that dissolved oxygen was below $80 \%$ saturation in most months. Dissolved oxygen at the bottom and middle levels dropped below the management action level of $5 \mathrm{mg} / \mathrm{L}$ during four months in 1998 (Figure 7-12).

Dissolved oxygen concentrations are controlled manually with aeration pumps, which are started whenever oxygen concentrations at any level of the DRB drop close to or below the critical management action level of $5 \mathrm{mg} / \mathrm{L}$. In 1998, two of these pumps were operated continuously from June through December. During the colder winter months the dissolved oxygen levels were consistently above $5 \mathrm{mg} / \mathrm{L}$ and, therefore, the pumps were not operated. Adequate dissolved oxygen concentrations prevent decaying organic matter in bottom sediments from releasing nutrients into the DRB water column.

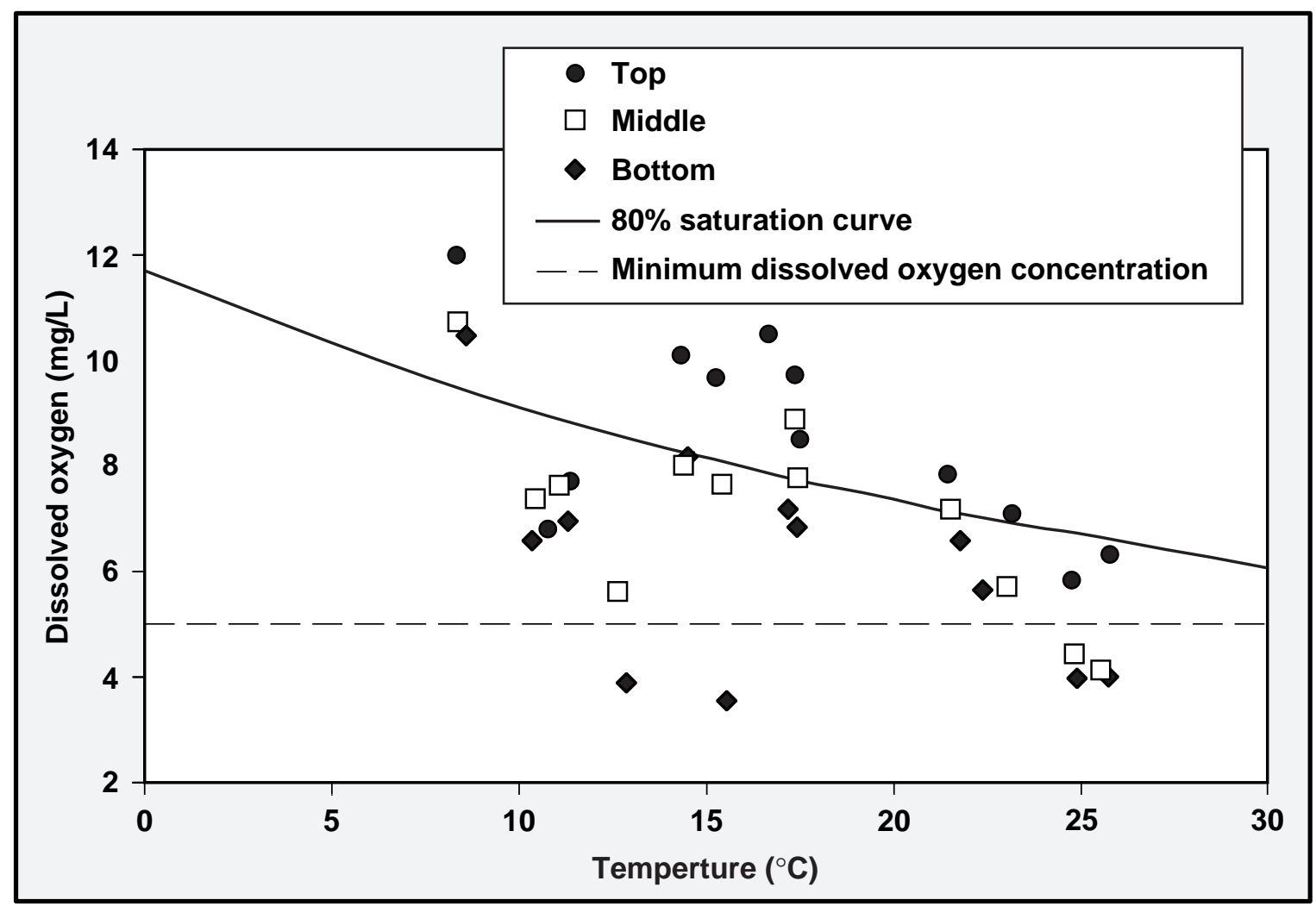

Figure 7-12. Monthly average dissolved oxygen vs. temperature at each depth location in the Drainage Retention Basin from January through December 1998. 


\section{Surface Water}

Operation of the aeration pumps was probably responsible for the relatively uniform distribution of dissolved oxygen at the surface, middle, and bottom elevations seen throughout the first five years of DRB operation. Halfway through 1997, dissolved oxygen concentrations at the surface, middle, and bottom elevations began uncoupling, indicating for the first time since start-up, that DRB oxygen levels vary from the surface to the bottom. The aerator pumps were no longer able to provide uniform mixing of oxygen at all elevations in the DRB (Figure 7-13). The cause of this uncoupling is unknown but may be related to an increase in biomass deposition that increased oxygendemand. Chemical oxygen demand was above management action levels for all four quarters of 1998. Chlorophyll-a was also higher than the historic levels in May, June, July, and December. However, the highest value $(40.3 \mu \mathrm{g} / \mathrm{L})$ was still well below the management action level of $10 \mathrm{mg} / \mathrm{L}$. Dissolved oxygen at the surface level was higher during 1998 then in any previous year. This is mostly a result of photosynthesis occurring during daylight hours while algae populations are high. The high oxygen levels correspond to the elevated chlorophyll-a levels.

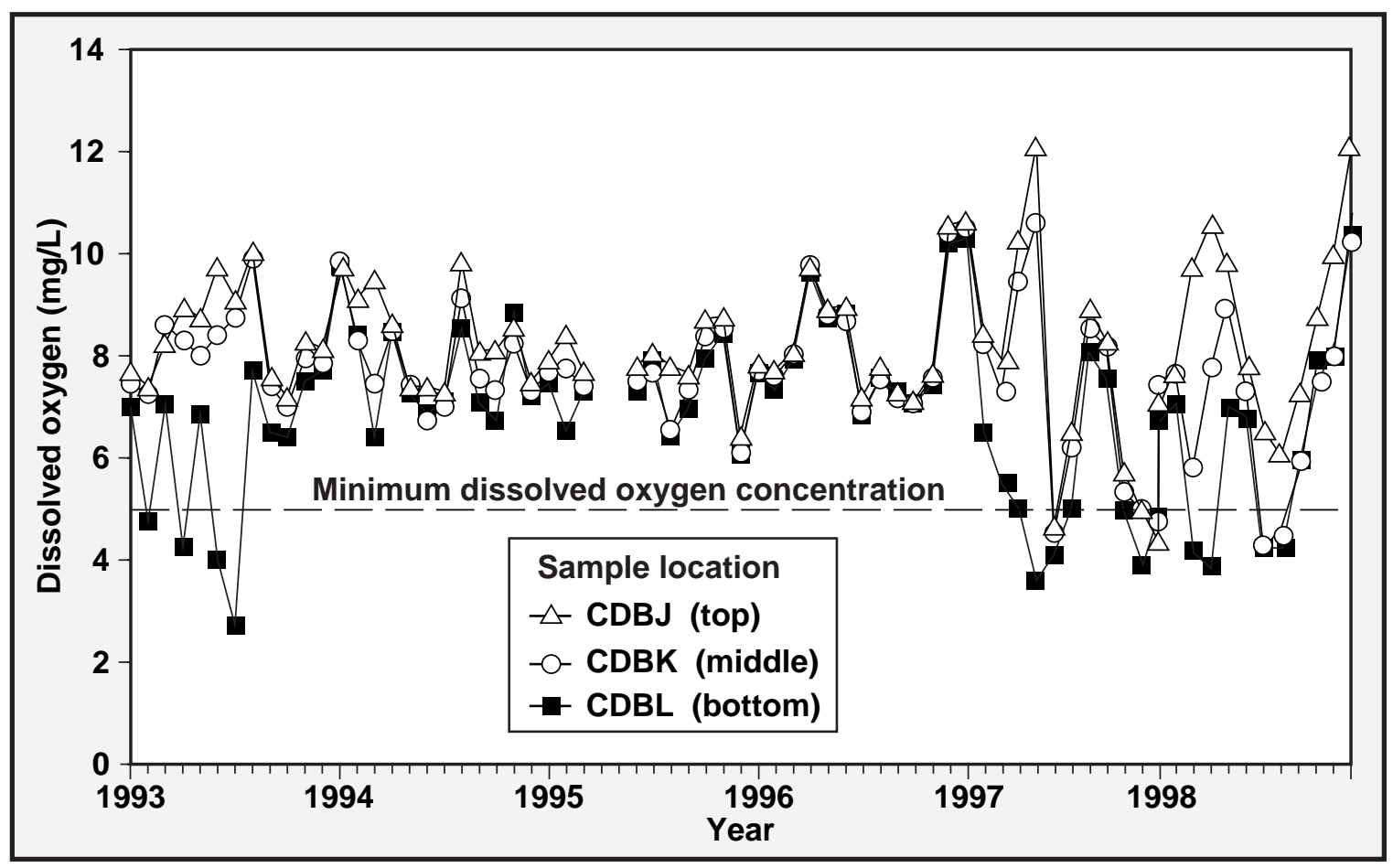

Figure 7-13. Dissolved oxygen concentration variations from the beginning of Drainage Retention Basin operations.

Temperature, the other important parameter in determining how much oxygen is dissolved in water, showed characteristic seasonal trends (Figure 7-14). The uniform 
distribution of temperature in the top, middle, and bottom elevations reflects that the aerators were providing uniform physical mixing of the water.

\section{Turbidity}

Turbidity rose above acceptable management levels during the 1993/1994 wet season and, through 1998, remained mostly above the turbidity management action levels. Wet season turbidity probably results from sediments that pass through the sediment traps discharging into the DRB. Turbidity seen during the warmer summer months is most likely the result of algae growth (Harrach et al. 1996). Turbidity is also caused by the operation of the aerators resuspending sediments and preventing smaller particulates from settling.

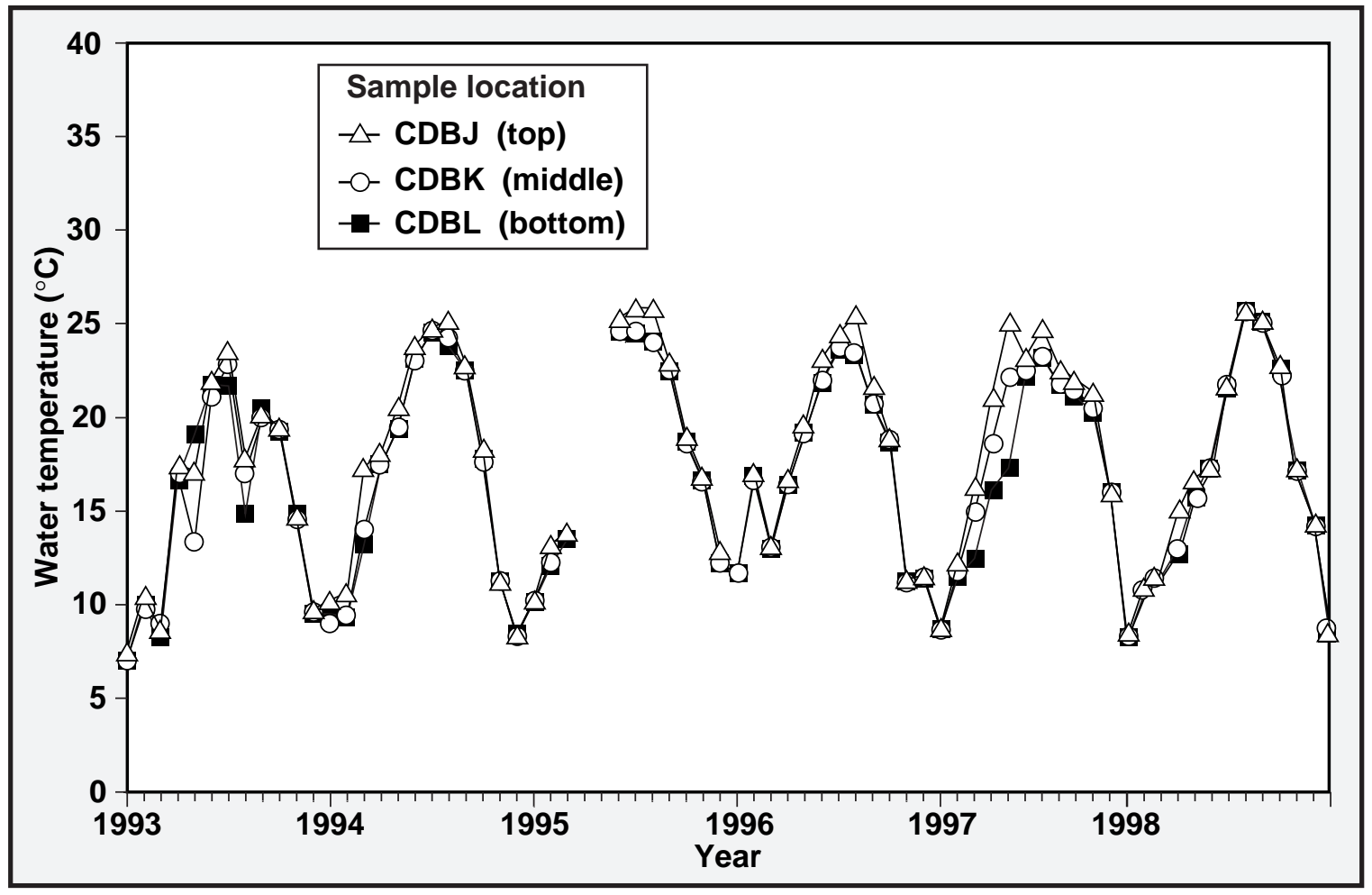

Figure 7-14. Seasonal temperature variation measured at sample top, middle, and bottom levels from the start of operation in 1993. No measurements were made in April and May 1995 because of equipment failure. The high January 1996 value, which was reported in the Environmental Report 1997 (Harrach et al. 1998) is almost certainly incorrect and is not in this year's plot. 


\section{Surface Water}

\section{Nutrients}

Nutrient levels continued to be high during 1998. Nitrate and total phosphorous concentrations were well above management action levels throughout the year. Nitrate exceeded management action levels for 9 months of the year while phosphorous exceeded management action levels every month. Sources of nitrate and phosphorous include storm water runoff and treated ground water discharges. In addition, ammonia exceeded the management action level during 6 months of the year. Elevated ammonia concentration indicates anaerobic activity. Total dissolved solids began exceeding management action levels for the first time from September 1997 through December 1997. In 1998, total dissolved solids exceeded the management action levels in 5 months. The increased dissolved solids levels correspond to the start of routine treated ground water discharges, which typically have high total dissolved solids. Increasing total dissolved solids often indicates decreasing water quality.

In October 1998, the DRB experienced a mild algae bloom (chlorophyll a levels up to $6 \mu \mathrm{g} / \mathrm{L}$ and the microbiological population dominated by single-cell algae (Aphanizomenon sp. and Peiastrum sp.). Mats of algae growth were visible on the water surface. The algae bloom, high nutrient levels, low oxygen saturation, high temperature, and elevated oxygen demand are believed to have contributed to a bacteria related catfish kill. Approximately 70 dead juvenile catfish were observed between October 14 and October 16. The Department of Fish and Game identified the probable cause of death to be an opportunistic bacteria, Flexibacter columnaris. Annual toxicity tests conducted in October showed no chronic or acute toxicity for fathead minnow and only mild toxicity for the water flea Ceriodaphnia dubia and the algae Selanastrum caprcornutum (two toxicity units each).

\section{Biological Monitoring}

Biological monitoring has not been conducted long enough to identify any trends as a result of the operation of the DRB. However, biological monitoring has shown an expansion in the wetland areas in Arroyo Las Positas as a result of the continuous discharges of water from the DRB and other sources of treated ground water throughout the dry season. The red-legged frog (Rana aurora draytonii), a federally listed threatened species has been identified as present in Arroyo Las Positas, the DRB, and in the southwestern DRB tributary (upstream from sample location CDB). 


\section{Releases}

LLNL began measuring the flow rate discharging from the DRB in 1996 (for 1998 flow, see Figure 7-15). Storm water runoff accounts for the majority of the water entering the DRB in the months from November through April. In May 1998, there was a late storm, which is shown in the peak flow at the end of May. The elevated discharge in late October was the result of a manual release to lower the water level in the DRB to allow adequate capacity for winter storms. 1998 was the first year the DRB received dry season flows from ground water treatment facility discharges in excess of evaporation rates, resulting in continuous discharges from March through early November. A total of 306-ML (81 million gal) of water was discharged from the DRB in 1998. This was approximately twice as much water as was discharged in 1997 and four times as much water as discharged in 1996. The largest discharge occurred on December 17, 1998, when $12 \mathrm{ML}$ of water was released. The majority of the water released from the DRB occurred during the months of January and December.

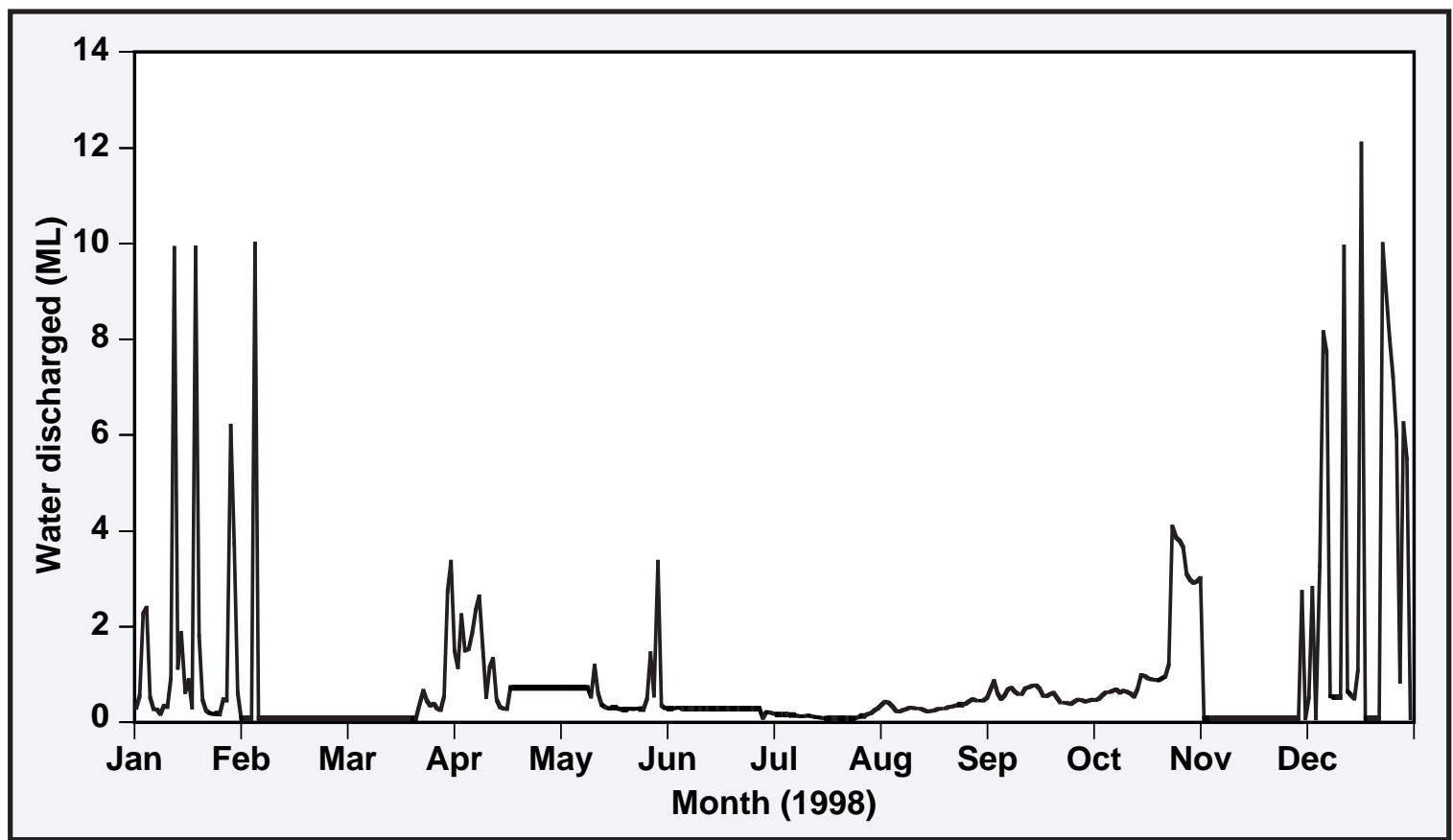

Figure 7-15. Water discharged from the Drainage Retention Basin in 1998.

Mass loading for discharges from the DRB, determined from flow and analytical data, is shown in Table 7-8. 


\section{Surface Water}

Table 7-8. Annual mass loading for detected metals and organic compounds in samples collected from Drainage Retention Basin sampling location CDBX.

\begin{tabular}{|l|r|r|}
\hline \multirow{2}{*}{ Parameter } & \multicolumn{2}{|c|}{ Loading (kg) } \\
\cline { 2 - 3 } Metals & Dissolved & Total \\
Aluminum & $n d^{(a)}$ & 339 \\
Arsenic & 1 & 1 \\
Barium & 38 & 41 \\
Boron & 319 & 303 \\
Cadmium & nd & 3 \\
Chromium & 1 & 3 \\
Copper & 1 & 2 \\
Iron & 19 & 352 \\
Manganese & nd & 13 \\
Nickel & 1 & 4 \\
Vanadium & nd & 3 \\
Zinc & 7 & 8 \\
Herbicides & & \\
Bromacil & na & 504 \\
\hline
\end{tabular}

a $\mathrm{nd}=$ Not detected above reporting levels.

b $n a=$ Not analyzed.

Data for maintenance and release monitoring at sampling locations CDBX, WPDC, CDBA, CDBC, CDBD, CDBE, CDBF, CDBJ, CDBK, and CDBL and from the biological and microbiological surveys are presented in Tables 7-12 to 7-18 in the Data Supplement.

\section{Site 300 Cooling Towers}

\section{Introduction}

LLNL samples cooling-tower wastewater discharges as required by the Self-Monitoring Program of WDR 94-131, NPDES Permit No. CA0081396, and reports the results of the compliance sampling to the Central Valley RWQCB quarterly.

Two primary cooling towers, located at Buildings 801 and 836A, regularly discharge to surface water drainage courses. Fourteen secondary cooling towers routinely discharge to percolation pits under a waiver of waste discharge requirements from the Central 
Valley RWQCB. The permit establishes separate effluent limits (dissolved solids must not exceed a monthly average of $2000 \mathrm{mg} / \mathrm{L}$ or $5000 \mathrm{mg} / \mathrm{L}$ daily; $\mathrm{pH}$ must not exceed 10) for these 14 towers in the event that discharge to surface water drainage courses is necessary. Two such discharges occurred in 1998 and are discussed later.

As required in the permit, blowdown flow is monitored biweekly from the cooling towers located at Buildings 801 and 836A. TDS and $\mathrm{pH}$ are monitored quarterly at both locations. In January 1998, LLNL discovered that the blowdown flow readings for the cooling tower at Building 836A had previously been incorrectly taken from the influent flow meter, which includes make-up water as well as blowdown, rather than from the discharge flow meter. Consequently, LLNL over-reported blowdown flow from the Building 836 cooling tower. All data for 1998 was taken from the correct (discharge) flow meter.

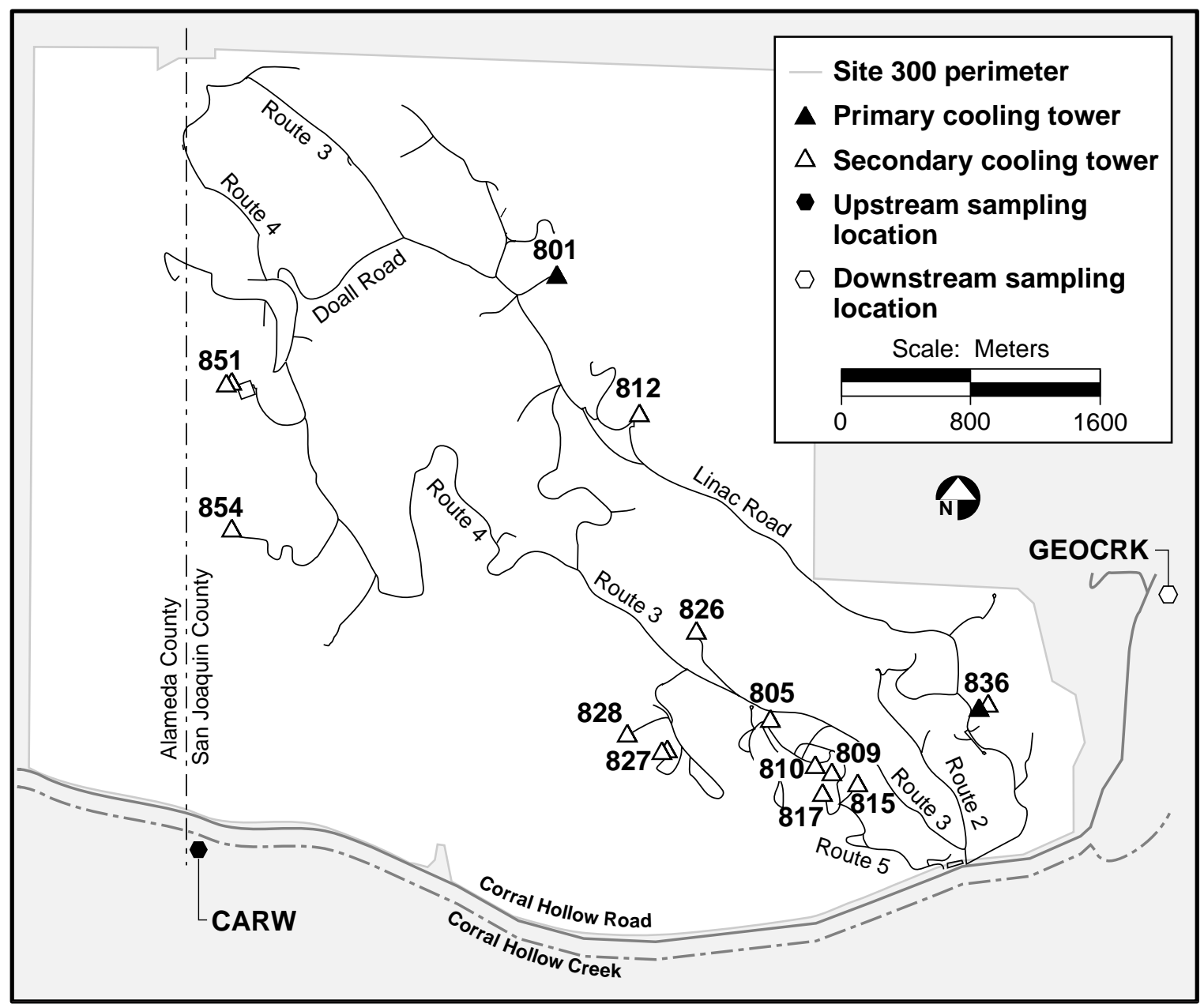

Figure 7-16. Site 300 cooling tower locations and receiving water monitoring locations, 1998. 


\section{Surface Water}

Methods

To determine the effects of the cooling tower blowdown on Corral Hollow Creek, the permit requires quarterly $\mathrm{pH}$ monitoring of the creek, both upstream (background) and downstream of the cooling tower discharges. CARW is the upstream sampling location, and GEOCRK is the downstream sampling location. Field $\mathrm{pH}$ measurements, taken by LLNL technicians using calibrated meters, are used to monitor Corral Hollow Creek. These technicians also perform the required visual observations, which are recorded on the field tracking forms (FTF) along with the field $\mathrm{pH}$ measurements.

Blowdown flow is determined once every two weeks by taking flow meter readings over a time period covering approximately 24 hours. Standard EPA methods are used for sample analysis; method E150.1 for $\mathrm{pH}$, and method E160.1 for TDS.

LLNL maintenance staff take operational TDS and $\mathrm{pH}$ measurements biweekly, using calibrated meters. LLNL reports these operational values at the request of the Central Valley RWQCB, but they are not used to determine compliance.

As previously stated, if the blowdown flow from one of the 14 secondary cooling towers is diverted from a percolation pit to a surface water drainage course, the discharge is sampled for $\mathrm{pH}$ and TDS. If the discharge continues, that location is monitored in the same manner as the primary cooling towers, i.e. biweekly flow measurements and quarterly $\mathrm{pH}$ and TDS monitoring.

\section{Results}

Biweekly and quarterly monitoring results are detailed in the quarterly self monitoring report to the Central Valley RWQCB. Summary data from primary cooling tower compliance monitoring and operational monitoring are found in Tables 7-9 and 7-10, respectively.

All $\mathrm{pH}$ samples collected from the cooling tower discharges were below the permitted maximum of 10. All TDS concentrations were below both the daily maximum $(2400 \mathrm{mg} / \mathrm{L})$ and monthly average $(2000 \mathrm{mg} / \mathrm{L})$ limits. These monitoring results demonstrate that cooling tower discharges were consistently in compliance with permitted limits (see Tables 7-9 and 7-10). As mentioned earlier, operational values are reported at the request of the Central Valley RWQCB, but they are not used to determine compliance. 
Table 7-9. Summary data from compliance monitoring of Site 300 primary cooling towers, 1998.

\begin{tabular}{|l|c|c|c|c|c|c|c|}
\hline \multicolumn{1}{|c|}{ Test } & $\begin{array}{c}\text { Tower } \\
\text { no. }\end{array}$ & $\begin{array}{c}\text { Permitted } \\
\text { maximum }\end{array}$ & Minimum & Maximum & Median & $\begin{array}{c}\text { Interquartile } \\
\text { range }\end{array}$ & $\begin{array}{c}\text { Number of } \\
\text { samples }\end{array}$ \\
\hline Total dissolved solids & 801 & 2,400 & 970 & 1,500 & 1,250 & -(a) $^{\text {(a) }}$ & 4 \\
(TDS) (mg/L) & & & & & & & \\
& $836 \mathrm{~A}$ & 2,400 & 1,100 & 1,400 & 1,250 & - (a) & 4 \\
Flow (L/day) & 801 & 16,276 & 0 & 14,211 & 3,923 & 5,713 & 26 \\
& $836 \mathrm{~A}$ & 8,138 & 0 & 5,495 & 1,438 & 1,735 & 26 \\
pH (pH units) & 801 & 10 & 8.8 & 9.1 & 9 & - (a) & 4 \\
& $836 \mathrm{~A}$ & 10 & 8.8 & 9.1 & 8.9 & -(a) $^{\text {(a) }}$ & 4 \\
\hline
\end{tabular}

a Not enough data points to determine.

Table 7-10. Summary data from operational monitoring of Site 300 primary cooling towers, 1998.

\begin{tabular}{|l|c|c|c|c|c|c|c|}
\hline \multicolumn{1}{|c|}{ Test } & $\begin{array}{c}\text { Tower } \\
\text { no. }\end{array}$ & $\begin{array}{c}\text { Permitted } \\
\text { maximum }\end{array}$ & Minimum & Maximum & Median & $\begin{array}{c}\text { Interquartile } \\
\text { range }\end{array}$ & $\begin{array}{c}\text { Number of } \\
\text { samples }\end{array}$ \\
\hline $\begin{array}{l}\text { Total dissolved solids } \\
\text { (TDS) (mg/L) }\end{array}$ & 801 & 2,400 & 1,100 & 1,500 & 1,400 & 150 & 26 \\
& $836 \mathrm{~A}$ & 2,400 & 1,000 & 1,400 & 1,200 & 150 & 26 \\
$\mathrm{pH}$ (pH units) & 801 & 10 & 8.7 & 9.1 & 9.0 & 0.1 & 26 \\
& $836 \mathrm{~A}$ & 10 & 8.8 & 9.1 & 9.10 & 0.1 & 26 \\
\hline
\end{tabular}

During 1998, flow occurred in Corral Hollow Creek during the first and second quarters, and at the downstream location only during the fourth quarter. There was no flow in Corral Hollow Creek during the third quarter.

Inadvertently, no Corral Hollow Creek samples were collected for the cooling tower monitoring program during the first quarter. However, data were obtained from storm water monitoring samples collected during this monitoring period from the same upstream (CARW) and downstream (GEOCRK) locations. Storm water sampling was at $\mathrm{pH} 8.3$ at both sampling locations, verifying that the $\mathrm{pH}$ did not exceed the 8.5 permit limit, and that the ambient $\mathrm{pH}$ had not changed by more than 0.5 unit.

For the second quarter, $\mathrm{pH}$ monitoring was done on two separate dates. The May 13, 1998 , results were $8.5 \mathrm{pH}$ units at both the upstream and downstream locations. On June 24,1998 , the upstream $\mathrm{pH}$ was 8.29 , and the downstream $\mathrm{pH}$ was 8.04 units. Both results are within the permitted range of 6.5 to 8.5 and indicate that cooling tower discharge did not alter the ambient $\mathrm{pH}$ by more than $0.5 \mathrm{pH}$ units. 


\section{Surface Water}

During the fourth quarter, flow was observed in Corral Hollow Creek at the downstream location only. The quarterly $\mathrm{pH}$ sample collected on November 10, 1998, resulted in a $\mathrm{pH}$ of 8.52 . Though this is above the 8.5 permit limit, biweekly flow monitoring data show that neither cooling tower discharged that day. Therefore, the cooling towers were not the cause of the slightly elevated $\mathrm{pH}$.

Visual observations of Corral Hollow Creek were performed each quarter as required in the permit. No visible oil, grease, scum, foam, or floating suspended material was noted in the creek during 1998.

Two discharges occurred from secondary cooling towers in 1998; one from the Building 812 cooling tower percolation pit, and one from the Building 827 cooling tower percolation pit. On July 21, 1998, the Building 812 cooling tower float valve stuck in the open position, with the result that the capacity of the percolation pit was exceeded and the pit overflowed to ground. LLNL maintenance staff diverted the flow from the pit to the ground until the pit was drained. The valve was repaired the same day, and flow returned to the percolation pit on July 23, 1998. As required by the permit, monitoring samples were collected on July 21, 1998. Analytical results $(990 \mathrm{mg} / \mathrm{L}$ TDS; $8.88 \mathrm{pH}$ units) were below the permit limits.

The Building 827 percolation pit overflowed on August 4, 1998, when water discharged during cooling tower maintenance exceeded the capacity of the pit. Approximately 75 to 100 gallons were discharged to the ground. No samples were taken because the discharge was small and had ended before a sampling team could be deployed.

\section{Other Waters}

\section{Introduction}

Additional surface water monitoring is driven by DOE Order 5400.1, General Environmental Protection Program, and DOE Order 5400.5, Radiation Protection of the Public and the Environment. Surface and drinking water near the LLNL Livermore site and in the Livermore Valley are sampled at locations shown in Figure 7-17. Sampling locations DEL, ZON7, DUCK, ALAG, SHAD, and CAL are surface water bodies; of these DEL, ZON7, and CAL are drinking water sources. BELL, GAS, PALM, ORCH, and TAP are drinking water outlets. Location POOL is the on-site swimming pool. Data from drinking water sources and drinking water outlets are used to calculate drinking water statistics (see Table 7-11) and doses. 


\section{Methods}

Samples are analyzed for gross alpha, gross beta, and tritium, according to procedures set out in Appendix A of the Environmental Monitoring Plan (Tate et al. 1995). LLNL sampled these locations semiannually for gross alpha, gross beta, and tritium. The on-site swimming pool (POOL) was sampled semiannually for gross alpha and gross beta, and quarterly for tritium.

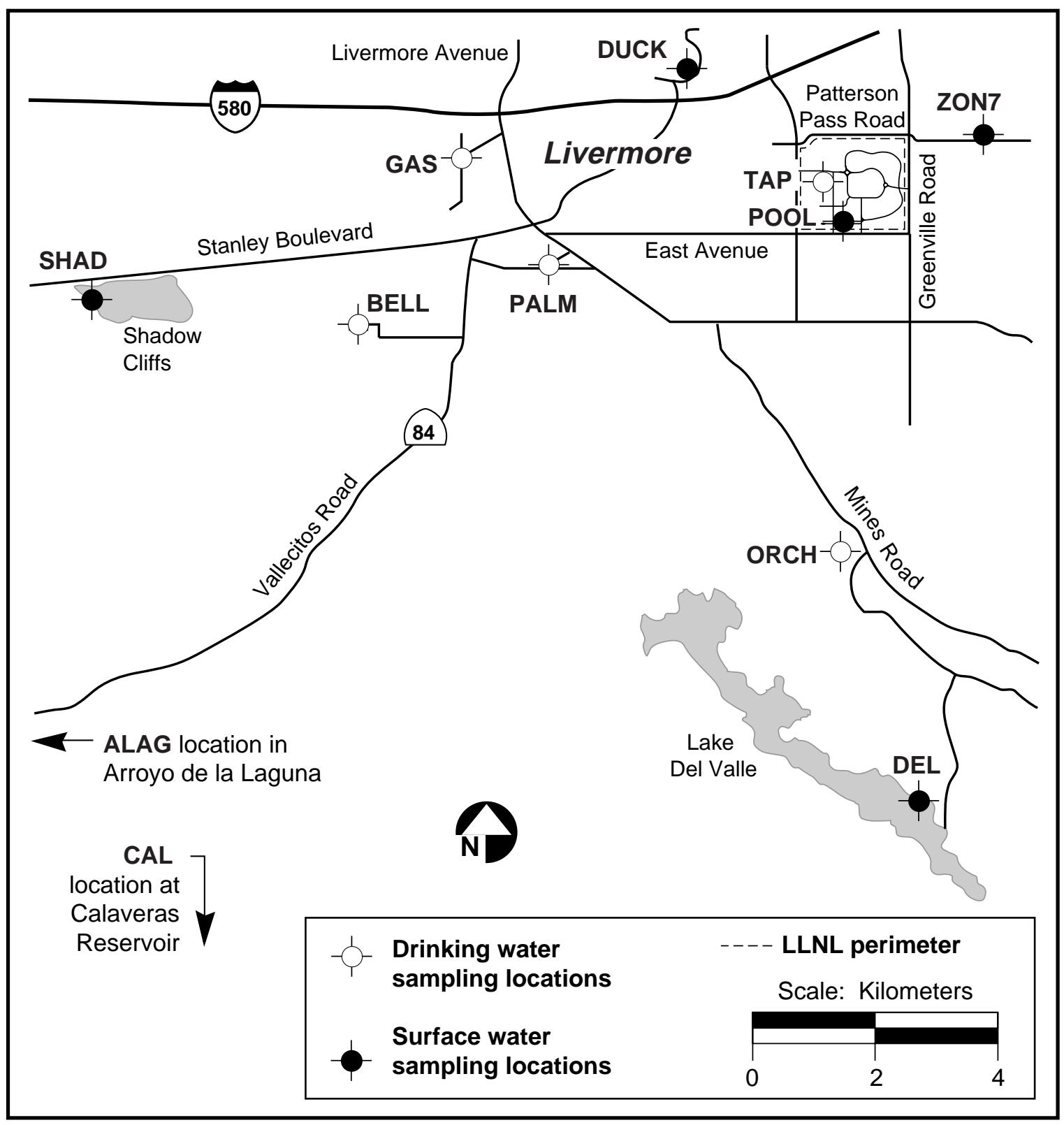

Figure 7-17. Surface and drinking water sampling locations, Livermore Valley, 1998. 


\section{Surface Water}

Results

Median activity for tritium was less than $0.2 \%$ of the drinking water Maximum Contaminant Level (MCL); the maximum tritium activity was $1 \%$ of the MCL. Median activities for gross alpha and gross beta radiation in surface water samples were approximately $5 \%$ of the MCL. However, maximum activities detected for gross alpha and gross beta, respectively, were $0.19 \mathrm{~Bq} / \mathrm{L}(5.1 \mathrm{pCi} / \mathrm{L})$ and $0.31 \mathrm{~Bq} / \mathrm{L}(8.3 \mathrm{pCi} / \mathrm{L})$ or $34 \%$ and $17 \%$ of their respective MCLs (see Table 7-11). Detailed data are in Table 7-19 of the Data Supplement. Historically, gross alpha and gross beta radiation have fluctuated about the laboratory reporting limits. At these very low levels, the error measurements are nearly equal to the measured values so that no trends are apparent in the data.

Table 7-11. Radioactivity (in Bq/L) in surface and drinking water in the Livermore Valley, 1998.

\begin{tabular}{|l|c|c|c|}
\hline & Tritium & Gross alpha & Gross beta \\
\hline All locations & & & \\
Median & $<1.22$ & 0.02 & 0.10 \\
Minimum & $<0.91$ & -0.01 & -0.05 \\
Maximum & 7.81 & 0.19 & 0.31 \\
Interquartile range & 0.33 & 0.05 & 0.11 \\
Drinking water locations & & & \\
Median & $<1.20$ & 0.02 & 0.08 \\
Minimum & $<0.91$ & -0.01 & -0.05 \\
Maximum & 2.07 & 0.12 & 0.27 \\
Interquartile range & 0.12 & 0.04 & 0.11 \\
\hline
\end{tabular}

\section{Environmental Impacts}

\section{Storm Water}

The potential off-site impact of tritium was estimated by determining the effective dose equivalent (EDE). Appendix A presents the method to calculate dose. Maximum tritium activity in storm water (runoff) was $31.4 \mathrm{~Bq} / \mathrm{L}$, about $4 \%$ of the MCL (see Table 7-2). The EDE to an adult who ingested two liters of water per day at the maximum storm water tritium concentration for one year would be less than $0.0004 \mathrm{mSv}(0.04 \mathrm{mrem})$, or $0.04 \%$ of the $1 \mathrm{mSv}$ DOE standard allowable dose for ingestion. Maximum gross alpha and gross beta activities in storm water were 0.38 and $0.32 \mathrm{~Bq} / \mathrm{L}$, or $68 \%$ and $17 \%$ of their respective MCLs (see Table 7-2). Past studies, however, have indicated that the majority of the gross alpha and beta activities observed in runoff are due to naturally occurring radioisotopes carried by sediments in the runoff. 


\section{Surface Water}

Concentrations of some metals in storm water seem to be increasing. Preliminary results indicate that these levels are related to suspended solids in the storm water. Further investigation into the source of these metals is planned. Samples collected during the $1998 / 1999$ wet season for both dissolved and total metals will be evaluated to determine how much of the increase can be attributed to LLNL activities, to off-site sources, and to naturally occurring sediments. Although some 1997 storm water results were above criteria, there is no evidence that indicates any impact to off-site biota. The acute and chronic fish toxicity tests conducted during 1997 for the 1997/1998 wet season further support the conclusion that LLNL storm water has no adverse effect on off-site biota.

\section{Rainfall}

The environmental impact of tritium measured in rainfall samples from the Livermore site was negligible. The median tritium activity measured in rainfall at the Livermore site has slightly increased from $3.85 \mathrm{~Bq} / \mathrm{L}(104 \mathrm{pCi} / \mathrm{L})$ in 1997 to $5.59 \mathrm{~Bq} / \mathrm{L}(151 \mathrm{pCi} / \mathrm{L})$ in 1998. However, median tritium activity measured in rainfall on site at LLNL has decreased more than tenfold since 1990: down from $65.9 \mathrm{~Bq} / \mathrm{L}(1780 \mathrm{pCi} / \mathrm{L})$ to $5.59 \mathrm{~Bq} / \mathrm{L}$ (151 pCi/L).

The measured tritium activities of rainfall samples taken at Site 300 were all either less than the minimum detectable activity or less than the $2 \sigma$ uncertainty. Over the past 26 years, 166 measurements of rainfall samples collected at Site 300 give a maximum tritium activity of only $9.1 \mathrm{~Bq} / \mathrm{L}$. The tritium activity measured in rainfall at Site 300 has been indistinguishable from atmospheric background levels over the past 26 years.

\section{Drainage Retention Basin}

There is no evidence of adverse environmental impact resulting from releases from the Drainage Retention Basin. Although internal measurements indicated that concentrations were above the management action levels for several constituents, no water was discharged with constituents above allowed limits. Though mild toxicity was observed in the DRB and in water discharged from the DRB, there is no evidence that the discharge had an effect on downstream receiving water. Because of the continuous discharge that occurred last year from the DRB and ground water treatment facilities and the wetter than normal rainfall years that occurred during 1997 and 1998, there has been an increase in wetland areas on site both up and down stream of the DRB. The 


\section{Surface Water}

federally listed threatened red-legged frog has colonized these wetland areas. The operation of the DRB has contributed to this habitat formation.

\section{Cooling Towers}

Both primary cooling towers that discharge to surface were within their permitted limits for flow, $\mathrm{pH}$, and TDS. Thus, data indicate no negative impact to surface waters from these cooling towers. The secondary cooling tower percolation pit overflow at Building 812 was also within permitted limits, which indicates no negative impact to surface waters from this one-time event.

The discharge from the 827 cooling tower percolation pit overflow did not reach the receiving water; due to its small size it immediately percolated to ground. Therefore, though confirmation data are not available, there was no negative impact to surface water from this one-time event.

Since blowdown flow from the cooling towers does not reach Corral Hollow Creek, it is unlikely to have a negative impact to the receiving water. Run-off from livestock areas, or natural $\mathrm{pH}$ variations may have a more significant impact than cooling tower blowdown.

\section{Other Waters}

The potential impact of tritium on drinking water supplies was estimated by determining the effective dose equivalent (EDE). Appendix A presents the method to calculate dose. Maximum tritium activity in drinking waters (see Table 7-11) was $2.07 \mathrm{~Bq} / \mathrm{L}$ (55.9 pCi/L). The EDE to an adult who ingested two liters of water per day at this maximum concentration for one year would be $0.00003 \mathrm{mSv}(0.003 \mathrm{mrem})$, or $0.06 \%$ of the DOE standard allowable dose of $0.04 \mathrm{mSv}$ for drinking water systems. Gross alpha and gross beta activities were well below their MCLs. The sample data indicate that the impact of LLNL Livermore site operations on surface and drinking waters is negligible. 


\section{Ground Water Investigation and Remediation}

Richard Blake

Michael Taffet

\section{Introduction}

During 1998, ground water investigations and remediations under the Comprehensive Environmental Response, Compensation and Liability Act (CERCLA) continued at both the Livermore site and Site 300. LLNL regularly samples and analyzes ground water from areas of known or suspected contamination. Portions of the two sites that contain ground water with concentrations of chemicals of concern are actively investigated to determine the magnitude of the contamination and its source. Remediation strategies are developed and evaluated in preparation for a CERCLA removal action or through the feasibility study process. An approved remedy for each study area is developed in consultation with the regulatory agencies and the community. This chapter reviews the distribution of contaminants in ground water, and the progress LLNL has made in removing contaminants from ground water and from the unsaturated zones (soil vapor) at the Livermore site and Site 300.

\section{Livermore Site Ground Water Project}

\section{Physiographic Setting}

The general topography of the Livermore site is described in Chapter 1 . The Livermore Valley ground water system is a sequence of semiconfined aquifers in which ground water moves downslope from the valley uplands toward the east-west axis of the valley. It then flows generally westward toward the southwest portion of the basin. From there, ground water has historically flowed south into the Sunol Valley Ground Water Basin. The largest quantities of ground water are pumped from the central and western portions of the Livermore Valley, where the valley fill is thickest.

The valley fill sediments make up two aquifers: the Livermore Formation and its overlying alluvium. The Livermore Formation averages about $1000 \mathrm{~m}$ in thickness and occupies an area of approximately $250 \mathrm{~km}^{2}$. The alluvium, which is about $100-\mathrm{m}$ thick, is the principal water-producing formation within the valley. 


\section{Ground Water Investigation and Remediation}

\section{Hydrogeology}

Sediment types at the Livermore site are grouped into four categories-clay, silt, sand, and gravel-based on dominant particle size. Ground water flow beneath the site is primarily in alluvial sand and gravel lenses and channels, bounded by the less permeable clays and silts. The alluvial sediments have been mapped into seven hydrostratigraphic units (HSUs) beneath the Livermore site using data collected over the years. HSUs can be defined as sedimentary sequences whose permeable layers show evidence of hydraulic connection. The HSUs of concern beneath the Livermore site are the Quaternary alluvial deposits of the upper Livermore member of the Livermore Formation (see Figure 8-1). HSUs 1B, 2, 3A, 3B, 4 and 5 contain contaminants, which are primarily solvents (Blake et al. 1995 and Hoffman et al. 1998).

\section{Remedial Activities}

In 1998, the Livermore site Ground Water Project (GWP) treated almost $1000 \mathrm{ML}$ of ground water, brought new treatment facilities on line, installed wells, conducted hydraulic tests, developed ground water models, published required documents, and maintained close contact with regulatory agencies and the community.

LLNL operated ground water treatment facilities and vapor treatment facilities (VTF) in the TFA, TFB, TFC, TFD, TFE, TFG, TF406, TF518, and TF5475 areas. A total of 60 ground water extraction wells operated at 16 separate locations at an average flow rate of $2.7 \mathrm{ML} /$ day in 1998 . VTF518 operated at an average vapor flow of $2000 \mathrm{~m}^{3} /$ day. Table 8-1 shows the volumes of ground water and soil vapor treated at the facilities and the estimated volatile organic compound (VOC) mass removed from the subsurface during 1998 and since the beginning of the remediation. A graph of VOC mass removal at the Livermore site since 1989 is presented in Figure 8-2. Concentrations of remaining VOCs in the fourth quarter of 1998 are depicted as concentration isopleths in the five HSUs in Figures 8-3 to 8-7.

Table 8-2 lists the extraction wells according to the hydrostratigraphic unit in which they are screened and the total flow rate for each treatment area. Together, these treatment facilities removed approximately $150 \mathrm{~kg}$ of VOC mass in 1998. Since operations began, approximately $3000 \mathrm{ML}$ of ground water and almost 0.21 million $\mathrm{m}^{3}$ of vapor have been treated, and more than $483 \mathrm{~kg}$ of VOCs have been removed. The VOC plumes in HSUs 1B, 2, 3A, 4 and 5 continue to be hydraulically controlled based on trends in ground water chemistry, capture zone analysis, and the total VOC isoconcentration maps (Figures 8-3-7) for each HSU. 


\section{Ground Water Investigation and Remediation}

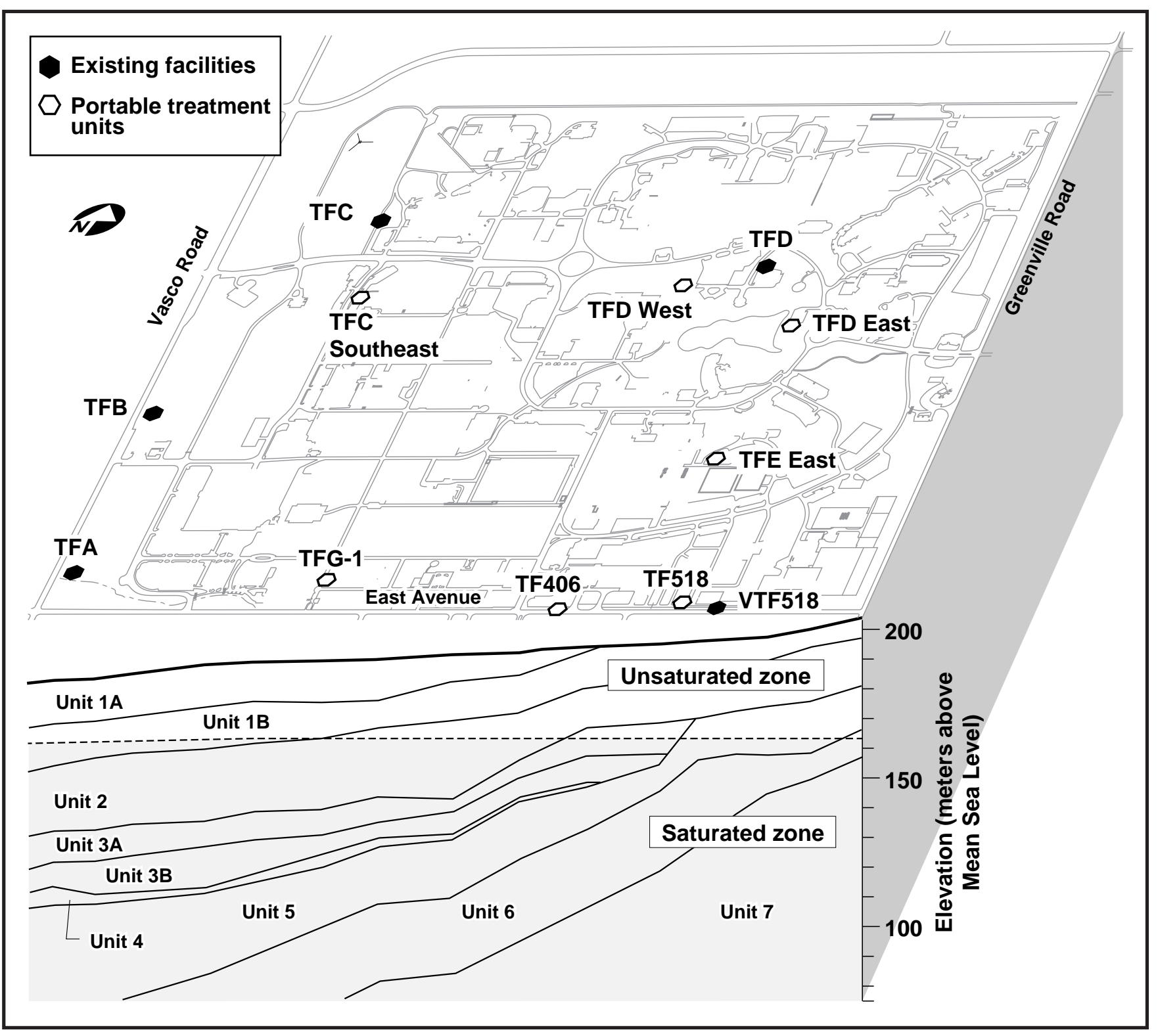

Figure 8-1. Map and cross section of the Livermore site showing hydrostratigraphic units and the locations of the treatment plants.

The numbers and locations of new wells installed in 1998 are shown in Table 8-3. Well construction details, well closure data, and results of drawdown tests are provided in the LLNL Ground Water Project 1998 Annual Report (Aarons et al. 1998). 


\section{Ground Water Investigation and Remediation}

Table 8-1. Volatile organic compounds (VOCs) removed from ground water and soil at the Livermore site.

\begin{tabular}{|c|c|c|c|c|c|}
\hline \multirow[b]{2}{*}{$\begin{array}{c}\text { Treatment } \\
\text { facility(a) }\end{array}$} & \multirow[b]{2}{*}{$\begin{array}{l}\text { Startup } \\
\text { date }\end{array}$} & \multicolumn{2}{|c|}{1998} & \multicolumn{2}{|c|}{ Cumulative total } \\
\hline & & $\begin{array}{l}\text { Water treated } \\
(\mathrm{ML})^{(\mathbf{b})}\end{array}$ & $\begin{array}{c}\text { VOCs } \\
\text { removed (kg) }\end{array}$ & $\begin{array}{l}\text { Water treated } \\
(\mathrm{ML})^{(\mathbf{b})}\end{array}$ & $\begin{array}{c}\text { VOCs } \\
\text { removed (kg) }\end{array}$ \\
\hline TFA & $9 / 89$ & 469 & 15 & 1950 & 109 \\
\hline TFB & $10 / 90$ & 68 & 5.2 & 316 & 31 \\
\hline TFC & $10 / 93$ & 87 & 7.9 & 223 & 23 \\
\hline TFD & 9/94 & 238 & 73 & 470 & 147 \\
\hline TFE & $11 / 96$ & 53 & 17 & 93 & 34 \\
\hline TFG1 & $4 / 96$ & 11 & 0.4 & 27 & 1.2 \\
\hline TF406 & $8 / 96$ & 45 & 2.1 & 56 & 1.2 \\
\hline TF518 & $1 / 98$ & 11 & 1.0 & 11 & 1.0 \\
\hline TF5475 & $9 / 97^{(\mathrm{c})}$ & 0.12 & 0.4 & 0.14 & 0.5 \\
\hline \multirow[t]{2}{*}{ Total } & & 982 & 121 & 3146 & 349 \\
\hline & & $\begin{array}{l}\text { Soil vapor } \\
\text { treated }\left(\mathrm{m}^{3}\right)\end{array}$ & $\begin{array}{c}\text { VOCs } \\
\text { removed (kg) }\end{array}$ & $\begin{array}{l}\text { Soil vapor } \\
\text { treated }\left(\mathbf{m}^{3}\right)\end{array}$ & $\begin{array}{c}\text { VOCs } \\
\text { removed (kg) }\end{array}$ \\
\hline VTF518 ${ }^{(d)}$ & 9/95 & 141,000 & 27.3 & 316,000 & 134 \\
\hline
\end{tabular}

a Includes fixed and portable units.

b $\mathrm{ML}=1$ million liters.

c Activation date.

d Volatile extraction well.

\section{Treatment Facility A}

Treatment Facility A (TFA) is a fixed facility that is located in the southwestern quadrant of the Livermore site near Vasco Road and East Avenue (Figure 8-1). Ground water is treated using the large-capacity air-stripping system that was installed in June 1997. The VOCs are stripped from the ground water, and the effluent air from the stripper is passed through granular activated carbon (GAC) filters to remove the VOCs. The treated effluent air is then vented to the atmosphere. The California Regional Water Quality Control Board (RWQCB) permits LLNL to treat up to 500 gallons per minute (gpm) of ground water. Treated ground water from TFA is discharged to the Recharge Basin, located about $600 \mathrm{~m}$ southeast of TFA on Department of Energy (DOE) property administered by Sandia National Laboratories/California. Since startup of the new system, TFA has not exceeded the 5 parts per billion (ppb) total VOC discharge limit. Two wells were installed in the TFA area in 1998 (see Table 8-3). Three other boreholes were drilled for infiltration studies. 


\section{Ground Water Investigation and Remediation}

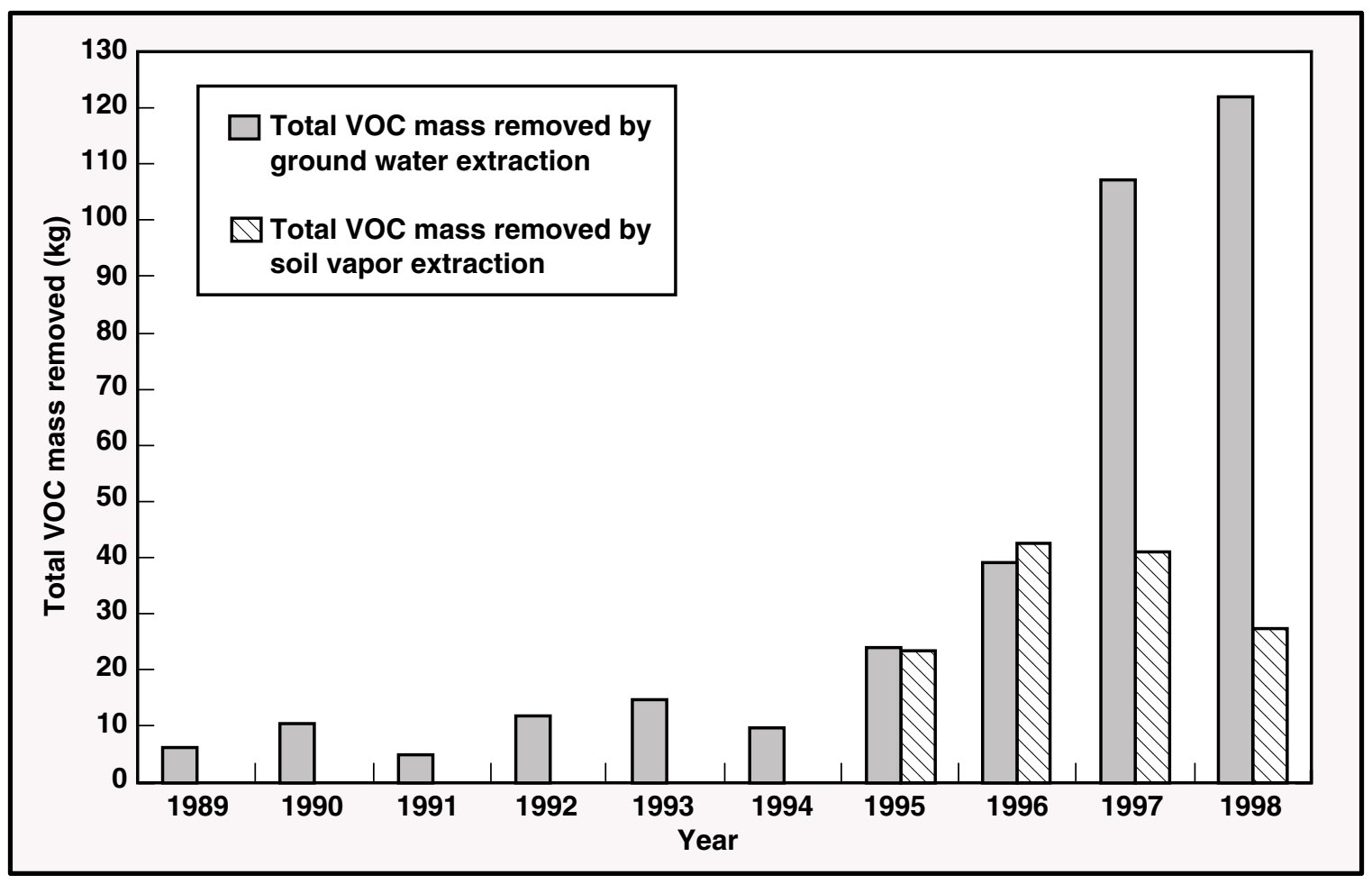

Figure 8-2. Total VOC mass removed from the subsurface of the Livermore site between 1989 and 1998.

\section{Treatment Facility $B$}

Treatment Facility B (TFB) is located in the west-central portion of the Livermore site. In October 1998, a new ground water treatment system was installed at TFB replacing an ultraviolet/hydrogen peroxide $\left(\mathrm{UV} / \mathrm{H}_{2} \mathrm{O}_{2}\right)$ system had been in use since 1990. The new system, a more cost-effective large-capacity air-stripping system, passes effluent air from the air stripper through granular activated carbon to remove VOCs. The treated effluent air is vented to the atmosphere. Ground water is treated for chromium(VI) in an ionexchange unit during the winter months, based on the current RWQCB discharge substantive requirements. This new system is designed to treat up to $75 \mathrm{gpm}$ of ground water. Treated ground water from TFB is discharged into the north-flowing drainage ditch parallel to Vasco Road that empties into Arroyo Las Positas to the north. TFB was in compliance throughout 1998. Three new wells were drilled and completed at TFB during 1998 (Table 8-3). 


\section{Ground Water Investigation and Remediation}

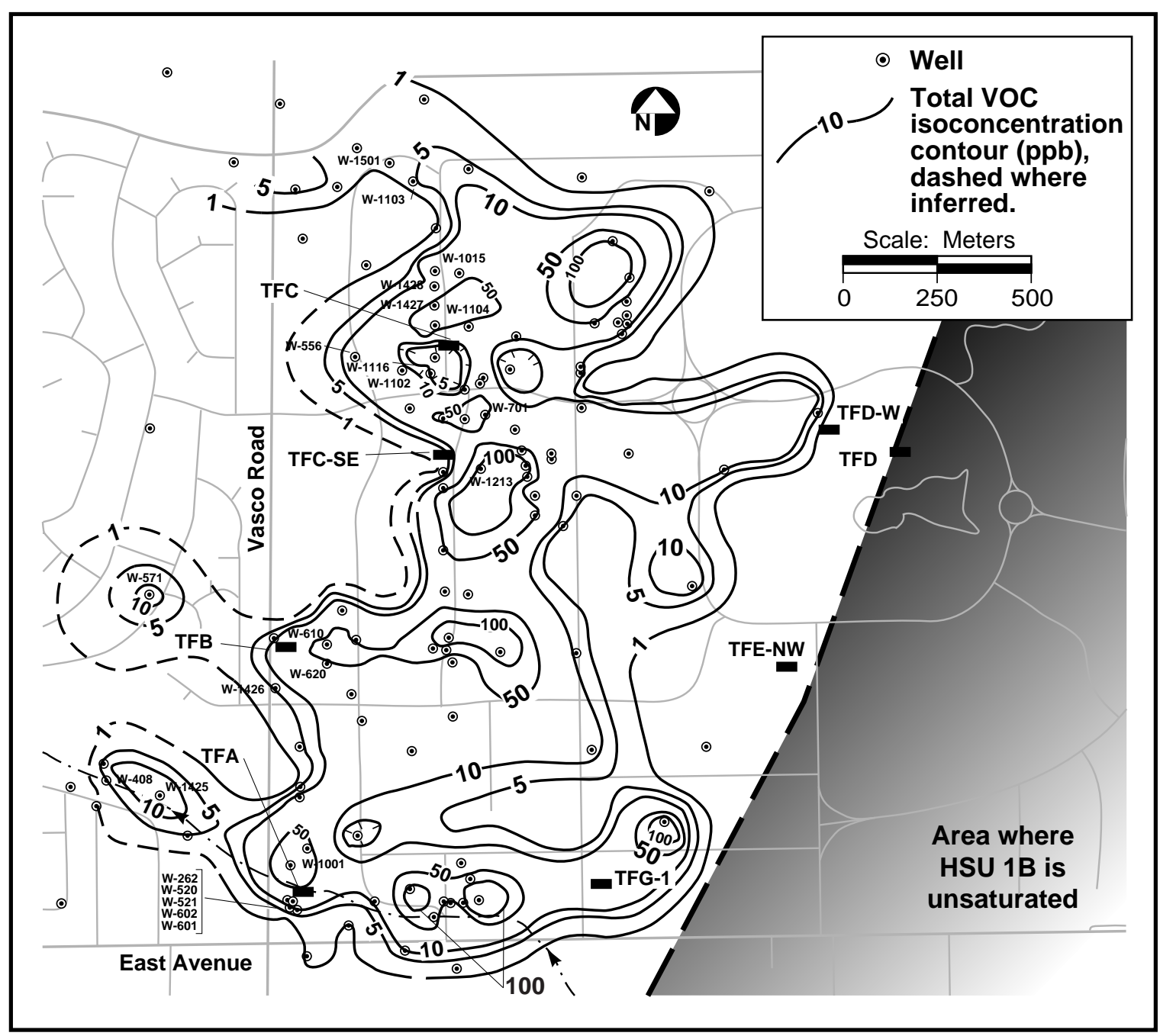

Figure 8-3. Isoconcentration contour map of total VOCs within hydrostratigraphic unit (HSU) $1 \mathrm{~B}$.

\section{Treatment Facility $C$}

Treatment Facility C (TFC) is located in the northwest quadrant of the Livermore site (Figure 8-1). Portable Treatment Unit (PTU) location TFC Southeast (TFC-SE), located near the intersection of Avenue A and Sixth Street in the northwest quadrant of the Livermore site, treats ground water from one HSU 1B well (W-1213). The combined TFC facilities operated at flow rates ranging from 47 to $55 \mathrm{gpm}$ in 1998. TFC and TFC-SE process VOCs in ground water using air stripping. The effluent air from the stripper is treated with granular activated carbon prior to discharge to the atmosphere. Ground water is treated for chromium(VI) in an ion-exchange unit during the winter months, 


\section{Ground Water Investigation and Remediation}

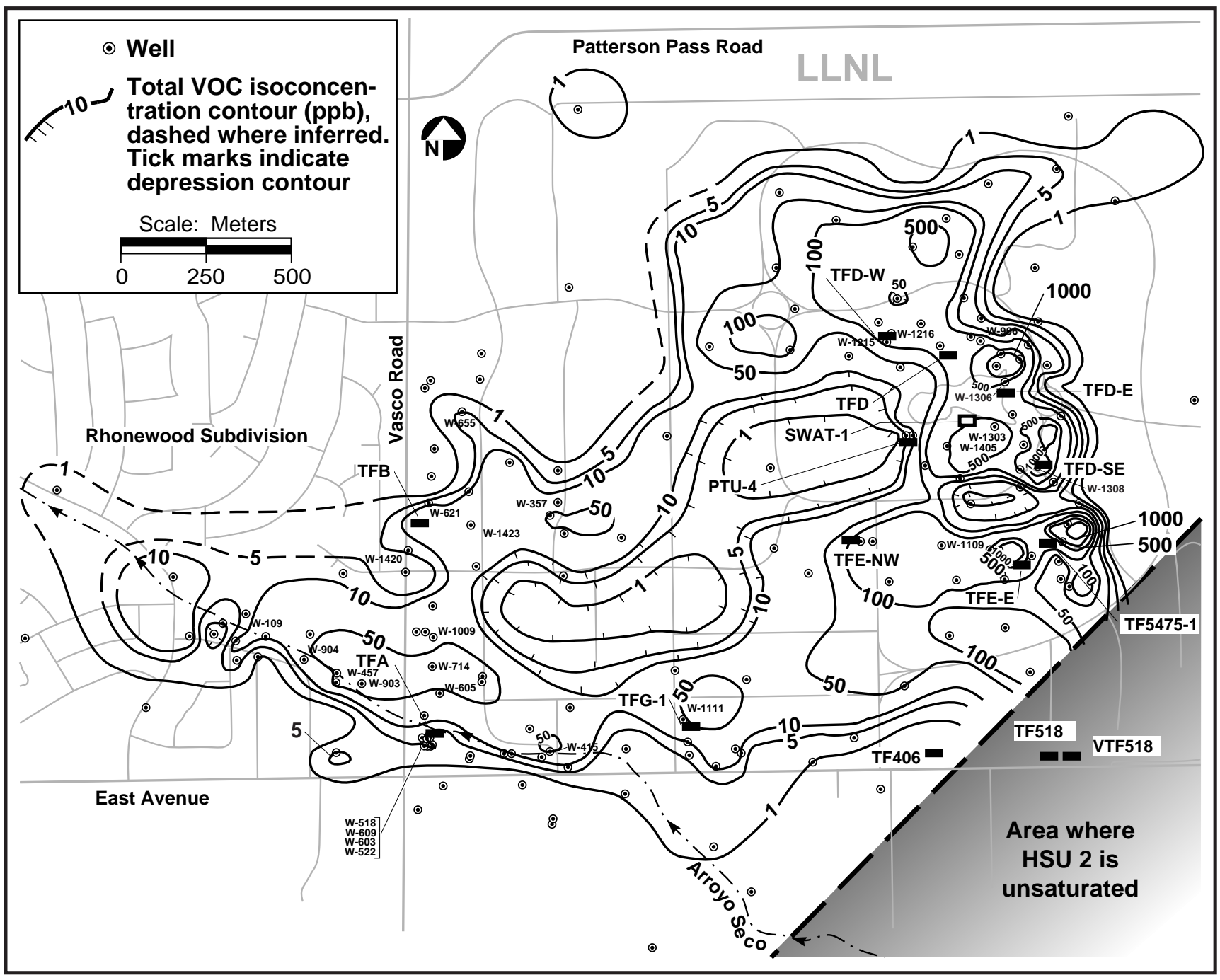

Figure 8-4. Isoconcentration contour map of total VOCs within hydrostratigraphic unit (HSU) 2.

based on the current RWQCB discharge substantive requirements. Treated ground water from TFC is discharged into a north-flowing drainage ditch that empties into Arroyo Las Positas. Treated ground water from TFC-SE is discharged into a storm sewer that empties into Arroyo Las Positas to the north. TFC was in compliance with all permits throughout 1998. Three new wells were drilled and completed at TFC during 1998.

\section{Treatment Facility D}

Treatment Facility D (TFD) is located north of the Drainage Retention Basin (DRB) in the east-central portion of the Livermore site (Figure 8-1). In 1998, TFD was expanded to include permanent connections for extraction wells W-1206 and W-1208. Dual screened 


\section{Ground Water Investigation and Remediation}

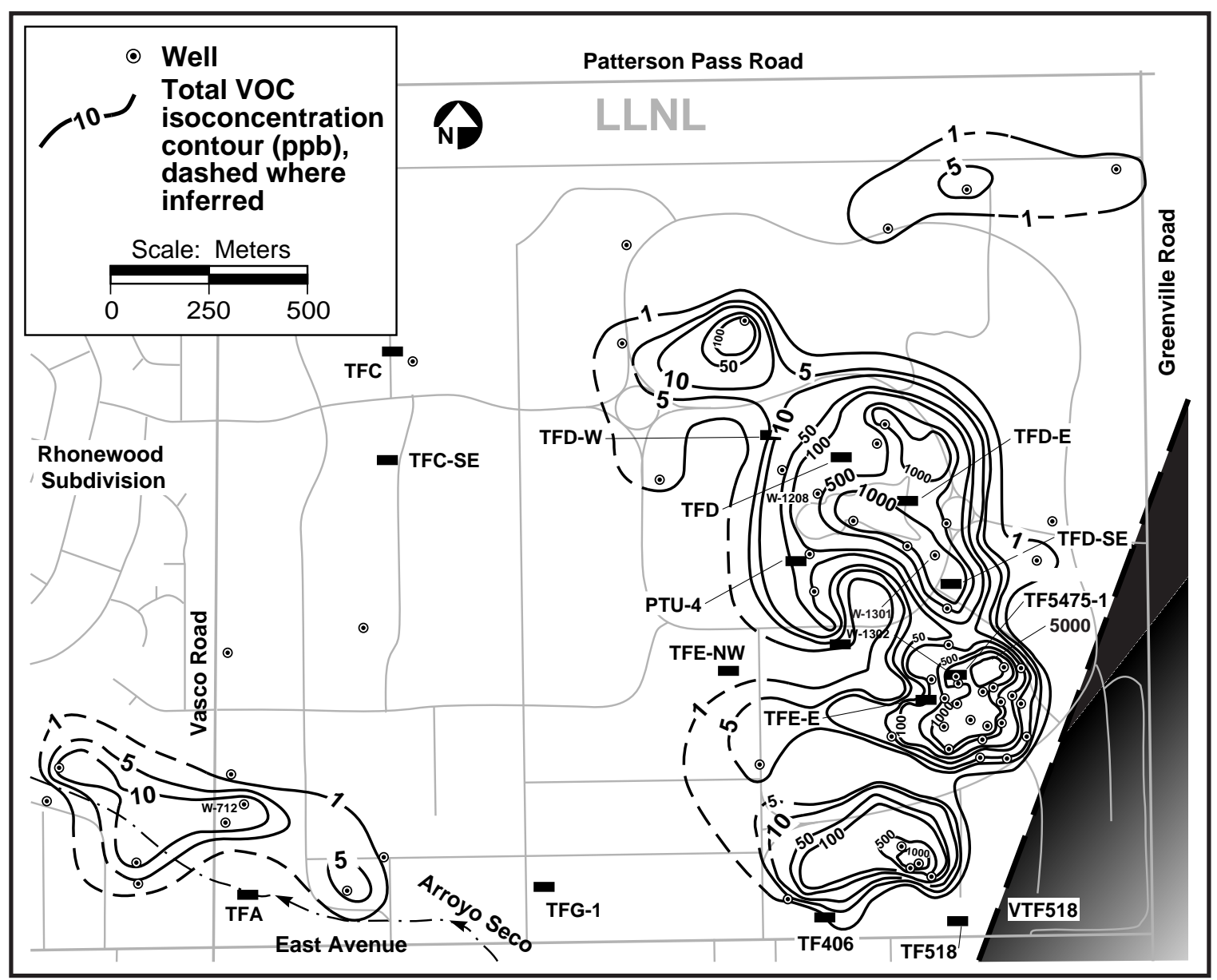

Figure 8-5. Isoconcentration contour map of total VOCs within hydrostratigraphic unit (HSU) 3A.

well, W-907, has a packer set to enable extraction from the lower screened interval (HSU 5) only. One new extraction location, TFD Southeast (TFD-SE), which is located south of the East Traffic Circle and east of Inner Loop Road, was activated in March 1998. Portable treatment unit (PTU) 11 was used to meet the Remedial Action Implementation Plan (RAIP) milestone date. TFD-SE treats ground water from two extraction wells, including one HSU 2 well (W-1308) and one HSU 4 well (W-314).

Two other extraction locations, TFD West (TFD-W) and TFD East (TFD-E), continued to treat ground water in 1998 using PTUs. TFD-W is located south of North Inner Loop Road in the central portion of the Livermore site and TFD-E is located east of the DRB in the east-central portion of the Livermore site. TFD, TFD-W, TFD-E, and TFD-SE remove VOCs by air stripping. The effluent air from the stripper is treated with granular activated carbon before it is vented to the atmosphere. Treated ground water from TFD and TFD-E is discharged either into the DRB or into an underground pipeline 


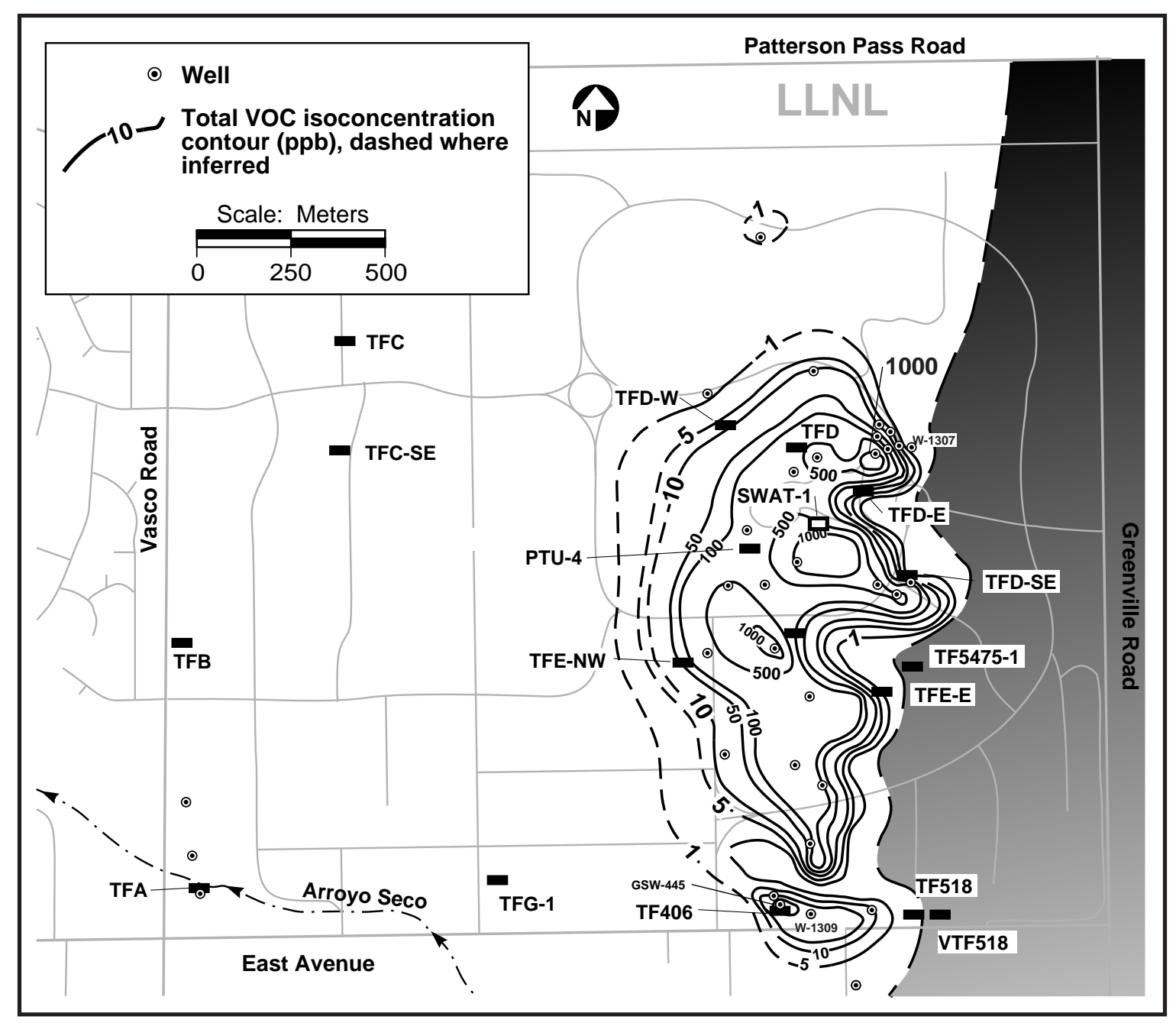

Figure 8-6. Isoconcentration contour map of total VOCs within hydrostratigraphic unit (HSU) 4.

downstream of the DRB weir and flows northward to Arroyo Las Positas. Treated ground water from TFD-W is discharged into a nearby storm sewer that also empties into Arroyo Las Positas. Treated ground water from TFD-SE is discharged into a lined drainage ditch, which flows northwest into the DRB. All TFD facilities were in compliance throughout 1998.

The TFD area extraction wells hydraulically control VOCs in HSUs 2, 3A, 4, and 5. Distal VOC plumes in the western TFD area should be hydraulically controlled once the planned TFC-East and TFC-Northeast treatment facilities are activated. 


\section{Ground Water Investigation and Remediation}

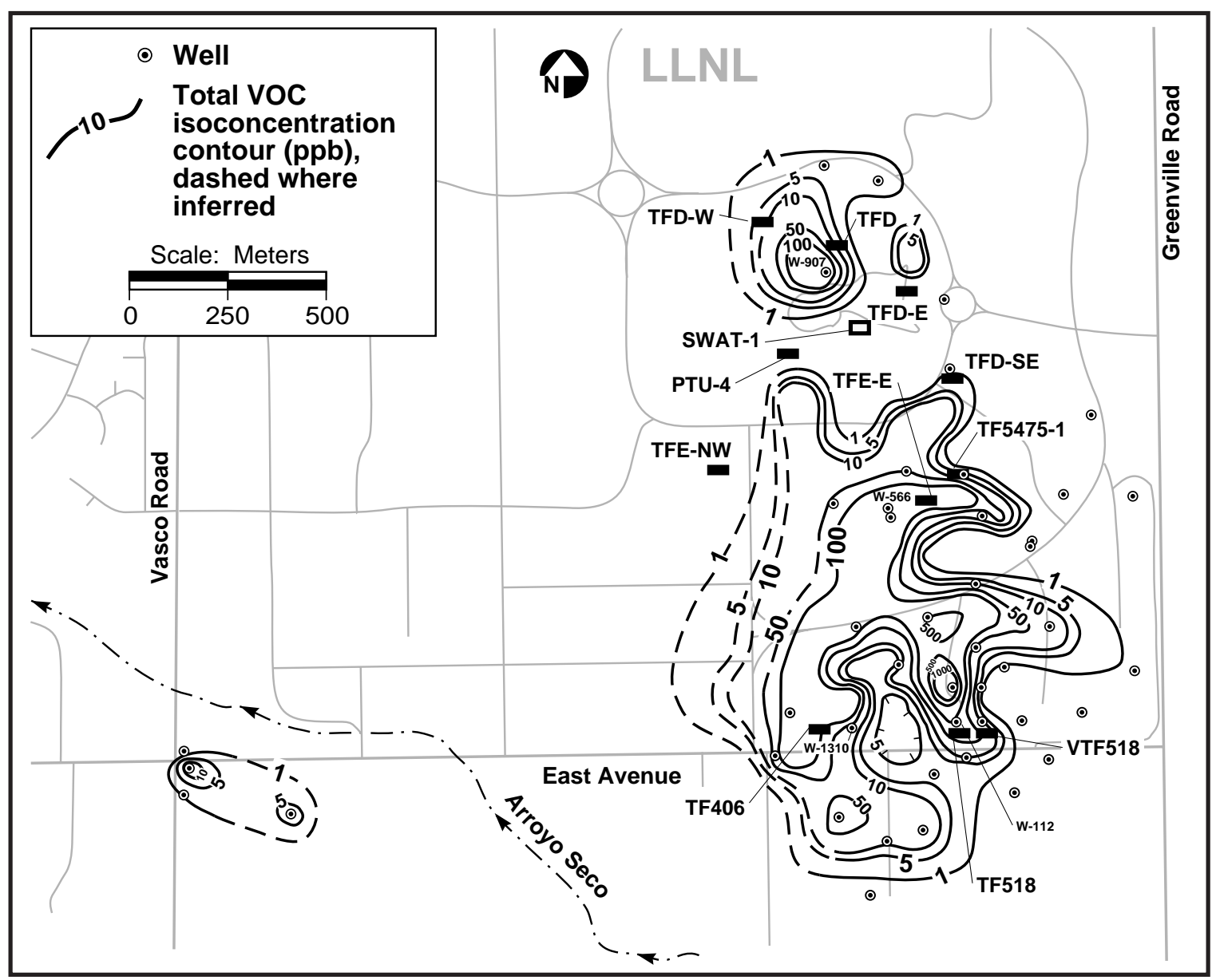

Figure 8-7. Isoconcentration contour map of total VOCs within hydrostratigraphic unit (HSU) 5.

In 1998, one-hour drawdown tests were conducted on TFD area wells W-1408, W-1416, W-1417, and W-1421. Eight-hour, step-drawdown tests were performed on proposed extraction wells W-1417, W-1419, and W-1421 to evaluate their effectiveness (see Aarons et al. 1998).

Following the successful treatability test conducted at TFD in 1997, the solar-powered water activated-carbon treatment (SWAT) unit was reconnected to well W-361, located south of the DRB in September 1998. The SWAT uses a solar-powered pump to extract ground water, which is then passed through a series of three 55-gal granular activated carbon canisters for treatment. The treated ground water was discharged to the DRB. During 1998, the SWAT unit treated about $0.3 \mathrm{ML}$ of ground water containing an estimated $0.6 \mathrm{~kg}$ of VOCs. 
Table 8-2. 1998 extraction wells and extraction rates.

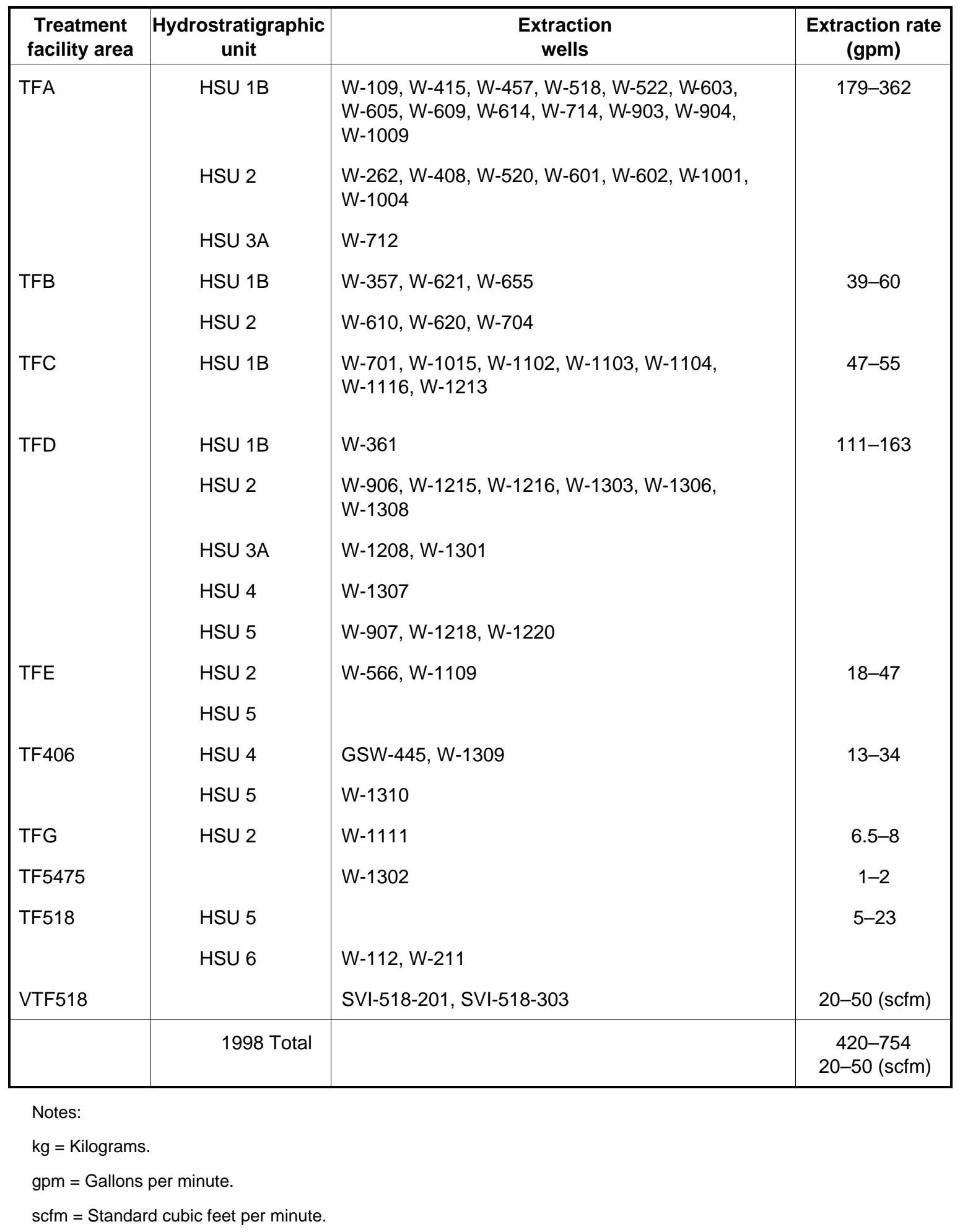




\section{Ground Water Investigation and Remediation}

Table 8-3. Wells installed in 1998.

\begin{tabular}{|c|l|l|}
\hline Treatment facility area & Hydrostratigraphic unit & \multicolumn{1}{|c|}{ Extraction wells } \\
\hline TFA & HSU 1B & W-1425 \\
& HSU 2 & W-1424 \\
TFB & HSU 1B & W-1426 \\
& HSU 2 & W-1420, W-1423 \\
TFC & HSU 1B & W-1427, W-1428, W-1501 \\
TFD & HSU 2 & W-1416, W-1419, W-1502 \\
& HSU 3A & W-1408, W-1417, W-1504 \\
TFU 4 & HSU 2 & W-1421, W-1503 \\
& HSU 3A & W-1409 \\
& HSU 4 & W-1422 \\
TF406 & HSU 4 & W-1411 \\
& HSU 5 & W-1410 \\
TF518 & HSU 3A & W-1412, W-1414 \\
& HSU 5 & W-1413 \\
TF5475 & HSU 2 & W-1415 \\
\hline
\end{tabular}

An additional PTU was operated at wells W-1220 and W-1218 from March 1998 to November 1998 in the southern part of the TFD area to expedite VOC mass removal and site cleanup. Wells W-1220 and W-1218 pumped at a combined flow rate of about $90 \mathrm{~L} / \mathrm{min}$, and treated about 2.6 ML of ground water containing an estimated $2.4 \mathrm{~kg}$ of VOCs. Eight new wells were drilled and completed at TFD during 1998 (Table 8-3).

\section{Treatment Facility E}

The TFE area is located in the southeastern quadrant of the Livermore site (Figure 8-1). In 1998, TFE East (TFE-E) continued treating ground water using a PTU. TFE-E is located in the east-central portion of the Livermore site. One additional extraction location, TFE Northwest (TFE-NW), which uses a PTU, was activated in 1998. TFE-NW, treats ground water from extraction wells in HSU 2 and HSU 4 and is located south of the Inner Loop Road, immediately west of Southgate Drive. TFE-E and TFE-NW process ground water for treatment of VOCs using an air stripper, and the effluent air is treated using granular activated carbon to remove VOCs before it is vented to the atmosphere. Treated ground water from TFE-E is discharged into a drainage ditch that flows north into the DRB. Treated ground water from TFE-NW is discharged into a storm drain that flows north into Arroyo Las Positas. TFE-E and TFE-NW were in compliance throughout 1998. 


\section{Ground Water Investigation and Remediation}

In the TFE area, the TFE-E extraction wells provide hydraulic containment of some portions of VOC plumes in HSUs 2, 4, and 5. The VOC plumes in HSUs 3A, 4, and 5, located in the western and southern TFE areas, should be hydraulically controlled once the TFE-Southwest, TFE-Southeast, and TFE-West treatment facilities are operating. The planned start-up dates for these treatment facilities are March and June of 2000, and January 2001, respectively.

An additional PTU was operated at wells W-1418 and W-1422 in December 1998 in the northern part of the TFE area to expedite VOC mass removal and site cleanup. Pumping at these wells is planned to continue into 1999. During 1998, wells W-1418 and W-1422 pumped at a combined flow rate of about $38 \mathrm{~L} / \mathrm{min}$, and treated about $0.5 \mathrm{ML}$ of ground water containing an estimated $0.9 \mathrm{~kg}$ of VOCs. Three new wells were drilled and completed at TFD during 1998 (Table 8-3).

\section{Treatment Facility G}

Treatment Facility G (TFG) is located in the south-central portion of the Livermore site (Figure 8-1). Treatment Facility G-1 (TFG-1) is located near Avenue B, about $90 \mathrm{~m}$ north of East Avenue in the south-central part of the Livermore site. TFG-1 treats ground water for VOC treatment using an air stripper, and the effluent air is treated using granular activated carbon to remove VOCs before it is vented to the atmosphere. Ground water is treated for chromium(VI) in an ion-exchange unit. Under the current RWQCB discharge substantive requirements, water from TFG-1 requires treatment for chromium(VI) only during the winter months. Treated ground water from TFG-1 is discharged to a storm drain located about $50 \mathrm{ft}$ north of TFG-1, which empties into Arroyo Seco. TFG-1 was in compliance throughout 1998. No boreholes or wells were drilled, and no hydraulic tests were conducted in the TFG area during 1998.

Since January 1998, a treatability study using granular activated carbon to treat ground water from extraction well W-1111 has been underway. Three 180-kg granular activated carbon canisters in series are used to process water from well $\mathrm{W}-1111$. The existing PTU was used for backup treatment during the test to ensure that no VOCs were discharged. Breakthrough of the first carbon canister occurred after three months of operation. At the time of breakthrough, $2.6 \mathrm{ML}$ of ground water had already been treated. The granular activated carbon treatment unit (GTU) has proved to be effective and efficient. Based on the results of the test, a GTU unit will replace the PTU at TFG-1 in 1999.

\section{Treatment Facility 406}

Treatment Facility 406 (TF406) is located east of Southgate Drive near East Avenue in the south-central part of the Livermore site. TF406 treats ground water to remove VOCs using an air stripper. The effluent air is passed over granular activated carbon to 


\section{Ground Water Investigation and Remediation}

remove VOCs before it is vented to the atmosphere. All treated ground water was discharged to a storm drain that flows to Arroyo Las Positas. TF406 was in compliance throughout 1998.

When activated in 1996, TF406 processed ground water from extraction wells GSW-445 and W-1114. In 1997, well W-1114 was destroyed and two new extraction wells, W-1309 and W-1310 were installed. TF406 began processing ground water from wells W-1309 and W-1310 in February 1998. Cumulative flow from the three extraction wells is about $100 \mathrm{~L} / \mathrm{min}$.

Passive bioremediation to remediate fuel hydrocarbons continued in the TF406 area during 1998 in HSUs 3A and 3B. Active ground water extraction and treatment for residual dissolved fuel hydrocarbons at Treatment Facility F was discontinued in 1996 with regulatory agency concurrence (San Francisco Bay Regional Water Quality Control Board 1996).

The TF406 extraction wells provide significant hydraulic control of VOC plumes in HSUs 4 and 5 in the TF406 area. The VOC plumes in HSUs 3A, 4, and 5 should be hydraulically controlled once treatment facilities at TF406-Northwest and TF518-North are installed. Two new wells were drilled and completed at TF406 during 1998 (Table 8-3).

\section{Ground Water Treatment Facility 518}

Treatment Facility 518 (TF518) is located in the southeastern quadrant of the Livermore site, north of East Avenue and near Avenue H, adjacent to VTF518 (Figure 8-1). TF518 was constructed in 1997 and began operating in January 1998. In 1998, TF518 treated ground water from two extraction wells, W-112 (HSU 5) and W-211 (HSU 6).

Pumping from well W-211 was discontinued in May 1998 after six consecutive sampling events between September 1997 and April 1998 showed TCE concentrations remained below the $5 \mathrm{ppb}$ maximum contaminant level (MCL). An additional sample taken four months after pumping ceased indicated that concentrations in the well remain below the MCL. Quarterly sampling of well W-211 will continue in 1999.

In July 1998, the first miniature portable treatment unit (MTU-1) was activated in the TF518 area, replacing the full-size PTU that had been in operation since January 1998. Both the units remove VOCs by means of an air stripper, and treat effluent air using granular activated carbon to remove VOCs. All treated ground water is discharged to a storm drain that ultimately empties into Arroyo Las Positas. TF518 was in compliance throughout 1998. Three new wells were drilled and completed at TF518 during 1998 (Table 8-3). 


\section{Ground Water Investigation and Remediation}

\section{Treatment Facility 5475}

The Treatment Facility 5475 (TF5475) area is located in the southeastern quadrant of the Livermore site where tritium is present in HSU 3A ground water in concentrations above the MCL. TF5475-1 which was activated in September 1998, uses down-hole, in situ catalytic reductive dehalogenation (CRD) to treat VOCs in ground water. This technology is based upon the reaction of dissolved hydrogen, introduced to the ground water through a hydrophobic membrane, with VOCs on a palladium-alumina catalyst to form ethane and chloride. Because of the high CRD reaction rates, water is treated in one pass through the unit, and the treatment unit can be placed in the well casing. This technology treats VOCs in ground water while keeping the tritium in the subsurface.

The CRD unit operates in extraction well W-1302, a dual-screened well in which the unit extracts ground water from the lower screened interval and injects treated ground water containing tritium into the upper screened interval. TF5475-1 was in compliance throughout 1998. One new well was drilled and completed at TF5475 during 1998 (Table 8-3).

\section{Vapor Treatment Facility 518}

Vapor Treatment Facility 518 (VTF518) is located in the southeastern quadrant of the Livermore site. Soil vapor is extracted from the vadose zone, and VOCs are removed from the vapor using granular activated carbon canisters. Following treatment, the effluent air is discharged to the atmosphere. VTF518 was in compliance with the Bay Area Air Quality Management District permit throughout 1998.

Two instrumented membrane system (IMS) sampling/monitoring wells, SEA-518-301 and SEA-518-304, continue to monitor vadose zone remediation in the VTF518 area. The IMS system is used to collect vapor pressure, soil temperature, soil moisture, and soil vapor concentration data at various discrete depths. VOC vapor concentrations at SEA-518-301, the IMS borehole nearest VTF518 vapor extraction well SVI-518-201, have declined from an average of 111 parts per million by volume (ppmv) in September 1995 to an average of 6.7 parts per million volume (ppmv) in the upper zones $(6,15,26$, and $37 \mathrm{ft}$ ) in September 1998. However, an increase in vapor concentration has recently been observed in the lowest zone at $85 \mathrm{ft}$, from 143 ppmv in September 1995 to 220 ppmv in September 1998. Monitoring of the vadose zone will continue to evaluate the progress of remediation of the vadose zone in the VTF518 area. No new vapor treatment wells were drilled at VTF518 during 1998. 


\section{Ground Water Investigation and Remediation}

\section{Ground Water Flow and Transport Modeling}

Ground water flow and transport models are used at the Livermore site to support remediation system design and performance evaluation; to support ongoing subsurface characterization activities; and improve LLNL's ability to forecast, monitor, and interpret the progress of the ground water remediation program. In 1998, development continued on our three-dimensional ground water model for the Livermore site. The three-dimensional model builds vertical resolution into the two-dimensional model previously developed for the Livermore site (Tompson et al. 1995).

\section{Treatment Facility A and B Model}

In 1998, LLNL continued to use the three-dimensional ground water flow and contaminant transport model of HSUs $1 B$ and 2 to evaluate perchloroethene (PCE) and trichloroethene (TCE) transport in the TFA and TFB areas. The development of this model is described in detail in Demir et al. (1997) and Vogele et al. (1996). This model, developed using the CFEST (Coupled Flow, Energy and Solute Transport) computer code (Gupta 1987), was calibrated to measured ground water elevation data collected from Livermore site monitoring wells.

In 1998, the model was used to compare simulated contaminant transport to ground water concentrations observed from 1996 through 1998. These simulations comprised a series of remedial pumping time steps that were constructed to reflect changes in extraction-well flow rates. Results from the preliminary simulations were within plausible uncertainty limits of the model.

\section{Sitewide Model for all HSUs}

In 1998, work continued to develop a three-dimensional ground water flow and transport model for all Livermore site HSUs using the FEFLOW (Finite Element subsurface FLOW system) computer code (Diersch 1998). To improve the accuracy of simulations and to better simulate contaminant migration in the source areas, all available subsurface hydraulic property data are being analyzed.

In 1998, work on the sitewide model consisted of improving the hydrogeological input data sets and beginning the flow calibration. The improvements of the hydrogeological data sets focused primarily on three major areas. First, the migration history of individual plumes was evaluated. As a result of this work, plume maps for 11 individual VOC constituents and total VOCs were generated for each quarter from 1987 to 1998 and displayed through a web-based graphical interface for analysis. Second, a revised set of HSU correlations across the entire eastern Livermore Basin was developed and put into the model. Third, heterogeneity within HSUs was evaluated by reviewing 


\section{Ground Water Investigation and Remediation}

lithologic, geophysical, and hydraulic test data to better define the distribution of hydraulic conductivity within HSUs across the site.

\section{Trailer 5475 Model}

In 1998, LLNL developed a two-dimensional FEFLOW model of the Trailer 5475 area to evaluate the use of recirculation cells with the deployment of the catalytic reductive dehalogenation (CRD) treatment units. The objective of the model is to evaluate different potential extraction and injection well configurations to improve overall remediation performance. This effort is part of an ongoing evaluation of the T5475 area for use with engineering design and long-term planning.

\section{Zone 7 Project}

In 1997, the Alameda County Flood Control and Water Conservation District, Zone 7 (Zone 7) approached LLNL about using the existing LLNL ground water models to assist Zone 7 evaluate future ground water use in the basin surrounding LLNL. LLNL submitted a report to Zone 7 (Hoffman and Bishop 1998) on February 28, 1998 and presented the results to the Zone 7 Board on March 5, 1998. The report summarized the results of an investigation to estimate the subsurface volume of ground water and the volume of potential subsurface storage in the basin to address short- and long-term water resources management issues. A volumetric calculation was performed to determine the volume of potential ground water storage in the basin, and a potential drawdown or buildup of ground water in the area of interest. The existing twodimensional CFEST flow model (Tompson et al. 1995) was used to estimate the volume of ground water flow in the basin, and to evaluate the influence of different rates of extraction and reinjection within the basin. The results of this analysis indicated about 1000 acre/ft of ground water flow through the basin with about 2000 to 5000 acre/ft of additional ground water storage.

\section{Regulatory Compliance}

In 1998, DOE/LLNL submitted documents required by CERCLA and the Livermore site Federal Facility Agreement (FFA). In addition, DOE/LLNL continued environmental restoration and community activities as discussed below.

\section{CERCLA Documents}

During 1998, DOE/LLNL issued two CERCLA documents for the Livermore site specified in the amended schedule in the RAIP (Dresen et al. 1993). Both Draft Final and Final Remedial Design Report No. 4 (RD4) (Berg et al. 1998) were submitted ahead 


\section{Ground Water Investigation and Remediation}

of schedule. Submission of RD4 marked the successful completion of all primary FFA document milestones until the second Five-Year Review in August 2002.

As required by the FFA, DOE/LLNL issued the LLNL Ground Water Project 1997 Annual Report (Hoffman et al. 1998) on March 31, 1998. DOE/LLNL also finalized and issued seven Remedial Project Managers' (RPMs') meeting summaries. The March RPM summary (Bainer and Littlejohn 1998a) included quarterly self-monitoring data. Subsequent 1998 quarterly self-monitoring data were reported in letter reports (Bainer and Littlejohn 1998b, 1998c, 1999). LLNL also updated the Quality Assurance Project Plan and is in the process of responding to the U.S. Environmental Protection Agency (EPA) comments.

An Action Memorandum for an emergency removal action was issued February 2, 1998 (Bainer and Berg 1998) in response to a discovery of undocumented buried capacitors containing polychlorinated biphenyls (PCBs) during excavation for the National Ignition Facility (NIF) in the northeast corner of the Livermore site. As part of the work on the GWP, LLNL also prepared sections of NIF quarterly progress reports pursuant to an agreement specified in the Joint Stipulation and Order, in partial settlement of a Natural Resources Defense Council (NRDC) vs Pena DOE lawsuit.

LLNL prepared a sampling plan for determining the extent of elevated plutonium concentrations in soil in Livermore's Big Trees Park (U.S. Department of Energy and Lawrence Livermore National Laboratory 1998). This plan and the associated sampling and analyses were LLNL's voluntary response to community concerns expressed in the Agency for Toxic Substances and Disease Registry/California Department of Health Services (CDHS) Environmental Health Investigations Branch's February 1998 draft Public Health Consultation. See Chapter 10, Soil and Sediment Monitoring, for details.

\section{Community Relations}

The Community Work Group (CWG) met once in 1998 to discuss the DOE budget, progress on the Livermore site cleanup, and the Livermore site Priority List/Consensus Statement. Correspondence and communication with CWG members continued throughout the year. DOE/LLNL met three times with members of Tri-Valley Citizens Against a Radioactive Environment and their scientific advisor as part of the activities funded by an EPA Technical Assistance Grant

Other Livermore site community relations activities in 1998 included communications and meetings with neighbors; local, regional and national interest groups; and other community organizations. LLNL also conducted public presentations including those to local realtors and to national and northern California peace leaders; produced and distributed the Environmental Community Letter; maintained the information repositories 
and administrative record; conducted tours of site environmental activities; and responded to public and news media inquiries.

\section{Environmental Impact}

Based on a comparison of 1998 and 1997 annual isoconcentration maps (Hoffman et al. 1998), a number of trends in VOC concentrations are evident.

1. In the TFA area, along the western margin of the site, total VOC concentrations east of Vasco Road near newly activated extraction well W-1001 (HSU 1B) declined below $100 \mathrm{ppb}$ for the first time (Figure 8-3). Off-site HSU 1B concentrations remained below the MCL for all contaminants of concern except for well W-1425, where PCE concentrations were $8.3 \mathrm{ppb}$ in September 1998. Total VOC concentrations in HSU 2 declined from over $100 \mathrm{ppb}$ to around $50 \mathrm{ppb}$ near extraction well W-415, and the $50 \mathrm{ppb}$ total VOC contour in HSU 2 is now east of extraction well W-904 (Figure 8-4).

2. VOC concentrations in the western part of the TFB HSU 1B plume continued to decline, while concentrations around the TFB source area remained relatively unchanged (Figure 8-3). VOC concentrations in HSU 2 in the TFB area also remained relatively unchanged in 1998 (Figure 8-4).

3. In the northwestern TFC area, concentrations of VOCs declined from over $100 \mathrm{ppb}$ to about $50 \mathrm{ppb}$ around extraction well W-1104 (Figure 8-3).

Concentrations in the TFC-SE area remain relatively unchanged from 1997.

4. In the TF406 area, along the southern margin of the Livermore site, VOC concentrations are relatively unchanged in HSU 4 since 1997 (Figure 8-4). Total VOC concentrations in HSU 5 south of the Livermore site boundary declined from over $150 \mathrm{ppb}$ to below 75 ppb in 1998 (well W-509, August 21, 1998 data) (Figure 8-7). In the TFG area south of the Livermore site boundary, total VOC concentrations in HSU 2 declined from a high of about 39 ppb to about 9 ppb total VOCs in 1998 (piezometer SIP-212-101, July 13, 1998 data) (Figure 8-4). 


\section{Ground Water Investigation and Remediation}

5. In the eastern and southeastern TFD areas, total VOC concentrations in HSU 2 are beginning to decline as shown by the smaller area encompassed by the 500 total VOC ppb contour (Figure 8-4). Total VOC concentrations in HSU $3 \mathrm{~A}$ in the eastern and southeastern part of the Livermore site remain relatively unchanged.

6. Total VOC concentrations in both HSU 4 and HSU 5 in the eastern part of the Livermore site remained relatively unchanged in 1998 (Figures 8-6 and 8-7). However, data from 1998 drilling indicate that there is an additional area of high concentration (over $1500 \mathrm{ppb}$ total VOCs) in HSU 4 in the TFD/TFE-NW area. A PTU will treat ground water in this high concentration area from HSU 4 monitor well W-1418 in 1999.

\section{Site 300 Ground Water Project}

Environmental investigations and cleanup activities at Site 300 began in 1981. Site 300 became a CERCLA/Superfund site in 1991, when it was placed on the National Priorities List (NPL). The CERCLA environmental restoration study areas are shown in Figure 8-8. The major contaminants of concern are listed in Table 8-4.

\section{Geology of Site 300}

Site 300 is located in the sparsely populated Altamont Hills, which are part of the Coast Ranges Physiographic Province and separate the Livermore Valley to the west from the San Joaquin Valley to the east. Site 300 stratigraphy is shown in Figure 8-9. Rocks exposed in the region are classified into three groups:

- Late Tertiary-Quaternary (0-5 million years ago)—alluvium and semilithified sediments, mainly of continental origin.

- Early to late Tertiary (5-65 million years ago)—shallow marine and continental sedimentary and volcaniclastic rocks.

- Jurassic-Cretaceous (65-180 million years ago)—Great Valley sequence (marine sedimentary rocks and ophiolites) and Franciscan Complex (sheared and variably metamorphosed sedimentary and igneous rocks). 


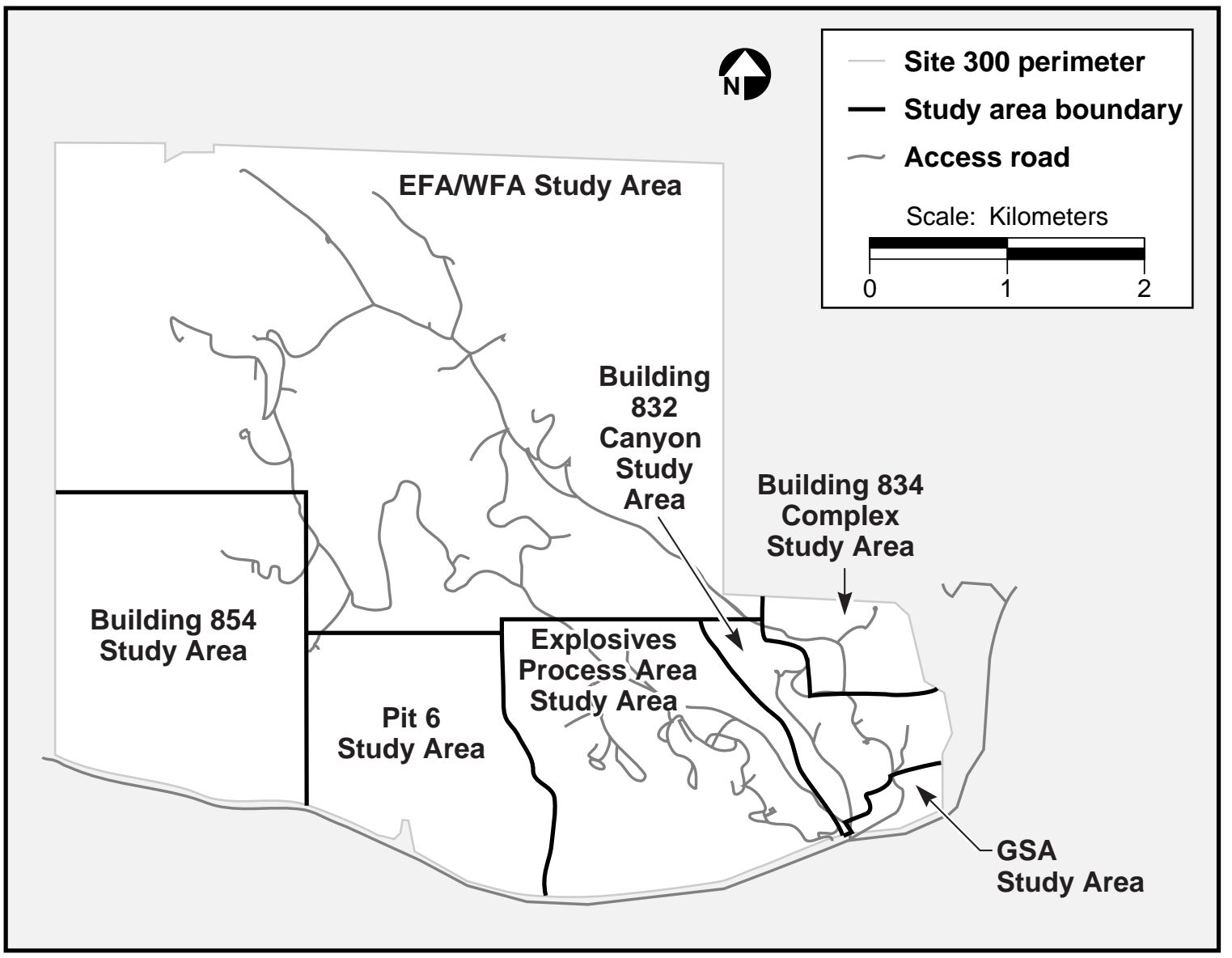

Figure 8-8. Environmental restoration study areas at Site 300.

Distinctive blue-gray to brown weathering volcaniclastic sandstone and sandy siltstone, interbedded with light gray weathering tuffaceous claystone and conglomerate, are exposed extensively within Site 300. These rocks are mapped as the late Miocene Neroly Formation (Huey 1948; Dibblee 1980). The Neroly Formation is also present in the subsurface beneath the southeastern portion of Site 300.

The Neroly Formation is the principal hydrologic unit within Site 300 and has therefore been the focus of the detailed geologic and hydrogeologic studies conducted during recent years (summarized in the Final Site-Wide Remedial Investigation Report, Lawrence Livermore National Laboratory Site 300, hereafter referred to as Final SWRI Report [Webster-Scholten 1994]). The complete section of the Neroly Formation is about 150-m thick beneath Site 300 . 


\section{Ground Water Investigation and Remediation}

Table 8-4. Major contaminants of concern found in soil, rock, and ground water at Site 300.

\begin{tabular}{|l|l|}
\hline \multicolumn{1}{|c|}{ Study area } & Contaminant of concern \\
\hline General Services Area (GSA) & VOCs (primarily TCE) \\
\hline Building 834 Complex & VOCs (primarily TCE), \\
& organosilicate oil, nitrate \\
\hline Explosives Process Area & VOCs (primarily TCE) \\
& HE (a) (primarily HMX ${ }^{[b]}$ ) \\
& Nitrate, perchlorate \\
\hline East and West Firing Areas (EFA/WFA) & Tritium \\
& Depleted uranium \\
& VOCs (primarily TCE) \\
& Nitrate, perchlorate \\
\hline Building 854 & VOCs (primarily TCE) \\
& Nitrate, perchlorate \\
\hline Pit 6 & VOCs (primarily TCE) \\
& Tritium, nitrate, perchlorate \\
\hline Building 832 Canyon & VOCs (primarily TCE) \\
& Nitrate, perchlorate \\
\hline
\end{tabular}

a $\mathrm{HE}=$ high explosives.

b $\mathrm{HMX}=$ octahydro-1,3,5,7-tetranitro-1,3,5,7-tetrazocine.

The floodplain of Corral Hollow Creek lies along the southern boundary of Site 300 and borders portions of the General Services Area (GSA), the Explosives Process Area, and the area of closed landfill Pit 6. Floodplain alluvium consists dominantly of coarse cobble and boulder-bearing terrace gravel derived from sources to the south, with lenses and local cappings of sandy silt and silty clay.

The bedrock sequence within Site 300 has been slightly deformed into several gentle, lowamplitude folds. The locations and characteristics of these folds, in combination with the regional fault and fracture patterns, locally influence ground water flow within the site and have therefore been studied in great detail as part of the CERCLA investigations.

\section{Hydrogeology of Site 300}

Site 300 is semiarid, with an average annual rainfall of $27 \mathrm{~cm}(10.5 \mathrm{in})$. The site is underlain by gently dipping sedimentary bedrock dissected by steep ravines. The bedrock comprises interbedded conglomerates, sandstones, siltstones, and claystones (see Figure 8-9). 


\section{Ground Water Investigation and Remediation}

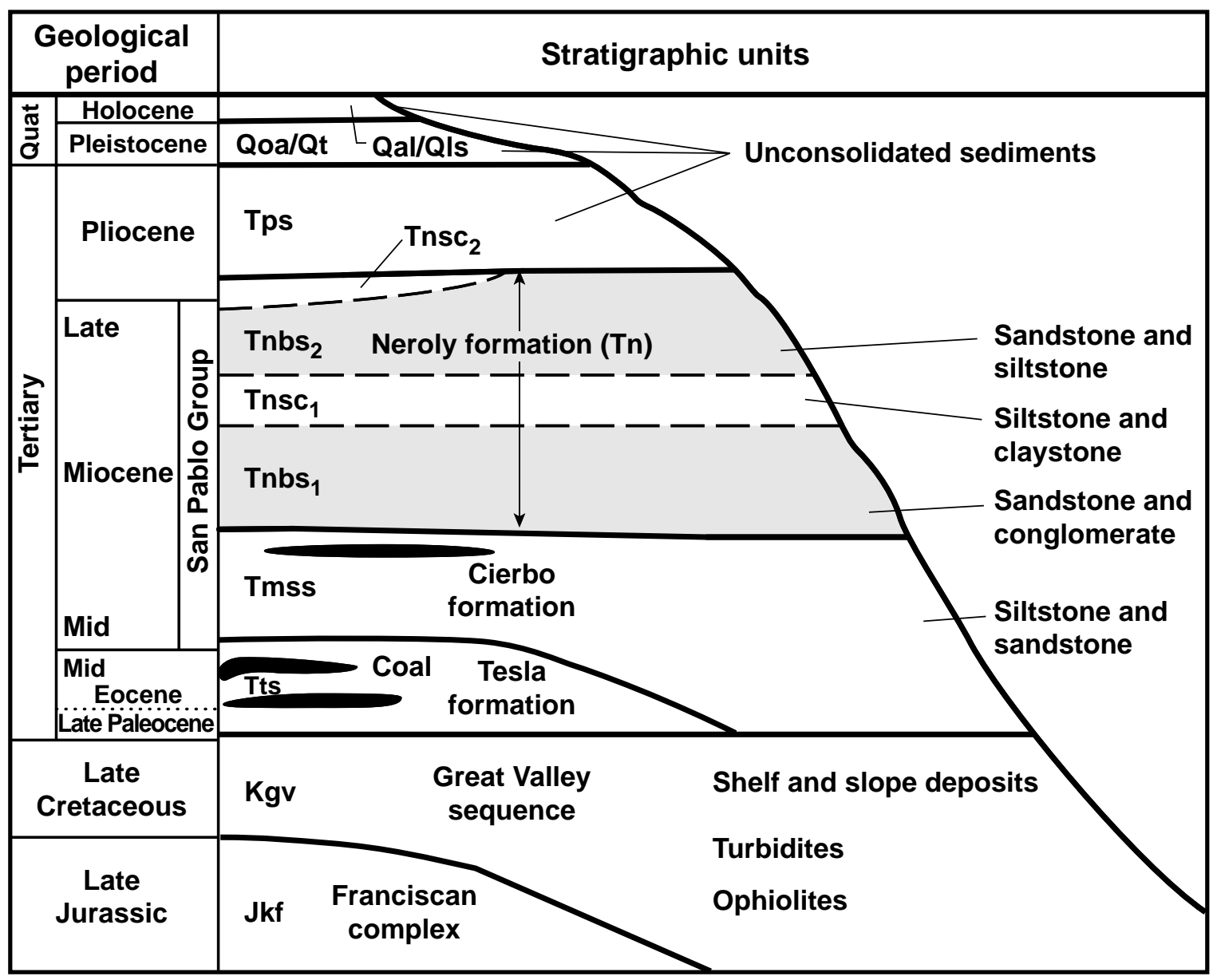

Figure 8-9. Site 300 stratigraphy (Webster-Scholten 1994).

Ground water primarily occurs in the Neroly Formation upper and lower blue sandstone units (Tnbs 2 and $\mathrm{Tnbs}_{1}$ ) and in the underlying Cierbo Formation (Tmss). Ground water can also be present in permeable Quaternary alluvium valley fill (Qal) during the winter rainy season. Some ground water is present as perched water-bearing zones beneath hilltops. The perched water-bearing zones primarily occur in the unconsolidated sediments of the Miocene-age nonmarine unit (Tps) in the Building 833 and 834 areas and in the Explosives Process Area. However, an extensive perched water-bearing zone occurs in Tnbs 1 sandstones in the northwestern portion of the East and West Firing Area. Fine-grained siltstone and claystone interbeds in Tnbs1 and Tmss act as aquitards, confining layers, or perching horizons. Portions of the bedrock section at Site 300 are abundantly fractured, and thus much of the ground water flow occurs in fractures as well as in pores. Ground water is present under confined conditions in the southern half of the site but is generally unconfined elsewhere. Figure 8-10 is a map of the potentiometric surface for the first continuous water-bearing zone at Site 300, which principally occurs in the Neroly lower blue sandstone aquifer $\left(\operatorname{Tnbs}_{1}\right)$. 


\section{Ground Water Investigation and Remediation}

Recharge occurs where saturated alluvial valley fill is in contact with underlying permeable bedrock, and where bedrock strata crop out. Local recharge occurs on hilltops, creating the perched water-bearing zones in the Building 832, 834, and 854 areas. Low rainfall, high evapotranspiration rates, steep topography, and intervening aquitards generally preclude direct vertical recharge to the deeper bedrock aquifers.

Ground water flow in the bedrock follows the inclination, or dip, of the layers. The tectonic forces that uplifted the Altamont Hills faulted, gently folded, and tilted the once-horizontal sedimentary strata. A major structure, the east-west trending Patterson anticline, occupies a central location within the site. North of the anticline, bedrock dips east-southeast, and ground water flows generally east-northeast. South of the anticline, bedrock dips south-southeast, and thus ground water flows roughly south-southeast.

The Cierbo Formation (Tmss) is saturated beneath Doall Ravine, the Building 851 and 854 areas, and the southern part of the East Firing Area. Tmss is unsaturated or does not otherwise yield water to wells in other parts of the East and West Firing Areas. The thickness of the Cierbo Formation is not well-known because most boreholes are not deep enough to completely penetrate this formation. Some of the deeper wells in the GSA penetrate the uppermost Tmss. The continuity of saturation in the Tmss between the northwest and southeast areas of Site 300 is undetermined. Ground water in the Tmss occurs under unconfined to artesian conditions.

The Tps unit is the youngest bedrock unit identified at Site 300 and is generally present only on hilltops. Where present, ground water is frequently perched, discontinuous, and ephemeral. The exception to this condition exists in the Explosives Process Area, where the extent of saturation in Tps sediments is significant. Ground water in the Tps unit is generally unconfined, although water under confined conditions does occur locally.

Quaternary alluvium (Qal) is present as valley fill in ravines throughout Site 300 but is saturated only in the Corral Hollow Creek stream channel, in Doall Ravine in the West Firing Area, and in southern Elk Ravine in the East Firing Area near a spring. Saturated Quaternary terrace alluvium deposits (Qt) are present at Pit 6, the GSA, and in the Building 832 Canyon area; some of these ground water occurrences are ephemeral. Small quantities of ground water are present in some local landslide (Qls) deposits.

All ground water contaminant plumes at Site 300 occur in Neroly Formation (Tn) rocks, unamed Pliocene nonmarine sediments (Tps), or unconsolidated Quaternary sediments (Qal , Qls, or Qt) stratigraphic units. The extent of ground water contamination at Site 300 is shown on Figure 8-11. 


\section{Ground Water Investigation and Remediation}

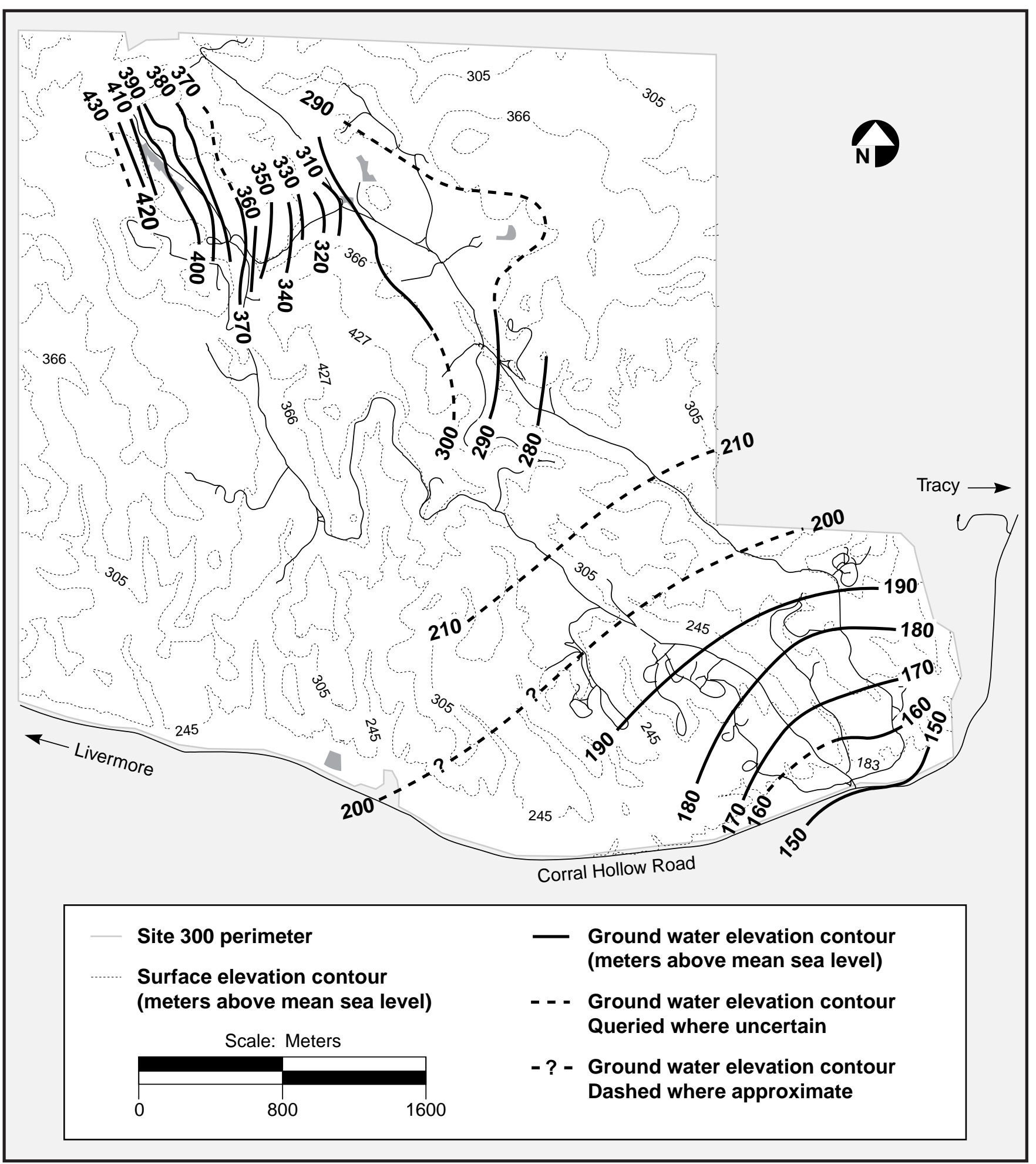

Figure 8-10. Approximate ground water elevations in the principal continuous water-bearing zone at Site 300. 

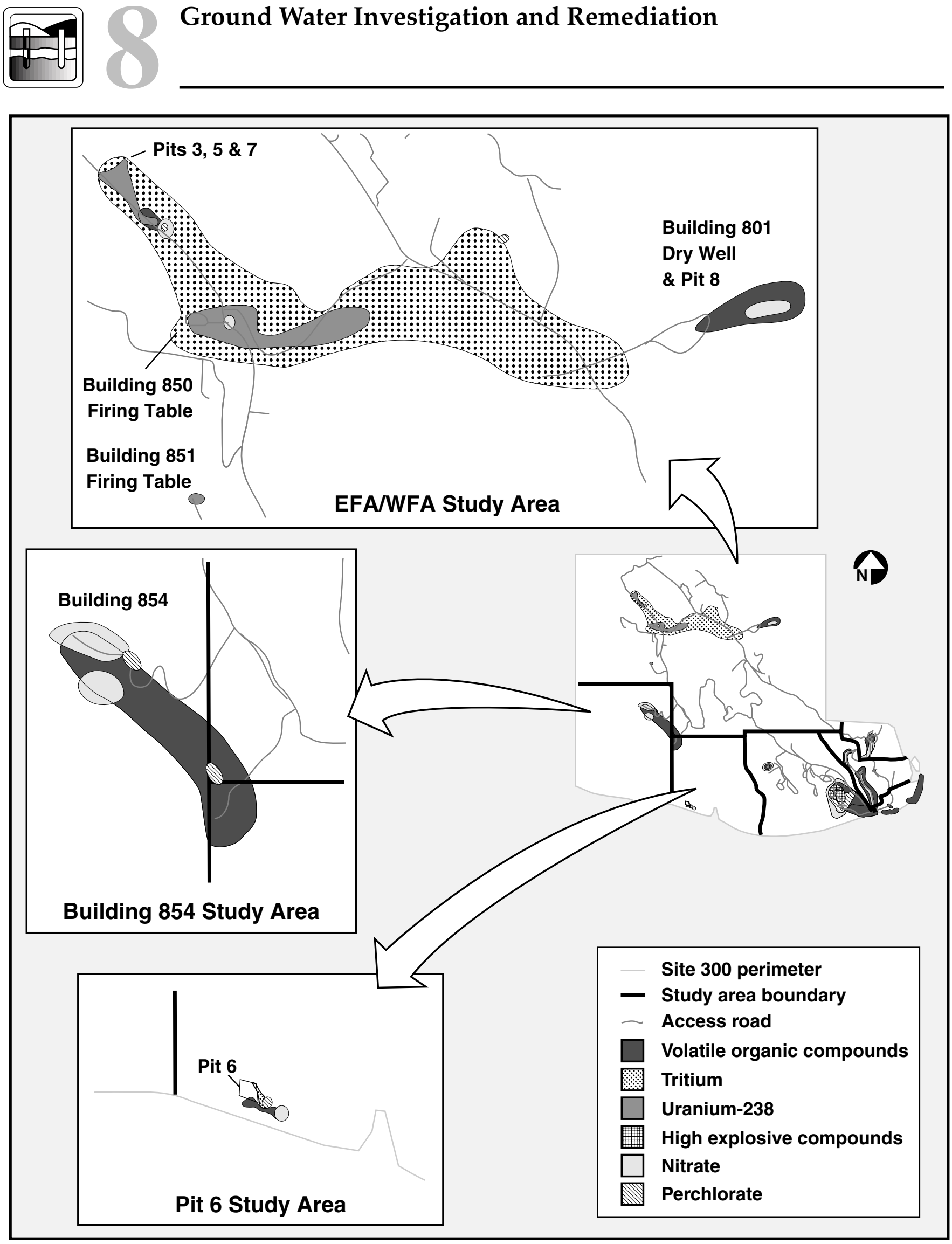

Figure 8-11. Extent of ground water contamination at LLNL Site 300. 
Site 300 perimeter

- Study area boundary

— Access road

$\square$ Volatile organic compounds

?ritium

Uranium-238

High explosive compounds

Nitrate

$\mathbb{P}$ Perchlorate

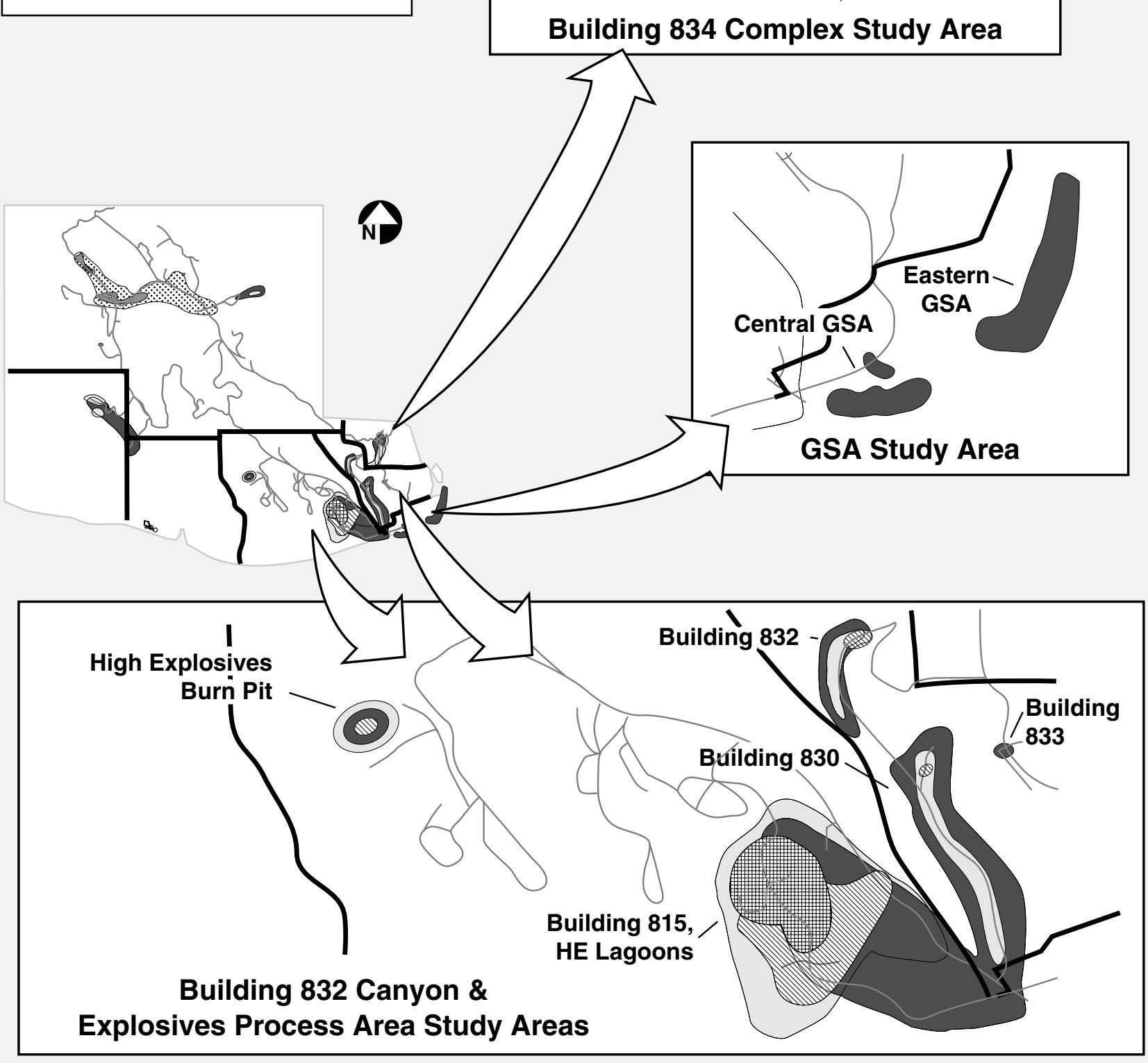




\section{Ground Water Investigation and Remediation}

\section{Study Area Highlights and Activities}

Background information for LLNL environmental characterization and restoration activities at Site 300 can be found in the Final Site-Wide Remedial Investigation Report, Lawrence Livermore National Laboratory Site 300 (Webster-Scholten 1994). Ground water remediation for Site 300 is discussed later in this chapter. See Chapter 9 for a discussion of 1998 ground water monitoring.

\section{General Services Area}

In the General Services Area (GSA), past leaks of solvents from storage areas and other facilities have resulted in several plumes of VOCs in ground water. Two ground water TCE plumes and two corresponding treatment facilities are present at both the eastern and central GSA. The VOC ground water plume in the eastern GSA is present in stream channel alluvium (Qal) at 3-9 $\mathrm{m}$ below ground surface; the plume is about $600-\mathrm{m}$ long (Figure 8-12). Ground water in the alluvium flows down Corral Hollow Creek, east and northeast. Maximum fourth quarter 1998 total VOC concentrations were $11 \mathrm{ppb}$. The Qal is hydraulically connected to the Neroly Formation lower blue sandstone (Tnbs 1 ) unit.

The two VOC ground water plumes in the central GSA are present in terrace alluvium (Qt) and Neroly Formation upper blue sandstone (Tnbs 2 ), at a depth of 3-9 m below ground surface. These VOC plumes are about 200-m and 430-m long (Figure 8-13). Maximum fourth quarter 1998 total VOC concentrations were $540 \mathrm{ppb}$. Deeper regional ground water also contains total VOCs at a maximum fourth quarter 1998 concentration of $27 \mathrm{ppb}$. This ground water occurs at depths of 11-56 $\mathrm{m}$ below ground surface.

Details of current and planned environmental restoration activities at the GSA are summarized in the Final Remedial Design document (Ferry et al. 1998), submitted to the regulatory agencies in February 1998. The remedial design document includes the Contingency Plan and Compliance Monitoring Plan for the GSA operable unit (OU).

\section{Building 834 Area}

The Building 834 facility contains buildings where, in the past, TCE was used as a heat transfer fluid. Several large spills of TCE to the ground resulted in TCE contamination of a shallow perched water-bearing zone beneath the site. An isolated, perched waterbearing zone occurs in Pliocene nonmarine gravels (Tpsg) and occurs at a maximum depth of $9 \mathrm{~m}(30 \mathrm{ft})$ below the center of the complex. This perched zone crops out on all sides of the hill housing the Building 834 complex and is isolated from the underlying regional aquifer by over $60 \mathrm{~m}$ of vadose zone. The water-bearing zone contains maximum 1998 concentrations of TCE and 1,2-DCE of about 120,000 and 60,000 ppb, respectively. The resulting VOC plume is about 600-m long (Figure 8-14). Maximum 


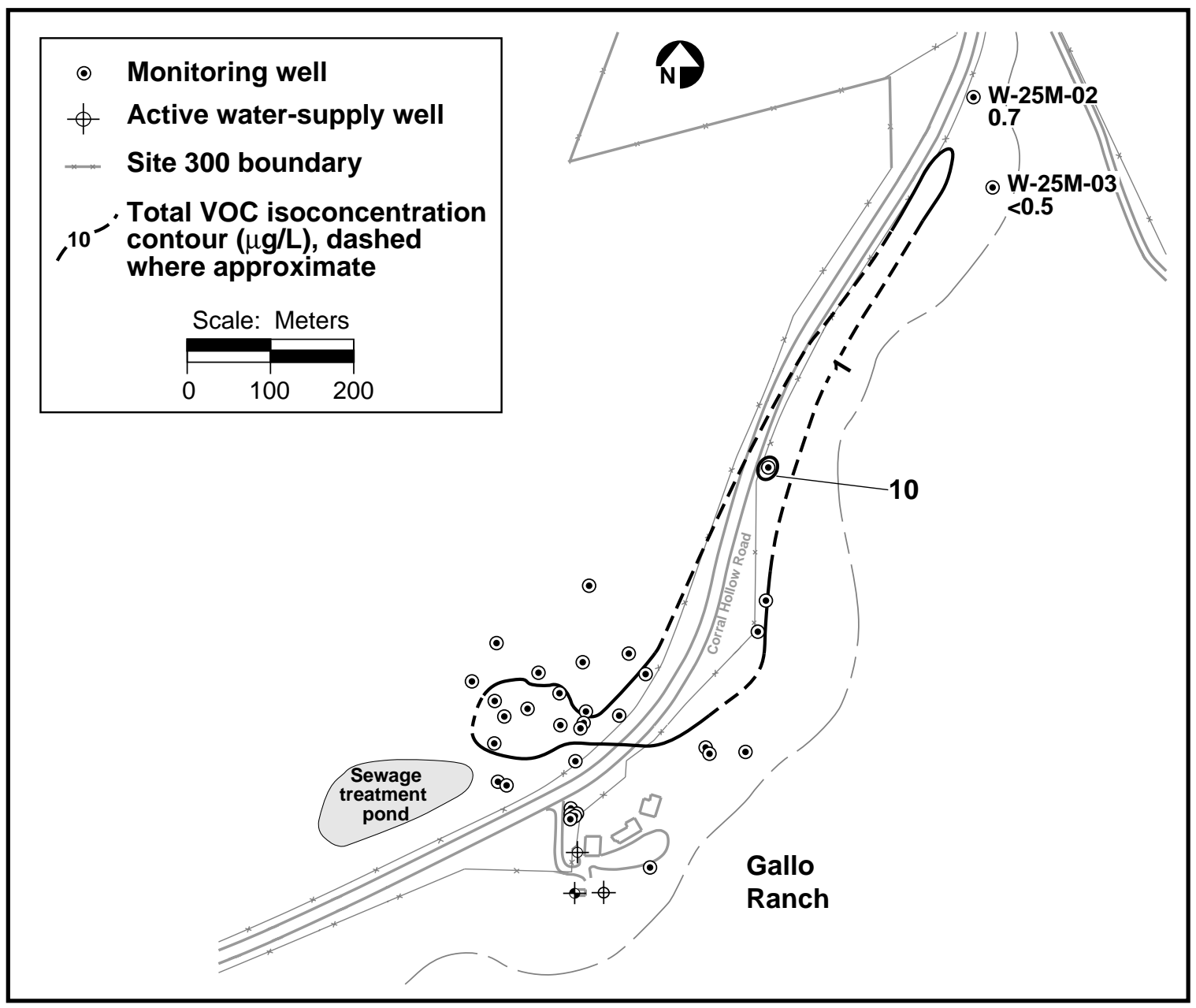

Figure 8-12. Total VOC concentrations in ground water in the eastern GSA and vicinity (second quarter, 1998). Monitor wells are completed in alluvial/shallow bedrock aquifer.

ground water nitrate concentrations are about $280 \mathrm{ppm}$. A silicate oil (tert-butyl orthosilicate) has been detected at maximum 1998 concentrations of 12,000 ppb. Currently, ground water and soil vapor extraction and treatment, using air-sparging and GAC, respectively, are in progress.

\section{Explosives Process Area}

The Explosives Process Area was established in the 1950s to chemically formulate, mechanically press, and machine high explosives (HE) compounds into detonation devices that are tested in explosives experiments in the East and West Firing Areas of Site 300. Process waste water from HE machining operations containing 

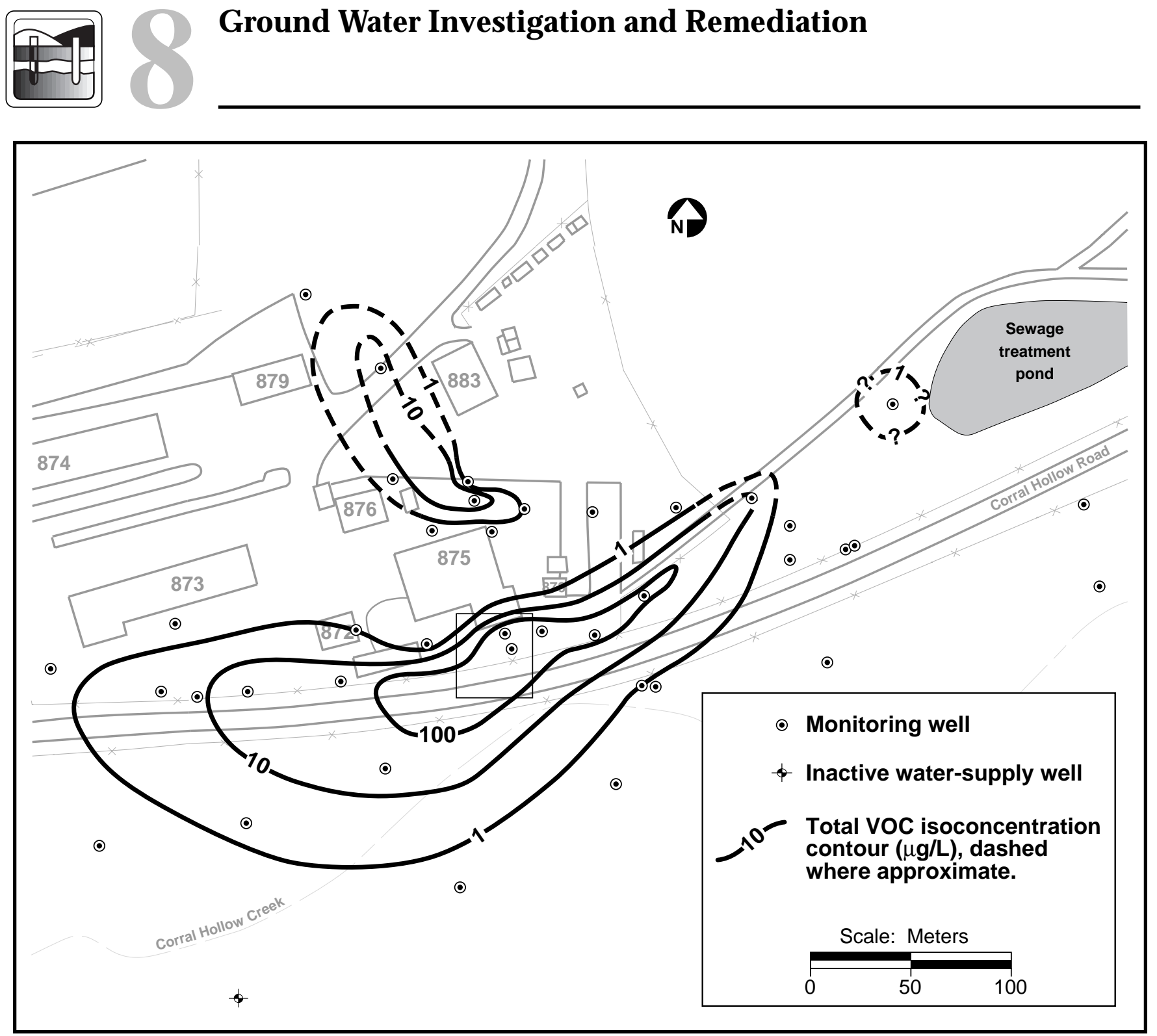

Figure 8-13. Total VOC concentrations in ground water in the central GSA (fourth quarter, 1998). Question marks indicate that the contour is unknown. Monitoring wells are completed in the Qt-Tnsc 1 hydrologic unit.

cyclotetramethyltetramine (HMX), hexahydro-1,3,5-trinitro-1,3,5-triazine (RDX), and nitrate was discharged to nine former unlined lagoons at concentrations high enough to impact ground water. A TCE hardstand located near the former Building 815 steam plant is considered to be the primary source of TCE ground water contamination. HMX and RDX are the most frequent and widespread HE compounds detected in soil and ground water. TCE, nitrates, and the RDX occur in two perched, water-bearing zones within the HE Process Area. These two water-bearing zones occur in Tps sediments and Tnbs $_{2}$ sandstone, respectively. Ground water occurs in these two zones at depths of 2-30 m, and 20-76 m, respectively. The VOC (principally TCE) plumes in Tps strata are 


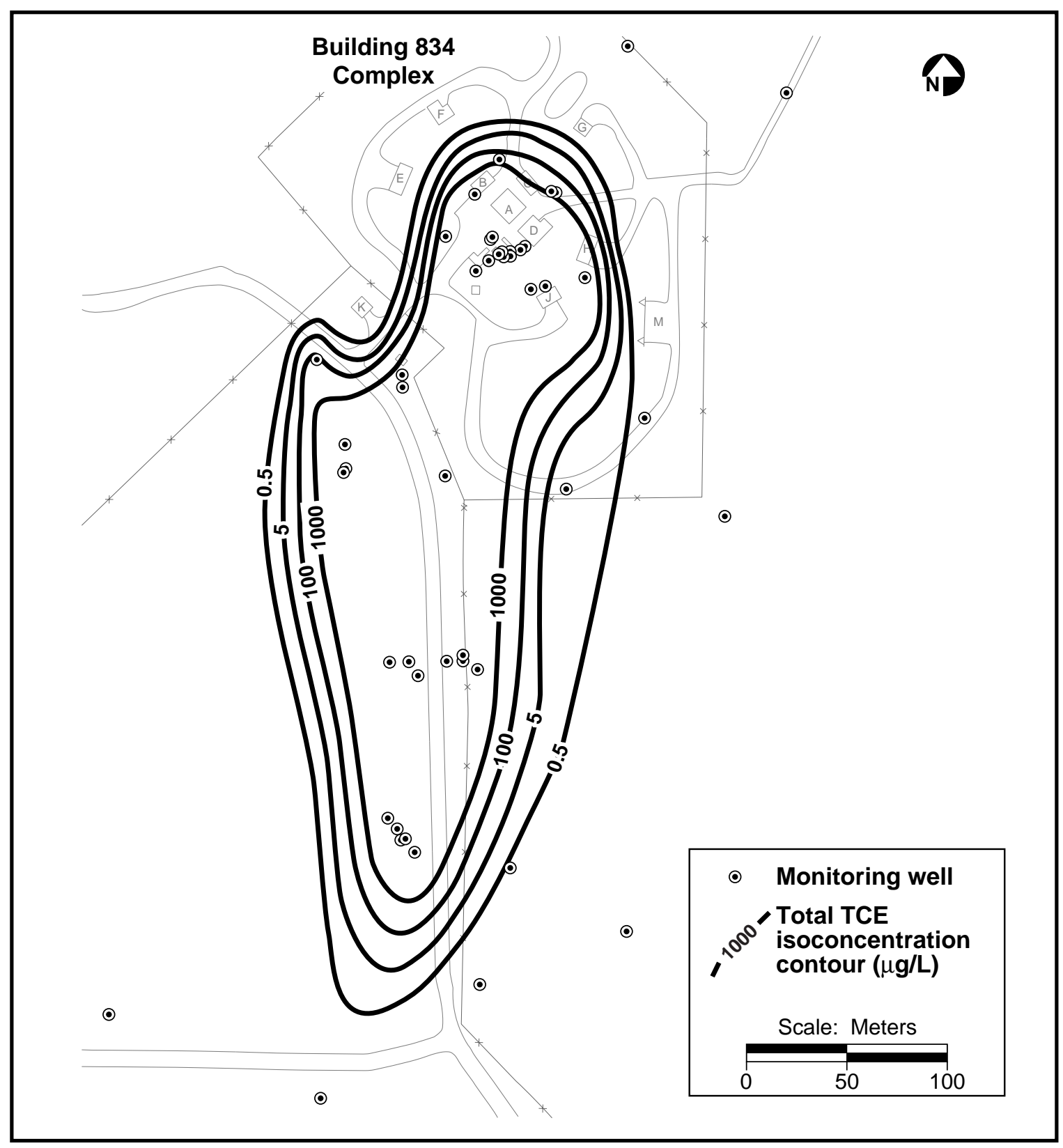

Figure 8-14. Distribution of trichloroethene in ground water in the Building 834 area (second quarter, 1998).

about 550-m and 200-m long (Figure 8-15). The RDX plume in Tnbs 2 strata is about 1200-m long. The perchlorate plume in Tnbs 2 strata is 4900-m long. Current 1998 maximum concentrations of 1,1-DCE, 1,2-DCE, and TCE are 4.7, 3, and $330 \mathrm{ppb,}$ respectively. Maximum concentrations of RDX, HMX, nitrate, and perchlorate are 87, 67, $102 \mathrm{ppm}$, and $50 \mathrm{ppb}$, respectively. A small plume of TCE (maximum 1998 


\section{Ground Water Investigation and Remediation}

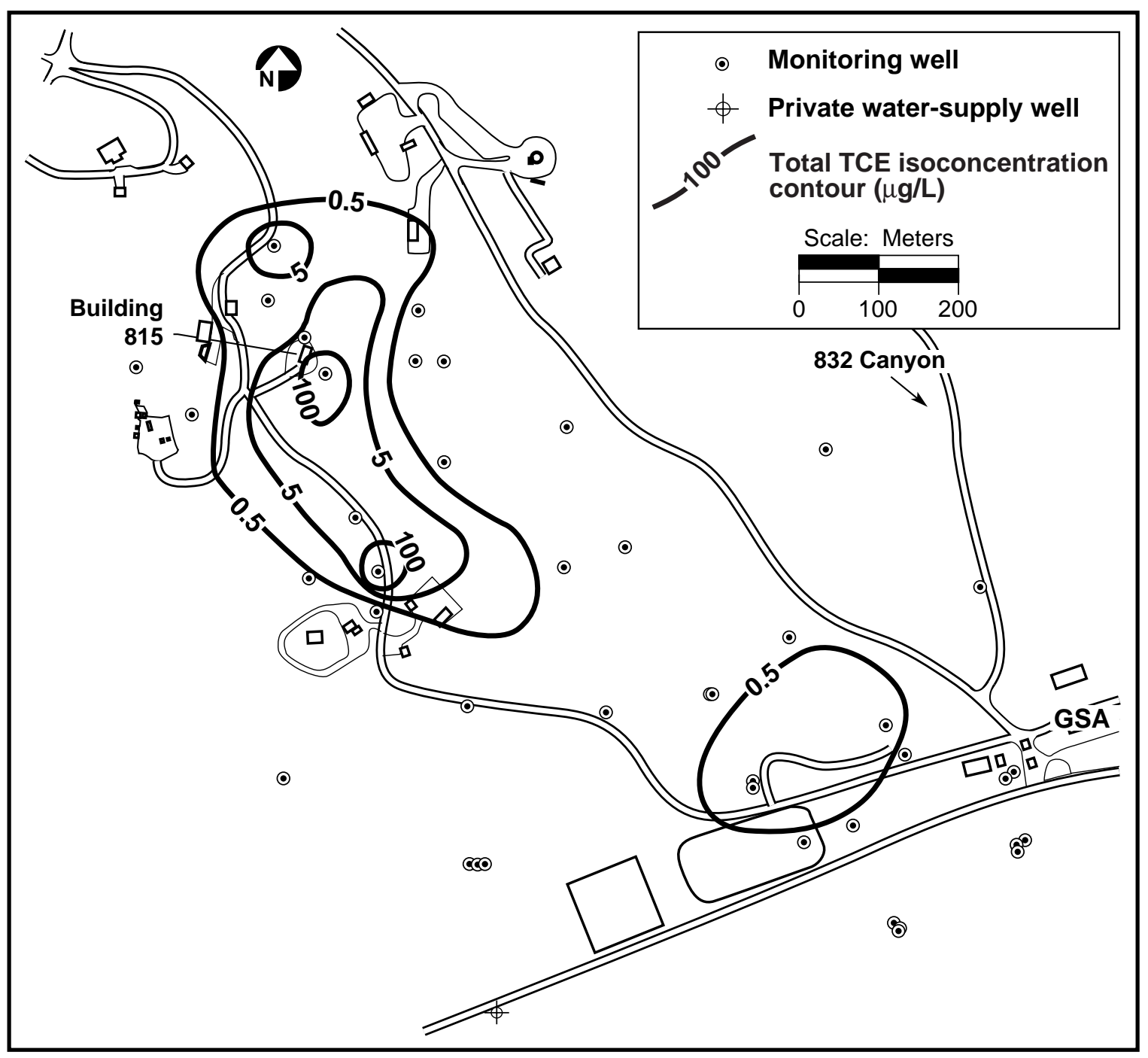

Figure 8-15. Distribution of trichloroethene in the Explosives Process area (second quarter, 1998). Monitoring wells are completed in the Tps aquifer.

concentration of $310 \mathrm{ppb}$ ) also occurs in a local perched water-bearing zone that occurs in Tnsc 1 strata at a depth of 24-30 m below the HE burn pits; this plume is less than 5-m long. These burn pits were closed and capped under RCRA in 1998.

\section{East and West Firing Areas}

Explosives experiments conducted at outdoor firing tables in this area have generated wastes that were disposed at several unlined landfills in the past. Tritium has been released to ground water from landfill Pits 3 and 5 and the Building 850 firing table (Figure 8-16). Depleted uranium has been released to ground water from landfill Pits 5 


\section{Ground Water Investigation and Remediation}

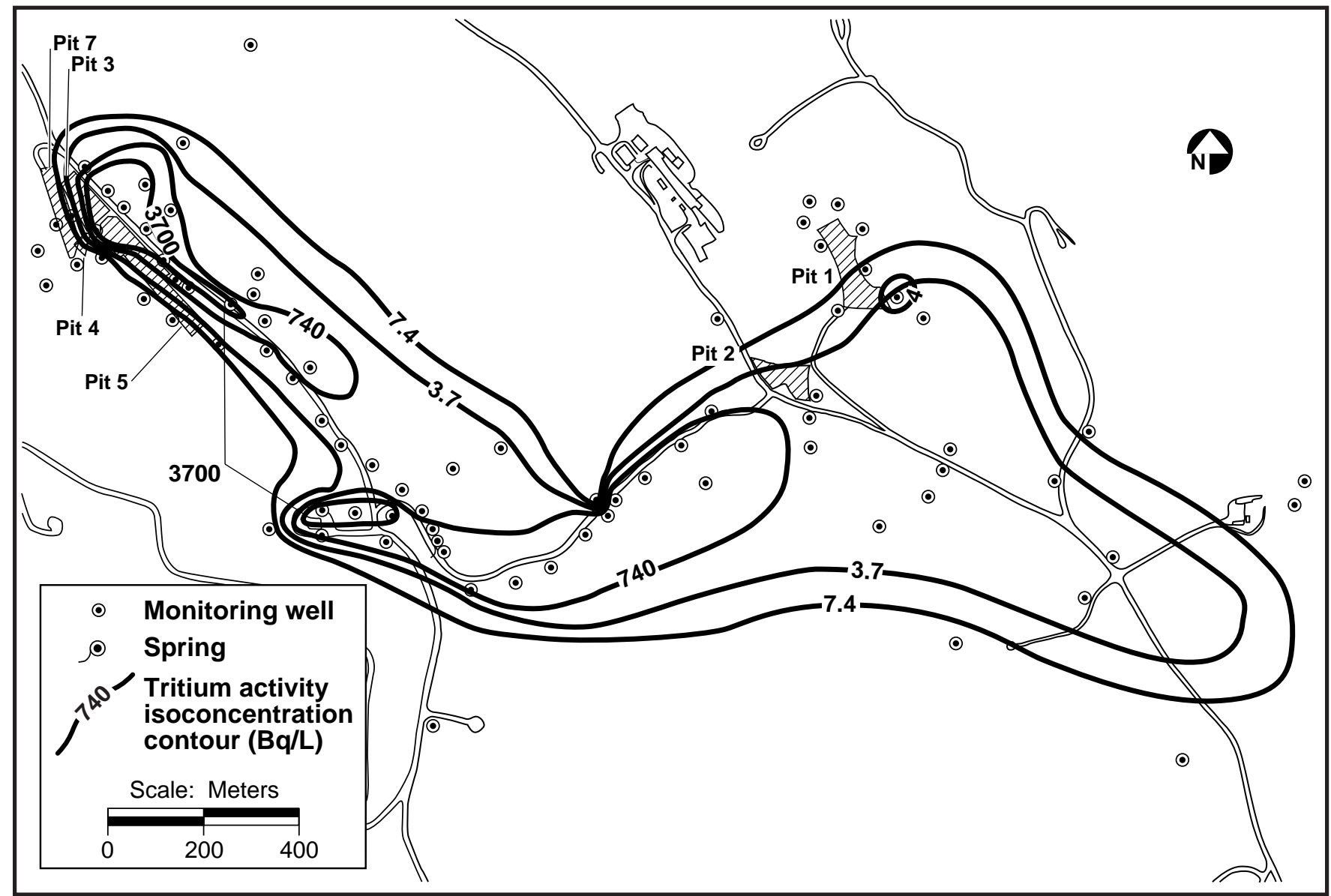

Figure 8-16. Distribution of tritium in ground water in the first water-bearing zone in the Building 850/Pit 3 and 5 area (second quarter, 1998).

and 7 and the Building 850 firing table. The resulting plumes occur in a perched waterbearing zone within Qal and Tnbs 1 . The water-bearing zone occurs at depths of 5-20 m below surface. There are two overlapping plumes of tritium in ground water at maximum 1998 activities of about 2.7 million $\mathrm{pCi} / \mathrm{L}$. The total length of the commingling tritium plumes is about $3000 \mathrm{~m}$. The perched water-bearing zone is connected to the regional Tnbs 1 aquifer at the Elk Ravine Fault. Maximum tritium activities in this aquifer are about $5000 \mathrm{pCi} / \mathrm{L}$. There are two smaller plumes of depleted uranium (uranium-238) in ground water, with maximum 1998 activities of less than $100 \mathrm{pCi} / \mathrm{L}$. The depleted uranium is confined to the perched water-bearing zone; the lengths of these two uranium plumes are $370 \mathrm{~m}$ and $500 \mathrm{~m}$. Computer modeling of the transport and fate of the tritium indicates that by the time the tritium and uranium in ground water reach the Site 300 boundary, these radionuclides will exist at near-background activities. 


\section{Ground Water Investigation and Remediation}

The annual assessment of tritium inventories in ground water that began in 1985 continued in 1998. The analysis, which included evaluation of the inventories of tritium in the vadose zone available for leaching to ground water, indicated that the two tritium plumes emanating from the landfill are stable with regard to measured tritium concentrations and area impacted, while the Building 850 plume is decreasing at the radioactive decay rate. Although tritium continues to leach into ground water from vadose zone sources, the long-term trend in total ground water tritium activity is one of decreasing activity at approximately the radioactive decay rate of tritium.

In 1998, LLNL submitted to the regulatory agencies the Ground Water Tritium Plume Characterization Summary Report for the Building 850/Pits 3 and 5 Operable Unit, Lawrence Livermore National Laboratory Site 300 on October 30, 1998 (Ziagos and Reber-Cox 1998b). The report documents our assessment of semiannual ground water tritium inventories, vadose-zone tritium inventory, and an update on hydrogeology in the operating unit.

Several other contaminants in ground water are being investigated by LLNL at the East and West Firing Areas. Nitrates and perchlorates in the Building 850/Pit 3 and 5 areas occur at maximum 1998 concentrations of less than 100 ppm and $8.7 \mathrm{ppb}$, respectively. Trace amounts of TCE (less than $3 \mathrm{ppb}$ ) are also present in ground water near Pit 5 . TCE also occurs in a small ground water plume monitored by two wells at the Building 801 firing table. Freon-113 at concentrations significantly below the California maximum contaminant level of $1.2 \mathrm{ppm}$ is present near Pit 1 and is the result of spills at Building 865 (Advanced Test Accelerator).

Depleted uranium isotopic signatures have been detected in ground water samples from wells adjacent to the Building 851 firing table, indicating that some depleted uranium is reaching ground water. No monitor wells have yet been drilled at Building 812, a firing table where depleted uranium and thorium were used in explosives experiments. However, samples from an adjacent perennial spring indicate depleted uranium signatures.

Remedial investigations for the Building 812 and 865 areas are planned for the near future.

\section{Building 854 Study Area}

Trichloroethene in the ground water was previously found to arise principally from leaks in the former overhead TCE brine system at Buildings 854E and 854F. Trichloroethene, nitrates, and perchlorates occur in ground water in the Building 854 area in Neroly Formation Tnbs ${ }_{1}$ strata at maximum 1998 concentrations of 410, 180, and $7.4 \mathrm{ppb}$, respectively. The affected aquifer occurs at depths of 9-50 m below ground surface. The TCE plume is about 970-m long (Figure 8-17). 


\section{Ground Water Investigation and Remediation}

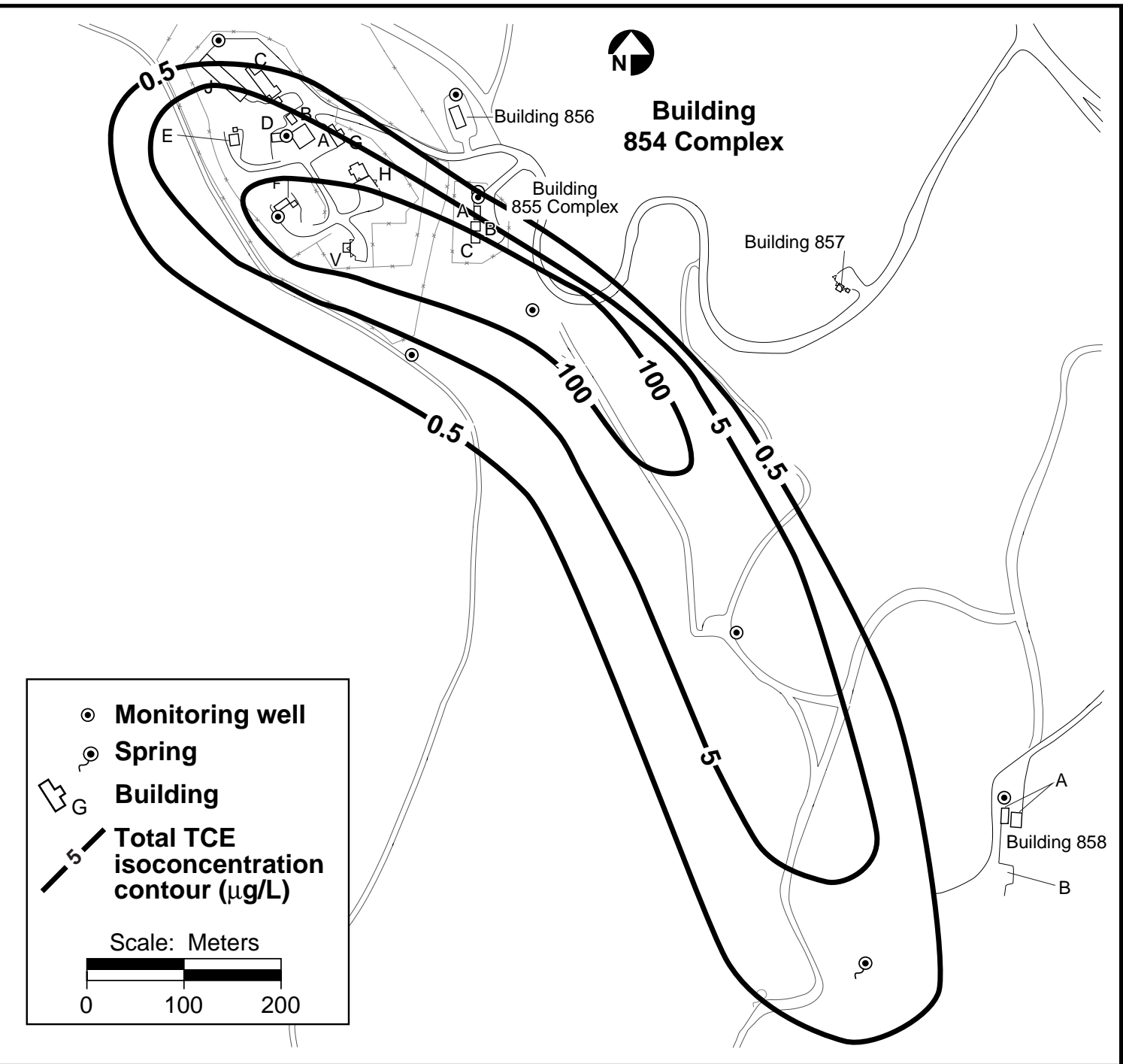

Figure 8-17. Distribution of trichloroethene in ground water in the Building 854 area (second quarter, 1998).

During 1998, LLNL continued to define the extent of TCE in soil, soil vapor, and ground water. Three new monitor wells were installed, and colloidal borescope surveys were performed. The colloidal borescope is an innovative downhole instrument that tracks natural colloids in the wellbore to measure ground water flow direction and seepage velocity. On April 1, 1998, LLNL submitted the Characterization Summary Report for the Building 854 Operable Unit (Ziagos and Reber-Cox 1998c) to the regulatory agencies. On May 28, 1998, LLNL submitted to the regulatory agencies a letter detailing the CERCLA pathway for the operable unit (U.S. Department of Energy 1998e). LLNL plans to begin installation and operation of a solar-powered potable treatment unit at Building 854 to treat extracted ground water containing VOCs in 1999. 


\section{Ground Water Investigation and Remediation}

\section{Pit 6 Area}

A small ground water TCE plume in a perched terrace alluvium $(\mathrm{Qt})$ water-bearing zone discharges to the surface at small springs at the southeastern edge of the Pit 6 area. The perched water-bearing zone occurs at depths of $0-11 \mathrm{~m}$ below ground surface. The source of the TCE plume is the southeast corner of the Pit 6 landfill. The TCE plume is about 200-m long (Figure 8-18). Because of natural volatilization of affected ground water at the springs, concentrations of VOCs in the plume have declined by more than tenfold since 1992. Current maximum TCE concentrations are about $16 \mathrm{ppb}$. Tritium (at maximum activities of $91 \mathrm{~Bq} / \mathrm{L}$ ), nitrate (at maximum concentrations of $228 \mathrm{ppm}$ ), and perchlorate (at maximum concentrations of $65.2 \mathrm{ppb}$ ) also occur in the perched waterbearing zone. Tritium also occurs in the Tnbs 1 regional aquifer which occurs at depths of 30-53 m below ground surface, at concentrations of up to $37 \mathrm{~Bq} / \mathrm{L}$. The lengths of the tritium and perchlorate plumes are 200 and $400 \mathrm{~m}$, respectively.

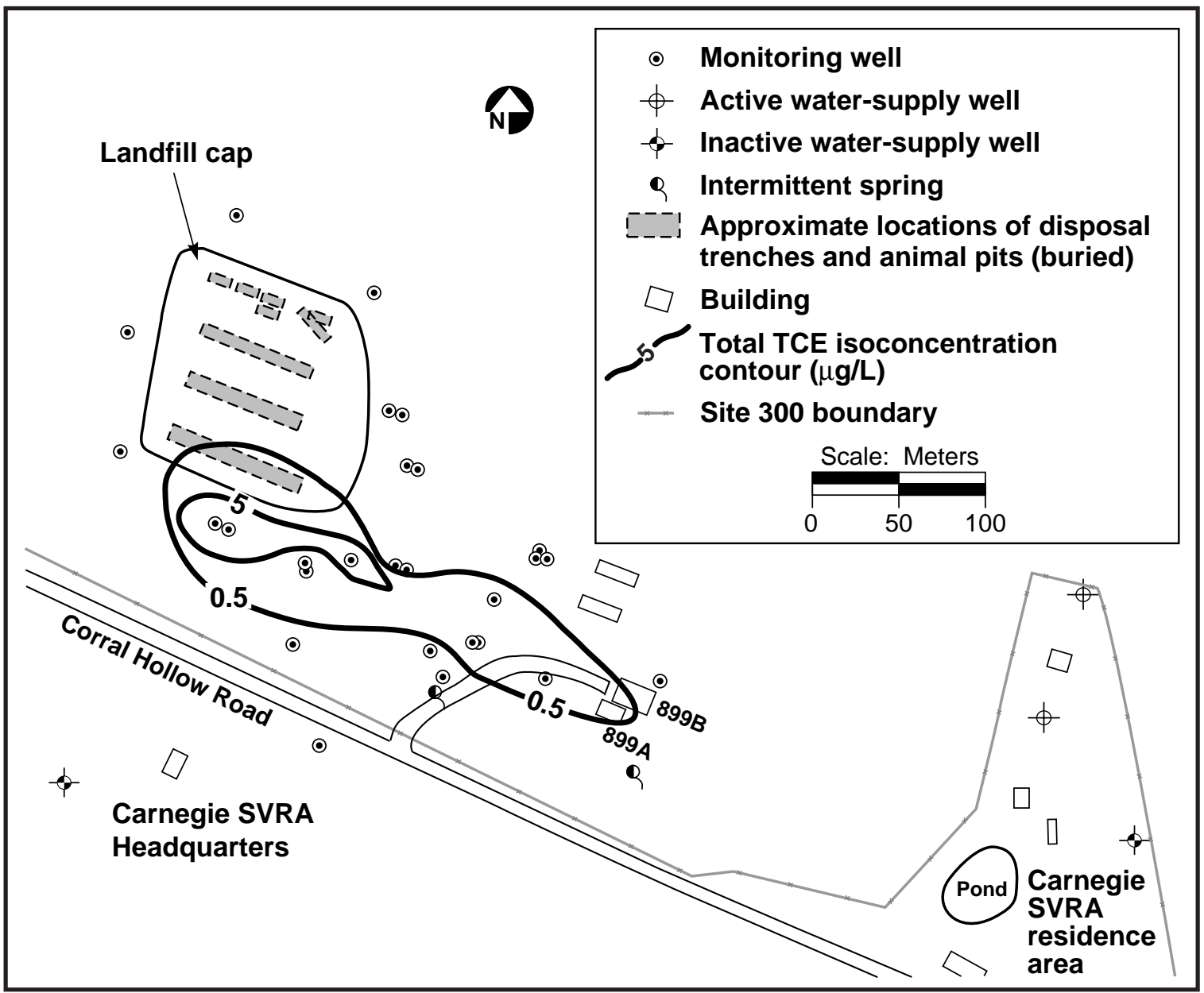

Figure 8-18. Distribution of trichloroethene in ground water in the Pit 6 area (second quarter, 1998). 


\section{Ground Water Investigation and Remediation}

During 1997, a 2.4-acre engineered cap was constructed over the landfill as a CERCLA nontime-critical removal action. During 1998, the Post-Closure Plan (Ferry et al. 1998) for the Pit 6 cap was submitted to the regulatory agencies. Additionally, a multi-well observation pump test was performed in the area of maximum ground water TCE concentration to determine hydraulic parameters and the effective radius of pumping. Volume and mass of ground water extracted and TCE treated, respectively, during this test are tabulated in Table 8-5.

\section{Building 832 Canyon Study Area}

At the Building 832 Canyon area (Buildings 830 and 832), solvents were released from weapons component test cells in the past. TCE and nitrate occur in ground water in Neroly Formation Tnsc1 silty-claystone strata 15-25 m beneath the Building 832 Canyon Study Area at maximum 1998 concentrations of 7900 ppb and 140 ppm, respectively. The TCE plume emanates from both the Building 830 and 832 areas and is about $1300-\mathrm{m}$ long (Figure 8-19). Perchlorate has also been detected at maximum concentrations of $22 \mathrm{mg} / \mathrm{L}$. Well drilling during 1998 indicated that the TCE contaminant plume and the nitrate in ground water, both emanating from the Building 832 complex, are likely merging with the TCE and nitrate in ground water coming from Building 830, giving rise to the TCE plume. Perchlorate has also been detected in ground water samples from 18 monitor wells in the area.

In 1998, LLNL completed 12 wells in the Building 832 complex, near the suspected test cell release sites, for TCE extraction and monitoring and began construction of the treatment system. LLNL plans to use green technologies to treat ground water in the Building 832 Canyon area. A DOE Technology Deployment Initiative (TDI) using iron filings as a treatment system for TCE is in the design and testing phase.

\section{Environmental Remediation at Site 300}

Dedicated ground water and soil vapor extraction and treatment facilities exist at the eastern GSA, central GSA, and Building 834 areas. The central GSA treatment facility and the eastern GSA treatment facility discharge to surface drainage courses. Treated water from a pump test at Pit 6 was also discharged to a drainage channel just south of the pit. Table 8-5 summarizes calendar year 1998 and cumulative totals of volumes and masses of contaminants removed from ground water and soil vapor at the Site 300 . Also in 1998, treatment facility construction, design, and treatability testing activities began for the Explosives Process and Building 832 areas. 


\section{Ground Water Investigation and Remediation}

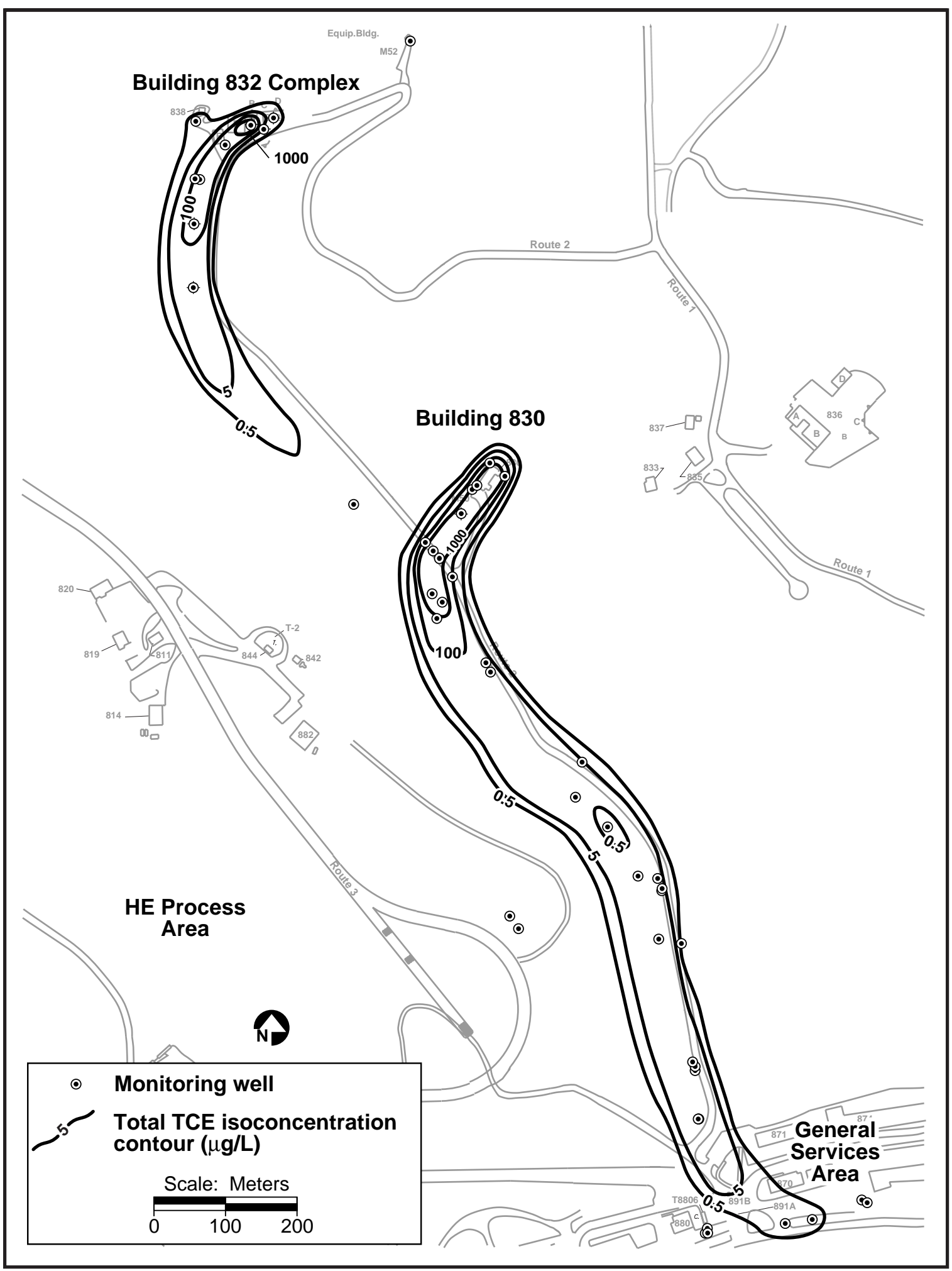

Figure 8-19. Distribution of trichloroethene in the combined Qal, Tnbs 2 , and Tnsc 1 aquifers in the Building 832 Canyon (second quarter, 1998). 
Table 8-5. Volatile organic compounds (VOCs) removed from ground water and soil vapor at Site 300.

\begin{tabular}{|c|c|c|c|c|c|}
\hline \multirow[b]{2}{*}{$\begin{array}{l}\text { Treatment } \\
\text { area }\end{array}$} & \multirow[b]{2}{*}{$\begin{array}{l}\text { Startup } \\
\text { date }\end{array}$} & \multicolumn{2}{|c|}{1998} & \multicolumn{2}{|c|}{ Cumulative total } \\
\hline & & $\begin{array}{l}\text { Water treated } \\
(\mathrm{ML})^{(a)}\end{array}$ & $\begin{array}{c}\text { VOCs } \\
\text { removed }(\mathrm{kg})\end{array}$ & $\begin{array}{l}\text { Water treated } \\
(M L)^{(a)}\end{array}$ & $\begin{array}{c}\text { VOCs } \\
\text { removed }(\mathrm{kg})\end{array}$ \\
\hline \multicolumn{6}{|l|}{ General Services Area } \\
\hline Eastern GWTF(b) & $6 / 91$ & 69.1 & 0.34 & 478 & 5.6 \\
\hline Central GWTF & $4 / 93$ & 1.6 & 0.93 & 4.8 & 6.5 \\
\hline Building 834 & $10 / 95$ & 0.164 & 3.66 & 0.413 & 19.2 \\
\hline Pit 6 & $11 / 98$ & 0.268 & 0.0014 & 0.268 & 0.0014 \\
\hline & & $\begin{array}{l}\text { Soil vapor } \\
\text { treated }\left(\mathbf{m}^{3}\right)\end{array}$ & $\begin{array}{c}\text { VOCs } \\
\text { removed }(\mathrm{kg})\end{array}$ & $\begin{array}{l}\text { Soil vapor } \\
\text { treated }\left(\mathbf{m}^{3}\right)\end{array}$ & $\begin{array}{c}\text { VOCs } \\
\text { removed (kg) }\end{array}$ \\
\hline \multicolumn{6}{|l|}{ General Services Area } \\
\hline Central & 1994 & 557,530 & 9.16 & $1,003,665$ & 39.46 \\
\hline Building 834 & 1998 & 49,191 & 7.27 & 49,191 & 7.27 \\
\hline
\end{tabular}

a $\mathrm{ML}=1$ million liters.

b GWTF = Ground water treatment facility.

\section{General Services Area}

The Remedial Design Document for the GSA Operable Units was submitted to the regulatory agencies on February 16, 1998. The soil vapor extraction and treatment system in the central GSA dry-well source area was consistently operated and maintained to reduce VOC concentrations in soil vapors, remediate dense nonaqueous-phase liquids in the soil, and mitigate the VOC inhalation risk inside Building 875 . The ground water extraction and treatment systems in the central and eastern GSA area were consistently operated and maintained to reduce VOC concentrations in the ground water to drinking water maximum contaminant levels (MCLs), prevent further migration of the contaminant plume, and dewater the shallow water-bearing zone in the Building 875 dry-well area to enhance soil vapor extraction. Wells W-7Q, W-7R, W-7S, and W-7T were installed within the central GSA as monitor wells. These wells are being considered as possible extraction wells for the expansion of the ground water treatment facility. Based on the NPDES permit 5-year review, sampling requirements were reduced at the eastern GSA groundwater treatment facility.

The eastern GSA treatment facility employs granular activated carbon (GAC) canisters to remove VOCs from extracted ground water. Extracted central GSA ground water is 


\section{Ground Water Investigation and Remediation}

run through an air-sparging PTU to remove VOCs. Extracted soil vapor at the central GSA is run through GAC canisters to remove VOCs.

Ground water treated at the eastern GSA ground water treatment facility was discharged off site to the Corral Hollow Creek, in accordance with NPDES Permit No. CA0082651.

Table 8-5 shows the amount of the water treated and VOCs removed at the eastern GSA. The length of the eastern GSA TCE plume with concentrations over the cleanup standard of $5 \mathrm{ppb}(\mathrm{MCL})$ has been reduced by over $1400 \mathrm{~m}$. The off-site portion of the plume now extends only $30 \mathrm{~m}$ beyond the site boundary. TCE concentrations in influent from the eastern GSA ground water treatment system were reduced from 64 ppb in January 1992 to $11 \mathrm{ppb}$ in November, 1998. Only one off-site well in the eastern GSA has a TCE concentration over the cleanup standard of $5 \mathrm{ppb}$ (MCL). LLNL estimates that seven more years of ground water extraction and treatment will be required to achieve and maintain ground water VOC concentrations below MCLs at the eastern GSA.

At the central GSA treated ground water was collected and batch-discharged in a remote Site 300 canyon, in accordance with the substantive requirement for wastewater discharge. TCE concentrations in central GSA ground water treatment system (GWTS) influent have been reduced from 9400 ppb in 1993 to 410 ppb in 1998.

Following dewatering of bedrock through ground water extraction, soil vapor extraction and treatment of VOCs began in 1994. Table 8-5 shows the amounts of soil vapor treated and VOCs removed at the central GSA. From 1994 through the end of 1998, VOC concentrations in the central GSA soil vapor extraction influent stream were reduced from $450 \mathrm{ppmv}$ to $2.3 \mathrm{ppmv}$. VOC concentrations in individual central GSA soil vapor extraction wells have been significantly reduced.

The central GSA ground water treatment system is operating under substantive requirements for wastewater discharge issued by the Central Valley RWQCB. The central GSA treatment facility discharges to bedrock in the eastern GSA canyon, where the water percolates into the ground. The eastern GSA ground water treatment system operates under NPDES Permit No. CA0082651, issued by the Central Valley RWQCB for discharges into Corral Hollow Creek. The system operated under WDR91-052 until December 5, 1997, when WDR 97-242 was issued. Permit requirements for the central and eastern GSA ground water treatment system are listed in Table 8-6. Both the central and eastern GSA treatment systems operated in compliance with regulatory requirements during 1998. LLNL submitted quarterly reports for the GSA treatment systems to the California EPA and the RWQCB in accordance with the National Pollutant Discharge Elimination System Order No. 97-242 for the eastern GSA and the Substantive Requirements for Waste Discharge for the Central GSA (Lamarre 1998a, b, c, and d). 


\section{Ground Water Investigation and Remediation}

Table 8-6. General Services Area ground water treatment system surface discharge permit requirements.

\begin{tabular}{|c|c|c|}
\hline \multirow[b]{2}{*}{ Parameter } & \multicolumn{2}{|c|}{ Treatment facility } \\
\hline & Central General Services Area & Eastern General Services Area \\
\hline VOCs & Halogenated and aromatic VOCs & Halogenated VOCs \\
\hline Maximum daily & $5.0 \mu \mathrm{g} / \mathrm{L}$ & $5.0 \mu \mathrm{g} / \mathrm{L}$ \\
\hline Monthly median & $0.5 \mu \mathrm{g} / \mathrm{L}$ & $0.5 \mu \mathrm{g} / \mathrm{L}$ \\
\hline Dissolved oxygen & $\begin{array}{l}\text { Discharges shall not cause the concentrations of } \\
\text { dissolved oxygen in the surface water drainage } \\
\text { course to fall below } 5.0 \mathrm{mg} / \mathrm{L} \text {. }\end{array}$ & $\begin{array}{l}\text { Discharges shall not cause the concentrations } \\
\text { of dissolved oxygen in the surface water } \\
\text { drainage course to fall below } 5.0 \mathrm{mg} / \mathrm{L} \text {. }\end{array}$ \\
\hline pH (pH units) & $\begin{array}{l}\text { Between } 6.5 \text { and } 8.5 \text {, no receiving water alteration } \\
\text { greater than } \pm 0.5 \text { units. }\end{array}$ & $\begin{array}{l}\text { Between } 6.5 \text { and } 8.5 \text {, no receiving water } \\
\text { alteration greater than } \pm 0.5 \text { units. }\end{array}$ \\
\hline Temperature & $\begin{array}{l}\text { No alteration of ambient receiving water conditions } \\
\text { more than } 3^{\circ} \mathrm{C} \text {. }\end{array}$ & $\begin{array}{l}\text { No alteration of ambient receiving water } \\
\text { conditions more than } 3^{\circ} \mathrm{C} \text {. }\end{array}$ \\
\hline Place of discharge & $\begin{array}{l}\text { To ground water during dry weather and to surface } \\
\text { water drainage course in eastern GSA canyon during } \\
\text { wet weather. }\end{array}$ & Corral Hollow Creek. \\
\hline Flow rate & $\begin{array}{l}272,500 \mathrm{~L} \text { (30-day average daily dry weather } \\
\text { maximum discharge limit). }\end{array}$ & 272,500 L per day \\
\hline Mineralization & $\begin{array}{l}\text { Mineralization must be controlled to no more than a } \\
\text { reasonable increment. }\end{array}$ & $\begin{array}{l}\text { Mineralization must be controlled to no more } \\
\text { than a reasonable increment. }\end{array}$ \\
\hline $\begin{array}{l}\text { Methods and } \\
\text { detection limits for } \\
\text { VOCs }\end{array}$ & $\begin{array}{l}\text { EPA Method } 601 \text { - detection limit of } 0.5 \mu \mathrm{g} / \mathrm{L} \text {. } \\
\text { EPA Method } 602-\text { method detection limit of } 0.3 \mu \mathrm{g} / \mathrm{L} \text {. }\end{array}$ & EPA Method 601 -detection limit of $0.5 \mu \mathrm{g} / \mathrm{L}$. \\
\hline
\end{tabular}

\section{Building 834 Complex}

In January 1998, the GWTS was returned to full-scale operation after running intermittently for the second half of 1997 . Work commenced to automate the system to allow for 24-hour operation in future years. Most importantly, a soil vapor extraction system was activated in July of 1998 that helped to triple mass removal at the site by extracting an additional $7 \mathrm{~kg}$ of VOCs from the subsurface over the course of the year. In order to increase the effectiveness of the treatment system even more, a work plan was put in place to expand the extraction wellfield by 1999 by converting a number of monitoring wells into combined ground water and soil vapor extraction wells. An analysis of historic site data with state-of-the-art computational tools was extremely valuable in visualizing the behavior of TCE and its derivatives at the site. Animated plume history analyses for TCE and its biotransformation product cis-1,2-dichloroethylene (cis-DCE) revealed that during 1989 to 1997: (1) the contour of the TCE plume did not expand, (2) concentrations of TCE decreased significantly in the release area, (3) biotransforma- 


\section{Ground Water Investigation and Remediation}

tion of TCE to cis-DCE was an important mechanism contributing to natural attenuation of TCE at the site, and (4) this biotransformation process depended on the presence of silicon oil in the plume. In laboratory experiments, staff from LLNL and the Oregon State University were able to reproduce and quantify some of the contaminant transformation processes occurring in the field. Two forthcoming peer-reviewed publications report on the novel microbial process that exploits alkoxysilane lubricants as drivers for TCE bioattenuation.

Table 8-5 shows amounts of water treated and VOCs removed at Building 834 .

Quarterly reports for the Building 834 treatment facility were submitted to the California EPA and the RWQCB in accordance with the Substantive Requirements for Waste Discharge (Lamarre 1998e, $\mathrm{f}, \mathrm{g}$, and h). Because treated ground water is discharged to misters and is not discharged to the ground, there are no treatment system surface discharge permit requirements for Building 834.

\section{Explosives Process Area}

The final Action Memorandum for the Building 815 Operable Unit Removal Action at Lawrence Livermore National Laboratory Site 300 (Jakub 1998) was submitted to the regulatory agencies on August 17, 1998. This report describes the main components of the removal action, estimates removal action costs, and addresses all verbal and written comments submitted by the community during the public workshop. The Building 815 Removal Action Design Workplan for the High Explosives Process Area at Lawrence Livermore National Laboratory Site 300 (Ziagos and Reber-Cox 1998a) was submitted to the regulatory agencies on November 15, 1998. This report describes the removal action in more detail and provides a contingency plan to address foreseeable problems that may arise during this removal action.

During 1998, LLNL capped the high explosives burn pits with an impermeable cap. A construction quality assurance report for the cap (Golder Construction Services 1998) was submitted to the regulatory agencies on September 9, 1998.

Two hydraulic tests were conducted during 1998 on wells located near the leading edge of the TCE plume at the Site 300 boundary to help design the extraction wellfield for the removal action. The objective of these tests was to determine long-term yield and hydraulic capture area. The hydraulic test results along with ground water modeling results were used to help design the removal action and prepare the removal action design work plan. The removal action consists of pumping and treating from two existing ground water monitoring wells, although additional wells may be added depending on the performance from these two wells. Ground water treatment will consist of removing TCE with aqueous phase granular activated carbon. 
Treatability testing began in 1998 to evaluate cost-effective ground water treatment technologies for the second phase of ground water cleanup. Most of the technologies being considered are dual-phase removal and destruction technologies to remediate nitrates and HE compounds, including perchlorate. These technologies use granular activated carbon, ion-exchange, or electro-migration for contaminant removal and ex-situ bioremediation for contaminant destruction. Phytoremediation, using indigenous grasses, is also being evaluated for treating nitrate-bearing ground water.

\section{Pit 6 Landfill Area}

During 1998, LLNL conducted a pump test at Pit 6, to determine hydraulic parameters of aquifer materials and to define the radial influence of pumping wells located in the center of mass of the ground water TCE plume. The test was also successful in reducing local ground water TCE concentrations to just slightly above detection limits. The volume of water extracted and TCE mass removed during the test is tabulated in Table 8-5. The test ran from October 11 to December 3, 1998.

\section{Building 832 Canyon}

The maximum concentration of TCE reported in ground water samples collected from wells in the Building 832 Canyon area was 7 ppm.

The first step toward TCE mass removal in the operable unit was completed with the submittal and acceptance of the Building 832 Canyon Operable Unit Treatability Study Workplan in November 1997. This workplan set forth plans for ground water and soil vapor TCE extraction and treatment in 1998 and beyond, using portable treatment units, solar-powered water activated-carbon treatment units, and soil vapor extraction systems. Also under consideration is the use of a subsurface iron filings permeable reactive treatment wall in the lower canyon area to intercept the TCE-laden ground water, destroy the TCE and degradation products, and help control the migration of the TCE plume off site.

\section{Community Relations}

LLNL met three times with members of Tri-Valley Citizens Against a Radioactive Environment and their technical advisor as part of the activities funded by an EPA Technical Assistance Grant. A public workshop for the Pit 6 removal action capping was held on January 15, 1997. 



\section{Ground Water Monitoring}

Eric Christofferson

Richard A. Brown

Rebecca Ward

Introduction

Sandra Mathews

Lawrence Livermore National Laboratory regularly samples and analyzes ground waters in the Livermore Valley and in the Altamont Hills. LLNL maintains multiple ground water monitoring programs to comply fully with environmental regulations, DOE orders, and the requirements of the Ground Water Protection Management Program (GWPMP). The two main objectives of the ground water monitoring programs described in this chapter are to measure compliance with waste discharge requirements and post-closure plans and to assess the impact, if any, of LLNL operations on ground water resources.

U.S. Department of Energy (DOE) Order 5400.1 and the to-be-promulgated 10 CFR 834 require all DOE facilities to prepare a GWPMP that describes the site's ground water regime, areas of known contamination, remediation activities, programs to monitor the ground water, and the means to monitor and control potential sources of ground water contamination. Considerable ground water monitoring and remediation, discussed in Chapter 8, is carried out under Comprehensive Environmental Response Compensation and Liability Act (CERCLA) restoration efforts. Soil and sediment surveillance monitoring under the GWPMP is described in Chapter 10. Additional programs address the sanitary sewer system, building drains, and underground storage tanks.

\section{Surveillance Monitoring}

Ground water monitoring at LLNL complies with DOE Order 5400.1, which affirms DOE's commitment to protect the environment. LLNL conducts surveillance monitoring of ground water in the Livermore Valley and in the Altamont Hills through networks that include private off-site wells and on-site wells. The two monitored areas and their aquifers are separated by a major drainage divide. The Livermore site in the Livermore Valley drains to San Francisco Bay via Alameda Creek. Most of Site 300 drains to the San Joaquin River via Corral Hollow Creek, with a small undeveloped portion in the north draining to the north and east toward Tracy. In order to have a comprehensive, cost-effective monitoring program, LLNL determines the number and 


\section{Ground Water Monitoring}

locations of surveillance wells, the analytes to be monitored, the frequency of sampling, and the analytical methods to be used.

A wide range of analytes is monitored to assess the impact of current LLNL operations on local water resources. Because surveillance monitoring is geared to detecting analytes at very low concentrations in ground water, it can detect contamination before it significantly impacts ground water resources. Wells at the Livermore site, in the Livermore Valley, and at Site 300 in the Altamont Hills are included in LLNL's surveillance monitoring plan.

\section{Compliance Monitoring}

The Compliance Ground Water Monitoring Program complies with numerous federal and state controls (see Chapter 2, Table 2-4, for a summary of LLNL permits). Compliance monitoring of ground water is conducted at Site 300 to satisfy state-issued permits associated with closed landfills containing solid wastes and with continuing discharges of liquid waste to surface impoundments, sewage ponds, and percolation pits. Ground water compliance monitoring at Site 300 is specified in Waste Discharge Requirement (WDR) orders issued by the Central Valley Regional Water Quality Control Board (CVRWQCB) and in landfill closure and post-closure monitoring plans. The WDRs and post-closure plans specify wells and effluents to be monitored, constituents of concern (COCs) to be measured, measurement frequency, inspections to be conducted, and the frequency and form of required reports. These monitoring programs include quarterly and semiannual monitoring of ground water, monitoring of various influent waste streams, and visual inspections. LLNL conducts additional operational monitoring of wastewater effluents discharged to surface impoundments and sewage ponds to comply with WDRs issued under California's Porter-Cologne Water Quality Control Act. Quarterly and annual written reports of analytical results, inspection findings, and maintenance activities are required for each monitoring network.

\section{Livermore Site and Environs}

\section{Livermore Valley}

LLNL has monitored tritium in water hydrologically downgradient of the Livermore site since 1988. Tritium is potentially the most mobile ground water contaminant emanating from LLNL. Rain and storm water runoff in the Livermore Valley, which recharge local aquifers, contain small amounts of tritium from natural sources, past 
worldwide atmospheric nuclear weapons tests, and atmospheric emissions from LLNL. (See Chapters 4, 5, and 7 for further discussion of air emissions, rain, and storm water runoff.) Ground water samples were obtained during 1998 from 20 wells in the Livermore Valley (Figure 9-1) and measured for tritium activity.

Ground water is recharged at the Livermore site from arroyos and by rainfall. Recharge enters primarily through the arroyos (see also Chapter 7). Ground water flow at the Livermore site, which is generally westward, is discussed generally in Chapter 1 and in detail in the CERCLA Remedial Investigation Report for the LLNL Livermore Site (Thorpe et al. 1990) and the annual LLNL Ground Water Project reports.

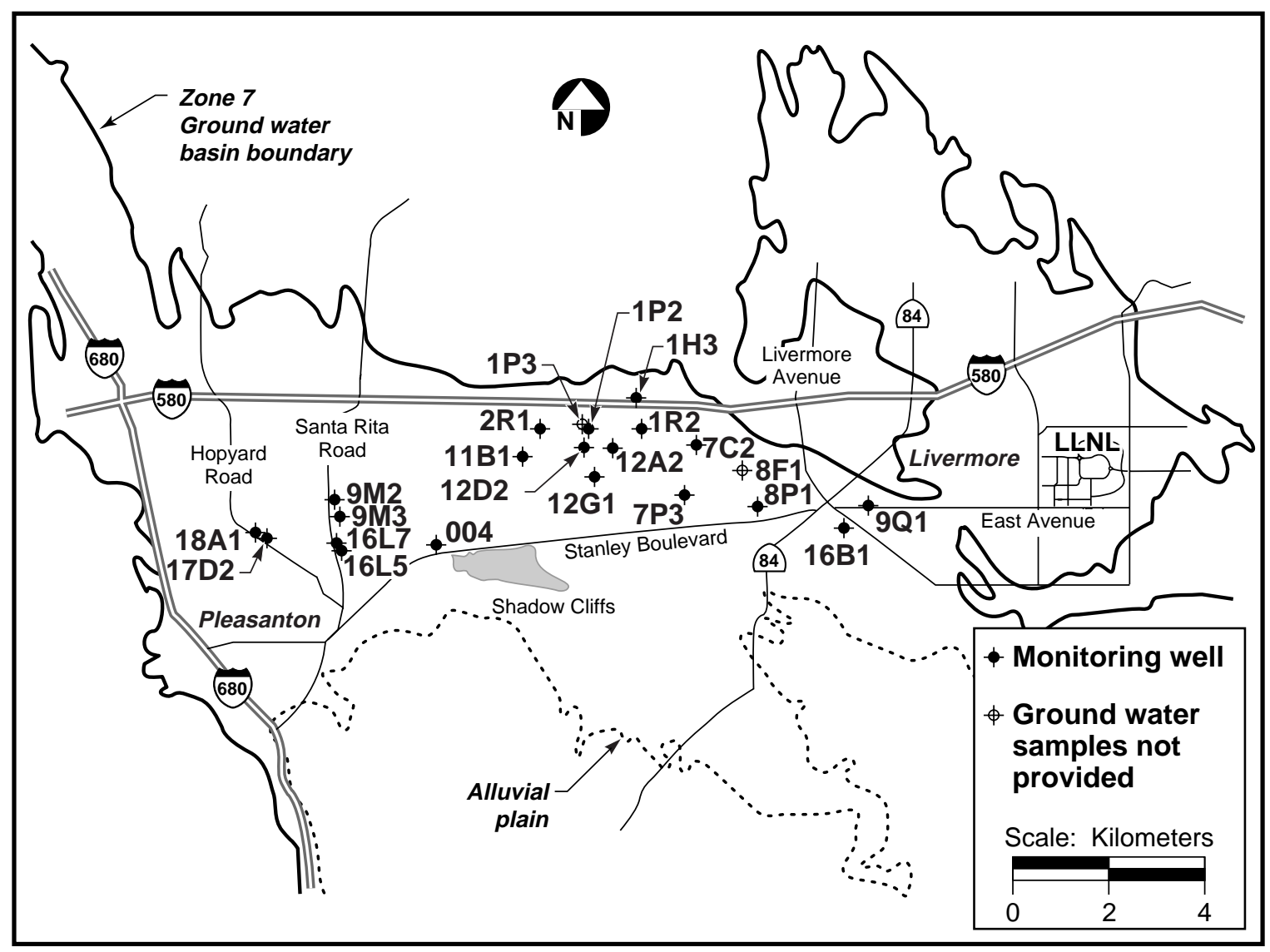

Figure 9-1. Locations of off-site tritium monitoring wells in the Livermore Valley. 


\section{Ground Water Monitoring}

\section{Livermore Site Perimeter}

LLNL designed a surveillance monitoring program to complement the Livermore Ground Water Project (discussed in Chapter 8). The intent of this network is to monitor for possible contaminants other than volatile organic compounds (VOCs), which are handled under the Livermore Site Ground Water Project. The perimeter portion of this surveillance ground water monitoring network makes use of two upgradient monitoring wells near the eastern boundary of the site and seven downgradient monitoring wells near the western boundary (Figure 9-2). Downgradient wells located in the regions of Treatment Facilities A, B, and C (see Figure 8-1) meet the requirements of DOE Order 5400.1. These seven downgradient wells monitor the uppermost aquifers for COCs that are outside the areas where ground water is being treated.

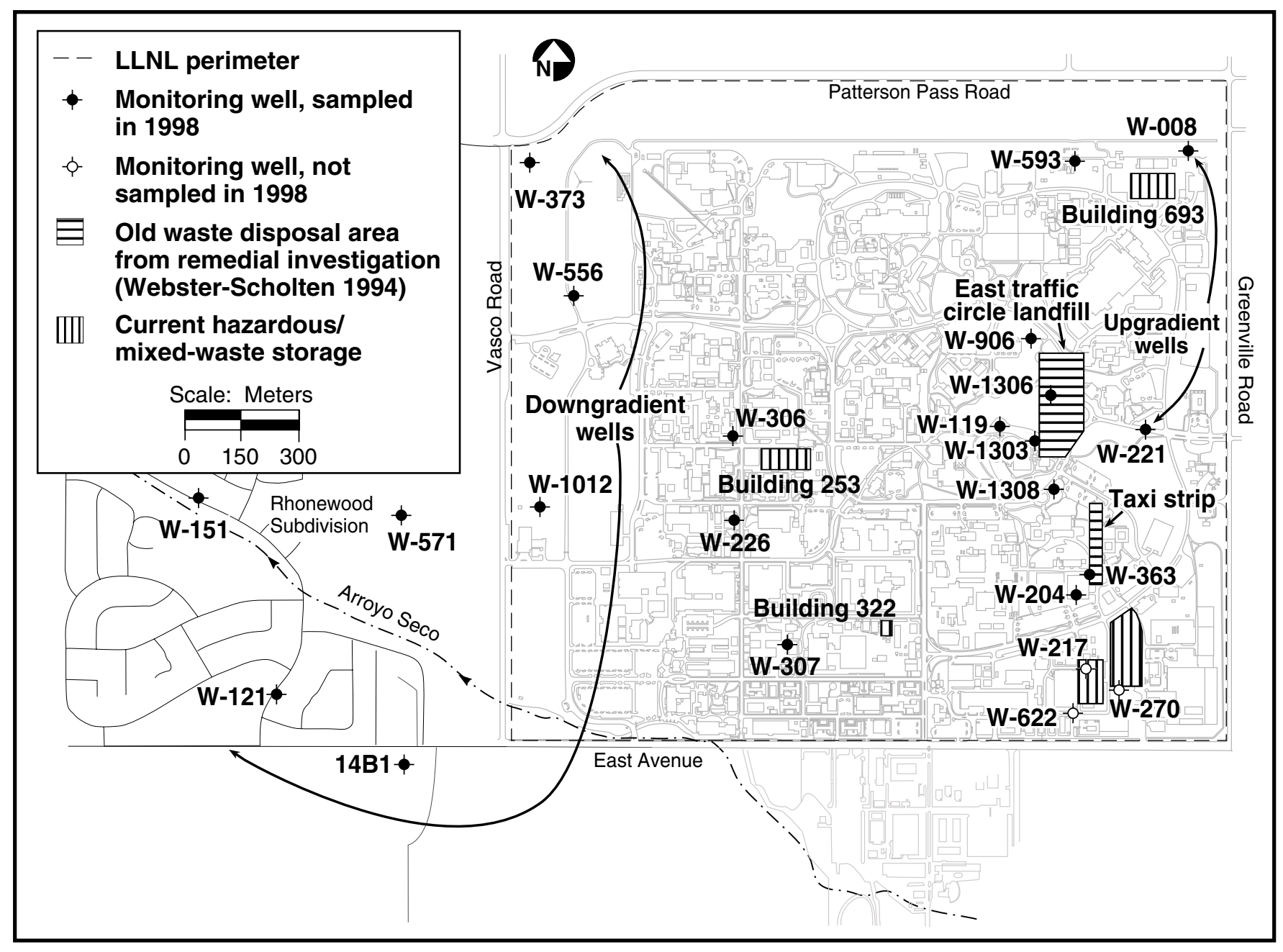

Figure 9-2. Locations of routine surveillance ground water monitoring wells at the Livermore site. 


\section{Ground Water Monitoring}

The two upgradient wells were sampled and analyzed semiannually for nonradioactive constituents and quarterly for most radioactive constituents in order to obtain sufficient data for statistical analyses; the seven downgradient wells were sampled and analyzed annually for nonradioactive constituents and semiannually for most radioactive constituents. Each well was sampled and the water analyzed for metals and minerals, herbicides, gross alpha and beta, tritium, and other radioisotopes. Routine surveillance monitoring data for 1998 are presented in the Data Supplement (Tables 9-1 through 9-9). These monitoring results will help establish baseline conditions for future monitoring and detect the presence of any contaminants of concern to public health or to the environment.

\section{Livermore Site}

Livermore site ground water sampling locations include areas where releases to ground may have occurred in the recent past or where previously detected COCs have low concentrations that do not require CERCLA remedial action. Monitoring wells screened in the uppermost aquifers are situated downgradient from, and as near as possible to, the potential release locations. The Taxi Strip Area and the East Traffic Circle Landfill are two potential sources of ground water contamination that were added to the surveillance monitoring network in 1997 (see Figure 9-2).

Ground water samples from monitoring wells screened in hydrostratigraphic units (HSU) 2 and 3A downgradient from the Taxi Strip Area and East Traffic Circle Landfill were analyzed for americium, plutonium, thorium, uranium, gross alpha and beta radiation, radium-226, radium-228, tritium, strontium-90, metals, polychlorinated biphenols (PCBs), herbicides, general minerals, and radioisotopes by gamma spectroscopy. The locations of these wells-W-119, W-906, W-1303, W-1306, and W-1308-are shown in Figure 9-2. (The hazardous waste/mixed waste storage facilities around Buildings 514 and 612 are monitored by four wells. These wells were not sampled in 1998 but are scheduled to be sampled in 1999.) HSUs are described in Chapter 8 and shown in Figure 8-1. All surveillance monitoring analytical data for the Taxi Strip Area and the East Traffic Circle Landfill are presented in Data Supplement Tables 9-10 through 9-16.

Another potential source of ground water contamination is the Mixed-Waste Storage Facility in the area of Building 693. Ground water samples were obtained downgradient from this facility during 1998 and were analyzed for the same suite of analytes as the East Traffic Circle Landfill and Taxi Strip Area (see Data Supplement Table 9-17). 


\section{Ground Water Monitoring}

Ground water samples were also obtained downgradient from areas where minor releases of metals to ground have occurred. Samples were obtained from monitoring well W-307 (screened in HSU 1B), downgradient from a fume hood vent on the roof of Building 322. Soil samples obtained from the area show elevated concentrations (in comparison with LLNL's site background levels) of chromium, copper, lead, nickel, zinc, and occasionally other metals. LLNL developed a plan for cleaning contaminated soils near Building 322 that is to be implemented in 1999.

Ground water samples were also obtained downgradient from a location where sediments containing metals (including mercury and chromium) had accumulated in a storm water catch basin near Building 253. These ground water samples were obtained from monitoring wells W-226 and W-306 screened in HSUs 1B and 2, respectively. Analytical results for dissolved metals in these samples are presented in Data Supplement Table 9-18.

\section{Site 300}

Monitoring of ground water at Site 300 utilizes on-site DOE wells and off-site private wells. Ground water samples from wells are routinely measured for various elements (primarily metals), a wide range of organic compounds, nitrate, general radioactivity (gross alpha and gross beta), uranium activity, and tritium activity. Typically, Environmental Protection Agency- (EPA-) approved methods are selected for their high sensitivity. (See Data Supplement Table 9-19 for a complete list of COCs and the EPA, or other standard analytical methods, used to measure them.)

Figure 9-3 shows the ground water sampling locations at, and near Site 300 that utilize wells and springs. Although ground water from the uppermost water-bearing zone is the target of most of the sampling locations, at several locations up to three vertically separated water-bearing zones are sampled by means of multiple-completion installations fitted with Barcad devices. Barcads are identified in Figure 9-3 by the capital letters $A, B$, and $C$ at the end of a monitoring installation's identifier code. (" $A$ " is assigned to the Barcad that samples the deepest, or deeper, water-bearing zone.)

Twelve ground water monitoring locations are off site. Two springs in the Altamont Hills, identified as MUL2 and VIE1, are near the northern boundary of Site 300. Off-site surveillance well VIE2 is located $6 \mathrm{~km}$ west of Site 300 in the upper reaches of the Livermore Valley watershed. Nine off-site surveillance locations are wells located near the southern boundary of Site 300 in, or adjacent to, the Corral Hollow Creek floodplain. 


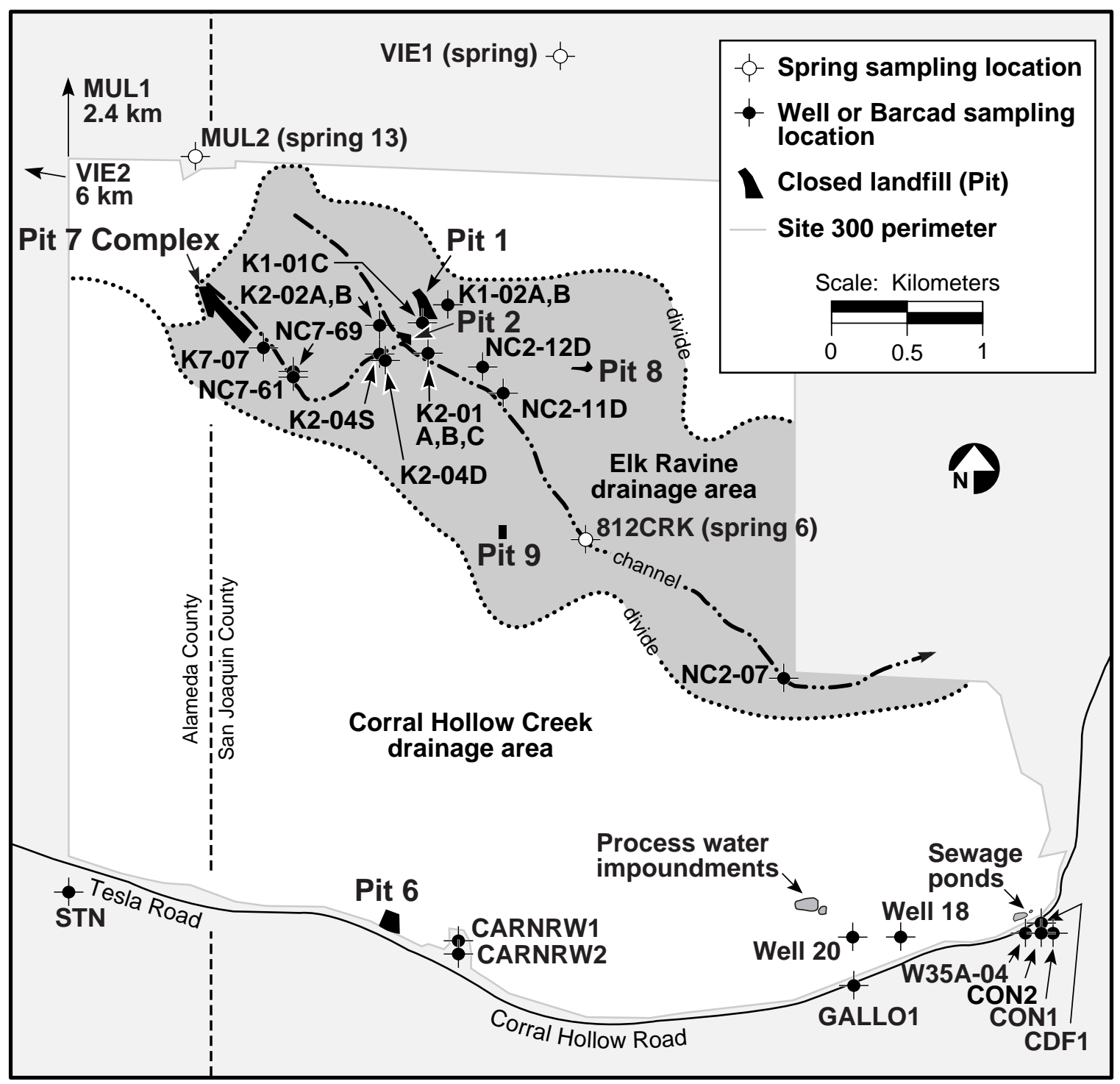

Figure 9-3. Locations of surveillance ground water wells, Barcads, and springs, Site 300.

On-site wells that were installed for CERCLA characterization studies during the 1980s continue to be used to monitor closed landfills, surface water impoundments, and sewer ponds. The closed landfills-which are identified as Pit 1, Pit 2, Pit 7 complex, Pit 8, and Pit 9-are located in the Elk Ravine drainage area, while Pit 6, two surface impoundments, and a sewer pond are located in the Corral Hollow Creek drainage area. Two on-site water production wells, Well 18 and Well 20, are also used for surveillance monitoring of ground water at Site 300 . Well 20 provides potable water to the site. Well 18 is maintained as a standby supply well. 


\section{Ground Water Monitoring}

Brief descriptions of the Site 300 ground water monitoring networks are given below. Tables of the ground water measurements made during 1998 are presented in the Data Supplement that accompanies this volume.

\section{Elk Ravine Drainage Area}

The Elk Ravine drainage area, a branch of the Corral Hollow Creek drainage system, includes most of northern Site 300 (Figure 9-3). Storm water runoff from closed landfills within the Elk Ravine drainage area (Pits 1-5 and 7-9) collects in arroyos but quickly infiltrates into the ground. Ground water from wells that lie within the Elk Ravine drainage area are monitored for COCs because of the system of surface and underground flows that connect the entire Elk Ravine drainage area.

\section{Pit 7 Complex}

Monitoring requirements for the closed Pit 1 and Pit 7 landfills in the Elk Ravine drainage area are specified in Waste Discharge Requirements Order 93-100 (WDR 93-100) administered by the CVRWQCB (1993 and 1998) and in LLNL Site 300 RCRA Closure and Post-Closure Plans — Landfill Pits 1 and 7 (Rogers/Pacific Corporation 1990).

The Pit 7 complex area is located at an elevation of about $400 \mathrm{~m}$ in the most elevated portion of the Elk Ravine drainage area. The complex comprises four adjacent landfills identified as Pits 3, 4, 5, and 7 (Figure 9-4). From 1963 to 1988, the landfills received waste gravels removed from firing tables at Site 300 . The gravels contained concrete, cable, plastic, wood, tritium, depleted uranium, beryllium, lead, and other metals in trace amounts. In 1988, $9440 \mathrm{~m}^{3}$ of gravel were removed from six firing tables at Site 300 and placed in Pit 7 (Lamarre and Taffet 1989). These were the last solid wastes to be placed in any landfills at Site 300.

Ground water samples were obtained quarterly from Pit 7 monitoring wells and analyzed for elements, general radioactivity, tritium, radium-226, uranium (234, 235, and 238), thorium (228 and 232), energetic compounds, and VOCs (EPA Method 601). Field measurements of ground water depth, temperature, $\mathrm{pH}$, and specific conductance were obtained at each well at the time of sample collection.

\section{Elk Ravine}

Ground water samples were obtained twice during 1998 from 8 of 10 Elk Ravine surveillance monitoring wells. Wells K2-01C and NC2-11D had inoperative pumps and were sampled only once. Samples of ground water were analyzed for elements, nitrate, energetic compounds, VOCs, general radioactivity, tritium, and total uranium. 


\section{Ground Water Monitoring}

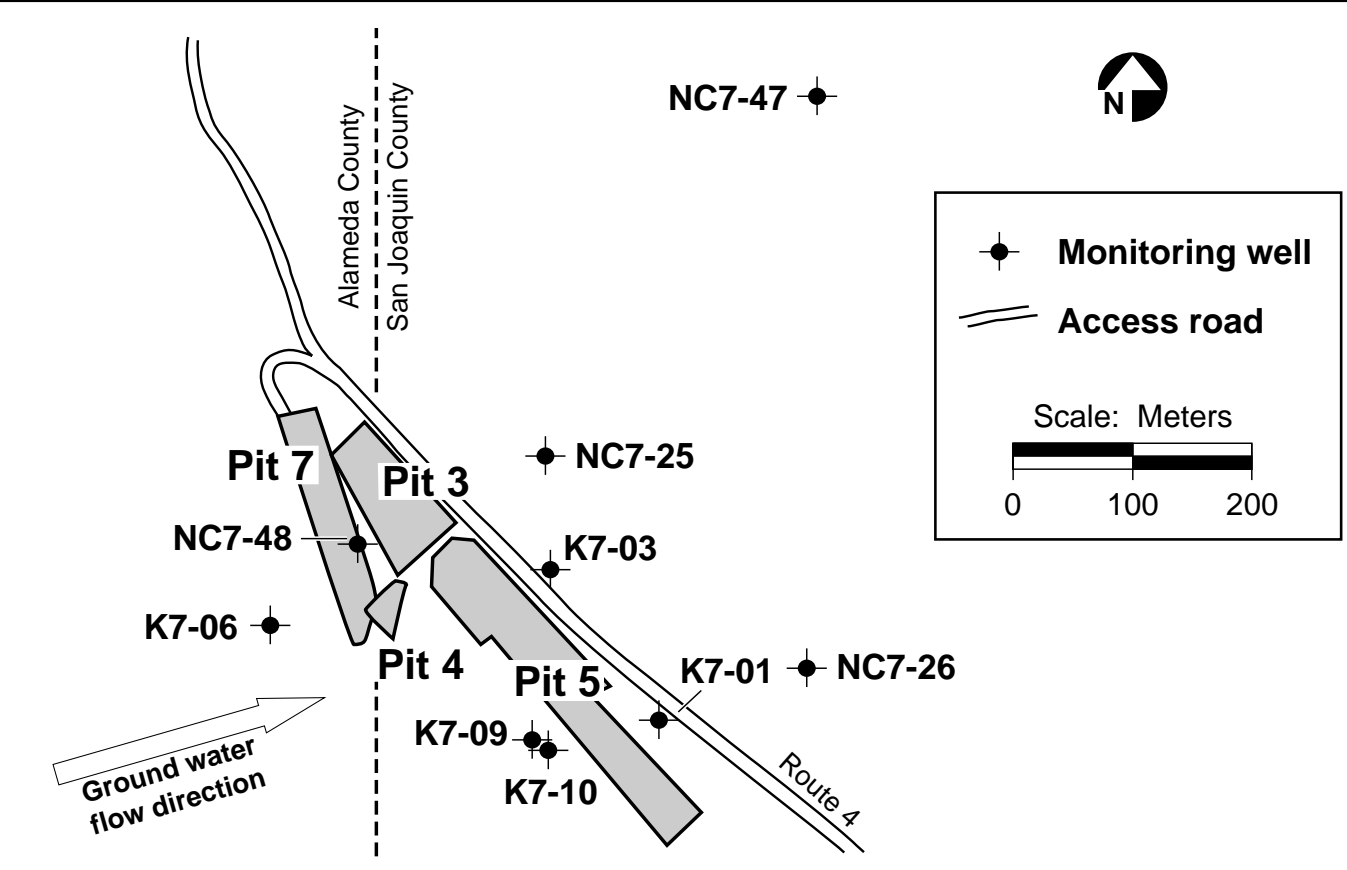

Figure 9-4. Locations of compliance ground water monitoring wells, Pit 7 complex.

\section{Pit 2}

The closed Pit 2 landfill lies in the upper portion of Elk Ravine, about $320 \mathrm{~m}$ above sea level (Figures 9-3 and 9-5). The landfill primarily contains gravels and debris from hydrodynamic tests of explosive devices conducted at the Building 801 and 802 firing tables. The buried waste material contains depleted uranium and trace amounts of beryllium, thorium, and (possibly) tritium.

Pit 2 ground water samples were obtained twice during 1998. Samples were analyzed for 18 elements, nitrate, VOCs; energetic compounds, general radioactivity, tritium, and total uranium.

Pit 1

The RCRA-closed Pit 1 landfill and the positions of the eight ground water wells used to monitor it are shown in Figure 9-5. Pit 1 lies in the Elk Ravine drainage area about $330 \mathrm{~m}$ above sea level.

Ground water samples were obtained quarterly from Pit 1 monitoring wells during 1998 , and they were analyzed for elements, nitrate, general radioactivity, tritium, radium-226, uranium $(234,235$, and 238$)$, thorium (228 and 232), and energetic 


\section{Ground Water Monitoring}

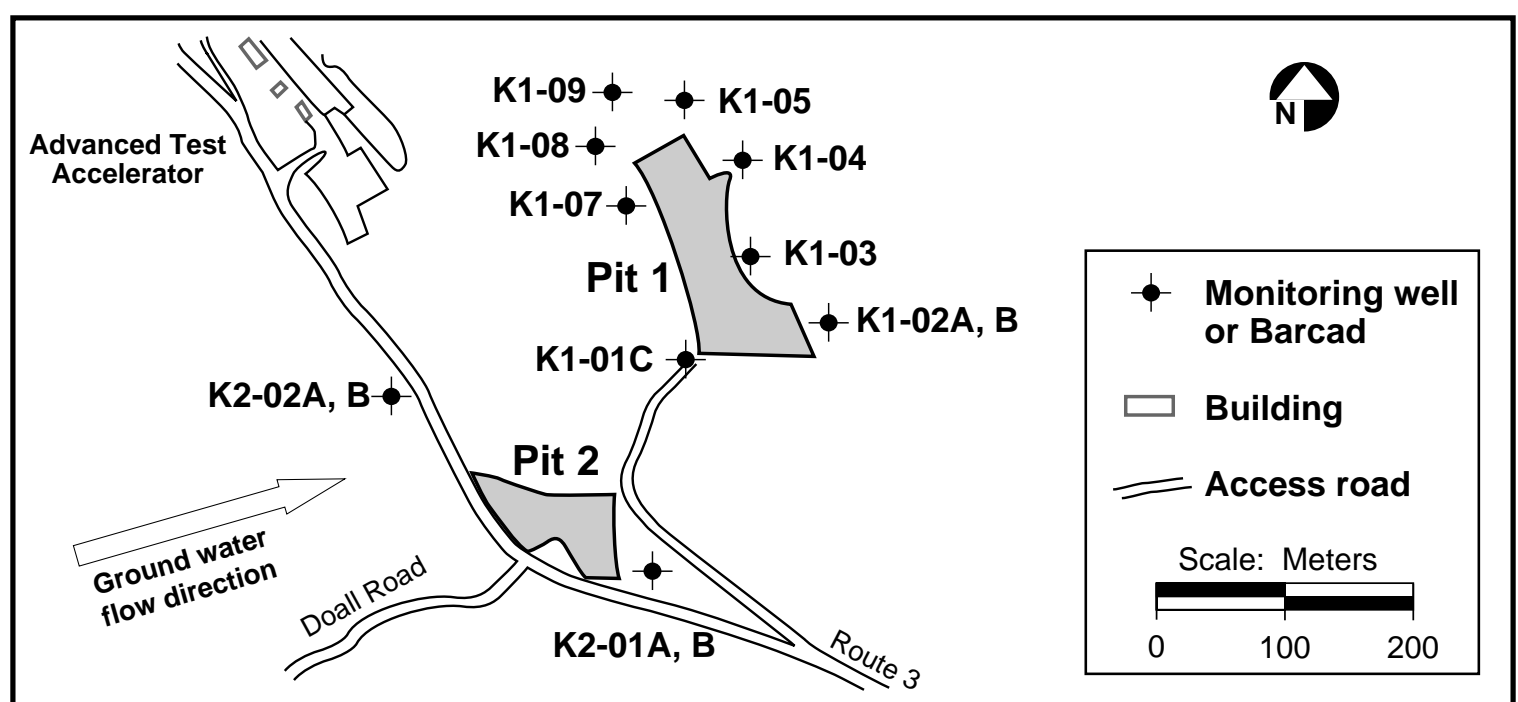

Figure 9-5. Locations of Pit 2 surveillance Barcads (K1-02A, K2-01A, K2-01B, and $\mathrm{K} 2-02 \mathrm{~A})$ and surveillance well $\mathrm{K} 2-02 \mathrm{~B}$, and Pit 1 compliance ground water monitoring wells (K1-01C, $-07,-02 \mathrm{~B},-03,-04,-05,-08$, and -09 ).

compounds. Semiannual measurements were made for an additional seven elements. Field measurements of ground water depth, temperature, $\mathrm{pH}$, and specific conductance were obtained at each well at the time of sample collection. Annual measurements were made for organic compounds (EPA Methods 601, 608, 624, and 625), total dissolved solids (TDS), total organic carbon (TOC), and total organic halides (TOX).

\section{Pit 8}

The closed Pit 8 landfill is located in the Elk Ravine drainage area adjacent to the Building 801 firing table, where explosives experiments were conducted from 1958 to 1974. Approximately $40 \mathrm{~m}^{3}$ of untreated debris from the firing table were placed in the pit during that time. Buried debris may contain trace amounts of tritium, depleted uranium, lead, and beryllium.

Figure 9-6 shows the Building 801 and Pit 8 areas and the locations of the monitoring wells. The pit is located in a narrow ravine within the Elk Ravine drainage area about $350 \mathrm{~m}$ above sea level. Chemical analysis of soil and rock samples obtained from this area during CERCLA remedial investigations showed no elevated concentrations of COCs (Webster-Scholten 1994). However, low concentrations of trichloroethylene (TCE) have been detected in ground water samples from upgradient well K8-01 since 1987. 


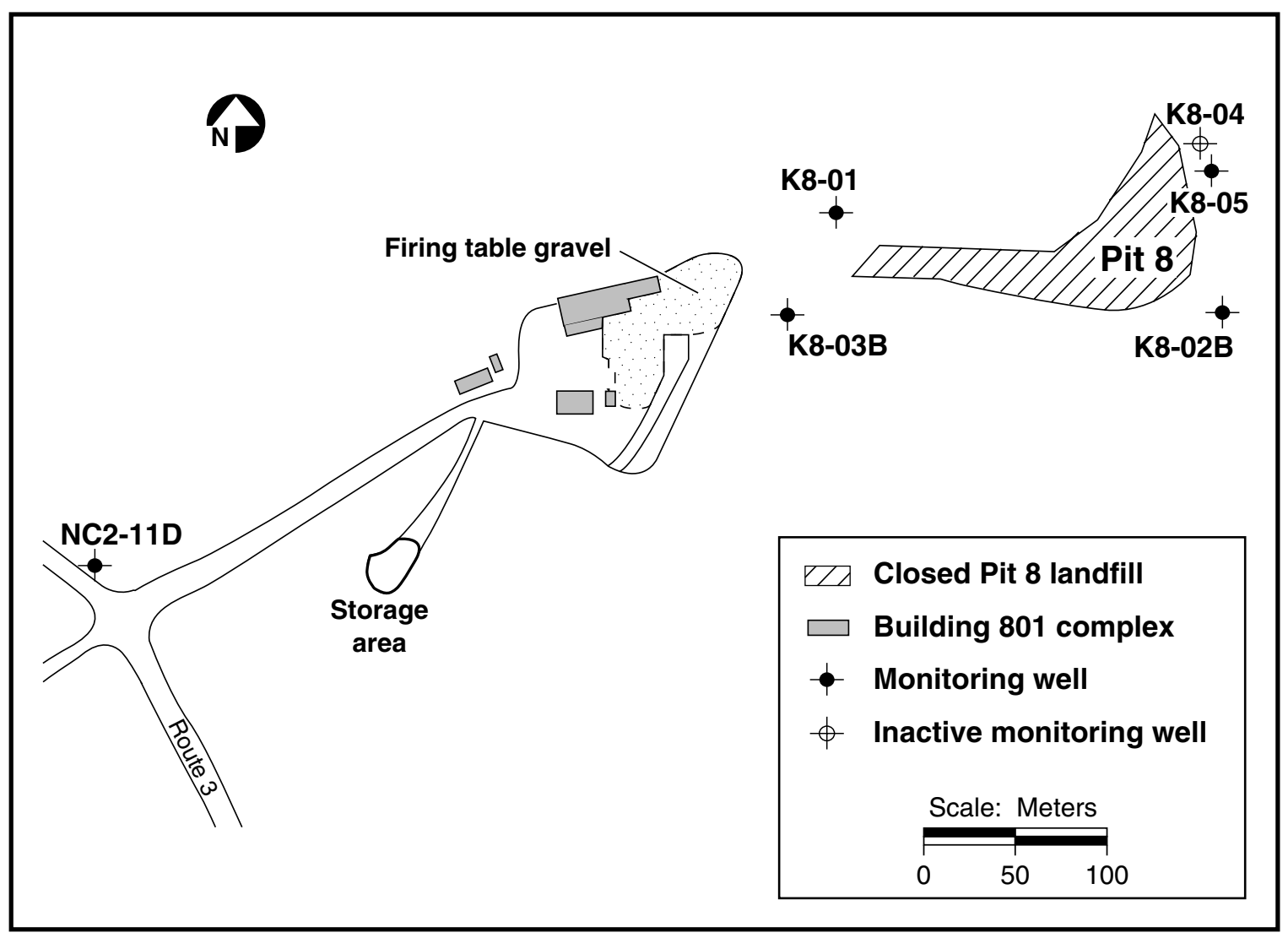

Figure 9-6. Locations of surveillance ground water monitoring wells, Pit 8, 1998.

Ground water samples from two monitoring wells, K8-01 and K8-02B, were analyzed once during 1998 for elements, nitrate, VOCs, explosive compounds, general radioactivity, tritium, and total uranium. The remaining wells were either dry or were inaccessible due to construction in this area.

\section{Pit 9}

The Pit 9 landfill is centrally located within Site 300 about $340 \mathrm{~m}$ above sea level. Similar to the other closed landfills in Elk Ravine, the closed Pit 9 landfill contains firing table gravels with debris from explosives experiments at the adjacent Building 845 firing table. Surface runoff from Pit 9 is northward to the Elk Ravine arroyo.

Figure 9-7 shows the locations of the four surveillance wells used to monitor the ground water in the vicinity of Pit 9. Ground water flows east-northeasterly beneath Pit 9 in the Neroly lower blue sandstone unit $\left(\operatorname{Tnbs}_{1}\right)$. The water table lies about $40 \mathrm{~m}$ below the ground surface at Pit 9. Monitoring well K9-02 is hydrologically upgradient from Pit 9, and wells K9-01, K9-03, and K9-04 are downgradient. 


\section{Ground Water Monitoring}

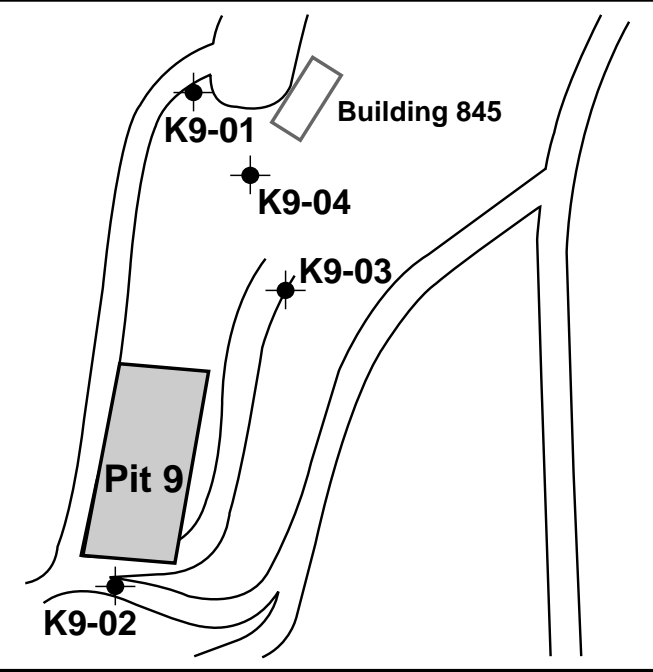

Monitoring well

Building

Access road

Scale: Meters
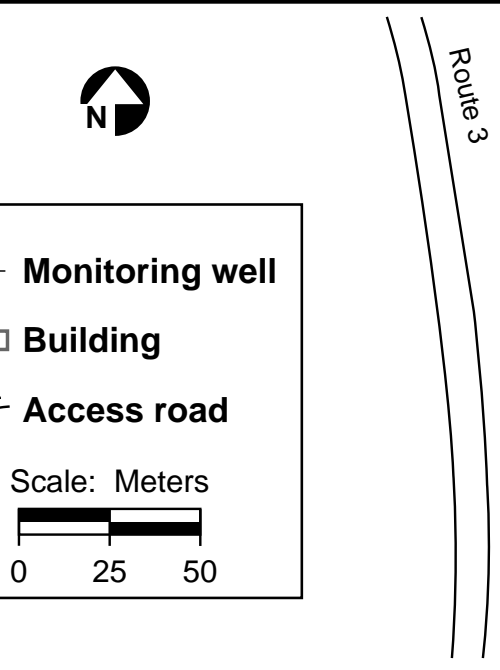

Figure 9-7. Locations of surveillance ground water monitoring wells, Pit 9, 1998.

The four Pit 9 monitoring wells were sampled once during 1998. The ground water samples were analyzed for 17 elements (mostly metals), nitrate, VOCs, energetic compounds, general radioactivity (gross alpha and gross beta), tritium, and total uranium.

\section{Corral Hollow Creek Drainage Area}

\section{Pit 6}

Monitoring requirements for the closed Pit 6 landfill in the Corral Hollow Creek drainage area are specified in the Post-Closure Plan for the Pit 6 Landfill Operable Unit Lawrence Livermore National Laboratory Site 300 (Ferry et al. 1998). The closed Pit 6 landfill covers an area of about 1 hectare ( 2.5 acres). Its elevation is approximately $215 \mathrm{~m}$ above sea level. From 1964 to 1973, approximately $1500 \mathrm{~m}^{3}$ of solid wastes were buried there in nine separate trenches. The trenches were not lined, consistent with historical disposal practices. Three larger trenches contain $1300 \mathrm{~m}^{3}$ of solid waste that includes empty drums, glove boxes, lumber, ducting, and capacitors. Six smaller trenches contain $230 \mathrm{~m}^{3}$ of biomedical waste, including animal carcasses and animal waste. Minor releases of VOCs-primarily the solvent TCE, and tritium-occurred prior to closure. During 1997, a multilayered cap was constructed over all the trenches, and a drainage control system was installed around the cap. The cap and the drainage control system are engineered to keep rainwater from contacting the buried waste (Ferry et al. 1998). 
The Pit 6 disposal trenches were constructed in Quaternary terrace deposits (Qt) above and north of the Corral Hollow Creek flood plain. Surface runoff from the pit area flows southward to Corral Hollow Creek. The Carnegie-Corral Hollow Fault zone extends beneath the southern third of Pit 6 . The northern limit of the fault zone is shown in Figure 9-8. Beneath the northern two-thirds of Pit 6, ground water flows south-southeast, following the inclination (dip) of the underlying sedimentary rocks. Ground water seepage velocities are less than $10 \mathrm{~m} / \mathrm{y}$. Depths to the water table range from 10-20 m. Beneath the southern third of Pit 6, a trough containing terrace gravel within the fault zone provides a channel for ground water to flow southeast, parallel to the Site 300 boundary fence (Webster-Scholten 1994).

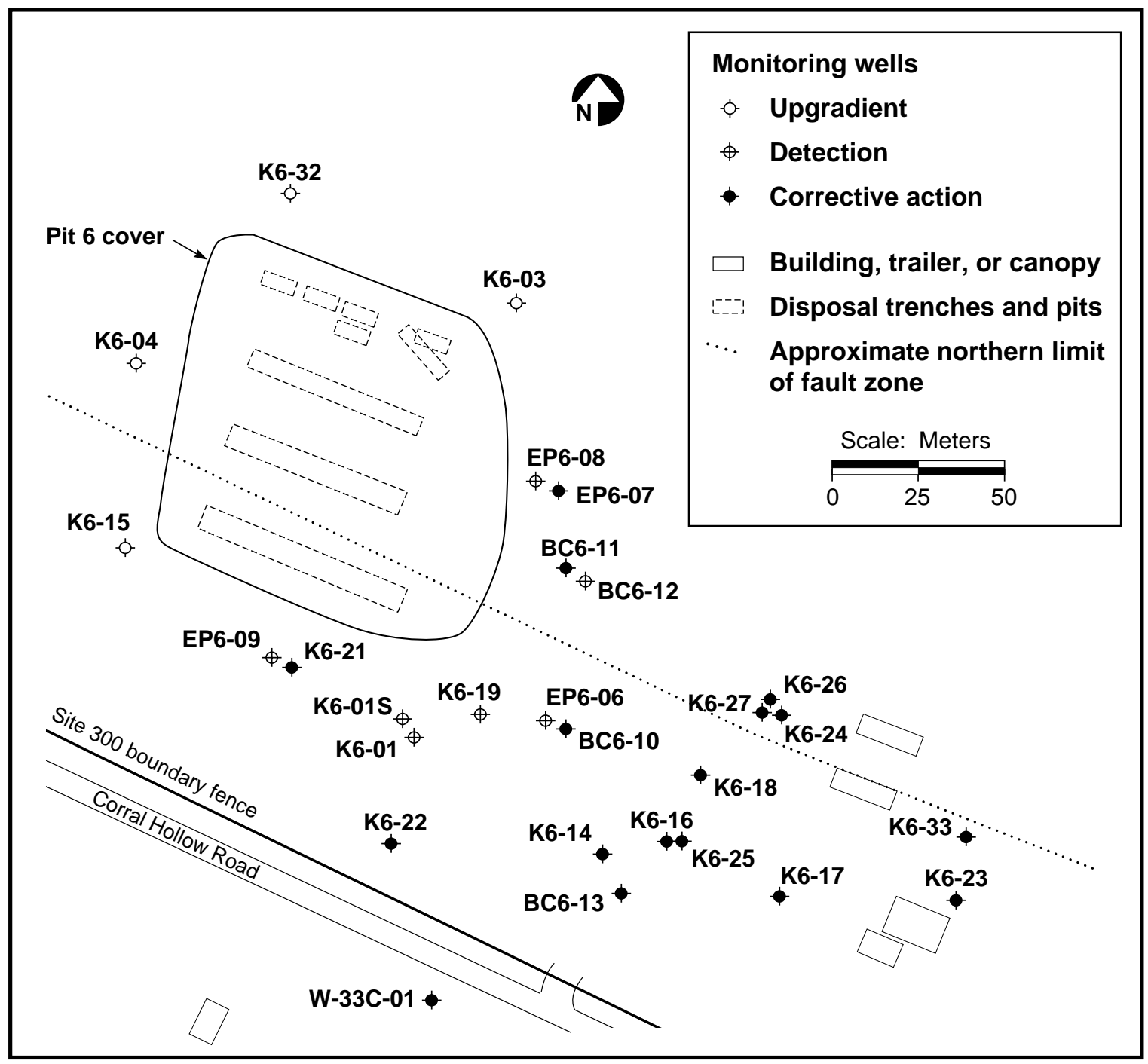

Figure 9-8. Locations of Pit 6 ground water monitoring wells. 


\section{Ground Water Monitoring}

Two new ground water monitoring programs were implemented at the Pit 6 landfill during 1998 to ensure compliance with all regulations. The Detection Monitoring Program (DMP) is designed to detect any new release of COCs to ground water from wastes buried in the Pit 6 landfill, while the Corrective Action Monitoring Program (CAMP), which operates under CERCLA, monitors the movement of existing releases (see Chapter 8 for a summary of CAMP monitoring results). Twenty-four COCs, including VOCs and radioisotopes, have been identified for monitoring in the ground water at Pit 6 (Ferry et al. 1998). Figure 9-8 shows the locations of the wells used to monitor ground water in the vicinity of Pit 6 .

Ground water at Pit 6 was sampled quarterly, beginning in the second quarter of 1998. Samples were measured for COCs required by the Pit 6 post-closure plan. Field measurements of ground water depth, temperature, $\mathrm{pH}$, and specific conductance were obtained at each well at the time of sample collection. Two quarterly reports and one annual report covering monitoring activities at Pit 6 during 1998 have been published previously (Christofferson 1998a, 1998b; Christofferson and Taffet 1999).

\section{Surface Impoundments}

WDR Order No. 96-248 establishes the basis for compliance monitoring of the two adjacent surface impoundments (see Figure 9-9). This includes quarterly monitoring of the ground water, monitoring of various influent waste streams to the surface impoundments, and visual observations of leachate collection and removal systems. Influent wastewater monitoring complements administrative controls that regulate the discharge of chemicals that could degrade the polyethylene liners of the impoundments. A three-tiered monitoring program comprising weekly visual inspections of the leachate collection and removal systems, quarterly inspections of lysimeters, and quarterly sampling of monitoring wells is in place to detect releases of chemicals from the surface impoundments in the Explosives Process Area.

As part of the Monitoring and Reporting Program (MRP) for the surface impoundments, contained in WDR 96-248, LLNL is required to obtain ground water samples quarterly from four monitoring wells (see Figure 9-9) and establishes statistical concentration limits for COCs in ground water beneath the surface impoundments.

WDR 96-248 establishes limits for discharges of COCs into the surface impoundments and requires monitoring of the photographic process and chemistry area wastewater retention tanks that discharge to the surface impoundments as well as direct discharges to the surface impoundments from explosives processing. Influent streams are monitored at a prescribed frequency for area-specific COCs. 


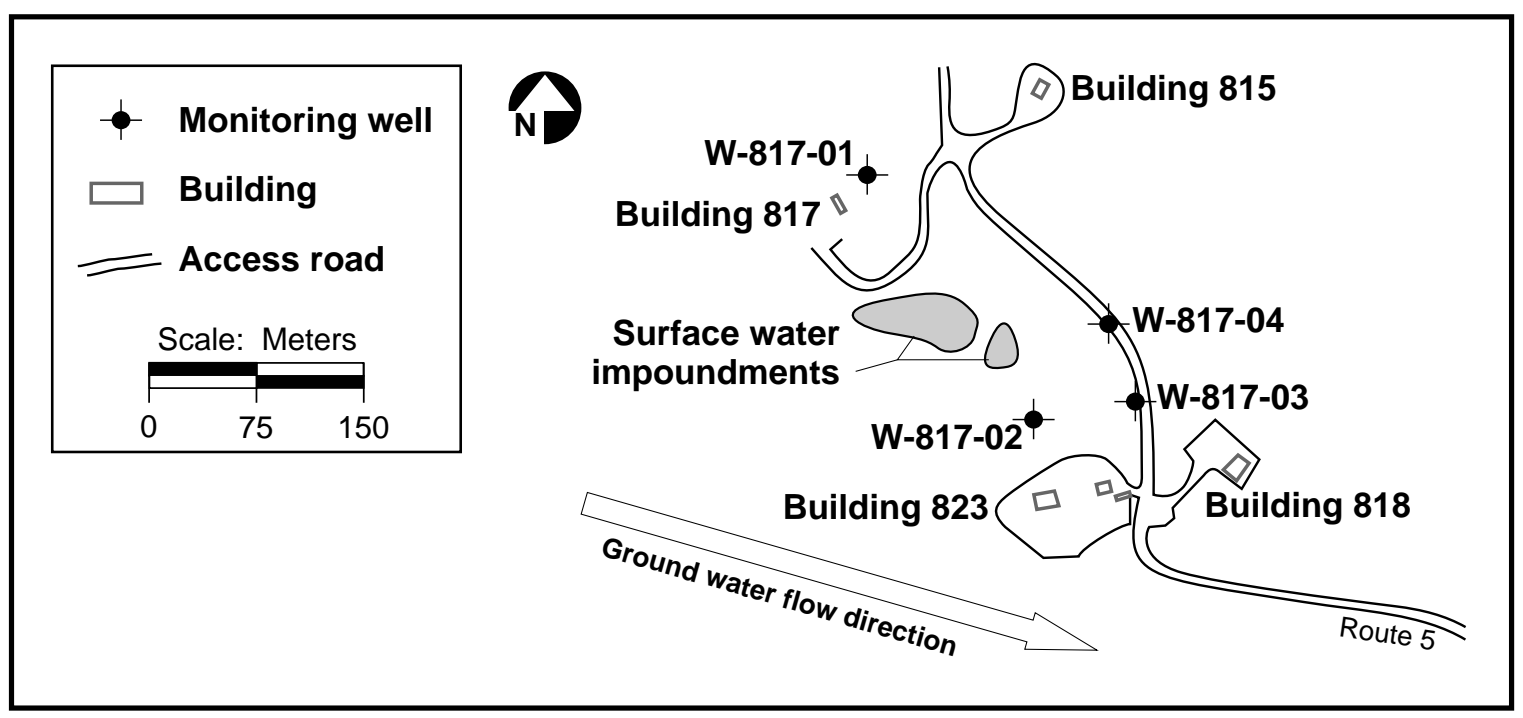

Figure 9-9. Locations of compliance ground water monitoring wells in the Explosives Process Area.

Retention tanks containing photographic process rinsewater from Buildings 801, 823, 850 , and 851 are sampled to confirm that discharges are consistent with COC limits specified in WDR 96-248. Discharges to the surface impoundments occur after samples are obtained, except for rinsewater from the Building 823 retention tanks, which is discharged automatically to the surface impoundments and sampled quarterly.

Wastewater from the Chemistry Area (Buildings 825, 826, and 827 complex) is held in retention tanks until analytical results indicate compliance with WDR 96-248.

Process water discharges to the surface impoundments are analyzed for COCs that have been found (or are likely to be found) in the process water from each specified building within the Explosives Process Area. This monitoring program includes process area wastewater from Buildings 806/807, 809, and 817. WDR 96-248 requires annual analysis of this waste stream at Buildings 806/807, 809, and 817 .

\section{Percolation Pits}

Percolation pits that are designed to accept discharges from mechanical equipment are located at Site 300 Buildings 806A, 827A, 827C, 827D, and 827E. In other remote Site 300 facilities, these types of waste streams are discharged to septic systems. This discharge is permitted by WDR 96-248. WDR 96-248 specifies monthly observations and monitoring requirements for overflows. Overflows of the percolation pits, should they occur, are sampled and analyzed for metals. 


\section{Ground Water Monitoring}

\section{Sewage Evaporation and Percolation Ponds}

Site 300 is not serviced by a publicly owned treatment works (POTW) as is the Livermore site; therefore, alternate methods of treating and disposing of sanitary waste are necessary. Sewage generated at buildings in the General Services Area is discharged into a lined evaporation pond. Most of the time, the wastewater evaporates from the sewage evaporation pond; however, during periods of high rainfall, treated wastewater may overflow into a connected percolation pond, where it enters the ground.

The environmental monitoring requirements for the sewage evaporation and percolation ponds (hereafter sewage ponds) are specified in the MRP 96-248 contained in WDR 96-248. The monitoring requirements include both wastewater monitoring and monitoring of the ground water to detect potential impacts of the sewage on ground water quality.

Wastewater is sampled quarterly at an influent location (ISWP) and within the pond (ESWP). Overflows are sampled as needed at location (DSWP). The sampling locations are shown in Figure 9-10.

Nine ground water monitoring wells are sampled semiannually to provide information on the ground water quality in the vicinity of the sewage ponds (Figure 9-10). The wells are screened in three different geological formations (Qal, Tnbs 1, and Tnsc 1 ). Tnbs 1 (Neroly Formation lower blue sandstone unit) is the regional aquifer.

\section{Sampling and Analytical Methods}

Representative samples of ground water from monitoring wells were obtained in accordance with the LLNL Livermore Site and Site 300 Environmental Restoration Project Standard Operating Procedures (SOPS) (Dibley and Depue 1998). The protocols cover sampling techniques and specific information for the analytes that are routinely searched for in ground water.

Different sampling techniques were applied to different wells depending on whether they were fitted with submersible pumps, had to be bailed, or contained Barcad devices. See the Data Supplement for sampling details. 


\section{Ground Water Monitoring}

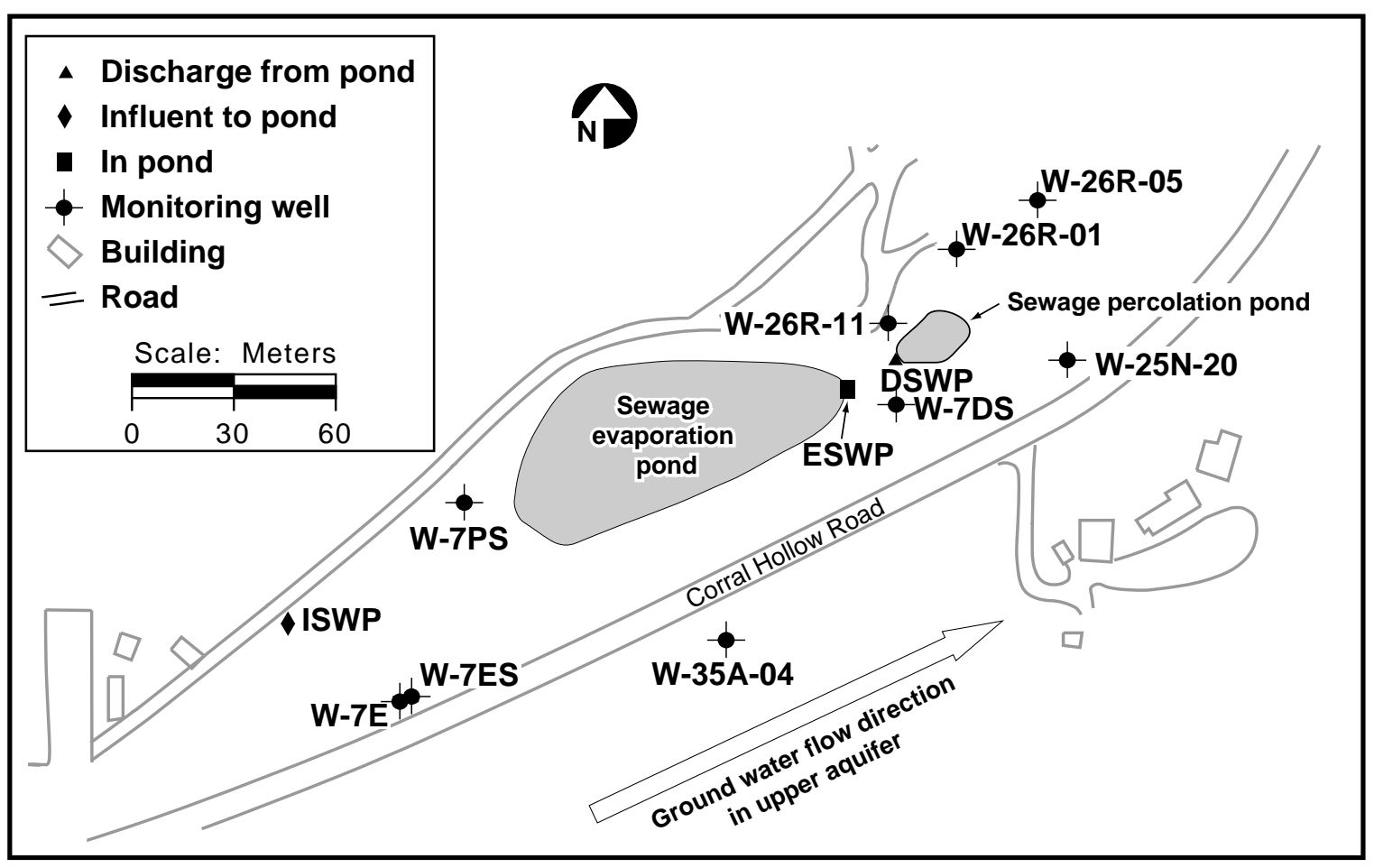

Figure 9-10. Sewage evaporation and percolation ponds, compliance ground water monitoring wells, and wastewater monitoring locations.

At Site 300, wastewater samples from the photographic and explosives process areas, sewage evaporation pond influent, water in the pond, and overflow water from percolation pits pond were obtained in accordance with the standardized procedures of the Operations and Regulatory Affairs Division (Tate et al. 1995). Standard sample handling and hygiene procedures were employed to prevent cross-contamination (e.g., wearing disposable gloves, decontaminating equipment between use, and maintaining samples at $4 \pm 2{ }^{\circ} \mathrm{C}$ ). Replicates, field blanks, and trip blanks were obtained for quality assurance/quality control purposes. Analyses were performed by state-certified contract analytical laboratories.

Technologists collected wastewater samples from retention tanks in the Chemistry Area associated with Buildings 825, 826, and 827 using Hazardous Waste Management Procedure 411. Wastewater was held in retention tanks until analytical results were reviewed for compliance with WDR No. 96-248. Most of the analyses were performed by LLNL, which is state-certified for some analyses. Some analyses were done by offsite contract laboratories late in the year. 


\section{Ground Water Monitoring}

Table 9-19 in the Data Supplement shows the analytical methods and reporting limits for inorganic constituents (including specific radioisotopes analyzed by alpha spectroscopy and other sensitive methods), organic constituents, and radioisotopes in ground water.

\section{Results}

This section presents the monitoring results for the Livermore site and environs as well as Site 300 .

\section{Livermore Site and Environs}

\section{Livermore Valley}

Measurements of water samples obtained during the summer of 1998 from 20 wells in the Livermore Valley show very low tritium levels compared with the $740 \mathrm{~Bq} / \mathrm{L}$ $(20,000 \mathrm{pCi} / \mathrm{L})$ maximum contaminant level (MCL) established by the State of California. The highest tritium activity measured off site was $9.03 \mathrm{~Bq} / \mathrm{L}$ in a ground water sample from well 12D2, (see Figure 9-1), located about $10 \mathrm{~km}$ west of LLNL (results are reported in Data Supplement Table 9-20).

Tritium activity has been decreasing in Livermore Valley ground waters downgradient of LLNL. The median activities of tritium in ground water samples from these downgradient wells decreased from $4.59 \mathrm{~Bq} / \mathrm{L}$ in 1989 to $-0.044 \mathrm{~Bq} / \mathrm{L}$ in 1998 based on the three positive detections of tritium and 17 calculated values.

\section{Livermore Site Perimeter}

Tritium activity ranged from -1.29 to $5.66 \mathrm{~Bq} / \mathrm{L}$ in ground water samples from on-site upgradient monitoring wells and from 0.15 to $11.1 \mathrm{~Bq} / \mathrm{L}$ in perimeter downgradient monitoring wells.

Bromacil, a herbicide, was detected in June 1998 in off-site surveillance well W-151 at $3.6 \mu \mathrm{g} / \mathrm{L}$ (see Data Supplement Table 9-6). Although there is no drinking water MCL for bromacil, the EPA has determined that concentrations of bromacil greater than $90 \mu \mathrm{g} / \mathrm{L}$ could be hazardous to human health. Bromacil above the reporting limit $(0.5 \mu \mathrm{g} / \mathrm{L})$ or any other herbicides were not detected in later samplings of W-151 in August and October. Herbicides detected in the ground water probably result from runoff through stream channels, including arroyos. (See Chapter 7 for storm water runoff results.) No 


\section{Ground Water Monitoring}

herbicides were detected in the upgradient monitoring wells, W-008 and W-221 during 1998 (see Data Supplement Tables 9-1 and 9-2).

The inorganic compounds detected, including dissolved trace metals and minerals, occur naturally in the ground water at variable concentrations. Table 9-1 shows the three anions with the highest concentrations in the two upgradient wells and the seven downgradient wells at LLNL. Concentrations of these major anions are higher in the upgradient wells than in the downgradient wells. (See Tables 9-1 through 9-9 in the Data Supplement.) The boron concentration of $9.1 \mathrm{mg} / \mathrm{L}$ in upgradient monitoring well W-008 in February 1998 is an order of magnitude higher than the downgradient wells. Poor ground water quality in the upgradient portions of the site has been described previously (Thorpe et al. 1990).

Table 9-1. Concentration ranges for three major anions in upgradient and downgradient monitoring wells.

\begin{tabular}{|l|c|c|c|c|c|c|}
\hline \multirow{2}{*}{ Flow } & \multicolumn{6}{c|}{ Concentration range (mg/L) } \\
\cline { 2 - 7 } & \multicolumn{1}{|c|}{ Bicarbonate $\left(\mathrm{HCO}_{3}{ }^{-}\right)$} & \multicolumn{2}{c|}{ Chloride $\left(\mathrm{Cl}^{-}\right)$} & \multicolumn{2}{c|}{ Sulfate $\left(\mathrm{SO}_{4}{ }^{2-}\right)$} \\
\cline { 2 - 7 } & Range & Median & Range & Median & Range & Median \\
\hline Upgradient & $229-356$ & 289 & $284-526$ & 392 & $84-326$ & 204 \\
Downgradient & $193-292$ & 243 & $78-131$ & 86 & $27-69$ & 40 \\
\hline
\end{tabular}

In 1996, nitrate was detected at concentrations greater than the MCL of $45 \mathrm{mg} / \mathrm{L}$ in ground water samples obtained from monitoring well W-1012 (screened in HSU 2). In 1998, the concentration of nitrate for this well was $78 \mathrm{mg} / \mathrm{L}$ (see Data Supplement Table 9-4). This is the highest nitrate concentration measured in any on-site monitoring well during 1998. The highest concentration measured in an off-site well was $39 \mathrm{mg} / \mathrm{L}$, in monitoring well W-151 (see Data Supplement Table 9-6). The nitrate may originate as an agricultural residue (Thorpe et al. 1990).

Aluminum, antimony, arsenic, cadmium, cobalt, manganese, mercury, molybdenum, silver, thallium, and vanadium were not detected in concentrations above laboratory reporting limits during 1998 in any of the Livermore site perimeter downgradient monitoring wells. Vanadium was detected in both upgradient wells, W-008 and W-221 (see Data Supplement Tables 9-1 and 9-2), and arsenic was detected in upgradient well $\mathrm{W}-008$. Lead was detected once in downgradient monitoring well W-571 at a concentration of $5.3 \mu \mathrm{g} / \mathrm{L}$ in a third quarter ground water sample (see Data Supplement Table 9-9). This concentration is below the EPA's Action Level of $15 \mu \mathrm{g} / \mathrm{L}$ for lead. Beryllium was detected once at $0.7 \mu \mathrm{g} / \mathrm{L}$ in a ground water sample obtained from 


\section{Ground Water Monitoring}

off-site downgradient well W-151. The drinking water MCL for beryllium is $4 \mu \mathrm{g} / \mathrm{L}$ (see Data Supplement Table 9-6).

None of the ground water samples obtained from surveillance monitoring wells during 1998 had concentrations of radioisotopes or radioactivity that exceeded a drinking water MCL. The highest tritium activity measured in a ground water sample was $11.1 \mathrm{~Bq} / \mathrm{L}$, equal to $1.5 \%$ of the tritium MCL. The sample was from monitoring well W-373 (see Data Supplement Table 9-7).

As in the past, concentrations of uranium continue to be highest in the upgradient wells W-008 and W-221. Concentrations of U-234 in those wells range from 0.107 to $0.202 \mathrm{~Bq} / \mathrm{L}$; concentrations of U-238 range from 0.0685 to $0.179 \mathrm{~Bq} / \mathrm{L}$ (see Data Supplement Tables 9-1 and 9-2). Activities of U-234 and U-238 are lower in ground water from each of the perimeter downgradient wells. Uranium and its radioactive daughters, Th-230 and Ra-226, occur naturally in the sediments and rock layers beneath and surrounding LLNL. Uranium activities did not exceed drinking water limits. Other monitored radioisotopes were below detection limits in the ground water samples.

\section{Livermore Site}

Atrazine, an herbicide, was detected at a concentration of $0.35 \mu \mathrm{g} / \mathrm{L}$ in a June 1998 ground water sample obtained from well W-593 in the northeastern portion of the site (see Figure 9-2) (see Table 9-17 in the Data Supplement). A very low concentration $(0.33 \mu \mathrm{g} / \mathrm{L})$ of atrazine was also detected in this well in December 1997. The California and federal drinking water MCL for atrazine is $3 \mu \mathrm{g} / \mathrm{L}$. The concentration of atrazine measured is $12 \%$ of the MCL.

Ground water downgradient showed some impact from two releases of metals to ground. Ground water at well W-307 near Building 322 showed the presence of beryllium $(1.7 \mu \mathrm{g} / \mathrm{L})$ and copper $(6.8 \mu \mathrm{g} / \mathrm{L})$ (see Data Supplement Table 9-18).

Background concentrations, from upgradient wells W-008 and W-221, are < $0.2 \mu \mathrm{g} / \mathrm{L}$ for beryllium and $3.4 \mu \mathrm{g} / \mathrm{L}$ or less for copper (see Data Supplement Tables 9-1 and 9-2). Chromium and copper were detected at elevated concentrations in ground water samples from wells W-226 and W-306, downgradient from the Building 253 catch basin. Chromium concentrations were $25 \mu \mathrm{g} / \mathrm{L}$ (well W-226) and $38 \mu \mathrm{g} / \mathrm{L}$ (well W-306); copper concentrations were $14 \mu \mathrm{g} / \mathrm{L}$ (well W-226) and $30 \mu \mathrm{g} / \mathrm{L}$ (well W-306) (see the Data Supplement, Table 9-18). The accumulated sediment in the catch basin is a potential source of chromium and copper. No measured concentration exceeded an MCL for drinking water. 


\section{Site 300}

The following summaries of analytical results for 1998 briefly discuss compliance monitoring results for Site 300 that exceed permitted concentration limits, i.e., statistical limits (SLs), or otherwise suggest that a release of a COC to ground water has occurred. Monitoring data and analyses were published quarterly for 1998 (Christofferson 1998a and b; Christofferson and MacQueen 1998a, b, c, and 1999; Christofferson and Taffet 1999).

\section{Elk Ravine Drainage Area}

\section{Pit 7}

Analytical results for the Pit 7 compliance ground water monitoring network for 1998 are presented in Data Supplement Tables 9-21 and 9-22. Third quarter total uranium activity exceeded the statistical limit of $2.33 \mathrm{~Bq} / \mathrm{L}$ in ground water at monitoring well NC7-48 (2.59 Bq/L), and LLNL notified the CVRWQCB by letter of this finding, which constituted statistically significant evidence of a uranium release (Galles 1998a). Depleted uranium was probably released to ground water from Pit 7 for a period of several months during 1998. Ground water may have risen into Pit 7 and dissolved some depleted uranium buried there. The change in ground water depth was the result of considerable local recharge from $58 \mathrm{~cm}$ of rainfall during the El Niño winter rainy season of 1997-1998 (mean total annual Site 300 rainfall is $27 \mathrm{~cm}$ ). Nearby Pits 3 and 5 are known to have been partially inundated by rising ground water during February 1998 (Ziagos and Reber-Cox 1998b). Three small ground water plumes contain depleted uranium released from Pit 5, Pit 7, and the Building 850 firing table area (Taffet et al. 1996). The maximum uranium activity detected is $4.4 \mathrm{~Bq} / \mathrm{L}$, which represents the sum of depleted uranium and naturally occurring uranium. Uranium activity in ground water at well NC7-48 decreased to $0.895 \mathrm{~Bq} / \mathrm{L}$ during the fourth quarter, suggesting that the release from Pit 7 was short lived and ceased during the latter part of the year when ground water levels fell (Christofferson and MacQueen 1999).

Tritium activity increased in ground water at the Pit 7 downgradient monitoring well NC7-25, and it reached 24,500 Bq/L in November, 33 times the MCL of $740 \mathrm{~Bq} / \mathrm{L}$. LLNL CERCLA remedial investigations link the increased activity to slug releases of tritium from Pit 3, beginning during the winter of 1992-93, and continuing during successive winters of 1994-95, 1995-96, 1996-97, and 1997-98 (El Niño winter), when Pit 3 was partially inundated by rising ground water (Taffet et al. 1996, Ziagos and Reber-Cox 1998b). The releases have produced elevated tritium activity in the ground water adjacent to Pit 3 that extends to monitoring well NC7-25. Modeling indicates that, given tritium's short half-life of 12.3 years and the relatively slow rate of ground water movement, the activity of the released tritium in ground water will decrease to below the MCL before it can travel off site (Taffet et al. 1996). 


\section{Ground Water Monitoring}

As in the past, the VOC trichlorofluoromethane (Freon 11) was detected each quarter in the ground water at Pit 7 monitoring well NC7-48. Concentrations ranged from 0.77 to $1.2 \mu \mathrm{g} / \mathrm{L}$, far below the MCL of $150 \mu \mathrm{g} / \mathrm{L}$. Pit 7 is the likely source of the Freon 11, because it is the only landfill upgradient of well NC7-48.

\section{Elk Ravine}

Analytical results for the Elk Ravine drainage area surveillance monitoring network are presented in Data Supplement Table 9-23. Generally, surveillance monitoring of Elk Ravine during 1998 showed no evidence of any new release of COCs to ground water in this area. As in past years, arsenic, barium, chromium, lead, selenium, vanadium, and zinc were detected at low concentrations typical of ground water in the Altamont Hills. No measurement was above a drinking water MCL. Nitrate was detected in all Elk Ravine ground water samples, except those from well NC7-69 that monitors a deeper water-bearing zone. Nitrate appears primarily in the uppermost water-bearing zone and was measured above the MCL of $45 \mathrm{mg} / \mathrm{L}$ in ground water at monitoring wells NC7-61 (97mg/L and $66 \mathrm{mg} / \mathrm{L}), \mathrm{K} 2-04 \mathrm{~S}$ (58 mg/L and $51 \mathrm{mg} / \mathrm{L})$, and K2-01C (48 mg/L).

No energetic compounds were detected. Gross alpha and beta activities were low and indistinguishable from background, as was total uranium activity. Tritium activity was above background in many ground water samples.

Tritium, as tritiated water (HTO), has been released in the past from the Pit 3 and 5 landfills and from beneath the firing table at Building 850. Tritiated water was released from Pit 3 and Pit 5 during wetter-than-normal winters when ground water rose and contacted buried firing table wastes. The wet El Niño winter of 1997/1998 caused ground water to rise significantly into Pits 3 and 5, releasing more HTO (Ziagos and Reber-Cox 1998b). HTO was transported to ground water beneath the Building 850 firing table gravels by percolating rainwater (Taffet et al. 1996). The configuration of the commingling HTO plumes at Site 300, updated for 1998, are shown in Chapter 8, Figure 8-1. The plumes are shallow and appear to be confined to the Neroly lower blue sandstone unit ( Tnbs $_{1}$ and Qal). Tritium activity was not discernible in ground water samples from the deeper water-bearing zone monitored at well NC7-69 that is screened in the Cierbo (Tmss) Formation, beneath Tnbs1.

The majority of the Elk Ravine surveillance network tritium measurements made during 1998 support CERCLA studies, which show that, despite additional releases, the tritium contents and extents of the plumes are generally diminishing over time because of natural decay and dispersive mixing (Ziagos and Reber-Cox 1998b). We observe small increases in tritium activity near the sources (well K7-07) and at the distal end of the 


\section{Ground Water Monitoring}

plume (wells K2-01C, NC2-11D, and NC2-12D), while those wells monitoring the bulk of the plume (NC7-61, K2-04D, and K2-04S) show relatively large decreases in tritium activity over the past several years. For example, tritium activity in ground water at well NC7-61 decreased from $6500 \mathrm{~Bq} / \mathrm{L}$ in 1996 to $4500 \mathrm{~Bq} / \mathrm{L}$ in 1998.

\section{Pit 2}

No release of a COC from Pit 2 to ground water is indicated by the surveillance monitoring data obtained during 1998. Analytical results for the Pit 2 surveillance monitoring network are presented in Data Supplement Table 9-24. Several metals were detected at low concentrations. Most were below analytical reporting limits, which are in the parts per billion (ppb) range. None exceeded an MCL. Arsenic and barium concentrations measured within the range of natural (background) concentrations in ground waters at Site 300 (Webster-Scholten 1994).

The radioactivity and radioisotope measurements show only low background activities for gross alpha and gross beta. Tritium activities were all low except for the intermediate water-bearing zone sampled by Barcad K2-01B (9.4 Bq/L) (Figure 9-5). This activity is associated indirectly with the plume of tritium-bearing water from the Building 850 firing table (see Chapter 8, Figure 8-16) (Webster-Scholten 1994; Taffet et al. 1996). The incursion of shallow, tritium-bearing ground water into the Pit 2 area is recorded in ground water samples from surveillance well K2-01C that showed a tritium activity of about 600 Bq/L during 1998 (see Elk Ravine Drainage Area). The trace of tritium detected in the K1-02B sample suggests that the shallow and intermediate-depth water-bearing zones are weakly connected, perhaps along the nearby Elk Ravine fault.

\section{Pit 1}

No release of a COC to ground water from Pit 1 is indicated by the compliance monitoring data obtained during 1998. Analytical results for the Pit 1 compliance ground water monitoring network for 1998 are presented in Data Supplement Tables 9-25 and 9-26. Fourth quarter tritium activity exceeded the statistical limit of $23.4 \mathrm{~Bq} / \mathrm{L}$ in the ground water at Pit 1 monitoring well K1-03 (25.1 Bq/L), and LLNL notified the CVRWQCB by letter of this finding, which constituted statistically significant evidence of a tritium release from Pit 1 (Galles 1999). However, previous CERCLA studies indicate that the tritium activity seen in ground water at several Pit 1 monitoring wells most likely comes from the Building 850 firing table, located about $1 \mathrm{~km}$ west and upgradient of Pit 1 (Webster-Scholten 1994, Taffet et al. 1996, Ziagos and Reber-Cox 1998b; see the tritium plume in Chapter 8, Figure 8-16). 


\section{Ground Water Monitoring}

Also from a source outside of Pit 1, the VOC 1,1,2-trichloro-1,2,2-trifluoroethane (Freon 113) was detected during the fourth quarter in ground water at monitoring wells $\mathrm{K} 1-05(40 \mu \mathrm{g} / \mathrm{L}), \mathrm{K} 1-08(65 \mu \mathrm{g} / \mathrm{L})$, and K1-09 $(140 \mu \mathrm{g} / \mathrm{L})$. The results are all far below the MCL of $1200 \mu \mathrm{g} / \mathrm{L}$ for this VOC. Previous CERCLA studies link the VOC to past spills in the Advanced Test Accelerator area (Figure 9-5), about $200 \mathrm{~m}$ west and upgradient of the affected wells (Webster-Scholten 1994b; Taffet et al. 1996).

\section{Pit 8}

No release of a COC to ground water from Pit 8 is indicated by the surveillance monitoring data obtained during 1998. Analytical results for the Pit 8 surveillance monitoring network are presented in Data Supplement Table 9-27. Two VOCs, TCE and 1,2-DCA, were detected below their $5 \mu \mathrm{g} / \mathrm{L}$ MCLs. Although only two monitoring wells could be sampled, the upgradient well, K8-01, contained the higher concentrations. The VOC TCE was detected in ground water at upgradient well $\mathrm{K} 8-01(2.8 \mu \mathrm{g} / \mathrm{L})$ and at downgradient well K8-02B contained $1.3 \mu \mathrm{g} / \mathrm{L}$ ). The ground water at upgradient well K8-01 contained $1.1 \mu \mathrm{g} / \mathrm{L} \mathrm{1,2-DCA}$. A relatively small VOC plume exists beneath this area (see Chapter 8 , Figure 8-11), which is believed to have originated before 1981 in wastes discharged to a dry well upgradient from Pit 8, near Building 801 (Webster-Scholten 1994).

Arsenic, chromium, and selenium were detected in concentrations below their MCLs, and similar to their natural concentrations in ground water in the Altamont Hills. As in the past, nitrate was detected above the MCL of $45 \mathrm{mg} / \mathrm{L}$ in the upgradient ground water at well K8-01 (47 mg/L). The origin of the nitrate is presently unknown. A CERCLA study of nitrate provenance in ground water at Site 300 was begun in 1998.

\section{Pit 9}

Analytical results for the Pit 9 surveillance monitoring network are presented in Data Supplement Table 9-28. COCs were either not detected or were indistinguishable from natural background concentrations during 1998 sampling. No evidence for a release from Pit 9 is indicated by the surveillance monitoring data obtained during 1998.

\section{Corral Hollow Creek Drainage Area}

\section{Pit 6}

Analytical results for the Pit 6 DMP ground water compliance monitoring network for 1998 are presented in Data Supplement Tables 9-29 and 9-30. Two COCs, tritium at well K6-19 and 1,2-dichloroethane (1,2-DCA) at well EP6-09, both measured above their respective statistical limits during 1998. Most likely, they were released from Pit 6, but the timing of their release is not known. Ground water at well EP6-09 contained 
$0.68 \mu \mathrm{g} / \mathrm{L}$ and $0.52 \mu \mathrm{g} / \mathrm{L}$ of 1,2-DCA during the third and fourth quarters, respectively. 1,2-DCA was not detected in ground water at any other Pit 6 monitoring wells during 1998. The measured concentrations of 1,2-DCA slightly exceeded the $0.5 \mu \mathrm{g} / \mathrm{L} \mathrm{MCL}$, and LLNL notified the CVRWQCB by letter of this finding, which constituted statistically significant evidence of a release of 1,2-DCA from Pit 6 (Galles 1998b).

LLNL notified Site 300 Remedial Program Managers (RPMs) prior to the implementation of post-closure monitoring regarding a potential tritium release from Pit 6 . The RPMs requested that further CERCLA studies be made to determine the source of the tritium. The highest tritium activity measured during 1998 was $91 \mathrm{~Bq} / \mathrm{L}$ in ground water at monitoring well K6-19. The highest measured activity is $12 \%$ of the MCL of $740 \mathrm{~Bq} / \mathrm{L}$ for tritium in drinking water.

The compound bis(2-ethylhexyl)phthalate, which had not been detected in ground water at Pit 6 since 1984, was detected in ground water at three wells (K6-04, EP6-06, and EP6-08) during the second quarter of 1998, in one well (EP6-08) during the third quarter, and it was absent from all wells during the fourth quarter. Concentrations ranged from $5.4 \mu \mathrm{g} / \mathrm{L}$ to $41 \mu \mathrm{g} / \mathrm{L}$, considerably above the $4 \mu \mathrm{g} / \mathrm{L}$ MCL set for this chemical. The chemical was used in explosives experiments at Site 300.

\section{Surface Impoundments}

The two leachate collection and removal systems were monitored weekly for the presence of liquids. In 1998, no water was recovered from the leachate collection and removal system. The visual inspections indicate that the impoundment liners did not leak wastewater during 1998. No water has been observed in the leachate collection and removal system since liner repairs were made in 1997. No water was found in five lysimeters, which also indicates that the impoundment liners did not leak wastewater during 1998. Analytical results for COCs in Site 300 ground water beneath the surface impoundments are listed in Data Supplement Tables 9-31, 9-33, 9-35, and 9-37.

The explosive compounds (HMX, RDX, and TNT) and perchlorate are the compounds most indicative of discharges to ground water from the Explosives Process Area surface impoundments. However, prior to 1985 explosives wastewater was discharged into unlined ponds in the vicinity of the surface impoundments, where it infiltrated the soil and some reached ground water. Because of this past practice, care must be exercised to discriminate between new releases from the surface impoundments and past releases from the unlined ponds. Analyses of ground water from upgradient monitoring well W-817-01 during 1998 show HMX concentrations between 15.0 and $17.5 \mu \mathrm{g} / \mathrm{L}$. HMX was not detected above the analytical reporting limit of 1.0 to $2.5 \mu \mathrm{g} / \mathrm{L}$ in any of the ground water samples from the downgradient monitoring wells. Ground water samples from three wells contained detectable concentrations of the explosive 


\section{Ground Water Monitoring}

compound RDX above the analytical reporting limit of $0.85 \mu \mathrm{g} / \mathrm{L}$. The ground water samples containing RDX were from upgradient well W-817-01 (from 44.2 to $58.3 \mu \mathrm{g} / \mathrm{L}$ ) and from downgradient wells W-817-03 (5.68 to $8.10 \mu \mathrm{g} / \mathrm{L}$ ) and W-817-04 (2.71 to $5.28 \mu \mathrm{g} / \mathrm{L})$. The RDX and HMX originated at closed disposal sites upgradient of the present surface impoundments (Raber and Carpenter 1983, Webster-Scholten 1994). Also, 4-amino-2,6-dinitrotoluene, a breakdown product, was detected in upgradient well W-817-01 (<2.2 to $11 \mu \mathrm{g} / \mathrm{L})$, and in downgradient wells W-817-03 $(<0.26$ to $0.64 \mu \mathrm{g} / \mathrm{L})$ and $\mathrm{W}-817-04(0.264$ to $0.556 \mu \mathrm{g} / \mathrm{L})$. The concentrations observed in the downgradient wells do not exceed their statistical limits. Additional compounds were detected by EPA Method 8330 but do not have statistical limits or MCLs and are presented in Data Supplement Tables 9-32, 9-34, 9-36, and 9-38. The source for these compounds is upgradient from the surface impoundments because the highest concentrations are detected in the upgradient ground water.

LLNL began monitoring ground water for perchlorate in 1998, soon after the California Department of Health Services approved an analytical method (EPA Method 300.0-IC). Ammonium perchlorate is one of the compounds potentially being discharged into the surface impoundments. Perchlorate was detected quarterly in the ground water beneath the surface impoundments during 1998 (Brown, Mathews, and Ward 1998a, b, and 1999). A CERCLA characterization of perchlorate in Site 300 ground water was begun in 1998 (see Chapter 8). Analytical results for perchlorate were highest (0.012 to $0.050 \mathrm{mg} / \mathrm{L}$ ) in samples obtained from monitoring well $\mathrm{W}-817-01$, which is upgradient of the surface impoundments. Perchlorate was also detected in samples from the downgradient wells W-817-02 (<0.004 to $0.032 \mathrm{mg} / \mathrm{L}), \mathrm{W}-817-03(0.005$ to $0.032 \mathrm{mg} / \mathrm{L})$, and W-817-04 (0.011 to $0.029 \mathrm{mg} / \mathrm{L}$ ). The California Department of Health Services has developed a regulatory action level of $0.018 \mathrm{mg} / \mathrm{L}$ for perchlorate.

TCE in the ground water exceeded the drinking water MCL of $5 \mu \mathrm{g} / \mathrm{L}$ in samples from wells W-817-03 and W-817-04 during 1998. The TCE has migrated from past spills at Building 815, upgradient of the impoundments (Webster-Scholten 1994). TCE is not discharged to the surface impoundments (see also Chapter 8).

As in the past, ground water concentrations of arsenic and nitrate continued to exceed drinking water MCLs in ground water samples from all the surface impoundment monitoring wells during 1998. Concentrations of both arsenic and nitrate in ground water have historically exceeded their respective MCLs $(0.050 \mathrm{mg} / \mathrm{L}$ for arsenic and $45 \mathrm{mg}$ /L for nitrate) in this area. Background concentrations of arsenic in ground water monitoring wells upgradient from the surface impoundments have been measured at concentrations above the drinking water MCL (Webster-Scholten 1994). Although the distribution of arsenic over time and throughout the area suggests a natural source, the occurrence and concentration of arsenic at Site 300 is the subject of a continuing 


\section{Ground Water Monitoring}

CERCLA study. Analytical results for the WDR 96-248 ground water COCs, are in Data Supplement Tables 9-31, 9-33, 9-35, and 9-37.

During 1998, all discharges into the surface impoundments were in compliance with discharge concentration limits (see Data Supplement Tables 9-39 through 9-43). An overflow of the Building 825 retention tank and secondary containment system occurred on February 3, 1998, as a result of heavy rain. A representative water sample was obtained and analyzed for COCs. The data were reported and showed no COC concentrations above permitted limits (Mathews and Brown 1998). Because all 1998 discharges were in compliance with WDR 96-248, the polyethylene liners were not subject to chemical degradation.

\section{Percolation Pits}

During 1998, the percolation pits at Building 806A, 827D, and 827E operated normally; no standing water was noted during monthly inspections and no overflows occurred. Standing water was noted in the Building 827C percolation pit during the first and fourth quarters, and the pit overflowed during the second quarter. A sample for metals analysis was collected from the overflow water. Seven metals were detected above the analytical reporting limit: boron, total chromium, chromium(VI), copper, iron, lead, and zinc (see Data Supplement Table 9-44). However, the chromium(VI) result exceeded the concentration of total chromium in the sample and is considered invalid.

\section{Water Supply Wells}

Analytical results for Site 300 water supply Wells 18 and 20 are presented in Data Supplement Tables 9-45 and 9-46. Barium (62 $\mu \mathrm{g} / \mathrm{L})$ and copper $(11 \mu \mathrm{g} / \mathrm{L})$ were detected once in well 20 water samples during 1998 at concentrations far below their MCLs of $1000 \mu \mathrm{g} / \mathrm{L}$. As in past years, TCE was detected below the MCL of $5 \mu \mathrm{g} / \mathrm{L}$ in ground water samples from well $18(0.32,0.29$, and $0.25 \mu \mathrm{g} / \mathrm{L})$. The source of the TCE has not yet been identified. Gross alpha, gross beta, and tritium activities in water samples from both production wells are very low and are indistinguishable from natural background activities.

\section{Sewage Evaporation and Percolation Ponds}

All wastewater parameters for the sewage evaporation and percolation ponds complied with permitted limits throughout 1998. Analytical results are presented in Tables 9-2 and 9-3. No samples were obtained from the percolation pond (location DSWP) during 1998 because there were no discharges from the evaporation pond into the percolation pond. 


\section{Ground Water Monitoring}

Table 9-2. Sewage pond monitoring results, location ESWP.

\begin{tabular}{|c|c|c|c|c|c|}
\hline Parameter & $\begin{array}{l}\text { Permit } \\
\text { limits }\end{array}$ & $\begin{array}{c}\text { First } \\
\text { quarter }\end{array}$ & $\begin{array}{l}\text { Second } \\
\text { quarter }\end{array}$ & $\begin{array}{c}\text { Third } \\
\text { quarter }\end{array}$ & $\begin{array}{l}\text { Fourth } \\
\text { quarter }\end{array}$ \\
\hline $\mathrm{pH}$ (pH units) & none & 9.7 & 9.5 & 9.6 & 9.5 \\
\hline Conductivity ( $\mu \mathrm{mho} / \mathrm{cm})$ & none & 550 & 5700 & 7200 & 10,000 \\
\hline Dissolved oxygen (mg/L) & 1.0 & 12 & 9.2 & 3.9 & 28 \\
\hline \multicolumn{6}{|l|}{ Nutrients (mg/L) } \\
\hline Ammonia nitrogen (as $\mathrm{N}$ ) & none & NS & NS & 0.3 & 0.2 \\
\hline Nitrate (as N) & none & NS & NS & $<0.1$ & $<1$ \\
\hline Nitrate $\left(\right.$ as $\left.\mathrm{NO}_{3}\right)$ & none & $<0.4$ & $<0.4$ & $<0.4$ & $<4.4$ \\
\hline Nitrite (as N) & none & NS & NS & 0.2 & $<0.2$ \\
\hline Nitrite (as $\mathrm{NO}_{2}$ ) & none & NS & NS & $<0.7$ & $<0.66$ \\
\hline Total Kjeldahl nitrogen & none & NS & NS & 13 & 54 \\
\hline
\end{tabular}

$N S=$ Not sampled. Nutrient sampling is part of a special study that began in the third quarter.

Table 9-3. Wastewater effluent monitoring results, location ISWP.

\begin{tabular}{|l|c|c|c|c|c|}
\hline \multicolumn{1}{|c|}{ Parameter } & $\begin{array}{c}\text { Permit } \\
\text { limits }\end{array}$ & $\begin{array}{c}\text { First } \\
\text { quarter }\end{array}$ & $\begin{array}{c}\text { Second } \\
\text { quarter }\end{array}$ & $\begin{array}{c}\text { Third } \\
\text { quarter }\end{array}$ & $\begin{array}{c}\text { Fourth } \\
\text { quarter }\end{array}$ \\
\hline $\mathrm{pH}(\mathrm{pH}$ units) & $6.5<\mathrm{pH}<10$ & 8.8 & 8.6 & 8.8 & 6.8 \\
Conductivity $(\mu \mathrm{mho} / \mathrm{cm})$ & none & 1400 & 1800 & 1700 & 1600 \\
Biochemical oxygen demand $(\mathrm{mg} / \mathrm{L})$ & none & 93 & 120 & 290 & 2100 \\
\hline
\end{tabular}

As a result of heavy rains in January 1998, LLNL received permission from the CVRWQCB in February to operate the sewage evaporation pond with less than the required freeboard of $0.61 \mathrm{~m}(2 \mathrm{ft})$. The sewage evaporation pond operated with less than the required freeboard from February 18 to June 22, 1998. All other observationslevee condition, color, and odor-indicated normal operations.

The ground water analytical data for the sewage pond monitoring network are presented in Data Supplement Tables 9-47 and 9-48. All of the monitored constituents were in compliance with permitted limits. Nitrate increased in downgradient monitoring wells W-26R-01 and W-26R-05 to 40 and $53 \mathrm{mg} / \mathrm{L}$, respectively, during the third quarter. LLNL is currently undertaking studies to determine the origin of this nitrate, including a special study of nitrate and other nutrients in the sewage evaporation pond. This study will continue into 1999. Analyses obtained during 1998 as part of this study are reported in Table 9-2 (location ESWP). 


\section{Off-Site Water Supply Wells}

Analytical results for the off-site water supply wells are presented in Data Supplement Tables 9-49 to 9-54. Generally, no COC attributable to LLNL activities was detected in the off-site ground water samples. Arsenic and barium were widely detected at these locations, but their concentrations were below MCLs and consistent with natural sources in the rocks. Scattered detections of metals were all below MCLs and were probably related to metals used in pumps and supply piping.

As in past years, TCE was detected below the MCL of $5 \mu \mathrm{g} / \mathrm{L}$ in the ground water samples obtained from well GALLO1 $(0.31 \mu \mathrm{g} / \mathrm{L})$ during the fourth quarter. LLNL CERCLA investigators previously concluded that the low concentration of TCE in the GALLO1 well water was probably because of a localized surface spill on the property, possibly from solvents used on a pump truck or another vehicle used to service the private well (Webster-Scholten 1994). (Monitoring of a similarly sited well, GALLO2, had to be terminated several years ago because of contamination from chemicals leaking from the pumping apparatus.) Radioactivity measurements of off-site ground water are all indistinguishable from natural background activities.

\section{Environmental Impacts}

The overall impact of LLNL Livermore site and Site 300 operations on off-site ground waters is minimal. With the exception of VOCs being remediated under CERCLA at both sites, LLNL operations have little or no adverse effect on the surrounding ground waters.

\section{Livermore Site and Environs}

Ground water monitoring at the LLNL Livermore site and in the Livermore Valley indicates that LLNL operations, both past and present, have minimal impact on ground water beyond the site boundary. (See Chapter 8 for CERCLA remediation activities with VOCs.) During 1998, neither radioactivity nor concentrations of elements or compounds detected in ground water from any off-site monitoring well exceeded primary drinking water MCLs. The maximum tritium activity of $11.1 \mathrm{~Bq} / \mathrm{L}(301 \mathrm{pCi} / \mathrm{L})$, only $1.5 \%$ of the MCL, was detected in the ground water sample collected from on-site well W-373 in June. The maximum tritium activity measured off site in the Livermore Valley was even lower, $9.03 \mathrm{~Bq} / \mathrm{L}$, in well 12D2. 


\section{Ground Water Monitoring}

Of the Livermore on-site monitoring wells, no inorganic data exceeded primary MCLs, with the exceptions of chromium in monitoring well W-373 and nitrate in monitoring well W-1012. Chromium(VI) in ground water in the vicinity of monitoring well W-373 is being removed at Treatment Facility C (TFC). The LLNL Ground Water Project reports on the treatment of ground water in the vicinity of the treatment facilities (see Chapter 8). Concentrations of nitrate in ground water samples collected from well W-1012 in June 1998 exceeded California's MCL of $45 \mathrm{mg} / \mathrm{L}$. Nitrate above the MCL has not migrated off site. LLNL continues to monitor this well and monitoring well W-571, which is off site and about 350 meters downgradient from well W-1012, to determine if nitrate at concentrations above the MCL migrates off site.

Concentrations of some nonradioactive dissolved metals detected in a few monitoring wells may be of concern. Dissolved chromium(VI) levels in monitoring well W-373 remain at levels greater than California's MCL of $50 \mu \mathrm{g} / \mathrm{L}$. (Dissolved chromium[VI] in all other wells monitored was found at concentrations less than the MCL.) Ground water in the area of Treatment Facility $C$ has been treated for chromium(VI) since October 1993 (see Chapter 8). The arroyo sediment data included in Chapter 10 indicate no adverse impact on ground water through the arroyos that cross the Livermore site.

\section{Site 300}

Ground water monitoring at Site 300 and adjacent properties in the Altamont Hills shows minimal impact of past and present LLNL operations on ground water beyond the site boundaries.

Within Site 300, the chemicals detected in ground water beneath the High Explosives Process Area will not migrate off site. Plans to remediate TCE, energetic compounds such as RDX, perchlorates, and nitrate are currently being implemented under CERCLA auspices (see Chapter 8). Additionally, LLNL is investigating the distribution and origins of arsenic and zinc in this area.

VOCs, primarily the solvent TCE, have been released historically to shallow ground water at numerous locations at Site 300 (see Chapter 8, and references cited therein). With the exceptions of a small plume in the General Services Area (GSA) area that extends minimally off site along Corral Hollow Road, all of the TCE-bearing ground water is on site. The plume extending off site from the Eastern GSA area is being drawn back to the site by pumping, and the TCE is being removed from the ground water. 
Tritiated water and depleted uranium have been released to ground water from landfills and several firing tables in the northern part of Site 300. The boundaries of the slowly moving ground water plumes lie entirely within the site boundaries. Fate and transport models predict that the tritium will decay naturally to an activity below the drinking water MCL before the tritium-bearing ground water reaches a site boundary (WebsterScholten 1994, Taffet et al. 1996).

Maximum uranium activities that could reach potential exposure points (hypothetical ground water supply wells) at the northern boundary of Site 300 are estimated to be $0.08 \mathrm{~Bq} / \mathrm{L}$ from plumes originating at Pits 5 and 7 , and $0.05 \mathrm{~Bq} / \mathrm{L}$ at the eastern boundary of Site 300 from the plume originating at Building 850 . These conservatively estimated maximum activities are small when compared with the $0.74 \mathrm{~Bq} / \mathrm{L}$ California MCL for uranium in drinking water. The predicted incremental lifetime cancer risks from the released uranium are less than one-in-a-million at the hypothetical exposure points on the Site 300 boundary (Taffet et al. 1996). The VOCs, tritium, nitrate, Freon, and depleted uranium in the shallow ground water beneath Site 300 present no current health risks because the contaminated water is not used for potable domestic, livestock, or industrial water supplies.

Percolation pits operated in compliance with the conditions of WDR 96-248. Of the seven metals detected in the overflow from the Building 827C percolation pit, three of the metals-copper, lead, and zinc-exceeded recommended water quality criteria, while the concentrations of copper, lead, and zinc exceeded thresholds of aquatic toxicity. However, the discharged water did not reach an on-site drainage channel or Corral Hollow Creek. Therefore, there was no impact on the environment from this one-time overflow. 



\section{Soil and Sediment Monitoring}

Gretchen M. Gallegos

Erich R. Brandstetter

Donald H. MacQueen

\section{Introduction}

Soil is weathered material, mainly composed of disintegrated rock and organic material, which will sustain growing plants. Soil can contain pollutants originally released directly to the ground, to the air, or through liquid effluents. Department of Energy (DOE) guidance for environmental monitoring states that soil should be sampled to determine if there is measurable long-term buildup of radionuclides in the terrestrial environment and to estimate environmental radionuclide inventories (U.S. Department of Energy 1991). The guidance recommends that radionuclides specific to a particular operation or facility as well as those that occur naturally should be monitored. Particulate radionuclides are of major interest in the LLNL soil monitoring program because airborne particulate releases are the most likely pathway for LLNL-induced soil contamination.

Sediments are defined, for the purposes of this chapter, as finely divided solid materials that have settled out of a liquid stream or standing water. The accumulation of radioactive materials in sediment could lead to exposure of humans through ingestion of aquatic species, through sediment resuspension into drinking water supplies, or as an external radiation source (U.S. Department of Energy 1991). However, the LLNL Livermore site and Site 300 do not have habitats for aquatic species that are consumed by people, nor do they have surface drainage that directly feeds drinking water supplies.

Soil monitoring in the arroyos is also targeted in the Ground Water Protection Management Program (GWPMP) because recharge of natural runoff through the stream beds of arroyos is a significant source of resupply to the Livermore Valley ground water basin (Webster-Scholten 1994). Infiltrating rainwater may carry with it any dissolved constituents that may be present.

In 1998, soil samples from Big Trees Park in Livermore were analyzed to better determine the extent and origin of plutonium present. Previous sampling at the park in 1995 and 1993 had detected plutonium at concentrations above fallout background. 


\section{Soil and Sediment Monitoring}

\section{Surface Soils and Sediments}

Since 1971, surface soil sampling in the vicinity of the LLNL Livermore site and Site 300 has been part of a continuing LLNL monitoring program designed to measure any changes in environmental levels of radioactivity and to evaluate any increase in radioactivity that might have resulted from LLNL operations. These samples have been analyzed for plutonium and gamma-emitting radionuclides, such as depleted uranium, which is used in some explosive tests at Site 300. The inclusion of other gamma-emitting naturally occurring nuclides $\left({ }^{40} \mathrm{~K}\right.$ and $\left.{ }^{232} \mathrm{Th}\right)$ and the long-lived fission product ${ }^{137} \mathrm{Cs}$ provides background information and baseline data on global fallout from historical aboveground nuclear weapons testing. In addition, LLNL analyzes Site 300 soils for beryllium because it is a potentially toxic metal used at this site.

Similarly, sediment samples have been collected from selected arroyos and other drainage areas at and around the Livermore site since 1988; these locations largely coincide with selected storm water sampling locations (see Chapter 7). The number of sediment sampling locations was reduced in 1994 to correspond to reductions in storm water sampling locations. In addition, in 1991, LLNL began analyzing surface soil samples for beryllium, a potentially toxic metal used at both the Livermore site and Site 300. However, analysis for beryllium was discontinued at the Livermore site in 1995 because beryllium was not ever measured above background values.

Location maps for soil and sediment sampling conducted during 1998 are provided in Figures 10-1 through 10-3. The locations were selected to represent background concentrations (distant locations unlikely to be affected by LLNL operations) as well as areas where there is the potential to be affected by LLNL operations. Areas with known contaminants, such as the Livermore Water Reclamation Plant (LWRP), are also sampled. In general, Site 300 soil sampling locations were established around firing tables and other areas of potential soil contamination. The PRIM location was added to the sampling program to correspond with air sampling conducted at that location. The PRIM site is downwind of Site 300 and sufficiently close to the Site 300 boundary to potentially be affected by Site 300 operations. Approximately $10 \%$ of samples are collected in duplicate; two identical samples are collected at each location chosen for this sampling. All soil and sediment sampling locations have permanent location markers for reference. 


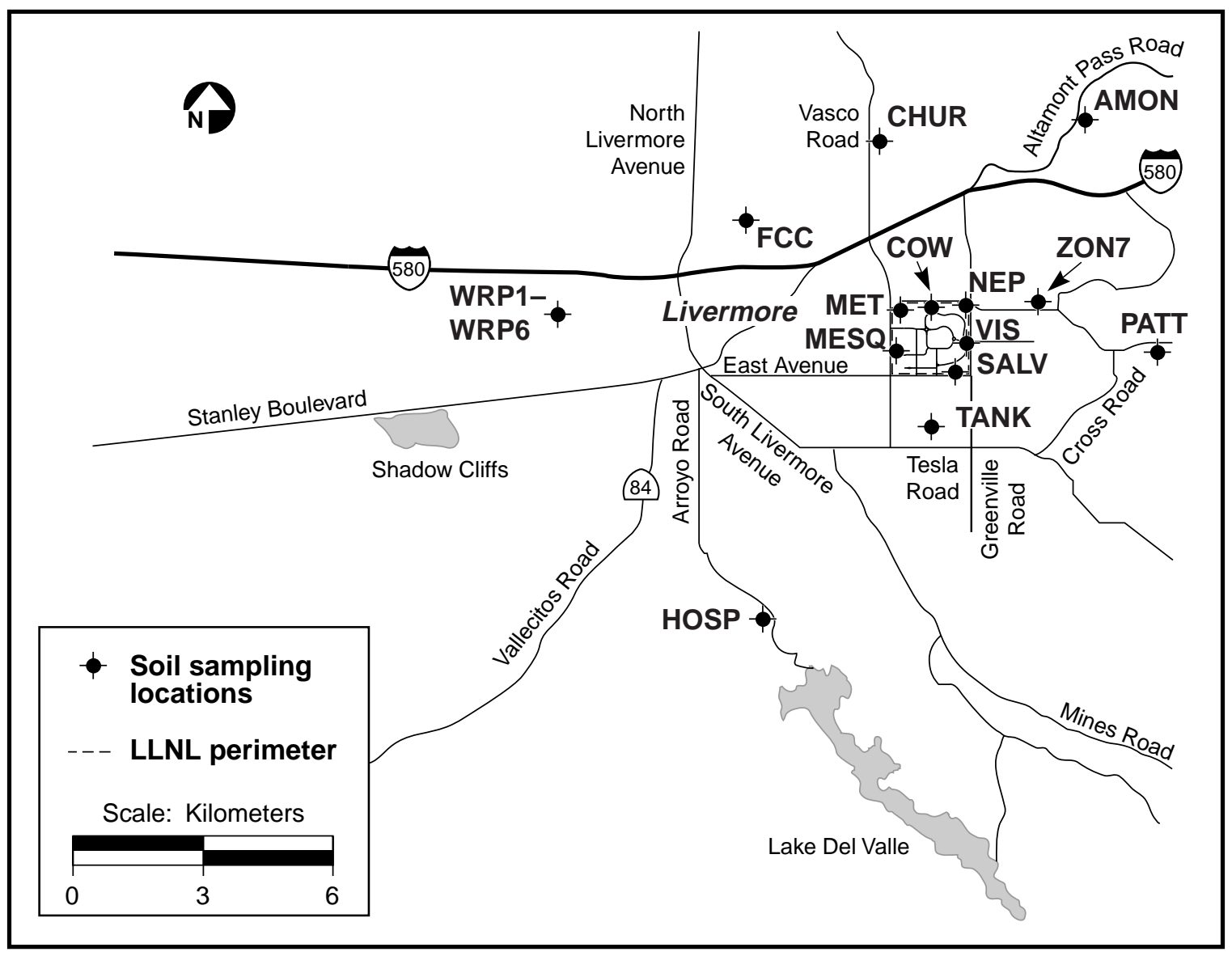

Figure 10-1. Soil sampling locations, Livermore Valley, 1998.

\section{Methods}

Soil and sediment sampling is conducted according to written, standardized procedures (Tate et al. 1995). Soil samples are collected from undisturbed areas near permanent location markers. These areas generally are level, free of rocks, and unsheltered by trees or buildings. All samples are collected from the top $5 \mathrm{~cm}$ of soil because aerial deposition is the primary pathway for potential contamination and resuspension of materials from the surface into the air is the primary exposure pathway to nearby human populations. Samples of sediment are collected annually from drainages at and around the LLNL Livermore site after the cessation of spring runoff. Although added as a new sediment sampling location in 1997, ALPO was not sampled in 1997 or 1998 because the location was constantly under water from releases upstream of the Livermore site. 


\section{Soil and Sediment Monitoring}

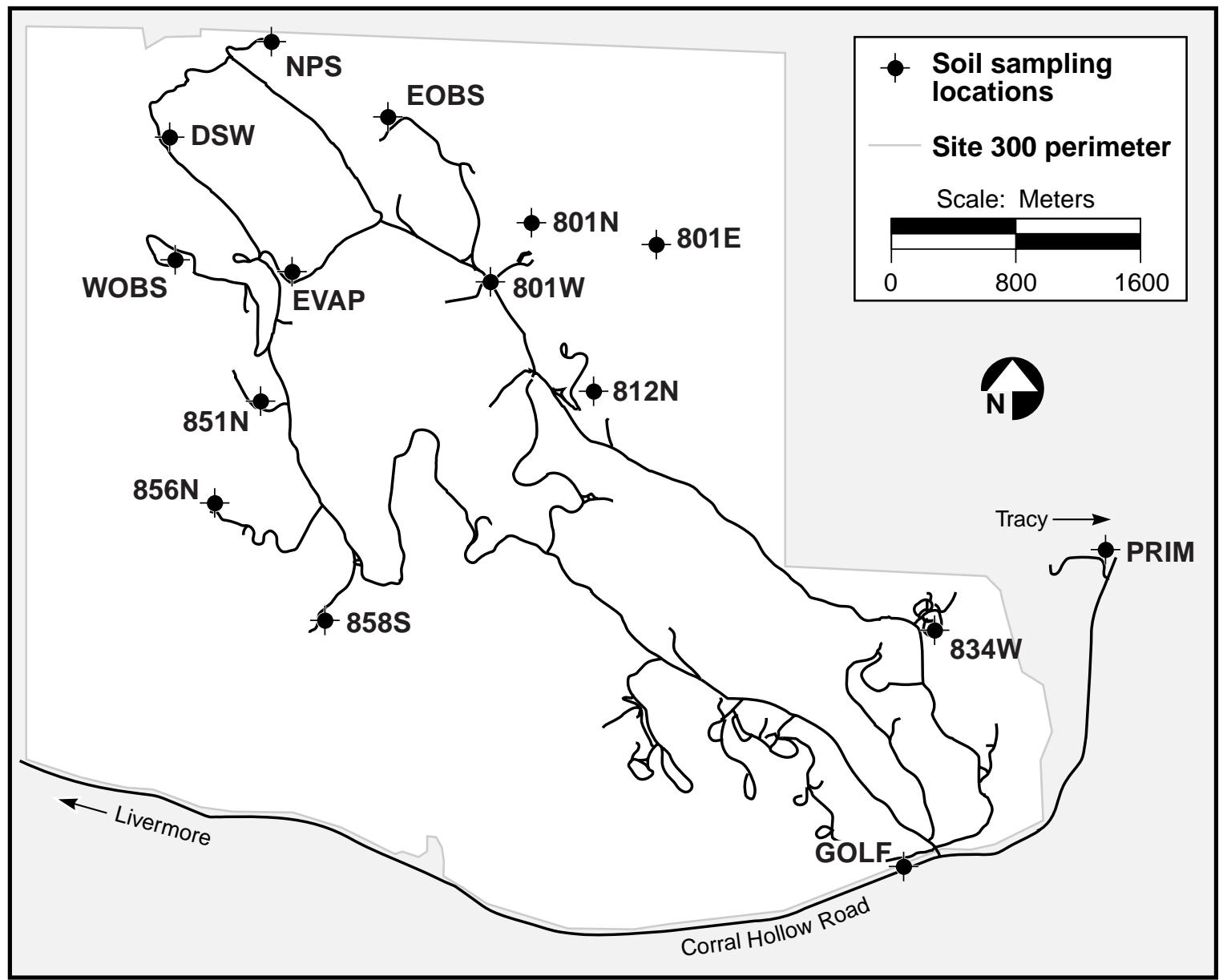

Figure 10-2. Site 300 soil sampling locations, 1998.

For 1998, soil samples in the Livermore Valley were analyzed for alpha- and gammaemitting radionuclides. Sediment samples collected at the Livermore site were analyzed for alpha- and gamma-emitting radionuclides and tritium. Samples from Site 300 were analyzed for gamma-emitting radionuclides and beryllium. Analysis of Site 300 soil samples for plutonium was discontinued in 1997 because plutonium has not been used at the site, and sample results have continuously been at background levels since sampling was begun in 1972.

Soil and sediment samples are dried, ground, sieved, and homogenized. The samples are analyzed by LLNL's Chemistry and Materials Science Environmental Services (CES) laboratory. The plutonium content of a 100-g sample aliquot is determined by alpha spectroscopy. Other sample aliquots ( $300 \mathrm{~g}$ ) are analyzed for more than 150 radionuclides by gamma spectroscopy using a high-purity germanium (HPGe) detector (Hall and Edwards 1994a, b, and c). The 10-g subsamples for beryllium 


\section{Soil and Sediment Monitoring}

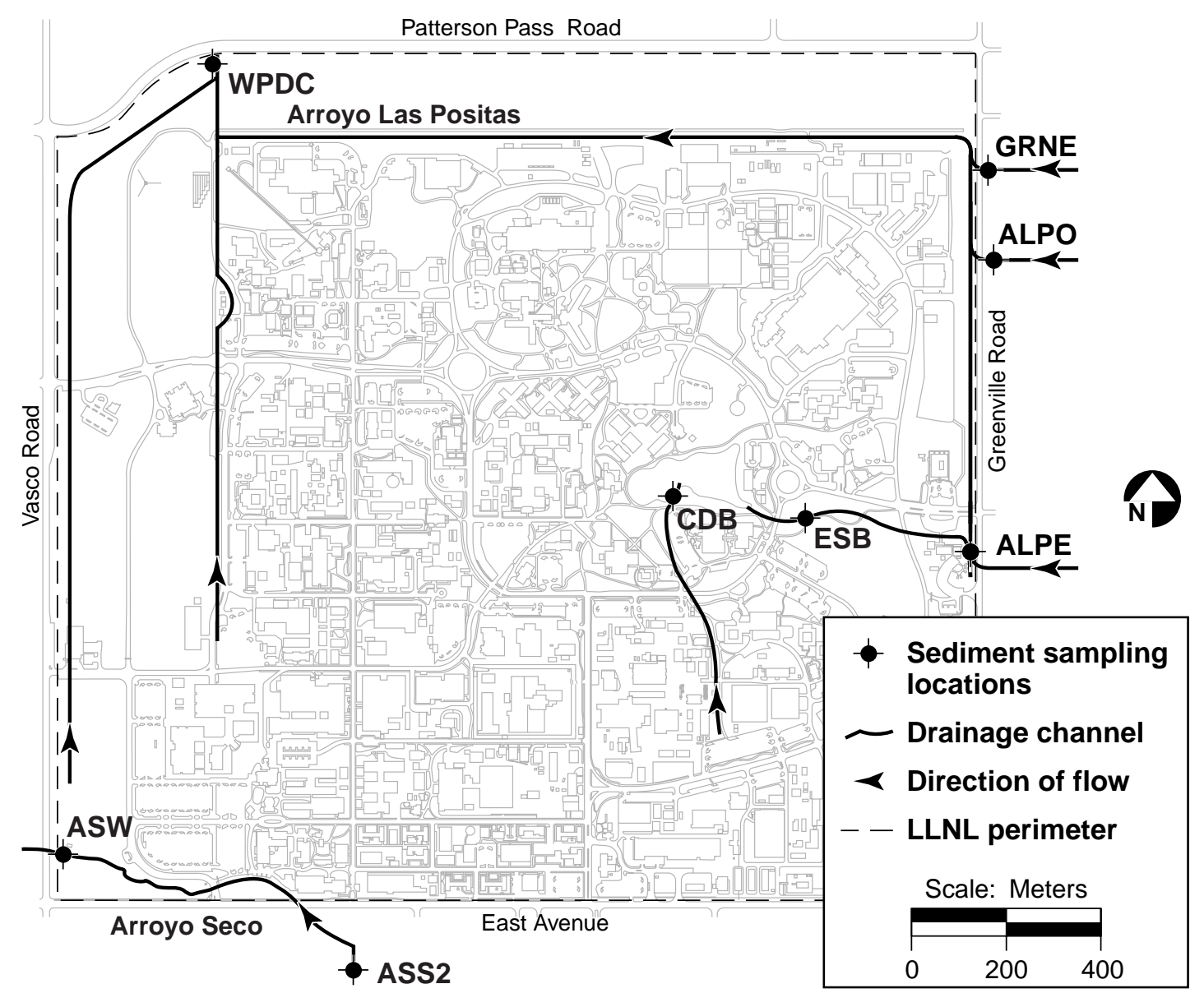

Figure 10-3. Arroyo and drainage basin sediment sampling locations, 1998.

analyses are sent to a contract analytical laboratory and are analyzed by graphite-furnace atomic absorption spectroscopy. For sediment samples collected for tritium analyses, CES uses freeze-drying techniques to recover water from the samples and determines the tritium content of the water by liquid-scintillation counting. Chain-of-custody procedures are followed throughout the sampling, delivery, and analytical processes.

\section{Livermore Valley Results}

Table 10-1 presents summary data on the concentrations of $239+240 \mathrm{Pu},{ }^{238} \mathrm{Pu},{ }^{137} \mathrm{Cs},{ }^{40} \mathrm{~K}$, ${ }^{232} \mathrm{Th}, 235 \mathrm{U}$, and ${ }^{238} \mathrm{U}$ in surface soils from the Livermore Valley sampling locations. The complete data for 1998 soil and sediment sampling is presented in Table 10-1 of the Data Supplement. The concentrations and distributions of all observed radionuclides in soil 


\section{Soil and Sediment Monitoring}

for 1998 are within the ranges reported in previous years and generally reflect worldwide fallout and naturally occurring concentrations. The ratio of ${ }^{235} \mathrm{U}$ to ${ }^{238} \mathrm{U}$ generally reflects the natural ratio of $0.7 \%$; however, there is significant uncertainty in the ${ }^{235} \mathrm{U} /{ }^{238} \mathrm{U}$ ratio because of the difficulty in measuring small quantities of ${ }^{238} \mathrm{U}$ by gamma spectroscopy.

Plutonium has, in the past, been detected at levels above background at ZON7, the off-site soils sampling location near the LLNL Livermore site and in the prevailing downwind direction. Because of the high level of variability inherent in the measurement of soils, we do not always find plutonium above background levels at this location. In 1998, as in 1991 and 1994 through 1997, 239+240 Pu was detected at background levels, $173 \mu \mathrm{Bq} / \mathrm{g}\left(4.7 \times 10^{-3} \mathrm{pCi} / \mathrm{g}\right)$, at location ZON7. Since 1973, soil samples in this area have generally shown $239+240 \mathrm{Pu}$ values that are higher than background, and one of the on-site locations upwind of ZON7 did exhibit a ${ }^{239+240} \mathrm{Pu}$ value slightly above background, $744 \mu \mathrm{Bq} / \mathrm{g}\left(2.0 \times 10^{-2} \mathrm{pCi} / \mathrm{g}\right)$, in 1998 . The slightly higher values at and near the Livermore site have been attributed to historic operations, which included the operation of solar evaporators for plutonium-containing liquid waste in the southeast quadrant (Silver et al. 1974). LLNL no longer operates the solar evaporators or engages in any other open-air treatment of plutonium-containing waste. Nonetheless, $239+240 \mathrm{Pu}$ from historic operations is carried off site by resuspension of soil by wind. Similarly, elevated levels of ${ }^{239+240} \mathrm{Pu}$ (resulting from an estimated $1.2 \times 10^{9} \mathrm{~Bq}$ [32 mCi] plutonium release to the sanitary sewer in 1967 and earlier releases) were first observed in soils near LWRP during the early 1970s, again were detected at LWRP sampling locations. As in 1990 through 1992 and 1997, ${ }^{241}$ Am was detected in LWRP samples; it is most likely caused by the natural decay of the trace concentrations of ${ }^{241} \mathrm{Pu}$ that were present in the release.

Historical plots of median ${ }^{239+240} \mathrm{Pu}$ concentrations in soil in the Livermore Valley upwind and downwind of the center of the LLNL Livermore site, at Site 300, and at LWRP are shown in Figure 10-4. Livermore Valley upwind and Site 300 concentrations have remained relatively constant since monitoring began and generally are indicative of worldwide fallout. Greater variation can be noted in the downwind concentration data, which in 1998 included sampling locations VIS, PATT, NEP, COW, and ZON7, compared to the upwind and historic Site 300 data. The concentrations of plutonium at the downwind locations reflect resuspension of low-level plutonium contamination from soils in the southeast quadrant of the Livermore site. Greater variability in ${ }^{239+240} \mathrm{Pu}$ is seen in samples from LWRP. The ${ }^{239+240} \mathrm{Pu}$ is likely to be present in discrete particles, so the random presence or absence of the particles will dominate the measured $239+240 \mathrm{Pu}$ in any given sample. 


\section{Soil and Sediment Monitoring}

Table 10-1. Summary of soil and sediment analytical data, 1998.

\begin{tabular}{|c|c|c|c|c|}
\hline $\begin{array}{c}\text { Analyte } \\
\text { and location }\end{array}$ & $\begin{array}{c}\text { Detection } \\
\text { frequency }(\mathrm{a})\end{array}$ & Median & $I_{Q} \mathbf{R}^{(b)}$ & Maximum \\
\hline \multicolumn{5}{|l|}{${ }^{238} \mathrm{Pu}(\mu \mathrm{Bq} / \mathrm{dry} \mathbf{g})$} \\
\hline Livermore Valley soils & $8 / 13$ & 2.5 & 2.4 & 49.6 \\
\hline LWRP(c) soils & $6 / 6$ & 60 & 130 & 381 \\
\hline Livermore site sediments & $3 / 7$ & 3.7 & 14.8 & 193 \\
\hline \multicolumn{5}{|l|}{${ }^{239+240} \mathrm{Pu}(\mu \mathrm{Bq} /$ dry g) } \\
\hline Livermore Valley soils & $13 / 13$ & 50.3 & 122 & 744 \\
\hline LWRP soils & $6 / 6$ & 1070 & 3030 & 6070 \\
\hline Livermore site sediments & $7 / 7$ & 25 & 230 & 1740 \\
\hline \multicolumn{5}{|l|}{${ }^{137} \mathrm{Cs}\left(10^{-3} \mathrm{mBq} / \mathrm{dry} \mathrm{g}\right)$} \\
\hline Livermore Valley soils & $13 / 13$ & 1.5 & 2.1 & 4.9 \\
\hline LWRP soils & $6 / 6$ & 0.7 & 1.5 & 4.7 \\
\hline Livermore site sediments & $6 / 7$ & 0.4 & 0.3 & 0.9 \\
\hline Site 300 soils & $14 / 15$ & 2.1 & 3.2 & 5.2 \\
\hline \multicolumn{5}{|l|}{${ }^{40} \mathrm{~K}(\mathrm{~Bq} /$ dry g) } \\
\hline Livermore Valley soils & $13 / 13$ & 0.481 & 0.118 & 0.566 \\
\hline LWRP soils & $6 / 6$ & 0.396 & 0.056 & 0.448 \\
\hline Livermore site sediments & $7 / 7$ & 0.474 & 0.039 & 0.603 \\
\hline Site 300 soils & $15 / 15$ & 0.488 & 0.063 & 0.577 \\
\hline \multicolumn{5}{|l|}{${ }^{232}$ Th $(\mu \mathrm{g} / \mathrm{dry} g)^{(d)}$} \\
\hline Livermore Valley soils & $13 / 13$ & 7.4 & 1.9 & 9.2 \\
\hline LWRP soils & $6 / 6$ & 7.1 & 0.5 & 7.9 \\
\hline Livermore site sediments & $7 / 7$ & 4.7 & 2.1 & 7.4 \\
\hline Site 300 soils & $15 / 15$ & 9.7 & 2.2 & 13.4 \\
\hline \multicolumn{5}{|l|}{ 235U ( $\mu$ g/dry g) $(e)$} \\
\hline Livermore Valley soils & $13 / 13$ & 0.022 & 0.003 & 0.025 \\
\hline LWRP soils & $6 / 6$ & 0.019 & 0.0004 & 0.023 \\
\hline Livermore site sediments & $7 / 7$ & 0.014 & 0.010 & 0.215 \\
\hline Site 300 soils & $15 / 15$ & 0.028 & 0.008 & 0.049 \\
\hline \multicolumn{5}{|l|}{${ }^{238} \mathrm{U}(\mu \mathrm{g} / \mathrm{dry} \mathrm{g})^{(\mathrm{f})}$} \\
\hline Livermore Valley soils & $13 / 13$ & 2.0 & 0.4 & 3.3 \\
\hline LWRP soils & $5 / 6$ & 2.3 & 0.6 & 3.4 \\
\hline Livermore site sediments & $7 / 7$ & 1.7 & 0.6 & 2.3 \\
\hline Site 300 soils & $14 / 15$ & 3.0 & 2.8 & 14.9 \\
\hline
\end{tabular}




\section{Soil and Sediment Monitoring}

Table 10-1. Summary of soil and sediment analytical data, 1998 (concluded).

\begin{tabular}{|c|c|c|c|c|}
\hline $\begin{array}{c}\text { Analyte } \\
\text { and location }\end{array}$ & $\begin{array}{c}\text { Detection } \\
\text { frequency }(a)\end{array}$ & Median & $\operatorname{IQR}^{(\mathbf{b})}$ & Maximum \\
\hline \multicolumn{5}{|l|}{${ }^{3} \mathrm{H}(\mathrm{Bq} / \mathrm{L} \text { extracted water })^{(\mathrm{g})}$} \\
\hline Livermore site sediments & $6 / 7$ & 6.5 & 5.8 & 15.7 \\
\hline \multicolumn{5}{|l|}{${ }^{241} \mathrm{Am}\left(10^{-3} \mathrm{mBq} / \mathrm{dry} \mathrm{g}\right)^{(\mathrm{h})}$} \\
\hline LWRP soils & $1 / 6$ & $<2.6$ & -(i) & —(j) \\
\hline \multicolumn{5}{|l|}{$\mathrm{Be}(\mathbf{m g} / \mathbf{k g})^{(\mathbf{k})}$} \\
\hline Site 300 soils & $15 / 15$ & 0.9 & 0.4 & 2.2 \\
\hline
\end{tabular}

a Detection frequency $=$ the fraction of samples having a measured value above the detection limit.

b $\quad \mathrm{IQR}=$ Interquartile range.

c $\quad$ LWRP = Livermore Water Reclamation Plant.

d Thorium-232 activities in Bq/dry g can be determined by dividing the weight in $\mu \mathrm{g} / \mathrm{dry} \mathrm{g}$ by 247.3 , and $\mathrm{pCi} / \mathrm{dry} \mathrm{g}$ can be determined by dividing by 9.15 .

e Uranium-235 activities in Bq/dry g can be determined by dividing the weight in $\mu \mathrm{g} / \mathrm{dry} \mathrm{g}$ by 12.5 , and $\mathrm{pCi} / \mathrm{dry} \mathrm{g}$ can be determined by dividing by 0.463 .

f Uranium-238 activities in Bq/dry g can be determined by dividing the weight in $\mu \mathrm{g} / \mathrm{dry} \mathrm{g}$ by 80.3 , and $\mathrm{pCi} / \mathrm{dry} \mathrm{g}$ can be determined by dividing by 2.97 .

g Only sediment samples are analyzed for tritium.

$\mathrm{h}$ Americium-241 is only detected in LWRP soil samples.

i Interquartile range not calculated because of high incidence of reported values below detection limits.

j Maximum value not presented because the only detection is within the range of values reported as below detection limits.

k Only Site 300 samples are analyzed for beryllium.

Table 10-1 presents summary data on radionuclides detected in the sediment samples; a complete presentation of 1998 sediment data is found in Table 10-1 of the Data Supplement. The levels of $239+240 \mathrm{Pu}$ were generally at background concentrations, reflective of worldwide fallout. The moderately higher values at sampling locations CDB and ESB (see Figure 10-3) may be attributed to historic activities in the southeast quadrant at LLNL; these locations are both in drainages for that area. Most other radionuclides were detected at levels similar to those reported from 1988 through 1997: ${ }^{137} \mathrm{Cs}$, a fission product, was found at worldwide background concentrations; and ${ }^{40} \mathrm{~K}$, ${ }^{232} \mathrm{Th},{ }^{235} \mathrm{U}$, and ${ }^{238} \mathrm{U}$-naturally occurring radionuclides-were detected at background concentrations. Tritium concentrations were within the range of previous data. Tritium in sediments was evaluated for differences upwind and downwind of the Livermore site for all data collected from 1988 to 1998. A statistically significant difference was found using the Tukey-Kramer honestly significant difference (HSD) test, with the downwind sediment samples having higher measured concentrations than the upwind sediment samples. Tritium in sediments will continue to be evaluated. 


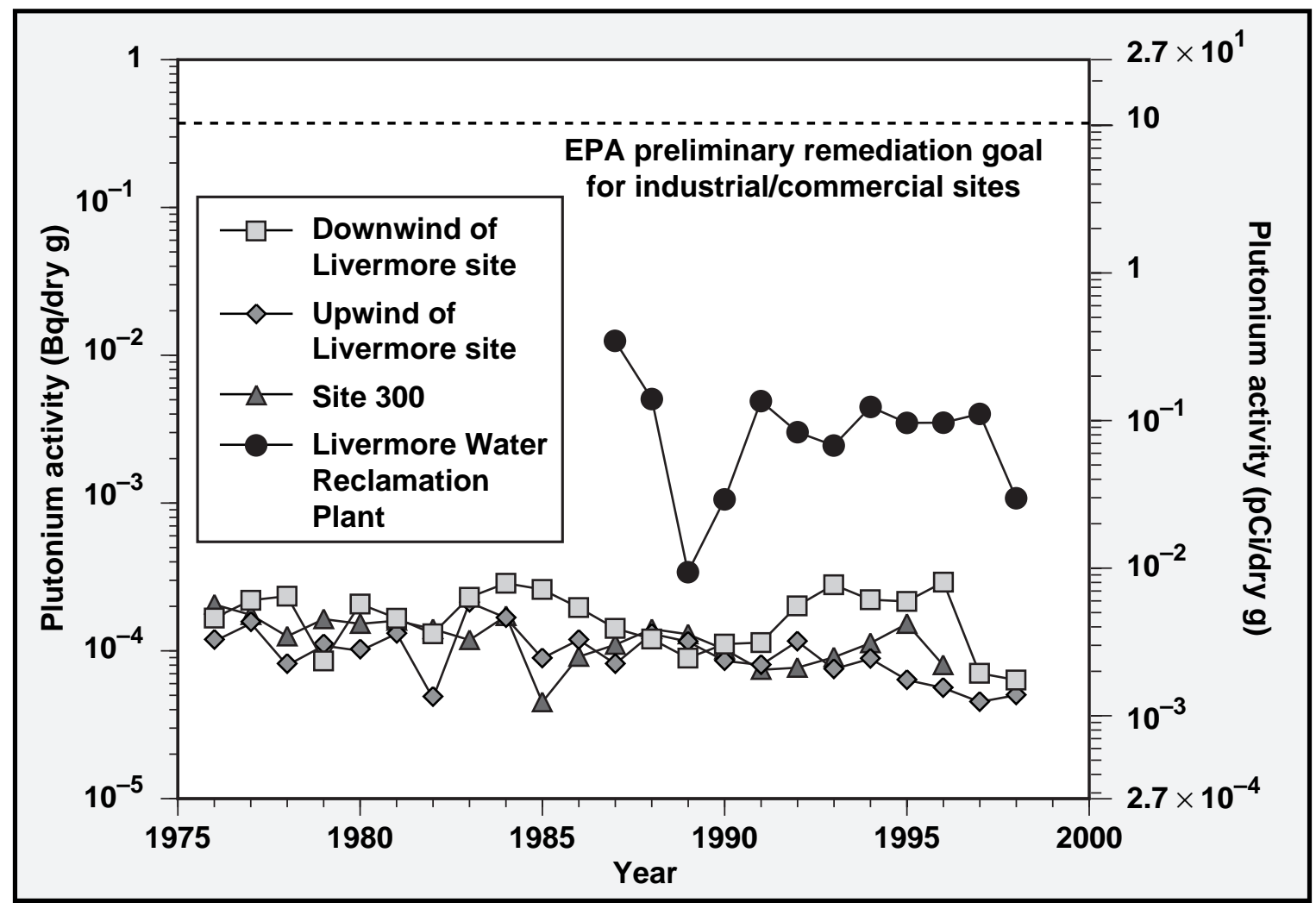

Figure 10-4. Median 239+240Pu activities in surface soils, 1976 to 1998 . Upwind and downwind designations are relative to the center of the Livermore site.

\section{Site 300 Results}

Table 10-1 presents summary data on the concentrations of ${ }^{40} \mathrm{~K},{ }^{137} \mathrm{Cs},{ }^{232} \mathrm{Th},{ }^{235} \mathrm{U}, 238 \mathrm{U}$, and beryllium in soil from the Site 300 sampling locations; a complete presentation of 1998 soils data for Site 300 is found in Table 10-2 of the Data Supplement. The concentrations and distributions of all observed radionuclides in Site 300 soil for 1998 lie within the ranges reported in all years since monitoring began. The ratio of $235 \mathrm{U}$ to ${ }^{238} \mathrm{U}$ generally reflects the natural ratio of $0.7 \%$. Historical trends of ${ }^{238} \mathrm{U}$ concentrations from both the Livermore Valley and Site 300 are shown in Figure 10-5. Median values have remained relatively constant for both places. The highest values at Site 300 result from the use of depleted uranium in high-explosive tests. 


\section{Soil and Sediment Monitoring}

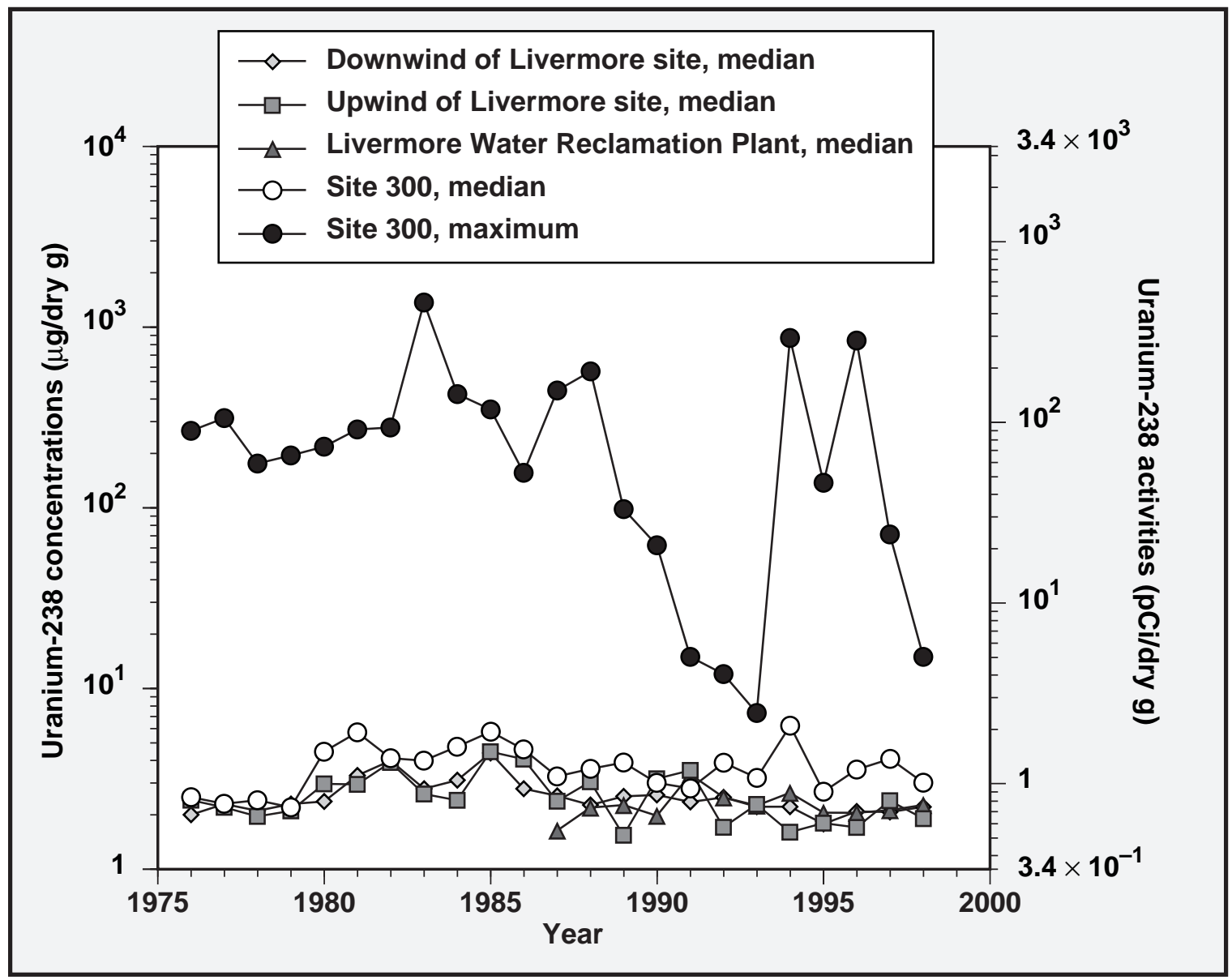

Figure 10-5. Uranium-238 concentrations in surface soils, 1976 to 1998.

\section{Environmental Impact}

This section discusses the environmental impacts at the LLNL Livermore site and Site 300 inferred from soil and sediment monitoring.

\section{Livermore Site}

Routine soil and sediment sample analyses indicate that the impact of LLNL operations on these media in 1998 has not changed from previous years and remains insignificant. Most analytes of interest or concern were detected at background concentrations, in trace amounts, or could not be measured above detection limits. 


\section{Soil and Sediment Monitoring}

The highest value of $6.1 \mathrm{mBq} / \mathrm{g}(0.16 \mathrm{pCi} / \mathrm{g})$ for $239+240 \mathrm{Pu}$ measured at LWRP during 1998 represents $1.6 \%$ of the Environmental Protection Agency (EPA) preliminary remediation goal for commercial or industrial sites of $0.37 \mathrm{~Bq} / \mathrm{g}(10 \mathrm{pCi} / \mathrm{g})$ (U.S. Environmental Protection Agency 1991). Statistical analysis shows there is no general increase or decrease in ${ }^{239+240} \mathrm{Pu}$ values with time. Moreover, all measured concentrations, regardless of location and year, have been a small fraction of the EPA preliminary remediation goal, which is shown in Figure 10-4 for comparison. Sampling of soils for radiological materials will continue on an annual basis.

\section{Site 300}

The concentrations of radionuclides and beryllium observed in soil samples collected at Site 300 are within the range of previous data and are generally representative of background or naturally occurring levels. The $235 \mathrm{U} / 238 \mathrm{U}$ ratios that are indicative of depleted uranium occur near active firing tables at Buildings 801 and 851, from a small fraction of the operations at the firing table that disperse depleted uranium.

\section{Vadose Zone Soils}

Soils in the shallow vadose zone are collected in arroyo channels at the Livermore site as part of the Ground Water Protection Management Program. Infiltration of natural runoff through arroyo channels is a significant source of ground water recharge, accounting for an estimated $42 \%$ of resupply for the entire Livermore Valley ground water basin. Soils in the shallow vadose zone are collected and analyzed to provide information about possible constituents that may be dissolved as runoff water infiltrates through the arroyo to the ground water. Sampling locations are generally chosen to coincide with selected stormwater locations (see Figure 10-3)

\section{Methods}

Vadose zone soil sampling is conducted according to written, standardized procedures. Samples are collected annually from drainages at and around the Livermore site after the cessation of spring runoff. Samples are collected at $30-45 \mathrm{~cm}$ for metals analysis and 45-55 cm deep for analysis for selected organic chemicals. Sediment samples were analyzed for organics using EPA Method 8240 for both total and soluble metals using California's Waste Extraction Test. Chain-of-custody procedures are followed throughout the sampling, delivery, and analytical processes. 


\section{Soil and Sediment Monitoring}

Analytical results for vadose zone soil samples are compared to soil reuse standards developed by LLNL and the San Francisco Bay Regional Water Quality Control Board (RWQCB) (Folks 1997, Marshack 1991) (see Tables 10-3 to 10-5 in the Data Supplement). Metals background concentrations are based on naturally occurring levels in the soil, considering first the results for total metals and then the soluble metals test. There are no background levels for organic compounds, gross alpha, gross beta, and tritium. Soils containing metals at levels above background or low-levels of organic compounds, gross alpha, gross beta, or tritium still may not adversely affect the ground water. If a metal exceeds both the total and soluble background values, or if there are any detected organic compounds, gross alpha, gross beta, or tritium, the designated level methodology (DLM) is used to determine the soluble levels of contaminants that would not adversely impact ground water beyond its beneficial uses by application of a simple attenuation factor and specific water quality objectives.

The San Francisco Bay RWQCB and LLNL agreed upon an attenuation factor of 100 except for certain metals; the attenuation factor for copper, lead, and zinc is 1000. Any constituents with soluble concentrations above these de minimis levels may adversely impact the ground water beneath.

\section{Vadose Zone Soil Results}

In 1998, LLNL sampled sediments in the shallow vadose zones in the arroyos at three influent locations (ASS2, ALPE, and GRNE), the two effluent locations (ASW and WPDC), and two on-site locations (CDB and EDB) in the settling basins upstream of the Drainage Retention Basin (see Figure 10-3).

All analytical results for organic compounds were below detection limits. All total metals concentrations were below background (see Tables 10-6 to 10-8 in the Data Supplement). Tritium results were all below de minimis levels, and gross alpha and gross beta analyses were not conducted in 1998 (see Data Supplement Table 10-1).

\section{Environmental Impact}

The results of vadose zone soil sampling show that the ground water is not being adversely affected by contaminants carried by infiltration stormwater at the LLNL Livermore site. 


\section{Soil and Sediment Monitoring}

\section{Big Trees Park}

During the 1993 EPA investigation of plutonium in soils present in the southeast quadrant of the LLNL Livermore site, EPA personnel collected a soil sample at Big Trees Park in Livermore to obtain a background sample. This soil sample showed plutonium at a concentration higher than what is expected from global fallout for this region. The park was resampled by the EPA, LLNL, and the California Department of Health Services (DHS) in 1995. (Over the years, LLNL has frequently investigated the presence of radionuclides in local soils. Several of the studies are listed in Table 10-2.)

Table 10-2. Special soil studies.

\begin{tabular}{|c|c|c|}
\hline Year & Subject & Reference \\
\hline $1971-1972$ & Radionuclides in Livermore Valley soil & $\begin{array}{l}\text { Gudiksen et al. 1972; } \\
\text { Gudiksen et al. } 1973\end{array}$ \\
\hline 1973 & Radionuclides in San Joaquin Valley soil & Silver et al. 1974 \\
\hline 1974 & Soil study of southeast quadrant of Livermore site & Silver et al. 1975 \\
\hline 1977 & Sediments from LLNL to the San Francisco Bay & Silver et al. 1978 \\
\hline 1980 & Plutonium in soils downwind of the Livermore site & Toy et al. 1981 \\
\hline 1990 & 195 samples taken in southeast quadrant for study & Gallegos et al. 1992 \\
\hline 1991 & Drainage channels and storm drains studied & Gallegos et al. 1991 \\
\hline 1993 & EPA studies southeast quadrant & Gallegos et al. 1994 \\
\hline 1993 & Historic data reviewed & Gallegos 1993 \\
\hline 1995 & LLNL, EPA, and DHS sample soils at Big Trees Park & MacQueen 1995 \\
\hline 1999 & Summary of results of 1998 sampling at Big Trees Park & Gallegos et al. 1999 \\
\hline
\end{tabular}

As reported in MacQueen (1995), samples from 13 of the 16 locations sampled during 1995 at the park had plutonium concentrations consistent with background levels found throughout the Bay Area. These levels were 1/600 to 1/10,000 of the EPA's risk-based preliminary remediation goal (PRG) for plutonium for residential areas of $0.09 \mathrm{~Bq} / \mathrm{g}$ (2.5 pCi/g) (U.S. Environmental Protection Agency 1991). Background values were found in all sandboxes, school grounds, picnic areas, and under the large eucalyptus trees for which the park is named. Samples from two locations had plutonium concentrations slightly above background levels, but still 1\% to $2 \%$ of the EPA's risk-based preliminary remediation goal for plutonium for residential areas. The four samples collected in 1995 near the 1993 EPA sampling location had results above background, with the highest concentration at this location, $0.038 \mathrm{~Bq} / \mathrm{g}(1.02 \mathrm{pCi} / \mathrm{g})$, being $40 \%$ of the PRG. 


\section{Soil and Sediment Monitoring}

Based on the 1995 work, both the EPA and the California Department of Health and Human Services (DHS) concurred that there was no regulatory concern from any of the sample results, that there was no significant lifetime cancer risk resulting from the low concentrations of $239+240 \mathrm{Pu}$ in the soil samples, and that there was no unacceptable risk to human health or the environment.

In 1997, the Agency for Toxic Substances Disease Registry (ATSDR), which had contracted with the California DHS, Environmental Health Investigations Branch to conduct a health consultation for plutonium, held a public meeting on the subject of plutonium at Big Trees Park. At this meeting, the regulatory agencies restated that although the levels of plutonium at Big Trees Park were not a health concern, they were interested in knowing how the plutonium got to the park, and that this question warranted further investigation. The report issued by ATSDR on this subject was issued in draft in 1998; the final report was issued in May 1999.

On the basis of the draft report, LLNL volunteered to conduct additional sampling and analysis to investigate how plutonium got to the park and to work with the regulatory agencies to assure public concerns were met. In August and September 1998, more than 300 additional soil samples were collected at Big Trees Park. The sampling strategy was based on choosing sampling locations and analytes (1) to provide data to better determine the vertical and lateral extent of plutonium in soils at Big Trees Park, (2) to provide data at locations and depths that are believed to be unique to each of three plutonium distribution pathways, (3) to provide data at areas of public concern, and (4) to provide additional data for locations previously identified as exhibiting above-background plutonium concentrations in soil.

The results of the 1998 sampling effort have provided much more information about the vertical and lateral extent of plutonium levels in soil at Big Trees Park. The results clearly show no systematic distribution of plutonium at depth. Only four of the 130 samples collected deeper than $10 \mathrm{~cm}$ to characterize the vertical extent of contamination had concentrations of $239+240 \mathrm{Pu}$ above background levels determined from historic surveillance sampling. The results for samples collected to evaluate the lateral extent of contamination clearly show an increased level of plutonium along the northern boundary of the park, where the ornamental trees are planted (see Figure 10-6).

The results can also be used to draw conclusions about the route of transport of the plutonium to the park. Three routes to the park were investigated: (1) water-borne plutonium-contaminated sediments transported via the Arroyo Seco, which cuts across the southwestern corner of the Livermore site and flows past Big Trees Park on its 


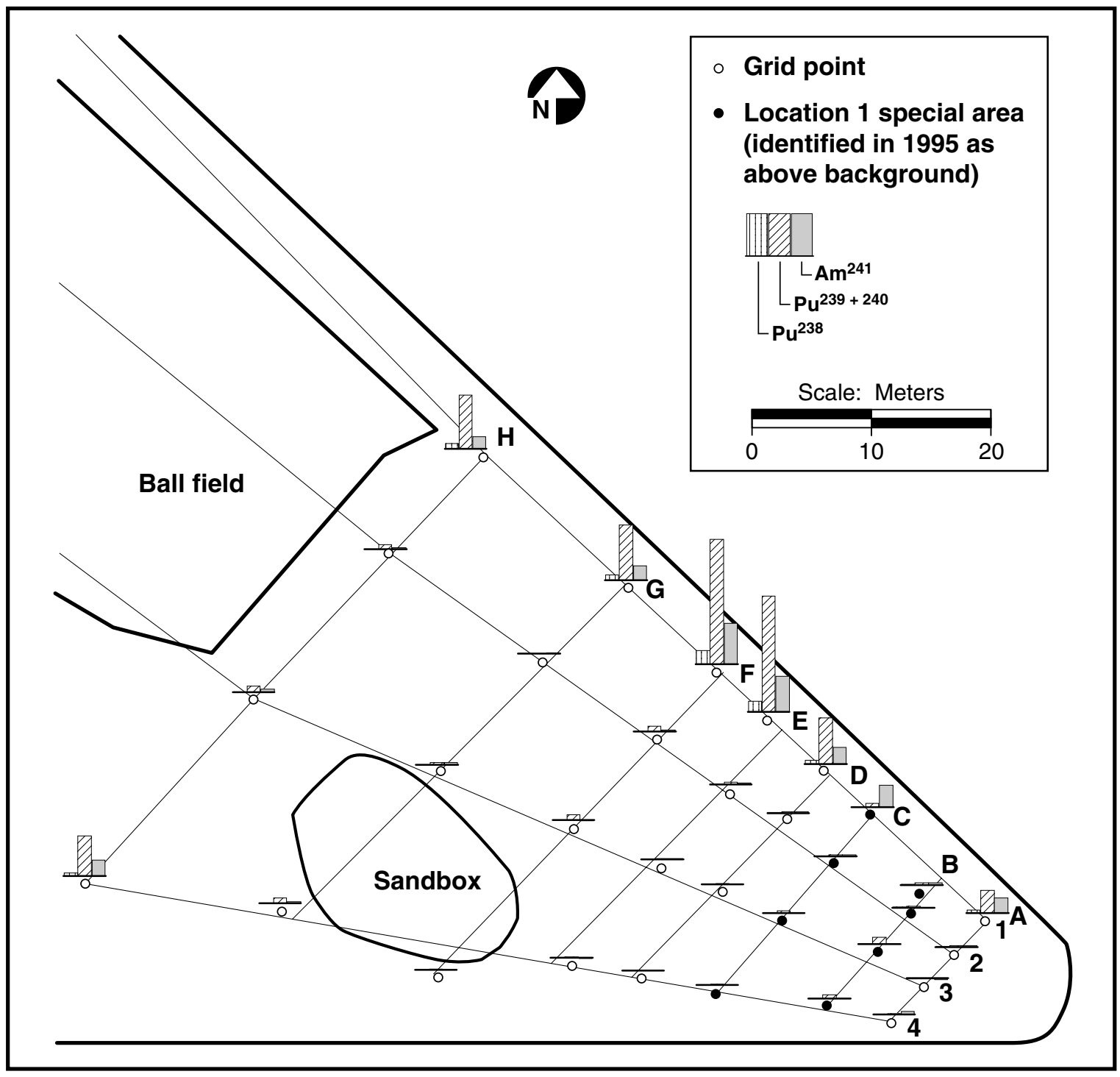

Figure 10-6. Bar graphs of relative radionuclide concentrations at grid locations at Big Trees Park in Livermore. Plutonium results are the averages for the $0-10 \mathrm{~cm}$ depth interval, and americium results are averages for the $0-5 \mathrm{~cm}$ depth interval. Highest concentrations are shown to lie along the northern park border, near the ornamental trees. (Numbers 1 through 4 identify grid radial lines; letters $\mathrm{A}$ through $\mathrm{H}$ identify grid perpendiculars.)

northern boundary; (2) plutonium-contaminated sewage sludge used as a soil amendment for planting the ornamental trees along the northern boundary of the Park; and (3) aerial distribution of releases from the Plutonium Facility. The results for the samples collected to investigate the water-borne hypothesis were nearly all below detection limits. 


\section{Soil and Sediment Monitoring}

Because the concentrations of ${ }^{239+240} \mathrm{Pu}$ were so low in these samples, the water-borne hypothesis is considered to be unlikely. In addition, annual surveillance monitoring of the arroyo shows no residual of past releases nor evidence of recent release.

The sewage sludge hypothesis is based on the fact that sewage sludge was distributed to the public by the LWRP from the early 1960s to the mid-1970s. The probable source of plutonium in the sludge is releases to the LLNL sanitary sewer, with the largest single release occurring in 1967. It is also known that ornamental trees were planted in a row along the northern border of the park, next to the arroyo sometime between 1972 and 1975 . Ten trees along the northern boundary of the park were selected for sampling. Paired with each tree location was another location at least 1 meter beyond the irrigation berm that surrounds each tree. The results from these samples clearly show elevated levels of plutonium in samples taken near the trees but only background levels outside the trees. This distribution of plutonium at the park supports the theory that contaminated sewage sludge was used to fertilize trees at the northern border of the park. Additional support for the sewage sludge hypothesis is the similarity of results from inside the tree wells compared to depth averaged values for grid radial 1. (To the extent possible, grid radial 1 and the line of trees were coincident.) These results are graphically displayed in Figure 10-7.

Another pathway that has been suggested for transmission of plutonium to Big Trees Park is aerial distribution. The pattern shown in Figure 10-6 is not consistent with aerial distribution because aerial distribution would show randomly distributed elevated levels of plutonium throughout the park. Additional data available about air dispersion of plutonium also are not consistent with an air route of transport of plutonium to the park. Sampling systems at the Plutonium Facility (Building 332) consistently show no emissions from that building, except in 1980 when a release occurred. (All plutoniumhandling operations are triple-high-efficiency particulate air [HEPA] filtered.) Air dispersion modeling of the 1980 release yields unmeasurable levels of plutonium at the park, even assuming the wind was blowing directly from the Plutonium Facility to the park. Similarly, modeling of resuspension of plutonium found on the southeast quadrant of the Livermore site also cannot explain the pattern of plutonium distribution at Big Trees Park. In addition, air surveillance data collected throughout the Livermore Valley do not yield any results that would indicate air deposition is the cause of the plutonium levels measured at the park.

Special sampling at locations at the Arroyo Seco School, which borders the park, including a playing field and an unimproved field that is annually disked for weed abatement, and at the eastern extension of the park yielded concentrations well within the range of background. Special sampling at the locations of the highest concentration found in 1995 generally confirmed above-background concentrations but not at the 1995 levels. 


\section{Soil and Sediment Monitoring}

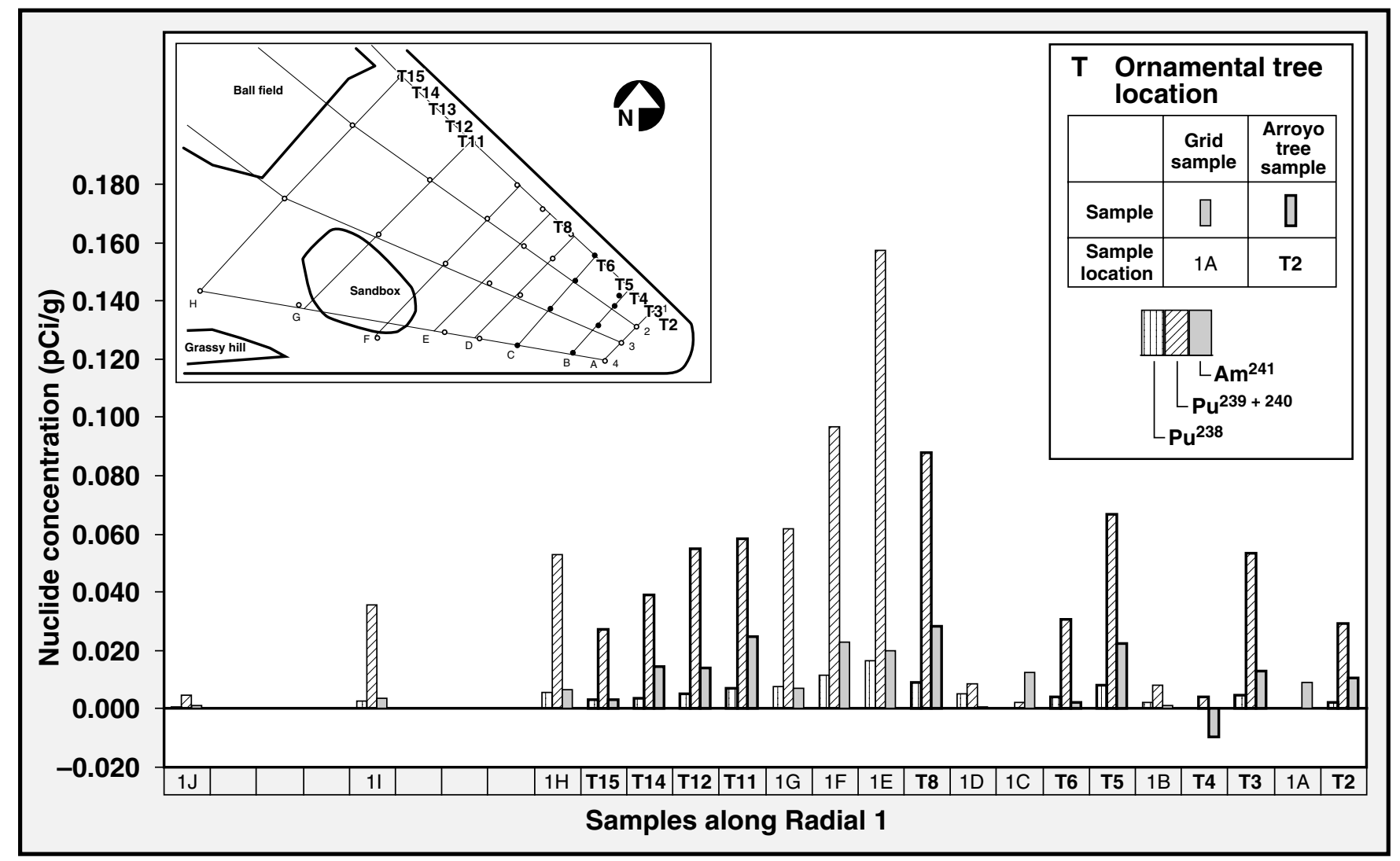

Figure 10-7. Plutonium and americium concentrations measured at grid locations on Radial 1 and in tree wells. Tree samples were taken at $0-45 \mathrm{~cm}$ depth intervals, and grid samples were normalized to the same depth interval. Tree locations are outlined with heavy lines for comparison with grid.

\section{Impact}

The results of this extensive sampling effort demonstrate again that the plutonium is not present at a level of health concern. All sample results were less than the PRG and were less than values measured as the result of previous sampling efforts at the park. The highest sample concentration from the 1998 sampling effort was $0.029 \mathrm{~Bq} / \mathrm{g}(0.79 \mathrm{pCi} / \mathrm{g})$ $239+240 \mathrm{Pu}$, well below the residential PRG of $0.093 \mathrm{~Bq} / \mathrm{g}(2.5 \mathrm{pCi} / \mathrm{g})$. Again, the EPA, California DHS, and ATSDR concur that there is no unacceptable risk to human health or the environment from the levels of plutonium at the park. 



\section{Vegetation and Foodstuff Monitoring}

S. Ring Peterson

\section{Introduction}

LLNL has a vegetation and foodstuff monitoring program to comply with Department of Energy (DOE) guidance, which states that periodic sampling and analysis of vegetation should be performed to determine if there is measurable long-term buildup of radionuclides in the terrestrial environment (U.S. Department of Energy 1991).

Tritium is the nuclide of major interest in the LLNL vegetation and foodstuff monitoring program because LLNL has historically released tritium to the air during routine operations and accidentally. Tritium moves through the food chain as tritiated water and can be rapidly assimilated into plant water and then incorporated into the organic matter of plants through photosynthesis. It can contribute to human radiation dose if it is inhaled or if vegetables or meats from animals having eaten tritiated vegetation are ingested. Although other radionuclides are released from LLNL and tritium does not build up over time, our assessments show that only tritium can be present in vegetation in detectable concentrations.

LLNL has been monitoring tritium in vegetation to some extent since 1966 and has performed vegetation sampling in the vicinity of the Livermore site and Site 300 as part of a continuing monitoring program since 1972. The monitoring program is designed to measure changes in environmental levels of radioactivity, to evaluate increases in radioactivity that might have resulted from LLNL operations, and to calculate potential human doses from radionuclides in the food chain. In 1977, LLNL added wine to the LLNL monitoring program.

During 1998, LLNL collected and analyzed samples of herbaceous vegetation and wine. Potential human doses from these foodstuffs were calculated using the monitoring data and dose models presented in Appendix A. In addition, as part of a continuing study, LLNL determined potential dose from inhalation, skin absorption, and ingestion to the maximally exposed individual from a pine tree on site. Because the roots grow in tritium-contaminated water, tritium is lost to the atmosphere via evapotranspiration, and the pine tree can be modeled as a diffuse source of tritium. Dose was calculated using the Environmental Protection Agency (EPA) model, CAP88-PC. 


\section{Vegetation and Foodstuff Monitoring}

\section{Methods}

Our methods for monitoring vegetation and wine are presented in the following sections.

\section{Vegetation}

LLNL collects vegetation samples, usually annual grasses, quarterly from fixed locations in the Livermore Valley, San Joaquin County, and Site 300, and then analyzes them for tritium.

Location maps are provided in Figures 11-1 and 11-2. These locations were selected so samples would represent vegetation from: (1) locations near LLNL that can be affected by LLNL operations, (2) background locations where vegetation is similar to that

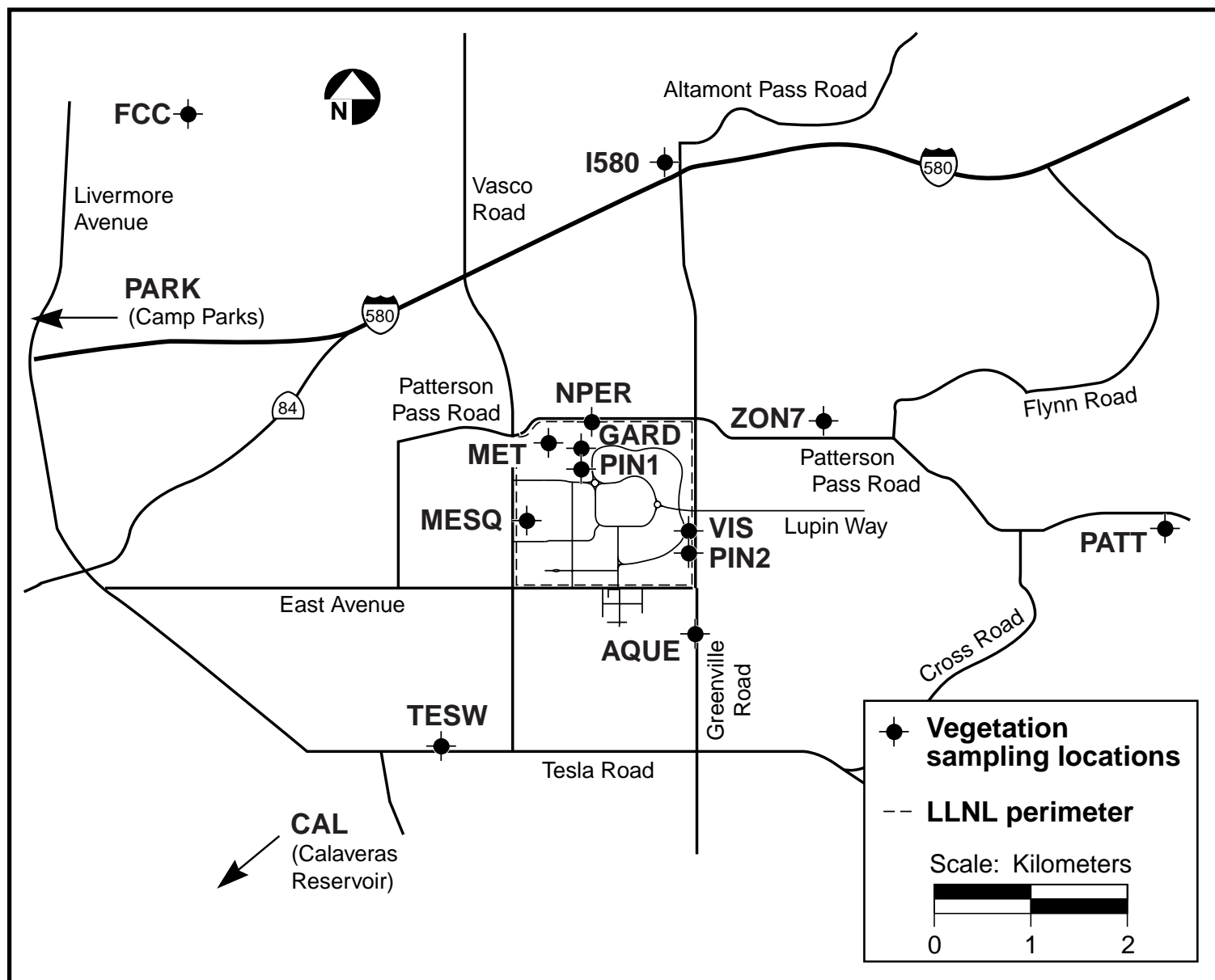

Figure 11-1. Livermore Valley vegetation sampling locations, 1998. 


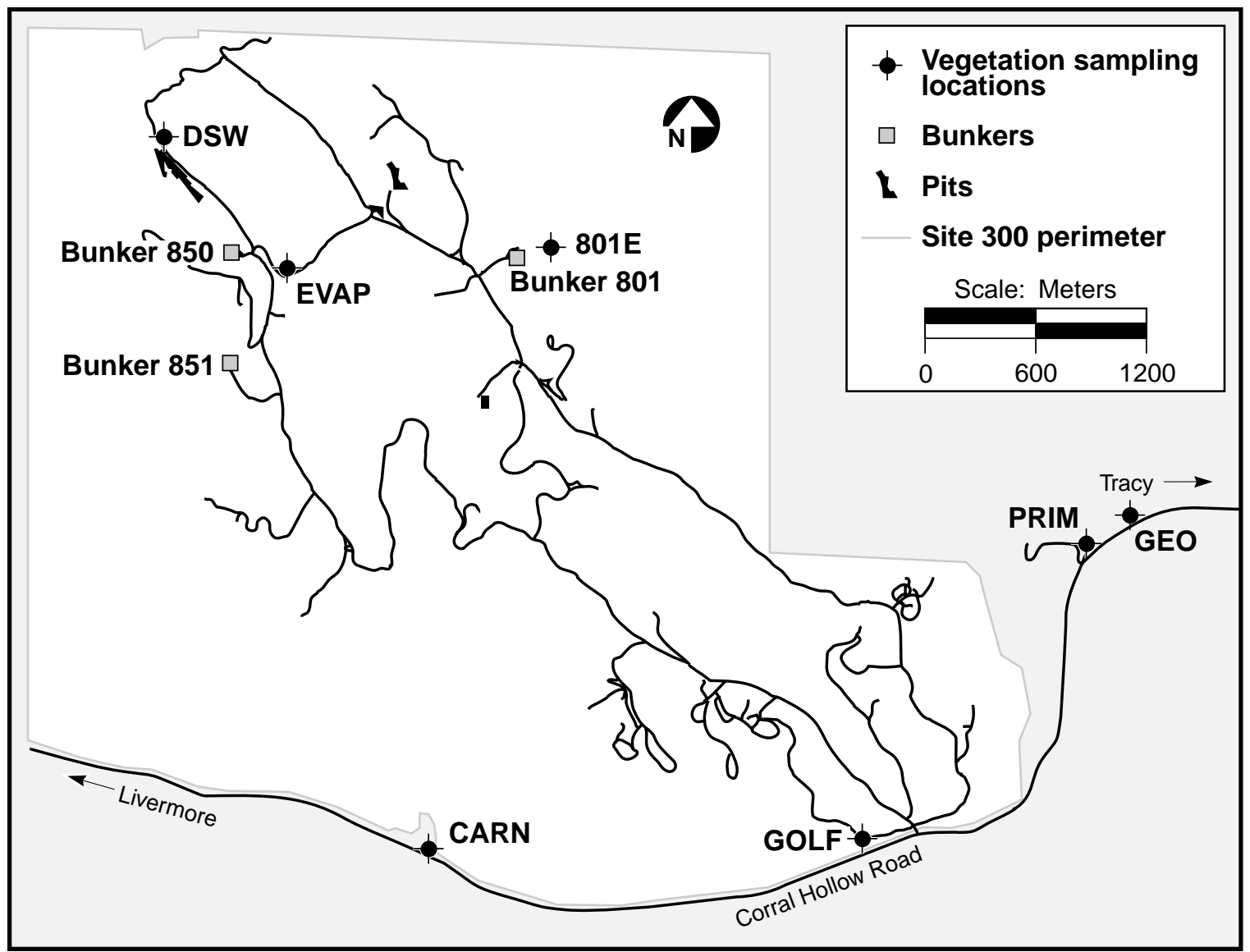

Figure 11-2. Site 300 vegetation sampling locations, 1998.

growing near LLNL but is unlikely to be affected by LLNL operations, and (3) areas of known or suspected LLNL-induced contamination. Sampling locations for 1998 were the same as in 1997, although sampling in 1998 at PIN1 and PIN2 was performed quarterly rather than monthly, as in 1997.

Vegetation samples are frozen when collected. When processed at the analytical laboratory, the samples are freeze-dried to collect the free water in the plant, and the tritium content of this water is determined by scintillation counting.

All vegetation sampling is conducted according to written and approved standardized procedures (Tate et al. 1995). Approximately $10 \%$ of the sites are sampled in duplicate to comply with quality assurance protocols. 


\section{Vegetation and Foodstuff Monitoring}

\section{Wine}

Wine is the most important agricultural product in the Livermore Valley, representing an approximately \$80-million annual industry. Although the tritium concentrations in all wines are low, the data indicate that Livermore Valley wines contain statistically more tritium than do other California counterparts.

Three types of wine samples were collected and analyzed for tritium concentrations: wine produced from grapes grown in the Livermore Valley, wine produced from grapes grown in California outside the Livermore Valley, and wine produced from grapes grown in Europe (France, Germany, and Italy).

The wines were purchased from local retailers to represent what the general public could buy during 1998 (Tate et al. 1995). Sample tritium concentrations are determined by helium-3 mass spectrometry. The resulting analytical data can be used to estimate the potential tritium dose received by consumers during the year of purchase. However, since wines purchased in 1998 are from grapes harvested in 1996 and 1997, the 1998 sampling data cannot be used to indicate how LLNL's operations affected wines produced from grapes grown in 1998. To analyze trends and help determine the impact of LLNL operations on tritium in wine for the year the grapes were harvested, LLNL corrects the wine sample concentrations for the radiological decay that has taken place between approximate date of harvest and the date of analysis in the laboratory. Comparisons can then be made of wine concentrations that represent the year the grapes were exposed to the tritium.

Approximately $10 \%$ of the total complement of wines was sampled in duplicate, $30 \%$ of all the samples were analyzed multiple times, and traceable standards were evaluated to comply with quality assurance protocols.

\section{Results}

The results of vegetation and wine monitoring for the Livermore site and Site 300 are presented in the following sections. 


\section{Vegetation and Foodstuff Monitoring}

\section{Livermore Site}

\section{Vegetation}

The Livermore Valley vegetation locations are put into four groups for statistical evaluation:

- Near-locations at or within $1 \mathrm{~km}$ of the Livermore site perimeter. Near locations include AQUE, GARD, MESQ, NPER, MET, PIN2, and VIS.

- Intermediate-locations in the Livermore Valley 1-5 $\mathrm{km}$ from the Livermore site perimeter that are often downwind and thus potentially under the influence of tritium releases at the site. The intermediate locations are I580, PATT, TESW, and ZON7.

- Far-locations unlikely to be affected by LLNL operations. One background location (CAL) is more than $25 \mathrm{~km}$ away. The other two (FCC and PARK), although in the Livermore Valley, are unlikely to be affected by LLNL operations because they are more than $5 \mathrm{~km}$ from the Livermore site and generally upwind.

- $\quad$ PIN1-location of a pine tree rooted in an area of known tritium contamination on site. Locations PIN1 and PIN2 (a pine tree not rooted in an area of known tritium contamination) were studied monthly during 1997 and quarterly during 1998

Table 11-1 shows summary tritium data for vegetation collected for the LLNL vegetation monitoring program in 1998 (the individual sampling values are presented in the Data Supplement of this report). Figure 11-3 shows the 1998 medians of the tritium concentrations for Near, Intermediate, and Far Livermore locations as well as historic median concentrations from 1971 to 1997.

In 1998, at our request, the analytical laboratory began reporting measured tritium activities, even if they were below the detection limit. This change only affected nondetected data. As a result, some numbers previously reported as "less than" values will now be negative. Since a negative median cannot be graphed on a logarithmic scale (e.g., Figure 11-3), the lowest positive measured concentration has been graphed instead. For the Far location, this new treatment of data has resulted in a drop in concentration between 1997 and 1998 of about a factor of 10, but it is highly likely that there is no difference between 1998 and recent preceding years. 


\section{Vegetation and Foodstuff Monitoring}

The data for tritium in vegetation were compared using the Tukey-Kramer honestly significant difference (HSD) test. As in 1997, the evaluation of the 1998 data show a significant difference between the Near group and the other two groups; that is, the Near values are significantly higher than the Intermediate and Far values, but the Intermediate values are not significantly different from the Far values. The highest median tritium results for individual vegetation sampling locations were found at AQUE and VIS, which are located downwind of the Livermore site and historically have exhibited higher values than other locations.

Table 11-1. Tritium in vegetation (in $\mathrm{Bq} / \mathrm{L}$ ), 1998

\begin{tabular}{|c|c|c|c|c|c|c|}
\hline \multirow[b]{2}{*}{ Location(a) } & \multirow{2}{*}{$\begin{array}{c}\text { Detection } \\
\text { Frequency }(b)\end{array}$} & \multirow[b]{2}{*}{ Median } & \multirow{2}{*}{$\begin{array}{c}\text { Interquartile } \\
\text { Range }\end{array}$} & \multirow[b]{2}{*}{ Maximum } & \multicolumn{2}{|c|}{ Dose $(\mu \mathrm{Sv} / \mathrm{y})(\mathbf{c})$} \\
\hline & & & & & Median & Maximum \\
\hline Near Livermore site ${ }^{(d)}$ & $23 / 27$ & 4.4 & 4.1 & 22 & 0.021 & 0.10 \\
\hline Livermore site PIN1 (e) & $4 / 4$ & 37 & 41 & 110 & $1.9 \times 10^{-6(f)}$ & $5.3 \times 10^{-6(f)}$ \\
\hline Intermediate distance from Livermore site & $7 / 16$ & 1.0 & 3.3 & 6.0 & 0.0050 & 0.029 \\
\hline Far from Livermore site & $3 / 12$ & -0.29 & 1.8 & 3.6 & $-(g)$ & 0.017 \\
\hline Location DSW at Site $300^{(e)}$ & $4 / 4$ & 390 & 1200 & 3300 & 1.9 & 16 \\
\hline Location EVAP at Site $300^{(e)}$ & $2 / 4$ & 4.7 & 130 & 510 & 0.023 & 2.5 \\
\hline All other locations at Site 300 & $0 / 20$ & -0.28 & 0.65 & 0.80 & -(g) & 0.0039 \\
\hline
\end{tabular}

Note: Radioactivity is reported as the measured concentration and an uncertainty ( $\pm 2 \sigma$ counting error). If the uncertainty is greater than the concentration, the result is considered to be a nondetection.

a See Figures 11-1 and 11-2 for sampling locations.

b Detection frequency means the fraction of samples taken having a measured value above the detection limit.

C Dose is calculated based on conservative assumptions that an adult's diet is exclusively vegetables with this tritium concentration, and that meat and milk are derived from livestock fed on grasses with the same concentration of tritium. See Appendix A, Methods of Dose Calculations.

d Includes PIN2; free-water concentrations are similar among plant types.

e Sampling location in known area of contamination.

$f$ For this dose calculation, PIN1 is treated as a diffuse source of tritium (since pine needles are not eaten by human beings). Dose, calculated using CAP88-PC, is to the maximally exposed individual.

$g$ Dose is not calculated when the median concentration is negative.

In 1997, PIN1, a pine tree growing in a known area of contamination, was monitored on a monthly basis to estimate emissions for compliance with National Emissions Standards for Hazardous Air Pollutants (NESHAPs). In 1998, the tree sampling was coordinated with the quarterly vegetation sampling, and NESHAPs calculations to the sitewide maximally exposed individual (SW-MEI) for 1998 are based on the observations from the quarterly samples. To assess the contribution of soil water tritium to 
PIN1, LLNL also sampled a second tree that is not in tritium-contaminated soil (PIN2). Concentrations of tritium in PIN2, like all in other vegetation sampled near the Livermore site, are from air and soil water in equilibrium with air. Concentrations from PIN2 are statistically higher than other Near locations (at the 5\% significance level). This may be because, compared with most of the other sampling locations, PIN2 is both closer to the main source of tritium and is in a direction towards which the wind blows frequently. It may also be caused by exposure of the needles to slightly higher air concentrations with height above ground-level.

\section{Wine}

The results from the 1998 wine tritium analyses are shown in Table 11-2. Tritium concentrations are within the range of those reported in previous years and remain low in wines from all areas.

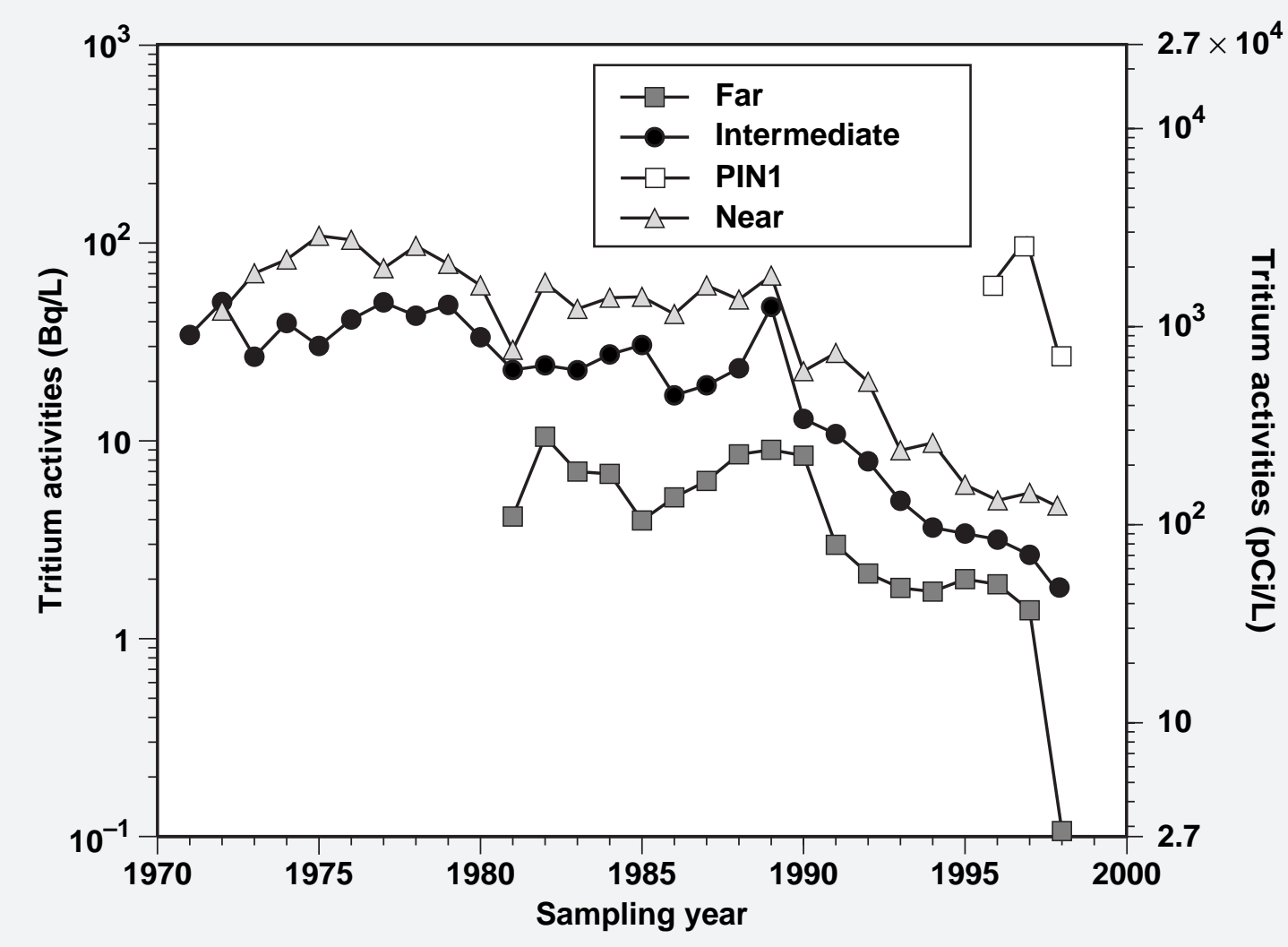

Figure 11-3. Median tritium activities in Livermore Valley vegetation samples, 1971 to 1998. 


\section{Vegetation and Foodstuff Monitoring}

Table 11-2. Tritium in retail wine (in Bq/L), 1998. (a)

\begin{tabular}{|l|c|c|c|c|c|c|}
\hline \multicolumn{1}{|c|}{ Region } & $\begin{array}{c}\text { Detection } \\
\text { frequency }\end{array}$ & Median & $\begin{array}{c}\text { Interquartile } \\
\text { range }\end{array}$ & Mean & Maximum & $\begin{array}{c}\text { Dose } \\
\mu \text { (c) }\end{array}$ \\
\hline Livermore Valley & $12 / 12$ & 2.8 & 2.2 & 3.2 & 8.2 & 0.0028 \\
California & $6 / 6$ & 0.40 & 0.10 & 0.42 & 0.58 & 0.00037 \\
Europe & $4 / 4$ & 1.6 & 0.24 & 1.5 & 1.7 & 0.0013 \\
\hline
\end{tabular}

a Wines from a variety of vintages were purchased and analyzed during 1998 . The concentrations shown are those at the time the bottle was opened.

b Detection frequency is the number of samples taken with results above the detection limit divided by the number of samples.

c This dose is calculated from the assumption of drinking $52 \mathrm{~L}$ wine/year and using the mean concentration of sampled wines.

The data for the 1998 sampling year were analyzed using analysis of variance (ANOVA). The statistical analyses show that the mean tritium concentration of the twelve Livermore wines sampled is statistically greater than that of the six California wines sampled. The statistical analyses also indicate that there is no significant difference between the mean tritium values of the European $(n=4)$ and California wines sampled or between the Livermore and European wines. Multiple comparison tests indicate that the mean levels of the 1998 sampling year data from all areas are not significantly different from those reported for the 1995, 1996 and 1997 sampling years despite the visually apparent downward trend in California wines in Figure 11-4.

Figures 11-4 and 11-5, which show historic means by sampling year and by vintage year, for 1998 look quite different from similar figures in previous years because concentrations have been plotted as logarithms so that differences in low concentrations can be distinguished easily.

Helium-3 mass spectrometry has been used since 1991 to analyze the wine data. Since results from different methods of analysis may not be strictly comparable, only wines measured with ${ }^{3} \mathrm{He}$ mass spectrometry have been compared for trends in decaycorrected concentrations, grouped by vintage year. Wines measured during this period include 1988-1997 vintages for California and Europe and 1983-1997 vintages for the Livermore Valley. Regression analysis shows tritium concentrations in California and European wines decreasing very slightly, while the tritium concentrations in Livermore wines are decreasing more sharply. However, none of these regression lines is statistically significant $(\mathrm{p}<5 \%$ ). In support of the regression analyses, the ANOVA results show some statistical differences between earlier (before 1988) and later vintage wines for Livermore but not for California or Europe. 


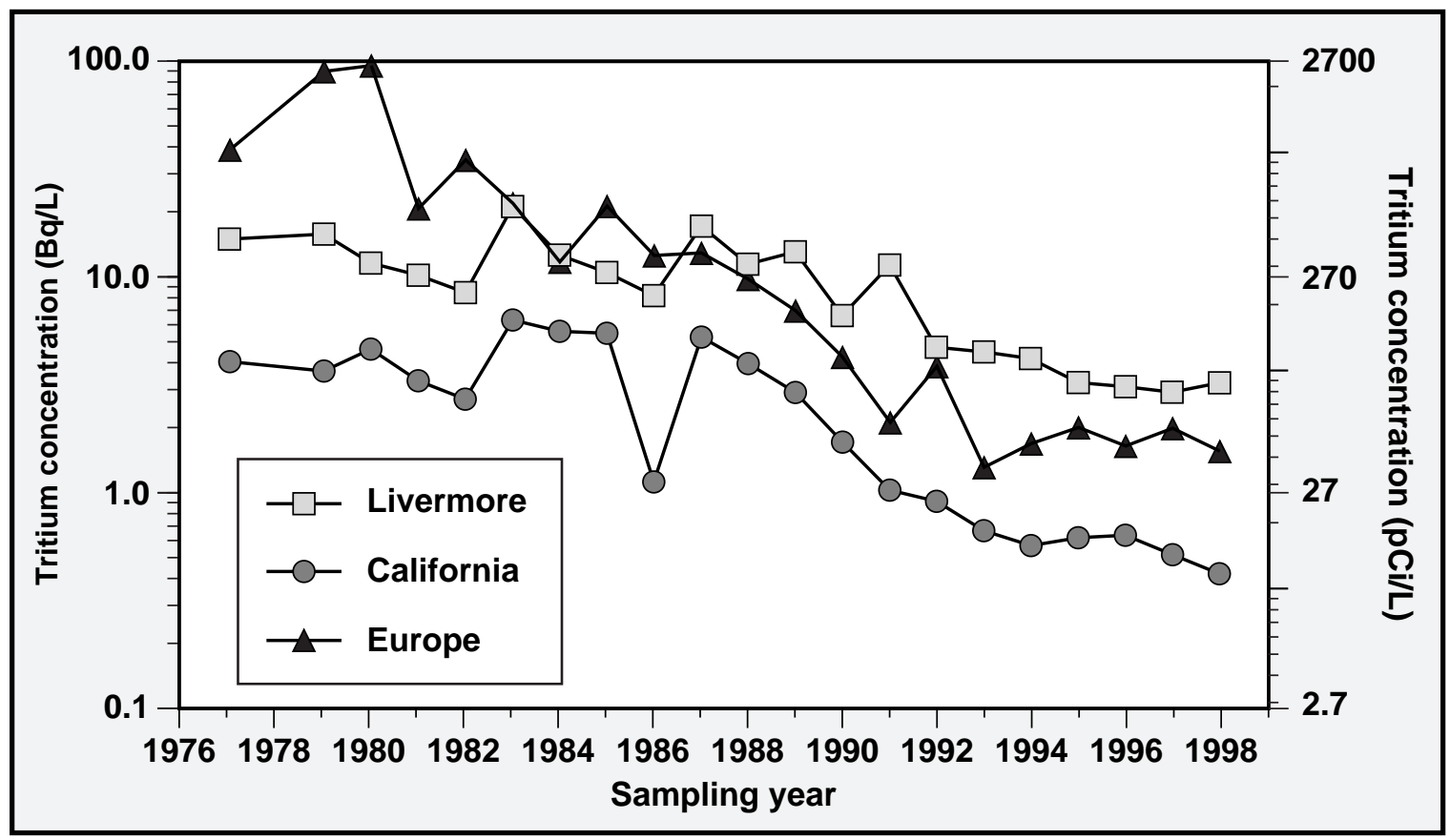

Figure 11-4. Mean tritium in retail wines, 1977 to 1998 , plotted as measured for each sampling year.

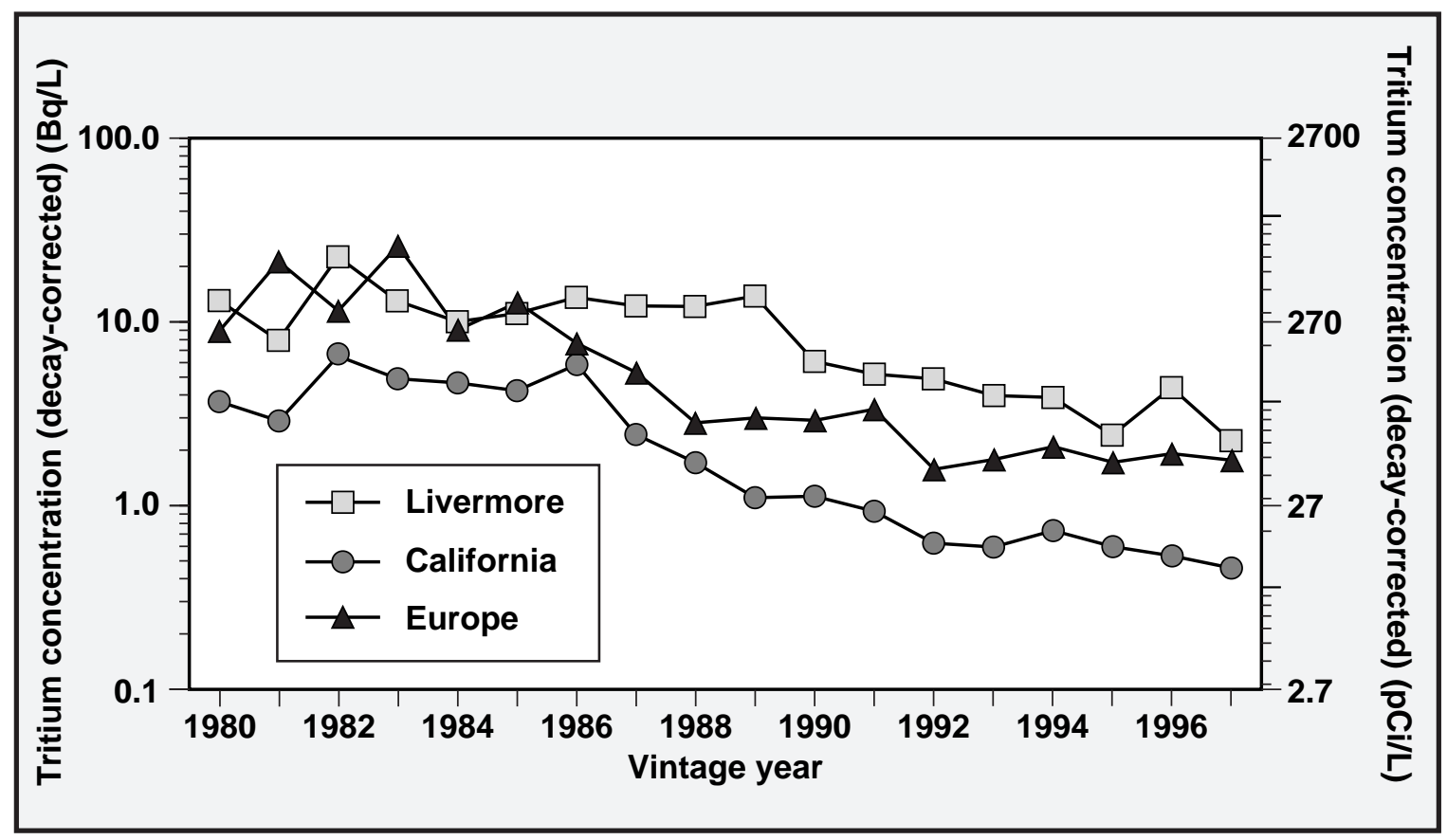

Figure 11-5. Mean tritium concentrations in retail wines decay-corrected from the sampling year to the vintage year. 


\section{Vegetation and Foodstuff Monitoring}

When all wines for 1988-1997, decay-corrected to vintage year, are compared, the concentrations in Livermore wines show higher tritium concentrations than do Californian or European wines, which are indistinguishable statistically (at the 5\% significance level) for that time period.

\section{Site 300}

\section{Vegetation}

Table 11-1 shows summary tritium data for vegetation collected at Site 300 during 1998. Historic values for tritium at Site 300 sampling locations are shown in Figure 11-6. Of the seven sampling locations at Site 300, five yielded results at or near the detection limits. Two locations, EVAP and DSW, yielded results above background levels. The extremely low concentration for all other locations is due to graphing the lowest positive result since the median is negative and the scale of the graph is logarithmic.

The highest tritium result for a single vegetation sample occurred at location DSW (see Table 11-1) where tritium has been observed in the vegetation since 1971. In 1996 and 1997 plants with relatively long taproots were collected (Urtica dioica and Datura wrightii, respectively); however, in 1998 a grass with seemingly shallow roots had the highest observed tritium concentration $(3300 \mathrm{~Bq} / \mathrm{L})$. This sampling location is adjacent to a landfill that contains debris contaminated with tritium from past experiments. The landfill area is currently being investigated under the Comprehensive Environmental Response, Compensation and Liability Act (CERCLA) for tritium contamination of ground water. Tritium in soil and ground water has been studied as part of LLNL's Environmental Restoration Program (Lamarre 1989a, b, and c; Taffet et al. 1989a and b; Taffet et al. 1991; Carlsen 1991a and b; and Webster-Scholten 1994). The tritium values in vegetation are also above background levels at location EVAP, which is near a spring where ground water flows near the surface and evaporates. The ground water in this area is contaminated with tritium that comes from three sources: Pit 3, Pit 5, and the firing table at Building 850 (see discussion of Wells NC7-61 and NC7-69 in Chapter 9, Ground Water Monitoring). Evaluation of the 1998 data for Site 300 using the TukeyKramer HSD test yielded no significant differences among the various sampling locations; this is a result of the high variability of the data and the low number of data points. Although it would be expected that combining data from earlier years (as was done in 1997) would reveal differences between at least locations DSW and EVAP compared with the others, this cannot be done because the 1998 results, with actual measured values, cannot be compared with "less than" detection limits used in previous years. 


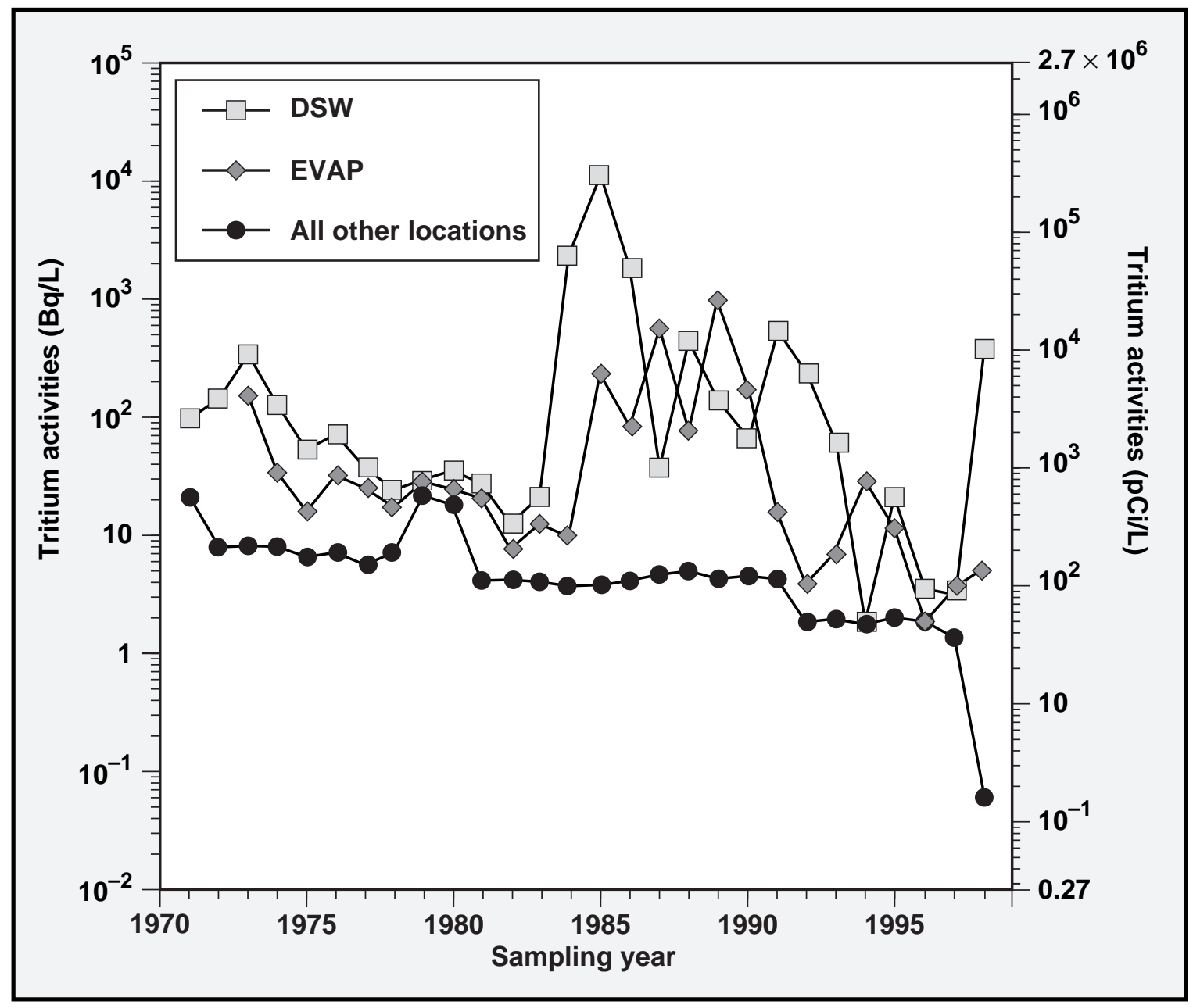

Figure 11-6. Median tritium activities in vegetation at Site 300 sampling locations, 1971 to 1998 . When the median is negative (e.g., all other locations), the lowest positive concentration has been substituted.

\section{Environmental Impact}

The environmental impacts of LLNL operations on vegetation and wine monitoring are small and are presented below for the Livermore site and Site 300. 


\section{Vegetation and Foodstuff Monitoring}

\section{Livermore Site}

LLNL impacts on vegetation in the Livermore Valley remained minimal in 1998. The effective dose equivalents shown in Table 11-1 were derived using the dose conversion factors provided by DOE (U.S. Department of Energy 1988) and the dose pathway model from U.S. Nuclear Regulatory Commission Regulatory Guide 1.109 (U.S. Nuclear Regulatory Commission 1977). Appendix A provides a detailed discussion of dose calculation methods. The dose from tritium in vegetation is based on the conservative assumptions that an adult's diet consists exclusively of leafy vegetables with the measured tritium concentrations and meat and milk from livestock fed on grasses with the same concentrations. Most vegetables consumed by an adult will contain tritium at lower levels than those reported because they will have been imported from other areas. Similarly, tritium concentrations in food consumed by local livestock will be at or below the concentrations in vegetation measured at the Intermediate and Far locations. Nevertheless, based on these extremely conservative assumptions, the maximum potential dose from ingestion of affected vegetation for 1998 for the Livermore site is $0.10 \mu \mathrm{Sv}(0.010 \mathrm{mrem})$.

Doses are calculated based on measured tritium in plant water; contribution of organically bound tritium (OBT) is not included. Dose conversion factors of $1.8 \times 10^{-11} \mathrm{~Sv} / \mathrm{Bq}$ for tritium in the plant or animal water $(\mathrm{HTO})$ and $4.2 \times 10^{-11} \mathrm{~Sv} / \mathrm{Bq}$ for OBT have been published by the International Commission on Radiological Protection (International Commission on Radiological Protection 1996). These show the relative importance of ingested HTO and OBT to dose. In vegetables, the dose from HTO is greater because the fraction of the plant that is organic matter is quite small (10-25\%). For example, about $10 \%$ of the ingestion dose from leafy vegetables (about $10 \%$ dry matter) is from OBT. OBT becomes increasingly important when the fraction of dry matter increases. Pork, for example, has a dry matter content of about $30-50 \%$ (Ciba-Geigy Ltd. 1981), and the resulting ingestion dose from pork will be about half from OBT and half from HTO. The OBT in grain, which is $88 \%$ dry matter, will contribute nearly $90 \%$ of the total grain ingestion dose. Given the differences in OBT dose contribution from different foods, the importance of OBT to ingestion dose depends on what quantities of what kinds of foods are consumed. An extremely unlikely diet very high in OBT would, at most, give an OBT contribution to dose equal to that of HTO. Thus, conservatively, the maximum total tritium dose from ingestion of vegetables and foodstuffs from the Livermore valley could be $0.20 \mu \mathrm{Sv}(0.020 \mathrm{mrem})$, well below any level of concern. 
The dose values for PIN1 shown in Table 11-1 are calculated in a different manner than those for edible vegetation because it is unreasonable to assume that any person is directly ingesting pine needles. The pine tree is treated as a diffuse source of tritium to the atmosphere via the contaminated transpirational stream. LLNL uses an estimated tritium transpiration rate from the tree as input data to the U.S. EPA regulatory model CAP88-PC. LLNL models air dispersion of the transpired tritium and calculates a resulting dose from inhalation, skin absorption, and potential ingestion from air concentrations at the location of the maximally exposed individual. This total dose is based on the conservative assumptions that $100 \%$ of the individual's time is spent at this location and that his/her diet consists exclusively of vegetables with the measured tritium concentration and meat from livestock fed on grasses with the same concentration. The resulting dose for PIN1 of $5.3 \times 10^{-6} \mu \mathrm{Sv}\left(5.3 \times 10^{-7} \mathrm{mrem}\right)$ is considerably lower than ingestion doses calculated directly from concentrations in vegetation because the tree is only an indirect source of air/vegetation contamination.

No health standards exist for radionuclides in wine. However, all the wine tritium levels were far below drinking water standards. In fact, even the highest detected Livermore Valley value $(8.2 \mathrm{~Bq} / \mathrm{L}$ or $222 \mathrm{pCi} / \mathrm{L})$ represents only $1.1 \%$ of the California drinking water standard $(740 \mathrm{~Bq} / \mathrm{L}$ or $20,000 \mathrm{pCi} / \mathrm{L})$. Doses from wine consumption can be calculated according to methods for water ingestion, described in Appendix A.

Based on the extremely conservative assumption that wine is consumed at the same rate as water ( $730 \mathrm{~L} /$ year or $2 \mathrm{~L} /$ day), the annual dose that corresponds to the highest detected 1998 Livermore Valley tritium value in wine is $0.10 \mu \mathrm{Sv}(0.010 \mathrm{mrem})$.

Assuming a more realistic wine consumption (52 L/year or $1 \mathrm{~L} /$ week of wine) and the mean tritium values from the three sampling areas, annual doses from Livermore, European, and California wines would be $0.0028 \mu \mathrm{Sv}(0.00028 \mathrm{mrem}), 0.0013 \mu \mathrm{Sv}$ $(0.00013 \mathrm{mrem})$, and $0.00037 \mu \mathrm{Sv}(0.000037 \mathrm{mrem})$, respectively.

The potential ingestion dose from all foodstuffs grown near the Livermore site is realistically well below $0.3 \mu \mathrm{Sv}(0.03 \mathrm{mrem})$. This is more than a factor of 10,000 lower than an annual background dose ( 3000 $\mu \mathrm{Sv}$ or $300 \mathrm{mrem})$ and a factor of 330 lower than the dose from a typical chest x-ray $(100 \mu \mathrm{Sv}$ or $10 \mathrm{mrem})$ (Shleien and Terpilak 1984). Therefore, although tritium levels are elevated slightly near the Livermore site, doses from tritium ingestion are negligible. 


\section{Vegetation and Foodstuff Monitoring}

Site 300

In general, LLNL impacts on tritium concentrations in vegetation at Site 300 for 1998 were insignificant. With the exception of vegetation from previously identified sites of contamination, the tritium levels at Site 300 were at or near the limits of detection and comparable to those observed in previous years. The areas where tritium is known to be present in the subsurface soil are well delineated and localized.

The calculated maximum potential annual ingestion dose from vegetation at sampling location DSW, based on the maximum value of $3300 \mathrm{~Bq} / \mathrm{L}(89,000 \mathrm{pCi} / \mathrm{L})$, is $16 \mu \mathrm{Sv}$ (1.6 mrem). This dose, based on conservative modeling assumptions described above, is theoretical, since vegetation at Site 300 is not ingested either by people or by livestock. In comparison, the potential annual dose (also theoretical) from vegetation at all other locations at Site 300 could not be calculated since the median concentration is negative and doses cannot be negative. 


\section{Environmental Radiation Monitoring}

Nicholas A. Bertoldo

\section{Introduction}

In accordance with federal regulations, Department of Energy (DOE) Orders 5400.1 and 5400.5, and Title 17, California Code of Regulations, Section 30250, LLNL monitors gamma radiation to establish radiation levels in its vicinity and to determine the direct environmental radiological impact of its operations. Gamma radiation in the environment primarily occurs naturally from terrestrial and cosmic sources. Because environmental radiological monitoring is used as one measure of the potential radiation dose the public receives as the result of LLNL operations, LLNL has developed an extensive radiological monitoring network for the Livermore site perimeter, Livermore Valley, Site 300 perimeter, and nearby off-site locations. Gamma radiation has been measured at the Livermore site since 1973, and the environmental radiation monitoring program was implemented at Site 300 in 1988. The absorbed gamma radiation dose imparted to thermoluminescent dosimeters (TLDs) is the result of TLD exposure from both terrestrial and cosmic radiation sources as well as LLNL sources, if any.

\section{Cosmic Radiation Component}

Gamma radiation in air is produced by the interaction of cosmic rays, which contain high-energy particles and emanate primarily from beyond the solar system, with atmospheric nuclei. The cosmic radiation component accounts for about half the observed site annual average gamma radiation.

\section{Terrestrial Radiation Component}

The elemental composition of the terrestrial gamma radiation component is primarily due to naturally occurring isotopes of the uranium, thorium, and actinium decay series present in soil worldwide that produce gamma radiation during radioactive decay. The concentration variability of the primordial nuclides found among soils is determined by the ratio of thorium-232 to uranium-238 $\left({ }^{232} \mathrm{Th} /{ }^{238} \mathrm{U}\right)$ present in these 


\section{Environmental Radiation Monitoring}

regions at the time of the earth's formation over four billion years ago and ranges from 3 to 4 around the world. Characterizing the natural background enables LLNL's monitoring effort to determine whether or not there is a contribution from LLNL operational effluents, if any.

\section{General Methods}

TLDs are deployed in the field to assess the environmental impact of laboratory operations at both the Livermore site and Site 300. This is done by comparing the gamma radiation data acquired from the LLNL perimeter site locations to various locations monitored in the Livermore valley, and gamma radiation data from Site 300 perimeter locations to locations in Tracy and near Site 300.

As previously mentioned, the variability of the naturally occurring radioisotopes present in the soil due to geological formations becomes the largest contributor. Additionally, the meteorological conditions present also contribute to seasonal variability.

Deployment of the TLDs is done following the annealing process at the beginning of each quarter of the year. The retrieval of the TLDs is done as near to the end of the quarter as possible in order to have a 90-day exposure period. All data are normalized to a 90-day standard quarter basis in order to make valid comparisons.

Details of the TLD calculations and reporting of external gamma radiation dose are described in ORAD EMP-TLD-CALC.

\section{Monitoring Locations}

In 1998, external doses from gamma radiation were monitored at 14 Livermore site perimeter locations (shown in Figure 12-1) and 23 Livermore Valley locations (Figure 12-2), which are used for background comparison to perimeter location data. Similarly, gamma doses are monitored at nine perimeter-monitoring locations at Site 300 (Figure 12-3). Additionally, five off-site locations, which are located near Site 300, and two locations in nearby Tracy were monitored. Summary dose calculations for all gamma-monitoring locations are presented in Table 12-1. 
Environmental Radiation Monitoring

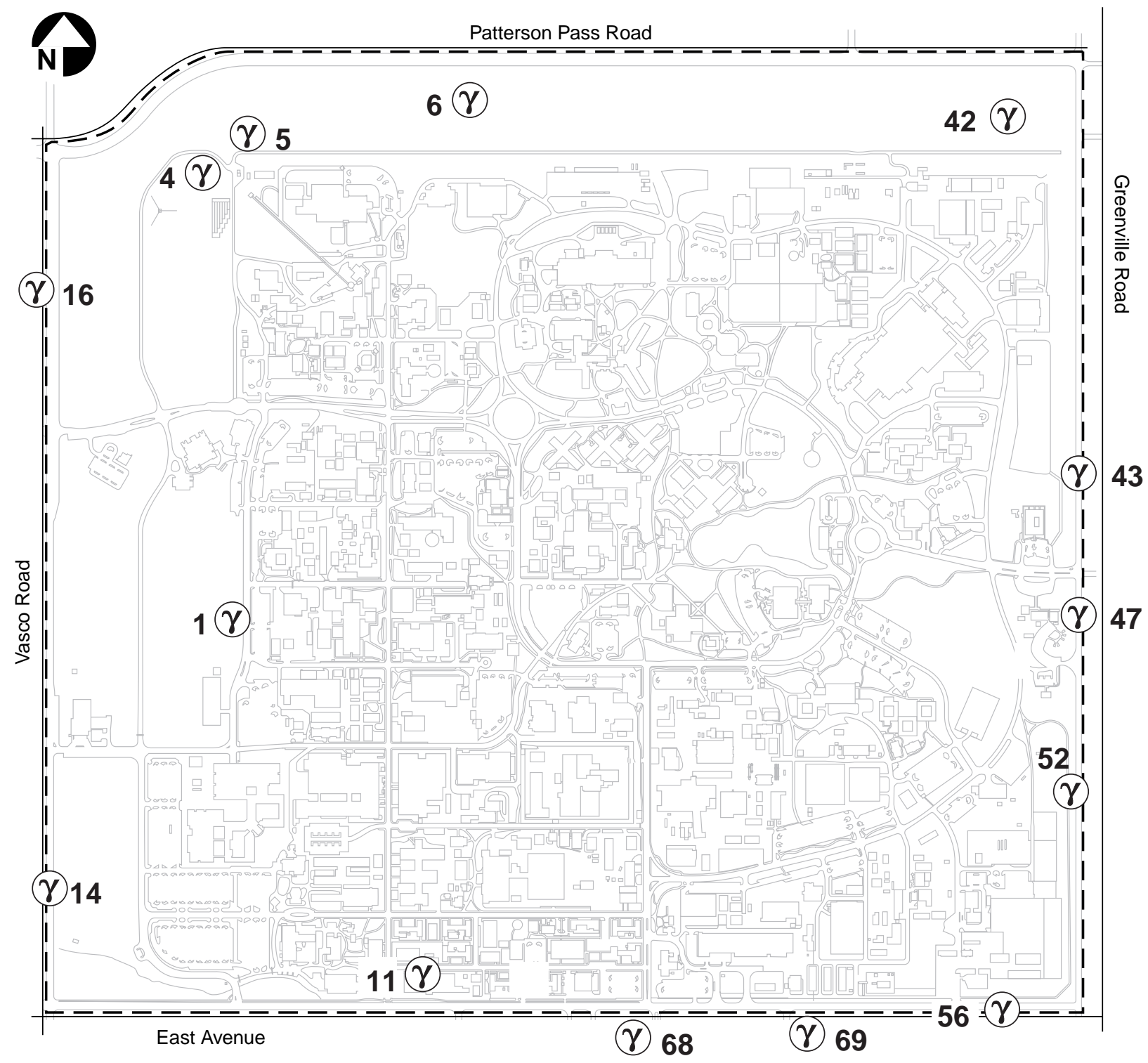

(ช) Gamma dosimeters

Scale: Meters

- - - LLNL perimeter

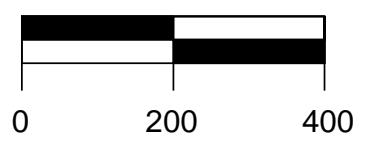

Figure 12-1. Gamma dosimeter locations, Livermore site, 1998. 


\section{Environmental Radiation Monitoring}

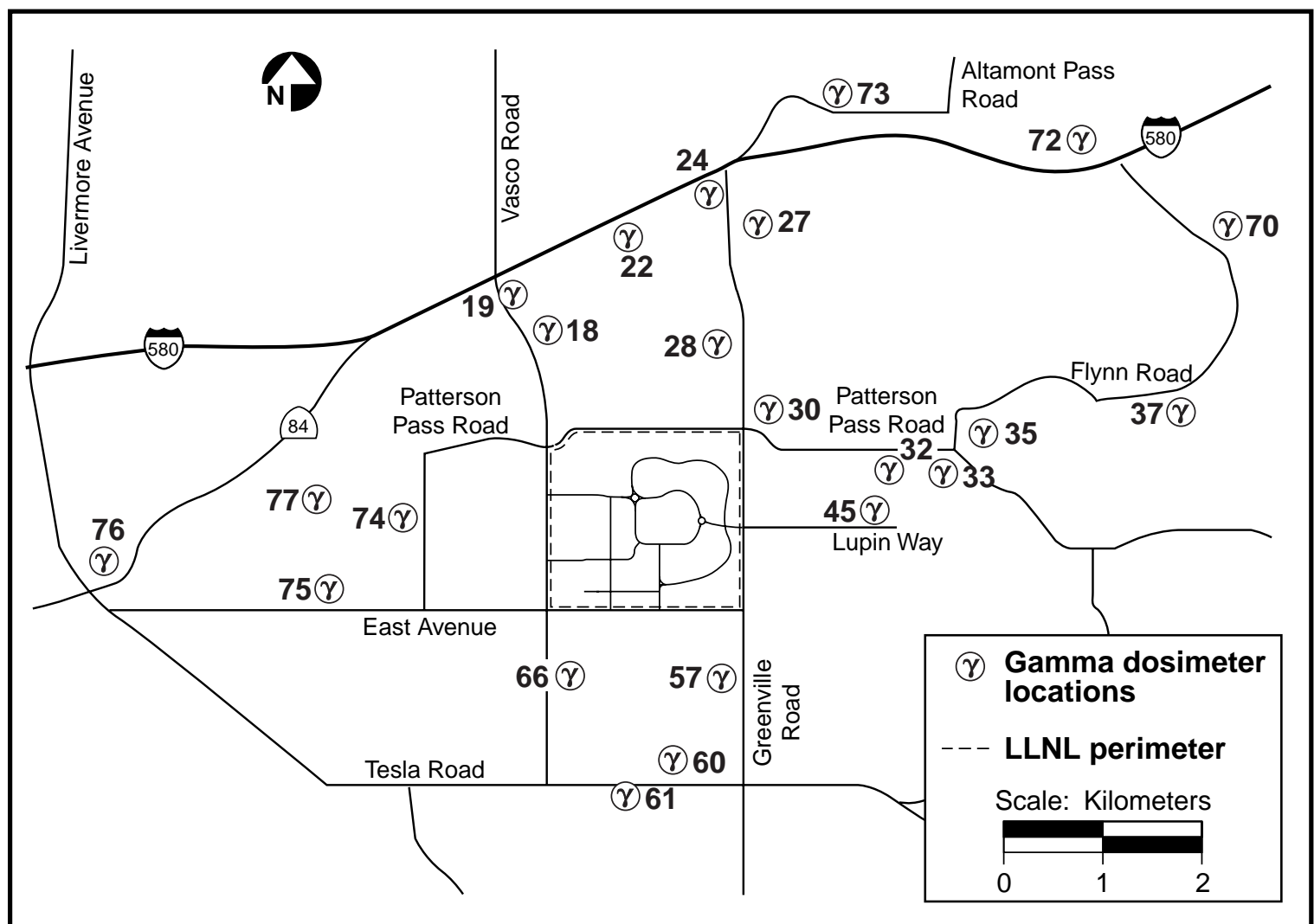

Figure 12-2. Gamma dosimeter locations, Livermore Valley, 1998.

\section{Collocated Monitoring Locations}

The State of California Department of Health Services (CDHS) Radiological Health Branch (RHB) performs routine independent gamma monitoring at several sites collocated with LLNL's TLD network. RHB site locations correspond to several LLNL perimeter, valley, Site 300, and off-site locations. Although RHB has been comonitoring these locations for several years, they have added sites to their network and continued to monitor at one LLNL perimeter location that was discontinued in LLNL's TLD monitoring network in 1995. This location, which lies approximately halfway between site 14 and site 16 on the Vasco Road perimeter, was formerly designated as a valley site location in 1994 although it actually is located just outside the LLNL perimeter at Vasco Road and the Mesquite Way perimeter entrance. The nine locations monitored by CDHS-RHB are LLNL-15, -19, -28, -47, -75, -78, -91, -96, and -99. RHB added location LLNL-47 to their network in the third quarter of 1998. (See Figures 12-1, 12-2, and 12-3 for these corresponding locations. 


\section{Environmental Radiation Monitoring}
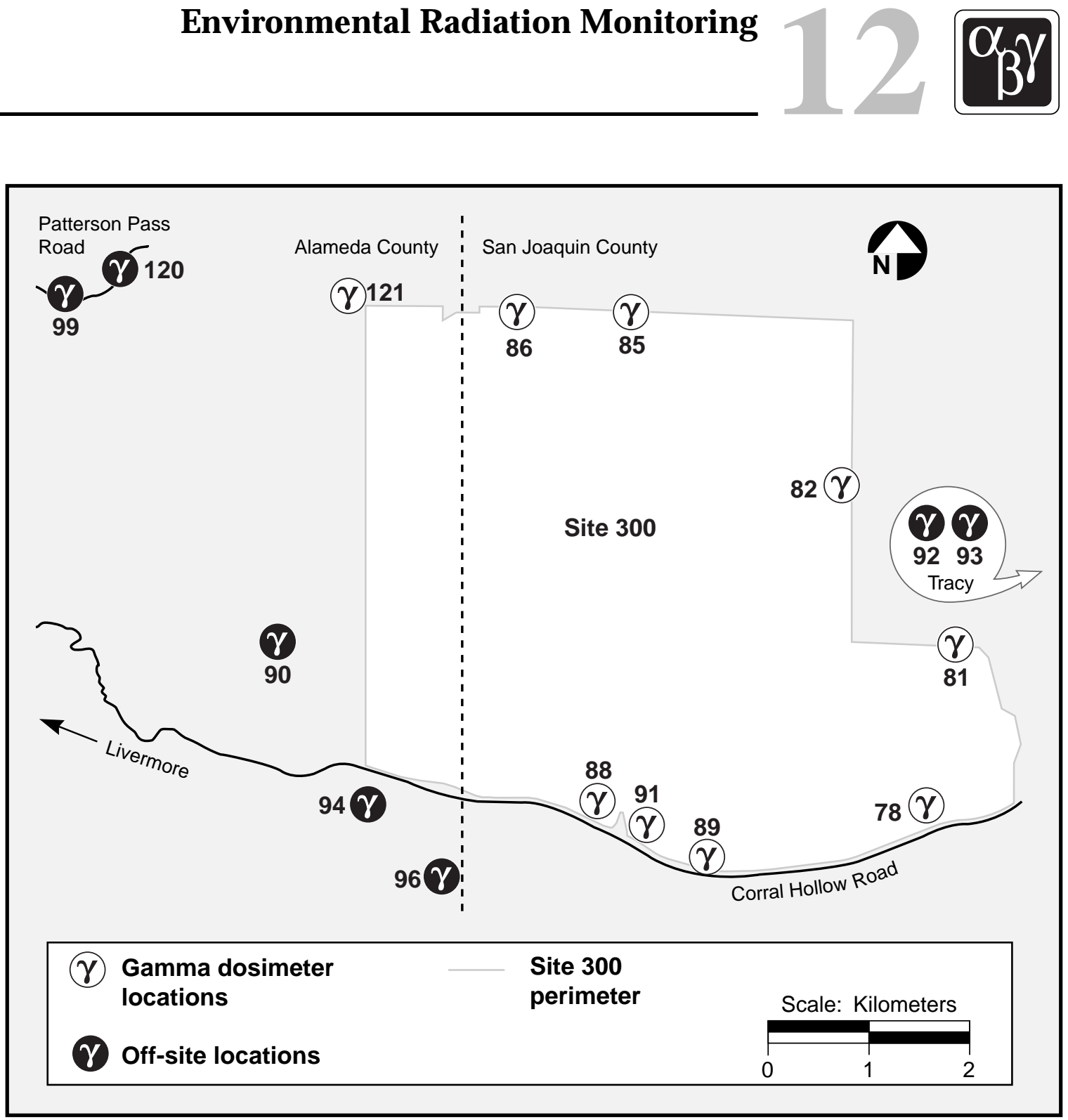

Figure 12-3. Gamma dosimeter locations, Site 300 and vicinity, 1998.

\section{Results of Gamma Monitoring}

Gamma doses for the Livermore site perimeter, Livermore Valley, and Site 300 from 1988 through 1998 are shown in Figure 12-5. Beginning in 1995, all of the quarterly gamma radiation data points were normalized to standard 90-day quarters, as is the practice of the Nuclear Regulatory Commission (NRC) (Struckmeyer 1994). When the data are corrected to standard quarters to normalize the data to the same number of days deployed, the variability due to exposure duration is reduced. 


\section{Environmental Radiation Monitoring}

\section{Livermore Site}

Table 12-1 presents a summary of the quarterly and annual TLD gamma radiation dose equivalents for the Livermore site perimeter locations and Livermore Valley off-site locations. The mean 1998 dose equivalent from external direct radiation exposure at the Livermore site perimeter, $0.597 \mathrm{mSv}$, is statistically the same as background external dose measured in the Livermore Valley, $0.597 \mathrm{mSv}$. Table 12-2 lists the yearly doses due to direct gamma radiation at the LLNL site perimeter. All doses fall within the predicted range for background radiation, and no LLNL operational impacts are discernible.

Table 12-1. Summary of dose calculations for gamma-monitoring locations at all sites in 1998 (in mSv).(a)

\begin{tabular}{|c|c|c|c|c|c|c|c|c|c|c|}
\hline \multirow{3}{*}{ Quarter } & \multicolumn{10}{|c|}{ Location } \\
\hline & \multicolumn{2}{|c|}{ Livermore site } & \multicolumn{2}{|c|}{ Livermore Valley } & \multicolumn{2}{|c|}{ Site 300} & \multicolumn{2}{|c|}{ Tracy } & \multicolumn{2}{|c|}{ Near Site $\mathbf{3 0 0}$} \\
\hline & Mean & $2 \mathrm{SE}^{(\mathrm{b})}$ & Mean & $2 \mathrm{SE}^{(\mathrm{b})}$ & Mean & $2 \mathrm{SE}^{(\mathrm{b})}$ & Mean & $2 \mathrm{SE}^{(\mathrm{b})}$ & Mean & $2 \mathrm{SE}^{(\mathrm{b})}$ \\
\hline First & 0.141 & 0.005 & 0.142 & 0.008 & 0.177 & 0.011 & 0.160 & 0.023 & 0.177 & 0.017 \\
\hline Second & 0.148 & 0.006 & 0.147 & 0.007 & 0.176 & 0.013 & 0.152 & 0.020 & 0.192 & 0.032 \\
\hline Third & 0.147 & 0.007 & 0.145 & 0.008 & 0.177 & 0.012 & 0.153 & 0.024 & 0.195 & 0.027 \\
\hline Fourth & 0.160 & 0.006 & 0.159 & 0.008 & 0.191 & 0.013 & 0.175 & 0.006 & 0.209 & 0.029 \\
\hline Total(c) & 0.597 & 0.024 & 0.597 & 0.027 & 0.718 & 0.041 & 0.640 & 0.073 & 0.775 & 0.106 \\
\hline
\end{tabular}

a $1 \mathrm{mSv}=100 \mathrm{mrem}$.

b $\mathrm{SE}=$ Standard Error (standard deviation of the mean).

c Annual totals, which account for missing data by averaging data for each site (see Data Supplement).

Table 12-2. Annual dose by year at the Livermore site perimeter due to direct gamma radiation. (a)

\begin{tabular}{|c|c|c|}
\hline Year & mSv & mrem \\
\hline 1988 & 0.59 & 59 \\
1989 & 0.58 & 58 \\
1990 & 0.58 & 58 \\
1991 & 0.56 & 56 \\
1992 & 0.56 & 56 \\
1993 & 0.57 & 57 \\
1994 & 0.56 & 56 \\
1995 & 0.56 & 56 \\
1996 & 0.55 & 55 \\
1997 & 0.59 & 59 \\
1998 & 0.60 & 60 \\
\hline
\end{tabular}

a Data normalized to standard 90 days per quarter (360 days per year). 


\section{Collocated Sites}

A convenient means by which a valid comparison for the collocated sites can be made is based on an annual average dose rate at that given site location. Although RHB does not deploy and retrieve their TLDs on the same days as LLNL, RHB does normalize their data similarly to a standard quarter of 91 days. The dose rate measured by RHB at each monitoring location is normalized to the LLNL 90-day standard quarter (i.e., LLNL's 90 day vs. RHB's 91 day) and compared to LLNL location data converted to an annual average dose rate. These results are depicted for each collocated monitoring site in Figure 12-4 below reported in dose rate units of $\mu \mathrm{Gy} / \mathrm{h}$, where $1 \mu \mathrm{Gy}=100 \mu \mathrm{R}$.

Although LLNL-15 is no longer monitored, LLNL-14 located approximately $1 / 4$ mile south is substituted in lieu of LLNL-15 for comparison.

When the data are combined together to formulate a combined location annual average, the two data sets are easily compared within 1 standard error of the combined annual mean absorbed dose rate. The standard error is calculated as the standard deviation $(\sigma)$ of the combined data set (i.e., CDHS and LLNL) divided by the square root of the

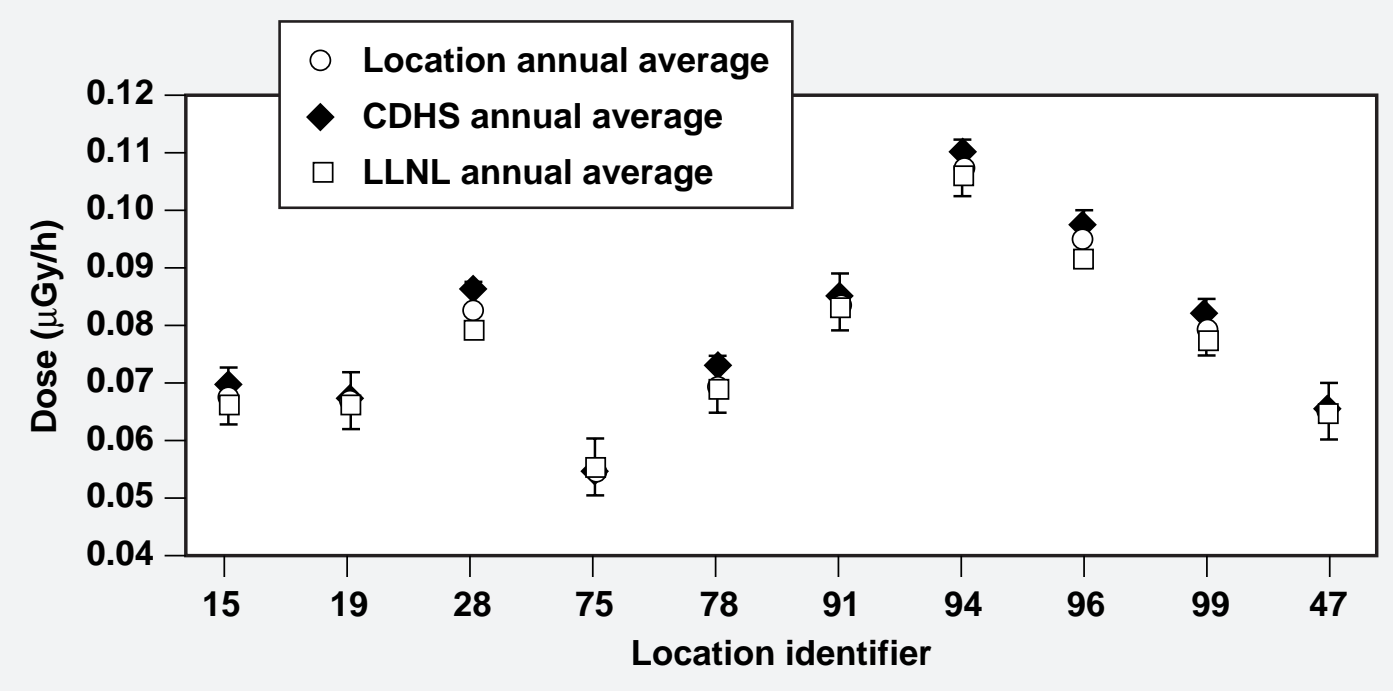

Figure 12-4. Comparison of gamma dose rates measured by CDHS-RHB and LLNL TLDs at several LLNL perimeter, Livermore Valley, Site 300, and off-site locations. TLD absorbed dose rates are compared by location error bars spanning one standard deviation of the combined RHB and LLNL annual mean. Locations are shown in Figures 12-1 and 12-3. 


\section{Environmental Radiation Monitoring}

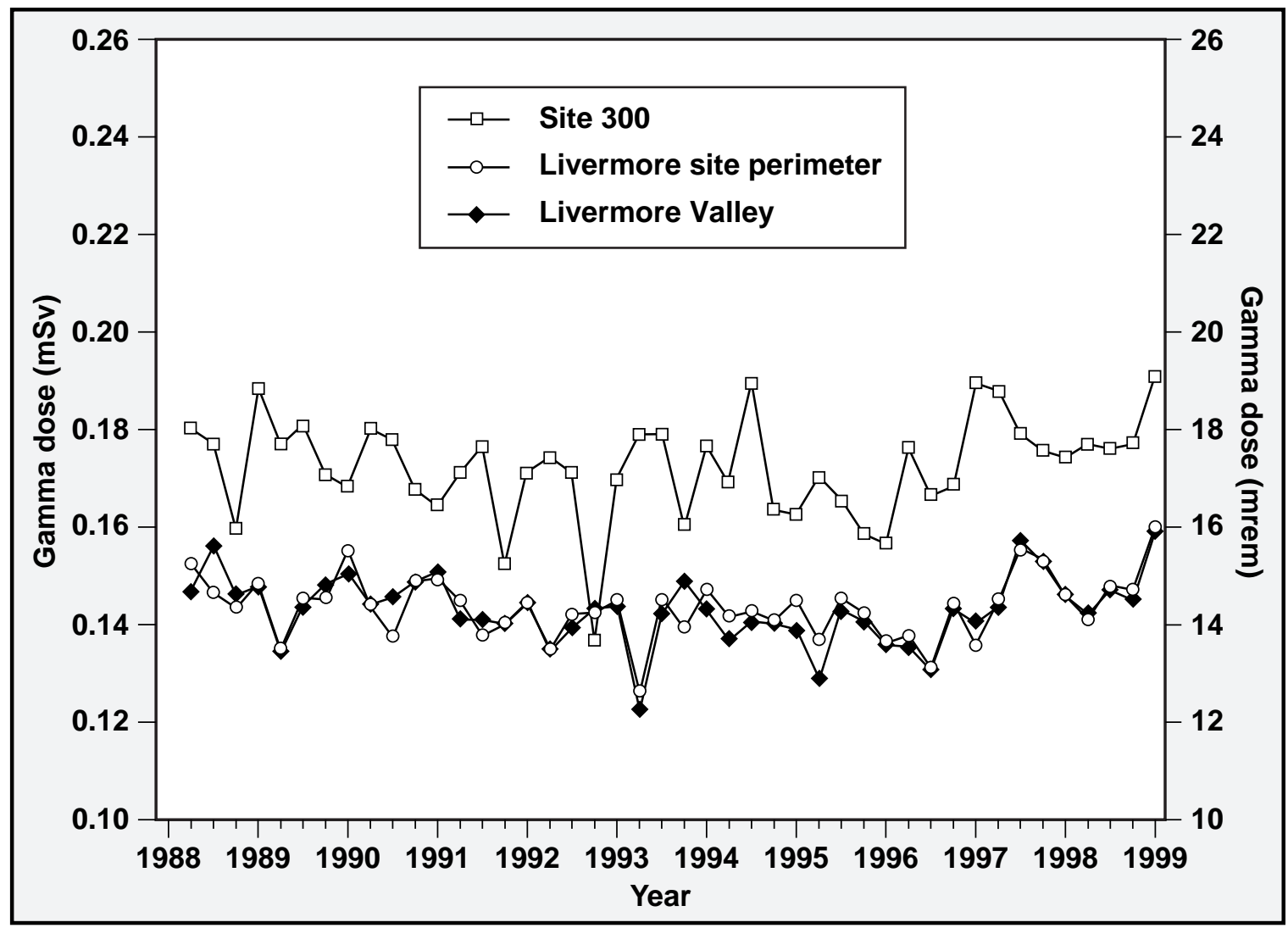

Figure 12-5. Quarterly gamma dose measurements at the Livermore site perimeter, Livermore Valley, and Site 300, 1988 to 1998.

number of data combined to create the data set $(n)$. Thus, the formula representing standard error of the combined mean is $\sigma / \sqrt{n}$. Although slightly elevated RHB data are depicted in Figure 12-4, which may be attributed to an uncorrected transit exposure, the variance is insignificant relevant to the combined annual average data.

Site 300

As seen in Table 12-1, the measured Site 300 perimeter annual average dose in 1998 was $0.718 \mathrm{mSv}$, the measured dose at the off-site locations near Site 300 was $0.775 \mathrm{mSv}$, and the measured doses in and near Tracy were $0.640 \mathrm{mSv}$. All doses are within the predicted range for background radiation, and no LLNL operational impacts are discernible. 


\section{Environmental Radiation Monitoring}

At Site 300, the initial TLD network design limited monitoring to the Site 300 perimeter and two locations in and near the city of Tracy, which were chosen to represent background radiation levels. However, the region around Site 300 has higher levels of naturally occurring uranium, present in the Neroly Formation. The mean dose measured in the off-site locations of the area around Site 300, which is used to represent the high end of background radiation from this formation, was $0.775 \mathrm{mSv}$ and is greater than the Site 300 perimeter dose of $0.718 \mathrm{mSv}$. The Tracy area, with a dose of $0.640 \mathrm{mSv}$, is underlain by a geological substrate composed of alluvial deposits of clays, sands, and silts overlying bedrock. The difference in doses can be directly attributed to the difference in geologic substrates.

The doses at the Livermore site perimeter and in the Livermore Valley are comparable from 1988 to 1998. However, while Site 300 doses are similarly comparable, TLDs continue to record slightly higher direct gamma doses than the Livermore site and the Livermore Valley, which is expected given the differences in geology between these sites.

\section{Environmental Impact}

Based on past measurements (Lindeken et al. 1973), terrestrial radiation doses in the Livermore Valley vary from 0.25 to $0.60 \mathrm{mSv} / \mathrm{y}$. Cosmic radiation, as calculated for the local elevation and geomagnetic latitude according to the data of Lowder and Beck (1966), is about $0.35 \mathrm{mSv} / \mathrm{y}$. This combination results in a typical total direct radiation dose level of 0.6 to $0.7 \mathrm{mSv} / \mathrm{y}$; however, local geological and meteorological factors will impact these dose levels. Direct radiation doses measured at the Livermore site perimeter in 1998 are near these predicted values and are statistically equivalent to the Livermore Valley doses, which are considered natural background levels. This indicates that any dose from LLNL operations is not large enough to be seen within the wide range of natural variation in background levels of these different locations. 



\section{Radiological Dose Assessment}

Robert J. Harrach

\section{Introduction}

Radiological doses to the public result from both natural and man-made radiation. The total dose received by individuals and populations can be determined by measurements and calculations. This chapter describes LLNL's radiological dose assessments, made to determine the impact of LLNL operations, and contains a discussion of the analyses performed to demonstrate LLNL's compliance with the radiological National Emission Standards for Hazardous Air Pollutants (NESHAPs; 40 Code of Federal Regulations [CFR] 61 Subpart H).

\section{Background Information}

Because this chapter is written for a diverse readership, from scientists and regulators to interested citizens with limited scientific training, some description is given of concepts, methods, tools, and other basic material in the first three sections, as well as in two "supplements" at the end of the chapter. Supplement 13-1: "Radiation Basics," covers the different sources and types of radiation and the units used to quantify it, and it provides perspective on the wide range of radiation levels people commonly encounter. Supplement 13-2: "Radiation Control Measures at LLNL," sketches the standard operating procedures used to protect employees and the public from uncontrolled releases and unsafe levels of radiation. Readers desiring to go directly to the chapter's principal results can turn to the section on "Radiological Doses from 1998 Operations."

\section{Releases of Radioactivity to Air}

Air releases are by far the major source of public radiological exposures from LLNL operations. In contrast, releases to ground, surface, and sewerable waters are not sources of direct public exposures, since these waters are not directly consumed or used by the public. Water releases can cause indirect exposures, which are treated as special cases; for example, a recent case considered the possible dose to the public from inhalation and ingestion of soil contaminated by sewer effluent containing radioactivity 


\section{Radiological Dose Assessment}

(U.S. Department of Health and Human Services 1999). Apart from such unusual occurrences, measurements and modeling of air releases determine LLNL's radiological dose to the public.

Data are gathered by three principal means: routine surveillance air monitoring for radioactive particles and gases, both on and off Laboratory property (described in Chapter 5); continuous monitoring of stack effluent at selected facilities at the Livermore site (described in Chapter 4); and usage inventories at all noncontinuously monitored or unmonitored facilities housing radioactive materials management areas and for radioactive materials used in explosive experiments at Site 300 (usage inventories are described in LLNL's NESHAPs annual reports [e.g., Biermann et al. 1999]).

Despite this "air emphasis," it should be noted that LLNL's extensive environmental monitoring program embraces all media and a wide range of potential contaminants, not limited to radioactive ones. In addition to air and the three categories of water already mentioned, the Laboratory samples soil, sediment, vegetation, and foodstuff, and measures environmental (gamma) radiation. Monitoring has been described extensively since 1971 in LLNL's environmental reports (e.g., Harrach et al. 1998; see also Chapters 4 through 11 in the present report) and in LLNL's triennially updated Environmental Monitoring Plan report (e.g., Tate et al. 1995) and its associated procedures and guidance documents.

\section{Air Dispersion and Dose Models}

Calculational models are needed to describe the transport and dispersion in air of contaminants and the doses received by exposed persons. Various factors dictate this need for modeling: (1) the amounts of LLNL-generated radioactive material dispersed into the atmosphere cause doses thousands of times smaller than those caused by natural background radiation (arising from irradiation by cosmic rays, inhalation of radon gas, exposure to radioactive materials in soil and rock, and ingestion of naturally occurring radionuclides present in our food and water; see Supplement 13-1), so it is difficult to demonstrate compliance with standards through physical measurements alone; (2) all potentially significant exposure pathways need to be taken into account when estimating dose impacts; and (3) the U.S. Department of Energy (DOE) and the U.S. Environmental Protection Agency (EPA) sanction the use of specific computer codes that implement their approved dosimetry and dispersion models for evaluating potential doses to the public from both routine and unplanned releases. Other advantages of a well-developed modeling capability include its utility in source design 


\section{Radiological Dose Assessment}

and optimization (e.g., estimating effects of hypothetical and/or dangerous sources) and in interpreting past events (e.g., in dose reconstruction).

The computer programs we use to model air releases and their impacts feature idealized gaussian-shaped plumes and can be run on personal computers. The CAP88-PC code (Parks 1992), in particular, incorporates dosimetric and health effects data and equations that are mandated by EPA to be used in compliance assessments. Furthermore, CAP88PC accommodates site-specific input data files to characterize meteorological conditions and population distributions for a collective dose evaluation, and the code is relatively easy to use and understand. For these reasons it has been the "workhorse" calculational tool for LLNL's regulatory compliance assessments since its availability in April 1992, particularly as applied to gradual releases occurring in the course of routine operations.

\section{Radiation Protection Standards}

The release of radionuclides from operations at LLNL and the resultant radiological impact to the public is regulated by both DOE and EPA.

DOE environmental radiation protection standards, provided under the authority of the Atomic Energy Act of 1954 and the DOE Organization Act of 1977 (both as amended), are defined in DOE Order 5400.5, Radiation Protection of the Public and the Environment. The standards for controlling exposures to the public from operations at DOE facilities that are incorporated in this order are based on recommendations by the International Commission on Radiological Protection (ICRP). The radiological impact to the public is assessed in accordance with DOE Order 5400.1, General Environmental Protection. Current indices and links to DOE orders appear on the Department of Energy Directives website (U.S. Department of Energy 1998c).

The primary DOE radiation standards for protection of the public are 1 millisievert per year ( $1 \mathrm{mSv} / \mathrm{y})$ or 100 millirem per year $(100 \mathrm{mrem} / \mathrm{y})$ whole-body effective dose equivalent (EDE) for prolonged exposure of a maximally exposed individual in an uncontrolled area and $5 \mathrm{mSv} / \mathrm{y}$ (500 mrem/y) EDE for occasional exposure of this individual. (EDEs and other technical terms are discussed in Supplement 13-1 and defined in the glossary of this report.) These limits pertain to the sum of the EDE from external radiation and the committed 50-year EDE from radioactive materials ingested or inhaled during a particular year that may remain in the body for many years.

Radionuclide emissions to the atmosphere from DOE facilities are further regulated by the EPA, under the authority of Section 112 of the Clean Air Act. Subpart H of 


\section{Radiological Dose Assessment}

NESHAPs under 40 CFR Part 61, sets standards for public exposure to airborne radioactive materials (other than radon) released by DOE facilities; radon is regulated by Subparts Q and T. NESHAPs implements the dosimetry system recommended by the ICRP in Publication 26 (International Commission on Radiological Protection 1977).

The EPA's radiation dose standard, which only applies to air emissions, limits the EDE to members of the public caused by activities/operations at a DOE facility to $0.1 \mathrm{mSv} / \mathrm{y}$ or $100 \mu \mathrm{Sv} / \mathrm{y}(10 \mathrm{mrem} / \mathrm{y})$. EPA regulations specify not only the allowed levels, but also specify the approved methods by which airborne emissions and their impacts must be evaluated. With respect to all new and/or modified projects, NESHAPs compliance obligations define the requirements to install continuous air effluent monitoring and to obtain EPA approval for startup of operations. NESHAPs regulations require that any operation with the potential to produce an annualaveraged off-site dose greater than or equal to $1 \mu \mathrm{Sv} / \mathrm{y}(0.1 \mathrm{mrem} / \mathrm{y})$, taking full credit for emission-abatement devices such as HEPA filters, must obtain EPA approval prior to startup of operations. This same calculation, but without taking any credit for emission abatement devices, determines whether or not continuous monitoring of emissions to air from this project is required. These requirements are spelled out in Chapter 12, "Air Quality Compliance," in LLNL's Environmental Compliance Manual (Lawrence Livermore National Laboratory 1996b); this report can be accessed electronically at http://www.llnl.gov/es_and_h/crosswalk.html\#ecm.

\section{Reporting Requirements}

All DOE facilities that conduct significant environmental protection programs are required by DOE to prepare an annual environmental report for the site, covering activities of the previous calendar year involving releases to all media via all pathways. Because DOE facilities and operations are subject to the regulatory requirements of EPA, in particular 40 CFR Part 61, Subpart H, DOE facilities are further required to submit an annual report to the EPA, via DOE, showing compliance with NESHAPs (addressing only releases to air). Other reporting requirements address "environmental occurrences," quality assurance program documentation, and other activities.

For details on reporting requirements and citation of pertinent DOE orders and federal regulations, the reader can consult the chapter on radiological dose assessment in earlier environmental reports (e.g., Harrach et al. 1998), which are accessible in hardcopy or on the Internet at the address http:/ / www.llnl.gov.saer, or LLNL's radiological dose assessment guidance document (Harrach 1998). 


\section{Radiological Dose Assessment}

\section{Evaluation of Sources of Radioactive Emissions}

The starting point for an assessment of radiological dose is to identify and properly characterize all significant sources of radioactive emissions at a site. LLNL's sources are determined in three principal ways: (1) by an inventory process, (2) by direct measurement of the emission rate at the source (continuous effluent monitoring), and (3) by monitoring airborne gases and particulate matter at selected field points in and around the site (continuous surveillance air monitoring).

\section{Inventoried Sources}

Radioactive materials management areas (RMMAs) are areas where radioactive materials are used or stored, or where activation products occur. Several RMMAs at the Livermore site have effluent monitoring systems in place in their exhaust pathways, allowing a direct measurement of their emission rates. For unmonitored or noncontinuously monitored RMMAs, source terms for potential releases are inferred from radionuclide inventories, in accordance with EPA methods.

Experimenters and facility managers provide inventory data following a protocol designed and administered by LLNL's Environmental Protection Department. A full $(100 \%)$ inventory is conducted every three years; only the "key" Livermore site facilities, defined as those in a ranked list that collectively accounted for $90 \%$ or more of the previous year's Livermore site radiological dose to members of the public, are reinventoried annually. LLNL conducted complete radionuclide inventories for operations in 1994 and again in 1997. In addition, all new RMMAs (ones that commenced operations in the year under evaluation) are inventoried, and radionuclide inventories for all Site 300 explosives experiments are newly evaluated each year. A description of LLNL's inventory process, including examples of the inventory form and accompanying instructions, is given in the guidance document for preparation of NESHAPs annual reports (Gallegos et al. 1998b).

For dose-assessment modeling of unmonitored or noncontinuously monitored sources, the effective emission rate is calculated from radiological usage inventories by applying EPA-specified fractions for potential release to air of materials in different physical states (solid, liquid, powder, or gas) for each radioisotope. The inventory quantity (in becquerels or curies) is multiplied by a state-dependent release fraction to give the potential annual release to air, i.e., the "effective" emission rate, in accordance with 40 CFR Part 61, Appendix D. If the material is an unconfined gas, the release fraction is 1.0; for liquids and powders, $1.0 \times 10^{-3}$ is used; and for solids, $1.0 \times 10^{-6}$. In this same spirit, if the radioactive material is encapsulated or sealed for the entire year (i.e., it was 


\section{Radiological Dose Assessment}

not used and release to air was prevented), then its release fraction is considered to be zero. For materials that were encapsulated or sealed for part of the year, or that resided in different facilities over the course of the year, "time weighting factors" are introduced to properly account for the release potential. Data on inventories and descriptions of the diffuse sources can be found in the guidance document (Gallegos 1998) and in NESHAPs annual reports for 1993 through 1998 (Harrach et al. 1994; Surano et al. 1995; Gallegos et al. 1996; Gallegos and Biermann 1997; Gallegos et al. 1998a; and Biermann et al. 1999).

\section{Monitored Sources}

\section{Stack Effluent Monitoring}

Actual measurements of radionuclides in effluent flow are the basis for reported emissions from continuously monitored sources. In 1998, eight buildings at the Livermore site had continuously monitored discharge points: Buildings 175, 177, 251, 292, 331, 332, 490, and 491. The monitoring systems are described in the LLNL NESHAPs 1998 Annual Report (Biermann et al. 1999), and in Chapter 4: "Air Effluent Monitoring," in this report. Taken together, these buildings feature about 100 continuously operating monitors.

The most significant monitored source in terms of public dose impact is the Tritium Facility, Building 331, at the Livermore site. Each of the two 30-m stacks on this facility has both a continuous-monitoring ion-chamber alarm system and continuous molecularsieve samplers (see Chapter 4 in the Data Supplement). The sieve samplers, which can discriminate between tritiated-water vapor (HTO) and molecular tritium (HT), provide the values used for environmental reporting. The alarmed ion chambers provide realtime tritium concentration release levels (HT plus HTO). Monitoring of these stacks provides an accurate measure of the total quantity (in becquerels or curies) of tritium released to the environment, time-resolved over the course of the year. Since the stacks have known properties (height, flow rate, and diameter) and the wind field properties (wind speed, direction, and fluctuation characteristics) are continuously monitored, these data are optimal inputs to modeling. The quality of data on source emission rates, emission conditions (such as stack height, diameter, and flow velocity), and wind patterns affects the accuracy of air dispersion and dose assessment modeling more than any other input factor.

Discharge points at Buildings 175, 177, 251, 292, 332, 490, and 491 are monitored for gross alpha and gross beta radioactivity. In contrast to monitoring unabated tritium gas 


\section{Radiological Dose Assessment}

effluent in the Building 331 stacks, air samples for particulate emissions are extracted downstream of high-efficiency particulate air (HEPA) filters and prior to the discharge point to the atmosphere. Particles are collected on membrane filters. Sample results are generally found to be below the minimum detectable concentration (MDC) of the analysis; for details, consult Chapter 4 in this report, and the 1998 NESHAPs annual report (Biermann et al. 1999).

Among the eight continuously monitored facilities at the Livermore site, probably only the Plutonium Facility (Building 332) requires monitoring under the EPA's $0.1 \mathrm{mrem} / \mathrm{y}$ standard alluded to earlier in the subsection on radiation standards. The other seven are continuously monitored for programmatic or other reasons. For example, continuous monitoring is maintained at the Tritium Facility to provide the most direct and accurate measure of its release of tritium to the atmosphere, and continuous monitoring is maintained at the Heavy Elements Facility (Building 251) in lieu of undertaking a modeling and measurement effort that would be required to demonstrate that monitoring is not needed.

Dose calculations based on effluent monitoring data are expected to be considerably more accurate than those relying on usage-inventory data, physical state release-to-air fractions, emission-abatement factors, and time factors.

\section{Surveillance Air Monitoring}

To provide wide-area coverage complementing the narrowly focused stack effluent monitoring, surveillance air monitors are placed at selected locations on and in the vicinities of the Livermore site and Site 300 to detect radioactive gases and particulate matter in ambient air. In addition, dose rates from external penetrating radiation (gamma rays) are measured using thermoluminescent dosimeters (TLDs). Siting of the air monitors and TLDs is done in accordance with the LLNL Environmental Monitoring Plan (Tate et al. 1995). Surveillance air monitors are also placed in the vicinity of known diffuse (extended area) emission sources at the Livermore site, specifically those associated with Buildings 292, 331, 514, and 612. Such monitors are also located in and around the Livermore site's southeast quadrant, and in on-site locations providing wide coverage of Site 300. These special monitors measure the concentrations of radionuclides present in the air near the sources and allow a direct determination of their environmental impact; see Chapter 5 in this report. In addition to their utility in connection with releases from routine operations, the surveillance air monitors have proven valuable in quantifying the magnitude of accidental releases and their dose impacts. 


\section{Radiological Dose Assessment}

\section{Determinations of Dose}

This section briefly describes the way LLNL estimates doses to the public for compliance purposes, touching on the main modeling approaches, identifying the key hypothetical receptors that represent the most exposed public individuals, discussing some important aspects regarding the modeling of tritium, and briefly noting some of the special modeling challenges raised by diffuse sources and explosives experiments.

\section{Principal Modeling Approaches}

LLNL's primary calculational tool for estimating dose and risk to the public from routine operations and most unplanned releases is the computer code CAP88-PC. The user's guide (Parks 1992) provides useful information on the code, including discussions of the basic equations and key input and output files. Additional information, e.g., about LLNL-site-specific data files and several important caveats on use of the code, has been presented in earlier environmental reports (e.g., Harrach et al. 1998) and more fully in the LLNL radiological dose assessment guidance document (Harrach 1998).

Other codes such as EPA's INPUFF code (Peterson and Lavdas 1986) or the HOTSPOT code (Homann 1994) are used as needed to address unplanned releases or transient releases from normal operations or accidents. Many other gaussian-plume-type computer models are available; see for example, the annotated lists in Atmospheric Dispersion Modeling Resources (Oak Ridge 1995) and Supplement B to the Guideline on Air Quality Models (U.S. Environmental Protection Agency 1993).

A complementary approach to deriving effective dose equivalents (EDEs) using the built-in dosimetry model in CAP88-PC or other codes is to explicitly calculate them using mathematical formulas from, e.g., the Nuclear Regulatory Commission's Regulatory Guide 1.109 (1977), which incorporate dose conversion factors consistent with those in the International Commission on Radiation Protection's document number 30 (1980). This approach, outlined in Appendix A of this report, has been used historically at LLNL (preceding the availability of CAP88-PC), and continues to be used to evaluate annual doses to the public inferred from sampling of local environmental media (air, water, vegetation, and wine).

\section{Identification of Key Receptors}

When assessing probable off-site impacts, three potential doses are emphasized. First is the dose to the "site-wide maximally exposed individual member of the public," 


\section{Radiological Dose Assessment}

(SW-MEI; defined below and in the glossary). Second is the dose to the maximally exposed individual (MEI) member of the public from a given emission point. Third is the collective or "population dose" received by people residing within $80 \mathrm{~km}$ of either of the two LLNL sites, adding the products of individual doses received and the number of people receiving them.

The SW-MEI is defined as the hypothetical member of the public at a single publicly accessible location (where members of the public reside or abide) who receives the greatest LLNL-induced EDE from all sources at a site (e.g., the Livermore site). This dose sums the contributions of all emission points for evaluation under the EPA's $100 \mu \mathrm{Sv} / \mathrm{y}$ (10 mrem/y) standard. Public facilities that could be the location of the SW-MEI include schools, churches, businesses, and residences. This hypothetical person is assumed to reside at this location 24 hours per day, 365 days per year, continuously breathing air having the ground-level radionuclide concentration, and consuming a specified fraction of his or her food and drinking water that is affected by the releases of radioactivity from the site. Thus, the SW-MEI dose is not actually received by any actual individual and should be viewed as a health-conservative estimate (i.e., over-estimate) of the highest possible dose to any member of the public. The location of the SW-MEI is sensitive to the frequency distribution of wind speeds and directions and locations of key sources in a given year and can change from one year to the next. At the Livermore site, the SW-MEI currently is located at the UNCLE Credit Union, about 10 m outside the controlled eastern perimeter of the site. This location lies $948 \mathrm{~m}$ from the principal radionuclide source, the Tritium Facility (Building 331), in an east-northeast direction (the typical prevailing wind direction). At Site 300, the SW-MEI currently is located in an experimental area termed "Bunker 2" operated by Primex Physics International. Bunker 2 lies about $300 \mathrm{~m}$ outside the east-central boundary of Site 300, $2.38 \mathrm{~km}$ eastsoutheast of the principal firing table at Building 801.

The location of the MEI is generally different for each emission point; the MEI dose is used to evaluate whether continuous monitoring of each particular emission point is required under a $1 \mu \mathrm{Sv} / \mathrm{y}(0.1 \mathrm{mrem} / \mathrm{y})$ standard (1\% of the EPA standard for allowable dose to the SW-MEI); no credit for emission abatement devices is permitted in making this determination. A related dose frequently needed is identical to the MEI dose, except that credit is allowed for abatement devices that are in place; this dose determines the necessity to petition the EPA for permission to start up an activity (new or modified project) that would cause a dose of $1 \mu \mathrm{Sv} / \mathrm{y}(0.1 \mathrm{mrem} / \mathrm{y})$ or more to the MEI.

Doses in this second category, with and without allowance for abatement, are a main concern when new projects or changes to existing projects (in which releases of radioactivity to the environment may occur) are reviewed for joint compliance with 


\section{Radiological Dose Assessment}

NESHAPs and the National Environmental Policy Act (NEPA). The possible environmental and worker safety issues raised by each proposed activity or project are examined from several different points of view in a process coordinated by LLNL's Environmental Protection Department, including a review and evaluation of potential emissions of radionuclides and air toxics. Air quality compliance requirements for projects are described in Chapter 12 of LLNL's Environmental Compliance Manual (1996).

\section{Assessment Assumptions Regarding Tritium}

Several aspects of tritium dose estimates based on CAP88-PC should be noted.

\section{Relative Contributions to Dose from HTO and HT Emissions}

Tritium (H-3) emissions account for the major dose from operations at the Livermore site. These emissions exist in two major chemical forms: tritium oxide or tritiated water vapor (HTO) and tritium gas (HT). The doses received by exposure to these two forms differ greatly. HTO enters the body by ingestion, inhalation, and dermal absorption. Ingested HTO is distributed throughout the entire body and eliminated at the same rate as body water. Inhaled HTO dissolves in the fluids of the lung and is absorbed. HT enters the body via inhalation, and very little is retained, most being exhaled. The effective dose equivalent from inhalation of tritium gas is lower by a factor of about 25,000 than that from tritium oxide inhalation (Eckerman et al. 1988). HT requires conversion to HTO (oxidation) to produce significant dose. Such conversion in air during plume transport and in soil and vegetation following deposition is a complicated process.

Emissions of HTO are expected to be the major contributor to the tritium dose, particularly for nearby individual receptors such as the MEI and SW-MEI, and we typically input to CAP88-PC only the curies of HTO released to air, disregarding the HT component. A more conservative approach would be to treat all HT as HTO in dose calculations. Recently, EPA has mandated that LLNL do exactly that when calculating dose to the public for NESHAPs compliance purposes; for a discussion of this issue and the dose impacts, see the LLNL NESHAPS 1998 Annual Report (Biermann et al. 1999). The result of treating HT as HTO for the 1998 assessment, for which Tritium Facility emissions were divided between 85 curies of HTO and 25 curies of HT, was to increase the Livermore site dose to the SW-MEI by about $12 \%$ compared to the value obtained using our usual procedure. The population dose from Livermore site operations, which gives greater weight to high-stack emissions, was increased by $24 \%$. As in previous years, this report emphasizes doses excluding contributions from HT because we believe it is more accurate to do so than to represent HT as fully converted to HTO, and to provide continuity with doses reported in the past. In addition, we provide the dose as calculated for the EPA. 


\section{Radiological Dose Assessment}

\section{Dose-rate Conversion Factor for Tritium}

The dose-rate-conversion factor that CAP88-PC uses for inhalation-plus-dermalabsorption of tritium is outdated and more conservative than values quoted in recent literature. In 1980, the ICRP in its publication ICRP 30 (1980) recommended that skin intake should be $50 \%$ of lung intake, revising its earlier recommendation stated in ICRP 2 (1959) that skin intake equals lung intake. The CAP88-PC dose-rate-conversion factor for tritium contains the 1959 recommendation, producing an inhalation-plus-dermalabsorption dose that is too large by a factor $4 / 3$ relative to the more recent recommendation; see Attachment 3 in the NESHAPs 1995 Annual Report (Gallegos et al. 1996).

\section{Overestimate of Ingestion Dose for Tritium}

Finally, CAP88-PC overestimates the ingestion dose from tritium in a manner that depends on input selections, according to a recent article by Barry Parks (Parks 1999). The cause can be traced to three key assumptions implicit in the software that may not be immediately apparent to the user: (1) the contribution of home-grown food, (2) the distances at which food is produced, and (3) the number of people consuming locally produced food. Documentation on how these overestimates can occur is also available on the Internet at the address http:/ / www.er.doe.gov/production/er-80/cap88/ tritium.html.

\section{Special Modeling Problems}

Nonstack releases may require special measurements and calculations to characterize the source. Both the Livermore site and Site 300 provide important examples in this regard.

\section{Diffuse Sources}

Nonstack releases often fall into the classification of "diffuse sources." One example is leakage of tritium-contaminated water from an underground tank at Building 292 at the Livermore site, which results in the release of tritium to the atmosphere via soil moisture evaporation and root-uptake and transpiration by plants, from one pine tree in particular. A discussion of this source appears in the section on "Livermore Site Diffuse Sources" in the NESHAPs 1993 Annual Report (Harrach et al. 1994), and subsequent NESHAPs annual reports provide updates. Emissions from certain difficult-tocharacterize sources sometimes can be inferred from data obtained by LLNL's routine surveillance air monitoring program, in which the ambient air at selected locations within and outside of Laboratory boundaries is continuously monitored for tritium gas 


\section{Radiological Dose Assessment}

and radioactive particles. An example in this category is provided by the operations in the Building 612 waste storage yard at the Livermore site, which are characterized using data from an air monitor in the yard. Another example is the diffuse source caused by resuspension of depleted uranium in soil at Site 300; an air monitor at the location of the SW-MEI measures the annual-average concentration of uranium in air. A theoretical model described in the NESHAPs 1995 Annual Report (Gallegos et al. 1996) was developed to distinguish between the contribution made to these Site 300 data by LLNLoperations-contributed uranium, compared to the considerably larger contribution from naturally-occurring uranium. The routine air surveillance monitoring program also has been particularly useful in registering the magnitude of unplanned releases; an example of this type is provided by the accidental release of curium-244 from Building 513 in 1997, discussed in the Executive Summary, Chapter 2, and Chapter 12 of last year's environmental report (Harrach et al. 1998), as well as in last year's NESHAPs annual report (Gallegos et al. 1998).

\section{Modeling Dose Impacts from Explosives Experiments at Site 300}

Modeling releases of radionuclides into the atmosphere from explosive tests at Site 300 requires special consideration compared to conventional stack or area sources. During experiments, an explosive device containing depleted uranium is placed on an open-air firing table and detonated. A cloud of explosive decomposition products forms promptly (on a roughly 1-minute time-scale) over the firing table, typically reaching a height of several hundred meters, and disperses as it is carried downwind. (The depleted uranium does not contribute to the explosive energy, which is entirely of chemical origin.) In the absence of measurements of the properties of the cloud, we assume for compliance modeling purposes that it instantaneously reaches an initial height and size governed by known empirical scaling laws for detonations, in which the scaling parameter is the TNT-equivalent explosive mass. The specific equations we use for the maximum elevation, $\mathrm{H}_{\max }$, reached by the plume and the diameter, $\mathrm{D}$, of the cloud of decomposition products have been described elsewhere (Harrach et al. 1998, Harrach 1998).

This prescription provides the initial condition for a cloud whose subsequent motion is modeled using a gaussian plume air dispersion code. A puff-code-based modeling methodology that would treat these transient explosive events as short-duration bursts or puffs, and which would incorporate some of the effects of the hilly terrain at Site 300, was submitted to EPA for approval in 1992 (Biermann et al. 1993). EPA decided that, from the standpoint of regulatory compliance, the use of CAP88-PC to model these explosives experiments was adequate, despite the recognized difficulties. CAP88-PC simulates each explosive experiment or shot as a continuous, year-long, stack-type emission (i.e., the total activity released in a time period of order one minute in the 


\section{Radiological Dose Assessment}

explosion is treated as though it were released gradually over the course of an entire year), with meteorological data corresponding to annual-average conditions at Site 300 . As inputs to the code, the scaling results for $\mathrm{H}_{\max }$ and $\mathrm{D}$ are used as the fixed plume height and the stack diameter.

Isotopic ratios for depleted uranium are used. The masses of the three uranium isotopes with atomic weights 238, 235, and 234 in depleted uranium occur in the weightpercentages $99.8,0.2$, and $5 \times 10^{-4}$, respectively. The inventory for each explosive experiment specifies the mass of depleted uranium used: $\mathrm{M}_{\mathrm{DU}}(\mathrm{kg})$. Multiplying this quantity by the respective specific activities gives the total number of curies for each isotope in the cloud. For example, the fraction by weight of U-238 in depleted uranium is 0.998 , and its specific activity is $3.33 \times 10^{-4} \mathrm{Ci} / \mathrm{kg}$, giving $3.33 \times 10^{-4}(\mathrm{Ci} / \mathrm{kg}) \times$ $\mathrm{M}_{\mathrm{DU}}(\mathrm{kg})$ as the number of curies of U-238 in the cloud. The corresponding values for $\mathrm{U}-235$ and $\mathrm{U}-234$ are $4.29 \times 10^{-6}(\mathrm{Ci} / \mathrm{kg}) \times \mathrm{M}_{\mathrm{DU}}(\mathrm{kg})$ and $3.10 \times 10^{-5}(\mathrm{Ci} / \mathrm{kg}) \times \mathrm{M}_{\mathrm{DU}}(\mathrm{kg})$, respectively.

In the absence of detailed data about the explosive experiments, we make several highly conservative assumptions in our calculations. We assume that (1) 100\% of the depleted uranium present in the experiment is completely aerosolized and dispersed as a cloud;

(2) the median particle size is the CAP88-PC default value of $1 \mu \mathrm{m}$; (3) the lung clearance class for inhaled material is class Y. (Note: Clearance of inhaled material from the lung to the blood or to the gastrointestinal tract depends on the chemical form [e.g., $\mathrm{U}_{3} \mathrm{O}_{8}$ ] of the radionuclide and is classified as $\mathrm{D}, \mathrm{W}$, and $\mathrm{Y}$, respectively, for clearance times of order days, weeks, and years.) These assumptions may produce a dose that is too high by a factor of 10 or more. We believe a more realistic release-to-air fraction for the uranium is no greater than 0.2 , but we lack sufficient documentation to use a value other than 1.0. Also, the median particle size may be much larger than $1 \mu \mathrm{m}$, and a sizable fraction of the aerosolized particles might be more properly characterized by lung clearance class $\mathrm{D}$, which produces a dose by inhalation of depleted uranium that is smaller by a factor of about 16 compared to class Y. Even with these assumptions, the MEI and SW-MEI individual doses, as well as the collective or population dose, that we calculate for the explosive experiments are very small (see, e.g., the Summary and Conclusions section of this chapter).

\section{Radiological Doses from 1998 Operations}

More than 200 emission points were reported on in the 1998 modeling runs. These emission sources were of several types: stacks and other exhaust pathways from buildings (including emissions from all RMMAs in which radiological operations took 


\section{Radiological Dose Assessment}

place); diffuse area sources generally external to buildings; and open-air firing tables at Site 300 where explosives experiments were conducted.

The principal diffuse sources at the Livermore site in 1998 were the waste storage and drum sampling areas at Hazardous Waste Management's Building 612 Yard, a waste accumulation area (WAA) at the Tritium Facility (Building 331), Hazardous Waste Management's Tank Farm at Building 514, and the Southeast Quadrant of the Livermore site, where resuspension of contaminated soil occurs. Diffuse sources at Site 300 included the total land area on site, where evaporation of tritium and resuspension of depleted uranium can occur, and a low-level-waste staging area at Building 804. This section summarizes the main results of our calculations for 1998 operations and exhibits the trends in these results over recent years. For further details, especially regarding the diffuse sources at the two sites, see the LLNL NESHAPs 1998 Annual Report (Biermann et al. 1999).

\section{Dose Breakdown by Facility}

Table 13-1 lists all LLNL facilities and diffuse sources having the potential to release radioactivity into the environment during 1998. For each facility or building, the table gives the number of stacks or other exhaust avenues discharging radionuclides, lists the dose to the SW-MEI caused by the single most dominant emission point at each facility, and identifies the types of operations occurring in the building or facility or the nature of the diffuse source. Corresponding data is included for the Site 300 explosive experiments. Facilities in which no operations using radionuclides took place in 1998 or in which any radionuclides present were encapsulated or sealed for the entire year are excluded from Table 13-1.

The principal feature shown in the table is that LLNL has a large number of very small radioactive sources, and only a few that could be considered significant. As shown more clearly in subsequent tables, about a half-dozen sources account for nearly all of the dose to members of the public, and the total dose is quite small compared to federal standards for radiation protection of the public.

\section{Unplanned Releases}

There were no unplanned atmospheric releases at the Livermore site or Site 300 in 1998. 
Table 13-1. Sources of radiation dose from LLNL releases (measured and potential) to air: stacks and other exhaust pathways from buildings containing radioactive materials management areas and diffuse area sources. $(a, b)$

\begin{tabular}{|c|c|c|c|c|}
\hline Bldg & Facility & $\begin{array}{l}\text { Potential } \\
\text { emission } \\
\text { points }\end{array}$ & $\begin{array}{l}\text { Maximum } \\
\text { EDE(c) } \\
(\mu \mathrm{Sv} / \mathrm{y})\end{array}$ & Operations \\
\hline 131 & $\begin{array}{l}\text { Livermore site point sources } \\
\text { Offices and laboratories, } \\
\text { Mechanical \& Electrical } \\
\text { Engineering }\end{array}$ & 3 & $6.5 \times 10^{-6}$ & Display of parts \\
\hline $132 N$ & $\begin{array}{l}\text { Offices and laboratories; } \\
\text { Chemistry \& Materials } \\
\text { Sciences; Nonproliferation, } \\
\text { Arms Control \& International } \\
\text { Security (NAI); and others }\end{array}$ & 9 & $3.3 \times 10^{-9}$ & $\begin{array}{l}\text { Preparation of aqueous solutions and waste samples for } \\
\text { analysis }\end{array}$ \\
\hline 151 & $\begin{array}{l}\text { Isotope Sciences; Chemistry \& } \\
\text { Materials Science Environ- } \\
\text { mental Services Laboratory }\end{array}$ & 27 & $1.5 \times 10^{-4}$ & $\begin{array}{l}\text { Application of nuclear and isotope sciences to a wide } \\
\text { range of research; sample analysis of waste streams } \\
\text { and environmental media for radionuclide content }\end{array}$ \\
\hline 174 & Laser Isotope Separation & 1 & $1.5 \times 10^{-11}$ & Pulse laser experimentation \\
\hline 175 & Laser Isotope Separation & 6 & $0.0^{(d)}$ & Cleaning and refurbishing of uranium parts \\
\hline 177 & Laser Isotope Separation & 8 & $1.2 \times 10^{-2}$ & $\begin{array}{l}\text { Sample preparation, cleaning of parts, processing } \\
\text { uranium oxide powders, melting of uranium in crucibles } \\
\text { under vacuum, liquid uranium corrosion studies }\end{array}$ \\
\hline 194 & Physics \& Space Technology & 2 & $9.4 \times 10^{-5}$ & $\begin{array}{l}\text { High-energy linear accelerator (LINAC), positron beam } \\
\text { generation and experiments }\end{array}$ \\
\hline 212 & Physics \& Space Technology & 2 & $6.8 \times 10^{-11}$ & $\begin{array}{l}\text { Physics experiments, residual contamination from } \\
\text { previous operation of rotating target neutron source (no } \\
\text { longer operating) }\end{array}$ \\
\hline 222 & Chemistry \& Materials Science & 7 & $5.0 \times 10^{-6}$ & $\begin{array}{l}\text { Chemical analyses, cleaning equipment, waste samples } \\
\text { preparation and analysis, decontamination, x-ray } \\
\text { fluorescence analysis, sample digestion }\end{array}$ \\
\hline 231 & $\begin{array}{l}\text { Chemistry \& Materials } \\
\text { Science, Engineering, } \\
\text { Safeguards \& Security }\end{array}$ & 14 & $2.8 \times 10^{-6}$ & $\begin{array}{l}\text { Materials research and testing, metals processing and } \\
\text { characterization, electron-beam welding, grinding/ } \\
\text { polishing, casting, microscopy, sample preparation, } \\
\text { storage }\end{array}$ \\
\hline 235 & Chemistry \& Materials Science & 3 & $3.1 \times 10^{-11}$ & $\begin{array}{l}\text { Material structure studies, precision cutting, ion } \\
\text { implantation, metallurgical studies, sample preparation }\end{array}$ \\
\hline 241 & Chemistry \& Materials Science & 3 & $1.8 \times 10^{-6}$ & Materials properties research and testing \\
\hline \multirow[t]{3}{*}{251} & $\begin{array}{l}\text { Heavy Elements Facility, } \\
\text { Physics \& Space Technology }\end{array}$ & & & Storage of transuranic isotopes prior to disposal \\
\hline & Seismically hardened area & 4 & $0.0^{(\mathrm{d})}$ & \\
\hline & & 37 & $1.3 \times 10^{-3}$ & \\
\hline
\end{tabular}




\section{Radiological Dose Assessment}

Table 13-1. Sources of radiation dose from LLNL releases (measured and potential) to air: stacks and other exhaust pathways from buildings containing radioactive materials management areas and diffuse area sources(a,b) (continued).

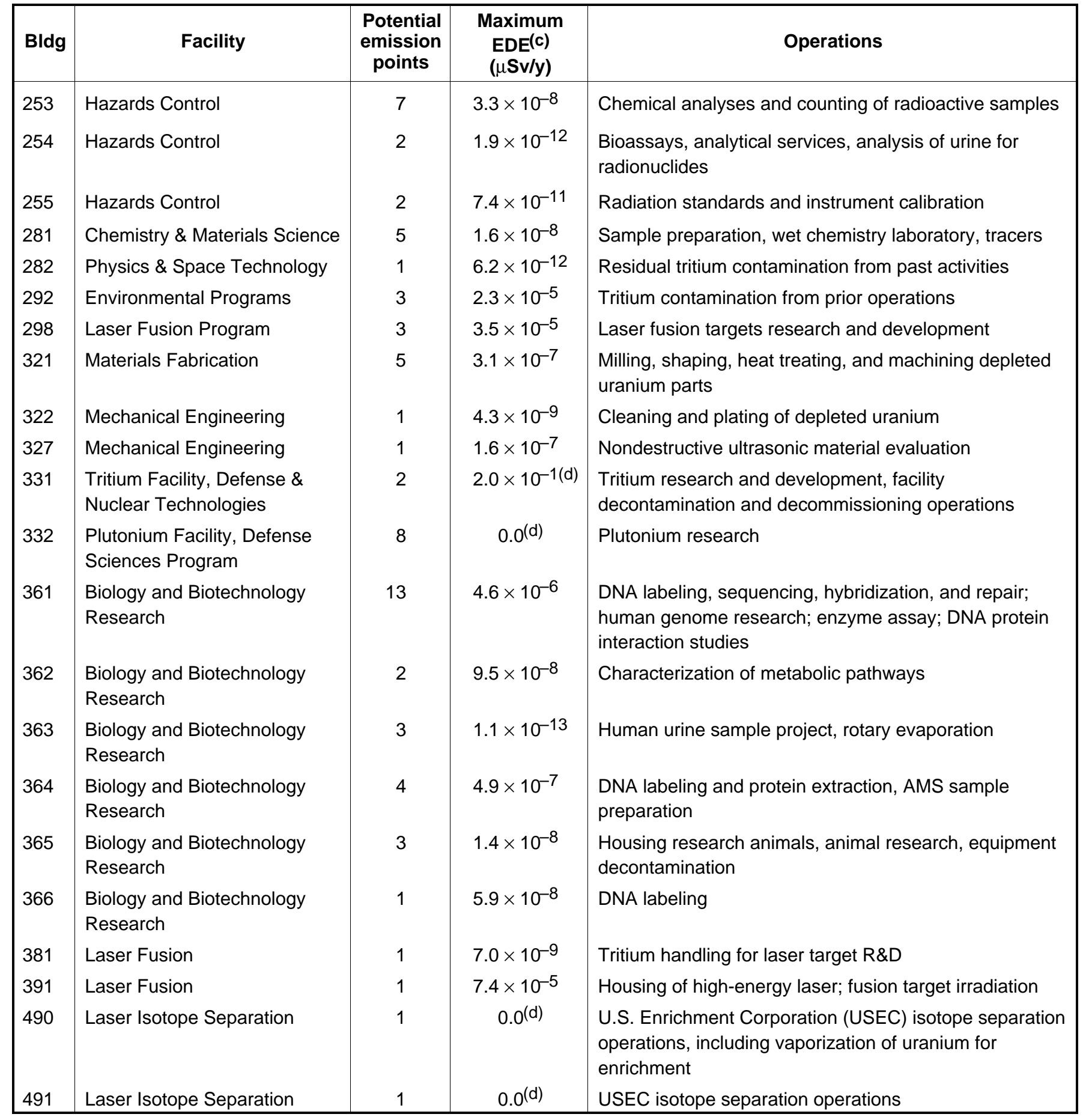


Table 13-1. Sources of radiation dose from LLNL releases (measured and potential) to air: stacks and other exhaust pathways from buildings containing radioactive materials management areas and diffuse area sources(a,b) (continued).

\begin{tabular}{|c|c|c|c|c|}
\hline Bldg & Facility & $\begin{array}{c}\text { Potential } \\
\text { emission } \\
\text { points }\end{array}$ & $\begin{array}{l}\text { Maximum } \\
\mathrm{EDE}^{(\mathbf{c})} \\
(\mu \mathrm{Sv} / \mathrm{y})\end{array}$ & Operations \\
\hline 513 & $\begin{array}{l}\text { Hazardous Waste } \\
\text { Management }\end{array}$ & 3 & $1.9 \times 10-5$ & $\begin{array}{l}\text { Sampling, treatment, and storage of hazardous, mixed, } \\
\text { and radioactive waste; process optimization and } \\
\text { treatability studies; decontamination and } \\
\text { decommissioning activities }\end{array}$ \\
\hline 514 & $\begin{array}{l}\text { Hazardous Waste } \\
\text { Management (see also diffuse } \\
\text { sources below) }\end{array}$ & 2 & $4.1 \times 10-4$ & $\begin{array}{l}\text { Waste consolidation, vacuum filtration of treated waste } \\
\text { water }\end{array}$ \\
\hline 612 & $\begin{array}{l}\text { Hazardous Waste } \\
\text { Management }\end{array}$ & 3 & $4.2 \times 10-3$ & $\begin{array}{l}\text { Waste sampling and treatment; laboratory analysis of } \\
\text { waste treatment and treatability samples }\end{array}$ \\
\hline 625 & $\begin{array}{l}\text { Hazardous Waste } \\
\text { Management } \\
\text { Site } \mathbf{3 0 0} \text { point sources }\end{array}$ & 2 & $8.4 \times 10^{-8}$ & Repackaging of wastes \\
\hline $810 \mathrm{~A}$ & Site 300 firing table support & 1 & $1.2 \times 10^{-7}$ & Assembly of explosives \\
\hline 801 & Flash x-ray machine (FXR) & 1 & $5.2 \times 10-7$ & Flash $\mathrm{x}$-ray photography of explosives experiments \\
\hline 801 & Site 300 firing table at 801 & -(e) & $1.7 \times 10-1$ & Detonation of explosives \\
\hline 851 & Site 300 firing table at 851 & -(e) & $1.9 \times 10-2$ & Detonation of explosives \\
\hline 851 & Linear accelerator & 1 & $9.6 \times 10-6$ & Research \\
\hline \multirow[t]{2}{*}{854} & Tent & 1 & $4.7 \times 10-6$ & Sampling of historical wastes \\
\hline & $\begin{array}{l}\text { Livermore site diffuse } \\
\text { sources }^{(f)}\end{array}$ & 6 & $\begin{array}{l}\text { See next } 5 \\
\text { entries below. }\end{array}$ & Storage areas and contaminated ground \\
\hline 292 & Spill area & 1 & $2.9 \times 10^{-7}$ & $\begin{array}{l}\text { Evaporation and transpiration of tritiated water from } \\
\text { underground tank leakage }\end{array}$ \\
\hline 331 & Tritium Facility (external) & 1 & $3.9 \times 10^{-2}$ & Outdoor waste accumulation area \\
\hline 514 & $\begin{array}{l}\text { Hazardous Waste } \\
\text { Management Tank Farm }\end{array}$ & 1 & $1.3 \times 10^{-3}$ & Liquid waste processing, treatment, and storage \\
\hline 612 & $\begin{array}{l}\text { Hazardous Waste } \\
\text { Management }\end{array}$ & 2 & $1.9 \times 10^{-1}$ & $\begin{array}{l}\text { Storage of low-level waste; drum sampling and waste } \\
\text { accumulation areas }\end{array}$ \\
\hline- & $\begin{array}{l}\text { Southeast quadrant of } \\
\text { Livermore site }\end{array}$ & 1 & $8.4 \times 10^{-4}$ & Contaminated ground \\
\hline
\end{tabular}




\section{Radiological Dose Assessment}

Table 13-1. Sources of radiation dose from LLNL releases (measured and potential) to air: stacks and other exhaust pathways from buildings containing radioactive materials management areas and diffuse area sources $(a, b)$ (concluded).

\begin{tabular}{|c|l|c|c|l|}
\hline Bldg & \multicolumn{1}{|c|}{ Facility } & $\begin{array}{c}\text { Potential } \\
\text { emission } \\
\text { points }\end{array}$ & $\begin{array}{c}\text { Maximum } \\
\mathrm{EDE}(\mathbf{c}) \\
(\mu \mathrm{Sv} / \mathbf{y})\end{array}$ & \multicolumn{1}{|c|}{ Operations } \\
\hline & Site 300 diffuse sources(f) & 3 & $\begin{array}{c}\text { See next 3 } \\
\text { entries below. }\end{array}$ & Contaminated ground and water \\
- & All Site 300 land area & 1 & $3.5 \times 10^{-4}$ & Evaporation of tritium from contaminated soil and water \\
- & All Site 300 land area & 1 & $5.3 \times 10^{-2}$ & Resuspension of uranium in contaminated soil \\
804 & Open area & 1 & $6.0 \times 10^{-6}$ & Low-level waste staging area \\
\hline
\end{tabular}

a LLNL NESHAPs 1998 Annual Report (Biermann et al. 1999).

b RMMAs in which no operations using radionuclides took place in 1998 or in which all radionuclides were encapsulated or sealed for the entire year are not included in this table. Table entries refer to routine operations, not unplanned releases.

c The maximum effective dose equivalent to the sitewide maximally exposed individual (SW-MEI) member of the public from a single discharge point, among all discharge points modeled for the indicated facility or building. The SW-MEI is defined in the section entitled Identification of Key Receptors: MEI and SW-MEI.

d The effluents from the facility are monitored. Zeroes refer to monitored values below the minimum detectable concentration, as discussed, for example, in the "Air-Emission Data" section of the NESHAPs 1998 annual report cited in footnote a.

e Open air dispersal in 1998.

$f$ Diffuse sources are described briefly in the section on Special Modeling Problems, and more fully in the NESHAPs 1998 annual report cited in footnote a.

\section{Doses to Site-Wide Maximally Exposed Individuals}

The 1998 calculated EDE to the SW-MEI from Livermore site point sources was $0.25 \mu \mathrm{Sv}$ (0.025 mrem). Emissions from the two 30-m stacks at the LLNL Tritium Facility (Building 331) accounted for most of this: $0.23 \mu \mathrm{Sv}(0.023 \mathrm{mrem})$, or about $92 \%$. For the Livermore site, the SW-MEI dose caused by diffuse emissions in 1998 was $0.24 \mu \mathrm{Sv}$ (0.024 mrem). Combining point and diffuse sources, the total annual dose was $0.49 \mu \mathrm{Sv}$ ( $0.049 \mathrm{mrem})$, divided $52 \%$ by $48 \%$ between point and diffuse source emissions. This is about half of last year's total, principally reflecting decreased emissions from the stacks of the Tritium Facility (Building 331): $4.1 \times 10^{12} \mathrm{~Bq}$ (110 Ci) of HTO in 1998, compared to $1.0 \times 10^{13} \mathrm{~Bq}(270 \mathrm{Ci})$ the previous year. Calculating dose as directed by EPA, the total annual dose to the SW-MEI from Livermore site operations was $0.55 \mu \mathrm{Sv}$ (0.055 mrem), with $57 \%$ attributed to point sources and $43 \%$ to diffuse sources (see the discussion in the Assessment Assumptions Regarding Tritium section earlier in this chapter). 
The calculated EDE to the SW-MEI at Site 300 in 1998 was $0.24 \mu$ Sv (0.024 mrem), with $0.19 \mu \mathrm{Sv}(0.019 \mathrm{mrem})$ caused by emissions in the course of explosives experiments at the Building 801 and 851 firing tables. The remaining $0.053 \mu \mathrm{Sv}(0.0053 \mathrm{mrem})$, or about $22 \%$ of the total, was attributed to Site 300 diffuse sources; resuspension of LLNL-contributed uranium in surface soils throughout Site 300 was responsible for nearly all of this dose from diffuse sources. Table 13-2 summarizes doses to the site-wide maximally exposed public individuals for the Livermore site and Site 300 over the past nine years.

Table 13-2. Doses ( $\mu$ Sv) calculated for the site-wide maximally exposed individual for the Livermore site and Site 300, 1990 to 1998.

\begin{tabular}{|c|c|c|c|}
\hline Year & Total dose & Point source dose & Diffuse source dose \\
\hline \multicolumn{4}{|c|}{ Livermore site } \\
\hline 1998 & $0.49^{(a)}$ & $0.25^{(a)}$ & 0.24 \\
\hline 1997 & 0.97 & 0.78 & 0.19 \\
\hline 1996 & 0.93 & 0.48 & 0.45 \\
\hline 1995 & 0.41 & 0.19 & 0.22 \\
\hline 1994 & 0.65 & 0.42 & 0.23 \\
\hline 1993 & 0.66 & 0.40 & 0.26 \\
\hline 1992 & 0.79 & 0.69 & 0.10 \\
\hline 1991 & 2.3 & -(b) $^{(\mathrm{n}}$ & $-^{(b)}$ \\
\hline 1990 & 2.4 & -(b) $^{(\mathrm{c}}$ & -(b) $^{(\mathrm{c}}$ \\
\hline \multicolumn{4}{|c|}{ Site 300} \\
\hline 1998 & 0.24 & 0.19 & 0.053 \\
\hline 1997 & 0.20 & 0.11 & 0.088 \\
\hline 1996 & 0.33 & 0.33 & 0.0045 \\
\hline 1995 & 0.23 & 0.20 & 0.03 \\
\hline 1994 & 0.81 & 0.49 & 0.32 \\
\hline 1993 & 0.37 & 0.11 & 0.26 \\
\hline 1992 & 0.21 & 0.21 & -(c) $^{(\mathrm{c}}$ \\
\hline 1991 & 0.44 & 0.44 & -(c) \\
\hline 1990 & 0.57 & 0.57 & -(c) \\
\hline
\end{tabular}

a Calculating dose as directed by the EPA, the total dose for 1998 is $0.55 \mu \mathrm{Sv}$, and the point source dose is $0.31 \mu \mathrm{Sv}$; see the discussion in the section on Assessment Assumptions Regarding Tritium.

b Diffuse source doses were not reported separately from the total dose for the Livermore site for 1990 and 1991.

C No diffuse emissions were reported at Site 300 for years prior to 1993. 


\section{Radiological Dose Assessment}

The 1998 firing tables total is typical of values in recent years (see the "point source dose" column for Site 300 in Table 13-2). Table 13-3 shows the potential public dose values attributed to firing table experiments for 1990 through 1998, correlated with the total amounts of depleted uranium and the total quantity of high explosives used each year in the experiments. (Only experiments that included depleted uranium are considered; most have none.) The data show that variations from year to year in these doses mainly correspond to differences in the amount of depleted uranium used in the tests.

Table 13-3. Annual dose to the SW-MEI from explosives experiments on firing tables at Site 300, 1990-1998, related to the total quantity of depleted uranium used in the experiments and the total quantity of high explosives (HE) driving the detonations.

\begin{tabular}{|c|c|c|c|c|}
\hline \multirow[b]{2}{*}{ Year } & \multicolumn{2}{|c|}{ Dose to SW-MEI } & \multirow{2}{*}{$\begin{array}{l}\text { Total depleted } \mathrm{U} \text { used in } \\
\text { experiments }(\mathrm{kg})\end{array}$} & \multirow{2}{*}{$\begin{array}{l}\text { Total HE used in depleted } \\
\mathrm{U} \text { experiments }(\mathrm{kg})\end{array}$} \\
\hline & $(\mu \mathrm{Sv})$ & (mrem) & & \\
\hline 1998 & 0.19 & 0.019 & 230 & 192 \\
\hline 1997 & 0.11 & 0.011 & 163 & 122 \\
\hline 1996 & 0.33 & 0.033 & 272 & 112 \\
\hline 1995 & 0.20 & 0.020 & 165 & 199 \\
\hline 1994 & 0.49 & 0.049 & 230 & 134 \\
\hline 1993 & 0.11 & 0.011 & 99 & 74 \\
\hline 1992 & 0.21 & 0.021 & 151 & 360 \\
\hline 1991 & 0.44 & 0.044 & 221 & 330 \\
\hline 1990 & 0.57 & 0.057 & 340 & 170 \\
\hline
\end{tabular}

Table 13-4 lists the facilities that were primarily responsible for the LLNL dose; the contributions from all emission points at each facility have been summed. These facilities collectively accounted for approximately $97 \%$ of the total EDE resulting from Livermore site operations and for more than 99\% of the total EDE from Site 300 operations. The principal radionuclide(s) are indicated for each facility. Tritium was the overall dominant radionuclide at the Livermore site, accounting for more than $93 \%$ of the Livermore site dose. At Site 300, practically the entire dose was attributed to the isotopes present in depleted uranium having atomic numbers 238, 235, and 234.

The relative significance of inhalation and ingestion is different for tritium and uranium and depends on the assumptions made about the origin of food consumed by a person receiving the dose. For the conditions we assumed when assessing individual doses, namely that milk is imported while the remainder of the food is produced locally, ingestion dose is larger than inhalation dose in the case of tritium, approximately in 
the ratio $80 \%$ to $20 \%$. For uranium, these numbers are nearly reversed: $17 \%$ by the ingestion pathway, versus $83 \%$ via inhalation. For both uranium and tritium, external doses from air immersion and ground irradiation were negligible.

Table 13-4. Major contributors to LLNL's radiation dose via airborne emissions, 1998.

\begin{tabular}{|c|c|c|c|}
\hline \multirow{2}{*}{$\begin{array}{l}\text { Facility or } \\
\text { operation (a) }\end{array}$} & \multirow{2}{*}{$\begin{array}{l}\text { Dominant } \\
\text { radionuclide(s) }\end{array}$} & \multicolumn{2}{|c|}{ EDE at SW-MEI(b) } \\
\hline & & $\mu \mathrm{Sv} / \mathbf{y}$ & $\mathrm{mrem} / \mathbf{y}$ \\
\hline \multicolumn{4}{|l|}{ Livermore site } \\
\hline B331/Tritium Facility & ${ }^{3} \mathrm{H}$ & $0.23^{(c)}$ & $0.023(\mathrm{c})$ \\
\hline B612 Yard Area(d) & ${ }^{3} \mathrm{H}$ & 0.19 & 0.019 \\
\hline B331 Waste Accumulation Area(d) & ${ }^{3} \mathrm{H}$ & 0.039 & 0.0039 \\
\hline B177, U-AVLIS & ${ }^{238} U,{ }^{234} U,{ }^{235} U$ & 0.015 & 0.0015 \\
\hline Sum of all other sources & Various & 0.016 & 0.0016 \\
\hline Total & & $0.49(c, e)$ & $0.049(\mathrm{c}, \mathrm{e})$ \\
\hline \multicolumn{4}{|l|}{ Site 300} \\
\hline B801/firing table & ${ }^{238} U,{ }^{234} U,{ }^{235} U$ & 0.17 & 0.017 \\
\hline Soil resuspension $(\mathrm{d})$ & ${ }^{238} U,{ }^{234} U,{ }^{235} U$ & 0.053 & 0.0053 \\
\hline B851/firing table & ${ }^{238} U,{ }^{234} U,{ }^{235} U$ & 0.019 & 0.0019 \\
\hline Total & & $0.24(\mathrm{e})$ & $0.024(e)$ \\
\hline
\end{tabular}

a The facilities cited here are discussed in the text of this report and in more detail in the NESHAPs annual reports.

b These doses represent the sum of all emission points from a given facility (for example, both stacks on Building 331), in contrast to the dose values in Table 13-1, which represent the dose from the single largest emission point at each facility. The site-wide maximally exposed individual (SW-MEI) member of the public is defined in the section on Identification of Key Receptors.

C Calculating dose as directed by EPA yields $0.29 \mu \mathrm{Sv} / \mathrm{y}$ for the Tritium Facility, which raises the total dose to $0.55 \mu \mathrm{Sv} / \mathrm{y}$. (See the section Assessment Assumptions Regarding Tritium.)

d Diffuse sources (see text).

e These Livermore site and Site 300 totals represent $0.49 \%$ and $0.24 \%$, respectively, of the federal standard.

\section{Temporal Trends in Dose to the SW-MEI}

The trends in dose to the SW-MEI from emissions at the Livermore site and Site 300 over the last nine years are shown graphically in Figure 13-1 (see also Table 13-2). The general pattern, particularly over the last seven years, shows year-to-year fluctuations around a quite low dose level, staying at or below about $1 \%$ of the federal standard. 


\section{Radiological Dose Assessment}

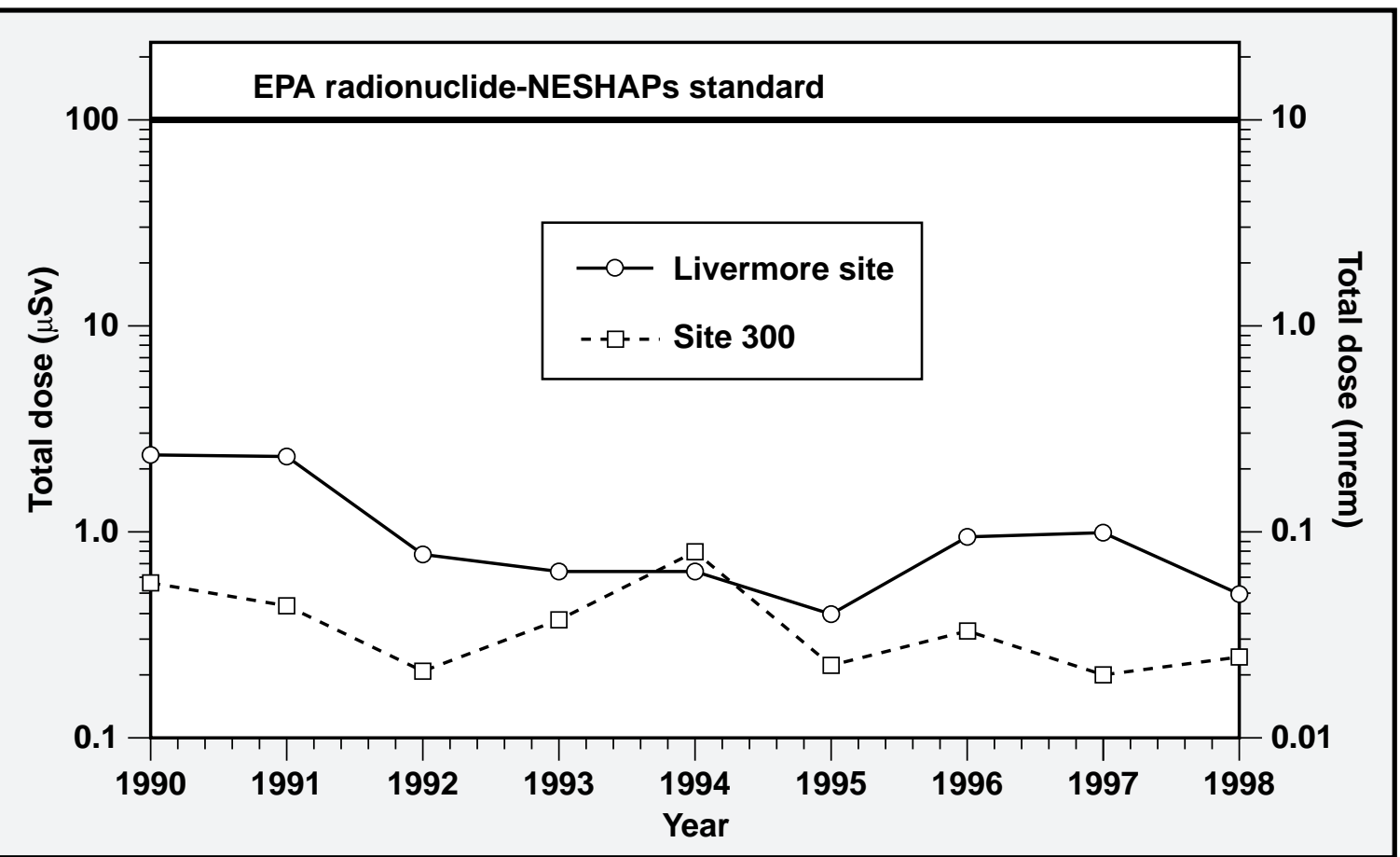

Figure 13-1. Dose to the site-wide maximally exposed individual member of the public, 1990 to 1998.

The SW-MEI dose estimates we report are intentionally conservative, erring on the side of predicting potential doses that are several times higher than would actually be experienced by any member of the public. Our potential doses from Site 300 firing table operations are especially so, as explained in the section on Special Modeling Problems.

\section{Collective Doses to Exposed Populations}

Population doses, or collective EDEs, for both LLNL sites were calculated out to a distance of $80 \mathrm{~km}$ in all directions from the site centers using CAP88-PC. For releases of radionuclides to air, CAP88-PC evaluates the four principal exposure pathways: ingestion through food and water consumption, inhalation, air immersion, and irradiation by contaminated ground surface.

The collective EDE caused by 1998 Livermore site operations was 0.68 person-rem (0.068 person-Sv), less than half of the 1997 result of 1.5 person-rem (0.015 person-Sv). Dose, when calculated as directed by EPA, was 0.84 person-rem (0.084 person-Sv). The corresponding collective EDE from Site 300 operations in 1998 was 11 person-rem 
(0.11 person-Sv), which exceeds the previous year's value of 7.2 person-rem ( 0.072 person-Sv) by about 1.5 times. These levels of variation in population dose from one year to the next are within the expected range of operations-driven fluctuations in small radiation quantities.

Table 13-5 compares background and medical-treatment-related doses to the maximum potential doses caused by LLNL operations. The population doses attributed to LLNL operations are some 200,000 times smaller than ones from natural background radiation, and the maximum potential individual doses to maximally exposed public individuals from Livermore site and Site 300 operations are more than 6000 times smaller.

Table 13-5. Comparison of background (natural and man-made) and LLNL radiation doses, 1998.

\begin{tabular}{|c|c|c|c|c|}
\hline \multirow[b]{2}{*}{ Location/Source } & \multicolumn{2}{|c|}{ Individual dose ${ }^{(a)}$} & \multicolumn{2}{|c|}{ Population dose ${ }^{(b)}$} \\
\hline & $(\mu \mathrm{Sv})$ & (mrem) & (person-Sv) & (person-rem) \\
\hline Livermore site sources & & & & \\
\hline Atmospheric emissions & $0.49^{(c)}$ & 0.049 (c) & $0.0068^{(c)}$ & $0.68^{(c)}$ \\
\hline Site 300 sources & & & & \\
\hline Atmospheric emissions & 0.24 & 0.024 & 0.11 & 11 \\
\hline Other sources $(d)$ & & & & \\
\hline Natural radioactivity $(\mathrm{e}, \mathrm{f})$ & & & & \\
\hline Cosmic radiation & 300 & 30 & 1,900 & 190,000 \\
\hline Terrestrial radiation & 300 & 30 & 1,900 & 190,000 \\
\hline Internal (food consumption) & 400 & 40 & 2,500 & 250,000 \\
\hline Radon & 2000 & 200 & 12,500 & $1,250,000$ \\
\hline $\begin{array}{l}\text { Medical radiation (diagnostic } \\
\text { procedures) })^{(\mathrm{f})}\end{array}$ & 530 & 53 & 3,300 & 330,000 \\
\hline Weapons test fallout $(\mathrm{f})$ & 11 & 1.1 & 68 & 6,800 \\
\hline Nuclear fuel cycle & 4 & 0.4 & 25 & 2,500 \\
\hline
\end{tabular}

a For LLNL sources, this dose represents that experienced by the site-wide maximally exposed individual member of the public.

b The population dose is the collective (combined) dose for all individuals residing within an 80-km radius of LLNL (approximately 6.3 million people for the Livermore site and 5.4 million for Site 300), calculated with respect to distance and direction from each site.

c Calculating dose as directed by the EPA, the individual dose is $0.55 \mu \mathrm{Sv}(0.055 \mathrm{mrem})$, and the population dose is 0.0084 person-Sv (0.84 person-rem); see the sections on Doses to Site-Wide Maximally Exposed Individuals, and Collective Doses to Exposed Populations.

d From National Council on Radiation Protection (NCRP 1987a and b).

e These values vary with location.

f This dose is an average over the U.S. population. 


\section{Radiological Dose Assessment}

\section{Summary and Conclusion}

The annual radiological dose from all emissions at the Livermore site and Site 300 in 1998 was found to be well below the applicable standards for radiation protection of the public, in particular the NESHAPs standard. This standard limits to $100 \mu \mathrm{Sv} / \mathrm{y}$ (10 mrem/y) the EDE to any member of the public, arising as a result of releases of radionuclides to air from DOE facilities. Using EPA-mandated computer models, actual LLNL meteorology, and population distributions appropriate to the two sites, the dose to the LLNL site-wide maximally exposed members of the public from 1998 operations were as follows:

- $\quad$ Livermore site: $0.49 \mu \mathrm{Sv}$ (0.049 mrem) — 52\% from point-source emissions, $48 \%$ from diffuse-source emissions, using LLNL's standard calculational assumptions. Calculating dose as directed by the EPA, the total annual dose to the SW-MEI from Livermore site operations is $0.55 \mu \mathrm{Sv}(0.055 \mathrm{mrem})$, divided $57 \%$ by $43 \%$ between point and diffuse sources.

- $\quad$ Site 300: $0.24 \mu \mathrm{Sv}$ (0.024 mrem) - 78\% from explosive experiments, classified as point-sources, $22 \%$ from diffuse-source emissions.

The major radionuclides accounting for the doses were tritium at the Livermore site and the three isotopes in depleted uranium $\left({ }^{238} \mathrm{U},{ }^{235} \mathrm{U}\right.$, and $\left.{ }^{234} \mathrm{U}\right)$ at Site 300.

The collective effective dose equivalent or population dose attributable to LLNL operations in 1998 was estimated to be 0.0068 person-Sv (0.68 person-rem) for the Livermore site and 0.11 person-Sv (11 person-rem) for Site 300. Calculating dose as directed by the EPA, the Livermore site number is 0.84 person-rem ( 0.084 person-Sv). These doses include exposed populations of 6.3 million people for the Livermore site and 5.4 million for Site 300 living within a distance of $80 \mathrm{~km}$ from the site centers, based on 1990 census data.

The dose to the maximally exposed member of the public resulting from Livermore site and Site 300 operations is seen to be about 6000 times smaller than the dose from background radiation, and the population dose from LLNL operations is about 200,000 times smaller than that caused by natural radioactivity in the environment (see Table 13-5 and Figure 13-2 in Supplement 13-1 below).

We conclude that the potential radiological doses from LLNL operations were well below regulatory standards and very small compared to doses normally received by these populations from natural background radiation sources, even though highly conservative assumptions were used in the determinations of LLNL doses. These maximum credible doses indicate that LLNL's use of radionuclides had no significant impact on public health during 1998. 


\section{Chapter 13 Supplements}

\section{Supplement 13-1: Radiation Basics}

Natural and man-made radiation. By far the greatest part of radiation received by the world's population comes from natural sources-primarily cosmic rays that impinge on the earth's atmosphere from space and radionuclides naturally present in our environment, such as radioactive materials in soil and rocks. Among these terrestrial sources are carbon-14, potassium-40, rubidium-87, uranium-238, thorium-232, and radioactive elements, such as radon, that arise from decay of uranium and thorium. The source of human exposure to natural radiation can be external (from substances staying outside the body) or internal (from substances inhaled in air or ingested in food and water). Individual doses vary with location. The level of cosmic radiation increases with altitude, because there is less air overhead to act as a shield, and the earth's poles receive more cosmic radiation than the equatorial regions, because the earth's magnetic field diverts the radiation. The levels of terrestrial radiation differ from place to place around the United States and around the world, mainly owing to variations in soil and rock composition.

Adding to this pervasive natural or background radiation is man-made radiation from radionuclides used in medicine, consumer products, the production of energy, and the production of nuclear weapons. Exposure to man-made sources can be controlled more readily than exposure to most natural sources. However, nuclear explosives tested in the atmosphere in the 1950s and 1960s spread radioactivity across the surface of the globe, and the nuclear reactor accident at Chernobyl in 1986 affected a large area. At present, medical treatment is the largest common source of public exposure to manmade radiation. Individual medical doses vary enormously-someone who has never had an x-ray examination may receive zero medical dose while patients undergoing treatment for cancer may receive many thousands of times the annual average dose they would receive from natural radiation. Another source of public exposure to man-made radiation is consumer products, including luminous-dial watches, smoke detectors, airport $\mathrm{x}$-ray baggage inspection systems, and tobacco products.

Radioactivity. Generally, naturally occurring isotopes are stable, but notable exceptions include carbon-14, potassium-40, thorium-232, uranium-235, and uranium238, which occur naturally but are radioactive. Nuclear decay divides into three main categories: alpha, beta, and gamma. Alpha decay is the spontaneous emission of an alpha particle (a bound state of two protons and two neutrons-the nucleus of a helium atom) from a nucleus containing a large number of protons (most commonly 82 or 


\section{Radiological Dose Assessment}

more). Beta decay is the spontaneous conversion of a neutron to a proton in the nucleus with the emission of an electron, and gamma decay is the spontaneous emission of highenergy photons (high-frequency electromagnetic radiation) by nuclei.

Radioisotopes decay at quite different rates; the "half-life," or length of time for half of the atoms to decay, spans a wide range from small fractions of a second to millions of years. For example, tritium (the radioactive form of hydrogen) has a 12.3-year half-life, compared to 24,131 years for plutonium-239.

Some radioisotopes decay by forming radioisotopes that in turn decay into other radioisotopes until a stable state is achieved. For example, an atom of uranium-238 can undergo alpha decay, leaving behind a daughter, thorium-234, which is also radioactive. The transformations of the decay chain continue, ending with the formation of lead-206, which is a stable isotope.

Radioactivity can be hazardous because radiation (alpha particles, beta particles, gamma rays, and other subatomic particles such as neutrons) can be released with great energy. This energy is capable of altering the electronic configuration of atoms and molecules, especially by stripping one or more electrons off the atoms of the irradiated material, thereby disrupting the chemical activity in living cells. If the disruption is severe enough to overwhelm the normal restorative powers of the cell, the cell may die or become permanently damaged. Cells are exposed to many naturally occurring sources of disruption, including naturally toxic chemicals in food, microbes that cause disease, high-energy radiation from outer space (cosmic rays), and heat and light (including the sun's rays, which can cause sunburn and skin cancer). Consequently, cells and living organisms have evolved the capacity to survive limited amounts of damage, including that caused by radioactivity.

Three main factors determine the radiation-induced damage that might be caused to living tissue: the number of radioactive nuclei that are present, the rate at which they give off energy, and the effectiveness of energy transfer to the host medium, i.e., how the radiation interacts with the tissue. Alpha radiation can be halted by a piece of paper and can scarcely penetrate the dead outer layers of skin. Radioisotopes that give off alpha radiation are generally not health hazards unless they get inside the body through an open wound or are ingested or inhaled. In those cases, alpha radiation can be especially damaging because its disruptive energy can be deposited within a small distance, resulting in significant energy deposition in a few cells. Beta radiation from nuclear decay typically penetrates a centimeter or two of living tissue. It therefore deposits energy over many cells, decreasing the damage to any single cell. Gamma 


\section{Radiological Dose Assessment}

radiation is extremely penetrating and can pass through most materials, only being significantly attenuated by thick slabs of dense materials, such as lead.

Measurement of Radioactivity and Dose. The rate at which a nucleus decays is expressed in units of becquerels, abbreviated $\mathrm{Bq}$, where 1 becquerel is one decay per second, or alternatively in curies, $\mathrm{Ci}$, where 1 curie equals $3.7 \times 10^{10}$ (37 billion) decays per second, or $3.7 \times 10^{10} \mathrm{~Bq}$ (approximately equal to the decay rate of 1 gram of pure radium). Becquerels and curies are not measures of the effect of radiation on living tissue. This depends on the efficiency of energy deposition as the radiation traverses matter.

The amount of energy deposited in living tissue is called the "dose." The amount of radiation energy absorbed per gram of tissue is called the "absorbed dose" and is expressed in units of rads or grays (Gy), where 1 Gy equals 100 rads. Because an absorbed dose produced by alpha radiation is more damaging to living tissue than the same dose produced by beta or gamma radiation, the absorbed dose is multiplied by a quality factor to give the dose equivalent. The quality factor for alpha radiation is 20; for beta and gamma, 1. The dose equivalent is measured in units of rem or sieverts (Sv); $1 \mathrm{~Sv}$ equals $100 \mathrm{rem}$. Also commonly used are millirem (mrem) and the millisievert $(\mathrm{mSv})$, which are one-thousandth of a rem and sievert, respectively.

Just as one type of radiation can be more damaging than others, some parts of the body are potentially more vulnerable to radiation damage than others, so the different parts of the body are given weightings. For example, a given radiation dose from iodine-131 is more likely to cause cancer in the thyroid than in the lung. The reproductive organs are of particular concern because of the potential risk of genetic damage. Once particular organs are weighted appropriately, the dose equivalent becomes the "effective dose equivalent" (EDE), also expressed in rem or sievert. This allows dose equivalents from nonuniform exposure of the body to be expressed in terms of an EDE that is numerically equal to the dose from uniform exposure of the whole body that entails the same risk as the nonuniform exposure.

The EDE describes doses to individuals. When individual EDEs received by a group of people are summed, the result is called the "collective effective dose equivalent," often referred to as the "population dose," and is expressed in person-sievert or person-rem. Finally, to account for the long-term effects of radionuclides as they continue to decay and affect generations of people, we calculate the dose over many years, summing the effect over time. This is termed the "collective effective dose equivalent commitment." Most of our discussion in this chapter deals with the EDE and the collective effective dose equivalent. 


\section{Radiological Dose Assessment}

Doses from Natural and Man-Made Radioactivity. The pie chart in Figure 13-2 illustrates the distribution of annual average radiation doses from natural and other common sources in the United States, according to the National Council on Radiation Protection and Measurement (1987b). The average radiation dose from natural sources is $3.0 \mathrm{mSv} / \mathrm{y}$ (300 mrem/y). Approximately $0.3 \mathrm{mSv} / \mathrm{y}(30 \mathrm{mrem} / \mathrm{y})$ of this exposure comes from high-energy radiation from outer space (cosmic rays). Terrestrial sources, mainly radionuclides in rock and soil, also account for approximately $0.3 \mathrm{mSv} / \mathrm{y}$ (30 mrem/y) of the average natural dose. Another significant part of the dose comes from radionuclides we ingest through food and drink, resulting in approximately $0.4 \mathrm{~m}$ $\mathrm{Sv} / \mathrm{y}$ (40 mrem/y). Potassium-40 and carbon-14 are common radionuclides in food.

The remaining $2.0 \mathrm{mSv} / \mathrm{y}$ ( $200 \mathrm{mrem} / \mathrm{y})$ or $67 \%$ of the average dose from natural sources in the United States comes from radon gas. Radon is one of the major radionuclides produced by uranium decay, and our inhalation dose is dominated by radon's short-lived decay products.

We noted earlier that medical treatment is the largest common source of public exposure to man-made radiation, and most of it is delivered as medical x-rays. These contribute $0.39 \mathrm{mSv}$ (39 mrem) to the average whole-body annual dose in the United States.

Nuclear medicine contributes $0.14 \mathrm{mSv}$ (14 mrem) to the average dose, and consumer products add $0.1 \mathrm{mSv}$ (10 mrem). Thus, for a typical member of the public in the United States, radiation from medical procedures and consumer products result in a dose of approximately $0.63 \mathrm{mSv} / \mathrm{y}(63 \mathrm{mrem} / \mathrm{y})$. The annual average dose from other manmade sources, including fallout from nuclear testing, is less than $0.03 \mathrm{mSv}$ ( $3 \mathrm{mrem}$ ). As described in this chapter, the contributions from LLNL operations to the dose of even the most affected resident are on the order of $1 \mu \mathrm{Sv} / \mathrm{y}(0.1 \mathrm{mrem} / \mathrm{y})$ or less and would not be discernible on the scale shown in Figure 13-2; LLNL's contributions are listed under "Other" in the figure.

Deviations from the average levels shown in Figure 13-2 can be quite large, depending on an individual's place of residency, occupation, eating habits, and other lifestyle choices, such as inclination to air travel. Radon dose, for example, varies significantly with geographic location; levels several times higher than the average occur in some regions of the United States, while at LLNL and its environs randon-induced doses as low as half the average are typical. Doses from cosmic rays increase with elevation above sea level, producing several tenths of $\mathrm{mSv}$ (tens of mrem) differences between cosmic ray doses in coastal and mountain communities, and imparting a dose of about $0.05 \mathrm{mSv}$ ( $5 \mathrm{mrem}$ ) to a passenger flying round-trip between Los Angeles and New York City. 


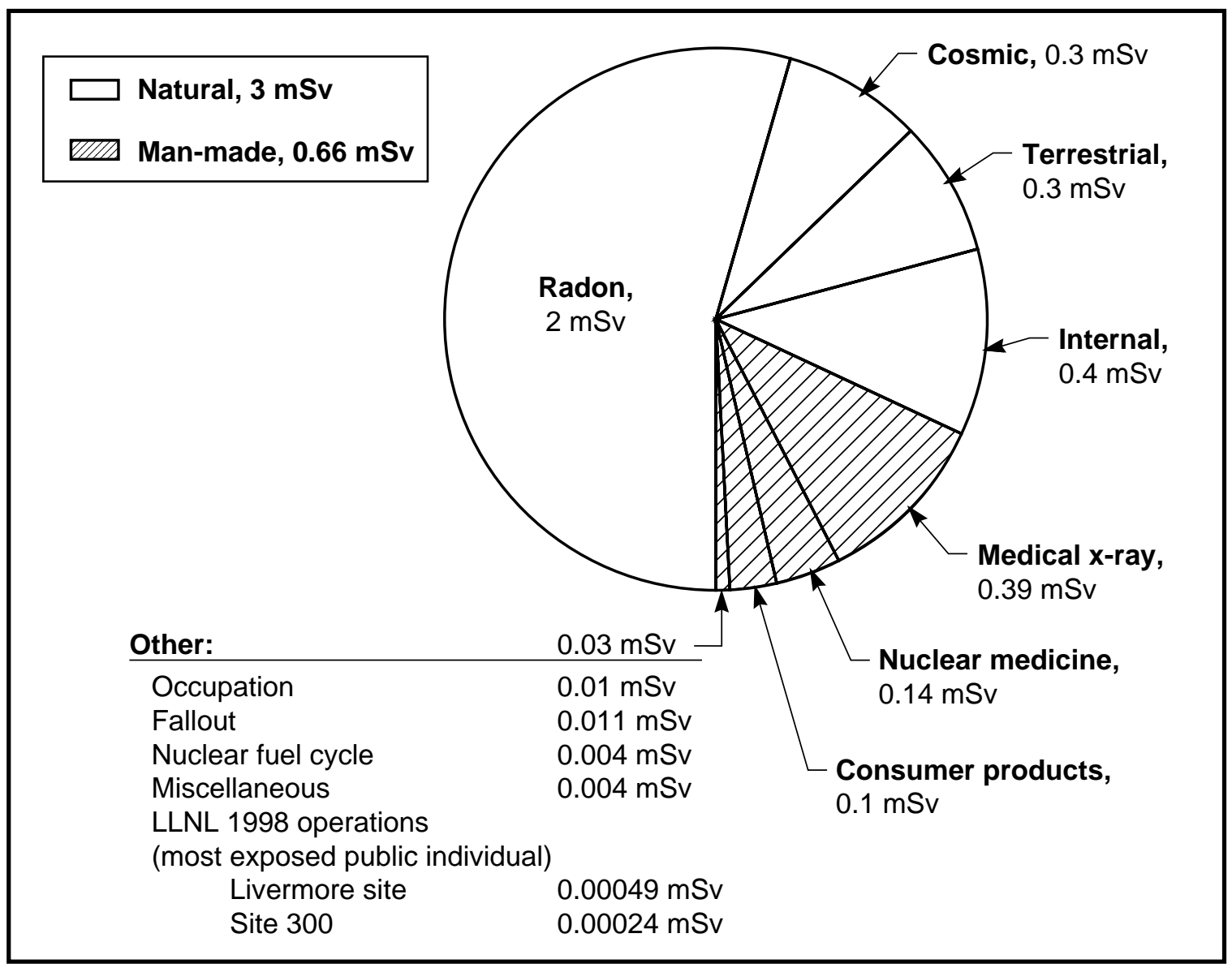

Figure 13-2. Typical annual radiation doses from natural and man-made sources (National Council on Radiation Protection 1987b).

For further reading, a useful Internet reference offering multiple linkages to a large quantity of interesting and educational material on effects and risks from radiation is the "Radiation Information Network" at the address http:/ / www.physics.isu.edu/ radinf/qanda.htm.

\section{Supplement 13-2: Radiation Control Measures at LLNL}

Radioisotopes used at LLNL include uranium, transuranics, biomedical tracers, tritium, and mixed-fission products. Protection of employees and the public from the uncontrolled release of radioactive materials into the environment is a primary consideration for LLNL. This effort takes several forms, as summarized here. 


\section{Radiological Dose Assessment}

When an operation or facility is designed, a thorough assessment of potential radiation hazards is conducted, and radioisotope-handling procedures and work enclosures are determined for each project, depending on the isotope, the quantity being used, and the type of operations being performed. Radioisotope handling and working environments include glove boxes, exhaust hoods, and laboratory bench tops. The controls might include limiting physical access and using shielding, filters, and remote handling equipment. Exhaust paths to the atmosphere include HEPA-filtered stacks, stacks lacking abatement devices, roof vents, and ordinary room air ventilation channels. Facility safety analysis reports and facility safety plans are written to document the need for specific measures and to spell out the requirements for maintenance, training, emergency response, and other administrative control measures.

When a facility is occupied for use, an operational safety plan (OSP) is written that specifies actions to be taken in conducting a research or development project. This procedure is reviewed by environmental analysts, industrial hygienists, and health physicists to assess the safety of the operation, its compliance with current occupational health and environmental standards, and the adequacy of proposed engineering and administrative controls. The OSP also specifies training requirements for personnel. This part of the control program enables LLNL personnel who work with radiation and radioactivity to recognize and prevent the execution of unsafe operations.

Another form of LLNL's radiation control program involves direct monitoring of the workplace environment. This includes sampling of the air and surfaces in facilities where radioactive materials are handled, and includes personal dosimetry and bioassay programs used to monitor potential worker exposure to direct radiation and radioactive isotopes. This monitoring program helps to determine the effectiveness of a facility's radiation control program as well as providing information on worker exposures.

The surveillance and effluent monitoring of radiation in air, ground and surface waters, sewerable water, soil and sediment, and vegetation and foodstuff, as discussed in Chapters 2 and 4 through 11 of this report, play an important role in LLNL's program to control radiation releases. These measurements can signal anomalous releases, should they occur, and directly gage the degree of success of LLNL's radionuclide discharge control program in limiting exposures of the public.

Development of the Livermore Valley and the San Joaquin Valley has enlarged the populations and decreased the distance between sources of emissions and the residents who might be exposed. People live and work within several hundred meters of LLNL's boundaries. It is therefore increasingly important that our assessments provide the best information possible regarding the radiological impact of LLNL operations. 


\section{Quality Assurance}

Lucinda M. Garcia

Donald H. MacQueen

\section{Introduction}

Quality assurance (QA) is a system of activities and processes put in place to ensure that monitoring and measurement data meet user requirements and needs. Quality control (QC) consists of procedures used to verify that prescribed standards of performance in the monitoring and measurement process are met. Department of Energy (DOE) orders and guidance mandate QA requirements for environmental monitoring of DOE facilities. DOE Order 5400.1 identifies QA requirements for radiological effluent and surveillance monitoring and specifies that a QA program consistent with the DOE order addressing quality assurance is established. This order sets forth policy, requirements, and responsibilities for the establishment and maintenance of plans and actions that assure quality in DOE programs.

LLNL conducted QA activities in 1998 at the Livermore site and Site 300 in accordance with the Environmental Protection Department Quality Assurance Management Plan, (Revision 3), based on DOE Order 5700.6C which prescribes a risk-based, graded approach to QA. This process promotes the selective application of QA and management controls based on the risk associated with each activity, maximizing effectiveness and efficiency in resource use.

The DOE Environmental Regulatory Guide for Radiological Effluent Monitoring and Environmental Surveillance (U.S. Department of Energy 1991) requires that an environmental monitoring plan be prepared. LLNL environmental monitoring is conducted according to procedures published in Appendix B of the LLNL Environmental Monitoring Plan (Tate et al. 1995). LLNL or commercial laboratories analyze environmental monitoring samples using Environmental Protection Agency (EPA) standard methods, when available. When EPA standard methods are not available, custom analytical procedures, usually developed at LLNL, are used. The radiochemical methods used by LLNL laboratories are described in procedures unique to the laboratory performing the analyses. LLNL uses only State-ofCalifornia-certified laboratories to analyze its environmental monitoring samples. In addition, LLNL requires all analytical laboratories to maintain adequate QA programs and documentation of methods. 


\section{Quality Assurance}

\section{Quality Assurance Activities}

Nonconformance reporting and tracking is an LLNL quality assurance process aimed at ensuring that Environmental Protection Department (EPD) activities meet the department's QA requirements and that problems are found, identified, resolved, and prevented from recurring. LLNL generated 92 Nonconformance Reports (NCRs) related to environmental monitoring in 1998 compared to 87 in 1997 and 106 in 1996.

Thirty-one of the 92 NCRs generated in 1998 were due to problems with analytical laboratories, and 26 were due to errors in documentation, training, or procedures. Minor problems with sewer monitoring equipment accounted for another 18 NCRs, 11 were related to air-monitoring equipment, and the remaining 6 were related to other monitoring networks.

LLNL addresses analytical laboratory problems with the appropriate laboratory as they arise. Many of the NCRs that were written in response to problems with the laboratories concern minor documentation or paperwork errors, which were corrected soon after they were identified. Other problems - such as missed holding times, late analytical results, and typographical errors on data reports-accounted for the remaining NCRs related to the analytical laboratories. The majority of these were corrected by reanalysis, resampling, reissued reports, or corrected paperwork, and associated sample results were not affected.

LLNL addresses internal documentation, training, and procedural errors by conducting formal and informal training. These errors generally do not result in lost samples but may require extra work on the part of sampling and data management personnel to resolve or compensate for the errors.

\section{Analytical Laboratories}

In March 1996, LLNL and Lawrence Berkeley National Laboratory entered into three-year Blanket Service Agreements (BSAs) with six off-site analytical laboratories (Harrach et al. 1998). In 1998, LLNL began a bidding process for future analytical laboratory work because those BSAs were scheduled to end in March 1999. As part of the rebid process, LLNL developed requirements for a statement of work, solicited and reviewed bids from laboratories, audited the laboratories, and reviewed their performance on evaluation samples. LLNL took the number and frequency of past NCRs with laboratories currently providing analytical services for LLNL into account when reviewing bids. 
New BSAs were signed with seven analytical laboratories in March 1999; of these seven, four are continuing service and three are serving the Laboratory for the first time. LLNL is working closely with its new and continuing analytical laboratories to minimize the occurrence of problems in the future.

\section{Participation in Laboratory Intercomparison Studies}

The LLNL Chemistry and Materials Science Environmental Services (CES) Environmental Monitoring Radiation Laboratory (EMRL) and the Hazards Control Department's Analytical Laboratory (HCAL) participated in both the annual EPA Environmental Monitoring Systems Laboratory (EMSL) intercomparison studies program and the annual DOE Environmental Monitoring Laboratory (EML) intercomparison studies program. A review of the EMSL study indicates that 29 of 31 analyses reported by CES and 13 of 14 analyses reported by HCAL fell within established acceptance control limits. For the EML studies, 66 of 73 reported by CES and 10 of 10 results reported by HCAL fell within the established acceptance control limits.

CES EMRL participated in a DOE Mixed Analyte Performance Evaluation Program (MAPEP) study in 1998. Eleven of 11 analytes reported by CES fell within acceptable limits. (Samples for a second 1998 MAPEP study were distributed in January 1999 so results will be reported in the Environmental Report 1999.)

HCAL also participated in four EPA Water Pollution and Water Supply intercomparison studies for metals during 1998. Review of these results shows that values for 24 of 24 samples fell within established acceptance control limits.

Both CES and HCAL have implemented changes that are intended to address the root causes of unacceptable intercomparison study results and prevent future results from falling outside the acceptance control limits.

Details of the intercomparison study results, including the follow-up explanation and response for data that fell outside the acceptance control limits, are presented in the Data Supplement. Although contract laboratories are also required to participate in laboratory intercomparison programs, permission to publish their results for comparison purposes was not granted for 1998.

LLNL uses the results of intercomparison program data to identify and monitor trends in performance and to solicit corrective action responses for unacceptable results. If a laboratory has unacceptable performance for a particular test in two consecutive 


\section{Quality Assurance}

performance evaluation studies, LLNL may chose to select another laboratory to perform the affected analyses until the original laboratory can demonstrate that the problem has been corrected. Continued unacceptable performance or failure to prepare and implement acceptable corrective action responses could result in formal notification of unsatisfactory performance by the LLNL Procurement Department (for off-site contract laboratories). If the problem still cannot be corrected, termination of the BSA with contract laboratories or suspension of use of the on-site laboratory could result.

A joint performance evaluation committee composed of members from EPD, CES, and Lawrence Berkeley National Laboratory is creating a systematic process for evaluating laboratory performance using performance evaluation samples. A method for evaluating the results of intercomparison studies will be developed by that committee.

\section{Duplicate Analyses}

Duplicate or collocated samples are distinct samples of the same matrix collected as closely to the same point in space and time as possible and are intended to be identical in all respects. Collocated samples processed and analyzed by the same organization provide intralaboratory information about the precision of the entire measurement system, including sample acquisition, homogeneity, handling, shipping, storage, preparation, and analysis. Collocated samples processed and analyzed by different organizations provide interlaboratory information about the precision of the entire measurement system (U.S. Environmental Protection Agency 1987). Collocated samples may also be used to identify errors-for example, mislabeled samples and data entry errors.

Tables 14-1 through 14-3 present statistical data for collocated sample pairs, grouped by sample matrix and analyte. Samples from both the Livermore site and Site 300 are included. Tables 14-1 and 14-2 contain data pairs in which both values are detections (see Statistical Methods in this chapter). Table 14-3 contains data pairs in which either or both values are nondetections.

Precision is measured by the percent relative standard deviation (\%RSD); see the EPA Data Quality Objectives for Remedial Response Activities: Development Process, Section 4.6 (U.S. Environmental Protection Agency 1987). Acceptable values for \%RSD vary greatly with matrix, analyte, and analytical method; however, lower values represent better precision. The results for \%RSD given in Table 14-1 are the 75th percentile of the individual precision values. 
Table 14-1. Quality assurance duplicate sampling. Summary statistics for analytes with more than eight pairs in which both results were above the detection limit.

\begin{tabular}{|c|c|c|c|c|c|c|}
\hline Media & Analyte & $N^{(a)}$ & $\% \mathrm{RSD}^{(\mathrm{b})}$ & Slope & $r^{2}(c)$ & Intercept \\
\hline \multirow[t]{5}{*}{ Air } & Beryllium (d) & 13 & 18.4 & 0.439 & 0.53 & $4.90\left(\mathrm{pg} / \mathrm{m}^{3}\right)$ \\
\hline & Gross beta & 94 & 21.4 & 1.04 & 0.91 & $1.55 \times 10^{-8}(\mathrm{~Bq} / \mathrm{L})$ \\
\hline & Uranium- 235 by mass & 12 & 3.27 & 1.10 & 0.96 & $-3.88 \times 10^{-7}\left(\mu \mathrm{g} / \mathrm{m}^{3}\right)$ \\
\hline & Uranium-238 by mass & 12 & 3.56 & 1.09 & 0.96 & $-4.80 \times 10^{-5}\left(\mu \mathrm{g} / \mathrm{m}^{3}\right)$ \\
\hline & Tritium (air) $(\mathrm{e})$ & 30 & 32.3 & 1.67 & 1.0 & $-0.0513(\mathrm{~Bq} / \mathrm{L})$ \\
\hline Radiation dose & 90-day radiation dose & 29 & 2.48 & 1.02 & 0.96 & -0.248 (mrem) \\
\hline \multirow[t]{14}{*}{ Ground water } & Arsenic & 21 & 6.73 & 1.00 & 1.0 & $-3.65 \times 10^{-5}(\mathrm{mg} / \mathrm{L})$ \\
\hline & Barium & 13 & 2.32 & 0.992 & 1.0 & $0.00149(\mathrm{mg} / \mathrm{L})$ \\
\hline & Chromium(e) & 13 & 10.3 & 0.867 & 0.55 & 0.00129 (mg/L) \\
\hline & Copper & 9 & 8.44 & 0.916 & 0.99 & $6.26 \times 10^{-5}(\mathrm{mg} / \mathrm{L})$ \\
\hline & Gross alpha & 17 & 25.4 & 0.941 & 0.82 & $0.0219(\mathrm{~Bq} / \mathrm{L})$ \\
\hline & Gross beta $(\mathrm{e})$ & 19 & 31.7 & 0.818 & 0.026 & $0.174(\mathrm{~Bq} / \mathrm{L})$ \\
\hline & Nitrate (as $\mathrm{NO}_{3}$ ) & 20 & 1.91 & 1.08 & 0.98 & $-3.35(\mathrm{mg} / \mathrm{L})$ \\
\hline & Potassium & 23 & 5.66 & 0.941 & 0.99 & $0.168(\mathrm{mg} / \mathrm{L})$ \\
\hline & $\operatorname{TDS}^{(\mathrm{f})}$ & 9 & 1.54 & 0.946 & 0.99 & $42.0(\mathrm{mg} / \mathrm{L})$ \\
\hline & Tritium & 10 & 2.01 & 0.989 & 1.0 & $3.65(\mathrm{~Bq} / \mathrm{L})$ \\
\hline & Uranium-233+234(e) & 19 & 30.3 & 0.848 & 0.43 & $0.0289(\mathrm{~Bq} / \mathrm{L})$ \\
\hline & Uranium-238 & 19 & 25.4 & 0.896 & 0.91 & $0.00744(\mathrm{~Bq} / \mathrm{L})$ \\
\hline & Vanadium & 9 & 3.89 & 0.957 & 0.97 & 0.00201 (mg/L) \\
\hline & $\mathrm{pH}$ & 9 & 0.538 & 1.03 & 0.98 & -0.234 (pH units) \\
\hline \multirow[t]{2}{*}{ Sewer } & Gross alpha $(d)$ & 14 & 41.6 & 0.439 & 0.057 & $0.121(\mathrm{~Bq} / \mathrm{L})$ \\
\hline & Gross beta & 48 & 6.78 & 1.04 & 0.99 & $-0.0324(\mathrm{BqL})$ \\
\hline
\end{tabular}

a Number of duplicate pairs included in regression analysis.

b 75th percentile of percent relative standard deviation (\%RSD) where \%RSD $=\left(\frac{200}{\sqrt{2}}\right)\left(\frac{\left|x_{1}-x_{2}\right|}{x_{1}+x_{2}}\right)$ and $x_{1}$ and $x_{2}$ are the reported
concentrations of each routine-duplicate pair

c Coefficient of determination.

d Outside acceptable range of slope or $r^{2}$ due to variability.

e Outside acceptable range of slope or $r^{2}$ due to outliers.

f $\quad$ TDS $=$ Total dissolved solids. 


\section{Quality Assurance}

Table 14-2. Quality assurance duplicate sampling. Summary statistics for selected analytes with eight or fewer pairs in which both results were above the detection limit.

\begin{tabular}{|l|l|l|l|c|c|}
\hline \multicolumn{1}{|c|}{ Media } & \multicolumn{1}{|c|}{ Analyte } & N(a) & $\begin{array}{c}\text { Mean } \\
\text { ratio }\end{array}$ & $\begin{array}{c}\text { Minimum } \\
\text { ratio }\end{array}$ & $\begin{array}{c}\text { Maximum } \\
\text { ratio }\end{array}$ \\
\hline Air & Gross alpha & 3 & 0.99 & 0.87 & 1.1 \\
Ground water & Plutonium-238(b) & 2 & 0.64 & 0.32 & 0.96 \\
& Radium-226(b) & 7 & 1.4 & 1.2 & 2.1 \\
& Radium-228 & 5 & 0.87 & 0.071 & 1.3 \\
& Trichloroethene & 6 & 0.91 & 0.81 & 1.0 \\
Rain & Uranium-235+236(b) & 7 & 1.6 & 0.34 & 3.7 \\
Runoff (from rain) & Tritium & 1 & 1.1 & 1.1 & 1.1 \\
& Gross alpha & 4 & 1.1 & 0.61 & 1.8 \\
& Gross beta & 2 & 1.2 & 0.91 & 1.5 \\
Soil & Tritium & 2 & 0.95 & 0.90 & 0.99 \\
& Beryllium & 2 & 1.3 & 1.1 & 1.5 \\
& Cesium-137 & 4 & 1.3 & 0.90 & 1.8 \\
Sewer & Plutonium-239+240(b) & 3 & 2.0 & 1.1 & 3.7 \\
Vegetation & Tritium & 5 & 0.99 & 0.93 & 1.0 \\
\hline
\end{tabular}

a Number of data pairs.

b Outside acceptable range of $0.7-1.3$, for mean ratio.

Regression analysis consists of fitting a straight line to the collocated sample pairs. Good agreement is indicated when the data lie close to a line with slope equal to one and intercept equal to zero, as illustrated in Figure 14-1. Allowing for normal analytical variation, the slope of the fitted line should be between 0.7 and 1.3, and the absolute value of the intercept should be less than the detection limit. The coefficient of determination $\left(\mathrm{r}^{2}\right)$ should be $>0.8$. These criteria apply to pairs in which both results are above the detection limit.

If there were more than eight data pairs with both results considered detections, then precision and regression analyses were performed; the results are presented in Table 14-1. If there were eight or fewer data pairs with both results above the detection limit, the ratios of the individual duplicate sample pairs were averaged; the average, minimum, and maximum ratios for selected analytes are given in Table 14-2. The mean ratio should be between 0.7 and 1.3 . 
Table 14-3. Quality assurance duplicate sampling. Summary statistics for analytes with at least four pairs in which one or both results were below the detection limit.

\begin{tabular}{|c|c|c|c|c|}
\hline Medium & Analyte & $\begin{array}{c}\text { Number of } \\
\text { inconsistent } \\
\text { pairs }\end{array}$ & $\begin{array}{c}\text { Number } \\
\text { of } \\
\text { pairs }\end{array}$ & $\begin{array}{c}\text { Percent of } \\
\text { inconsistent } \\
\text { pairs }\end{array}$ \\
\hline Air & Tritium (air) & 1 & 16 & 6.3 \\
\hline \multirow[t]{7}{*}{ Ground water } & Barium & 1 & 13 & 7.7 \\
\hline & Beryllium & 1 & 25 & 4.0 \\
\hline & Chromium & 1 & 7 & 14.3 \\
\hline & Copper & 1 & 23 & 4.4 \\
\hline & Gross alpha & 2 & 7 & 28.6 \\
\hline & Lead & 1 & 26 & 3.9 \\
\hline & $\mathrm{U}-235+236$ & 1 & 12 & 8.3 \\
\hline \multirow[t]{2}{*}{ Runoff } & Carbonate alkalinity $\left(\mathrm{as} \mathrm{CaCO}_{3}\right)$ & 2 & 5 & 40 \\
\hline & Nitrite (as N) & 1 & 4 & 25 \\
\hline \multirow[t]{6}{*}{ Sewer } & Aluminum & 1 & 4 & 25 \\
\hline & Arsenic & 1 & 6 & 16.7 \\
\hline & Cadmium & 1 & 8 & 12.6 \\
\hline & Chromium & 1 & 4 & 25 \\
\hline & Gross alpha & 2 & 34 & 5.9 \\
\hline & Silver & 1 & 6 & 16.7 \\
\hline
\end{tabular}

If one of the results in a pair is a nondetection, then the other result should be less than two times the detection limit. Table 14-3 identifies the sample media and analytes for which at least one pair failed this criterion. Analytes with fewer than four pairs total are omitted from the table.

Collocated sample comparisons are more variable when the members of the pair are analyzed by different methods or with different criteria for analytical precision. For example, radiological analyses using different counting times will have different amounts of variability. 


\section{Quality Assurance}

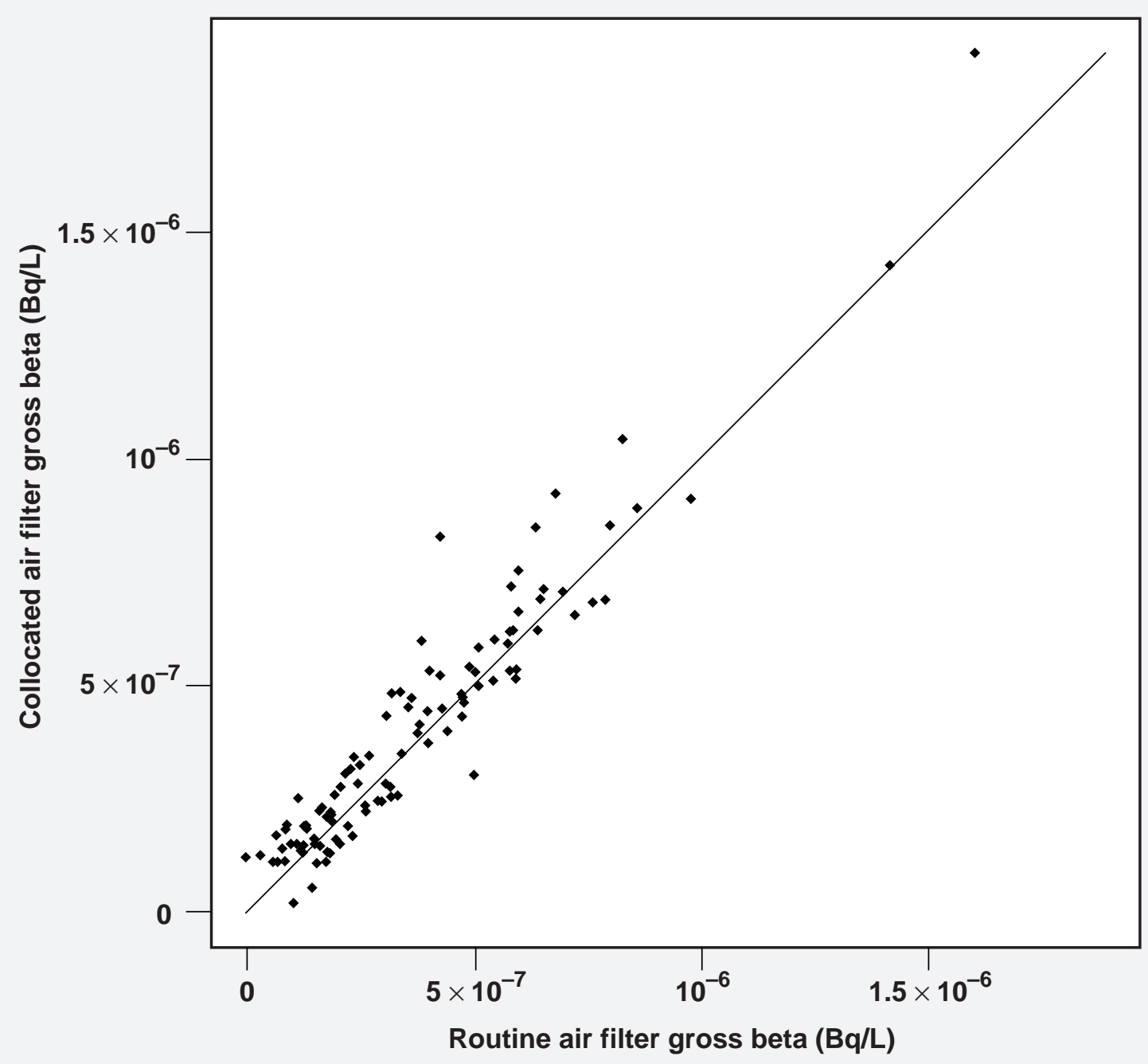

Figure 14-1. Air-filter gross beta concentrations from collocated samples. These data lie close to a line with slope equal to one and intercept equal to zero.

These analyses show generally good agreement between routine samples and quality assurance duplicates: approximately $90 \%$ of the pairs have a precision better than $30 \%$. Data sets not meeting our precision criteria generally fall into one of two categories. The first category, outliers, can occur because of data transcription errors, measurement errors, or real but anomalous results. Of 22 data sets reported in Table 14-1, 4 did not meet the criterion for acceptability because of outliers. Figure 14-2 illustrates a set of collocated pairs with two outliers. The other category of results that does not meet the criterion for acceptability consists of data sets in which there is a lot of scatter. This tends to be typical of nondetections and measurements at extremely low concentrations, 


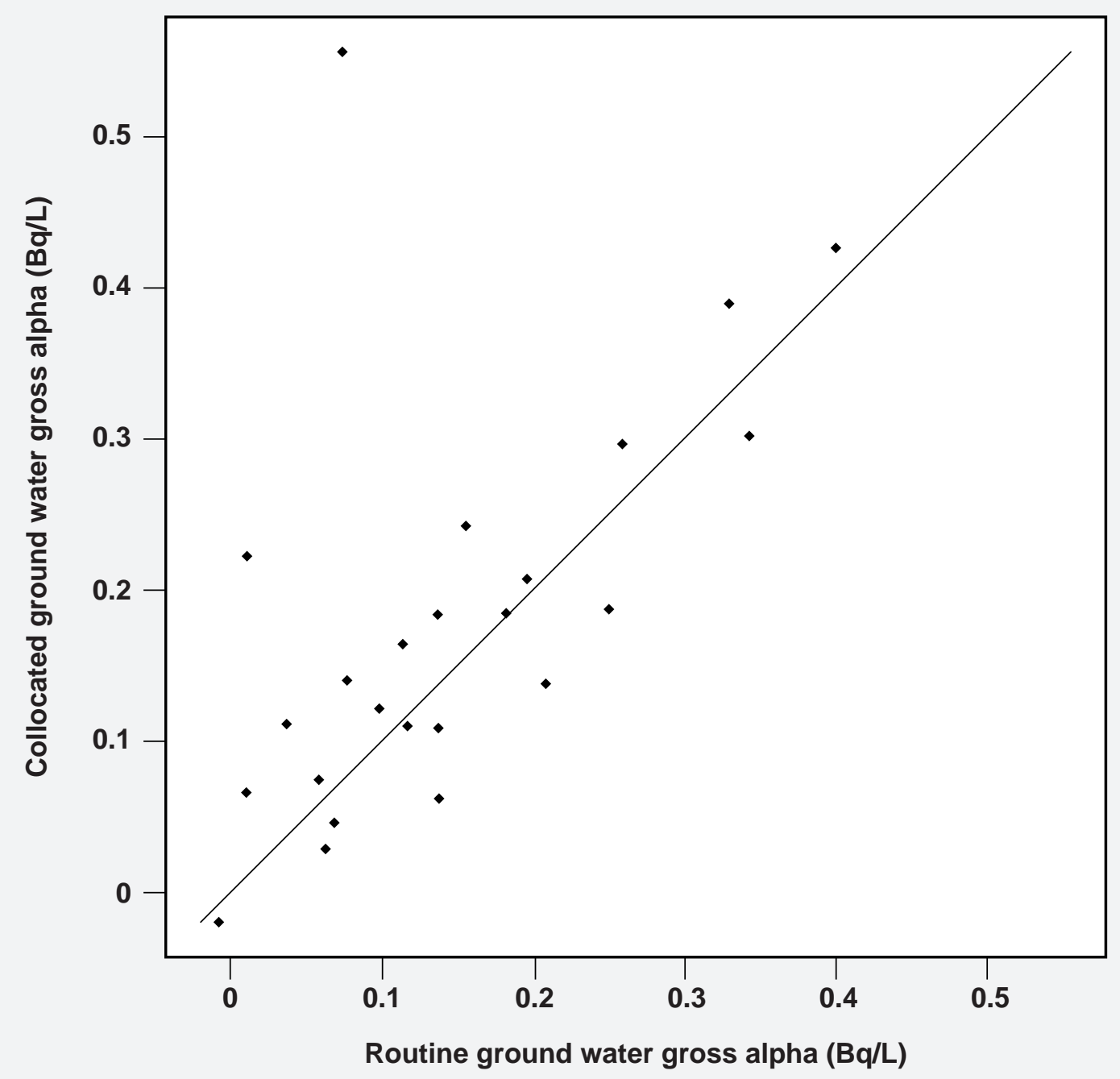

Figure 14-2. Ground water gross alpha concentrations from collocated samples showing two outliers.

as illustrated in Figure 14-3. Only three of the data pairs in Figure 14-3 are above the detection limit, which illustrates why the acceptability criteria apply only to pairs in which both results are detections.

Low concentrations of radionuclides on particulates in air highlight this effect even more because one or two radionuclide-containing particles on an air filter can significantly affect results. Another cause of high variability is sampling and analytical 


\section{Quality Assurance}

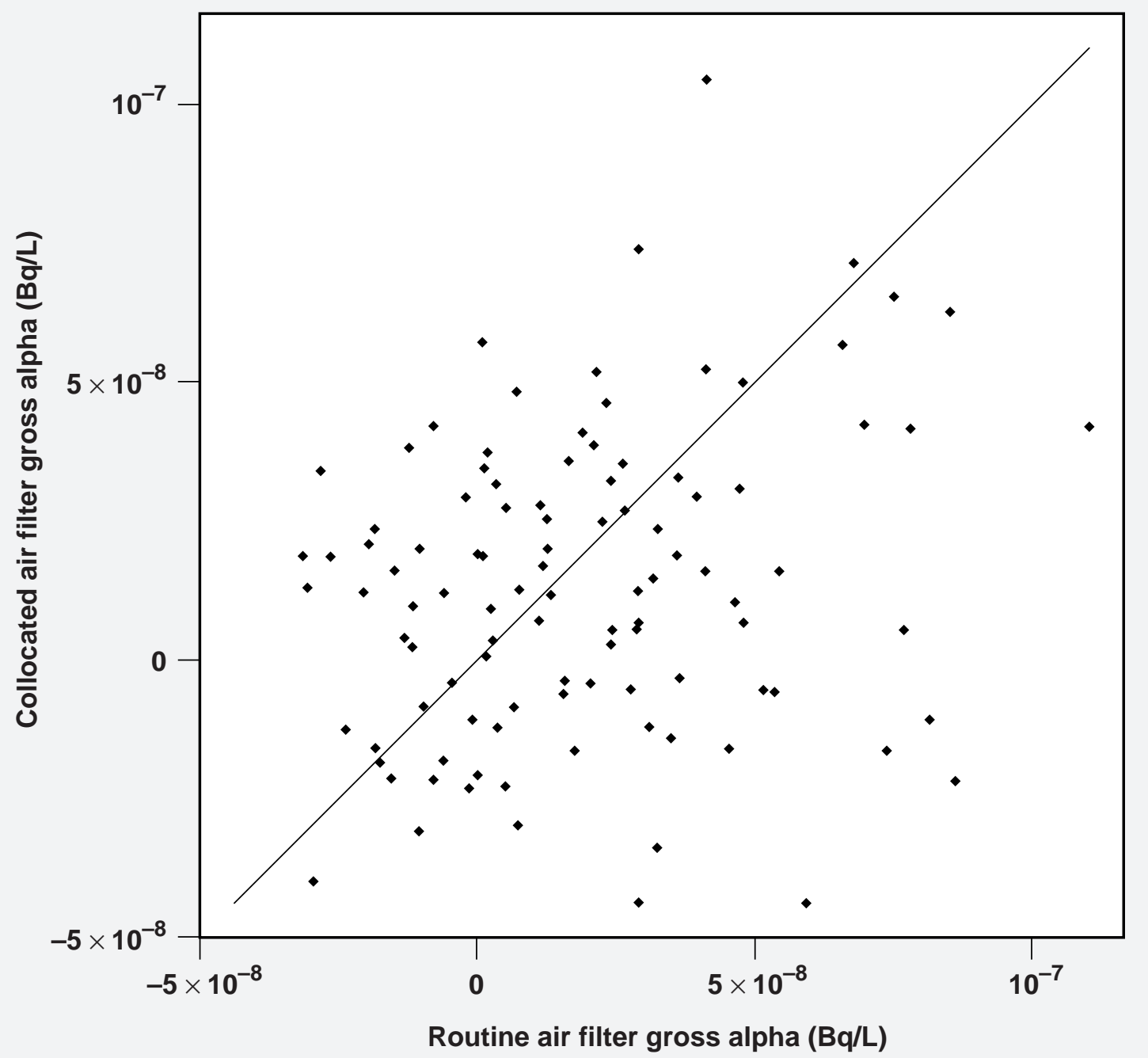

Figure 14-3. Air-filter gross alpha concentrations from collocated samples showing a lot of scatter.

methodology. Analyses of total organic carbon and total organic halides in water are particularly difficult to control. Of the 22 data sets in Table 14-1, 2 show sufficient variability in results to make them fall outside of the acceptable range.

\section{Deviations and Changes to the Sampling Program}

The sections that follow summarize changes to the environmental sampling effort made during 1998, deviations from planned environmental sampling, and omissions of data expected from regularly scheduled samples. 


\section{Changes to Environmental Monitoring Networks}

Changes that were made to environmental monitoring networks in 1998 are summarized in Table 14-4.

Table 14-4. Changes to environmental monitoring networks in 1998.

\begin{tabular}{|c|c|c|}
\hline Environmental medium & Livermore site & Site 300 \\
\hline Air particulate & Added location L-AMON, 3/98 & No changes \\
\hline Air tritium & Added location L-AMON, 3/98 & Added 3-PRIM \\
\hline Soil & No changes & No changes \\
\hline Arroyo sediment & No changes & No changes \\
\hline Vegetation & $\begin{array}{l}\text { Sampling frequency for locations L-PIN1 } \\
\text { and L-PIN2 changed from monthly to } \\
\text { quarterly }\end{array}$ & No changes \\
\hline Wine & No changes & Not applicable \\
\hline Rain & No changes & No changes \\
\hline Storm water runoff & Minor changes to requested analyses & $\begin{array}{l}\text { Minor changes to requesteo } \\
\text { analyses }\end{array}$ \\
\hline Drainage retention basin & $\begin{array}{l}\text { Minor changes to requested analyses; } \\
\text { added suite of samples for dry season } \\
\text { releases in second quarter } 1998\end{array}$ & Not applicable \\
\hline Other surface water & No changes & Not applicable \\
\hline Ground water & No changes & No changes \\
\hline Sewage & No changes & Not applicable \\
\hline WDR-248 networks & Not applicable & No changes \\
\hline $\begin{array}{l}\text { Thermoluminescent } \\
\text { dosimeters (TLDs) }\end{array}$ & No changes & No changes \\
\hline Cooling towers & Not applicable & No changes \\
\hline
\end{tabular}

\section{Sampling Completeness}

Planned samples and actual samples collected and analyzed in 1998 are summarized in Table 14-5. 


\section{Quality Assurance}

Table 14-5. Sampling completeness in 1998, Livermore site and Site 300.

\begin{tabular}{|c|c|c|c|c|}
\hline Environmental medium & $\begin{array}{l}\text { Number of } \\
\text { analyses } \\
\text { planned }\end{array}$ & $\begin{array}{l}\text { Number of } \\
\text { analyses } \\
\text { completed }\end{array}$ & $\begin{array}{c}\text { Completeness } \\
(\%)\end{array}$ & $\begin{array}{l}\text { Reason(s) for } \\
\text { lost samples }\end{array}$ \\
\hline \multicolumn{5}{|l|}{ Air particulate (Livermore) } \\
\hline Radiological parameters & 1300 & 1298 & 99.8 & $\begin{array}{l}\text { Equipment problems (1), sample } \\
\text { lost at laboratory (1) }\end{array}$ \\
\hline Beryllium & 96 & 95 & 99 & Sampler oversight (1) \\
\hline \multicolumn{5}{|l|}{ Air particulate (Site 300) } \\
\hline Radiological parameters & 592 & 586 & 99 & $\begin{array}{l}\text { Equipment problems (3), sample } \\
\text { lost at laboratory (1), access to } \\
\text { area denied (2) }\end{array}$ \\
\hline Beryllium & 72 & 71 & 99 & Sampler oversight (1) \\
\hline \multicolumn{5}{|l|}{ Air tritium } \\
\hline Livermore & 529 & 509 & 96 & $\begin{array}{l}\text { Equipment problems (16), flask } \\
\text { broke in transit (4) }\end{array}$ \\
\hline Site 300 & 26 & 24 & 92 & Equipment problems (2) \\
\hline \multicolumn{5}{|l|}{ Soil } \\
\hline Livermore & 42 & 42 & 100 & \\
\hline Site 300 & 32 & 32 & 100 & \\
\hline Arroyo sediment (Livermore only) & 54 & 48 & 89 & $\begin{array}{l}\text { Location inundated; could not } \\
\text { sample (6) }\end{array}$ \\
\hline \multicolumn{5}{|l|}{ Vegetation } \\
\hline Livermore & 68 & 67 & 99 & No vegetation (1) \\
\hline Site 300 & 32 & 32 & 100 & \\
\hline Wine & 22 & 22 & 100 & \\
\hline \multicolumn{5}{|l|}{ Rain } \\
\hline Livermore & 34 & 33 & 94 & Sample missing \\
\hline Site 300 & 8 & 6 & 75 & $\begin{array}{l}\text { Insufficient rainfall during sample } \\
\text { period (2) }\end{array}$ \\
\hline \multicolumn{5}{|l|}{ Storm water runoff } \\
\hline Livermore & 350 & 348 & 96 & $\begin{array}{l}\text { Sample not submitted for } \\
\text { analyses (1); sample lost at } \\
\text { laboratory (1) }\end{array}$ \\
\hline Site 300 & 264 & 153 & 58 & No flow at locations (111) \\
\hline \multicolumn{5}{|l|}{ Drainage Retention Basin } \\
\hline Field measurements & 874 & 809 & 93 & Sampler error (65) \\
\hline Samples & 126 & 119 & 94 & Sampler error (7) \\
\hline Releases & 35 & 35 & 100 & \\
\hline
\end{tabular}


Table 14-5. Sampling completeness in 1998, Livermore site and Site 300 (concluded).

\begin{tabular}{|c|c|c|c|c|}
\hline Environmental medium & $\begin{array}{l}\text { Number of } \\
\text { analyses } \\
\text { planned }\end{array}$ & $\begin{array}{l}\text { Number of } \\
\text { analyses } \\
\text { completed }\end{array}$ & $\begin{array}{c}\text { Completeness } \\
(\%)\end{array}$ & $\begin{array}{l}\text { Reason(s) for } \\
\text { lost samples }\end{array}$ \\
\hline Other surface water (Livermore only) & 58 & 58 & 100 & \\
\hline \multicolumn{5}{|l|}{ Ground water } \\
\hline Livermore & 662 & 662 & 100 & \\
\hline Site 300 & 2210 & 2138 & 96.7 & $\begin{array}{l}\text { Wells dry or inaccessible, } \\
\text { barcard inoperable (72) }\end{array}$ \\
\hline Livermore Valley wells & 27 & 24 & 88.9 & $\begin{array}{l}\text { Wells not in operation (2), } \\
\text { sampler error (1) }\end{array}$ \\
\hline \multicolumn{5}{|l|}{ Sewage } \\
\hline B196 & 910 & 908 & 99.8 & Sampler error (2) \\
\hline C196 & 376 & 372 & 99 & $\begin{array}{l}\text { Equipment error (2), sampler } \\
\text { error (2) }\end{array}$ \\
\hline LWRP effluent & 128 & 128 & 100 & \\
\hline Digester sludge & 80 & 78 & 98 & Lost during transport (2) \\
\hline \multicolumn{5}{|l|}{ WDR-96-248 } \\
\hline $\begin{array}{l}\text { Surface impoundment } \\
\text { wastewater }\end{array}$ & 78 & 78 & 100 & \\
\hline $\begin{array}{l}\text { Surface impoundment ground } \\
\text { water }\end{array}$ & 96 & 96 & 100 & \\
\hline Sewage ponds wastewater & 42 & 42 & 100 & \\
\hline $\begin{array}{l}\text { Sewage ponds ground water } \\
\text { Thermoluminescent dosimeters } \\
\text { (TLDs) }\end{array}$ & 72 & 72 & 100 & \\
\hline Livermore & 180 & 156 & 87 & Missing (24) \\
\hline Site 300 & 76 & 66 & 87 & Missing (10) \\
\hline Cooling towers (Site 300 only) & 24 & 24 & 100 & \\
\hline
\end{tabular}

\section{Statistical Methods}

Statistical methods used in this report have been implemented in accordance with the Environmental Monitoring Plan (Tate et al. 1995). These methods reduce the large volumes of monitoring data to summary estimates suitable for temporal and spatial comparisons. Attention is given to estimating accuracy, bias, and precision of all data. 
Data review and analyses are conducted in accordance with the Environmental Monitoring Plan and the Operations and Regulatory Affairs data analysis procedure. These documents contain detailed information regarding the acceptability of data and the procedures that are followed for the identification, notification, and correction of suspect data.

\section{Radiological Data}

The precision of radiological analytical results is displayed in the Data Supplement tables as the $2 \sigma$ counting uncertainty. The counting uncertainties are not used in summary statistic calculations. Any radiological result exhibiting a $2 \sigma$ counting uncertainty greater than or equal to $100 \%$ is considered to be a nondetection. The reported concentration is derived from the number of sample counts minus the number of background counts. A sample with a low concentration may, therefore, have a negative value; such results are reported in the tables and used in the calculation of summary statistics and statistical comparisons.

Some Data Supplement tables provide radioactivity sensitivity measurements instead of, or in addition to, a reported value when the radiological result is below the detection criterion. These measurements can be described as the smallest concentration of radioactive material that can be detected (distinguished from background) with some specified degree of confidence. These radioactivity sensitivity measurements are referred to as minimum detectable concentration (MDC) in Chapters 4 and 5, limit of sensitivity (LOS) in Chapter 6, and detection limit (DL) in Chapters 7 and 9. The Chemistry and Materials Science Environmental Services Laboratory (CES) calculates these three terms (MDC, LOS, and DL) in the same manner and reports them in units of $\mathrm{Bq} / \mathrm{kg}$ or $\mathrm{pCi} / \mathrm{g}$ or $\mathrm{Bq} / \mathrm{L}$ and $\mathrm{pCi} / \mathrm{L}$ depending on the sample matrix.

\section{Nonradiological Data}

Nonradiological data that are reported as being below the reporting limit also are displayed in the tables with a less-than symbol. The reporting limit values are used in the calculation of summary statistics as explained below. 


\section{Statistical Comparisons}

Standard comparison techniques (such as regression, $\mathrm{t}$-tests, and analysis of variance) have been used where appropriate to determine the statistical significance of trends or differences between means. All such tests of significance have been performed at the 0.05 level. When such a comparison is made, it is explicitly stated in the text as being "statistically significant" or "not statistically significant." Other uses of the word "significant" in the text do not imply that statistical tests have been performed. These uses instead relate to the concept of practical significance and are based on professional judgment.

\section{Summary Statistics}

Determinations of measures of central tendency and associated measures of dispersion are calculated according to the Environmental Monitoring Plan (Tate et al. 1995). For data sets not containing values below the detection criterion, the measures of central tendency and dispersion are the median and interquartile range (IQR). The IQR is the range that encompasses the middle $50 \%$ of the data set. Radiological data sets that include values less than zero may have an IQR greater than the median.

For data sets with one or more, but fewer than one half, values below the detection criterion, the measure of central tendency is the median. If the values of the detection limits and the number of values below the detection limit permit (determined on a caseby-case basis), dispersion is reported as the IQR. Otherwise, no measure of dispersion is reported. Statistics are calculated using the reported detection limit value for nonradiological data or the reported value for radiological data.

For data sets with one half or more of the values below the detection criterion, the central tendency is reported as less than the median value. Dispersion is not reported.

\section{Radiation Units}

Data for 1998 have been reported in Système Internationale (SI) units to conform with standard scientific practices and federal law. Values in the text are reported in becquerels $(\mathrm{Bq})$ and millisieverts $(\mathrm{mSv})$; equivalent values in picocuries $(\mathrm{pCi})$ and millirems (mrem) are given in parentheses. 


\section{Quality Assurance}

\section{Quality Assurance Process for the Environmental Report}

Unlike the preceding discussion, which focused on standards of accuracy and precision in data acquisition and reporting, a discussion of quality assurance/quality control procedures for a technical publication per se, must deal with how to retain content accuracy through the publication process. Because publication of a large, data-rich document like this site annual environmental report involves many operations and many people, the chances for introducing errors are great. At the same time, ensuring quality is more difficult because a publication is less amenable to the statistical processes used in standard quality assurance methods.

The QA procedure we used concentrated on the tables and figures in the report and enlisted 37 authors, contributors, and technicians to check the accuracy of sections other than those they had authored or contributed to. In 1998, the 91 illustrations and 77 tables in the main volume and the 108 tables in the Data Supplement were checked. Checkers were assigned illustrations and tables and given a copy of each item they were to check along with a quality control form to fill out as they checked the item. Items to be checked included figure captions and table titles for clarity and accuracy, data accuracy and completeness, figure labels and table headings, units, significant figures, and consistency with text. When checking numerical data, checkers randomly selected $10 \%$ of the data and compared it to values in the master database. If all $10 \%$ agreed with the database, further checking was considered unnecessary. If there was disagreement in the data, the checker compared another $10 \%$ of the data with the database values. If more errors were found, the checker had then to verify every piece of data in the table or illustration.

A coordinator guided the process to ensure that forms were tracked and the proper approvals were obtained. Completed quality control forms and the corrected illustrations or tables were returned to the report editors, who were responsible for ensuring that changes, with the agreement of the original contributor, were made. This quality assurance check resulted in nearly 250 data errors or omissions being corrected. Other corrections were made to footnotes, headings, titles in tables, and graph axes, callouts, and captions in figures. 


\title{
Appendix A. Methods of Dose Calculations
}

\author{
S. Ring Peterson
}

\section{Introduction}

Radiological doses calculated from measured activities are a principal indicator of the potential impact of LLNL operations on surrounding populations. The doses from ingestion of water and locally produced foodstuffs are based on actual measurements of radionuclide concentrations in the various media, determined by sampling, as described in Chapters 7 through 11. Data needed to evaluate potential doses from the inhalation pathways are provided by air surveillance monitoring, as described in Chapter 5.

The data on radionuclide concentrations or activities in these media are necessary inputs to the dose-rate equations described here. The examples presented below concern dose assessments for significant agricultural products of the Livermore Valley, including wine and general vegetation, and, in particular, describe the forage-cow-milk/meat pathway for ingestion of tritium. The rate equations can also be used to estimate doses that would occur from ingestion of water at each of the Livermore Valley and Site 300 water sampling locations, though none of these is actually a primary source of drinking water.

\section{Dose Calculation Methods}

The dose calculation methods given here for the ingestion and inhalation/skin absorption pathways for tritiated water (HTO) are based on the NRC Regulatory Guide 1.109, Calculation of Annual Doses to Man from Routine Releases of Reactor Effluents (U.S. Nuclear Regulatory Commission 1977). The dose and dose-rate conversion factors used in these calculations were obtained from the committed dose equivalent tables for DOE dose calculations (U.S. Department of Energy 1988) and are consistent with those specified in ICRP 30, Limits of Intakes of Radionuclides by Workers (International Commission on Radiological Protection [ICRP] 1980). The dose calculation for inhalation of tritiated hydrogen (HT) gas uses a dose-rate conversion factor from ICRP 68, Limits of Intakes of Radionuclides by Workers (ICRP, 1994). 
Although the analytical laboratories report concentrations in $\mathrm{pCi}$ and the $\mathrm{DOE}$ 's dose rate conversion factors have units of $\mathrm{mrem} / \mathrm{pCi}$, the trend in reporting is to use the units of the Système Internationale (SI) of becquerel $(\mathrm{Bq})$ for concentration and millisievert $(\mathrm{mSv})$ or microsievert $(\mu \mathrm{Sv})$ for dose.

$1 \mathrm{~Bq}=27 \mathrm{pCi}$

$1 \mathrm{mSv}=100 \mathrm{mrem} ; 1 \mu \mathrm{Sv}=0.1 \mathrm{mrem}$

All units have been converted to SI units in the following dose calculations.

The annual whole-body dose rate from ingestion of a particular food or drink is expressible as a product of three factors: the rate the food or drink is consumed (e.g., $\mathrm{kg} / \mathrm{y}$ ), the radionuclide concentration (e.g., Bq/ $\mathrm{kg}$ ) in the food or drink, and the dose rate conversion factor (e.g., $\mu \mathrm{Sv} / \mathrm{Bq}$ ) for the radionuclide. In the following subsections, equations of this type are used to estimate the annual dose from tritium in water and wine (directly consumed), from tritium ingested by humans via the forage-cow-milk pathway, and, more generally the annual dose from radionuclides in meat, and leafy vegetables. Similar formulas are given for the inhalation/skin absorption dose for HTO and inhalation dose for HT. Similar dose calculations for other radionuclides can be made using these equations with dose rate conversion factors specific to the radionuclide.

Generally, concentrations are measured, while appropriate consumption-rate factors are taken from the literature. The water and milk consumption rates are estimated to be $730 \mathrm{~L} / \mathrm{y}$ and $310 \mathrm{~L} / \mathrm{y}$, respectively, in Appendix E of the NRC Regulatory Guide 1.109 (U.S. Nuclear Regulatory Commission 1997). In the absence of consumption data on locally produced wine, we employ the conservative (high dose) assumption that the intake rate for wine is the same as that for water. The resultant dose is expected to be several times too high for wine but well below levels of health concern.

LLNL's first use of these dose-rate formulas in our environmental annual reports is described by Silver et al. (1980).

\section{Annual Dose from Potable Water}

Based on the assumption that all water sampled is available as drinking water, the annual whole-body dose for tritium in $\mu \mathrm{Sv} / \mathrm{y}$ is calculated using the following equation:

$D_{\text {whole body }}(\mu \mathrm{Sv} / \mathrm{y})=C_{\mathrm{w}} \times U_{\mathrm{w}} \times D_{\mathrm{w}}$ 
where

$$
\begin{aligned}
C_{\mathrm{w}}= & \text { concentration of tritium in water }(\mathrm{Bq} / \mathrm{L}) \\
U_{\mathrm{w}}= & \text { water consumption rate }(\mathrm{L} / \mathrm{y})=730 \mathrm{~L} / \mathrm{y} \text { for maximally exposed } \\
& \text { individual } \\
D_{\mathrm{w}}= & \text { dose conversion factor }(\mu \mathrm{Sv} / \mathrm{Bq}) \\
= & 1.73 \times 10^{-5} \mu \mathrm{Sv} / \mathrm{Bq}\left[6.4 \times 10^{-8} \mathrm{mrem} / \mathrm{pCi}\right] \text { for tritium for the whole- } \\
& \text { body ingestion pathway for an adult } \\
D_{\text {whole body }=} & \text { effective dose equivalent }(\mu \mathrm{Sv} / \mathrm{y}) \text { from ingestion of } 730 \mathrm{~L} \text { of potable } \\
& \text { water with tritium concentration } C_{\mathrm{w}} .
\end{aligned}
$$

This equation has been used to estimate maximum doses from drinking water from various locations (see Chapter 7). This equation can also be used to calculate effective dose equivalent from wine (see Chapter 11).

\section{Annual Dose from Food Ingestion}

The effective dose equivalent from ingestion of food is calculated by summing the contributions from leafy vegetables, milk and meat to the diet. The concentrations in these foodstuffs are based on measured tritium concentrations in annual grasses (see Chapter 11), and it is assumed that concentrations in leafy vegetables will be similar. Concentrations in milk and meat are calculated from measured concentrations in vegetation using the equations from the NRC Regulatory Guide, as mentioned.

Therefore

$D_{\text {whole body }}(\mu \mathrm{Sv} / \mathrm{y})=D_{\text {veg }}+D_{\text {meat }}+D_{\text {milk }}$

where

$$
\begin{aligned}
D_{\text {veg }} & =\mu \mathrm{Sv} / \mathrm{y} \text { dose from ingestion of leafy vegetables } \\
D_{\text {meat }} & =\mu \mathrm{Sv} / \mathrm{y} \text { dose from ingestion of meat } \\
D_{\text {milk }} & =\mu \mathrm{Sv} / \mathrm{y} \text { dose from ingestion of milk. }
\end{aligned}
$$

\section{Leafy Vegetation}

$$
D_{\text {veg }}(\mu \mathrm{Sv} / \mathrm{y})=U_{\text {veg }} \times C_{\text {veg }} \times D_{\text {HTO }}
$$


where

$$
\begin{aligned}
U_{\mathrm{veg}}= & \text { intake rate }(\mathrm{kg} / \mathrm{y}): 64 \mathrm{~kg} / \mathrm{y} \text { for maximally exposed individual } \\
C_{\mathrm{veg}}= & \text { concentration measured }(\mathrm{Bq} / \mathrm{kg}) \\
D_{\mathrm{HTO}}= & \text { dose factor }(\mu \mathrm{Sv} / \mathrm{Bq}): 1.73 \times 10^{-5} \mu \mathrm{Sv} / \mathrm{Bq}\left[6.4 \times 10^{-8} \mathrm{mrem} / \mathrm{pCi}\right] \\
& \text { for }{ }^{3} \mathrm{H} \text { for the adult whole-body ingestion pathway }
\end{aligned}
$$

The tritium dose from ingestion of vegetation is then

$$
\begin{aligned}
& D_{\text {veg }}(\mu \mathrm{Sv} / \mathrm{y})=64(\mathrm{~kg} / \mathrm{y}) \times 1.73 \times 10^{-5}(\mu \mathrm{Sv} / \mathrm{Bq}) \times C_{\text {veg }}(\mathrm{Bq} / \mathrm{L}) \\
& D_{\text {veg }}(\mu \mathrm{Sv} / \mathrm{y})=1.1 \times 10^{-3} \times C_{\text {veg }}(\mathrm{Bq} / \mathrm{L})
\end{aligned}
$$

Note: In this and some of the following equations, the dimensions associated with a multiplicative factor are not shown explicitly; the dimensions of the dependent variable and measured quantity are shown explicitly. For example, the above factor $1.1 \times 10^{-3}$ carries units of $\frac{(\mathrm{L} \cdot \mu \mathrm{Sv})}{(\mathrm{y} \bullet \mathrm{Bq})}$.

Also, for dose calculations, the conservative assumption is made that the plant is $100 \%$ water. Hence $\mathrm{Bq} / \mathrm{L}=\mathrm{Bq} / \mathrm{kg}$.

\section{Meat (beef)}

Based on the assumption that all feed for cattle was pasture grass and that cows drink water having the same tritium levels as water drunk by humans:

$D_{\text {meat }}(\mu \mathrm{Sv} / \mathrm{y})=U_{\text {meat }} \times C_{\text {meat }} \times D_{\text {HTO }}$

where

$$
\begin{aligned}
U_{\text {meat }}= & \text { intake rate }(\mathrm{kg} / \mathrm{y}): 110 \mathrm{~kg} / \mathrm{y} \text { for maximally exposed individual } \\
C_{\text {meat }}= & \text { predicted concentration in meat at time of consumption from the } \\
& \begin{array}{l}
\text { contribution of vegetation }\left(C_{\text {meat_veg }}\right) \text { and drinking water } \\
\end{array} \\
& \left(C_{\text {meat_w }}\right) \\
D_{\mathrm{HTO}}= & \text { dose factor }(\mu \mathrm{Sv} / \mathrm{Bq}): 1.73 \times 10^{-5} \mu \mathrm{Sv} / \mathrm{Bq}\left[6.4 \times 10^{-8} \mathrm{mrem} / \mathrm{pCi}\right] \\
& \text { for }{ }^{3} \mathrm{H} \text { for the adult whole-body ingestion pathway }
\end{aligned}
$$


and

$$
\begin{aligned}
C_{\text {meat_veg }} & =F_{\mathrm{f}}(\mathrm{d} / \mathrm{kg}) \times Q_{\mathrm{f}}(\mathrm{kg} / \mathrm{d}) \times C_{\text {veg }}(\mathrm{Bq} / \mathrm{kg}) \times \exp \left(-\lambda_{\mathrm{i}} t_{\mathrm{s}}\right) \\
C_{\text {meat_w }} & =F_{\mathrm{f}}(\mathrm{d} / \mathrm{kg}) \times \mathrm{Q}_{\mathrm{w}}(\mathrm{kg} / \mathrm{d}) \times C_{\mathrm{w}}(\mathrm{Bq} / \mathrm{kg}) \times \exp \left(-\lambda_{\mathrm{i}} t_{\mathrm{s}}\right)
\end{aligned}
$$

where

$$
\begin{aligned}
& F_{\mathrm{f}}= \text { average fraction of an animal's daily intake of radionuclide } \\
& \begin{array}{l}
\text { appearing in each kilogram of animal flesh }[(\mathrm{Bq} / \mathrm{kg}) \text { in meat per } \\
\end{array} \\
&(\mathrm{Bq} / \mathrm{d}) \text { ingested by the animal }](\mathrm{d} / \mathrm{kg}): 1.2 \times 10^{-2} \mathrm{~d} / \mathrm{kg} \\
& Q_{\mathrm{f}}= \text { amount of feed consumed }(\mathrm{kg} / \mathrm{d}): 50 \mathrm{~kg} / \mathrm{d} \\
& Q_{\mathrm{w}}= \text { amount of water consumed }(\mathrm{kg} / \mathrm{d}): 50 \mathrm{~L} / \mathrm{d}(1 \mathrm{~L}=1 \mathrm{~kg}) \\
& C_{\mathrm{veg}}= \text { concentration measured in vegetation }(\mathrm{Bq} / \mathrm{kg}) \\
& C_{\mathrm{W}}= \text { concentration measured in drinking water }(\mathrm{Bq} / \mathrm{L}) \\
& \lambda_{\mathrm{i}}= \text { radiological decay constant }\left(\mathrm{d}^{-1}\right): 1.5 \times 10^{-4} \mathrm{~d}^{-1} \\
& t_{\mathrm{s}}= \text { time between slaughter to consumption }(\mathrm{d}): 20 \mathrm{~d}
\end{aligned}
$$

Therefore

$$
\begin{aligned}
C_{\text {meat_veg }}= & 1.2 \times 10^{-2}(\mathrm{~d} / \mathrm{kg}) \times 50(\mathrm{~kg} / \mathrm{d}) \times C_{\text {veg }}(\mathrm{Bq} / \mathrm{kg}) \\
& \times \exp \left[\left(-1.5 \times 10^{-4}\right) \times(20)\right] \\
= & 0.6 \times C_{\text {veg }}(\mathrm{Bq} / \mathrm{L}) \\
C_{\text {meat_w }}= & 1.2 \times 10^{-2}(\mathrm{~d} / \mathrm{kg}) \times 50(\mathrm{~L} / \mathrm{d}) \times C_{\mathrm{w}}(\mathrm{Bq} / \mathrm{L}) \times \exp \left[\left(-1.5 \times 10^{-4)} \times(20)\right]\right. \\
= & 0.6 \times C_{\mathrm{w}}(\mathrm{Bq} / \mathrm{L})
\end{aligned}
$$

The tritium dose rate from meat consumption is then

$$
\begin{aligned}
D_{\text {meat }}(\mu \mathrm{Sv} / \mathrm{y})= & \left(110(\mathrm{~kg} / \mathrm{y}) \times\left[\left(0.6 \times \mathrm{C}_{\mathrm{veg}}(\mathrm{Bq} / \mathrm{kg})\right)+\left(0.6 \times \mathrm{C}_{\mathrm{w}}(\mathrm{Bq} / \mathrm{L})\right)\right]\right. \\
& \times 1.73 \times 10^{-5}(\mu \mathrm{Sv} / \mathrm{Bq}) \\
= & \left(1.1 \times 10^{-3} \times \mathrm{C}_{\text {veg }}(\mathrm{Bq} / \mathrm{L})\right)+\left(1.1 \times 10^{-3} \times \mathrm{C}_{\mathrm{w}}(\mathrm{Bq} / \mathrm{L})\right)
\end{aligned}
$$




\section{Cow Milk}

Based on the assumption that all feed for cattle was pasture grass and that cows drink water having the same tritium levels as water drunk by humans:

$D_{\text {milk }}(\mu \mathrm{Sv} / \mathrm{y})=U_{\text {milk }} \times C_{\text {milk }} \times D_{\mathrm{HTO}}$

where

$$
\begin{aligned}
& U_{\text {milk }}=\text { intake rate }(\mathrm{L} / \mathrm{y}): 310 \mathrm{~L} / \mathrm{y} \text { for maximally exposed individual } \\
& C_{\text {milk }}=\text { predicted concentration in milk at time of consumption from the } \\
& D_{\mathrm{HTO}}=\text { dose factor }(\mu \mathrm{Sv} / \mathrm{Bq}): 1.73 \times 10^{-5} \mu \mathrm{Sv} / \mathrm{Bq}\left[6.4 \times 10^{-8} \mathrm{mrem} / \mathrm{pCi}\right] \\
& \text { for }{ }^{3} \mathrm{H} \text { for the adult whole-body ingestion pathway }
\end{aligned}
$$

and

$$
\begin{aligned}
C_{\text {milk_veg }} & =F_{\mathrm{m}}(\mathrm{d} / \mathrm{L}) \times Q_{\mathrm{f}}(\mathrm{kg} / \mathrm{d}) \times C_{\text {veg }}(\mathrm{Bq} / \mathrm{kg}) \times \exp \left(-\lambda_{\mathrm{i}} t_{\mathrm{f}}\right) \\
C_{\text {milk_w }} & =F_{\mathrm{m}}(\mathrm{d} / \mathrm{L}) \times \mathrm{Q}_{\mathrm{w}}(\mathrm{L} / \mathrm{d}) \times C_{\mathrm{w}}(\mathrm{Bq} / \mathrm{L}) \times \exp \left(-\lambda_{\mathrm{i}} t_{\mathrm{f}}\right)
\end{aligned}
$$

where

$$
\begin{aligned}
F_{\mathrm{m}}= & \text { average fraction of an animal's daily intake of radionuclide } \\
& \text { appearing in each kilogram of milk }[(\mathrm{Bq} / \mathrm{L}) \text { in milk per }(\mathrm{Bq} / \mathrm{d}) \\
& \text { ingested by the animal] }(\mathrm{d} / \mathrm{L}): 1.0 \times 10^{-2} \mathrm{~d} / \mathrm{L} \\
Q_{\mathrm{f}}= & \text { amount of feed consumed by the animal }(\mathrm{kg} / \mathrm{d}): 50 \mathrm{~kg} / \mathrm{d} \\
Q_{\mathrm{w}}= & \text { amount of water consumed by the animal }(\mathrm{kg} / \mathrm{d}): 60 \mathrm{~L} / \mathrm{d}(1 \mathrm{~L}=1 \\
& \mathrm{kg}) \\
C_{\mathrm{veg}}= & \text { concentration measured in vegetation }(\mathrm{Bq} / \mathrm{kg}) \\
C_{\mathrm{w}}= & \text { concentration measured in drinking water }(\mathrm{Bq} / \mathrm{L}) \\
\lambda_{\mathrm{i}}= & \text { radiological decay constant }\left(\mathrm{d}^{-1}\right): 1.5 \times 10^{-4} \mathrm{~d}^{-1} \\
t_{\mathrm{f}}= & \text { time from milking to milk consumption }(\mathrm{d}): 2 \mathrm{~d}
\end{aligned}
$$


Therefore

$$
\begin{aligned}
C_{\text {milk_veg }}= & 1.0 \times 10^{-2}(\mathrm{~d} / \mathrm{L}) \times 50(\mathrm{~kg} / \mathrm{d}) \times C_{\text {veg }}(\mathrm{Bq} / \mathrm{kg}) \\
& \times \exp \left[\left(-1.5 \times 10^{-4}\right) \times(2)\right] \\
= & 0.5 \times C_{\text {veg }}(\mathrm{Bq} / \mathrm{L}) \\
C_{\text {milk_w }}= & 1.0 \times 10^{-2}(\mathrm{~d} / \mathrm{L}) \times 60(\mathrm{~L} / \mathrm{d}) \times C_{\mathrm{W}}(\mathrm{Bq} / \mathrm{L}) \times \exp \left[\left(-1.5 \times 10^{-4}\right) \times(2)\right] \\
= & 0.6 \times C_{\mathrm{w}}(\mathrm{Bq} / \mathrm{L})
\end{aligned}
$$

The tritium dose rate from directly consumed milk is then

$$
\begin{aligned}
\mathrm{D}_{\text {milk }}(\mu \mathrm{Sv} / \mathrm{y})= & 310(\mathrm{~L} / \mathrm{y}) \times\left[\left(0.5 \times \mathrm{C}_{\mathrm{veg}}(\mathrm{Bq} / \mathrm{kg})\right)+\left(0.6 \times \mathrm{C}_{\mathrm{w}}(\mathrm{Bq} / \mathrm{L})\right)\right] \\
& \times 1.73 \times 10^{-5}(\mu \mathrm{Sv} / \mathrm{Bq}) \\
= & 2.6 \times 10^{-3} \times \mathrm{C}_{\mathrm{veg}}(\mathrm{Bq} / \mathrm{L})+3.2 \times 10^{-3} \times \mathrm{C}_{\mathrm{w}}(\mathrm{Bq} / \mathrm{L})
\end{aligned}
$$

\section{Whole Body}

$$
\begin{aligned}
& D_{\text {whole body }}(\mu \mathrm{Sv} / \mathrm{y})=\left(1.1 \times 10^{-3} \times C_{\mathrm{veg}}(\mathrm{Bq} / \mathrm{kg})\right) \quad(\text { dose from leafy vegetables }) \\
& \left.\left.\begin{array}{l}
+\left(1.1 \times 10^{-3} \times C_{\mathrm{veg}}(\mathrm{Bq} / \mathrm{kg}]\right) \\
+\left(1.1 \times 10^{-3} \times C_{\mathrm{w}}(\mathrm{Bq} / \mathrm{L})\right)
\end{array}\right\} \text { (dose from meat }\right) \\
& \left.\begin{array}{l}
+\left(2.6 \times 10^{-3} \times C_{\mathrm{veg}}(\mathrm{Bq} / \mathrm{kg})\right) \\
+\left(3.2 \times 10^{-3} \times C_{\mathrm{w}}(\mathrm{Bq} / \mathrm{L})\right)
\end{array}\right\} \text { (dose from milk) }
\end{aligned}
$$

The total annual dose rate from the injestion pathway for tritium (measured tritium in vegetation and drinking water) and water is then

$D_{\text {whole body }}(\mu \mathrm{Sv} / \mathrm{y})=\left(4.8 \times 10^{-3} \times C_{\text {veg }}(\mathrm{Bq} / \mathrm{Kg})+\left(5.4 \times 10^{-3} \times C_{\mathrm{w}}(\mathrm{Bq} / \mathrm{L})\right)\right.$ 


\section{Inhalation and Skin Absorption Doses}

Doses due to inhalation of radionuclide-contaminated air can be estimated in an analogous way to the preceding treatment of ingestion doses. The starting point is to evaluate the radionuclide concentration in air, $\chi\left(\mathrm{Bq} / \mathrm{m}^{3}\right)$ at the location of interest. Measurements of tritium in air are found in the chapter on air monitoring (Chapter 5).

The dose from HTO arises from the processes of inhalation and skin absorption. For inhalation/skin absorption dose, once the concentration of tritium in air is known, it is multiplied by the inhalation rate of a human to obtain the number of bequerels of tritium inhaled. Dose and dose-rate conversion factors provided by the DOE (U.S. Department of Energy 1988), which are consistent with those specified in ICRP 30 (International Commission on Radiological Protection 1980), are used to relate the intake of radioactive material into the body to dose commitment. The dose-rate conversion factor for inhalation is the same as for ingestion. However, to account for skin absorption, the inhalation factor is multiplied by 1.5. These dose factors provide estimates of 50-year dose from a one-year intake of radioactivity.

The inhalation/skin absorption dose is expressible as

$D_{\text {whole body }}(\mu \mathrm{Sv} / \mathrm{y})=U_{\text {air }} \times C_{\text {air }} \times D_{\text {HTO_inh } / \text { abs }}$

where

$$
\begin{aligned}
U_{\text {air }}= & \text { air intake rate }\left(\mathrm{m}^{3} / \mathrm{y}\right): 8400 \mathrm{~m}^{3} / \mathrm{y} \text { for an adult } \\
C_{\text {air }}= & \text { radionuclide concentration measured in air at the receptor } \\
& \left(\mathrm{Bq} / \mathrm{m}^{3}\right) \\
D_{\mathrm{HTO} \_ \text {inh } / \text { abs }}= & \text { dose conversion factor }(\mu \mathrm{Sv} / \mathrm{Bq}): 1.5 \times 1.73 \times 10^{-5} \mu \mathrm{Sv} / \mathrm{Bq} \\
= & 2.6 \times 10^{-5} \mu \mathrm{Sv} / \mathrm{Bq}\left[1.5 \times 6.4 \times 10^{-8} \mathrm{mrem} / \mathrm{pCi}\right. \\
= & \left.9.6 \times 10^{-8} \mathrm{mrem} / \mathrm{pCi}\right] \text { for the adult whole body inhalation } / \mathrm{skin} \\
& \text { absorption pathway }
\end{aligned}
$$

The whole body inhalation dose rate from HTO is then

$D_{\text {whole body }}(\mu \mathrm{Sv} / \mathrm{y})=0.22 \times \mathrm{C}_{\text {air }}\left(\mathrm{Bq} / \mathrm{m}^{3}\right)$

For tritium gas (HT) an inhalation dose is similarly expressible as

$D_{\text {whole body }}(\mu \mathrm{Sv} / \mathrm{y})=C_{\text {air_HT }} \times U_{\text {air_HT }} \times D_{\text {HT }}$ 
where

$$
\begin{aligned}
C_{\text {air_HT }}= & \text { concentration of HT in air at location } X ; \text { estimated by dispersion } \\
& \text { modeling }\left(\mathrm{Bq} / \mathrm{m}^{3}\right) \\
U_{\text {air }}= & \text { air intake rate }\left(\mathrm{m}^{3} / \mathrm{y}\right): 8400 \mathrm{~m}^{3} / \mathrm{y} \text { for an adult } \\
D_{\mathrm{HT}}= & \text { effective dose per unit intake: } 1.8 \times 10^{-9} \mu \mathrm{Sv} / \mathrm{Bq}(\text { ICRP } 1994)
\end{aligned}
$$

The whole body inhalation dose rate from HT is then

$D_{\text {whole body }}(\mu \mathrm{Sv} / \mathrm{y})=1.5 \times 10^{-5} \times C_{\text {air_HT }}\left(\mathrm{Bq} / \mathrm{m}^{3}\right)$

In the recent past, HT doses were treated as immersion doses (Eckermann and Ryman 1993), since HT has a low-energy $\beta$ particle and behaves similarly to ${ }^{41} \mathrm{Ar}$. However, the dose from HT is dominated by the small fraction which is taken to be metabolized. HT is therefore treated presently as a soluble gas, and an inhalation dose is calculated.

\section{Comparison of Model Predictions}

As has been shown, there are different ways to model doses from tritium. In CAP88 PC, doses are based on air concentrations calculated from dispersion of annual releases to the atmosphere. The transfer of tritium from air concentration to dose is based on assumptions within the code that cannot be altered by the user (e.g., absolute humidity, quantities of food consumed), although the user can select the fractions of each food type that are contaminated. In this appendix, equations have been shown which calculate dose from measured (or predicted) air concentrations using a different set of assumptions than are used in CAP88-PC. The assumptions set forth here are based on maximum, rather than average, consumption rates and should assure that the dose predicted is greatly in excess of any that could possibly be received. The total dose from HTO predicted using CAP88-PC is a factor of three times higher than the dose predicted using the equations shown here.

There is a great deal of uncertainty associated with doses predicted by simulation models. Because the health of people is at stake, the models err on the side of overestimating doses. One way to reduce the uncertainty and increase the accuracy of model predictions is to use environmental monitoring data whenever possible. Because of the comprehensive monitoring program at LLNL, reliable concentration data for air, vegetation and water can be used in models to improve dose predictions.

Concentrations of tritium in air (Chapter 5) are monitored at 11 on-site locations, including the Visitor's Center (VIS), which is a convenient location for comparing doses from different modeling approaches. The measured median air concentration (HTO) 


\section{Appendix A. Methods of Dose Calculations}

at the Visitor's Center for 1998 was $0.0914 \mathrm{~Bq} / \mathrm{m}^{3}$, which is only $30 \%$ of $\mathrm{HTO}$ at VIS $\left(0.301 \mathrm{~Bq} / \mathrm{m}^{3}\right)$. Also measured at VIS are vegetation (median value $\left.6.5 \mathrm{~Bq} / \mathrm{L}\right)($ Chapter 11 ) and rainwater $(5.365 \mathrm{~Bq} / \mathrm{L})$ (Chapter 7$)$. Measured concentrations in vegetation can be used, as shown, to estimate tritium intake from vegetables by people and from pasture vegetation by animals. A conservative assumption can be made that rainwater is consumed as drinking water, which will result in a much higher estimated dose than could ever be achieved by drinking local tap water. Wine from the Livermore Valley is also measured and for 1998 had a median concentration of $2.75 \mathrm{~Bq} / \mathrm{L}$ (Chapter 11). Consumption of tritiated rainwater gives the highest (i.e., most conservative) dose estimate.

In Chapter 13, the dose to the SW-MEI from releases of tritiated water (HTO) from the Tritium Facility is calculated as $0.23 \mu \mathrm{Sv} / \mathrm{y}$ using CAP88-PC, and the dose to the SW-MEI from all sources of tritium at the Livermore site is similarly calculated to be $0.46 \mu \mathrm{Sv} / \mathrm{y}$. Doses from HTO released from the Tritium Facility and all Livermore site sources (also calculated with CAP88-PC) at the nearby Visitor's Center are 0.21 and $0.44 \mu \mathrm{Sv} / \mathrm{y}$ respectively. The dose calculated using the equations and assumptions in this appendix is $0.145 \mu \mathrm{Sv} / \mathrm{y}$, less than a third of the dose calculated by CAP88-PC.

The assumptions behind both CAP88-PC and NRC Regulatory Guide 1.109 are extremely conservative and different from each other. They are chosen so that a predicted dose will be far in excess of what is likely to be received. In our example, both models assume the person lives at VIS $100 \%$ of the time. For LLNL calculations, CAP88-PC assumes that $100 \%$ of the vegetables and meat in the diet are grown at the site; for our comparison, the NRC Regulatory Guide 1-109 assumes that 100\% of leafy vegetables, milk, and meat (beef) are grown there. CAP88-PC, being a model for atmospheric releases only, does not calculate concentrations in water, so the drinking water pathway is ignored. Drinking water can be included in Regulatory Guide 1-109.

Doses calculated by CAP88-PC for both predicted $\left(0.3013 \mathrm{~Bq} / \mathrm{m}^{3}\right)$ and observed $\left(0.0914 \mathrm{~Bq} / \mathrm{m}^{3}\right)$ air concentrations are compared in Table A-1 with doses calculated using the NRC equations and observed air concentrations. The CAP88-PC predictions for observed air concentrations result from multiplying predicted dose rates by the ratio of observed to predicted air concentrations (0.303). Line 1 of Table A-1 compares inhalation dose rates. Line 2 compares predictions when milk is not included in the diet (as in CAP88-PC) and animals drink uncontaminated water. Since CAP88-PC assumes all vegetables consumed contain tritium and the Regulatory Guide assumes only leafy vegetables contain tritium, the numbers in brackets have been added to show what would be predicted by the Regulatory Guide if all vegetables consumed contained tritium. Similarly, line 3 compares predictions when the assumed diets include 


\section{Appendix A. Methods of Dose Calculations}

Table A-1. Comparison of hypothetical annual doses from HTO at the Visitor's Center.

\begin{tabular}{|c|c|c|c|c|}
\hline & Doses in $\mu$ Sv/y & $\begin{array}{c}\text { CAP88-PC } \\
\text { predicted air } \\
\text { concentrations }\end{array}$ & $\begin{array}{c}\text { CAP88-PC } \\
\text { observed air } \\
\text { concentrations }\end{array}$ & $\begin{array}{c}\text { NRC RG } 1.109 \\
\text { observed air } \\
\text { concentrations }\end{array}$ \\
\hline 1 & Inhalation & 0.0826 & 0.0251 & 0.0190 \\
\hline 2 & $\begin{array}{l}\text { Food ingestion - } \\
\text { (no milk) }\end{array}$ & 0.360 & 0.109 & $\begin{array}{l}0.0142 \\
{[0.0722]}\end{array}$ \\
\hline 3 & Food ingestion & 0.521 & 0.158 & $\begin{array}{l}0.0312 \\
{[0.0892]}\end{array}$ \\
\hline 4 & $\begin{array}{l}\text { Food ingestion - } \\
\text { Animal water ingestion }\end{array}$ & Not Calculated & Not Calculated & $\begin{array}{l}0.0542 \\
{[0.112]}\end{array}$ \\
\hline 5 & Drinking water ingestion & Not Calculated & Not Calculated & 0.0677 \\
\hline 6 & Comparison \#1 & 0.442 & 0.134 & 0.145 \\
\hline 7 & Comparison \#2 & 0.604 & 0.183 & {$[0.199]$} \\
\hline
\end{tabular}

vegetables, milk and beef. Results in line 4 show the considerable effect on dose of animals consuming drinking water with the same tritium concentration as rainwater at the Visitor's Center. Drinking water dose for humans is shown in line 5. Line 6 compares dose predictions from the two models based on the assumptions used in each model, and line 7 compares doses based on assumptions that all vegetables, milk and meat in the diets contain tritium.

Table A-1 shows that dose depends strongly on assumptions in the model. The Regulatory Guide's dose $(0.145 \mu \mathrm{Sv} / \mathrm{y})$ is known to be much higher than would be expected because of the maximum ingestion rates used $(730 \mathrm{~L}$ per year drinking water, $64 \mathrm{~kg}$ leafy vegetables, $310 \mathrm{~L}$ milk and $110 \mathrm{~kg}$ of meat consumed). Average consumption rates (370 L drinking water, $21 \mathrm{~kg}$ leafy vegetables \{estimated\}, $110 \mathrm{~L}$ milk and $95 \mathrm{~kg}$ meat \{beef\}) recommended by the Regulatory Guide will produce lower doses. The dose from the drinking water pathway, totally neglected in CAP88-PC, can be significant depending on tritium concentrations in drinking water. All of the dose estimates for HTO shown in Table A-1 are high because of unreasonable assumptions. The Visitor's Center is not a subsistence farm, nor does anyone live there. Realistically, the assumptions used in these calculations can only be applied to someone living at a location where the majority of that person's diet is grown and consumed, in which case the dose would be lower (probably significantly) since no such locations are near the perimeter of LLNL.

A small contribution to dose will arise from air concentrations of tritium gas, HT. The concentration of HT in air is not measured at VIS, but using release rates from the Tritium Facility and the dispersion model in CAP88-PC, a concentration of $0.041 \mathrm{~Bq} / \mathrm{m}^{3}$ is calculated. From this an insignificant inhalation dose from HT of $6.2 \times 10^{-7} \mu \mathrm{Sv} / \mathrm{y}$ is calculated. 



\section{Appendix B. Reports for Regulatory Agencies}

\begin{tabular}{|c|c|c|}
\hline Title & Agency & Frequency \\
\hline AB2588 Emissions Report & $\begin{array}{l}\text { Bay Area Air Quality Management District } \\
\text { San Joaquin Valley Unified Air Pollution Control } \\
\text { District }\end{array}$ & Biennial \\
\hline $\begin{array}{l}\text { Air Emission Permit Renewals and Emissions } \\
\text { Report }\end{array}$ & $\begin{array}{l}\text { Bay Area Air Quality Management District } \\
\text { San Joaquin Valley Unified Air Pollution Control } \\
\text { District }\end{array}$ & Yearly \\
\hline Quarterly Solvent Usage & Bay Area Air Quality Management District & Quarterly \\
\hline Recycling Unit Contingency/Business Plans & Department of Toxic Substances Control & As required \\
\hline Conditional Exemption Unit Contingency Plans & Department of Toxic Substances Control & As required \\
\hline PCB Annual Report & Environmental Protection Agency & Yearly \\
\hline Medical Waste Permit & $\begin{array}{l}\text { Alameda County Emergency Health Services and } \\
\text { Department of Public Health Services, San Joaquin } \\
\text { County }\end{array}$ & As required \\
\hline $\begin{array}{l}\text { Explosive Waste Treatment Facility_Site } 300 \\
\text { Permit }\end{array}$ & Department of Toxic Substances Control & Every 10 years \\
\hline $\begin{array}{l}\text { Main Site Part A\&B Hazardous Waste Permit } \\
\text { Application (includes contingency plans and } \\
\text { closure plans) }\end{array}$ & Department of Toxic Substances Control & As required \\
\hline $\begin{array}{l}\text { Site } 300 \text { Container Storage Area (B883) and } \\
\text { Explosive Waste Storage Facility Permit }\end{array}$ & Department of Toxic Substances Control & Every 10 years \\
\hline Cultural Resource Management Plan & $\begin{array}{l}\text { Department of Energy } \\
\text { California State Historic Preservation Officer }\end{array}$ & As required \\
\hline $\begin{array}{l}\text { RCRA Section } 3016 \text { Report, Inventory of Federal } \\
\text { Agency Hazardous Waste Facilities }\end{array}$ & $\begin{array}{l}\text { Department of Energy } \\
\text { Environmental Protection Agency }\end{array}$ & As required \\
\hline $\begin{array}{l}\text { Less-than-90-Day Waste Accumulation Area } \\
\text { Contingency Plans }\end{array}$ & Department of Toxic Substances Control & As required \\
\hline SB14 Documentation Plan & Department of Toxic Substance Control & Every 4 years \\
\hline Ozone Depleting Chemicals Phase Out Report & $\begin{array}{l}\text { Department of Energy } \\
\text { Environmental Protection Agency }\end{array}$ & Upon request \\
\hline DOE Annual Waste Minimization Report & Department of Energy & Yearly \\
\hline
\end{tabular}




\section{Appendix B. Reports for Regulatory Agencies}

\begin{tabular}{|c|c|c|}
\hline Title & Agency & Frequency \\
\hline Waste Minimization Certification for Site 300 & Department of Toxic Substances Control & Yearly \\
\hline Monthly NEPA Report & Department of Energy under NEPA & Monthly \\
\hline $\begin{array}{l}\text { NEPA Reviews, Proposed LLNL/Department of } \\
\text { Energy Projects }\end{array}$ & Department of Energy & As required \\
\hline $\begin{array}{l}\text { CEQA Review for Department of Energy/UC } \\
\text { Contract Renewal }\end{array}$ & University of California & As required \\
\hline CEQA Reviews, Proposed LLNL/UC Projects & University of California & As required \\
\hline $\begin{array}{l}\text { Spill Prevention Control and Countermeasures } \\
\text { Plans (Livermore Site and Site 300) Plan }\end{array}$ & $\begin{array}{l}\text { Environmental Protection Agency } \\
\text { San Francisco Bay Regional Water Quality Control } \\
\text { Board } \\
\text { Central Valley Regional Water Quality Control } \\
\text { Board }\end{array}$ & $\begin{array}{l}\text { Every } 3 \text { years } \\
\text { or when there } \\
\text { are significant } \\
\text { changes }\end{array}$ \\
\hline $\begin{array}{l}\text { Closure Plans for any hazardous waste/product } \\
\text { underground storage tanks (UST) removed from } \\
\text { service }\end{array}$ & $\begin{array}{l}\text { Alameda County Emergency Health Services or } \\
\text { Department of Public Health Services, San Joaquin } \\
\text { County }\end{array}$ & As required \\
\hline $\begin{array}{l}\text { Closure Report for any hazardous waste/product } \\
\text { UST removed from service }\end{array}$ & $\begin{array}{l}\text { Alameda County Emergency Health Services or } \\
\text { Department of Public Health Services, San Joaquin } \\
\text { County }\end{array}$ & As required \\
\hline $\begin{array}{l}\text { Monitoring Program for any hazardous waste/ } \\
\text { product UST (underground storage tank) removed } \\
\text { from service }\end{array}$ & $\begin{array}{l}\text { Alameda County Emergency Health Services or } \\
\text { Department of Public Health Services, San Joaquin } \\
\text { County }\end{array}$ & As required \\
\hline $\begin{array}{l}\text { Closure Reports for greater than 90-day hazardous } \\
\text { waste AST (aboveground storage tank) operated } \\
\text { under Interim Status or a Permit and removed from } \\
\text { service }\end{array}$ & Department of Toxic Substances Control & As required \\
\hline $\begin{array}{l}\text { Engineering Assessments for RCRA hazardous } \\
\text { waste tanks }\end{array}$ & Environmental Protection Agency & As required \\
\hline $\begin{array}{l}\text { Installation Plans for new hazardous waste/product } \\
\text { UST }\end{array}$ & $\begin{array}{l}\text { Alameda County Emergency Health Services or } \\
\text { Department of Public Health Services, San Joaquin } \\
\text { County }\end{array}$ & As required \\
\hline Hazardous Waste/Product UST Operating Permit & $\begin{array}{l}\text { Alameda County Emergency Health Services or } \\
\text { Department of Public Health Services, San Joaquin } \\
\text { County }\end{array}$ & Yearly \\
\hline $\begin{array}{l}\text { Less-than-90-Day Hazardous Waste Tank } \\
\text { Contingency Plans (for Permitted Underground } \\
\text { Tank Systems at Livermore Site) }\end{array}$ & Department of Toxic Substances Control & As required \\
\hline Tank Operating Plans & $\begin{array}{l}\text { Alameda County Emergency Health Services or } \\
\text { Department of Public Health Services, San Joaquin } \\
\text { County }\end{array}$ & As required \\
\hline $\begin{array}{l}\text { Tank Monitoring Program for Hazardous Waste } \\
\text { UST }\end{array}$ & $\begin{array}{l}\text { Alameda County Emergency Health Services or } \\
\text { Department of Public Health Services, San Joaquin } \\
\text { County }\end{array}$ & $\begin{array}{l}\text { Prior to new } \\
\text { tank use }\end{array}$ \\
\hline
\end{tabular}




\section{Appendix B. Reports for Regulatory Agencies}

\begin{tabular}{|c|c|c|}
\hline Title & Agency & Frequency \\
\hline Tank Modification/Approval Plan & $\begin{array}{l}\text { Alameda County Emergency Health Services or } \\
\text { Department of Public Health Services, San Joaquin } \\
\text { County }\end{array}$ & As required \\
\hline Monthly Sewer Monitoring Report & Livermore Water Reclamation Plant & Monthly \\
\hline $\begin{array}{l}\text { Site } 300 \text { Pit } 1 \text { and } 7 \text { Compliance Monitoring } \\
\text { Reports }\end{array}$ & $\begin{array}{l}\text { Central Valley Regional Water Quality Control } \\
\text { Board } \\
\text { Environmental Protection Agency } \\
\text { Department of Toxic Substances Control }\end{array}$ & $\begin{array}{c}\text { Quarterly and } \\
\text { yearly }\end{array}$ \\
\hline $\begin{array}{l}\text { Site } 300 \text { Quarterly Cooling Tower Discharge } \\
\text { Report }\end{array}$ & $\begin{array}{l}\text { Central Valley Regional Water Quality Control } \\
\text { Board }\end{array}$ & Quarterly \\
\hline $\begin{array}{l}\text { Wastewater Point-Source Monitoring Semi-Annual } \\
\text { Report }\end{array}$ & Livermore Water Reclamation Plant & Twice a year \\
\hline $\begin{array}{l}\text { Storm Water Pollution Prevention Plans (Livermore } \\
\text { Site and Site 300) }\end{array}$ & $\begin{array}{l}\text { San Francisco Bay Regional Water Quality Control } \\
\text { Board } \\
\text { Central Valley Regional Water Quality Control } \\
\text { Board }\end{array}$ & As required \\
\hline $\begin{array}{l}\text { Storm Water Pollution Prevention Plans for } \\
\text { Construction (Livermore Site and Site 300) }\end{array}$ & $\begin{array}{l}\text { San Francisco Bay Regional Water Quality Control } \\
\text { Board } \\
\text { Central Valley Regional Water Quality Control } \\
\text { Board }\end{array}$ & As required \\
\hline Ground Water Protection Management Program & Department of Energy & $\begin{array}{l}\text { Every } 3 \text { years } \\
\text { or as required }\end{array}$ \\
\hline $\begin{array}{l}\text { Storm Water Monitoring Programs (Livermore Site } \\
\text { and Site 300) }\end{array}$ & $\begin{array}{l}\text { San Francisco Bay Regional Water Quality Control } \\
\text { Board } \\
\text { Central Valley Regional Water Quality Control } \\
\text { Board }\end{array}$ & As required \\
\hline $\begin{array}{l}\text { Industrial Storm Water Discharge Annual Reports } \\
\text { (Livermore Site and Site 300) and } \\
\text { Site } 300 \text { Cooling Tower Annual Report }\end{array}$ & $\begin{array}{l}\text { San Francisco Bay Regional Water Quality Control } \\
\text { Board } \\
\text { Central Valley Regional Water Quality Control } \\
\text { Board }\end{array}$ & Yearly \\
\hline $\begin{array}{l}\text { Storm Water Pollution Prevention Annual } \\
\text { Certifications for Construction Projects } \\
\text { (Livermore Site and Site } 300 \text { ) }\end{array}$ & $\begin{array}{l}\text { San Francisco Bay Regional Water Quality Control } \\
\text { Board } \\
\text { Central Valley Regional Water Quality Control } \\
\text { Board }\end{array}$ & Yearly \\
\hline $\begin{array}{l}\text { Quarterly and Annual Compliance Reports for } \\
\text { Explosive Process Area Surface Impoundments, } \\
\text { Sewage Evaporation and Percolation Ponds, and } \\
\text { Percolation Pits }\end{array}$ & $\begin{array}{l}\text { Central Valley Regional Water Quality Control } \\
\text { Board }\end{array}$ & $\begin{array}{c}\text { Quarterly and } \\
\text { yearly }\end{array}$ \\
\hline DRB Quarterly/Annual Monitoring Reports & CERCLA & $\begin{array}{l}\text { Quarterly and } \\
\text { yearly }\end{array}$ \\
\hline $\begin{array}{l}\text { Hazardous Material Business Plan and Chemical } \\
\text { Inventory }\end{array}$ & $\begin{array}{l}\text { Alameda County Health Care Services Agency and } \\
\text { San Joaquin County Office of Emergency Services }\end{array}$ & $\begin{array}{l}\text { Yearly or as } \\
\text { required }\end{array}$ \\
\hline
\end{tabular}




\section{Appendix B. Reports for Regulatory Agencies}

\begin{tabular}{|c|c|c|}
\hline Title & Agency & Frequency \\
\hline SARA 311/MD+SDS Reporting & $\begin{array}{l}\text { California Emergency Planning and Response } \\
\text { Commission }\end{array}$ & As required \\
\hline SARA 313/Toxic Release Inventory & Department of Energy/State and Federal EPA & Yearly \\
\hline Beryllium in Ambient Air Monitoring & Bay Area Air Quality Management District & Quarterly \\
\hline Radiological NESHAPs Annual Report & Environmental Protection Agency & Yearly \\
\hline Environmental Monitoring Plan & Department of Energy & $\begin{array}{l}\text { Every three } \\
\quad \text { years }\end{array}$ \\
\hline Site Annual Environmental Report & Department of Energy & Yearly \\
\hline $\begin{array}{l}\text { Site } 300 \text { Pits } 1 \text { and } 7 \text { Landfill Closure Caps } \\
\text { Inspection/Monitoring Independent Engineering } \\
\text { Evaluation }\end{array}$ & $\begin{array}{l}\text { Department of Toxic Substances Control } \\
\text { Central Valley Regional Water Quality Control } \\
\text { Board } \\
\text { Environmental Protection Agency }\end{array}$ & Yearly \\
\hline Biennial Hazardous Waste Report & $\begin{array}{l}\text { Department of Toxic Substances Control (under } \\
\text { Environmental Protection Agency delegated } \\
\text { authority) }\end{array}$ & Every 2 years \\
\hline Annual Hazardous Waste Report & Department of Toxic Substances Control & Yearly \\
\hline $\begin{array}{l}\text { Conceptual Site Treatment Plan (CSTP) } \\
\text { Draft Site Treatment Plan (DSTP) } \\
\text { Final Site Treatment Plan (FSTP) }\end{array}$ & $\begin{array}{l}\text { Department of Toxic Substances Control } \\
\text { Environmental Protection Agency } \\
\text { Department of Energy }\end{array}$ & As required \\
\hline Safety Analysis Report & Department of Energy & As required \\
\hline Contingency Plans & Department of Toxic Substances Control & As required \\
\hline Closure Plans & Department of Toxic Substances Control & As required \\
\hline EIR Mitigation Monitoring Annual Report & University of California & Yearly \\
\hline FFA-CERCLA Reports & $\begin{array}{l}\text { Environmental Protection Agency } \\
\text { Department of Toxic Substances Control } \\
\text { San Francisco Bay Regional Water Quality Control } \\
\text { Board } \\
\text { Central Valley Regional Water Quality Control } \\
\text { Board } \\
\text { Department of Energy/EM-40 }\end{array}$ & As required \\
\hline
\end{tabular}




\section{References}

Aarons, J., L. Berg, F. Hoffman, G. Howard, R. Bainer, E. Folsom, M. Dresen (1998), LLNL Ground Water Project 1998 Annual Report, Lawrence Livermore National Laboratory, Livermore, CA (UCRL-AR-126020-98).

Althouse, P. E. (1998), Radiological Background Levels Found in Glass Fiber Filters Used for Low-Level Environmental Surveillance Air Sampling, Lawrence Livermore National Laboratory, Livermore, CA (UCRL-JC-131844).

Bainer, R. W., and L. L. Berg, eds. (1998), Action Memorandum for an Emergency Removal Action at the National Ignition Facility Construction Site, Lawrence Livermore National Laboratory, Livermore Site, Lawrence Livermore National Laboratory, Livermore, CA (UCRL-AR-128728).

Bainer, R. W., and J. Littlejohn (1998a), Letter Report: LLNL Livermore Site March 24, 1998 Remedial Program Managers' Meeting Summary and First Quarter SelfMonitoring Report, dated May 29, 1998.

Bainer, R. W., and J. Littlejohn (1998b), Letter Report: LLNL Livermore Site Second Quarter Self-Monitoring Report, dated August 28, 1998.

Bainer, R. W., and J. Littlejohn (1998c), Letter Report: LLNL Livermore Site Third Quarter Self-Monitoring Report, dated November 30, 1998.

Bainer, R. W., and J. Littlejohn (1999), Letter Report: LLNL Livermore Site Fourth Quarter Self-Monitoring Report, Lawrence Livermore National Laboratory, Livermore, CA, dated February 28, 1999.

Berg, L. L., E. N. Folsom, M. D. Dresen, R. W. Bainer, and A. L. Lamarre, eds. (1997a), Explanation of Significant Differences for Metals Discharge Limits at the Lawrence Livermore National Laboratory Livermore Site, Lawrence Livermore National Laboratory, Livermore, CA (UCRL-AR-125927).

Berg, L. L., E. N. Folsom, M. D. Dresen, R. W. Bainer, and A. L. Lamarre, eds. (1997b), Explanation of Significant Differences for Treatment Facilities A and B, Lawrence Livermore National Laboratory, Livermore Site, Lawrence Livermore National Laboratory, Livermore, CA (UCRL-AR-125555). 


\section{References}

Berg, L. L., M. D. Dresen, R. W. Bainer, E. N. Folsom, and A. L. Lamarre, eds. (1998), Remedial Design Report No. 4 for the Trailer 5475 Treatment Facilities, Lawrence Livermore National Laboratory, Livermore Site, Lawrence Livermore National Laboratory, Livermore, CA (UCRL-AR-126014).

Biermann, A. H., G. M. Gallegos, R. J. Harrach, N. A. Bertoldo, L. C. Hall, R. L. Berger, and K. A. Surano (1999), LLNL NESHAPs 1998 Annual Report, Lawrence Livermore National Laboratory, Livermore, CA (UCRL-ID-113867-99).

Biermann, A. H., R. J. Harrach, R. L. Berger, and K. A. Surano (1993), LLNL NESHAPS Project Quarterly Progress Report, First Quarter 1993, Lawrence Livermore National Laboratory, Livermore, CA (UCRL-AR-108419-93-1).

Blake, R. G., C. M. Noyes, and M. P. Maley (1995), Hydrostratigraphic Analysis-The Key to Cost-Effective Ground Water Cleanup at Lawrence Livermore National Laboratory, Lawrence Livermore National Laboratory, Livermore, CA (UCRL-JC-120614).

Brandstetter, E. R. (1998), Livermore Site Annual Storm Water Monitoring Report for WDR 95-174, Lawrence Livermore National Laboratory, Livermore, CA (UCRL-AR-126783-98).

Brown, R., and S. Mathews (1998), LLNL Experimental Test Site 300 Compliance Monitoring Report for Waste Discharge Requirements 96-248, Second Quarter 1998, Lawrence Livermore National Laboratory, Livermore, CA (UCRL-AR-125915-98-2).

Brown, R., R. Ward, and S. Mathews (1998), LLNL Experimental Test Site 300 Compliance Monitoring Report for Waste Discharge Requirements 96-248, Third Quarter 1998, Lawrence Livermore National Laboratory, Livermore, CA (UCRL-AR-125915-98-3).

Brown, R. A., S. Mathews, and R. Ward (1999), LLNL Experimental Test Site 300 Compliance Monitoring Report for Waste Discharge Requirements 96-248, Annual/Fourth Quarter Report 1998, Lawrence Livermore National Laboratory, Livermore, CA (UCRL-AR-125915-98-4).

Campbell, B. (1995), Spill Prevention Control and Countermeasure (SPCC) Plan, Livermore Site, Lawrence Livermore National Laboratory, Livermore, CA (UCRL-MA-105699 Rev 1).

Cantwell, B. and J. Celeste (1998), National Ignition Facility Pollution Prevention and Waste Minimization Plan, Lawrence Livermore National Laboratory, Livermore, CA (UCRL-AR-131194). 
Carlsen, T. M. (1991a), LLNL Site 300 Environmental Investigations Quarterly, JanuaryMarch 1991, Lawrence Livermore National Laboratory, Livermore, CA (UCAR-10194-91-1).

Carlsen, T. M. (1991b), LLNL Site 300 Environmental Investigations Quarterly, April-June 1991, Lawrence Livermore National Laboratory, Livermore, CA (UCAR-10194-91-2).

Carlsen, T. M., E. Bissell, and B. Pavlik (1998), Restoration of the Large-Flowered Fiddleneck (Amsinckia grandiflora) at Lawrence Livermore National Laboratory Site 300 Project Progress Report Fiscal Year 1998 October 1997-September 1998, Lawrence Livermore National Laboratory, Livermore, CA (UCRL-AR-131846).

Carpenter, D. W., J. J. Sweeney, P. W. Kasameyer, N. R. Burkhard, K. G. Knauss, and R. J. Shelmon (1984), Geology of the Lawrence Livermore National Laboratory Site and Adjacent Areas, Lawrence Livermore National Laboratory, Livermore, CA (UCRL-53316).

Celeste, J. (1997), FY97 Pollution Prevention Plan: A Strategy for the Future, Lawrence Livermore National Laboratory, Livermore, CA (UCRL-AR-127073).

Celeste, J., S. Coleman, B. Nisbet, and B. Campbell (1998), A Comprehensive Opportunity Assessment for Pollution Prevention at Lawrence Livermore National Laboratory, Lawrence Livermore National Laboratory, Livermore, CA (UCRL-AR-127890).

Central Valley Regional Water Quality Control Board (1993), Order No. 93-100, Waste Discharge Requirements for University of California Lawrence Livermore National Laboratory Sit 300 and U.S. Department of Energy, Landfill Pits 1 and 7, San Joaquin County (June 25, 1993).

Central Valley Regional Water Quality Control Board (1998), Revised Monitoring and Reporting Programs No. 93-100 and 96-248, Lawrence Livermore National Laboratory Site 300 and U.S. Department of Energy, Landfill Pits 1 and 7, San Joaquin County (June 25, 1993).

Christofferson, E. (1998a), LLNL Experimental Test Site 300 Compliance Monitoring Program for the CERCLA-Closed Pit 6 Landfill, Second Quarter Report, April-June 1998 (UCRL-AR-132057-98-2). 


\section{References}

Christofferson, E. (1998b), LLNL Experimental Test Site 300 Compliance Monitoring Program for the CERCLA-Closed Pit 6 Landfill, Third Quarter Report, July-September 1998 (UCRL-AR-132057-98-3).

Christofferson, E. and D. H. MacQueen (1998a), LLNL Experimental Test Site 300 Compliance Monitoring Program for RCRA-Closed Landfill Pits 1 and 7, First Quarter Report, January-March, 1998 (UCAR-10191-98-1).

Christofferson, E. and D. H. MacQueen (1998b), LLNL Experimental Test Site 300 Compliance Monitoring Program for RCRA-Closed Landfill Pits 1 and 7, Second Quarter Report, April-June, 1998 (UCAR-10191-98-2).

Christofferson, E. and D. H. MacQueen (1998c), LLNL Experimental Test Site 300 Compliance Monitoring Program for RCRA-Closed Landfill Pits 1 and 7, Third Quarter Report, July-September, 1998 (UCAR-10191-98-3).

Christofferson, E. and D. H. MacQueen (1999), LLNL Experimental Test Site 300 Compliance Monitoring Program for RCRA-Closed Landfill Pits 1 and 7, Annual Report for 1998 (UCAR-10191-98-4).

Christofferson, E. and M. J. Taffet (1999), LLNL Experimental Test Site 300 Compliance Monitoring Program for the CERCLA-Closed Pit 6 Landfill, Annual Report for 1998 (UCRL-AR-132057-98-4).

Ciba-Geigy Ltd. (1981). "Units of Measurement, Body Fluids, Composition of the Body, Nutrition." In Geigy Scientific Tables, Vol. 1, Eighth Edition, Basel, Switzerland.

Cooperrider, A. Y., B. J. Boyd, and H. R. Stuart, eds. (1986), Inventory and Monitoring of Wildlife Habitat, U. S. Department of Interior, Bureau of Land Management, Service Center, Denver, CO.

Demir, Z., R. J. Gelinas, P. F. McKereghan, and T. J. Vogele (1997), Preliminary 3-D Simulations of Contaminant Migration in Ground Water Beneath LLNL Livermore Site: Second Interim Report-The TFB Area, Lawrence Livermore National Laboratory, Livermore, CA (ERD/LS/3DIR:2).

Dibblee, T. W., Jr. (1980), Preliminary Geologic Map of the Midway Quadrangle, Alameda and San Joaquin Counties, California, USGS Open File Report 80-535. 
Dibley, V., and R. Depue (1998), LLNL Livermore Site and Site 300 Environmental Restoration Project Standard Operating Procedures (SOPS), Lawrence Livermore National Laboratory, Livermore, CA (UCRL-MA-109115 Rev. 4).

Diersch, H. J. G. (1998), “Graphics-Based, Interactive Finite-Element Simulation System for Modeling Ground Water Flow, Contaminant Mass and Heat Transport Processes (FEFLOW)." In WASY Institute for Water Resources Planning and System Research Ltd., Berlin, Germany.

Dresen, M. D., J. P. Ziagos, A. J. Boegel, E. M. Nichols, K. Anderson, R. O. Devany, E. N. Folsom, J. L. Iovenitti, J. K. McDonald, P. F. McKereghan, and C. N. Noyes (1993), Remedial Action Implementation Plan for the LLNL Livermore Site, Lawrence Livermore National Laboratory, Livermore, CA (UCRL-AR-110532) (page 43 revised September 2, 1993; Table 5 revised June 1998).

Eadie, G. G. and D. E. Bernhardt (1976), Sampling and Data Reporting Considerations for Airborne Particulate Radioactivity, U.S. Environmental Protection Agency, Office of Radiation Programs, Las Vegas, Nevada (ORP/LV-76-9).

Eccher, B., K. Folks, R. Goluba, M. Gonzalez, D. Hieb, W. Isherwood, M. Kelly, S. Mathews, V. Mode, B. Schumacher, T. Schmiegel, and S. Thomson (1994a), Storm Water Pollution Prevention Plan (SWPPP) Livermore Site, Lawrence Livermore National Laboratory, Livermore, CA (UCRL-AR-110573-94).

Eccher, B., K. Folks, R. Goluba, M. Gonzalez, D. Hieb, W. Isherwood, M. Kelly, S. Mathews, V. Mode, B. Schumacher, T. Schmiegel, and S. Thomson (1994b), Storm Water Pollution Prevention Plan (SWPPP), Experimental Test Site (Site 300), Lawrence Livermore National Laboratory, Livermore, CA (UCRL-AR-110572-94).

Eckerman, K. F., A. B. Wolbarst, and A. C. B. Richardson (1988), Limiting Values of Radionuclide Intake and Air Concentration and Dose Conversion Factors for Inhalation, Submersion, and Ingestion, U.S. Environmental Protection Agency, Washington, DC (Federal Guidance Report No. 11, EPA-520/1-88-020).

Eckerman, K. F., and J. C. Ryman (1993), External Exposure to Radionuclides in Air, Water and Soil, U.S. Environmental Protection Agency, Washington, DC (Federal Guidance Report No. 12, EPA 402-R-93-081). 


\section{References}

Environmental Laboratory (1987), U.S. Army Corps of Engineers Wetlands Delineation Manual, U.S. Army Engineer Waterways Experiment Station, Vicksburg, Mississippi (Technical Report Y-87-1).

Ferry, L., T. Berry, and D. MacQueen (1998), Post-Closure Plan for the Pit 6 Landfill Operable Unit Lawrence Livermore National Laboratory Site 300, Lawrence Livermore National Laboratory, Livermore, CA (UCRL-AR-128638).

Folks, K. (1997), LLNL Report of Waste Discharge for Beneficial Reuse of Soil at the Livermore Site, Lawrence Livermore National Laboratory, Livermore, CA (UCRL-AR-126943).

Gallegos, G. M. (1991), Assessment of Sediment Monitoring at LLNL, Lawrence Livermore National Laboratory, Livermore, CA (UCRL-ID-121236).

Gallegos, G. M. (1993), “Surveillance Monitoring of Soils for Radioactivity: Lawrence Livermore National Laboratory 1976 to 1992," Health Physics 69(4), 487-493.

Gallegos, G. M. (1998), NESHAPs Annual Report Guidance Document, Lawrence Livermore National Laboratory, Operations and Regulatory Affairs Division, Livermore, CA (EMP-NS-S).

Gallegos, G. M., and A. H. Biermann (1997), LLNL NESHAPs 1996 Annual Report, Lawrence Livermore National Laboratory, Livermore, CA (UCRL-ID-113867-97).

Gallegos, G. M., A. H. Biermann, R. J. Harrach, N. A. Bertoldo, L. C. Hall, R. L. Berger, and K. A. Surano (1998), LLNL NESHAPs 1997 Annual Report, Lawrence Livermore National Laboratory, Livermore, CA (UCRL-ID-113867-98).

Gallegos, G. M., B. K. Balke, K. A. Surano, W. G. Hoppes, P. J. Tate, J. C. Steenhoven, B. C. Fields, L. M. Garcia, K. C. Lamson (1992), Environmental Report 1991, Lawrence Livermore National Laboratory, Livermore, CA (UCRL-50027-91).

Gallegos, G. M., R. J. Harrach, A. H. Biermann, F. J. Gouveia, P. J. Tate, B. C. Fields, and K. Surano (1996), LLNL NESHAPS 1995 Annual Report, Lawrence Livermore National Laboratory, Livermore, CA (UCRL-ID-113867-96).

Gallegos, G. M., D. MacQueen, K. Surano (1999), Livermore Big Trees Park: 1998 Summary Results, Lawrence Livermore National Laboratory, Livermore, CA (UCRL-ID-134581). 
Gallegos, G. M., P. J. Tate, B. K. Balke, E. Christofferson, R. J. Harrach, W. G. Hoppes, R. A. Failor, S. Wander, B. C. Fields, L. M. Garcia, and A. R. Grayson (1994), Environmental Report for 1993, Lawrence Livermore National Laboratory, Livermore, CA (UCRL-50027-93).

Galles, H. L., to S. Timm (1997), Letter re: Statistically Significant Evidence for a Release of Barium at Pit 7 Under Waste Discharge Requirements (WDR) Order 93-100, Lawrence Livermore National Laboratory, Livermore, CA (WGMG97-249, July 10, 1997).

Galles, H. L., to J. Cho (1997), Letter re: Lawrence Livermore National Laboratory Drainage Retention Basin Monitoring Plan Amendment (WGMG97-439, December 9, 1997)

Galles, H. L., to S. Timm (1998a), Letter re: Statistically Significant Evidence for a Release of Uranium from Lawrence Livermore National Laboratory Experimental Test Site (Site 300) Pit 7 (WGMG98-306, November 10, 1998).

Galles, H. L., to S. Timm (1998b), Letter re: Statistically Significant Evidence for a Release of 1-2 Dichloroethane from Lawrence Livermore National Laboratory Experimental Test Site (Site 300) Pit 6 (WGMG98-282, October 13, 1998).

Galles, H. L., to S. Timm (1999), Letter re: Statistically Significant Evidence for a Release of Tritium from Lawrence Livermore National Laboratory Experimental Test Site (Site 300) Pit 1 (WGMG99-006, January 14, 1999).

Golder Construction Services, Inc. (1998), Construction Quality Assurance for the RCRA Closure of the High Explosives Open Burn Treatment Facility, Lawrence Livermore National Laboratory Site 300, Livermore, CA, September 9, 1998 (UCRLCR-131701).

Gouveia, F., and K. R. Chapman (1989), Climatology of Lawrence Livermore National Laboratory, Lawrence Livermore National Laboratory, Livermore, CA (UCID-21686).

Grandfield, C. H. (1989), Guidelines for Discharges to the Sanitary-Sewer System, Lawrence Livermore National Laboratory, Livermore, CA (UCAR-10235).

Greenberg, A. E., L. S. Clesceri, A. D. Eaton, eds. (1992), Standard Methods for the Examination of Water and Wastewater, American Public Health Association, Baltimore, Maryland. 


\section{References}

Gudiksen, P. H., C. L. Lindeken, C. Gatrousis, and L. R. Anspaugh (1972), Environmental Levels of Radioactivity in the Vicinity of the Lawrence Livermore Laboratory, January through December 1971, Lawrence Livermore National Laboratory, Livermore, CA (UCRL-51242).

Gudiksen, P. H., C. L. Lindeken, J. W. Meadows, and K. O. Hamby (1973), Environmental Levels of Radioactivity in the Vicinity of the Lawrence Livermore Laboratory, 1972 Annual Report, Lawrence Livermore National Laboratory, Livermore, CA (UCRL51333).

Gupta, S. K., C. R. Cole, C. T. Kincaid, and A. M. Monti (1987), Coupled Fluid, Energy, and Solute Transport (CFEST) Model: Formulation and User's Manual, Office of Nuclear Waste, Battelle Memorial Institute, Columbus, OH (Report BMI/ONWI-660).

Hall, H. L., and W. L. Edwards (1994a), Radiation Analytical Sciences Quality Assurance Plan, Quality Implementing Procedures and Quality Assurance Project Plans, Vol. 1, Lawrence Livermore National Laboratory, Livermore, CA (M-078-142).

Hall, H. L., and W. L. Edwards (1994b), Radiation Analytical Sciences Integrated Software Documentation, Vols. 2a, 2b, and 3, Lawrence Livermore National Laboratory, Livermore, CA (UCRL-MA-116560).

Hall, H. L., and W. L. Edwards (1994c), Technical Implementing Procedures, Radiation Analytical Sciences, Vol. 2a, Lawrence Livermore National Laboratory, Livermore, CA (UCRL-MA-116560).

Harrach, R. J. (1998), Guidance for Radiological Dose Assessment, Operations and Regulatory Affairs Division, Lawrence Livermore National Laboratory, Livermore, CA (EMP-R-DA).

Harrach, R. J., K. A. Surano, A. H. Biermann, F. J. Gouveia, B. C. Fields, and P. J. Tate, (1994), LLNL NESHAPs 1993 Annual Report, Lawrence Livermore National Laboratory, Livermore, CA (UCRL-ID-113867-94).

Harrach, R. J., R. A. Failor, G. M. Gallegos, P. J. Tate, E. Christofferson, E. R. Brandstetter, J. M. Larson, A. H. Biermann, R. A. Brown, B. C. Fields, L. M. Garcia, and A. R. Grayson (1996), Environmental Report 1995, Lawrence Livermore National Laboratory, Livermore, CA (UCRL-50027-95), http://www.llnl.gov/saer/. 
Harrach, R. J., G. M. Gallegos, P. J. Tate, E. Christofferson, E. R. Brandstetter, J. M. Larson, A. H. Biermann, B. C. Fields, L. M. Garcia, and K. A Surano (1997), Environmental Report 1996, Lawrence Livermore National Laboratory, Livermore, CA (UCRL-50027-96), http:/ / www.llnl.gov/saer/.

Harrach, R. J., J. M. Larson, G. M. Gallegos, E. Christofferson, E. R. Brandstetter, P. J. Tate, A. H. Biermann, B. C. Fields, L. M. Garcia, and P. Althouse (1998), Environmental Report 1997, Lawrence Livermore National Laboratory, Livermore, CA (UCRL-50027-97), http:/ / www.llnl.gov/saer/.

Heffner, B. (1998), Third Site 300 Environmental Restoration Fact Sheet, Lawrence Livermore National Laboratory, Livermore, CA.

Hoffman, F., and D. Bishop (1998), Letter Report: LLNL Report of Preliminary Results to David Lunn of Alameda County Flood Control and Water Conservation District, Zone 7, February 27, 1998, presenting an evaluation of hydrogeology of the Mocho I and Spring sub-basins, based on LLNL hydrogeological investigations.

Hoffman, J., M. Maley, B. Qualheim, R. Bainer, E. Folsom, and M. Dresen (1998), LLNL Ground Water Project 1997 Annual Report, Lawrence Livermore National Laboratory, Livermore, CA (UCRL-AR-126020-97).

Homann, S. G. (1994), HOTSPOT Health Physics Codes for the PC, Lawrence Livermore National Laboratory, Livermore, CA (UCRL-MA-10615).

Huey, A. S. (1948), "Geology of the Tesla Quadrangle, California," California Division of Mines and Geology, Bulletin 140.

International Commission on Radiological Protection (ICRP) (1959), Recommendations of the International Commission on Radiological Protection, Report of Committee 2 on Permissible Dose of Internal Radiation, Publication 2, Pergamon Press, New York, NY.

International Commission on Radiological Protection (ICRP) (1977), Recommendations of the International Commission on Radiological Protection, Publication 26 (Pergamon Press, New York, NY).

International Commission on Radiological Protection (ICRP) (1980), Limits for Intakes of Radionuclides by Workers, Publication 30, Pergamon Press, New York, NY. 


\section{References}

International Committee on Radiation Protection (ICRP) (1994). Dose Coefficients for Intakes of Radionuclides by Workers. Publication 68, Vol. 24, No. 4, Pergamon Press, Oxford.

International Committee on Radiation Protection ICRP (1996). "Compilation of Ingestion and Inhalation Dose Coefficients." In Age-dependent Doses to Members of the Public from Intake of Radionuclides: Part 5. Annals of the ICRP Vol. 26 No. 1. ICRP No. 72 ISSN 0146-6453, Pergamon Press, Oxford.

Isherwood, W. F., C. H. Hall, M. D. Dresen, and A. J. Boegel (1991), CERCLA Feasibility Study Report for the LLNL Livermore Site, Lawrence Livermore National Laboratory, Livermore, CA (UCRL-AR-104040).

Jakub, B. (1998), Action Memorandum for the Building 815 Operable Unit Removal Action at Lawrence Livermore National Laboratory Site 300, August 1998.

Lamarre, A. L., ed. (1989a), LLNL Site 300 Environmental Investigations Quarterly, JulySeptember 1989, Lawrence Livermore National Laboratory, Livermore, CA (UCAR-10194-89-3).

Lamarre, A. L., ed. (1989b), LLNL Site 300 Environmental Investigations Quarterly, October-December 1989, Lawrence Livermore National Laboratory, Livermore, CA (UCAR-10194-89-4).

Lamarre, A. L. (1989c), Lawrence Livermore National Laboratory Site 300 Environmental Restoration Work Plan, Lawrence Livermore National Laboratory, Livermore, CA (UCAR-10247 Rev. 1).

Lamarre, A. L. (1998a), Fourth Quarter 1997 Compliance Report for the Eastern and Central GSA Ground Water Treatment Systems at Lawrence Livermore National Laboratory Site 300, January 30, 1998.

Lamarre, A. L. (1998b), First Quarter 1998 Compliance Report for the Eastern and Central GSA Ground Water Treatment Systems at Lawrence Livermore National Laboratory Site 300, April 30, 1998.

Lamarre, A. L. (1998c), Second Quarter 1998 Compliance Report for the Eastern and Central GSA Ground Water Treatment Systems at Lawrence Livermore National Laboratory Site 300, August 30, 1998. 
Lamarre, A. L. (1998d), Third Quarter 1998 Compliance Report for the Eastern and Central GSA Ground Water Treatment Systems at Lawrence Livermore National Laboratory Site 300, October 30, 1998.

Lamarre, A. L. (1998e), Fourth Quarter 1997 Compliance Report for the Building 834 Ground Water Treatment System at Lawrence Livermore National Laboratory Site 300, March 30, 1998.

Lamarre, A. L. (1998f), First Quarter 1998 Compliance Report for the Building 834 Ground Water Treatment System at Lawrence Livermore National Laboratory Site 300, June 30, 1998.

Lamarre, A. L. (1998g), Second Quarter 1998 Compliance Report for the Building 834 Ground Water Treatment System at Lawrence Livermore National Laboratory Site 300, September 30, 1998.

Lamarre, A. L. (1998h), Third Quarter 1998 Compliance Report for the Building 834 Ground Water Treatment System at Lawrence Livermore National Laboratory Site 300, December 28, 1998.

Lamarre, A. L., and M. J. Taffet (1989), Firing Table Gravel Cleanup at Lawrence Livermore National Laboratory Site 300, Lawrence Livermore National Laboratory, Livermore, CA (UCAR-10282).

Lawrence Livermore National Laboratory (1996a), The Environmental, Safety, and Health Program at Lawrence Livermore National Laboratory, Lawrence Livermore National Laboratory, Livermore, CA (UCRL-AR-119618 Rev 1). Accessible from LLNL home page at http://www.llnl.gov/.

Lawrence Livermore National Laboratory (1996b), Environmental Compliance Manual, Lawrence Livermore National Laboratory, Livermore, CA (UCRL-MA-118090 $\operatorname{Rev} 2)$.

Limnion Corporation, The (1991), Drainage Retention Basin Management Plan, Lawrence Livermore National Laboratory, Livermore, CA.

Lindeken, C. L., R. O. Morgin, and K. F. Petrock (1963), “Collection Efficiency of Whatman-41 Filter Paper for Submicron Aerosols," Health Physics 9, 305-308. 


\section{References}

Lindeken, C. L., P. H. Gudiksen, J. W. Meadows, K. O. Hamby, and L. R. Anspaugh (1973), Environmental Levels of Radioactivity in Livermore Valley Soils, Lawrence Livermore National Laboratory, Livermore, CA (UCRL-74424).

Littlejohn, J., and A. L. Lamarre (1997), Letter Report: LLNL Livermore Site December 10, 1996 Remedial Program Manager's Meeting Summary and Fourth Quarter Self-Monitoring Report, dated February 27, 1997.

Longley, K. E., H. V. Johns, and H. Abraham (1994), The Water Quality Control Plan (Basin Plan) for the California Regional Water Quality Control Board, Central Valley Region, Central Valley Regional Water Control Board, Sacramento, CA.

Lowder, W. M., and H. L. Beck (1966), "Cosmic Ray Ionization in the Lower Atmosphere," J. Geophys. Res. 71, 4661-4668.

MacQueen, D. H. (1995), Livermore Big Trees Park January 1995 Soil Survey Results, Lawrence Livermore National Laboratory, Livermore, CA (UCRL-ID-121045).

Marshack, J. B. (1991), The Designated Level Methodology for Waste Classification and Cleanup Level Determination, a summary of the Staff Report of the Central Valley RWQCB.

Marshack, J. B. (1998), A Compilation of Water Quality Goals, Central Valley Regional Water Quality Control Board, Sacramento, CA.

Marshall, M. and D. C. Stevens (1980), "The Purposes, Methods and Accuracy of Sampling for Airborne Particulate Radioactive Materials," Health Physics 39, September 1980, Pergamon Press Ltd., pp. 409-423.

Mathews, S., and R. A. Brown (1998), LLNL Experimental Test Site 300 Compliance Monitoring Report for Waste Discharge Requirements 96-248, First Quarter 1998, Lawrence Livermore National Laboratory, Livermore, CA (UCRL-AR-125915-98-1).

Mathews, S., and M. Taffet (1997), Final Closure Plan for the High-Explosives Open Burn Facility at Lawrence Livermore National Laboratory Experimental Test Site 300, Lawrence Livermore National Laboratory, Livermore, CA (UCRL-ID-111753 Rev 1). 
National Council on Radiation Protection and Measurements (NCRP) (1987a), Recommendations on Limits of Exposure to Ionizing Radiation, Report No. 91, National Council on Radiation Protection and Measurements, Washington, DC.

National Council on Radiation Protection and Measurements (NCRP) (1987b), Ionizing Radiation Exposure of the Population of the United States, Report No. 93, National Council on Radiation Protection and Measurements, Washington, DC.

Oak Ridge Institute for Science and Education (1995), Atmospheric Dispersion Modeling Resources, Second Edition.

Parks, B. F. (1999), "Tritium dose overestimates by CAP88-PC." In Operational Radiation Safety, Supplement to Health Physics 76, No. 2, February 1999.

Parks, B. S. (1992), User's Guide for CAP88-PC, Version 1.0, U.S. Environmental Protection Agency, Office of Radiation Programs, Las Vegas, NV (EPA 402-B-92-001).

Pendleton, B., A. Giron, B. A. Millsap, K. W. Cline, D. M. Bird, eds. (1987), Raptor Management Techniques Manual, National Wildlife Federation, Washington, DC.

Peterson, W. B. and L. G. Lavdas (1986), "INPUFF 2.0—A Multiple Source Gaussian Puff Dispersion Algorithm," In User's Guide, U.S. Environmental Protection Agency, Research Triangle, NC.

Raber, E., and D. W. Carpenter, eds. (1983), An Evaluation of the Hydrogeology and Groundwater Chemistry Associated with Landfills at LLNL's Site 300, Lawrence Livermore National Laboratory, Livermore, CA (UCRL-53416).

Rogers/Pacific Corporation (1990), Lawrence Livermore National Laboratory Site 300 Resource Conservation and Recovery Act Closure and Post-Closure Plans-Landfill Pits 1 and 7, Vols. I and II, Van Nuys, CA (California EPA No. CA2890090002).

San Francisco Bay Regional Water Quality Control Board (RWQCB) (1982a), Water Quality Control Plan, San Francisco Bay Basin, State of California, Oakland, CA.

San Francisco Bay Regional Water Quality Control Board (RWQCB) (1982b), Waste Discharge Requirements and National Pollutant Discharge Elimination System (NPDES) Storm Water Permit for: U.S. Department of Energy and Lawrence Livermore National Laboratory, State of California, Oakland, CA (Order No. 95-174, NPDES No. CA030023). 


\section{References}

San Francisco Bay Regional Water Quality Control Board (RWQCB) (1995), Water Quality Control Plan, San Francisco Bay Basin, State of California, Oakland, CA.

San Francisco Bay Regional Water Quality Control Board (RWQCB) (1996), Letter from Loretta Barsamian and Richard McMurtry, RWQCB Executive Officer and Ground Water Protection and Waste Containment Division Chief, respectively, to Paul Ko, DOE Project Manager, stating that no further remedial action related to the fuel hydrocarbons is required, dated October 30, 1996.

Schemnitz, S. D., ed. (1980), Wildlife Management Techniques Manual, The Wildlife Society, Washington, DC.

Shleien, B., and M. S. Terpilak (1984), The Health Physics and Radiological Health Handbook, Nucleon Lectern Associates, Inc., Olney, MD.

Silver, W. J., C. L. Lindeken, J. W. Meadows, W. H. Hutchin, and D. R. McIntyre (1974), Environmental Levels of Radioactivity in the Vicinity of the Lawrence Livermore Laboratory, 1973 Annual Report, Lawrence Livermore National Laboratory, Livermore, CA (UCRL-51547).

Silver, W. J., C. L. Lindeken, J. W. Meadows, W. H. Hutchin, and D. R. McIntyre (1975), Environmental Levels of Radioactivity in the Vicinity of the Lawrence Livermore Laboratory, 1974 Annual Report, Lawrence Livermore National Laboratory, Livermore, CA (UCRL-50027-74).

Silver, W. J., C. L. Lindeken, K. M. Wong, E. H. Willes, and J. H. White (1978), Environmental Monitoring at the Lawrence Livermore Laboratory, 1977 Annual Report, Lawrence Livermore National Laboratory, Livermore, CA (UCRL-50027-77).

Silver, W. J., C. L. Lindeken, J. H. White, and R. W. Buddemeir (1980), Environmental Modeling of Lawrence Livermore Laboratory: 1979 Annual Report, Lawrence Livermore National Laboratory, Livermore, CA (UCRL-50027-79).

Stone, R., and M. R. Ruggieri (1983), Ground-Water Quality and Movement at Lawrence Livermore National Laboratory, Lawrence Livermore National Laboratory, Livermore, CA (UCRL-53474).

Struckmeyer, R. (1994), NRC TLD Direct Radiation Monitoring Network, Progress Report, July-September, 1994, Nuclear Regulatory Commission, Washington, DC (NUREG-0837, Vol. 14, No. 3). 
Surano, K. A., G. B. Hudson, R. A. Failor, J. M. Sims, R. C. Holland, S. C. MacLean, and J. C. Garrison (1991), “Helium-3 Mass Spectrometry for Low-Level Tritium Analysis of Environmental Samples," J. Radioanal. Nucl. Chem 6, 443-453.

Surano, K. A., A. H. Biermann, R. J. Harrach, F. J. Gouveia, R. L. Berger, B. C. Fields, G. M. Gallegos, and P. J. Tate (1995), LLNL NESHAPs 1994 Annual Report, Lawrence Livermore National Laboratory, Livermore, CA (UCRL-ID-113867-95).

Taffet, M. J., A. L. Lamarre, and W. A. McIlvride (1989a), LLNL Site 300 Environmental Investigations Quarterly, January-March 1989, Lawrence Livermore National Laboratory, Livermore, CA (UCAR-10194-89-1).

Taffet, M. J., J. A. Oberdorfer, and W. A. McIlvride (1989b), Remedial Investigation and Feasibility Study for the Lawrence Livermore National Laboratory Site 300 Pit 7 Complex, Lawrence Livermore National Laboratory, Livermore, CA (UCID-21685).

Taffet, M. J., J. R. Copland, and R. A. Ferry (1991), Draft Feasibility Study for Landfill Pit 6, Lawrence Livermore National Laboratory Site 300, Lawrence Livermore National Laboratory, Livermore, CA (UCRL-AR-106307DR).

Taffet, M. J., L. Green-Horner, L. C. Hall, T. M. Carlsen, and J. A. Orberdorfer (1996), Addendum to Site-Wide Remedial Investigation Report, Building 850/Pit 7 Complex Operable Unit, Lawrence Livermore National Laboratory Site 300, Lawrence Livermore National Laboratory, Livermore, CA (UCRL-AR-108131, Add. 1).

Tate, P., S. Brigdon, G. Gallegos, B. Balke, A. Biermann, F. Gouveia, L. Garcia, D. MacQueen, N. Hankla, S. Mathews, E. Christofferson, R. Brown, E. Brandstetter, R. Harrach, A. Grayson, B. Fields, J. Larson, R. Vellinger, R. Failor, K. Surano, W. Hoppes, P. Althouse, and B. Ward (1995), Environmental Monitoring Plan, Lawrence Livermore National Laboratory, Livermore, CA (UCRL-ID-106132 Rev. 1).

Thorpe, R. K., W. F. Isherwood, M. D. Dresen, and C. P. Webster-Scholten (1990), CERCLA Remedial Investigation Report for the LLNL Livermore Site, Vols. 1-5, Lawrence Livermore National Laboratory, Livermore, CA (UCAR-10299).

Tompson, A. F. B., P. F. McKereghan, and E. M. Nichols, eds. (1995), Preliminary Simulation of Contaminant Migration in Ground Water at the Lawrence Livermore National Laboratory, Lawrence Livermore National Laboratory, Livermore, CA (UCRL-ID-115991). 


\section{References}

Toy, A. J., C. L. Lindeken, K. S. Griggs, and R. W. Buddemeier (1981), Environmental Monitoring at the Lawrence Livermore National Laboratory, 1980 Annual Report, Lawrence Livermore National Laboratory, Livermore, CA (UCRL-50027-80).

U.S. Department of Energy (1988), External Dose-Rate Conversion Factors for Calculation of Dose to the Public, U.S. Department of Energy, Washington, DC (DOE/EH-0070).

U.S. Department of Energy (1991), Environmental Regulatory Guide for Radiological Effluent Monitoring and Environmental Surveillance, U.S. Department of Energy, Washington, DC (DOE/EH-0173T).

U.S. Department of Energy (1994), Annual Report of Waste Generation and Pollution Prevention Progress 1993, Washington, DC.

U.S. Department of Energy (1996a), Annual Report of Waste Generation and Pollution Prevention Progress 1994, Washington, DC (Report No. DOE/EM-0310).

U.S. Department of Energy Office of the Secretary (1996b), Pollution Prevention Program Plan, 1996, U.S. Department of Energy, Washington, DC (DOE/S-0118).

U.S. Department of Energy, Assistant Secretary for Environmental Management (1997), Annual Report of Waste Generation and Pollution Prevention Progress 1995, Washington, DC (Report No. DOE/EM-0323).

U.S. Department of Energy (1998), Annual Report on Waste Generation and Pollution Prevention Progress, U.S. Department of Energy, Washington, DC.

U.S. Department of Energy (1998a), Agreement to Revise Schedules Contained in the Lawrence Livermore National Laboratory Site 300 Federal Facility Agreement, Appendix A, U.S. Department of Energy, October 1998.

U.S. Department of Energy (1998b), August 1998 Quarterly Report Regarding the National Ignition Facility, Oakland Operations Office, Oakland CA, August 25, 1998.

U.S. Department of Energy (1998c), "Department of Energy Directives Web Site," http:/ / www.explorer.doe.gov:1776/htmls/directives.html.

U.S. Department of Energy (1998d), Annual Report of Waste Generation and Pollution Prevention Progress 1997, Albuquerque, NM (Report No. DOE/EM-0365). 
U.S. Department of Energy (1998e), Proposed Regulatory Pathway for the Building 854 Operable Unit, Lawrence Livermore National Laboratory Site 300, Livermore, CA, May 28, 1998.

U.S. Department of Energy (1999), Annual Report of Waste Generation and Pollution Prevention Progress 1998, Washington, DC.

U.S. Department of Energy and Lawrence Livermore National Laboratory (LLNL) (1998), Livermore Big Trees Park 1998 Soil Sampling Plan, Lawrence Livermore National Laboratory, Livermore, CA (UCRL-ID-130551).

U.S. Department of Energy and University of California (1992a), Final Environmental Impact Statement and Environmental Impact Report for Continued Operation of Lawrence Livermore National Laboratory and Sandia National Laboratories, Livermore, Lawrence Livermore National Laboratory, Livermore, CA (DOE/EIS-0157, SCH90030847).

U.S. Department of Energy and University of California (1992b), Final Environmental Impact Statement and Environmental Impact Report Executive Summary, Lawrence Livermore National Laboratory, Livermore, CA (DOE/EIS-0157).

U.S. Department of Health and Human Services (1999), Health Consultation: "Plutonium Contamination in Big Trees Park," Lawrence Livermore National Laboratory, Public Service, Agency for Toxic Substances and Disease Registry, CERCLIS No. CA28900125584, pp. 7-8.

U.S. Environmental Protection Agency (1987), Data Quality Objectives for Remedial Response Activities: Development Process, U.S. Environmental Protection Agency, Office of Emergency and Remedial Response, Washington, DC (EPA 540/G-87/003, OSWER Directive 9355-0).

U.S. Environmental Protection Agency (1991), Risk Assessment Guidance for Superfund: Volume I-Human Health Evaluation Manual (Part B, Development of Risk-based Preliminary Remediation Goals), U.S. Environmental Protection Agency, Office of Emergency and Remedial Response, Washington, DC.

U.S. Environmental Protection Agency (1993), Supplement B to the Guideline on Air Quality Models (Revised), EPA Report No. EPA-450/2-78-027R (Supplement B). 


\section{References}

U.S. Nuclear Regulatory Commission (1977), Calculation of Annual Doses to Man from Routine Releases of Reactor Effluent for the Purpose of Evaluation Compliance with 10 Code of Federal Regulations, Part 50, Appendix 1, Washington, DC (Regulatory Guide 1.109).

Vogele, T. J., P. F. McKereghan, R. Gelinas, and A. F. B. Tompson (1996), Technical Note: Preliminary 3D Simulations of Contaminant Migration in and Removal from Ground Water at the LLNL's Livermore Site, Summary of First Interim Results, TFA Area, Lawrence Livermore National Laboratory, Livermore, CA (MI-ERD/LS/3DIR:1).

Webster-Scholten, C. P., and C. H. Hall (1988), Work Plan, Lawrence Livermore National Laboratory, Livermore Site: CERCLA/SARA Remedial Investigations/Feasibility Studies, Lawrence Livermore National Laboratory, Livermore, CA (UCAR-10225).

Webster-Scholten, C. P., ed. (1994), Final Site-Wide Remedial Investigation Report, Lawrence Livermore National Laboratory Site 300, Lawrence Livermore National Laboratory, Livermore, CA (UCRL-AR-108131).

Wilson, K. L. (1999), Assessing the Nonhazardous Solid Waste Stream at Lawrence Livermore National Laboratory, Lawrence Livermore National Laboratory, Livermore, CA (UCRL-AR-134220).

Wood, J., R. Michalik, and K. Doiron (1999), Radioactive Waste Storage Facility and Tank System Design Criteria Standards, Lawrence Livermore National Laboratory, Livermore, CA (UCRL-AR-133355 Rev 1).

Ziagos, J., and E. Reber-Cox (1998a), Building 815 Removal Action Design Workplan for the High Explosives Process Area Operable Unit at Lawrence Livermore National Laboratory Site 300, Livermore California, November 17, 1998.

Ziagos, J., and E. Reber-Cox (1998b), Ground Water Tritium Plume Characterization Summary Report for the Building 850/Pits 3 and 5 Operable Unit, Lawrence Livermore National Laboratory Site 300, Livermore California, October 30, 1998.

Ziagos, J., and E. Reber-Cox (1998c), Characterization Summary Report for the Building 854 Operable Unit, Lawrence Livermore National Laboratory, Livermore California. 


\section{Glossary}

\section{Acronyms and Abbreviations}

A $\mathrm{ACDEH}$

ACEHS

ACG

ACOE

ALARA

ANOVA

ANSI

ATSDR

AWQC

B BAAQMD

BETX (or BTEX)

BMP

BOD

$\mathrm{Bq}$

C $\mathrm{Cal} / \mathrm{EPA}$

CAM

CAMP

CAP88-PC

CARB

CARES

CCR
Alameda County Department of Environmental Health.

Alameda County Environmental Health Services.

Ambient Concentration Guide.

Army Corps of Engineers.

As low as reasonably achievable.

Analysis of variance (see Technical Terms).

American National Standards Institute.

Agency for Toxic Substances and Disease Registry.

Ambient water quality criteria.

Bay Area Air Quality Management District. The local agency responsible for regulating stationary air emission sources (including the LLNL Livermore site) in the San Francisco Bay Area.

Benzene, ethyl benzene, toluene, and xylene.

Best management practice.

Biochemical oxygen demand.

Becquerel (see Technical Terms).

California Environmental Protection Agency.

Continuous air monitor.

Corrective Action Monitoring Plan.

Computer code required by the EPA for modeling air emissions of radionuclides.

California Air Resources Board.

(Tri-Valley) Citizens Against a Radioactive Environment.

California Code of Regulations. Codification of regulations promulgated by the State of California. 
CDFG

CDHS

CEI

CEPRC

CEQA

CERCLA

CES

CFC

CFF

CFR

CHP

$\mathrm{Ci}$

COC

CRD

CRMP

CRWQCB

CVRWQCB

CWG

D DCG
California Department of Fish and Game.

California Department of Human Services.

Compliance Evaluation Inspection.

Chemical Emergency Planning and Response Commission.

California Environmental Quality Act of 1970. CEQA requires that all California state, local, and regional agencies document, consider, and disclose to the public the environmental implications of their actions.

Comprehensive Environmental Response, Compensation and Liability Act of 1980. Administered by EPA, this program, also known as Superfund, requires private parties to notify the EPA after the release of hazardous substances and undertake short-term removal and long-term remediation. If conditions exist that could create the threat of hazardous substances being released, the Act also requires the remediation of those conditions.

In 1986, the Superfund Amendments and Reauthorization Act (SARA) was enacted, which amended and reauthorized CERCLA for five years at a total funding level of $\$ 8.5$ billion.

Chemistry and Materials Science Environmental Services. An LLNL laboratory that analyzes environmental samples.

Chlorofluorocarbon (see Technical Terms).

Contained Firing Facility.

Code of Federal Regulations. A codification of all regulations promulgated by federal government agencies.

California Highway Patrol.

Curie (see Technical Terms).

Constituent of concern.

Catalytic reductive dehalogenation.

Cultural Resource Management Plan.

California Regional Water Quality Control Board.

Central Valley Regional Water Quality Control Board.

Community Work Group.

Derived Concentration Guide (see Technical Terms). 
DMP

$\mathrm{DO}$

DoD

DOE

DOI

DOT

DRB

DTSC

DWTF

E EDE

EDO

EIR

EIS

EOG

EPA

EPCRA
Detection Monitoring Program.

Dissolved oxygen.

U.S. Department of Defense.

U.S. Department of Energy. The federal agency that is responsible for conducting energy research and regulating nuclear materials used for weapons production.

U.S. Department of the Interior.

U.S. Department of Transportation.

Drainage Retention Basin. Man-made, lined pond used to capture storm water runoff and treated water at the LLNL Livermore site.

California Environmental Protection Agency, Department of Toxic Substances Control.

Decontamination and Waste Treatment Facility.

Effective dose equivalent (see Technical Terms).

Environmental Duty Officer.

Environmental Impact Report. A detailed report prepared pursuant to CEQA on the environmental impacts from any action carried out, approved, or funded by a California state, regional, or local agency.

Environmental Impact Statement. A detailed report, required by the National Environmental Policy Act, on the environmental impacts from a federally approved or funded project. An EIS must be prepared by a federal agency when a "major" federal action that will have "significant" environmental impacts is planned.

Environmental Operations Group.

U.S. Environmental Protection Agency. The federal agency responsible for enforcing federal environmental laws. Although some of this responsibility may be delegated to state and local regulatory agencies, EPA retains oversight authority to ensure protection of human health and the environment.

Emergency Planning and Community Right-to-Know Act of 1986. EPCRA requires facilities that produce, use, or store hazardous substances to report releases of reportable quantities or hazardous substances to the environment. 


\section{Glossary}

EPD

ERD

ES\&H

EST

EWSF

EWTF

F FFA

FONSI

Freon 113

FTF

G $\quad g$

GAC

$\mathrm{GBq}$

GENMIN

GFI

GSA

GWP

GWPMP

GWTF

GWTS

Gy

H HCD
Environmental Protection Department (LLNL).

Environmental Restoration Division of the Environmental Protection Department at LLNL.

Environmental, Safety, and Health.

Environmental Support Team.

Explosives Waste Storage Facility.

Explosives Waste Treatment Facility.

Federal facility agreement. A negotiated agreement that specifies required actions at a federal facility as agreed upon by various agencies (e.g., EPA, RWQCB, and DOE).

Finding of no significant impact.

1,1,2-trichloro-1,2,2-trifluoroethane.

Field tracking forms.

Gram. The standard metric measure of weight approximately equal to 0.035 ounce.

Granulated activated carbon.

Gigabecquerel. $1 \times 10^{9}$ Becquerel.

General mineral site of analyses performed on ground water samples.

Ground fault interrupt.

General Services Area (LLNL Site 300).

Ground Water Project.

Ground Water Project Management Program.

Ground Water Treatment Facility.

Ground Water Treatment System.

Gray. The SI unit of measure for absorbed dose; the quantity of energy imparted by ionizing radiation to a unit mass of matter, such as tissue. One gray equals 100 rads, or one joule per kilogram. (See "Gray" in Technical Terms.)

Hazards Control Department. 
$\mathrm{HE}$

HEPA

HEPA filter

High explosives. Materials that release large amounts of chemical energy when detonated.

High-efficiency particulate air (filter).

A high-efficiency particulate air filter used to capture particulates in an air stream. A HEPA filter is a throwaway, extended-media, dry type filter with a rigid casing enclosing the full depths of the pleats. HEPA filter collection efficiencies are at least $99.97 \%$ for 0.3 micrometer diameter particules.

HMX Cyclotetramethyltetramine, a high-explosive compound. Also referred to as octahydro-1,3,5,7-tetranitro-1,3,5,7-tetrazocine.

HPGe High-purity germanium.

HSD

(Tukey-Kramer) honestly significant difference (test).

HSU Hydrostratigraphic unit.

HT

HTO

Tritiated hydrogen gas. Tritium is the hydrogen isotope with one proton and two neutrons in the nucleus. It emits a low-energy beta particle and has a half-life of 12.3 years.

HWCA

HWM

Tritiated water and water vapor (see HT).

California Hazardous Waste Control Act. This legislation specifies requirements for the management of hazardous wastes in California.

Hazardous Waste Management Division of the Environmental Protection Department at LLNL.

I ICRP

IMS

International Commission on Radiological Protection. An international organization that studies radiation, including its measurement and effects.

IQR

Instrumented Membrane System.

Interquartile range (see Technical Terms).

ISD

Interim status document.

ISMS

Integrated safety management system.

ITRC

Environmental Council of States Interstate Technology and Regulatory Cooperation.

L $\quad$ LLNL

Lawrence Livermore National Laboratory.

LUFT Leaking underground fuel tank. 
LWRP

M MCL

MDC

MDL

MEI

ML

$\mathrm{mL}$

MOLE

MPN

$\mathrm{mR}$

mrem

MRP

MSDS

$\mathrm{mSv}$

MTBE

N NCR

NCRP

NEPA

NESHAPs

NHPA

NIF
Livermore Water Reclamation Plant. The City of Livermore's municipal wastewater treatment plant, which accepts discharges from the LLNL Livermore site.

Maximum contaminant level in drinking water established by EPA or DTSC.

Minimum detectable concentration.

Minimum detection limit.

Maximally exposed individual member of the public.

Megaliter. $10^{6}$ liters.

Milliliter. $10^{-3}$ liter $=1 \mathrm{~cm}^{3}$.

Miniature Optical Lair Explorer.

Most probable number.

Milliroentgen. $10^{-3}$ roentgen.

Millirem. $10^{-3}$ rem.

Monitoring and Reporting Program.

Material Safety Data Sheet.

Millisievert. $10^{-3}$ sievert.

Methyl tertiary-butyl ether.

Nonconformance Report.

National Council on Radiation Protection.

National Environmental Policy Act. This federal legislation, enacted in 1969, requires all federal agencies to document and consider environmental impacts from federally funded or approved projects. DOE is responsible for NEPA compliance at LLNL.

National Emission Standards for Hazardous Air Pollutants. These standards are found in the Clean Air Act and set limits for hazardous air pollutants.

National Historical Preservation Act.

National Ignition Facility. 
NIST

NOV

NPDES

NPDESMETALS

NPL

NRC

O OBT

ORAD

OSP

$\mathrm{OU}$

P P2

PCB

PCE

$\mathrm{pCi}$

PeerRP

PEIS

PHA

PM

PMCL

$\mathrm{ppb}$
National Institute for Standards and Technology. The federal agency, formerly known as the National Bureau of Standards, responsible for reference materials against which laboratory materials are calibrated.

Notice of Violation.

National Pollutant Discharge Elimination System. This federal regulation, under the Clean Water Act, requires permits for discharges into surface waterways.

Suite of metal analysis performed on ground water samples required under NPDES.

National Priorities List.

Nuclear Regulatory Commission. The federal agency charged with oversight of nuclear power and nuclear machinery and applications not regulated by DOE or the Department of Defense.

Organically bound tritium.

Operations and Regulatory Affairs Division of the Environmental Protection Department at LLNL.

Operational safety plan.

Operable Unit.

Pollution Prevention.

Polychlorinated biphenyl.

Tetrachloroethene (or perchloroethylene).

Picocurie. $1 \times 10^{-12} \mathrm{Ci}$.

Peer Review Panel.

Programmatic Environmental Impact Statement.

Public Health Assessment.

Performance measure.

Primary maximum contaminant level.

Parts per billion. A unit of measure for the concentration of a substance in its surrounding medium. For example, one billion grams of water containing one gram of salt has a salt concentration of one part per billion. 


\section{Glossary}

ppm

ppmv

PPOA

PRG

PTU

Q QA

QC

R R

RAIP

RCRA

RDX

RHB

RL

RML

RMMA

ROD

RPM

RWQCB

S SAA

SARA

Scfm
Parts per million. A unit of measure for the concentration of a substance in its surrounding medium. For example, one million grams of water containing one gram of salt has a salt concentration of one part per million.

Parts per million by volume.

Pollution Prevention Opportunity Assessment.

Preliminary remediation goal.

Portable treatment unit.

Quality assurance.

Quality control.

Roentgen, (see Technical Terms).

Remedial Action Implementation Plan.

Resource Conservation and Recovery Act of 1976. RCRA is a program of federal laws and regulations that govern the management of hazardous wastes. RCRA is applicable to all entities that manage hazardous wastes.

Hexahydro-1,3,5-trinitro-1,3,5-triazine. A high-explosive compound.

Radiological Health Branch

Reporting limit.

Radiological Measurements Laboratory.

Radioactive Materials Management Area.

Record of Decision.

Remedial Project Manager.

Regional Water Quality Control Board. The California regional agency responsible for water quality standards and the enforcement of state water quality laws within its jurisdiction. California is divided into a number of RWQCBs; the Livermore site is regulated by the San Francisco Bay Region, and Site 300 is regulated by the Central Valley Region.

Streambed Alteration Agreement.

Superfund Amendment and Reauthorization Act of 1986 (see CERCLA/SARA).

Standard cubic feet per minute. 
SFBRWQCB

SHPO

SI

Site 300

SJCHD

SJVUAPCD

SL

SMCL

Sandia/California

SOV

STAR

Sv

SVE

SVRA

SWAT

SWDA

SW-MEI

SWPPP

SWRCB

SWRI

T TBOS

$\mathrm{TBq}$
San Francisco Bay Regional Water Quality Control Board. The local agency responsible for regulating stationary air emission sources (including the Livermore site) in the San Francisco Bay Area.

California State Historic Preservation Office.

Système International d'Unités. An international system of physical units. Units of measure in this system include meters (length), kilogram (mass), kelvin (temperature), becquerel (radioactivity), gray (radioactive dose), and sievert (dose equivalent).

LLNL's Experimental Test Site, located approximately $24 \mathrm{~km}$ east of the Livermore site.

San Joaquin County Health District. The local agency that enforces underground-tank regulations in San Joaquin County, including Site 300.

San Joaquin Valley Unified Air Pollution Control District. The local agency responsible for regulating stationary air emission sources (including Site 300) in San Joaquin County.

Statistical limit.

Secondary maximum contaminant level.

Sandia National Laboratories, California.

Summary of violations.

Sample tracking and receiving (computer system).

Sievert. (See Technical Terms.)

Soil vapor extraction.

State Vehicular Recreation Area.

Solar-powered water activated-carbon treatment.

State Water Drinking Act.

Sitewide maximally exposed individual member of the public.

Storm Water Pollution Prevention Plan.

California State Water Resources Control Board.

(LLNL) Site-wide Remedial Investigation (Report).

Tetrabutyl orthosilicate.

Terabecquerel. $1 \times 10^{12}$ Becquerel. 


\section{Glossary}

TCE

TDS

TLD

TNT

TOC

TOX

TRU

TSS

TWMS

U UC

USEC

USFWS

UST

UV

v VOC

VPP

VTF

W WAA

WDR

WGMG

WQO

WSS
Trichloroethene.

Total dissolved solids. The portion of solid material in a waste stream that is dissolved and passed through a filter.

Thermoluminescent dosimeter. A device used to measure external beta or gamma radiation levels. TLDs contain a material that after exposure to beta or gamma radiation emits light when processed and heated.

Trinitrotoluene.

Total organic carbon. The sum of the organic material present in a sample.

Total organic halides. The sum of the organic halides present in a sample.

Transuranic waste.

Total suspended solids.

Total Waste Management System.

University of California.

U.S. Enrichment Corporation.

U.S. Fish and Wildlife Service.

Underground storage tank.

Ultraviolet light.

Volatile organic compound. Liquid or solid organic compounds that have a high vapor pressure at normal pressures and temperatures and thus tend to spontaneously pass into the vapor state.

Voluntary Protection Program.

Vapor Treatment Facilities.

Waste accumulation area. An officially designated area that meets current environmental standards and guidelines for temporary (less than 90 days) storage of hazardous waste before pickup by the Hazardous Waste Management Division for off-site disposal.

Waste Discharge Requirements. Issued by the California Regional Water Quality Control Board.

Water Guidance and Monitoring Group

Water quality objective.

Work Smart Standards. 
WTF

Z $\quad$ Zone 7

\section{Technical Terms}

A Absorbed dose

Accuracy

Action Level

Aerosol

Alluvium

Alpha particle

Ambient air

Analyte

Anion

ANOVA

Aquifer

Aquitard

Atom

Atomic absorption spectroscopy
Working task force.

Alameda County Flood Control and Conservation District, Zone 7.

The amount of energy imparted to matter by ionizing radiation per unit mass of irradiated material. The absorbed dose is expressed in units of rad or gray (1 rad $=0.01$ gray).

The closeness of the result of a measurement to the true value of the quantity measured.

Defined by regulatory agencies, it is the level of pollutants which, if exceeded, requires regulatory action.

A gaseous suspension of very small particles of liquid or solid.

Sediment deposited by flowing water.

A positively charged particle emitted from the nucleus of an atom, having mass and charge equal to those of a helium nucleus (two protons and two neutrons).

The surrounding atmosphere, usually the outside air, as it exists around people, plants, and structures. It is not considered to include the air immediately adjacent to emission sources.

The specific component that is being measured in a chemical analysis.

A negatively charged ion, for example $\mathrm{Cl}^{-}$.

Analysis of variance. A test of whether two or more sample means are statistically different.

A saturated layer of rock or soil below the ground surface that can supply usable quantities of ground water to wells and springs. Aquifers can be a source of water for domestic, agricultural, and industrial uses.

Low-permeability geologic formation that bounds an aquifer.

The smallest particle of an element capable of entering into a chemical reaction.

Abbreviated AA. A method used to determine the elemental composition of a sample. In this method, the sample is vaporized and its light absorbance measured. 


\section{Glossary}

B Barcad

Becquerel (Bq)

Beta particle

Biochemical

(biological) oxygen

demand

C Categorical

discharge

CFC

Chain-of-custody

Chlorocarbon

Collective dose

equivalent and collective effective dose equivalent
Committed dose equivalent

Committed effective dose equivalent
Device that samples water in a well. Water, collected in a discrete water bearing zone, is forced to the surface by pressurized nitrogen.

The SI unit of activity of a radionuclide, equal to the activity of a radionuclide having one spontaneous nuclear transition per second.

A negatively charged particle emitted from the nucleus of an atom, having charge, mass, and other properties of an electron.

A measure of the amount of dissolved oxygen that microorganisms need to break down organic matter in water. It is used as an indicator of water quality.

Discharge from a process regulated by EPA rules for specific industrial categories.

Chlorofluorocarbon. A compound that has fluorine and chlorine atoms on a carbon backbone. Freons are common CFCs.

A method for documenting the history and possession of a sample from the time of its collection, through its analysis and data reporting, to its final disposition.

A compound of carbon and chlorine, or carbon, hydrogen, and chlorine, such as carbon tetrachloride, chloroform, and tetrachloroethene.

The sums of the dose equivalents or effective dose equivalents to all individuals in an exposed population within $80 \mathrm{~km}$ (50 miles) of the radiation source. These are evaluated by multiplying the dose received by an individual at each location by the number of individuals receiving that dose, and summing over all such products for locations within $80 \mathrm{~km}$ of the source. They are expressed in units of person-rem or person-sievert. The collective EDE is also referred to as the "population dose."

The predicted total dose equivalent to a tissue or organ over a 50-year period after an intake of a radionuclide into the body. It does not include contributions from external dose. Committed dose equivalent is expressed in units of rem (or sievert; 100 rem equals one sievert).

The sum of the committed dose equivalents to various tissues in the body, each multiplied by an appropriate weighting factor representing the relative vulnerability of different parts of the body to radiation. Committed effective dose equivalent is expressed in units of rem or sievert. 
Cosmic radiation Radiation with very high energies, originating outside the earth's atmosphere. Cosmic radiation is one source contributing to natural background radiation.

Curie A unit of measurement of radioactivity, defined as the amount of radioactive material in which the decay rate is $3.7 \times 10^{10}$ disintegrations per second or $2.22 \times 10^{12}$ disintegrations per minute; one $\mathrm{Ci}$ is approximately equal to the decay rate of one gram of pure radium.

D Daughter nuclide

A nuclide formed by the radioactive decay of another nuclide, which is called the parent.

Depleted uranium Uranium having a lower proportion of the isotope ${ }^{235} U$ than is found in naturally occurring uranium; the fractions of ${ }^{238} \mathrm{U},{ }^{234} \mathrm{U}$, and ${ }^{235} \mathrm{U}$ that we use for depleted uranium are defined in Supplement 12-3. Depleted uranium is sometimes referred to as D-38.

DCG Derived Concentration Guide. Concentrations of radionuclides in water and air that could be continuously consumed or inhaled for one year and not exceed the DOE primary radiation standard to the public (100 mrem/y EDE).

De minimis Shortened form of "de minimis non curat lex," which means, "The law does not care for, or take notice of, very small or trifling matters." A "de minimis level" would be a level that is so inconsequential that, by definition, it cannot be cause for concern.

Dose The energy imparted to matter by ionizing radiation; the unit of absorbed dose is the rad, equal to 0.01 joules per kilogram for irradiated material in any medium.

Dose commitment The dose which an organ or tissue would receive during a specified period of time (e.g., 50 or 70 years) as a result of one year's intake of one or more radionuclides.

Dose equivalent The product of absorbed dose in rad (or gray) in tissue and a quality factor representing the relative damage caused to living tissue by different kinds of radiation, and perhaps other modifying factors representing the distribution of radiation, etc. Dose equivalent is expressed in units of rem or sievert (1 rem $=0.01$ sievert).

Dosimeter A portable detection device for measuring the total accumulated exposure to ionizing radiation.

Dosimetry The theory and application of the principles and techniques of measuring and recording radiation doses. 


\section{Glossary}

Downgradient In the direction of ground water flow from a designated area; analogous to downstream.

E Effective dose

An estimate of the total risk of potential effects from radiation exposure. equivalent (EDE)

It is the summation of the products of the dose equivalent and weighting factor for each tissue. The weighting factor is the decimal fraction of the risk arising from irradiation of a selected tissue to the total risk when the whole body is irradiated uniformly to the same dose equivalent. These factors permit dose equivalents from nonuniform exposure of the body to be expressed in terms of an effective dose equivalent that is numerically equal to the dose from a uniform exposure of the whole body that entails the same risk as the internal exposure (ICRP 1980). The effective dose equivalent includes the committed effective dose equivalent from internal deposition of radionuclides and the effective dose equivalent due to penetrating radiation from sources external to the body, and is expressed in units of rem (or sievert).

Effluent A liquid or gaseous waste discharged to the environment.

Evapotranspiration A process by which water is transferred from the soil to the air by plants that take the water up through their roots and release it through their leaves and other aboveground tissue.

F Federal facility A facility that is owned or operated by the federal government. Federal facilities are subject to the same requirements as other responsible parties once placed on the Superfund National Priorities List.

Federal Register A document published daily by the federal government containing notification of government agency actions. The Federal Register contains notification of EPA and DOE actions, including notification of EPA and DOE decisions concerning permit applications and rule-making.

G Gamma ray High-energy, short-wavelength, electromagnetic radiation emitted from the nucleus of an atom. Gamma radiation frequently accompanies the emission of alpha or beta particles.

Gray The SI unit of measure for absorbed dose; the quantity of energy imparted by ionizing radiation to a unit mass of matter, such as tissue. One gray equals 100 rads, or 1 joule per kilogram.

Ground water All subsurface water. 
H Half-life (radiological)

Hazardous waste
The time required for one-half the radioactive atoms in a given amount of material to decay. After one half-life, half of the atoms will have decayed; after two half-lives, three-fourths; after three half-lives, seveneighths; and so on, exponentially.

Wastes exhibiting any of the following characteristics: ignitability, corrosivity, reactivity, or EP-toxicity (yielding toxic constituents in a leaching test). In addition, EPA has listed as hazardous other wastes that do not necessarily exhibit these characteristics. Although the legal definition of hazardous waste is complex, the term more generally refers to any waste that EPA believes could pose a threat to human health and the environment if managed improperly.

Hydraulic conductivity

Hydraulic gradient In an aquifer, the rate of change of total head (water-level elevation) per unit distance of flow at a given point and in a given direction.

Hydrology The science dealing with the properties, distribution, and circulation of natural water systems.

I Inorganic compounds

In situ

Interim status

IQR

Isotopes

$\mathbf{L} \quad$ Liter
Compounds that either do not contain carbon or do not contain hydrogen along with carbon. Inorganic compounds include metals, salts, and various carbon oxides (e.g., carbon monoxide and carbon dioxide).

A term that can be used to refer to the treatment of contaminated areas in place, i.e., without excavation or other removal, as in the in situ treatment of soils through biodegradation of contaminants on site.

A legal classification that applies to hazardous waste incinerators or other hazardous waste management facilities that were under construction or in operation by November 19,1980, and can meet other interim status requirements. Interim status facilities may operate while EPA considers their permit application.

Interquartile range. The distance between the top of the lower quartile and the bottom of the upper quartile. The IQR provides a measure of the spread of data.

Forms of an element having the same number of protons in their nuclei, but differing numbers of neutrons.

The SI measure of capacity approximately equal to 1.057 quart. 
Less than detection A phrase indicating that a chemical constituent was either not identified limits or not quantified at the lowest level of sensitivity of the analytical method being employed by the laboratory. Therefore, the chemical constituent either is not present in the sample, or it is present in such a small concentration that it cannot be measured by the analytical procedure.

Low-level waste Waste defined by DOE Order 5820.2A. Low-level waste contains transuranic nuclide concentrations less than $100 \mathrm{nCi} / \mathrm{g}$.

Lower limit of The smallest concentration or amount of analyte that can be detected in a detection

Lysimeter sample at a $95 \%$ confidence level.

An instrument for measuring the water percolating through soils and determining the dissolved materials.

M Maximally

Exposed Individual

The maximally exposed individual is a hypothetical member of the public at a fixed location who, over an entire year, receives the maximum effective dose equivalent (summed over all pathways) from a given source of radionuclide releases to air. Generally, the MEI is different for each source at a site.

Multiple completion

A borehole with water surveillance monitoring devices (Barcads) placed at various levels and separated by impermeable layers of material such as grout. Usually the uppermost "completion" is accessible from the surface, making physical sample-taking possible (as opposed to Barcads), and is referred to as a well.

Mixed waste Waste that has the properties of both hazardous and radioactive waste.

N Nonpoint source

Any nonconfined area from which pollutants are discharged into a body of water (e.g., agricultural runoff, construction runoff, and parking lot drainage), or into air (e.g., a pile of uranium tailings).

Nuclide A species of atom characterized by the constitution of its nucleus. The nuclear constitution is specified by the number of protons, number of neutrons, and energy content; or, alternatively, by the atomic number, mass number, and atomic mass. To be regarded as a distinct nuclide, the atom must be capable of existing for a measurable length of time.

O Off-site Outside the boundaries of the LLNL Livermore site and Site 300 properties.

On-site Within the boundaries of the LLNL Livermore site or Site 300 properties. 
P Part B permit

Perched aquifer

Performance

standards

(incinerators)

$\mathrm{pH}$

Piezometer

Pliocene

PM-10

Point source

Pretreatment

Pretreatment regulations

Priority pollutants

Q Quality assurance (QA)

Quality control (QC)
The second, narrative section submitted by generators in the RCRA permitting process. It covers in detail the procedures followed at a facility to protect human health and the environment.

Aquifer that is separated from another water-bearing stratum by an impermeable layer.

Specific regulatory requirements established by EPA limiting the concentrations of designated organic compounds, particulate matter, and hydrogen chloride in incinerator emissions.

A measure of hydrogen ion concentration in an aqueous solution. Acidic solutions have a $\mathrm{pH}$ from 0 to 6 ; basic solutions have a $\mathrm{pH}$ greater than 7; and neutral solutions have a $\mathrm{pH}$ of 7 .

Instrument for measuring fluid pressure. Generally used to measure the elevation of the water table in a small, nonpumping well.

Geological epoch of the Tertiary period, starting about 12 million years ago.

Fine particulate matter with an aerodynamic diameter equal to or less than 10 microns.

Any confined and discrete conveyance (e.g., pipe, ditch, well, or stack).

Any process used to reduce a pollutant load before it enters the sewer system.

National wastewater pretreatment regulations, adopted by EPA in compliance with the 1977 amendments to the Clean Water Act, which required that EPA establish pretreatment standards for existing and new industrial sources.

A set of organic and inorganic chemicals identified by EPA as indicators of environmental contamination.

A system of activities whose purpose is to provide the assurance that standards of quality are attained with a stated level of confidence.

Procedures used to verify that prescribed standards of performance are attained. 


\section{Glossary}

Quality factor

Quaternary

R Rad

\section{Radioactivity}

Radionuclide

Rem

Risk assessment

Roentgen

S Sampling and Analysis Plan
The factor by which the absorbed dose (rad) is multiplied to obtain a quantity that expresses (on a common scale for all ionizing radiation) the biological damage to exposed persons. Quality factor is used because some types of radiation, such as alpha particles, are biologically more damaging than others. Quality factors for alpha, beta, and gamma radiation are in the ratio 20:1:1.

The geologic era encompassing the last 2-3 million years.

The unit of absorbed dose. It is the quantity of energy imparted by ionizing radiation to a unit mass of matter such as tissue. One rad equals 0.01 joule per kilogram, or 0.01 gray.

Radioactive decay The spontaneous transformation of one radionuclide into a different nuclide (which may or may not be radioactive), or de-excitation to a lower energy state of the nucleus by emission of nuclear radiation, primarily alpha or beta particles, or gamma rays (photons).

The spontaneous emission of nuclear radiation, generally alpha or beta particles, or gamma rays, from the nucleus of an unstable isotope.

An unstable nuclide. See nuclide and radioactivity.

A unit of radiation dose equivalent and effective dose equivalent describing the effectiveness of a type of radiation to produce biological effects; coined from the phrase "roentgen equivalent man." It is the product of the absorbed dose (rad), a quality factor (Q), a distribution factor, and other necessary modifying factors. One rem equals 0.01 sievert.

The use of established methods to measure the risks posed by an activity or exposure. In the present context, risk assessments evaluate: (1) the relationship between exposure to radioactive substances and the subsequent occurrence of health effects; and (2) the likelihood for that exposure to occur.

A unit of measurement used to express radiation exposure in terms of the amount of ionization produced in a volume of air.

A detailed document describing the procedures used to collect, handle, and analyze ground water samples. The plan details quality control measures that will be implemented to ensure that sample-collection, analysis, and data-presentation activities meet the prescribed requirements. 
Sanitary waste

Saturated zone

Sensitivity

Sewerage

Sievert (Sv)

Sitewide Maximally

Exposed Individual (SW-MEI):

Specific conductance Superfund

Surface impoundment
Most simply, waste generated by routine operations that is not regulated as hazardous or radioactive by state or federal agencies.

A subsurface zone below which all rock pore-space is filled with water; also called the phreatic zone.

The capability of methodology or instrumentation to discriminate between samples having differing concentrations or containing varying amounts of analyte.

The system of sewers.

The SI unit of radiation dose equivalent and effective dose equivalent. This is the product of the absorbed dose (gray), quality factor (Q), distribution factor, and other necessary modifying factors. One sievert equals 100 rem.

The sitewide maximally exposed individual member of the public is defined as the hypothetical person who receives, at the location of a given publicly accessible facility (such as a church, school, business, or residence), the greatest LLNL-induced effective dose equivalent (summed over all pathways) from all sources of radionuclide releases to air at a site. Doses at this receptor location caused by each emission source are summed, and yield a larger value than for the location of any other similar public facility. This individual is assumed to continuously reside at this location 24 hours per day, 365 days per year.

Measure of the ability of a material to conduct electricity. Also called conductivity.

The common name used for the Comprehensive Environmental Response, Compensation and Liability Act of 1980 (CERCLA). California has also established a "State Superfund" under provisions of the California Hazardous Waste Control Act.

A facility or part of a facility that is a natural topographic depression, man-made excavation, or diked area formed primarily of earthen materials, although it may be lined with man-made materials. The impoundment is designed to hold an accumulation of liquid wastes, or wastes containing free liquids, and is not an injection well. Examples of surface impoundments are holding, storage, settling and aeration pits, ponds, and lagoons. 


\section{Glossary}

T Tritium

Tukey-Kramer HSD Test

U Unsaturated zone

V Vadose zone

W Wastewater treatment system

Water table

Weighting factor

Wind rose

Z $\quad$ Zone 7
The radioactive isotope of hydrogen, containing one proton and two neutrons in its nucleus. It decays at a half-life of 12.3 years by emitting a low-energy beta particle.

Material contaminated with alpha-emitting transuranium nuclides, which have an atomic number greater than 92 (e.g. ${ }^{239} \mathrm{Pu}$ ), half-lives longer than 20 years, and are present in concentrations greater than $100 \mathrm{nCi} / \mathrm{g}$ of waste.

The Tukey-Kramer honestly significant difference test, a statistical technique for testing differences among group means.

That portion of the subsurface in which the pores are only partially filled with water. The direction of water flow is vertical in this zone; which is also referred to as the vadose zone.

The partially saturated or unsaturated region above the water table that does not yield water to wells.

A collection of treatment processes and facilities designed and built to reduce the amount of suspended solids, bacteria, oxygen-demanding materials, and chemical constituents in wastewater.

The water-level surface below the ground at which the unsaturated zone ends and the saturated zone begins. It is the level to which a well that is screened in the unconfined aquifer would fill with water.

A value used to calculate dose equivalents. It is tissue-specific and represents the fraction of the total health risk resulting from uniform, whole-body irradiation that could be contributed to that particular tissue. The weighting factors used in this report are recommended by the International Commission on Radiological Protection (ICRP 1980).

A diagram that shows the frequency and intensity of wind from different directions at a specific location.

The common name for the Alameda County Flood Control and Water Conservation District. Zone 7 is the water management agency for the Livermore-Amador Valley with responsibility for water treatment and distribution. Zone 7 is also responsible for management of agricultural and surface water and the ground water basin. 


\section{External Distribution}

Air Resources Board

J. Morgester

Compliance Division

P.O. Box 2815

Sacramento, CA 95812

Alameda County Department of

Environmental Health

Robert Weston

Environmental Protection Division

1131 Harbor Bay Parkway, 2nd Floor

Alameda, CA 94502

Alameda County Flood Control and Water

Conservation District, Zone 7

David Lunn

5997 Parkside Drive

Pleasanton, CA 94566

Alameda County Water District

E. L. Lenahan

43885 S. Grimmer Blvd.

Fremont, CA 94537

Argonne National Laboratory

Norbert Golchert

9700 S. Cass Avenue

Building 200, Room B-117

Argonne, IL 60439

Argonne National Laboratory

Michael Lazaro

9700 S. Cass Avenue

Building 200, Room B-900

Argonne, IL 60439

Assistant Administrator for Air Radiation

(ANR-443)

U.S. Environmental Protection Agency

401 "M" Street, S.W.

Washington, DC 20460
Bay Area Air Quality

Management District

Milton Feldstein

939 Ellis Street

San Francisco, CA 94109

Biomedical \& Environmental

Sciences Lab

O. R. Lunt, Director

University of California

900 Veteran Avenue

Los Angeles, CA 90024

Brookhaven National Laboratory

Robert Miltenberger

G. L. Schroeder

Bldg. 535A

Upton, NY 11973

Brookhaven National Laboratory

J. Naidu

Safety \& Environmental Protection

Bldg. 535A

Upton, NY 11973

California Department of Energy

Barbara J. Byron

Executive Office

1515 - 9th Street/MS-36

Sacramento, CA 95814

California Department of Health Services

Dorice Bailey

Edgar D. Bailey

K. Jackson

DHS/EMB, MS-396

601 N. 7th Street, Box 942732

Sacramento, CA 95814 
California Environmental

Protection Agency

Mark Piros

Northern California Coastal Cleanup

Operations Branch

700 Heinz Avenue, Suite 200

Berkeley, CA 94710-2737

California Environmental

Protection Agency

C. Williams

Department of Toxic Substances Control

700 Heinz Avenue, Bldg. F

Berkeley, CA 94710-2737

California Environmental

Protection Agency

Robert Feather

Department of Toxic Substances Control,

Region 2

700 Heinz Avenue, Suite 200

Berkeley, CA 94710-2737

California Regional Water Quality Control

Board

S. Timm

Central Valley Region

3443 Routier Road

Sacramento, CA 95827-3098

California Regional Water Quality Control

Board

M. Bessette

L. Barsamian

San Francisco Bay Region

2101 Webster Street \#500

Oakland, CA 94612

California State Water Resources Control Board

W. Pettit

J. Diaz, Chief

Division of Water Quality

901 "P" Street

Sacramento, CA 95814
CDM Federal

Christina Thelen

2301 Buena Vista SE

Albuquerque, NM 87106

Continuous Electron Beam

Accelerator Facility

Bob May

Radiation Control

12000 Jefferson Avenue

Newport News, VA 23606

Chow Engineering

Sam Kreitem

770 Edgewater Dr., \#729

Oakland, CA 94621

EG\&G Mound Applied Technologies

Daniel G. Carfagno

P.O. Box 3000

Miamisburg, OH 45343

EG\&G Rocky Flats, Inc.

Keith Anderson

Environmental Operations

P.O. Box 464

Golden, CO 80402-0464

EG\&G Rocky Flats, Inc.

Catherine Madore

Environmental Protection

Management

P.O. Box 464

Golden, CO 80402-0464

EG\&G Rocky Flats, Inc.

Joan Novy

RMRS/Technical Publications

P.O. Box 464

Golden, CO 80402-0464

EG\&G Rocky Flats, Inc.

George H. Setlock

P.O. Box 464

Golden, CO 80402-0464 
EG\&G Rocky Flats, Inc.

Laura Tyler

RMRS/Document Services

P.O. Box 464

Golden, CO 80402-0464

Environmental Measurements Lab

Edward P. Hardy, Jr., Director

Environmental Studies Division

U.S. Department of Energy

376 Hudson Street

New York, NY 10014-3621

FERMCO

P. A. Kraps

Allan Lydic

Xenos J. Sroka

Site Restoration Services

P.O. Box 538704

Cincinnati, $\mathrm{OH}$ 45253-8704

FERMCO

Caran Siefert

Environmental Protection

P.O. Box 538704

Cincinnati, $\mathrm{OH}$ 45253-8704

Fermilab

Sam Baker

Paul Kesich

P.O. Box 500, MS-119

Batavia, IL 60510

GRUPE Communities, Inc.

Doug Unruh

P.O. Box 7576

Stockton, CA 95267

Hanford Environmental Health Foundation

Joseph K. Samuels

Environmental Health Services

P.O. Box 100, H1-78

Richland, WA 99352
Ernest Orlando Lawrence

Berkeley National Laboratory

Ron Pauer

Environmental Monitoring Group

MS75B-101

One Cyclotron Road,

Berkeley, CA 94720

Ernest Orlando Lawrence

Berkeley National Laboratory

Henry Tran,

MS75B-101

One Cyclotron Road

Berkeley, CA 94720

Livermore Water Reclamation Plant

W. Adams

101 West Jack London Blvd.

Livermore, CA 94550

Lockheed Idaho Technologies Co.

Leah Street

Environmental Protection

P.O. Box 1625

Idaho Falls, ID 83415-4110

Los Alamos National Laboratory

Tom Buhl

Doris Garvey

Environmental Assessments and Resource

Evaluation

Section HSE-8, MS-K490

P.O. Box 1663

Los Alamos, NM 87545

Los Alamos National Laboratory

Bruce Gallahar

Steven Rae

Environment, Safety, \& Health Division

MS-K497, ESH-18

P.O. Box 1663

Los Alamos, NM 87545 
Los Alamos National Laboratory

Keith Jacobson

Air Quality Division

ESH-17, MS-J978

P.O. Box 1663

Los Alamos, NM 87545

Los Alamos National Laboratory

Julie Johnston

Environment, Safety, \& Health Division

ESH-20, MS-M887

P.O. Box 1663

Los Alamos, NM 87545

Los Alamos National Laboratory

John M. Puckett, Division Leader

Safeguards Systems

NIS-7

P.O. Box 1663

Los Alamos, NM 87545

Los Alamos National Laboratory

David B. Rogers (3 sets)

Water Quality \& Hydrology Group

ESH-18 MS-K497

P.O. Box 1663,

Los Alamos, NM 87545

Los Alamos National Laboratory

Lars Soholt

Environmental Surveillance Group

MS-M992E-ER

P.O. Box 1663

Los Alamos, NM 87545

Massachusetts Institute of Technology

STS Program

E51-296F

77 Massachusetts Avenue

Cambridge, MA 02139

Mountain Environmental

Katherine Hunninen

P.O. Box 1010

Silver Plume, CO 80476
Nevada Operations Office

Bruce W. Church

Asst. Manager for Environment,

Safety and Health

P.O. Box 98518

Las Vegas, NV 89193-8518

Oak Ridge National Laboratory

Laury Hamilton

Building 4500S, MS-6137

Oak Ridge, TN 37831-6137

Oak Ridge National Laboratory

John B. Murphy

Head, Environmental Surveillance

and Protection Section

Building 4500N, MS-6198

Oak Ridge, TN 37831-6198

Oak Ridge National Laboratory

Frank O'Donnell

Building 4500S., MS-6102

Oak Ridge, TN 37831-6102

Oak Ridge National Laboratory

Mark Tardiff

Office of Environmental Compliance and

Documentation

Building 4500N, MS-6198

Oak Ridge, TN 37831-6198

Pacific Northwest National Laboratory

P. Evan Dresel

Stuart Luttrell

Earth and Environmental Sciences

P.O. Box 999

Richland, WA 99352

Pacific Northwest National Laboratory

Richard Jaquish

Office of Health and Environment

P.O. Box 999

Richland, WA 99352 
Pacific Northwest National Laboratory

W. W. Laity, General Manager

Environmental Management Operations

Battelle Blvd.

P.O. Box 999

Richland, WA 99352

Questa Engineering Corporation

Jeff Peters

1220 Brickyard Cove Road

Point Richmond, CA 94807

Radiobiology \& Environmental

Health Laboratory

Sheldon Wolff, Director

University of California

Medical Center

San Francisco, CA 94143

REECO

Stuart C. Black

Health Physics Department

P.O. Box 98521, MS-708

Las Vegas, NV 89193-8521

\section{REECO}

Wayne M. Glines

Alan Latham

Analytical Services Department

P.O. Box 98521

Las Vegas, NV 89193-8521

Regional Water Quality Control Board

San Francisco Region

Joseph Chow

2101 Webster Street, Suite 500

Oakland, CA 946122

San Francisco Public Utilities Commission

Water Quality Bureau

David Quinones

1000 El Camino Real

Millbrae, CA 94030
San Francisco Public Utilities Commission

Water Quality Bureau - Engineering

Raymond Mah

1000 El Camino Real

Millbrae, CA 94030

San Joaquin County Public Health Services

Donna Heran, Director

Environmental Health Division

P.O. Box 388

Stockton, CA 95201

San Joaquin Local Health District

V. V. Williams

P.O. Box 388

Stockton, CA 95201

San Joaquin Valley Unified Air Pollution

Control District

Anthony Mendes

Engineering Manager

4230 Kiernan Avenue, Suite 130

Modesto, CA 95356

Sandia National Laboratories/California

Robert Holland

P.O. Box 969, MS-9221

Livermore, CA 94551

Sandia National Laboratories/California

Tricia Larson

P.O. Box 969

Livermore, CA 94551-0969

Sandia National Laboratories

H. S. Hwang

F. Ghanbari

Lih-Jenn Shyr

Dept. 7575

P.O. Box 5800, MS-1311

Albuquerque, NM 87185

Sandia National Laboratories

Marion McDonald

Dept. 6500, MS-1143

P.O. Box 5800

Albuquerque, NM 87185 
Savannah River Plant

Tim Jannik

WSRC-Env. Analysis Section

Building 733-42A, Room 226

Aiken, SC 29808

Robert L. Schlegel

12321 Tampico Way

Silver Spring, MD 20904

Stanford Linear Accelerator Center

Michael P. Grissom

Environment, Safety, \& Health, MS-84

2575 Sand Hill Road

Menlo Park, CA 94025-7015

William N. Taber

4211 S. Yuron Way

Lakewood, CO 80235

TetraTech, Inc.

John Nash

5203 Leesburg Pike, Suite 900

Falls Church, VA 22041

U.S. Department of Energy

Brookhaven Area Office

Gerald Granzen

Environmental Programs Division

Bldg. 464

Upton, NY 11973-5000

U.S. Department of Energy

B. Sue Lantz

Idaho Operations Office

850 Energy Drive, MS-1146

Idaho Falls, ID 83401-1563

U.S. Department of Energy

Stephen Chase (5 Volumes)

Office of Env. \& Tech. Support

Defense Programs, DP-45

1000 Independence Avenue S.W.

Washington, DC 20585
U.S. Department of Energy

Office of Scientific \& Technical Information

P.O. Box 62

Oak Ridge, TN 37831

U.S. Department of Energy

Rocky Flats Area Office

James K. Hartmen

Environmental Program Branch

P.O. Box 928

Golden, CO 80402-0928

U.S. Department of Energy

Rocky Flats, Site Support Division

Brent Evans

P.O. Box 928, Bldg. T115A

Golden, CO 80402-0928

U.S. Environmental Protection Agency

Federal Facilities Cleanup Office SFD8-1

Kathy Setian

Region IX

75 Hawthorne Street

San Francisco, CA 94195-3901

U.S. Environmental Protection Agency

S. Rosenblum, AIR-6

P. Wood, AIR-6

Region IX

75 Hawthorne Street

San Francisco, CA 94195-3901

U.S. Environmental Protection Agency

K. Silva, WTR-7

M. Gill, SFD-8

Region IX

75 Hawthorne Street

San Francisco, CA 94195-3901

University of California Berkeley

James Hunt

Department of Civil and Environmental

Engineering

631 Davis Hall, MS-1710

Berkeley, CA 94720 
West Valley Nuclear Services Co., Inc.

Anthony Nagel

Environmental, Safety, Health

and Quality Assurance

10282 Rock Springs Road

P.O. Box 191

West Valley, NY 14171-0191

Westinghouse Hanford Co.

Austin R. Johnson

P.O. Box 1970, H6-30

Richland, WA 99352

Westinghouse Savannah River Co.

James Heffner

Pete Fledderman

Environmental Protection

P.O. Box 616, Bldg. 735A

Aiken, SC 29802 



\section{Reader Survey and Data Supplement Order Form}

Our goal in providing this report is to give you a clear accounting of the range of environmental activities we undertake, the methods we employ, and the degree of accuracy of our results. It is important that the information we provide is easily understood, is of interest, and communicates LLNL's efforts to protect human health and the environment and to comply with environmental regulations. We would like to know from you whether we are successful in these goals. Your comments are welcome.

1. Is the technical level $\square$ too high? $\square$ too low? $\square$ uneven? $\square$ just right?

2. Is the writing $\square$ too concise? $\square$ too verbose?

uneven? $\square$ just right?

3. Do the illustrations help you understand the text better?

Are there enough?

Too few?

Too many?

4. Is the background information sufficient?

5. Are the methodologies being described understandable? Interesting?

6. Are the glossaries and appendices useful?

7. Are the data tables of interest?

Would you prefer short summaries of data trends instead? Other comments:

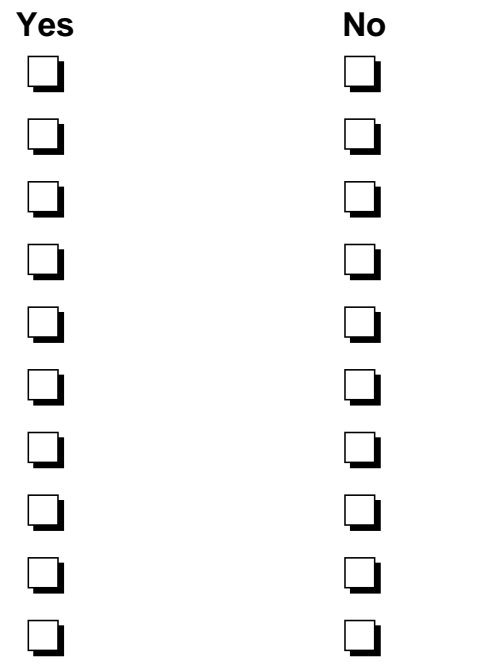

OPTIONAL: If you complete this reader survey but do not wish to order a Data Supplement, providing the following information here would be helpful:

Name: Occupation:

Address:

\section{Data Supplement Order Form}

$\square$ Please send me a copy of the LLNL Site Annual Environmental Report 1997 Data

Supplement. My name and address are:

To return this reader survey and data supplement order form to the Laboratory, please detach it, fold it with this side in, tape it closed, and mail it. Laboratory staff may simply send their survey forms through Lab mail to Jennifer Larson, L-627. 
Please fold on dotted line and seal before mailing.

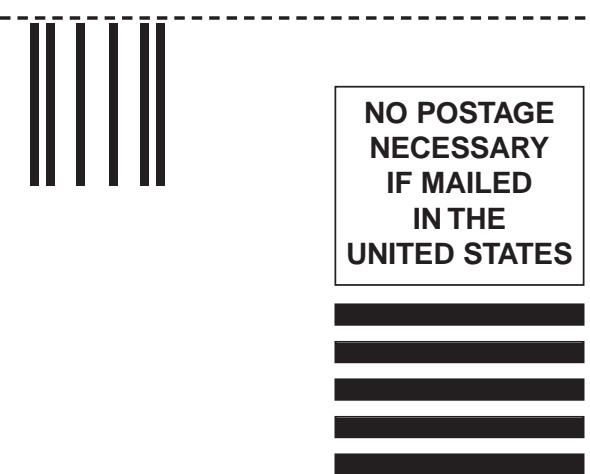

\section{BUSINESS REPLY MAIL FIRST-CLASS MAIL PERMIT NO. 16 LIVERMORE, CA}

POSTAGE WILL BE PAID BY THE LLNL

University of California

Lawrence Livermore National Laboratory

Attn: Jennifer Larson

L-627

P.O. Box 808

Livermore, California 94551-9989

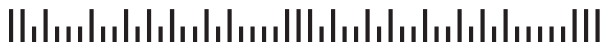





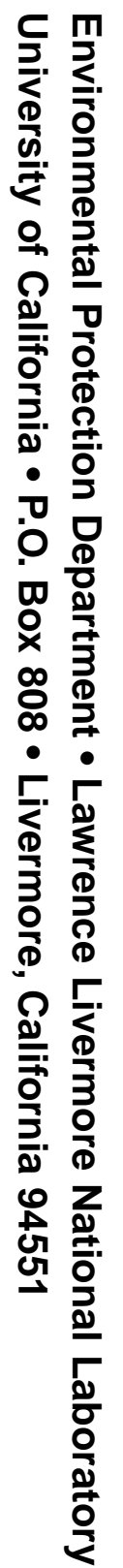

